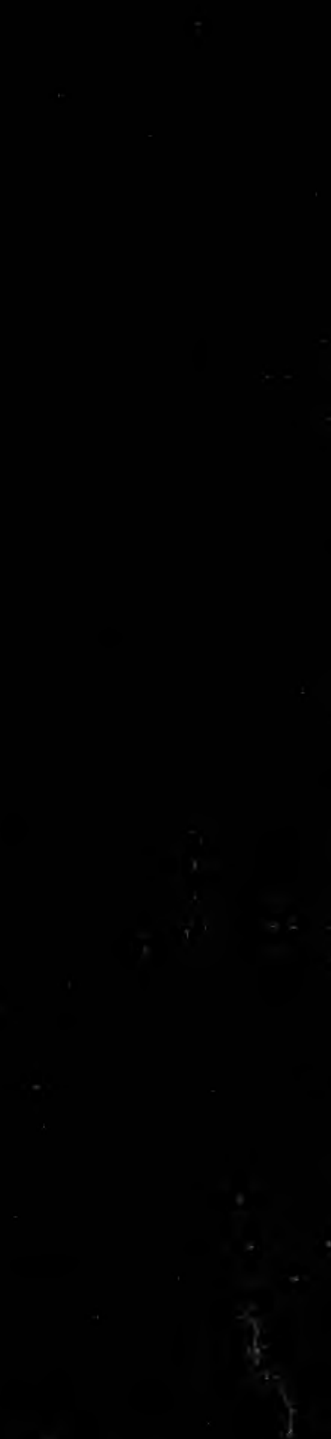

*is

as:

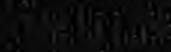

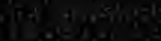

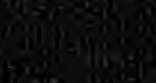

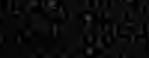

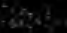

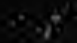
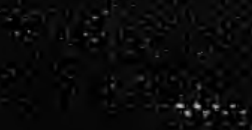


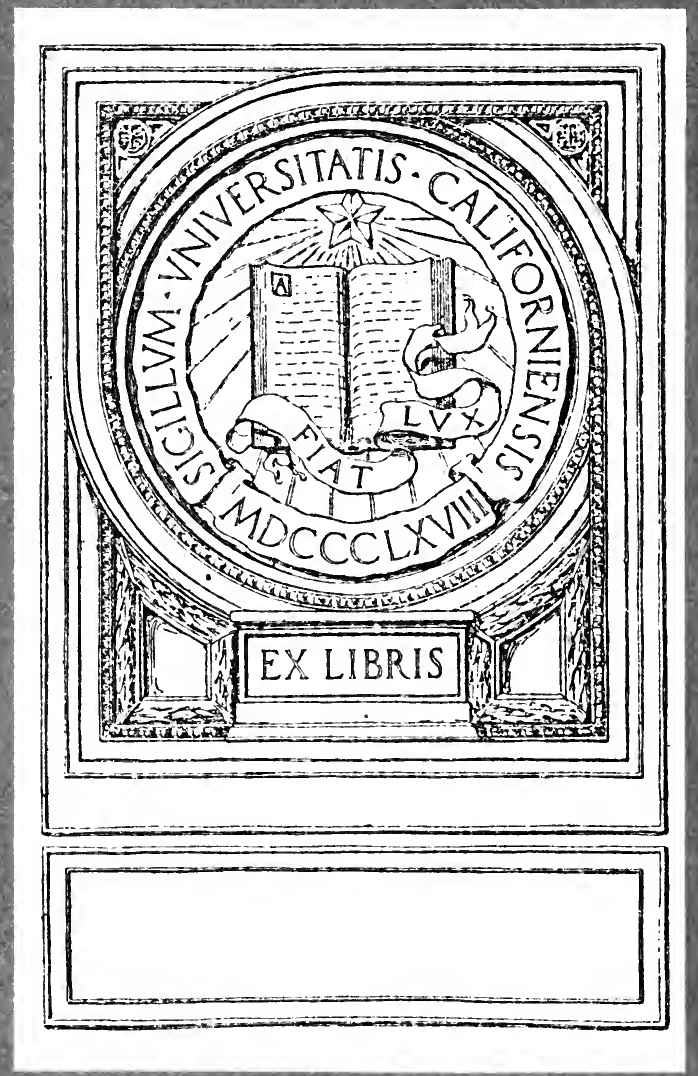




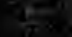





\section{$\cdot \mathrm{IN}$ INSURANCE}

AGAINST

\section{UNEMPLOYMENT}

WITH SPECIAL REFERENCE TO BRITISH AND AMERICAN GONDITIONS

\section{BY \\ JOSEPH L. COHEN \\ B.A. (Cantab), M.A. (Columbia, U.S.A.) \\ Richard Watson Gilder Fellow in Economics (Columbia)}

\section{LONDON \\ P. S. KING \& SON LTD. \\ ORCHARD HOUSE, WESTMINSTER}




$$
\begin{gathered}
1+D>095 \\
C_{6}
\end{gathered}
$$




\section{DEDICATED TO}

\section{RT. HON. ARTHUR HENDERSON, P.C., M.P.}

SECRETARY TO THE BRITISH LABOUR PARTY 



\section{PREFACE}

THE latest comprehensive study* of Insurance against Unemployment was written before the British National Scheme of Unemployment Insurance of I9I2 had been put into effect. At that time it was commonly regarded as impossible to apply the principles of insurance on a national scale because the nature of the risk of unemployment could not be calculated, and it was believed that no effective device for meeting the likelihood of malingering could be devised. The extension of the British scheme from about two million employees in seven insured trades to twelve million in all industrial occupations, and the adoption of comprehensive national schemes in Austria and Italy demonstrates that the main difficulties have been overcome: Indeed, perhaps the chief effect of voluntary schemes of unemployment insurance has been to prepare the way for national compulsory schemes. Certain it is that where trade unionism is weak, as in France, the grant of a subsidy has not been sufficient to induce a majority of employees to join organizations which provided unemployment benefits, and where it is strong, as in Germany, the employees feel that those responsible for the management and organization of industry, the employers, ought to

* I. G. Gibbon, Unemployment Insurance, I9 II. 
bear the burden of unemployment, rather than its victims the unemployed workers. Therefore in both types of countries there is a growing movement in favour of comprehensive national schemes. The main conclusion that emerges from the study of the schemes attempted is that compulsory unemployment insurance is a well-nigh universal movement in the industrial world to-day.

The acute depression of I920-I is everywhere leading to the institution of relief schemes which are made to resemble unemployment insurance schemes. The movement in favour of insurance, too, has been greatly strengthened.

The main questions relating to unemployment insurance are best considered in the discussion of the British scheme. These include such debated subjects as the merits of non-contributory as against contributory schemes, the rates of benefits, and whether trades rather than the State should be made to bear the burden of their own unemployed.

An effort has been made to collect the most interesting schemes of unemployment insurance in individual plants. Their existence should finally dissipate the fear of old-fashioned employers that unemployment insurance must result in their bankruptcy, and that it is class legislation and "veiled robbery."

This study has been made with special reference to conditions in Great Britain and the United States. The author spent three and a half years in the United States, and has ventured, on the advice of American economists, employers, and Labour officials, to make a number of proposals for consideration. 
This study was begun as a thesis for the Ph.D. degree in Economics at Columbia University, New York, and was approved by the faculty. The author feels under a deep and abiding sense of obligation to that University not only for its M.A. degree and its award of the Richard Watson Gilder Fellowship, one of its most cherished prizes, but also for the advantages it afforded him of studying under some of the leaders of economic thought in America, and for the opportunities it gave him of coming into contact with prominent men and women in the Labour world, with the directors of large plants, and with leading social workers. $\mathrm{He}$ is grateful especially to Professor Henry R. Seager, under whom the thesis was prepared and who advised the author, revised his MSS., and made the path of the stranger easy and pleasant, and to Professor Edwin R. Seligman, the Chairman of the Economics Faculty of the University.

He takes this opportunity of thanking also Miss Lilian D. Wald, Dr. H. G. Enelow, Mr. Bruno Lasker, and Dr. Philip Sargant Florence, for their aid whilst in the States. In England he is indebted to, amongst others, Sir William Beveridge, K.B.E., B. M. Headicar, Esq., G. R. Clutterbuck, Esq., to the Ministry of Labour, and to the Labour Research Department. 



\section{CONTENTS}

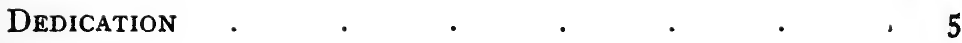

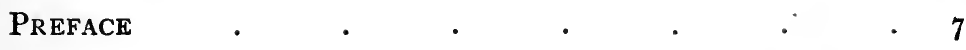

\section{PART I}

\section{THE PROBLEM OF UNEMPLOYMENT} INSURANCE

CHAPTER

I. The Prevention of Unemployment . - I 7

II. Mitigating the Effects of Unemployment $\cdots 54$

III. Definition of Unemployment Insurance 67

\section{PART II}

\section{THE GHENT SYSTEM OF UNEMPLOY-} MENT INSURANCE

,IV. Trade Union Unemployment Insurance 75

- V. The "Ghent Scheme" . . . . . 84

- VI. Unemployment Insurance in France $\cdot \quad 9^{2}$

$\checkmark$ VII. Switzerland.$\quad$. $\quad . \quad$. $\quad$. 105

$\checkmark$ VIII. NORWAY . . . . . . . . II5

$\checkmark$ IX. Holland . . . . . . . I I I

$\checkmark \mathrm{X}$. Denmark . . . . . . . . I 24

XI. Germany . . . . . . . . 140

XII. Notes on Canada, Japan, Spain, Czecho- 


\section{PART III}

\section{THE BRITISH SYSTEM OF UNEMPLOY- MENT INSURANCE}

CHAPTER

XIII. EMPLOYMENT EXCHANGES AND UNEMPLOYMENT

$$
\text { INSURANCE }
$$

. 159

XIV. OUtlines of the British Unemployment INSURANCE SCHEME

XV. The Principle of Compulsion . . . 218

XVI. The Scope of Unemployment Insurance 235 XVII. Contributions and Benefits . . 250

- XVIII. The Influence of the Unemployment INSurance Scheme on Trade Unions . . 270

XIX. Unemployment Insurance as a Device for Reducing Unemployment . . . 292

XX. The Scheme at Work . . . . 3 12

XXI. Next Steps in Unemployment Insurance 333

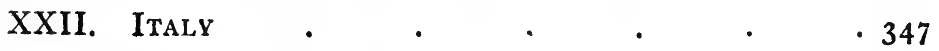

XXIII. Austria, with a Note on Russia $\cdot \quad 358$

XXIV. EsTABlishment UNEMPLOYMENT INSURANCE

FundS . $\quad . \quad$. $\quad . \quad$. $\quad . \quad 366$

\section{PART IV}

\section{THE UNEMPLOYMENT PROBLEM IN THE UNITED STATES}

XXV. The Establishment of Trade Union Out-of-

Work Benefits in the United States

XXVI. The Influence of OUt-of-Work Benefits on

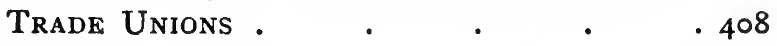

XXVII. OUtlines of a National Programme for UNEMPLOYMENT . 
INSURANCE AGAINST UNEMPLOYMENT 13

CHAPTER

XXVIII. Standards of Unemployment Insurance

PAGE

XXIX. The Massachusetts Bill on Unemployment

INSURANCE

- 465

ApPendix I.-Unemployment Insurance (Great Britain), Special Scheme $\cdot 495$

Appendix II.-Unemployment Insurance in Agriculture 519 Appendix III.-The Scale of Benefits . . . $52 \mathrm{I}$ Appendix IV.-The I92I CRisis:-Unemployment : A National or Local Problem . $\quad . \quad 522$

Chief Books and Papers Used . . . . 525

Official Papers $\quad . \quad$. $\quad . \quad$. $\quad . \quad 530$

INDEX . $\quad . \quad . \quad . \quad . \quad . \quad 533$ 

PART I

THE PROBLEM OF UNEMPLOYMENT INSURANCE 


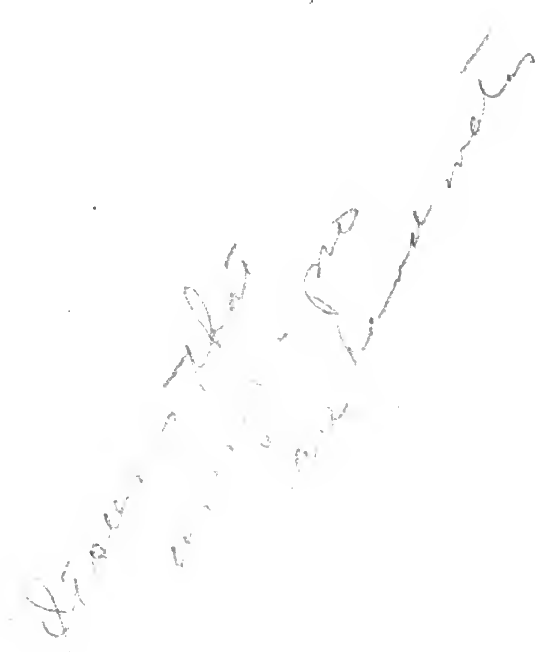

6 


\section{CHAPTER I}

\section{THE PREVENTION OF UNEMPLOYMENT}

UNEMPLOYMENT has been well termed the shadow-side of progress. It is essentially a by-product and characteristic of this, the latest stage, the capitalist stage, of production.*

Material development has gone on at an ever-increasing pace since the beginning of the Industrial Revolution. Human output has increased many-fold, and mankind as a whole has been greatly enriched by the opening out of large tracts of land, the discovery of new fields of enterprise, the invention of new machinery, and the introduction of new methods. But pari passu with the increasing productivity of the people of this country and of the rising wages of labour, unemployment, $\uparrow$ uncertainty, and destitution have not grown less acute. These onstitute chronic evils ever menacing. the workman's security and comfort. How to retain the benefits accruing from the growth of the national dividend and yet do away with the evils consequent on unemployment is a problem which still confronts us. Increased production is not necessarily a solution.

To the labourer unemployment is his gravest and most appalling problem. It is the paramount evil in his life. His livelihood, his savings, his belongings, the happiness of his household and all he cherishes are continually threatened by this Damocles' sword. At

* For a critical analysis of Capitalism, see The Sickness of an Acquisitive Society, by R. H. Tawney.

$\dagger$ Unemployment is really not a single problem. It is a mosaic, a composite of problems, inherent in our present industrial organization. 
any moment, and for reasons over which he has no control, it may fall and reduce him to penury.

It would, however, be dangerous to regard unemployment merely as a problem affecting the individual. In certain of its aspects it is one of the most disquieting and difficult of social problems. The sufferings of millions of citizens in which it results, the threatening complaints of hundreds of thousands, the appeals for public aid from whole armies of people, the crop of social evils that it aggravates-of child-labour, woman-labour, low wages, prostitution and drink-constitute a malady which no enlightened democratic country can ignore. It is, moreover, one of those major evils which prevent or hinder the development of that "national efficiency" which is no longer an ideal but an essential pre-requisite to the continued existence of the Western nations. Louis D. Brandeis, now Justice of the Supreme Court of the United States, has, therefore, justly termed unemployment the "worst and most extended of the industrial evils of to-day."

Whenever the healthy willing worker is unable to find work at the prevalent rates of pay an atmosphere is created in which every extreme, hasty and unbalanced political and industrial proposal gains support. The dangers thus created are increased now that those from whom the State has asked the highest sacrifice are allowed to eke out an existence with grants and allowances.

The suffering caused by unemployment has been recognized in most European countries, and is beginning to be appreciated in the United States. But its reactions on production have been ignored. The labouring classes oppose every device for increasing output lest it should cause unemployment. Improvements in machinery are resisted. The reorganization of labour in the factory so as to use skilled grades more effectively by means of dilution is opposed. The methods of scientific management are fought. Trade unions wage a war against payment by results. In every case fear of 
unemployment is largely responsible for this opposition, and no one has been able to convince the rank and file of workmen that the proposed productive improvement may be to their ultimate interest. It is evident that without a complete removal of the menace of unemployment an immense potential increase in the productivity of industry cannot be released.

\section{Unemployment-An Old Problem in England and the United States.}

Contrary to general opinion, evidence of the existence of unemployment in England and in America goes back to an early date.

Unemployment in England is at least as old as the days of Queen Elizabeth, as is seen from the Poor Law of r6or. Cunningham refers to the unemployed-who became tramps and obtained licences to beg, as a result of the enclosure movement in the fifteenth and sixteenth centuries. In the eighteenth century every financial crisis was accompanied by a certain amount of unemployment. But as a social problem, distinct from other problems of poverty, it does not seem to have been recognized for much more than a quarter of a century. Mr. Edward R. Pease writes in reference to the term "unemployment" that the editors of the Oxford English Dictionary informed him that the earliest quotation they have yet found is dated December I894.*

It is even less known that unemployment has been recorded in the United States for the last hundred and fifty years. As in this country, whenever the old farm life was replaced by industrial occupations, the change was accompanied by the emergence of unemployment. Indeed, whenever the pecuniary gains of business men became the motivating forces and supplanted the old order based on tradition in industry, it became a serious problem. Thus with the introduction of the factory system in New England at the

* History of the Fabian Society, p. 217. 
close of the eighteenth century, the conditions for its occurrence arose.*

During Mathew Carey's "Crusade against Low Wages," we learn from a speech delivered in Philadelphia in I829 that

" even when the seamstresses have constant work their earnings are inadequate for their support, whereas the work is so precarious that they are often unemployed-sometimes for a whole week together, and very frequently one or two days in each week. In any case, no small portion of their time is spent in seeking and waiting for work, and in taking it home when done."

Unemployment seems to have been as great an evil in Boston as in Philadelphia.

One large tailoring establishment which has not infrequently given employment to eight or nine hundred women, and during the business year of 1828 . employed on an average . . 300 females every day, now, and for some months past, has not had work for more than an average of $170 . \dagger$

\section{In August I8I9 Niles' Register stated that}

There are 20,000 persons daily seeking work in Philadelphia; in New York I0,000 able-bodied men are said to be wandering the streets looking for it, and if we add to them the women who desire something to do, the amount cannot be less than 20,000; in Baltimore there may be about 10,000 persons in unsteady employment, or actually suffering because they cannot get into business. $\ddagger$

Ignorance as to the existence of this problem was due to the fact that in England and America, before the

* (a) Report on Conditions of Women and Child Wage-earners in United States, vol. Ix, p. 43. Helen L. Summer, History of Women in Industry in the United States.

(b) "In I812 Mr. Batchelor, of Walton, New Hampshire, had about one hundred weavers in his employ, not constantly at work, but as they had leisure from their other household employment."-Ibid., p. 38 .

(c) See also Ibid., pp. 123-4.

The Virginia Act of 1755 provided for the building of a workhouse for the "unemployed poor."-Report, Commission on Unemployment (Chicago), 1914, p. 99.

$\dagger$ Ibid., p. 126. See also p. 89, vol. vii, and Simons' Social Forces in American History, p. 172, and Hourwich's Immigration and Labour, pp. I I $4-15$.

$\ddagger$ Quoted from Simons, p. 166 . 
end of the nineteenth century, the unemployed were not encouraged to advertise their state. Indeed, they would then be regarded as little less criminal than a thief. Thus in Maryland in 1776 a thief was branded with a $T$ on his left hand, and the rogue or vagabond - the unemployed man-with an $\mathbf{R}$ on his shoulder.

There is similar evidence which amply proves the existence of unemployment right through the nineteenth century, whilst with the growth of factory life it developed into an increasingly serious problem. 'The growing urbanization of the population of the United States and of Great Britain resulted in concentrating the unemployed into small areas where they could be organized with ease. They were then able to arrange dramatic meetings, to hold picturesque processions, and to issue the appeals which seem to have been necessary to educate the public mind as to its seriousness. If, however, it is still necessary to insist that the risk of unemployment is nothing new, it must be conceded that the conditions surrounding it have changed. A generation ago growing industries, the wide West, and new countries were open to those who were prepared to work. A reserve fund for the labourers in large cities lay in the continual demand for workmen in the fields and mines. Under such circumstances most people came to believe that every man that wanted work could always obtain it or could at least bear the strain of rare and short periods of unemployment. The unemployed workman was therefore suspect. He was treated as a wastrel, a "won't work," as well as a burden on society. Although this view is still met with and applied to the unemployed workman of to-day, it is not held by thoughtful members of the community. Skilled, conscientious workers compose a large percentage of those who stand in bread lines or march in unemployment processions. But those who publicly display their misery are only a small number compared with the sullen thousands who, because of it, nurse a silent grudge against society.

Even during the busiest periods in normal times, there 
is a fringe of unemployed workmen constituting in all in this country an army of hundreds of thousands. During cyclical depressions their numbers swell to such proportions that society at large grows nervous as to their temper and purpose. And every year we have come to expect a sharp outcry from large numbers of those for whom temporarily industry makes no effective demand. With the end of the war unemployment is the lot of millions of discharged soldiers and of those who were engaged in war industries.

Scarcely a winter goes by during normal years without seeing men marching in procession up the streets of the large cities of Great Britain and of the United States, with banners unfurled, demanding the " right to work," the " right to live," " the right to obtain a day's food for a day's work." In such times of acute distress citizens call upon Government authorities and upon the charity organizations to provide work or relief for the unemployed. They invariably fail, however, in the attempt. The machinery for coping with the situation is hastily erected and inefficient; there is no comprehensive, carefully thought-out plan which can be acted upon, and the funds for relief are generally quite inadequate for the purpose of relieving all those who are in distress. Destitution and misery then fall to the lot of a vast body of labourers, and "crime" and "vice" noticeably increase.

\section{Unemployment Statistics in Great Britain.}

In Great Britain The Labour Gazette, published monthly by the Ministry of Labour, contains all the available statistics on unemployment. These include :-

I. Monthly returns from trade unions covering about I,500,000 workpeople who have made provision for unemployment.

2. Returns from employers in the most important trades, giving the numbers employed and the - total wages paid at different dates. 
3. Returns from local and trade correspondents covering these and other trades.

4. Returns of the employment offices showing the number applying for work, the number finding work, and the number remaining unemployed at the end of each month.

5. Returns from the National Insurance Act administrators showing the number of insured workers who have lodged their unemployment books on becoming unemployed, the amount paid in benefits and the duration of unemployment. Since the number of persons insured under the Act was I2,000,000 on February 25, I92I, it is evident that this is the best source of information.

The charts and analyses made by the Ministry of Labour give a clear indication of the trend of the employment market, and a ready comparison with other periods is possible. It is not necessary to demonstrate, therefore, with respect to Great Britain, that unemployment is a problem constantly menacing the workman. This conclusion is not challenged. It will suffice to quote only a few recent figures.

UNEMPLOYMENT IN INSURED TRADES COVERING ABOUT TWELVE MILLION EMPLOYEES. •

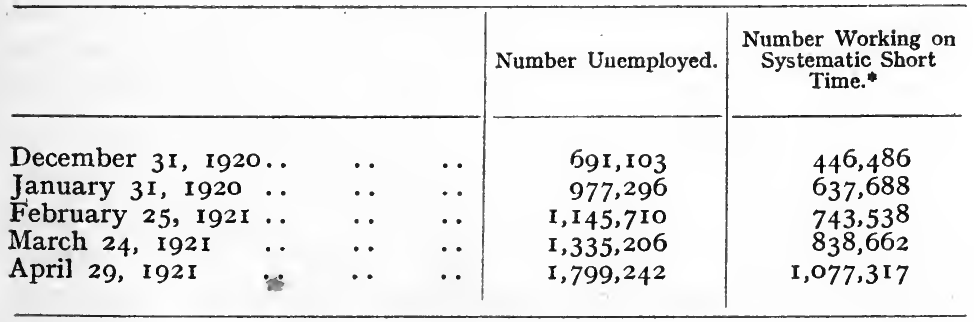

In April I92I, about 15.0 per cent. of those insured were totally unemployed and about 9 per cent. on short time.

* The persons included in column 2 are employed in establishments where, owing to the depression in trade, the number of working days has been reduced on a systematic basis in such a manner as to entitle claimants to benefit under the Unemployment Insurance Act. Persons working one day short time per week, or reduced hours each day or on certain days, are not eligible for benefit and are not included. 
The percentage of totally unemployed is higher than at any previous date. In I908-9, it reached a maximum of 9.5 per cent.

\section{Extent of the Evil in the United States.}

The statistics dealing with the amount of unemployment in the United States are extremely unsatisfactory. As a result the very existence of the problem is still denied by many. There is no national system of employment exchanges providing a continuous body of information on this subject, nor are the figures of the trade unions dealing with unemployment amongst organized labourers as complete as they are in England and other European countries where out-of-work benefits are more common. Adequate official statistics on the problem are thus lacking -a fact which is all the more deplorable when it is recalled that the fine official publications of the Government are the envy of European students. Most of the available statistics have been collected through occasional Governmental questionnaires or by special investigators. It is desirable to present these together.

In I900 the census returns showed that $6,468,964$ people over ten years of age, i.e. nearly 25 per cent. of all those engaged in gainful occupations, had been unemployed for periods varying from one to twelve months each during the year I899. Very nearly half of this number were unemployed for a period of more than three months. 3,I77,753 had lost from one to three months' work each, $2,554,925$ lost from four to six months each.

The absence of more complete later figures has resulted in a number of investigations amongst representative groups by the Federal Bureau of Labour Statistics and by a number of State labour and statistical departments, as well as by private agencies.*

A careful canvass undertaken independently by the Metropolitan Life Insurance Company and the United States Bureau of Labour Statistics indicated that in January and February of I9I5 the unemployment rate

* U.S. Bureau of Labour Statistics, Bulletin No. 172, 1915. 
was 18 per cent., and on this basis the total number of unemployed in the City of New York alone was estimated at 434,080. In September of that year it had fallen to approximately I45,000. In March and April an investigation of some 400,000 families covering 644,000 wage-earners indicated that II. 5 per cent. of the wageearners were totally unemployed, and that 16.6 per cent. were working only part time. In June and July a similar investigation of twelve cities in the Rocky Mountains and the Pacific Coast States showed that a survey covering 36,537 families in which were found 49,333 wage-earners revealed that 12.9 per cent. were totally unemployed and $20 \cdot 2$ per cent. were working short time.

The Department of Commerce has compared the month of least employment with the month of greatest employment in selected industries in IgI2.

Employment in the Month of Least Employment Calculated as a Percentage of Employment in the Month of Greatest Employment in Selected Industries.*

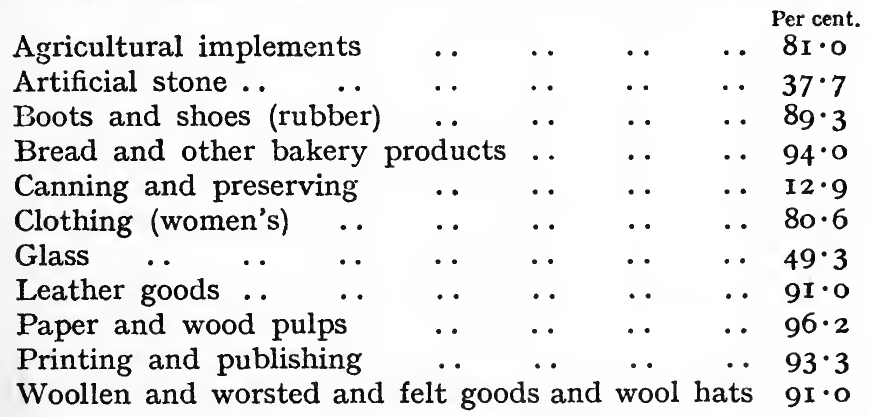

Average number employed in manufactures during year 1909, 6,6 ז 5,046 .

If it is recalled that during the month of greatest employment only about 95 per cent. of all the workmen associated with each trade are employed, and this assumption is warranted by the fact that trade union figures record a fringe of about 5 per cent. of unemployed

* U.S. Bureau Labour, Bulletin Whole No. ro9, p. 128. Statistical Abstract of the United States, p. 237, No. I59. (Source : Reports of the Bureau of the Census Department of Commerce.) 
during all periods of the year, then it becomes evident from this table what a large percentage of those attached to these trades are unemployed during the month of least employment.

The following table summarizes the statistics of the report of the New York State Department of Labour showing the percentage of idle wage-earners in representative trade unions for each month, I902 to I9I4 inclusive.*

\begin{tabular}{|c|c|c|c|c|c|c|}
\hline Year. & January. & February. & March. & April. & May. & June. \\
\hline 1902 & $20 \cdot 9$ & I $8 \cdot 7$ & $17 \cdot 3$ & I $5 \cdot 3$ & $\mathrm{I}_{4} \cdot \mathrm{O}$ & $x 4^{\cdot} 5$ \\
\hline 1903 & $20 \cdot 5$ & $17 \cdot 8$ & $17 \cdot 6$ & $17 \cdot 3$ & $20 \cdot 2$ & $23 \cdot I$ \\
\hline 1904 & $25 \cdot 8$ & $2 I \cdot 6$ & $27 \cdot I$ & $17 \cdot 0$ & $15 \cdot 9$ & $13 \cdot 7$ \\
\hline 1905 & $22 \cdot 5$ & $19 \cdot 4$ & $19 \cdot 2$ & I I $\cdot 8$ & $8 \cdot 3$ & $9 \cdot I$ \\
\hline 1906 & 15.0 & $15 \cdot 3$ & I I $\cdot 6$ & $7 \cdot 3$ & $7 \cdot 0$ & $6 \cdot 3$ \\
\hline 1907 & $2 I \cdot 5$ & $20 \cdot 1$ & I $8 \cdot 3$ & $I O \cdot I$ & $10 \cdot 5$ & $8 \cdot \mathbf{I}$ \\
\hline 1908 & $36 \cdot 9$ & $37 \cdot 5$ & $37 \cdot 5$ & $33 \cdot 9$ & $32 \cdot 2$ & $30 \cdot 2$ \\
\hline 1909 & $29 \cdot 3$ & $26 \cdot 5$ & $23 \cdot 0$ & $20 \cdot 3$ & $17 \cdot 1$ & $17 \cdot 4$ \\
\hline I9IO & $24 \cdot 5$ & $22 \cdot 4$ & $22 \cdot 6$ & I6.o & $14 \cdot 5$ & $15 \cdot 4$ \\
\hline I9 I I & $26 \cdot 7$ & $24 \cdot 8$ & $25 \cdot 6$ & $2 I \cdot 3$ & $27 \cdot 2$ & $22 \cdot 9$ \\
\hline 1912 & $25 \cdot 8$ & $17 \cdot 6$ & r $8 \cdot 8$ & I $3 \cdot 3$ & $20 \cdot 1$ & $22 \cdot 8$ \\
\hline I9I3 & $3^{8 \cdot 2}$ & $33 \cdot 4$ & $2 \mathrm{I} \cdot 8$ & $2 \mathrm{I} \cdot 7$ & $22 \cdot 9$ & $22 \cdot 2$ \\
\hline I9I 4 & $32 \cdot 3$ & $30 \cdot 7$ & $28 \cdot 3$ & $23 \cdot 6$ & $22 \cdot 7$ & $25 \cdot 5$ \\
\hline Mean, $1902-13$ & $25 \cdot 6$ & $22 \cdot 9$ & $2 \mathrm{I} \cdot 7$ & I $7 \cdot I$ & $17 \cdot 5$ & I $7 \cdot \mathrm{I}$ \\
\hline
\end{tabular}

\begin{tabular}{|c|c|c|c|c|c|c|}
\hline Year. & July. & August. & September. & October. & November. & December. \\
\hline 1902 & $15 \cdot 6$ & $7 \cdot I$ & $6 \cdot 3$ & I I $\cdot 2$ & $14 \cdot 3$ & $22 \cdot 2$ \\
\hline 1903 & $17 \cdot 8$ & $15 \cdot 4$ & $9 \cdot 4$ & I I $\cdot 7$ & $16 \cdot 4$ & $23 \cdot 1$ \\
\hline 1904 & $14 \cdot 8$ & I $3 \cdot 7$ & $12 \cdot 0$ & $10 \cdot 8$ & I I $\cdot \mathbf{I}$ & $19 \cdot 6$ \\
\hline 1905 & $8 \cdot 0$ & $7 \cdot 2$ & $5 \cdot 9$ & $5 \cdot 6$ & $6 \cdot I$ & I I $\cdot \mathbf{I}$ \\
\hline 1906 & $7 \cdot 6$ & $5 \cdot 8$ & $6 \cdot 3$ & $6 \cdot 9$ & $7 \cdot 6$ & I $5 \cdot 4$ \\
\hline 1907 & $8 \cdot 5$ & $12 \cdot I$ & $12 \cdot 3$ & I $8 \cdot 5$ & $22 \cdot 0$ & $32 \cdot 7$ \\
\hline 1908 & $26 \cdot 8$ & $24 \cdot 6$ & $24 \cdot 6$ & $23 \cdot I$ & $21 \cdot 5$ & $28 \cdot 0$ \\
\hline 1909 & $13 \cdot 9$ & II 99 & $14 \cdot 5$ & $13 \cdot 7$ & $13 \cdot 3$ & $20 \cdot 6$ \\
\hline I910 & $19 \cdot 4$ & $22 \cdot 3$ & $12 \cdot 5$ & $15 \cdot 0$ & $17 \cdot 5$ & $27 \cdot 3$ \\
\hline I9 I I & $15 \cdot 5$ & I I $\cdot 7$ & I I $\cdot 2$ & I I 6 & $20 \cdot 0$ & $34 \cdot 2$ \\
\hline 1912 & $2 I \cdot I$ & $9 \cdot \mathbf{I}$ & $5 \cdot 9$ & $7 \cdot 4$ & $15 \cdot 3$ & $30 \cdot 1$ \\
\hline I9I 3 & $20 \cdot 8$ & $19 \cdot 6$ & $16 \cdot 2$ & $19 \cdot 3$ & $27 \cdot 8$ & $40 \cdot 0$ \\
\hline 1914 & $32 \cdot 5$ & $30 \cdot 3$ & $24 \cdot 3$ & $24 \cdot 9$ & $35 \cdot 8$ & $35 \cdot 7$ \\
\hline Mean, I902-13 & I $5 \cdot 8$ & $13 \cdot 4$ & I I $\cdot 4$ & $12 \cdot 9$ & $16 \cdot I$ & $25 \cdot 4$ \\
\hline
\end{tabular}

* New York Department of Labour, Bulletin No. 69, Idleness of Organized Wage-earners in I9I4. 
The report, in summarizing, states: That the increased idleness was due entirely to a lessened demand for labour. The unemployment for the year I9I4 as a whole nearly equalled that for 1908, which was the highest in recent years.*

\section{Unemployment in the United States, January 1921.}

The result of the Unemployment Survey conducted by the Employment Service of the United States Department of Labour, shows that in January I92I, in 48 States and the district of Columbia, there were $3,473,446$ less workers employed in industry than in January rg20-a reduction of $36 \cdot 9$ per cent. Assuming that this number is not much less than the total of unemployed for the whole country, and that there was a fringe of 5 per cent. of unemployed in January I92I, one may fairly estimate the present number of unemployed to be four million. $\dagger$ The American Federation of Labour has estimated the number of unemployed at that time at four and a half million, and Congressman Meyer London at five and a half million.

It is estimated that since January there has been a steady increase of unemployment, so that by September there was one million and a half more unemployed.

Unemployment manifests itself with varying degrees of intensity in the industrial countries of the world. Most of these publish figures at regular intervals showing the state of unemployment. $\neq$

* A Government Commission which investigated the amount of unemployment reported that in 1911 organized workers lost on the average 20 per cent. of their possible income through unemployment. The amount of enforced idleness amongst coal miners has varied from 20 to 50 per cent. between 1890 and roro. During $1914,4 \mathrm{I}$ per cent. of those engaged in the men's clothing industry worked less than roo per cent. of full time and 13 per cent. under 75 per cent. of full time.

For curve representing the fluctuation in the deviation from the maximum in manufacturing industries during January 1907-December 1913, see Chart ro in the Massachusetts Bureau of Statistics, r868-1915, Sketch of its History, Organization, and Functions, p. 83.

$\dagger$ Industrial Employment Survey, Bulletin No. r, January r921, Washington.

$\ddagger$ The Report on Unemployment, published by the League of Nations 


\section{Definition of Unemployment-Unemployment Due to Lack of Work.}

Following the example of the British National Insurance Act, unemployment is best defined indirectly.

Sickness, invalidity, old age, and accidents are effective causes keeping workmen away from work. Against these emergencies and conditions, therefore, trade unions have often provided through special funds.

Even more important in the history of workmen's organizations have been strike funds. The lock-out is the employer's weapon corresponding to the strike, and it is used by him to further his ends in trade disputes. The loss of time involved is generally treated by trade unions on the same footing as that arising from strikes. Strike pay is given to those locked out, because employers generally resort to it when a strike is threatened or is actually in progress.

In addition to unemployment due to these causes, against which it is possible to provide special insurance funds, there is unemployment due to other causes against which it is impossible to insure. There is the wilful idleness of the cantankerous individual, who is a source of trouble to his fellow-workers and to his employers; the individual who cannot hold his job for more than a few days; and the individual who would not work at all if a minimum of existence were guaranteed him. These suffer, of course, from unemployment, but not from involuntary unemployment.* They pro-

and prepared by the organizing committee for the International Labour Conference, Washington, 1919, contains a brief comprehensive statement of the problem as it presents itself in a large number of countries.

* Excepting in so far as their attitude is the result of heredity or of early education. John Burns, whilst still a prominent and active English Labour Leader, said that: "In spite of what some advocates of work for the unemployed may say, I contend, as a socialist ... that until the differentiation of the labourer from the loafer takes place, the unemployed question can never be properly discussed and dealt with. Till the tramp, thief, the ne'er-do-well, however pitiable he may be, is dealt with distinctly from the genuine worker, no permanent benefit will result to any of them. The gentleman who gets up to look for work at midday, and prays that he may not find it, is undeserving of pity." As a Cabinet 
duce the real but by no means insuperable obstacles which make unemployment a contingency against which it is difficult to insure. Lack of employment due, as is the case with such individuals, to their own acts or defaults, is not referred to here by the term unemployment.

Other difficulties in the way of a definition of unemployment arise from trade union policy. Unemployment may be due to a refusal to work at a wage lower than the trade union rate, or under conditions regarded as being below standard. Considerable friction has hitherto resulted also from the contention of trade union organizations that a person engaged in one trade, e.g. as an engineer, should not accept employment in another trade, e.g. as stevedore, at a rate of wages, hours, or conditions below those current in his trade and district.* This attitude is due, of course, to the determination of workmen to prevent the lowering of the standard rates and terms which they have attained at such great effort. $\uparrow$

We are now in a position to attempt a definition of unemployment. A workman is unemployed when he is able-bodied, efficient, and, though reilling to work in his own trade at the current rates of pay, is unable to find employment because of lack of work.

Minister for nine years, Mr. Burns held this view with great pertinacity, in spite of Conservatives and his erstwhile colleagues.

In the long run the fact that unemployment insurance will be the means of severing the inefficient and the ne'er-do-well from the willing, capable workman will commend it to the working classes more than any other of its beneficial features.

* For it is evident that when a workman trained in one trade takes up work in a trade for which he has not been trained, he would be willing to take a.smaller wage than the man engaged in the second trade continuously.

$\dagger$ But many trade unionists argue that it is permissible in times of slackness to allow lower rates if work that would not otherwise be undertaken is begun. The writer has found many trade unionists who have taken this view, especially amongst the builders' unions of Massachusetts.

$\ddagger$ But in Germany many trade unionists have urged that all involuntary unemployment of able-bodied persons, and this would cover unemployment due to a lock-out, ought to be provided for by unemployment insurance.-See Chapman, Wages and Employment, p. 333. 


\section{Causes of Unemployment.}

Sir W. H. Beveridge has analysed the three principal economic factors in unemployment as changes

\section{INDUSTRIAL CAUSES OF UNEMPLOYMENT.}

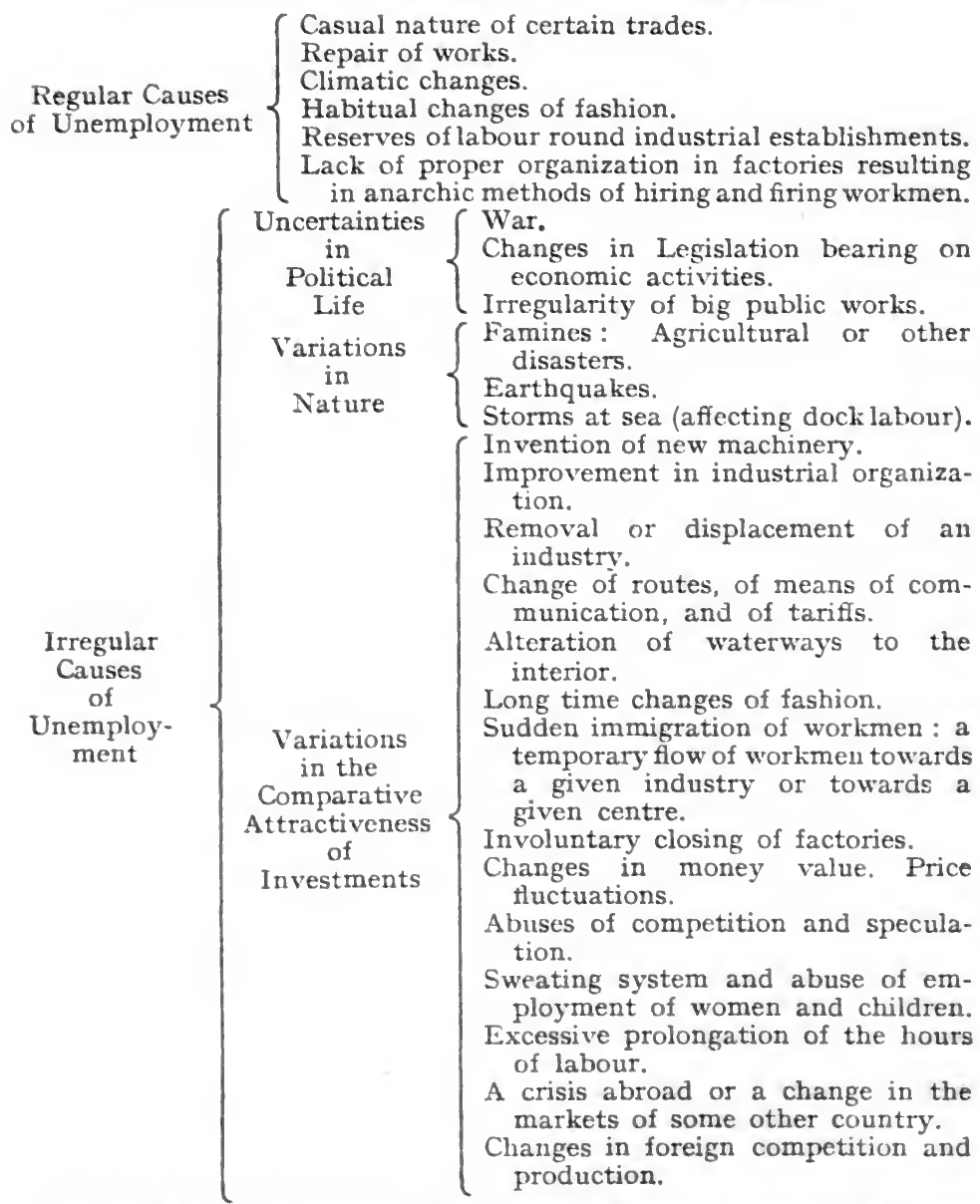

Compare with this outline of the causes of unemployment the views of Croisson de Cormier, Le Chomage, and Wealth and Welfare, Part IV, by A. C. Pigou.

of industrial structure, fluctuations of industrial activity, and the reserve of labour. Under each of these 
three broad headings he has shown their many and varied manifestations. Unfortunately, many writers on the subject now talk of "three causes of unemployment." Perhaps nothing is doing more to keep back an attempt at the proper study of the unemployment problem than the induced simplicity of certain writers on the subject. No analysis of its catues is adequate which does not demonstrate that, in addition to those causes of unemployment over which the individual employer has little direct control, there are other factors which he himself is able to direct so as to keep the amount of unemployment at a minimum. The descriptive analysis of the causes given on p. $j^{0}$ is meant to illustrate the difficulty and complexity of the subject.

A well-known classification of the causes of unemployment points to the casual nature of certain trades, the best known of which are included under docls labour, and to the seasonal character of certain others, such as women's clothing, hotel business, sport accessories, etc., and to cyclical fuctuations of industry, i.e, to the great variations in the activity of trade as a whole. The latter are much more important than the other causes. Indeed, Jevons, who believed that they were due to the variations of the bounty of nature, could write before the Great War, of course, that "the loss of capital in one year caused by natural calamities and even by great wars is small in comparison with the fluctuations of nature"s bounty." * His view that cyclical fiuctuations of industry are due to climatic conditions is now endorsed by the high authority of Professor A. C. Pigou, of Cambridge University, Sir W. Beveridge, and Professor H. L. Moore, of Columbia University.

- H. S. Jevons, "Trade Flectrations and Solar Activity" Condampurary Ravider, Algust rgog.

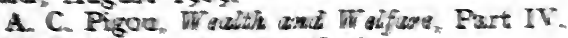

H. L. Moore, Bussinass Cyclas.

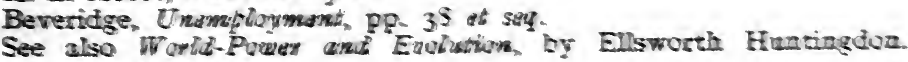
Yale University Press. 


\section{"After-the-War" Unemployment.}

This analysis of the causes of unemployment needs to be supplemented by reference to the special causes operating in the period immediately after the war.

The causes of unemployment in Great Britain in the winter I920-I were directly traceable, at least in part, to the policy pursued by the Allied Powers in relation to Germany, to the countries of South-East Europe, and to Soviet Russia. The execution of deferred orders from the home market and from foreign markets, which British industries had been unable to satisfy during the war, produced a boom shortly after the armistice, but this soon came to an end, and the fundamental facts of the situation began to produce their effect. The impoverishment of Central and Eastern Europe, as well as the reduction in the real capital of this country, has diminished the capacity of Europe to produce. This has been aggravated by allied policy. British exports to Soviet Russia, Germany, Austria and Hungary have fallen to something between a seventh and a tenth of what they were in I9I3-I4. This fact in itself would be sufficient to account for most of the present unemployment. The uncertainty and waste produced by large armies actually at war, or at least mobilized, in Poland, Hungary, Rumania and Mesopotamia, are a contributing factor, whilst the payment of the indemnity may continue to produce fluctuations in industry long after this present crisis is passed. Unless the European market can be re-established or replaced by new markets overseas, and it is difficult to foresee where these will be found, it is not unlikely that Great Britain will have a surplus of labour. This threatens a more or less permanent and large number of unemployed, unless emigration on a large scale takes place.

\section{"Hiring and Firing."}

The fluctuating nature of most of modern industry is one of the main causes of unemployment, but this 
manifests itself frequently, and indeed is aggravated by the anarchic methods of "hiring "and firing" workmen which still prevails in many establishments.*

Thus one automobile factory in the United States was reported in I9I2 to have hired $2 \mathrm{I}, 000$ employees in order to maintain an operating force of I0,000.

In some lumber camps and saw-mills on the Pacific Coast all men are discharged twice a year, in July and December, and completely new forces are hired when work is resumed. In the logging camps it is customary to hire five men during the season to keep one job filled.

A large steel plant, during the years when it wanted to increase its forces, hired three and a half times as many as were actually needed to make up the increase.

Mr. Magnus W. Alexander found that twelve electrical works "above the average in economical conduct," in order to increase their working force by 6,697 employees, hired 42,57I people and dropped 35,874. In other words, about six and one-third times as many people were engaged during the year as constituted the permanent increase in the force at the end of that period.

The situation was similar in eleven large department stores in New York City. In order to maintain an average force of 27,264 , they took on 44,308 additional employees and dismissed 42,000.

The drift amounted to I6o per cent. of the positions to be filled.

But some establishments in this group have a larger turnover than others. One New York department store with an average pay-roll of 3,750 employees actually engaged 12,759 people and dropped 10,382. Its labour turnover was 340 per cent. of the existing positions.

Similarly, in nine paper box factories ordinarily employing 792 hands, 2,295 different persons were on the pay-roll in a year. The labour turnover was 289 per cent.

Again, in the box and candy factories we find that

* Report to Legislature of N.Y. State, Unemployment and Lack of Farm Labour, Third Report, p. 54 . 
nineteen plants employed 3,400 persons within a year to maintain a working force of 1,700 . Further inquiry into this group showed that less than one-half of those who passed in and out of positions within the twelve months stayed as long as four months. A very large number were kept but a few weeks.*

The Government of the United States was making an investigation into the whole problem of labour turnover in industry before it entered the war. Our present knowledge of the wastes produced by careless methods of engaging workmen comes from fragmentary sources. When all the evidence is collected, it is safe to assume that the estimate of the national losses due to this cause will prove to be enormous. $\dagger$

Such huge labour turnover as the available facts do indicate is only possible because each factory tends to be an almost independent market for the "hiring and firing " of workmen. Many employment centres have

* "In a packing house in Kansas City work would progress with full force until the warehouses and cold storage were filled to the rafters, and then the plant would shut down except killing two hours a day, until the supply formerly laid up was getting low, when full gangs would again be put on, and the plant would rush full blast until again filled up as before, and so on. By this method the employees of the company got steady work only about half the time, and during the other half only enough to keep them waiting around for full time again."

I also found, wrote Mr. Graham, that the same course was pursued by the same company at Chicago, South Omaha, St. Joseph, and Fort Worth.-A. A. Graham, "The Problem of the Unemployed," Machinists" Monthly Journal, May 1914, vol. 26, No. 5, p. 443.

It is not suggested that those workmen who are dismissed necessarily remain unemployed for any great length of time. But these figures suffice to show that the unsocial, irresponsible, anarchic manner of "hiring and firing" workmen must result in a terrible sense of uncertainty as to future employment. Furthermore, the fundamental causes of unemployment are largely aggravated by them. Workmen, it is well known, lose a number of days in changing from one job to another, and therefore, as a rule, a large turnover must result in a large amount of unemployment for the individuals dismissed.

$\dagger$ The figures quoted here are taken from authoritative reports such as the Factory Investigation Commission of New York State, and of the Industrial Relation Commission. Similar figures have been gathered by the author from a number of important establishments. The Ford Motor Car Company, The Plimpton Press of Massachusetts, and the Clothcraft Shops of Cleveland, and other scientifically run establishments have shown what a striking curtailment of labour turnover can be brought about when attention is devoted to this problem by the management of the personnel department. 
groups of individuals who call daily on the off chance of getting a job. "Each factory gate and industrial district of a city tends to become a market. Each draws a reserve of labour ready to meet the fluctuating demands of employers. This reserve is increased by the multiplication of markets and a maladjustment is caused between supply and demand."*

\section{Effects of Unemployment.}

The one thing certain to the workman about his employment is its uncertainty. When employed he is subject to dismissal for any one of a number of causes aver which he has not the least control. The cyclical fluctuations of national trade, the yearly succession of the seasons, the imperious changes in fashion, the invention of new machines, the discovery of new materials, the closing of old, or even the opening of new markets, the shifting of individuals or the migrations of peoples, the change in political relations with other countries, the introduction of new laws, the bankruptcy of his employer or the decay of his trade-any of these causes may result in his losing his precarious means of earning his livelihood.

But whatever be the industrial cause of his unemployment, the workman always finds himself in a similar position. For a number of weeks or months he is deprived of the opportunity of remunerative employment. At any moment he may be cast down into the abyss of destitution or left hanging on to the precipitous ledge of casual employment above it. It tends among other effects to produce a psychological servility altogether disastrous in a democratic community, and particularly dangerous to the healthy development of trade unions.

The effects of unemployment are of two kinds. There is first the ever present fear and dread of the workman that he may become unemployed. The paralysing effect of this insecurity leads to results profound and mani-

* Leiserson, American Labour Legislation Review, vol. iv, No. 2, p. 318. 
fold but incapable of economic measurement. Secondly, there are the losses of the labourer and the economic loss to the nation, both of which can be estimated roughly.

\section{The Drain of Unemployment on the National Wealth in the United States.}

The figures relating to the amount of unemployment already quoted suffice to show that unemployment is a constant feature of modern industry which results in heavy losses to wage-earners. Let us attempt some estimate of the aggregate loss to the United States.

The figures of the Federal Census for I900 showed that there were nearly 6,500,000 unemployed during the year 1899.* Assuming that the average weekly wage of these people was $£ 2$ Ios. od., it is estimated on the assumption that they were unemployed for an average of sixteen weeks that the total loss in wages for that year alone was about $£ 260,000,000$. $\dagger$

There was also the loss of about $£ 800,000,000$ to the community, the census figures showing that an output of $£ 3$ in new products is realized with every pound paid in wages.

The 260 million pounds were covered in part from the savings of the unemployed by trade union grants, by the relatives and friends of workmen (whose standard of life was thus lowered), by organized public and private relief; and in so far as it was not covered by these means it resulted in a lessening of vitality and a deterioration of physique and in consequence a total or partial disability to re-enter competitive industry. A part of this wage deficit was made up by crime.

We thus find that in the year I899, the last year for which we have national census figures, the wageearners of the United States lost over $£ 260,000,000$

* The figures for I910 were not published by the Census Bureau.

+ See also The Survey, January 23, 1915, for an estimate of the loss due to unemployment by Dr. N, T, Stone, 
$(\$ 1,250,000,000)$, whilst the wealth of the community was diminished by nearly four times that sum.

The amount wasted in this manner was much greater in I9I4 owing to the depression produced by the war. This may be gathered from the later and supplementary evidence of unemployment in New Jersey. Figures collected from 2,556 firms showed the actual output for the year rgr2. They also give the output for those plants if "all the existing facilities were brought into use."* They show that for the normal industrial year of rgr2 these plants were running only to 74 per cent. of their capacity. This meant a loss in possible output of $£ 73,000,000$. In a year of depression it is certain that the loss for this one State alone was over Eroo,000,000 (about half a billion dollars). From the figures of unemployment in Great Britain and in the United States in I920-I it is easy to calculate the enormous economic loss to those countries.

But this loss was obvious and tangible. There are other losses no less serious and in the aggregate perhaps more important, the demoralization or organization and the heavy waste involved in "hiring and firing" men. $\dagger$

Nor is this loss confined to employers and their workmen. The public is made to bear part of it. It provides hospitals, lodging houses, emergency workshops, penitentiaries and lunatic asylums through the usual process of taxation, and bears the cost of special relief measures through charity organizations. $\ddagger$

In addition to these costs, which are directly traceable to unemployment, there are others which are manifested through a lowering of physique and morale. This point is well made by Mr. John A. Hobson. He writes :

By the workers themselves, and even by social reformers, the injury inflicted upon wages and the standard of living by irregu-

* These figures were estimated by the firms themselves. See The Unemployed in Philadelphia, p. 57.

$\dagger$ This is estimated at amounts varying from 50 cents to hundreds of dollars for each workman.

$\ddagger$ See American Labour Legislation Review, vol. v, No. 3, p. 505 et pas. 
larity of employment is appreciated far more adequately than the related injury inflicted on the physique and morale of the workers by sandwiching periods of over-exertion between intervals of idleness.*

\section{The Cumulative Effects of Unemployment.}

Irregularity of employment is an aspect of the wages problem, and is therefore at the very basis of the modern labour contract. The standard of living of the working man-the quantity and quality of his food, shelter and clothing-is controlled by his average earnings, i.e. for periods covering terms of employment and unemployment, and not merely by his wage during some short busy period. This standard of living, in turn, affects his efficiency and the possibilities of his advancement. It also decides for large numbers whether the wife shall add to her other duties that of supplementing her husband's wages. Even more significant, in the long run, is the sort of upbringing which it will enable the working man to give to his children. On it depends whether they are to go through school insufficiently nourished, and to be forced into some unskilled trade at an early age.

Unemployment results in lowering the quality of the workers. The worse fed are the children of the unemployed the less will they earn when they eventually engage in some occupation themselves, and the less able will they be in turn to provide for the needs of their children, and so on. Again, the less trained they are the less will they realize the importance of giving their children a good training and the less able will they be to provide adequately for so doing. These evils are cumulative.

Another group of evils and deep influences which are produced by unemployment result from its effect on trade unions. Periods of unemployment constitute a menace to trade unions; they result in a lowering of membership, a drain on the funds, and a weakening of their morale. Their power to bargain effectively * Work and Wealth, p. 80. 
is thus lessened. This disadvantage is cumulative in two ways: It lowers workmen's wages; this lowers their efficiency as workers and consequently the normal value of their labour. And in addition it diminishes their efficiency as bargainers still more, and thus makes it more likely that they will sell their labour for even less than the employer could afford to pay them.

\section{The Unemployed Workmen and Destitution.}

A study of the reports during normal times of such societies as the Charity Organization Society and the United Hebrew Charities of New York show that from 25 to 35 per cent. of those who apply to them for relief every year have been brought to their destitute condition primarily through lack of work, and this cause, investigation proves, is responsible also for frequent recourse to virtual loans from the corner grocery store and to pawnshops.* Investigations in the large cities of Great Britain show similar results.

\section{Fallacious Explanations of Unemployment.}

Unemployment is mainly due to the maladjustment between the price at which labour is demanded and the price at which workmen are willing and able to accept employment. During periods when thousands are clamouring for work it would probably prove profitable for many employers to engage more workmen if they could lower the wage level. $\uparrow$ Unemployment is not due to an excess of labour in general nor to a lack of capital. It is due to the reduction by entrepreneurs of the number of people whom they employ because they cannot employ them all at the rate of profit they

* Cf. Reports of New York Mayor's Committee on Unemployment, I9I 5. I9I6.

$\dagger$ This applies to normal periods only. In $192 \mathrm{r}$, owing to the crippling of economic life in Central and Eastern Europe and the unfavourable exchanges, it is very doubtful whether even a wage reduction of 25 to 50 per cent. of the r914 level would enable employers gainfully to employ all the workpeople. 
desire and at the same time pay the wage demanded by the workmen.

That unemployment is not due to an excess of labour in general is shown by the steady increase in every decade of the number of people who find employment in practically all countries. Nor is it due to lack of capital in general. In Great Britain and in the United States the wealth of the country and the income of the average family has steadily increased, and yet the amount of unemployment has probably not been reduced.*

THE GROWTH OF THE INCOME OF THE PEOPLE OF THE UNITED STATES.

\begin{tabular}{c|c|c}
\hline Year. & $\begin{array}{c}\text { Total Money Income in Millions } \\
\text { of Dollars. }\end{array}$ & $\begin{array}{c}\text { Average Family Money } \\
\text { Income, Dollars. }\end{array}$ \\
\hline 1870 & 6,270 & 889 \\
1880 & 7,391 & 753 \\
1890 & 12,082 & $94 \mathbf{1}$ \\
1900 & 17,965 & $\mathbf{1}, 109$ \\
1910 & 30,530 & $\mathbf{1}, 494$ \\
\hline
\end{tabular}

Whilst the average family money income has shown a great increase, there are still millions of families whose incomes are insufficient to buy them that amount of food, clothing, and shelter necessary for health and efficient labour.

Even when employed, there are millions of wageearners in the United States who are unable to earn a standard of living which is regarded as "normal" or

* Data for computing wage statistics and the standard of living are widely scattered through the State and Federal Reports. As a rule they supply information relating to members of labour unions only, or to specific industries investigated at the order of the Government, such as the telephone industry and the steel industry. The estimates of average wages made by Professor Streigthoff, Professor John A. Ryan, Professor Scott Nearing and Professor King are based on these official figures. The Standards of Living were investigated by Professor Chaplin, Mrs. Louise More and the United States Bureau. The conclusions reached by these authorities as a result of independent studies are substantially similar, and show that for large numbers the wages are inadequate to maintain health or retain efficiency.

$t$ In view of the great fluctuations of foreign money in relation to the British pound it is thought desirable not to convert foreign moneys into British values. In 1914 the dollar equalled 4 s. I $\frac{1}{4} d$. normally. 
"adequate." It is clear therefore why unemployment soon forces them into destitution by way of the pawnshop and the charity agency. In Great Britain and other European countries where the income of workpeople is not as high as it is in the United States, unemployment soon has even more dire results.

\section{Existing Methods for Dealing with Unemployment.}

The great human suffering in which unemployment results has been alleviated in some measure, at public expense, both by permanent institutions for relief and by temporary provision. Penitentiaries, public lodging houses and hospitals represent the former; unemployment relief workshops, loan funds and emergency charity funds, the latter. Probably much greater in the aggregate is the amount spent by the fellow workmen and relatives of those who are unemployed.

The problem of mitigating the effects resulting from this evil is not one which will necessarily result in increasing these expenditures, but is rather one of directing them, and, more important still, the whole organization of industry, along the most socially desirable channels. It is part of the great problem of poverty which at last is beginning to have centred upon it that organized thought which promises to abolish it, and, in so doing, to decrease the human costs of modern industrial life and to increase both the opportunities and means of gaining welfare.

Few to-day believe that unemployment is due to personal depravity, and that therefore society is powerless to cope with it. The views on this matter of Professor E. T. Devine, of the New York Charity Organization Society, are shared by enlightened Liberals and Conservatives alike.

I hold that personal depravity is as foreign to any sound theory of the hardships of our modern poor as witchcraft or demoniacal possession; that these hardships are economic, social, transitional, measurable, manageable. Misery (or destitution), as we.say of 
tuberculosis, is communicable, curable and preventable. It lies not in the unalterable nature of things, but in our particular human institutions, our social arrangements, our tenements and streets and subways, our laws and courts and jails, our religion, our education, our philanthropy, our politics, our industry and our business.*

Similarly, Mr. and Mrs. Webb have urged that destitution due to other causes as well as to unemployment can be eradicated.

We have both the power and the knowledge to cope with destitution, as we have coped with cholera and typhus, highway robbery, and the slave trade, if only we have the will. $\dagger$

Not only do we now recognize that destitution and unemployment are not due to personal causes, but we know also what remedies to apply to these evils. We can not only diagnose these diseases, but we can prescribe for them. Within five years the average amount of unemployment could be halved, and the suffering resulting from it could be reduced to one-quarter of what it is to-day, if only social legislators had the will and the necessary training for tackling the problem.

Measures in the future for dealing with the evil of unemployment should not, however, be undertaken as the result of a panic. Society must not wait until it is galvanized into sudden and feverish activity as the result of another serious crisis.

Many remedies have, of course, been suggested to cure society of this disease. But some of them, if tried, would result in more disastrous results than the ill itself. Others, again, look to a complete reorganization of society on a more equitable basis.

\section{Proposed Remedies for Unemployment.}

One of the remedies most generally advocated for unemployment, especially by less informed trade unionists, is the reduction of the hours of labour. This pro-

* Professor E. T. Devine : Misery and Its Causes, p. II.

$\uparrow$ Sidney and Beatrice Webb: The Prevention of Destitution, p. 5. 
posal has appeared repeatedly since the armistice in England. Similarly, with a view to finding work for the unemployed, the American Federation of Labour at its conference at Seattle in I9I3 recommended its executive to present a series of bills to Congress embodying a provision that "by so shortening the hours of those employed no one should be employed more than eight hours per day." * In this way it is surmised that workmen unemployed during periods of depression would be retained in industry. The fallacy lying behind this view is the assumption that there is an oversupply of labour in general. It is a matter of common knowledge, however, that in most industries there are periods when needed labourers cannot be obtained. For even assuming that by reducing the hours of labour all the workmen attached to an industry were employed during the slack period, there would be such a demand for labour during the busy period that others would join the industry; the number of people attached to it would be increased. But as soon as the slack period came on again many would be dismissed and unemployment would again result. It is, of course, a wellestablished fact that unemployment continues when the hours of labour in any trade are shortened. Fluctuations of industrial life, fluctuations due to the growth and decay of trades due to climate and social habits, and to the existence of reserves of labour-these are causes of unemployment which a general reduction of the hours of labour cannot materially affect. $\dagger$ Unemployment is due to the mal-

* See the Report of the Thirty-third Annual Convention of the American Federation of Labour.

+ "The shortening of hours was no remedy at all for the disease of unemployment : not even in those cases where they could prove that owing to the shortening of hours, extra men had been taken on." - Sidney Webb : National Conference on Prevention of Destitution, Report of the Proceedings of the Unemployment and Industrial Regulation Section, p. I40.

But it should be noted, "wherever the hours of labour have been shortened employment tends to become more regular. In place of alternating periods of intense overwork and periods of idleness, employers have found it possible to distribute work more evenly throughout the year."-Quoted from the brief presented before the Supreme Court of 


\section{INSURANCE AGAINST UNEMPLOYMENT}

adjustments at any particular moment between the supply of and demand for labour, and it is only in so far as lowering the hours of labour will result in improved organization that these maladjustments are likely to be lessened. Even then the influence due to this cause alone is likely to be small, * and in any case is of little significance as a solution of the great problem of unemployment.

A clear distinction must be drawn between the proposal of a general reduction in the hours of labour and between the proposal that during periods of depression organized short time should be resorted to as an expedient. It is evident that it is more desirable that where possible all the workmen in a factory should be employed, say, for four days in the week rather than that about one-third of the staff should be dismissed and the rest work at full time.

Much may be hoped for also during the immediate future from such proposals as the regularization of industry through the carrying out of public works during periods of depression. In the I920-I unemployment crisis the British Government placed a few thousand workmen, of the millions unemployed, on the task of constructing arterial roads, and a grant in aid was made to local authorities to encourage them to undertake public works. This is but a mean beginning.

the United States in the case of Franklin O. Bunting $v$. the State of Oregon. This brief, prepared by Mr. Louis D. Brandeis, Professor Felix Frankfurter, and Josephine Goldmark, devotes considerable attention to the "relation of short hours to regularity of employment" (see pp. 876-92).

* Shorter hours likewise tend to steady employment. When no restrictions are placed on hours of work in a seasonal industry, the tendency is to concentrate the work in a brief busy season with long hours of overtime. Hour regulations, except in the case of perishable products and those subject to changes in fashion, forces a more even distribution of the work over a longer period. When the Women's Eight-hour Law was enforced in Illinois, factory inspectors noted " a greater uniformity of work and rest" as one of its results.-Commons and Andrews : Principles of Labour Legislation, pp. 203-4. The report of the Chief Inspector for Great Britain of Factories and Workshops, for 1920 (Cmd. 1403), discusses this question and arrives at the conclusion that the diminution of hours in the special seasonal trades has led " to improved organization of work and better means of transport." 


\section{Regularization of Industry-A Universal Problem.}

When the war broke out a committee, including Sir W. H. Beveridge, who was then Director of the Labour Exchanges, had been appointed to investigate the question of how to regularize industry in Great Britain in such a way as to prevent unemployment. Unfortunately this committee had to be dissolved owing to the claims of more pressing problems. When the war ended the Labour Party introduced a "Prevention of Unemployment Bill," * which proposed that such arrangements should be made as would enable local and national authorities to provide work when unemployment was slack. The Bill endeavoured to put into legislative effect the following clause of the Labour Party's programme :-

The duty of organizing the national labour market so as to prevent or minimize unemployment should be laid on a special Ministry of Labour, which should arrange a ten-years programme of Government work, to cost $£ 4,000,000$ a year, but to be undertaken only in "the lean years of the trade cycle" and carried out by ordinary labour paid at ordinary local rates. $\dagger$

From the discussion on the Bill it transpired that "the Ministry of Labour had for months past been instructing the different Government departments to distribute their work and contracts among those trades which showed the greatest number of unemployed." The Minister of Labour added, that "under the Ministry of Supply, when the provision of the needs of all the departments was in the hands of one minister, it would be possible to arrange contracts in such a way as to provide work in what were known as the slack seasons."

In the United States, with its vast resources still untapped, the possibilities along these lines seem much better than they are in Great Britain, but it is high time

* The Second Reading took place on March 21, 1919. See also the Labour Party Report on Unemployment, 1921.

† Hayes: British Social Politics, pp. 185 et seq. 
that all worthless speculation be ended and the facts collected and presented to us.*

Two State legislatures establishing State employment bureaux in Illinois and Pennsylvania in I915 instructed the administrative authorities to take steps toward regularizing employment through a careful distribution of public works. The Illinois statute provided that:-

The said general advisory board in co-operation with the secretary of the Bureau of Labour Statistics and the local advisory boards shall place themselves in communication with large employers of labour, including municipal and other authorities, and attempt to bring about such co-operation and co-ordination between them by the dovetailing of industries, by long contracts, or otherwise, as will most effectively distribute and utilize the available supply of labour and keep it employed with the greatest possible constancy and regularity. They shall devise plans of co-operation with this object in view, and shall seek to induce the organization of concerted movements in this direction. They shall also endeavour to enlist the aid of the Federal Government in extending these movements beyond the State. $\dagger$

It will be noted that federal action is contemplated to supplement State action. $\neq$ Whilst experiments along these lines will have great value it may be doubted whether much towards the regularization of industry will be. achieved unless a national scheme planned by a central bureau is developed. The need for attempting the regularization of industry has been felt in other countries too, but as yet few have instituted any definite

* The view that works of public utility might be undertaken during periods of unemployment is found in the economic writings of at least the last two centuries. J. B. Say admitted in $18 \mathbf{I}_{4}$ that it was a proper governmental function to employ those men who are thrown out of employment on account of the introduction of machinery. The real problem, however, has been how to prevent such undertakings from becoming mere relief works.

† Illinois, Laws, 1915, S/B. 24. sec. IC.

$\ddagger$ An initiated measure of the State of Arizona authorizes the State to engage in any work of manufacture or public utility. The business of banking may be engaged in, and a State printing establishment may be set up for the printing of school books and the State's work. A general appropriation of the necessary funds is made. See Bureau of Labour Statistics, Bulletin, Whole No. 186, p. 19. Such powers will enable States to regularize industry. 
plan. Proposals have been made to this effect in Italy, Great Britain, the United States, Germany, India,* Canada, and other countries.

A very interesting example of the "dovetailing" of ordinary agricultural employment with work provided by "remunerative State enterprise" is to be found in the arrangements for the reclamation of the marshy lands of the Po Valley carried out by the Italian Government. $\dagger$ A circular concerning the organization of the Provision of Employment was issued by the Prussian Minister of Commerce in I904.

We further request you to have the goodness to direct your attention to those measures, which are calculated to prevent the occurrence of want of work on a wide scale, or to mitigate its effects when it is unavoidable. Not only the State, but also the provinces, districts, and communes, in their capacity as employers, are bound to do their utmost to counteract the evil in question by paying general and methodical attention to the suitable distribution and regulation of the works to be carried out for their account. In almost every industrial establishment of importance there are tasks which do not absolutely need to be performed at a fixed time; just so in every State and communal administration there are works, for the allotment of which the time may, within certain limits, be freely chosen according to circumstances. If all public administrations, in making their arrangements, would in due time provide that such works should be carried out when want of employment is to be expected; if especially works in which unemployed people of all kinds, including especially unskilled labourers, can be made use of, were reserved for times when there is a threat of want of employment, and such times have almost recurred of late in winter in the large towns and industrial centres, the real occurrence of widespread want of employment could certainly be prevented in many cases, and serious distress warded off.+

* The Government of British India includes in the budget a sum of rot million rupees annually for the relief of famine, although it occurs only intermittently in different parts of the country. In the case of famine in India and unemployment in England and the United States, the unexpected never fails to happen.

$\dagger$ Cf. Rapport de M. W. F. Treub, "L'influence que peut exercer sur le chômage la mode d'execution des travaux publics," International Bulletin Against Unemployment, Second Year, No.4, p. 785.

$\ddagger$ Report on Agencies and Methods of Dealing with the Unemployed in Foreign Countries, p. 18, D. F. Schloss. 
For similar reasons, the Massachusetts Bill on Unemployment Insurance provides that

it shall be the duty of the Chief Commissioner of Unemployment Insurance to recommend to the legislature any changes which may be deemed advisable, and shall suggest schemes to employers, employees and to the legislature for diminishing unemployment in the state generally, and for diminishing the demands on the fund which arise in the insured industries.*

The experience of India with public works shows that if they are to be of highest advantage they must be decided upon well ahead of the occurrence of the emergency.

The Indian Government has, probably, the most highly organized system of administration known. Yet even with the advantage of these rare administrative powers, experience has taught the Government that public works for the relief of distress cannot be improvised, that unless an emergency is anticipated by a careful preparation of schemes in advance, waste and demoralization are certain to ensue when the emgency arises. The duty is, therefore, imposed upon every province and district to have schemes of this character thought out and periodically revised, and ready to be put at once into operation when the emergency arises; and all the engineering departments of the different provinces are so instructed and so act. The Poor Law Commission therefore suggested that "the schemes for special works be prepared and drawn up by the local authorities in co-operation with other authorities and be revised from time to time." $\dagger$

The Ontario Commission on Unemployment, rgr6, found that

expenditure by the Federal authorities on public works amount to a very large sum, so great, indeed, that if they were planned

* r916, House, No. 825, Part XII, Section 16, Monthly Review of the Bureau of Labour Statistics, vol. i, July 1915, p. 16.

$\dagger$ Majority Report of the Royal Commission on the Poor Laws, Part 6, chap. iv, p. 4 II, 
with this in view, they would help materially to counterbalance the falling-off in the demand for labour when ordinary business declines.*

Most students of the problem of unemployment are agreed that the Government, national and local, could so organize the total demand for labour as to make it fairly level over a period of, say, ten years, provision being made, of course, for the natural growth of industry. Government employment would, of course, grow most active when capitalist employment slackened.

There seems little doubt but that rarely, if ever, will there be such another opportunity for employing this device than during this period after the armistice, when capitalists are nervous and industry is suffering from a great depression. Government housing schemes, construction works, and afforestation proposals should be pressed forward now. If, however, the Government should be found to be unable sufficiently to affect the labour market in the desired manner, then it is arguable that a bounty might be provided to employers during the slack season which will enable them to carry on with the processes of production. This has indeed been attempted in the British Government's housing scheme.

Mr. Arthur Balfour, ex-Prime Minister of England, evolved the idea that during depressions of industry " a bounty might be given to firms making for foreign orders, in such wise as to enable them to accept contracts." Professor A. C. Pigou, in commenting on it, adds that "Some persons might, perhaps, prefer to see the bounty given to firms making for British orders, so that the proceeds of it should go to British rather than to foreign consumers." $\dagger$ The execution of such offers could be made to " vary inversely with the demand in the open market." The usual objections to bounties, it must of course be remembered, would also apply here.

* Report of the Ontario Commission on Unemployment, 1916, p. 135. See also the Bill before the Legislature of Winconsin advocated by Professor R. E. Commons in 1921 .

$\dagger$ Wealth and Welfare, p. $4^{8 \mathrm{I}}$. 
Yet there are times when these objections are outweighed by the urgency of immediate needs. Thus to-day the Government might by this, as well as by other means, stimulate the development of new industries and thus increase the demand for labour. The present period of slackness provides an excellent opportunity for introducing schemes and bounties that are likely to have this effect.*

\section{Can Periods of Unemployment be Transformed into Periods of Vacation?}

To workmen generally a period of unemployment is to-day a heavy burden on their earnings, past or future. But perhaps worse than that is the anxiety due to uncertainty of the morrow. Serious deterioration of physique and morale soon affects the workman who has nothing to do but to walk the streets in search of work, or to a lesser extent when he sits in the office of an employment exchange waiting for a job to turn up. It is frequently asserted that the strain and wear of being unemployed is more severe than that of being employed.

That this period of non-employment should have this effect constitutes not merely a waste but a needless waste.

Employers of labour can with the assistance of the employment exchange arrange, in advance, that where workmen are likely to be without work for a definite period they should then take their vacation. $\dagger$

* The difficulties involved in undertaking public works during periods of depression are not sufficiently realized. Thus, towards the end of the year 1920, it was evident that very heavy unemployment was certain. There was at the same time a very great need for housing and business premises. But the price of building material was so high that municipalities, like private firms, preferred to wait with their schemes. The house which would have cost $£ 1,25^{\circ}$ to erect in August r920 could be erected in May $192 \mathrm{I}$ for less than $\ell^{1}, 000$. When it is planned to spend millions of pounds the price of materials is a very significant factor to be taken into account.

$\dagger$ This custom prevails already in Lancashire, where hundreds of thousands of workmen go to the seaside during "wakes" week. 
Through the leadership of well-informed employers, and the co-operation of the employment exchange, periods of unavoidable unemployment might, at least in certain trades, become customary holidays.* Instead of unemployment being regarded as a time of suffering and of distress it can be made into a period of change and recreation.

Experiments with small holdings, especially where industrial working men live in the country, although continuing to work in the town, might make it even easier to ensure that a period of unemployment should be used as a healthful change from normal labour. It would also have the merit of creating for such a workman a financial reserve which would enable him, in conjunction with his benefit from the unemployment fund, to tide over periods of unemployment

Such a policy is widely adopted in Belgium, where it is found that the crops grown on the land attached to the houses, along with the produce from live stock, just supply that reserve of wealth necessary to prevent men from becoming destitute directly they are unemployed. In this way the independence, self-respect and efficiency of the unemployed will be preserved. $\uparrow$

\section{Treatment of Unemployment During Normal Periods.}

In his presidential speech at the First American National Conference on Unemployment, held in New York, Professor Henry R. Seager stated the conclusions justified by British experience of the employment exchanges and unemployment insurance in IgI4.

Now, has the United Kingdom solved the problem of unemployment? We are very much inclined to see with rose-coloured glasses things that are happening a long way off. Our information about them really comes from enthusiastic advocates, and we are very easily misled. We do not wish to make any extravagant claim for this policy, but I do wish to say that it seems to me the United Kingdom is on the road to a solution of the problem of unemployment. $\neq$

* Cf. Seager: Social Insurance, pp. 107-8.

$\dagger$ Rowntree and Lasker: Unemployment, pp. 144, 262-89.

F Professor Henry R. Seager: American Labour Legislation Review, p. 292, vol. iv, No. 2. 
The successful working of the scheme of unemployment insurance until August I9I4, the ease with which the unemployment fund bore the drain on it during the early months of the war, and the extension of the scheme during war-time justify the view that the United Kingdom now possesses the necessary machinery for dealing with this great evil and is now well on the road to its solution.

\section{Employment Exchanges.}

More has been done in England and America for dealing with the unemployment problem by means of employment exchanges than by any other means. England has a national scheme. In the United States half the states now have such clearing houses for labour whereby workmen and employers may come together with least delay. In this manner the time lost by the workman between one job and another, and by the employer between engaging one workman and his substitute, is reduced. It also accomplishes the work not only of bringing a workman to a vacancy, but, what is more important, helps to bring the best workman to the given position. In this way, as we shall see, employment exchanges may be used for reducing an excessive surplus of workmen in any district, or attached to a given trade. Although not yet sufficiently developed, nor rightly understood, some of the better State schemes of employment exchanges already demonstrate that it will be possible to reduce the reserves of labour which tend to gather round every centre where labour is engaged, when a well-knit system connects these isolated units. But even if employment exchanges were more efficient than they are, trade fluctuations, it must be remembered, would still continue and unemployment and its consequences would result.* An added reason, for the ex-

* "There is one interesting question with regard to unemployment which Socialists have hitherto shirked, and which demands an answer from the Socialist students of the problem, viz. do they conceive that under a state of socialism there will be no unemployment? If they believe that there will be unemployment, then it would be interesting to hear 
tension of employment exchanges, is that they constitute the indispensable machinery for a system of unemployment insurance.

\section{Insurance against Unemployment.}

The leading authorities on the subject of unemployment have been of the opinion for about a decade that in addition to regularizing labour through a thoughtful distribution of public works, and reducing the reserves of labour which attach themselves to certain trades and factories, by means of employment exchanges, special insurance funds against unemployment ought to be collected. The latter, unlike the two former proposals, is not intended to reduce the quantity of unemployment directly.

Schemes of insurance are based on the assumption that whilst the risk might be and indeed should be prevented as far as possible, it is not likely, for many years to come, to be entirely eliminated. Unemployment insurance is aimed primarily at reducing the evil effects resulting from a given percentage of unemployment. Its nature will be examined in the next two chapters.

how they intend to treat the problem of fluctuation due to abnormal causes, such as fires, floods and earthquakes, of seasonal variation in climate and the disturbing influences of inventions, the development of new commodities, and the introduction of new organization in industry." -Quoted from an article by the present writer which appeared in the New York Evening Post of September 4, r915.

See also report of a speech by Dr. I. M. Rubinow in the New York Evening Post, September 8, I9I5. 


\section{MITIGATING THE EFFECTS OF UNEMPLOYMENT}

\section{Insurance and the Prevention of Risk.}

Ir is not the primary aim of any insurance scheme to prevent the specified contingency from occurring. Neither death, accident, invalidity, sickness, old age, fire, nor any other contingency against which people or property can now be insured, is entirely eliminated as a result of an insurance policy taken out against it. And similarly, unemployment will not be prevented from remaining a serious problem of industry even if adequate insurance against it be universally effected. But since the introduction of the existing schemes of insurance encouraged the invention of preventive methods, so unemployment insurance is likely to lead to the perfection of devices that will reduce the amount of unemployment.

"Mutual fire insurance has appealed to certain manufacturers because in twenty years it has resulted in measures that have prevented more than two-thirds of the expected losses by fire."

Similarly (wrote Mr. Brandeis) if society and industry and the individual were made to pay from day to day the actual cost of sickness, accident, invalidity, premature death or premature old age, consequent upon excessive hours of labour, of unhygienic conditions of work, of unnecessary risk, and of irregularity of employment, these evils would be rapidly reduced.*

This view is justified also by the experience of Germany and Great Britain, where the method of meeting certain

* Louis D. Brandeis in The Outlook, June Igrr. 
industrial losses through insurance has been widely developed.

In Germany it has long been shown, under sickness and accident insurance, that it pays to have the best appliances for the sick and the injured, the best medicines, the best physicians and the best nurses. Great Britain, benefiting by this experience, endeavoured to arrange for the most up-to-date sanatoria and for good medical attendance under her health insurance arrangement. Measures were taken to reduce the amount of sickness as well as to cure the sick. Parsimony would in these matters have proven the most wasteful extravagance. When, in like manner, Great Britain introduced a scheme of unemployment insurance, devices calculated to reduce the amount of unemployment were made an intrinsic part of it.

Yet, even if insurance against a given contingency does not necessarily result in any substantial reduction in its occurrence, it always acts as a palliative. The life of the breadwinner who dies from an industrial accident cannot be recalled, but his widow and children might be saved from pauperism if he is insured. The carpenter and the machinist may not be engaged in gainful pursuit owing to unemployment, but if they are insured they need not be reduced to penury.

The main object of schemes of unemployment insurance must be regarded then as being, not the entire abolition of unemployment, but the lessening of the evil effects that result from it.

\section{Unemployment and Individual Savings.}

The common assumption of many "self-made men" who look backwards to their own experience is that unemployment is a matter which concerns the individual and is to be provided for by individual means. Self-help through individual savings seems to them to be the obvious method of meeting periods of unemployment. If, therefore, workmen do cry out during 
those periods for relief it is due, it is alleged, to their lack of providence and forethought. To remedy this moral delinquency they urge the teaching and practice of these virtues. Unfortunately, this view fails to recognize the changed order of society in which the workman now moves. It disregards the hard facts of the wageearner's existence. We have already seen that with respect to most workmen to-day it would be even more beneficial to society for them to spend all their income in maintaining their health and vigour and that of their dependents rather than attempt to save against emergencies.*

There is also the consideration that wage-earners are not, as a matter of fact, becoming more provident, but are indeed probably growing less provident in their habits. $\dagger$ When the United States, for example, were predominantly agricultural in character and there were huge tracts of land open to the toiling, sparing worker, there was a great motive for saving. To own a wellrun farm with a home made a great appeal to the agricultural worker.

It is now so difficult for the farm hand to become a landowner that in very few cases does he even make the attempt. The best land in that country is in the hands of private owners, and a permanent and growing body of agricultural wage-earners is to-day a characteristic of the United States as of many European countries.

Similarly, in the United States as well as in the indus-

* It is true in the early decades of the twentieth century as it was in the early decades of the nineteenth that "for many homes, both in town and country, life is one privation," and that thrift "implies, not the curtailment of useless commodities, such as expediency and humanity would welcome, but a diminution of the real needs of life, which is a standing condemnation of the economic system of many governments." -J. B. Say, Traité, 6th edition, p. I 6 .

$\dagger$ It is impossible to discover what percentage of the $\$ 4,000,000,000$ of deposits in savings banks in the United States in 1910, and of the $\$ 12,513,000,000$ invested in ordinary life insurance policies in 1909, and of the $\$ 2,967,000,000$ in industrial insurance in 1908 , or of the sums invested in building and loan associations, was subscribed by those earning less than $\$ 1,000$ a year. It is, however, certain to have been very small. 
trial countries of Europe the town dweller also once had a strong incentive to saving in the desire to own a house and the tools and implements necessary to his craft. But among wage-earners in the cities these old motives for saving have weakened even more. Not only is it rarely possible for a wage-earner to own his house, but it is no longer desirable for him to do so. Its high cost and the comparative smallness of his wages have made him regard himself as destined to be a tenant all his life, whilst the idea of owning his own tools under the factory system would appear to the average workman like a nightmare. Moreover, the workman who is easily able to shift from place to place is at an advantage as compared with one who is so situated that movement is more difficult. The former can move to any part where his economic value to society is highest. We can therefore understand why, in the words of Professor Seager : *

The call of the savings bank and of the insurance companies is weak in comparison with the old-time call of free land and a home of one's own.

Another leader of economic thought even argues that modern industry develops a spirit inimical to saving. Professor Veblen writes :

The conditions of life imposed upon the population by the machine industry discourage thrift. But after allowances have been made for this almost physical restraint upon the acquisition of property by the working classes something is apparently left over, to be ascribed to the moral effect of the machine technology. The industrial classes appear to be losing the instinct of individual ownership. The acquisition of property is ceasing to appeal to them as a natural, self-evident source of comfort and strength. The natural right of property no longer means as much to them as it did. $\dagger$

Since workmen, both in the city and on the farms, have lost the habit of saving, it has been suggested that they

* Seager: Social Insurance, p. II8.

$\dagger$ Veblen: The Theory of Business Enterprise, pp. 326-7. 
should be compelled to save. Although it sounds rather odd to those brought up in democratic countries, let us examine this proposal.

\section{Compulsory Savings.}

Professor Schanz has long advocated a system of compulsory savings. According to him the practical difficulties in the way of introducing a scheme of insurance are so great, and even when overcome a system of insurance must necessarily be so complex, that a popular scheme of saving is to be preferred. Recognizing that even to-day there is nothing to hinder the workman from making any provision he can afford or may desire with which to face unemployment, and that in spite of this fact comparatively few workers make such provision, Professor Schanz boldly proposes that workmen shall be compelled to save.* His scheme, he urges, is simplicity itself. Each workman shall be forced to contribute weekly to a special fund. His contributions, as in the existing Post Office Savings Bank, will be regarded as his own personal resources. The money in the fund will be invested and interest will be added. But his savings are to be used by the workman only during periods of unemployment. Since each workman must bear his own risk of unemployment, and since his own savings come directly into play, he will be interested, even though there is no special control to effect it, not to provoke nor to prolong unemployment. There are great advantages in such a scheme. "The individualization of risks" will permit the workman to employ at any time, or to leave to his children, the fruits of his accumulated contributions; there will be little danger of malingering, since if the unemployed workman merely pretends to be unemployed he alone suffers. There would thus be less reason to inquire into the cause of unemployment. Above all, the scheme has the negative virtue of avoiding all need for a com- 
plex organization and the unfairness involved in some schemes of insurance in the treatment of the more regularly employed workman.

Professor Schanz's proposal would make the working classes bear the burden of unemployment alone, although they are not responsible for the maladjustments of industry. It does not introduce any forces making for the reduction of the amount of unemployment, and ignores the particularly serious problem of the lower strata of workmen who can hardly ever afford to save from their current earnings. There is reason also to believe that the apparent simplicity of this scheme is illusory. How much should a man be compelled to save? How can he be prevented from drawing his savings even when employed? As soon as a solution is attempted to these and kindred problems it will be found that compulsory saving involves the introduction of as complex a machinery as does compulsory unemployment insurance. The average wage of large bodies of manual labourers is so low that as a matter of fact many workmen cannot afford, and therefore should not attempt, to save against the emergencies which affect them. Assuming even that wages were sufficiently high for the workman to be able to save to meet a given emergency, it would still be more advantageous for him to resort to the method of insurance. This is clearly demonstrated by the fact that it is precisely the men of the successful classes who realize the wisdom of distributing risks and of providing against incapacity for labour or against death by the method of insurance, rather than by depending entirely upon savings.

\section{Saving versus Insurance.}

Moreover, the method of saving, used as a means of securing the workman against unemployment, is not only costly but wasteful. It implies that each person must retain on the average a reserve large enough to make good the variations that occur in his individual 
income owing to that contingency. Thus, assuming that he wishes to have $\AA^{2}$ ros. a week during periods of unemployment and wants to guarantee himself against a maximum period of $I_{5}$ weeks, he is forced to save a reserve of $£ 37$ Ios.

At the rate of $2 \mathrm{~s}$. a week it will take him over seven years to save this amount. Assuming now that there are I20 such workmen, then $£ 4,500$ must be saved to guarantee them against a maximum period of I5 weeks of unemployment. But when a group of persons wish to secure themselves against the given emergency, it is virtually certain that it will include some workmen less liable and others more liable to unemployment, and that when some are unemployed others will be employed. Instead of withholding $£ 37$ Ios. in respect of each workman, this sum can be taken from the current deposits of those still at work.

Thus, still assuming that there is a group of 120 workmen, not more than five of whom are unemployed at one time, and needing $f_{2} 2$ Ios. a week, then a weekly levy of something over $2 \mathrm{~s}$. on those that work will provide each unemployed workman with the required income. No reserve at all would then be necessary. Hence, by saving collectively instead of individually, a group of people can greatly lessen the amount of saving that is required to guarantee them against a given emergency. This is known as the advantage of mutuality. In the case chosen for illustration the investment of $£ 4,500$ in the bank instead of in education, recreation or food, would be avoided, and the uncertainty of receiving benefits during the seven initial years would be eliminated.

We have already seen that there are influences which tend to weaken the workman's motives for saving, but opposite tendencies can be introduced. These must, however, be based on the recognition that the unaided efforts of large numbers of workmen will be insufficient to guarantee them against the great emergencies in their lives. To meet such emergencies it is urged that 
resort ought to be had to insurance. Once, however, a State scheme were established, it would indirectly tend to encourage thrift and saving to supplement the benefit. In actual practice schemes of social insurance provide only for a minimum of benefits. They constitute only a small portion of average wages, generally much less than half, and are limited to a certain number of weeks Additional saving will be encouraged when the workman is assured of the minimum amount, because his fight to save his self-respect would then not be a hopeless one. There is a further direction in which unemployment benefits would encourage individual effort. The prevailing method of helping the unemployed is through the support of relatives and friends. Only too frequently these same relatives and friends are very poor and the burden is too great, so that they are discouraged from even attempting it. Why help when charity societies can do as 'much or more? Even when help is extended it is often given grudgingly, for it merely saves the funds of the charity organizations. But if a relative's help or a friend's gift meant the addition of tobacco or coffee to the bare subsistence that would be provided for by the State scheme, assistance is a great deal more likely to be given than when it means merely the reduction of their friends' cost to the charity organization. We deliberately dry up and starve at present one of the most promising means of enabling the lower-paid workmen to help one another in distress.*

Instead, therefore, of insurance resulting in the demoralization of character, it will, on the contrary, act as an impetus to self-reliance. The method of insurance thus has the advantage that it can be supplemented by savings.

It may be argued that higher wages and better conditions of labour would remove the necessity for schemes of social insurance altogether. The urgent need for both these improvements cannot be denied, but that

*Contemporary Review, 1890, p. 107, "The Reform of the Poor Law," Sidney Webb. 
objection against these schemes results from a misconception of their purpose. As Dr. Rubinow writes:*

"It does not deal with the normal standard of working men's life, except indirectly, and in so far as the normal standard of wages and as the standard of living depending on wages are unsatisfactory. The corrective measures are much broader than anything social insurance can offer. It is the direct object of social insurance to protect this standard of life from the onslaught upon it by various physical and economic changes, though it goes without saying that by this amount of protection the general standard is upheld and its improvement facilitated."

Where the conditions of life are already below the standard of physiological necessity and economic efficiency-unfortunately no higher standard than this is yet demanded by Labour leaders-it is evident that the wage-earner is in a hopeless position to meet any emergency which might attack him. Such a situation demands both increased wages and the protection of the standard of life through some scheme of insurance.

\section{Insuring against Unemployment.}

Three preliminary questions of fundamental importance present themselves on the threshold of our subject :

(a) Is unemployment a contingency against which it is possible to insure?

(b) And if it is, is it a contingency against which it is advisable to insure?

(c) And even if it is advisable to insure against unemployment, is it a rightful function of the modern State, by encouraging this activity, to make itself responsible for evils which are in the main the result of the relationship between employer and employees?

(a) Until recently it was commonly held that unemployment was not an insurable risk.

* Dr. I. M. Rubinow : Social Insurance, p. 45. 
The more we examine the schemes that have been worked (wrote Professor Chapman), the question of the insurability of the risks dealt with and the possibility of isolating them, the more surely we find ourselves driven to the conviction that ordinary insurance against unemployment is impracticable.

\section{Unemployment Satisfies the Requisites of an Insurable Risk.}

There are four requisites which a contingency must satisfy before insurance principles can be applied to it.

(I) There must be a risk whose nature must be clearly specified.

(2) To this risk large numbers must be exposed.

(3) It must be a risk which appeals to those on whom it is likely to fall, as a menace against which they would, if they could, provide.

(4) The risk must be capable of being calculated with some degree of certainty.

If by unemployment insurance we mean insurance of able-bodied men out of work for a definitely limited period, and a test of willingness to work is provided, then the risk may be regarded as clear. The second and third of these requisites clearly apply to unemployment, since large numbers are subject to it and many would be glad to provide against it.

The statistics necessary to satisfy the fourth condition, it has been argued, cannot be regarded as satisfactory for the introduction of a scheme of unemployment insurance in many countries. In a measure this is true. There is not sufficient and satisfactory data of unemployment on which to base a fixed, scientific insurance. But it may be doubted whether there often has existed quite sufficient data dealing with the occurrence of any contingency until after the inception of a scheme of insurance against it. Opponents of social insurance of all kinds have always been able to argue that there were not sufficient data on which to base any scientific scheme of insurance. And the vicious circle 
was completed by the fact that until there was a scheme of insurance instituted there would never be satisfactory figures.

It is, however, quite evident that on the basis of statistics available in most Western countries the estimates of a competent actuary would supply us with a sufficiently stable scheme with which to begin. This was so in England, where the available data were better, though not, as is frequently affirmed, immeasurably better than the data that could be obtained in, say, Massachusetts, New York, and Wisconsin.

There is convincing evidence already available of a concrete kind which makes it no longer necessary to insist on the possibility of insuring against unemployment. There is the actual experience of trade unions in Great Britain, France, Germany, Belgium, Holland, and the United States.

Mr. Gephart urges that

whatever plans are in practice among trade unions and other organizations are not based on any scientific insurance principles. They are but mutual agreements to pay certain sums in cases of unemployment without any reference to the particular source of the funds or their recipients.*

Although this may be true of some of the weaker trade unions, this criticism is certainly invalid when applied to the bigger and better organized labour organizations. Even when all their benefits are pooled into one fund the dues collected in respect of out-ofwork insurance are calculated to cover its cost to the organization. But when each benefit is paid from a different fund it is more clearly seen that such schemes are much more than merely "mutual agreements to pay certain sums in cases of unemployment without any reference to the particular source of the funds or their recipients." They are, more or less, scientifically calculated schemes of insurance against unemployment.

Moreover, we have now some nine years' successful

* Gephart: Principles of Insurance. New York, 1915. 
experience of the British National Unemployment Insurance Act. Thus unemployment insurance is not merely a possibility; it is a fact.*

It was due to experience already gained that the "International Association against Unemployment" declared even before the war that unemployment was a risk against which it was possible to insure.

(b) Is unemployment a risk against which it is advisable to insure? We have seen that most workmen are unable to make adequate provision when unaided against unemployment. It has also been seen that saving is technically inferior in achieving the end of guaranteeing workmen, subject to this emergency, a certain sum of money. $\dagger$ Two false judgments have hitherto discouraged workmen from making provision against unemployment. First, most workmen do not, as a matter of fact, estimate their earnings at their true value. They fail to appreciate how large an amount needs to be discounted owing to the unhealthy or fluctuating nature of their work. Second, most workmen optimistically assume that whatever may happen as a rule or on the average to workmen, they as individuals will escape from harm.

But once a workman is insured, the true risk comes to be more clearly conceived and better appreciated.

Not only is the loss of wages due to the regularly recurring periods of unemployment a matter of great concern in that it results in forcing many people below the necessary minimum of existence, but also the fact of fluctuation of earnings is highly objectionable in itself.

An average wage of, say, $£ 3$ a week leads to greater welfare than a wage of, say, $£ 5$ a week for six months in the year and $f_{\mathrm{r}}$ a week for the other six months in the year. If the workman's foresight were perfect and his will adamant, he would arrange for an expenditure

* The whole subject of unemployment insurance was investigated by the German Imperial Statistical Department, which published one of the best reports on the subject in I906. It of course needs revising.

$\dagger$ See A. C. Pigou: Unemployment, chap. xiii. 
of $£ 3$ a week. But as he is not in this respect superior to other human beings, he enjoys his "bust up" during busy periods and suffers from the effects of insufficient nutrition during slack periods.

Any arrangements tending to reduce this unevenness in his wages, and consequently in consumption, such as is produced by a scheme of insurance, therefore tend to increase the welfare of the workman. These conditions justifying insurance against the emergency of unemployment have been so common that workmen in many parts of the world have arranged schemes for this purpose. We shall see in Chapter IV what the trade unions in the leading industrial countries have effected in the way of unemployment insurance.

We have now answered two of the preliminary questions, and we may conclude that unemployment is a contingency against which it is both possible and advisable to insure. The third question as to the advisability of the State encouraging this form of activity will be taken up later.I We must here analyse the types of " unemployment insurance" schemes. 
INSURANCE implies an agreement to pay a certain sum of money as compensation against a loss which may or may not occur. Fire, physical accident, sickness, unemployment are such contingencies, and their occurrence is likely to result in great loss to those whose property or person is attacked by them. To protect individuals from overwhelming suffering the device of insurance has been perfected, so that the losses sustained by the few may be distributed over the many and thus great risks eliminated. Those who desire to be insured, or others on their behalf, pay regular small contributions towards a fund from which any insured member will be reimbursed should the emergency happen against which insurance is sought. Unemployment is only one of the many types of risk against which individuals may now insure.

Unemployment insurance may therefore be defined as an agreement, which is legally enforceable, to pay a certain sum of money as compensation against the loss of wages resulting from involuntary unemployment due to lack of work.* It therefore constitutes a buffer against one of the most dangerous emergencies to which the wage-earner is subject. Marine and fire losses are only two of the many kinds of emergencies against which property owners may insure their property. Schemes of social insurance are advocated on the ground that it

* Politicians who constantly refer to unemployment insurance "benefits" as "doles" or charity gifts thus not only betray their bias but their ignorance. 
will pay workmen, even more than property owners, $\downarrow$ to have their property insured too, their property being, of course, their health and capacity to earn a livelihood. To save them and their families from exceptional economic risks they will need insurance against the effects resulting from accidents, sickness, invalidity, premature old age, and unemployment. To-day, when the working man no longer owns the materials and instruments of production, and where the conditions of life in the factory are imposed upon him, his normal earnings are, as a rule, not sufficient to provide more than the minimum standard of health and efficiency, and since he has no reserve of wealth to fall back upon, it is particularly urgent that he be protected from exceptional economic risks.

\section{Types of Unemployment Insurance Schemes.}

Insurance against unemployment has hitherto been provided through one of four different kinds of organizations: (I) through trade unions, (2) through associations recognized and subsidized by public bodies, (3) through establishment funds, and (4) through national compulsory schemes.*

(I) For some two hundred years trade unions have insured their workmen against unemployment in the United Kingdom, and until recently they distributed in the industrially developed countries of the world in the form of unemployment insurance nearly as much as all the other organizations providing such insurance put together.

(2) During the last two decades a movement for subsidizing trade union insurance has gained momentum. Under the name of the Ghent scheme this plan has been adopted by eight countries and is likely to be introduced in others.

* An entirely new type of social insurance was contemplated by the Seamen's Conference held at Genoa in June 1920. An international system of insurance for seamen was contemplated.-See League of Nations, Report II, on Unemployment, p. 50. 
(3) Hitherto schemes of establishment funds, i.e. schemes conducted by individual firms for insuring workmen against unemployment, have received their greatest development in Great Britain, Germany, and Austria, though some few firms in France and even in America have instituted similar provisions for periods when their employees are laid off.

(4) Great Britain was the first country with a national comprehensive compulsory scheme of unemployment insurance. It has been followed by Austria, Italy, and Soviet Russia.

The first and third of these organizations for insurance are voluntarily introduced by the people affected, whilst the second and fourth types of insurance result from legislative enactment.

Mr. Gibbon's analysis of all schemes of assisted insurance into provided voluntary schemes and autonomous trade insurance is neither clear nor helpful.*

Certainly the term "autonomous trade insurance" is misleading. By it the ordinary reader would understand the general form of insurance carried on by unions without any public intervention. $\mathrm{He}$, however, learns that it means "a scheme of insurance established and maintained by themselves," but which nevertheless receives public support. $\mathrm{He}$ is again at sea when he learns that such unions must always satisfy certain requirements and submit to supervision. The two important distinctions which have been drawn between provided voluntary schemes and autonomous trade insurance do not in fact have much force.

In a provided scheme (we are told) insurance as a rule is open to workers generally, and is not confined to any particular trade or trades. In an autonomous scheme insurante is generally confined to a particular trade or to a number of allied trades ; such insurance is almost exclusively effected through trade unions.

As a matter of fact, however, most provided schemes do assist trade unions and have very few members from

* See I. G. Gibbon's Unemployment Insurance, pp. 44, 45. 
different trades belonging to their funds, whilst the autonomous schemes frequently provide for the assistance of non-unionized members. It is more helpful to regard both these forms of assistance to unemployment insurance schemes as species of the Ghent scheme. This certainly is the view now current amongst students of the problem.*

In the world of social institutions, as in that of the animal kingdom, the idea that progress takes place mainly, if not exclusively, by the process of variation and selection holds good. Without variation there can be no selection, and without variation and selection there is no progress. This process is proceeding apace in the field of unemployment insurance. Experiments of the most varied kinds have been made with each of the four types of schemes.

We shall see that whilst many countries in Europe have begun with voluntary organizations of workers and a few with private employers' funds, a number have developed subsidized unemployment insurance schemes, and one country has actually successfully operated a national compulsory scheme of unemployment insurance for almost a decade, which other countries are now copying.

Unemployment insurance as an organized venture is, however, yet too new for it to be said that the recent spread of the idea of the national compulsory form of insurance is an unmistakable and incontrofvertible proof of the survival of the fittest form. Insurance by trades is a new form that has to-day very many powerful supporters.

\section{Summary.}

Let us now summarize the argument developed in the first three chapters. It is evident that whilst for many millions of workers it is impossible unaided to make adequate provision against unemployment, for others

* See, for example, Professor Giovanni Montemartini in The International Bulletin against Unemployment, Fourth Year, No. I, pp. 189-92. 
their wages are large enough to enable them to do so. Not all of these latter, however, do at present save against a period of unemployment. A comprehensive programme of reform will therefore provide that an impetus be given to voluntary saving and that some special method be developed for those who need aid during periods of unemployment. Through savings banks and trade unions, funds are collected by workmen which they can use when out of work. Facilities for saving should be increased for some, a very small minority, who to-day could afford it but who through laziness and the lack of habit fail to make provision against unemployment. More trade unions should introduce schemes of out-of-work benefits; establishment saving funds might be increased. Co-operative undertakings might be able to take the place of the old motives for thrift, as they have done in such large measure in Great Britain and Denmark. Again, it is an established fact that saving is most characteristic of well-paid, wellorganized workmen whose labour requires skill and reliance. Forces making towards the upbuilding of such groups of labourers should therefore be encouraged.

Still, it is impossible to wait until the vast body of labourers have attained such conditions. Distress due to involuntary unemployment is an insistent problem and brooks no delay. The intermittent but frequent clamours that arise that unemployment should be faced by the community cannot be answered by reference to aspirations for the future concerning personal providence and thrift. When large numbers of workmen are paid at such a low scale that saving is not merely inadvisable but criminal, when expenditure on food and clothing for themselves and their families is the best possible way of disposing of any savings, then some other means for f teing unemployment must be discovered.

Professor Schanz's proposal of compulsory savings is on examination found to be unsatisfactory as a means of providing against unemployment. It ignores the considerations that by the acceptance of mutual obli- 


\section{INSURANCE AGAINST UNEMPLOYMENT}

gations and the pooling of risks and distributing them evenly the cost of defence against unsteadiness of income is greatly reduced. We may therefore push ahead with our inquiry and proceed to investigate the schemes of insurance against unemployment which have proven beneficial. 


$$
\begin{gathered}
\text { PART II } \\
\text { THE GHENT SYSTEM } \\
\text { OF UNEMPLOYMENT INSURANCE }
\end{gathered}
$$





\section{TRADE UNION UNEMPLOYMENT INSURANCE}

INSURANCE companies operating for profit do not institute schemes of insurance against unemployment, because it would not prove a profitable activity. There is a great likelihood that only those workmen would be disposed to insure with them who were most subject to the risk of unemployment. Moreover, the expense involved in investigating every claim in order to reduce the likelihood of malingering to a minimum would be very heavy. The premium for insurance under these circumstances would be so high that, even if an insurance company were prepared to make out a policy against unemployment, very few workmen could afford to take one.

\section{Friendly Societies and Consumers' Associations.}

Since workmen's organizations can, as a rule, provide an adequate check on malingering and can devise means for limiting the claims to benefit of those workmen who are likely to be frequently unemployed, the cost of insurance can be kept comparatively low. Thousands of workmen in all highly industrialized countries have been able through their own organizations to insure against unemployment. These organizations have, as a rule, been trade unions. But occasionally friendly societies and consumers' associations provide schemes of out-of-work insurance. Unfortunately no attempt has yet been made to ascertain the amount which is distributed towards the relief of the unemployed through these sources.

The Chief Registrar of Friendly Societies of the United 
Kingdom does not publish in his annual report a statement of the sums expended on unemployment and travelling benefit by the friendly societies. This information is given only infrequently and at long intervals. In I908 thirty-four registered friendly societies in England and Wales distributed about $£ \mathrm{I} 2,000$ to unemployed members. Provision for such benefits was made only by the smaller societies. Some of the larger societies, however, including the Independent Order of Oddfellows (Manchester Unity) provided travelling benefits.

These societies distributed, in addition, substantial sums in relief grants to those in distress through unemployment and other causes. In I907, $£ 80,000$ were distributed by them. The disbursement of this sum is comparable with the emergency relief granted by trade unions in the United States. They represent the goodwill of workmen towards their fellows in distress. The chief objections to them are that they are uncertain, and unemployed workmen cannot claim them as a right. This criticism applies also, as a rule, to the relief provided by consumers' associations.

Particularly interesting is the work of the Hamburg association of consumers, which in I909 had 4I,875 members. This fund differs from others in that at the end of the year dividends are not paid out in cash but are transferred to relief funds belonging to individual members; unemployment is one of the evils to be provided against by such funds. In I909, I5,456 members had such deposits with an aggregate amount of 5I4,I77 marks.* In the same year 6,642 members withdrew I79,943 M.; especially large amounts were withdrawn after the lockout of building workers took place.

Friendly societies and consumers' associations, both of them, in fact, selling to workmen certain of their requirements on a co-operative basis, have not made much progress in insuring workmen against unemployment. It is evident why this was inevitable. Both these types

* Owing to the great fluctuations in the value of foreign money in terms of English money no attempt is made to give their English equivalent. 
of workmen's selling agencies are forced by their very nature to allow workmen from all trades to become members. They cannot confine themselves merely to printers, weavers, clerks, or to the members of a single trade. Workmen subject to varying risks of unemployment due to the nature of their trade are thus all heaped together, and it is of course highly unlikely that comparatively regularly employed workmen will voluntarily join an unemployment society of such a kind. They would in effect be called upon to subsidize those workmen who are subject to a much greater risk of unemployment. In the case of trade union out-of-work benefit schemes, on the other hand, each separate organization works out its own rates of contributions and benefits on the assumption that all its members are subject practically to the same risk.

\section{"Special" Trade Unions for Unemployment Insurance.}

The signers of the Majority Report of the Poor Law Commission of Great Britain contemplated the growth of a special type of friendly society to insure workmen against unemployment. To encourage its organization they proposed that a special governmental subsidy be distributed.

If, however, the subsidy were to be offered to any provident organization which would make unemployment insurance a leading feature of its business, we should look for the advent of a new type of friendly society composed of men of similar or allied trades, who would have the necessary trade solidarity and knowledge of each other's circumstances, and whose interests would be sufficiently similar to prevent the " bad risks " crowding out the good. It would, in fact, be a trade union organized for provident benefits alone. If such societies came into existence under the encouragement of a subsidy, we might hope for insurance against unemployment becoming general over the field of labour. Such a result, we would venture to say, would far more than counterbalance the expense of the subsidy.

Mr. Gibbon gives half-hearted support to this proposal. He wrote that

It is not improbable that, with the incentive of a subsidy, some societies would be formed expressly for providing insurance against 
unemployment, especially among the steadier and more enlightened members of occupations which are not yet organized in trade unions; and every encouragement should be given to the formation of societies of this kind.*

We shall see that these expectations are quite unwarranted in the light of the results obtained in the past through Government subsidies to "associations" providing outof-work benefits. Even where strong trade unions have been ready to take advantage of these subsidies it cannot be said that any very marked proportion of the workpeople who were able to do so took advantage of them by joining the unions and thus insuring themselves against unemployment. Moreover, this suggestion of the Poor Law Commissioners is objectionable to-day because it focuses attention on the granting of subsidies when the leading authorities on the subject have lost faith in their efficacy and are now advocating compulsory national schemes of unemployment insurance.

\section{Trade Union Unemployment Benefits.}

Experience shows that in order to have a promising ground for the encouragement of unemployment insurance workmen must not merely be organized, but they must be organized for the specific purpose of securing better economic conditions. To do so they must be organized along trade or industrial lines. The trade union is not only able to provide such insurance at a comparatively low rate to members desiring it, but its experience of the demoralizing effects of unemployment on its membership and its morale impel it to introduce this benefit feature. It is therefore through trade unions that workmen have as a rule sought insurance against unemployment.

Trade unions provide the oldest form of out-of-work insurance. Most industralized countries have developed these organizations of workmen, and these have, as a rule, regarded mutual insurance against the emergencies common to workmen, as one of their chief functions.

* I. G. Gibbon: Unemployment Insurance. 


\section{International Trade Union Statistics.}

The United States Bureau of Labour Statistics* has prepared tables from the latest official sources available, showing the membership in trade unions in the years I9I2, I9I3 and I9I4 in each of fourteen principal countries, including the United States. It should be said that these figures are by no means complete, and, furthermore, that they are not comparable, as between the different countries, except in the most general way. They serve, however, as an indication of the development of the trade union movement within the respective countries.

MEMBERSHIP OF TRADE UNIONS IN VARIOUS COUNTRIES FOR THE YEARS I912, I913 AND 1914.

\begin{tabular}{|c|c|c|c|c|c|c|c|c|}
\hline & & & \multicolumn{6}{|c|}{ Membership. } \\
\hline \multirow{2}{*}{\multicolumn{3}{|c|}{ Country. }} & \multicolumn{2}{|c|}{$19 \times 2}$. & \multicolumn{2}{|c|}{ x9x3. } & \multicolumn{2}{|c|}{ 19x4. } \\
\hline & & & Total. & $\begin{array}{l}\text { Number } \\
\text { of } \\
\text { Women. }\end{array}$ & Total. & $\begin{array}{l}\text { Number } \\
\text { of } \\
\text { Women. }\end{array}$ & Total. & $\begin{array}{l}\text { Number } \\
\text { of } \\
\text { Women. }\end{array}$ \\
\hline \multicolumn{3}{|c|}{ Australia (Commonwealth). } & 497,925 & 20,204 & - & - & - . & 一 \\
\hline Austria $\quad$. & . & .. & $692,68 x$ & 69,340 & 748,760 & 65,652 & 一 & - \\
\hline Belgium & .. & . & 231,835 & $\underline{-13+0}$ & 202,746 & - & - & - \\
\hline Denmark $\quad .$. & $\ddot{0}$ & $\because$ & 139 ,012 & 15,896 & $\times 52,787$ & - & $I_{55,783}$ & 一 \\
\hline France & $\because$ & $\ldots$ & $1,027,059$ & 96,008 & $x, 026,302$ & 89,346 & $\underline{-1000}$ & - \\
\hline Germany $\quad$. & . & .. & $3,753,807$ & $3 \times 8,868$ & $3,835,660$ & 332,567 & - & - \\
\hline Great Britain & .. & . & $3,281,003$ & 318,443 & $3,928,191$ & 357,783 & $3,959,863$ & 352,944 \\
\hline Italy $\because$ & $\cdots$ & . & $97 x, 667$ & - & - & & - & - \\
\hline Netherlands (D & 3rst) & .. & 189,030 & 8,394 & 220,275 & 8,809 & 一 & - \\
\hline New Zealand & .. & .. & 60,622 & - & 71,544 & - & - & - \\
\hline \multirow{2}{*}{\multicolumn{2}{|c|}{ Sweden (Dec. 3 rst) }} & .. & 60,975 & - & 64,108 & 4,156 & 67,235 & 4,809 \\
\hline & & . & 87,024 & - & 97,252 & - & $10 x, 207$ & - \\
\hline Switzerland & .. & .. & 131,380 & 16,487 & - & 一 & - & 一 \\
\hline United States & .. & . & $2,389,723$ & - & $2,604,701$ & - & & - \\
\hline
\end{tabular}

The official publications from which figures were taken are as follows: Australia.-Commonvealth Bureau of Census and Statistics, Labour and Industrial Branch, Report No. 5, P. 7: Austria.-Die Arbeitseinstellungen und A ussperrungen in Oesterreich während des Jahres, 1912. Herausgegeben vom $k . k$. Arbeitsstatis ischen Amte im Handelsministerium. Appendix, pp. 102 ff.; r913, pp. 80 ff. Belgium.-Revue du Travail, rgr4, p. 754. Denmark. -Statistisk Aarbog, 1913, p. 130; 1914, p. 132 ; 1915, p. 140. France.-Bullctin du Ministere du Travail et de la Prévoyance Sociale, 1913, p. I173; 1915, p. 29. Germany.-Statistisches Jahrbuch fïr das Deutsche Reich, I915, p. $79+$; annual average. Great Britain.-The Board of Trade Labour Gazette, 1914, p. 123; 1915, p. 318 . Italy.-Bollettino dell' Ufficio del Laroro, 1914, p. 7x. Netherlands. - Bijdragen tot de Statistiek van Nederland, Nienwe volgreeks, Beknopt overzicht van den omvang der Vakbeweging op I Januari, r914, p. 7. New Zealand.-Twenty-third Annual Report of the Department of Labour, r914, p. 7. Norway.-Arbeidernes faglige Landsorganisation Bereitung, 19:3, r914. Sweden.-Sociala Meddelanden, 1913, p. 741; r914, p. ro49; 1915, p. x254. 'Switzerland. - Schweizerischer Gewerkschaftsbund, Jahresbericht, x912. United States.Bulletin of the Department of Labour, State of Nes' York, I913, No. 56, p. 407; exclusive of membership in Canada and including only those unions from which actual returns were received; No. 67, p. $\mathrm{r}$.

* Vol. ii, May r9i6, No. 5, pp. 82-3.

+ For the latest figures of tra le union membership, see The Labour International Handbook, $192 \mathrm{I}$. 
哇

号

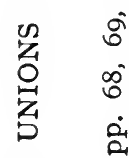

愌苔

㝳里

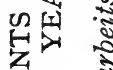

का जा है

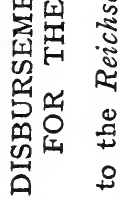

詹苟

(1) थे

要

S

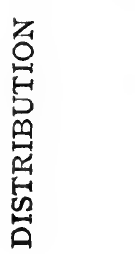

\begin{tabular}{|c|c|c|}
\hline \multirow{2}{*}{ 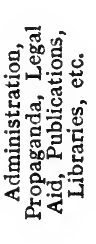 } & 岂莒 & $\begin{array}{l}\infty \\
\infty \\
\infty \\
\dot{y}\end{array}$ \\
\hline & 莣 & 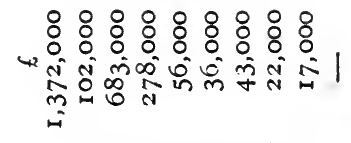 \\
\hline \multirow{2}{*}{ 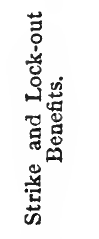 } & 岕蓠 & 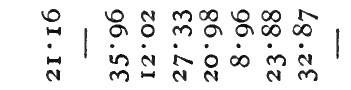 \\
\hline & $\begin{array}{l}\dot{\Xi} \\
\dot{\Xi} \\
\dot{E}\end{array}$ & 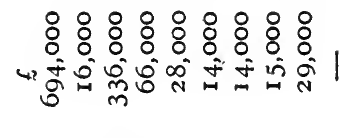 \\
\hline \multirow{2}{*}{ 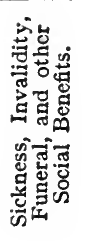 } & 岕莣 & 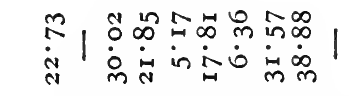 \\
\hline & 莒 & 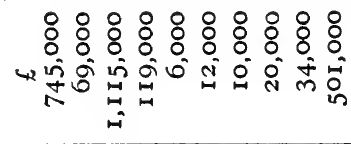 \\
\hline \multirow{2}{*}{ 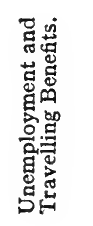 } & 岕莣 & 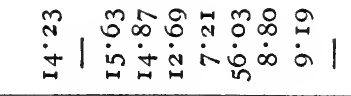 \\
\hline & $\begin{array}{l}\text { 莣 } \\
\dot{0}\end{array}$ & 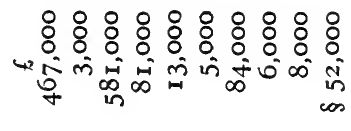 \\
\hline \multicolumn{2}{|c|}{ 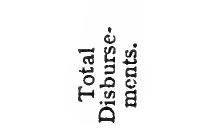 } & 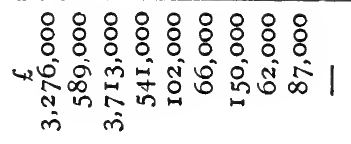 \\
\hline
\end{tabular}

志

苋苞

8 च

요

点

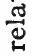

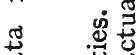

ช

$\therefore \quad 0$

ธี ํㅕ

․ वี

$\because \quad$ g

$\therefore \quad$.

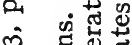

品

ब

ल क 鸟

ᄒ

3 곤

乙

-

- 5

ธ

泡实

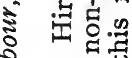

\&

\

तี

₹

ह .2

ㅎ.

\&.

A

จต范吉

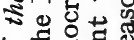
का

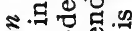

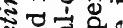
ऽ s. 产 
The preceding table, relating to the distribution of the annual disbursements of trade unions in various countries, relates to the year I9I2, the latest for which information with any degree of completeness was available.

\section{British Trade Unions.}

In I9Io the British trade unions spent nearly 30 per cent. of their total expenditure on out-of-work pay. In that year the annual returns furnished to the Central Office by unions represented $r, 884,28 \mathrm{I}$ out of a total of r, 957,903 , or 96 per cent. of the whole membership of registered trade unions.* Contributions of members during I909 amounted in the aggregate to $£ 2,67 \mathrm{I}, 087$, while the income derived from other sources amounted to $£ 253,921$, giving a total revenue of $£ 2,925,008$.

The expenditure amounted to $£ 3,027,522$, and was applied in the following manner:-

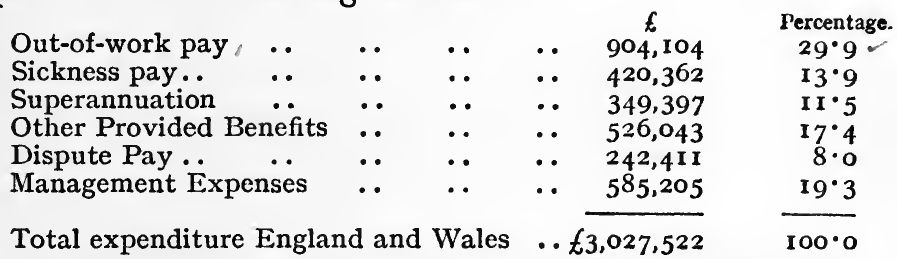

More information is available as to the selected trades which were included in the Government scheme of unemployment. It is interesting here to note the average benefits provided by their own trade unions.

MEAN COST OF UNEMPLOYED BENEFITS, I900-9, OF ALL TRADE UNIONS IN INSURED TRADES.

\begin{tabular}{|c|c|c|c|}
\hline & & No. of Unions. & Membership. \\
\hline 30 shillings and over .. & $\cdots$ & 7 & 36,540 \\
\hline 25 and under 30 shillings & .. & 12 & 56,302 \\
\hline 20 and under 25 shillings & .. & 2 I & 150,188 \\
\hline I 5 and under 20 shillings & .. & 21 & 27,366 \\
\hline Io and under I 5 shillings & .. & 27 & 47,131 \\
\hline 5 and under to shillings & .. & 14 & 7,072 \\
\hline 2s. $6 \mathrm{~d}$. and under 5 shillings & .. & 5 & $2 I, 99$ I \\
\hline Under $2 \mathrm{~s} .6 \mathrm{~d} . \quad \ldots \quad \ldots$ & .. & 15 & 57,500 \\
\hline
\end{tabular}

* Report of Chief Registrar Friendly Societies, I9I I, Part A, p. 33. 
The total number of workmen in the insured trades who were able to claim unemployed benefits before the Government Insurance Scheme was introduced in I9I2 was 404,090 .*

This table on page 80 shows that the Danish trade unions spent a much higher percentage of their income on unemployment and travelling benefits than those of any other country in the world. The American trade unions, on the other hand, spent less than any other industrial country. This is a result of the different policies pursued by the two groups of bodies. In socialized Denmark the benefit features of the unions are their prime purpose ; in trustified America their prime object is to strengthen their strike funds. In the former country organized labour demands better conditions of labour through the legislature. In the latter it fights the employers for them directly.

These figures relate to conditions in rgr2. Since then the British Unemployment Insurance Scheme has resulted in greatly stimulating the amount which unions devote to unemployment insurance in that country.

\section{State Intervention in Unemployment Insurance.}

We are now in a position to consider the advisability of State interference with unemployment insurance. Such interference in the past has been of two kinds: that of subsidizing existing schemes and of compelling workmen to insure in a Governmental scheme. All civilized states to-day recognize the duty of helping those who are reduced to destitution through lack of work or through other causes. It will be seen later that in order to carry out their function effectively various plans for money relief and relief works have been attempted. These have, however, proven so unsatisfactory that in most industrialized countries it has been found better to provide against the

* See Tables showing the Rules and Expenditure of Trade Unions in respect of Unemployed Benefits, and also showing earnings in the Insured Trades, I9I I, Cd. 5703, p. 16. 
effects of unemployment by helping individuals to insure against them. The justification of State intervention, therefore, rests on (I) the inability of workmen to bear unaided the effects of unemployment and '(2) the acceptance by modern society of the humanitarian duty of preventing starvation through want. 


\section{THE “GHENT SCHEME"}

\section{Unemployment Insurance in Belgium.}

IN order to encourage insurance against unemployment in Belgium,* grants are made from the communal unemployment funds to unemployed members of trade unions affiliated to the communal fund and to members of provident societies. This system of subsidies from public funds towards provision made by workmen against unemployment is known as the "Ghent Scheme," from the name of the town where it was first successfully operated in I90I. $\dagger$ This scheme has been adopted with slight modifications throughout the country and in various other countries.

In I902 there were eight communes which assisted schemes of insurance against unemployment. In I9I4 there were in existence 29 municipal or inter-municipal funds representing IOI municipalities. Most of these operations were suspended during the war, but since the armistice the number of unemployment insurance societies and municipal insurance funds have greatly increased. There are now 84 municipal funds representing 627 municipalities. The membership of the unemployment insurance societies at the end of December I920, was over 800,000 , as compared with 126,278 in I9I3.

Since 1907 the national Government, through the

* For further information on general labour conditions The Labour International Handbook, $192 \mathrm{I}$, is recommended.

$\dagger$ Such an arrangement existed in the province of Liége in 1898 , but it was not until Ghent adopted it in I90I that the idea began to spread.

$\ddagger$ Moniteur Belge, January I, I921. 
Minister of Industry and Labour, has granted a subsidy in addition to that granted by the Communes towards funds of insurance against involuntary unemployment. In that year only communal funds were subsidized; but since then direct encouragement has been accorded also by the State to funds affiliated to communal funds, and even to certain non-affiliated funds provided that they belonged to a recognized $*$ professional union.

\section{Measures for Treating Unemployment before 1901.}

Until the introduction of the Ghent system of unemployment insurance the only signs of a recognition of public responsibility for the unemployed in Belgium were the existence of a number of free municipal, co-operative, and philanthropic employment bureaus in almost every city, and of labour colonies, dépôts de mendicants of Merxplas, and the Maisons de Refuge of Wortels and of Hoogstraeten, which are in fact punitive institutions for beggars and vagrants. In addition, the Belgian Labour Office published in the Revue $d u$ Travail annual reports of unemployment. Until fifteen years ago the number of trade unionists in Belgium was on the whole very insignificant, and these aimed chiefly at mutual aid during trade disputes. Moreover, these labour organizations were in a precarious condition, and thus no permanent unemployment insurance scheme could be organized.

\section{Trade Union Activities.}

Yet out of the 145 unions existing in I90 r, 50 had organized unemployment insurance. In Ghent, out of

* The unions which desire legal recognition are as a general rule the Catholic unions. Unions affiliated to the party of working class socialists and independent unions, such as the Typographers' Union, are loath to submit to the conditions necessary to gain the benefits of recognition, especially to the obligation to give the administration detailed accounts of receipts and expenditures of the union, as well as an undertaking in advance to try and settle all disputes concerning the conditions of labour by conciliation and arbitration.-Bulletin de l'Association pour la lutte contre le ch6mage, No. I, pp. $67,68$. 
the total working-men population of 36,500 , about 20,000 belonged to trade unions.

A few characteristics of Belgian trade unions are worth noting. The practice of granting higher or lower benefits according to the length of time during which a member has belonged to the union, so common in the British and German labour organizations, is not followed in Belgium. Nor does length of membership in the union affect the period for which benefits are provided. The unions usually lay down uniform rules relating to all members, with no regard to the length of time for which they have been connected with the organization.

The Belgian unions recognize two kinds of unemployment. One is ordinary unemployment caused by lack of work, and the other is temporary unemployment caused, e.g., by a breakdown of a chimney or by a fire. There exist two different rates of assistance for these two species of unemployment. But in some unions the compensation in case of unemployment of the first class is higher than that of the second, whilst in others exactly contrary rules prevail.

Many Belgian unions grant benefits also in case of partial unemployment.

Towards the close of the nineteenth century the question of unemployment in Belgium became urgent. In I894 the city officials of Brussels and of its six suburbs ordered an inquiry into the problem, the results of which were to serve as a basis for the organization of a mutual insurance fund against the risks of unemployment within the territory represented, such fund to be aided out of the public treasury.

A similar investigation was made in Mons in 1896. In I898 the City Council of Ghent appointed a Commission to devise some effective agency for unemployment relief.

\section{The Ghent Commission on Unemployment.}

The Commission recognized the difficulty of establishing a stable basis for unemployment insurance on 
account of the lack of sufficient data on which to formulate probability tables, the lack of uniformity in risks, and the difficulty of distinguishing between simulated and real involuntary unemployment. It disapproved of both voluntary and compulsory unemployment insurance schemes. It was then proposed that the city distribute annually among workmen who, previous to their unemployment, had made some effort to provide for such a contingency, an amount proportional to their savings. This distribution, it was suggested, should be made through trade union unemployment insurance funds as well as through a savings fund to be established especially for that purpose. In this way it was hoped not only to increase the number of working men who would insure themselves against unemployment through their trade unions, but also to net into the scheme those workmen who did not already belong to and who were not willing to join trade unions.

\section{The Law of June 3, 1901.}

The recommendations of the Commission were embodied in a law which came into operation on August I, I90I. In I903 the three suburbs of Ghent-Ledeberg, with a population of I4,226, Mont Saint Armand, with a population of about the same number, and Gendbrugge, with a population of II,743-joined the Ghent fund, thus forming the so-called Ghent Intercommunal Fund. (The communes of Waerschoot, Wettenen, and Hensden have since been admitted to membership in the fund.)

The trial period of three years showed that the scheme was successful in stimulating self-help, and so the City Council voted unanimously to continue the system and to make it a permanent institution.

Workmen involuntarily unemployed, living in Ghent and in the communes which are participating in the scheme, are entitled to subsidy by making provision against unemployment either through organizations or through individual savings. The only organizations 
which in fact make such provision are the trade unions, and the success of the Ghent scheme has been attributed to their freedom in administering their own funds. On the other hand, the provision of subsidy to individual savings, whether through savings banks or provident societies, has hitherto met with little success. Claims have been very few, though all that was necessary to receive the subsidy was to show that the withdrawal of funds was due to unemployment. This seems all the more remarkable when it is recalled that the rate of subsidy provided to workmen claiming trade union unemployment insurance and to those withdrawing private savings is the same.

\section{The State Grant.}

The State grants to approved societies a subsidy equal to 50 per cent. of the contributions paid by members, subject, however, to the restriction that contributions in excess of 75 centimes* a week in industries with seasonal unemployment, and 50 centimes a week in others, were not to make exhaustive claims on the fund. This provision was necessary both as a protection to the funds and to prevent members of unions paying high benefits for long periods from receiving in addition most aid from communal funds. It was meant to prevent the poorer trade unions from being discriminated against.

The general conditions in trade unions for the receipt of unemployment benefit are recognized by the State as acceptable. These provide that the unemployed member shall have paid an unemployment contribution for a defined period and of an amount which is more or less arbitrary. Benefits are not paid until the recipient has been out of work for a certain number of days, usually three to eight. Limits are, as a rule, laid down for the period during which the benefit will be paid. The State, in providing grants, allows members who have

* In 1914 there were $25^{\circ} 2$ francs (Ioo cents $=$ I franc) to $€ \mathrm{I}$. 
not completed the qualifying period to draw the same benefit as full members up to a maximum of three francs a day.

It should be noted that the State subsidy is in addition to the communal subsidy, but previous to the war it was generally regarded by State officials to be undesirable for the total subsidy from public funds to be greater than the trade union benefits.

The Government pays, in addition, 50 per cent. of the administrative expenses of the municipal unemployment fund.

\section{Advantages and Disadvantages of the Ghent Plan.}

The Ghent plan was thought to have many advantageous features. First, there was the ease with which it could be started and at once operated on a large scale. As over 50 per cent. of the workmen were organized in trade unions, the expenses of organization and propaganda could be saved. Second, it was thought that this system would induce workmen to make greater efforts in providing against the possibility of unemployment, since subsidies were to be given in proportion to personal thrift. Third, the administration of the system would be very simple and inexpensive. It left the whole management to the trade unions, organizations well adapted to judge whether a man is really involuntarily unemployed or not. It was then to the interest of every member of the union to see that no abuse was tolerated. Every month each trade union desiring to share in the municipal subsidy was to submit to the special Controller designated by the municipality an account of the state of employment and of the benefits paid to the unemployed members. The Controller was pledged not to divulge any personal information to anyone but to members of the administrative committee of the municipal fund. The operation of a scheme of unemployment insurance through trade unions thus tended to reduce both the cost of the scheme and the danger of malinger- 
ing to a minimum. Fourth, in Belgium trade unions are regarded as having an indisputable social value and are treated as powerful engines for forcing up the standard of life of the working class. Their indirect encouragement through the disbursement of public subsidies was therefore used as an argument in favour of the Ghent plan in many quarters.

But the optimism of the early supporters of the scheme has now given way to the view that it is inadequate as a solution of a pressing national problem, and indeed the growth of opinion in Belgium, the country where the scheme of subsidizing voluntary arrangements against unemployment was first introduced, in favour of a compulsory scheme of unemployment insurance is characteristic of the change which has taken place on this subject in most industrialized countries within recent years.

The Belgian section of the International Association on Unemployment adopted the following principles as regards insurance against unemployment:-

(I) Insurance against unemployment ought to be compulsorily extended by degrees to all who are subject to the risk of unemployment.

(2) It ought to be organized on a trade basis and in close connection with the employment exchanges.

(3) The existing institutions ought to be utilized and developed.

(4) An insured person ought to be free to choose his unemployment society.

(5) The efforts of the workers ought to be supplemented by the support of employers and public authorities.

In effect, the body consisting of experts in unemployment questions and of experienced administrators has definitely thrown over all confidence in the possibility of extending the Ghent scheme sufficiently to meet the evils of unemployment and has declared in favour of a 
scheme on the lines of the one in Great Britain. When, however, we learn that in spite of the considerable increase in the number of trade unions probably only one-half of the industrial population of Belgium has yet been reached, and that the workmen who have been subsidized are, as a rule, the better paid workmen, then it is not difficult to appreciate the reason for the growth of opinion favourable to a compulsory comprehensive scheme.*

* "Growth of the Compulsory Principle," p. 422, Avril-Juin I914, Bulletin Trimestriel pour la luttre contre le chomage. 


\section{UNEMPLOYMENT INSURANCE IN FRANCE}

THE peculiar interest which attaches to the institution of unemployment insurance in France arises first from the fact that, unlike the English and German and very much like those of the United States, French trade unions have not yet developed to any degree schemes of unemployment benefit, and secondly, from the consideration that it was the first country to adopt as a national system the Ghent plan of subsidizing voluntary funds of insurance against unemployment.

National encouragement to voluntary associations did not come into effect until I905, although repeated efforts had been made since 1893 to carry a Bill in the National Assembly for this purpose. Between I893 and I905 there were no less than thirteen Bills introduced on the subject of unemployment insurance.

The investigations of the French Labour Office in r 896 showed that a large number of cities and communes provided an annual budget of more than I00,000 francs for relief works to support unemployed persons. Many of these provided only work in removing snow and ice, while others engaged in such work as improving local parks, draining and grading the common land, work on sewers, and a variety of outdoor construction works.*

In addition there were the philanthropic organizations similar to those in Great Britain and the United States which provided work or relief for the unemployed.

* Workmen's Insurance in Europe, vol. i, Twenty-fourth Annual Report, p. 946 . 
These two classes of relief measures, public and private, and the annual attempts to introduce a Bill dealing with unemployment insurance show the measure of appreciation of the importance of and interest in the problem of alleviating distress due to unemployment. This interest was at once an effect and a cause of the growth of a vast body of literature dealing with various aspects of the unemployment problem, much of which was of the highest scientific value.

Trade union unemployment benefit funds were, and still are, of minor significance in France. Created at a later date than in England or Germany, they have never enjoyed wide popularity.

In I894 there were 87 trade unions with 16,250 members which regularly provided out-of-work benefits to their unemployed members. In 1902 there were 3 Io unemployment funds organized by trade unions. About one-half of this number were local organizations of the Typographical Union. They had about 30,000 members and an expenditure of about 200,000 francs. Less than 5 per cent. of the workmen in all the trade organizations were entitled to unemployment benefits. The Typographical Union was the only nationally organized union which provided this feature. With the exception of that union, little progress had been made in trade union insurance against unemployment before I902. In that year the Permanent Committee of the Conseil Supérieur du Travail investigated the whole problem, and in 1903 its views, somewhat modified by the general body, were accepted. It recommended :-

(I) That the creation and development of institutions for insurance against unemployment should be facilitated.

(2) That all the local funds for providing relief against unemployment should be subsidized by municipalities to the extent of a share of the normal annual subvention smaller in amount than the dues paid by the members participating. 
(3) That local funds should receive subventions from such bodies as chambers of commerce and employers' associations, and that it is the duty of employers to aid unemployment funds.

(4) That recognition shall be given such trade union unemployment funds or other funds engaged in finding employment for persons involuntarily out of work, whose organization is susceptible of an effective control. The subventions of the State should be especially intended to assist in defraying the expense of transferring unemployed persons, and should not exceed 50 per cent. of the expenditures for removal paid out in the course of the year by each fund.

(5) That the State should intervene in behalf of the creation and development of institutions for the relief of unemployment either by means of subvention or by other methods.

(6) That unemployment benefits should not exceed one-half of the workman's usual wage.

(7) That the State shall subsidize working men's funds which are not local but which give unemployment insurance to whole regions or districts or to the country as a whole.

The Council thus proposed that strictly local societies should be subsidized by the local authorities and that national societies or institutions which cover wider areas should be subsidized by the National Government. It also urged that bodies directly responsible for and interested in unemployment, such as employers' associations, chambers of commerce, etc., should contribute to the support of unemployment societies.

We shall see how the State has subsidized the funds of national organizations and how in Lyons and Paris the city authorities have subsidized local funds, while in Roubaix the employers co-operating with the city have encouraged organized provision against unemployment. 


\section{The National Scheme (amended in 1906, 1908, and 1912).}

The finance law of April 22, I905, provided an appropriation of II0,000 francs for "subventions for the purpose of relieving unemployment." Subsidy was granted by the State:-

(I) To funds composed of members engaged in the same occupation, in the same trades, or in allied occupations belonging to establishments turning out a specified product, on condition that there were at least roo members in them.

(2) In communes of less than 20,000 inhabitants, to local funds composed of members belonging to different occupations on condition that they received subventions from the communes and had at least 50 members.

(3) To funds organized by federations of unions to provide relief in the form of travelling benefits which were supported by lump-sum contributions from each affiliated union, on condition that the normal resources of these unions were derived from dues of their members.

Subsidy was granted in proportion to the benefit paid in respect of involuntary unemployment due strictly to want of work. The rates of subsidy were at the outset 20 per cent. to funds extending to at least three departments, i.e. to general associations, and 16 per cent. to local associations. In 1908 these rates were raised to 30 per cent. and 20 per cent. respectively. The reasons for this differentiation are obvious. The intercommunal or interdepartmental character of the districts or national funds diminish their chances of receiving local subventions, and they have, therefore, a claim to higher subventions from the State. Moreover, they were regarded as more effective agencies for dealing with the unemployment problem. It is, moreover, unlikely that 
its members will all suffer from unemployment at the same time or in the same degree.

In order to be entitled to claim the State subsidy, a fund must have been in operation for at least six months, and the total amount received by it as members' contributions in respect of unemployment insurance must at least equal one-third of the total amount paid as unemployed benefit to members out of employment.

Subsidy is paid half-yearly to the associations, most of which are trade unions. A proportion of the unemployment benefit paid out by them from their own resources is then refunded to them. Subsidy is not paid on more than two francs per day of benefit or in respect of more than sixty days in any one year; the maximum amount of subsidy for each insured workman in any one year amounts to 27 francs.

A separate record has to be kept of the benefits paid to each member. But in the case of trade unions it is sufficient to earmark part of their total contribution for unemployment benefit purposes, and thus to calculate the amount of subsidy that can be claimed for members.

\section{Check on Unemployment.}

y. The fund must supply the free service of an employ$\checkmark$ ment exchange to unemployed persons. This requirement produces no difficulties, since most unions already have an organization of this nature. In I9I3 there were I 40 employment exchanges administered by trade unions. Indeed, Professor Sombart writes that "French trade unions have one special characteristic in that they have brought labour exchanges to a high state of development."

The unemployed person is required to accept employment in his occupation when it is offered him by the fund. He must sign the register kept at headquarters or in special offices of the fund at least three times each week during the hours of labour. The Unemployment

* Sombart: Socialism and the Social Movement, p. 236. 
Commission can, however, accept the entire method of control specified in a constitution which offers an equivalent guarantee.

Provision was made for the formation, in connection with this scheme, of an Unemployment Insurance Fund Commission, whose duty it is to supervise the proper execution of the decrees. This Commission is annually appointed, and consists of one Senator, one Deputy, one Director of Labour, the Director of Insurance and Social Providence or his delegate, the Director-General of Public Accounts or his delegate, and the Inspector of Finances, the Assistant Director of Labour and four representatives of the Unemployment Insurance Fund representing the insured members. These latter are chosen by the Minister of Labour.

STATISTICS SHOWING THE GROWTH OF INSURANCE AGAINST UNEMPLOYMENT, I9IO-I2.

\begin{tabular}{|c|c|c|c|c|}
\hline & & s910. & IgII. & 1912. \\
\hline Subsidized funds ... & .. & 106 & I I 4 & $I_{4}$ \\
\hline Membership $\quad$.. & . & 42,305 & 48,089 & 49,595 \\
\hline Cases of unemployment . & & 8,493 & 8,609 & 8,429 \\
\hline Days for which benefits w & aid & $\mathrm{IO}_{4}, \mathrm{O}_{4} \mathrm{O}$ & I 6,373 & 209,564 \\
\hline Total benefits (francs) & $\ldots$ & 205 , I 59 & $224, I_{5}$ I & $209,5^{64}$ \\
\hline Subsidies granted (francs) & - & 42,869 & 50,726 & 47,542 \\
\hline
\end{tabular}

Most of the State grant went in subsidies to the funds of five national trade unions. These had 275 local branches. They covered, however, those of only two industries, of typography and engineering.

The State has also subsidized fourteen funds which were not attached to trade unions; eight of these belonged to benefit societies and six were independent organizations inaugurated for this purpose.

It is instructive to find that the general funds for workmen of many professions have made no progress in cities of over 50,000 inhabitants. In I9I2 there were four such funds having a membership of 502 . 
SUBSIDIES VOTED AND GRANTED DURING I910-12 TO DEPARTMENTS AND CITIES.

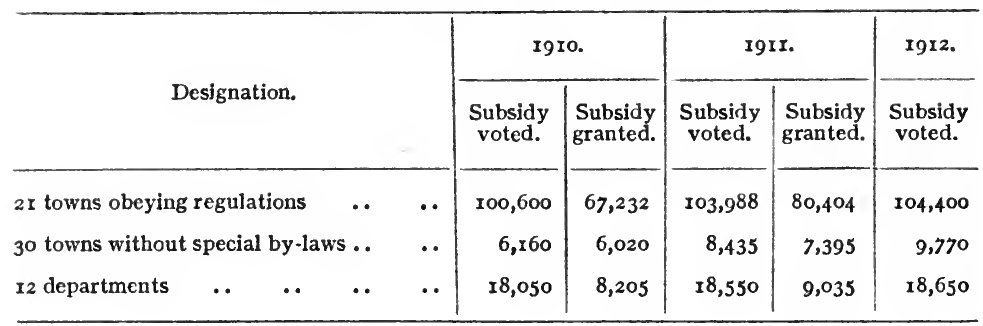

OPERATIONS OF THE STATE SUBVENTION IN 1913.

$\begin{array}{lllll}\text { Number of funds subsidized } & \text {. } & \text {. } & \text {. } & \text { II } 7\end{array}$

Aggregate membership $\quad . . \quad \ldots \quad$. $\quad$.

Expenditure of funds on unemployment bencfits 233,482 francs

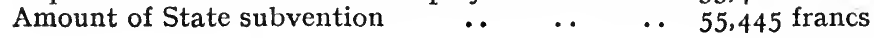

\section{Municipal Schemes.}

The two towns in which the subsidy against unemployment is of most importance are Paris and Lyons. The city of Roubaix has a scheme which differs somewhat from that in the larger cities.

\section{PARIS.}

In 1902 the Municipal Council of Paris received the proposal to assist insurance against unemployment. In I904 a credit of 25,000 francs was voted for this purpose, but a scheme was not developed and distribution of subsidies did not begin until I909. In that year $2 I, 82 I$ francs were distributed amongst 22 unemployment insurance funds. 20 per cent. of the benefit paid out by them was provided by the municipality on the same conditions as had been adopted by the State since I905.

In I9II the subsidy was raised to 25 per cent. Meanwhile the number of funds had increased to 29 , the credit voted was now 106,255 francs, and the amount distributed 26,555 francs. The typographical and engineering unions received the highest subsidies. 
Lyons has made greater progress with respect to the increase of insurance funds claiming subsidies than any other town in France. This is because the subsidy to workmen is extraordinarily high-higher, in fact, than is allowed them under any other system.

When the subsidies were introduced in 1905 there were 25 funds supported by 2,868 members. In I9I2 there were 48 funds and 3,834 members.

The following figures show the situation during the last three years for which we have statistics:-

SUBSIDIZED FUNDS IN LYONS, I'IO-I2.

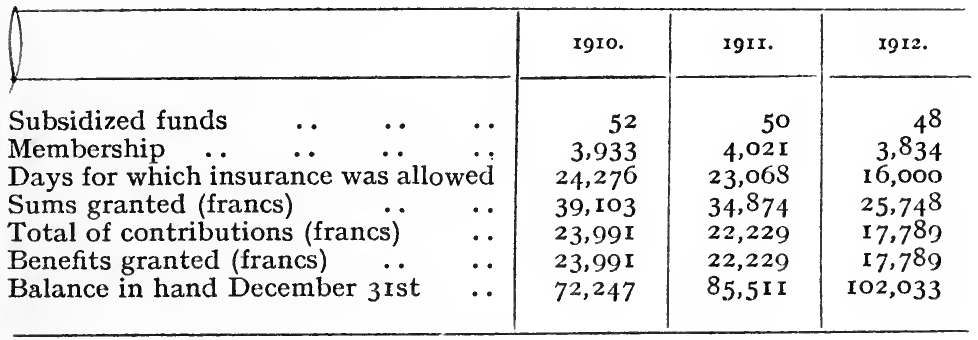

I,003 silk weavers distributed II,360 francs in unemployment insurance and received a subsidy of 6,736 francs. There were 740 members of the printing trades who distributed 9,642 francs and received 4,565 francs in subsidy. $5 \mathrm{I} 6$ woodworkers expended 1,567 francs and received 2,784 francs, i.e. nearly double their expenditure.

As a result the city subsidies formed more than half the amounts distributed: 61 per cent. in I9Io, 63 per cent. in IgII, and 69.5 per cent. in IgI2. In addition the State subsidy of 20 per cent. or 30 per cent. must be added. Thus over 80 per cent., and in some cases 90 per cent., of the expenses of unemployment insurance was provided by public bodies, whilst in individual cases funds received more than the total amount of their expenditure on this object. 
It would be absurd to argue that the experience of Lyons shows that the idea of subsidizing insurance funds against unemployment has proven at all successful there. What is surprising is that the whole scheme has not been taken much greater advantage of, and that the evils of demoralization in an aggravated form that might have been anticipated have so far not disclosed themselves.

\section{Roubaix.}

The scheme at Roubaix (a centre of the textile industry, with a population of 120,000 ) has a number of distinguishing features.

The present scheme was launched in December I907, and was supported by the municipality and a group of employers. The municipality does not control it, and, as a result, a serious distrust of the whole scheme was manifested by the workmen concerned. Subsidy is paid by an association to funds for insurance against unemployment effected through such organizations as friendly societies or trade unions, and privately, either through the Roubaix savings banks or the postal savings banks. The same rate of subsidy is paid on insurance and savings.

When the scheme was inaugurated there were only two associations which provided unemployment insurance. In IgI2 there were eleven.

STATISTICS SHOWING GROWTH OF ROUBAIX SCHEME, I9ro-I 2.

\begin{tabular}{|c|c|c|c|c|c|}
\hline & & & I9Io. & I9Ix. & 1912 \\
\hline Subsidized funds & .. & .. & 7 & 9 & I I \\
\hline Membership $\quad . \quad \ldots$ & 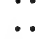 & $\ddot{0}$ & - & 2,408 & 2,408 \\
\hline Number of unemployed & $\cdots$ & $\cdots$ & 205 & 317 & 383 \\
\hline Days of unemployment & .. & .. & 3,075 & 6,100 & 7,351 \\
\hline Benefits distributed (francs) & $\cdots$ & $\cdots$ & 4.791 & 8,957 & 8,957 \\
\hline Subsidies granted (francs) & .. & $\cdots$ & I,537 & $3,8 \mathrm{r} 6$ & 5,521 \\
\hline
\end{tabular}


Although the results indicate a steady growth of members of unions claiming a subsidy, they are on the whole disappointing. This is accounted for by the facts that when the scheme was inaugurated in Roubaix, only two associations provided unemployment insurance, and because the unions were suspicious of the motives which impelled employers to contribute to the scheme. The unions were opposed to the receipt of charity and feared that the employers wanted to use the scheme for their own purposes. In order to disarm any further hostility on the part of trade unions, arrangements were made by the administrators of the scheme which would protect their members' interests. Industrial disputes are not interfered with, and workmen are not obliged to accept a post offered them which is vacant because of a strike. Now, each member of an affiliated society has a number, and when the committee passes on a case concerning the right to receive a benefit it cannot know whose case is being decided. The State Inspector of Labour exercises the necessary check on the cases in respect of which subsidy is claimed. But even if this suspicion be slowly removed, it is now realized that the granting of a subsidy to those already making provision against unemployment cannot be expected to lessen materially the evil consequences of unemployment in Roubaix.

The insurance organization in the silk-spinning industry merits at least a reference. An Act of June II, I909, provided for a mutual insurance society in the industry. Six per cent. of the bonuses paid to the spinners is subtracted and is placed in a fund which insures members against sickness and unemployment. Everyone employed in the industry, and a big majority are women, has the right to enter the society. In I9I2, 8,238 workers, nearly half of whom lived in the Gard district, were thus insured. It is a significant fact that this insurance organization has a membership which is dwindling from year to year. 


\section{INSURANCE 'AGAINST UNEMPLOYMENT}

\section{Recent Developments.}

In I9I5 there were about I35 trade union unemployment insurance funds with a membership of about I8,000. The State subsidies granted in that year had diminished to 30,022 francs.

During the war the activities of the existing unemployment insurance funds greatly decreased. Special unemployment relief funds were instituted by the Government to deal with the unemployment problem. Since the armistice, however, the trade unions and the State have operated the I905 Decree.

According to the Journal Officiel, * three departmental and forty-five municipal unemployment funds were in operation, the total number of persons in receipt of outof-work benefits being 30,608 (28,696 men and I,9I2 women).

The maximum number of unemployed in receipt of benefit, viz. II6,000, was reached in April I9I9. Of these 77,5I4 were in Paris and I7,300 in other communes of the Seine Department.

Special measures were adopted for meeting the problem of unemployment during the war. Early in the war each department or town with more than 5,000 inhabitants was asked to set up an unemployment fund, to which the State repaid a third of the relief distributed. These funds were administered in conjunction with the employment exchanges by commissions representing employers and workers in equal numbers.

The dislocation created by the war produced a considerable volume of unemployment, but the demands for munitions and war industries soon reduced the calls on the unemployment funds. Thus in October I9I4 the unemployment fund of Paris distributed relief to about 300,000 persons, but the numbers of recipients gradually decreased, and at the end of I9I8 was less than I0,000. In I9I8 the increasing difficulty of pro- 
visioning and the increased cost of living resulted in a decree promoting the creation of funds to provide against partial unemployment. Employers were obliged to contribute at least one-third of the expenses and a State subsidy of one-third was granted. The Government grant was raised after the armistice to 60 per cent., then to 75 per cent. of the expenditure, until November 15, 19I9. In addition, women on their discharge from Government factories or factories engaged on Government work were granted a gratuity equal to one month's pay.

An interesting measure adopted by the Minister of Munitions refers to " temporary," or rather " partial," unemployment. A minimum wage is provided, even in the event of workmen becoming partially or totally unemployed for want of work, without rescinding the contract of service. They are maintained in employment, notwithstanding cessation of work due to lack of coal or raw materials, except in the case of dismissal authorized by the Minister of Munitions. The unemployment allowance provided by this means is equal to the difference between the wages actually earned and the minimum wage. It is borne partly by the State and partly by the employer in a proportion fixed by the contract.

\section{Summary.}

It is clear that whilst the growth of insurance against unemployment has not been very marked, it has been influenced by the incentive of the subsidy offered by the State, Department, and Commune. This progress, however, has not justified the sanguine hopes of those who were instrumental in introducing the scheme. This result is of particular significance to the United States where the number of unions providing out-of-work benefits is even smaller than it was in France when that country decided to endeavour to stimulate insurance against unemployment.

There is little evidence to show that the very serious 


\section{INSURANCE AGAINST UNEMPLOYMENT}

amount of unemployment in France is likely to result in a compulsory scheme of unemployment insurance on the British model.*

For a description of the schemes of Armentières, Troyes, Lille, Limoges, Rheims, Dijon, Loire, see I. G. Gibbon, Unemployment Insurance, and the International Bulletin against Unemployment, Fourth Year, No. I, pp. I20-I.

* The Organization of Unemployment Insurance and Employment Exchanges in France, International Labour Office, Geneva. Studies and Reports, Series C, No. 5 . 


\section{S W I T ZER L A N D}

SwITZERLAND has played a great part in the development of the world movement for unemployment insurance. She boldly experimented with a compulsory scheme more than two decades ago, and although this proved a failure, is now, with her added experience, undertaking another scheme of insurance embodying the principle of compulsion. Trade union unemployment insurance is highly developed. Employers have subsidized schemes of workmen's funds. Most communes provide grants to voluntary systems of unemployment insurance.

Here, as in most other countries in Europe, trade union unemployment insurance is by far the most important method of protecting workers against unemployment.

In I9I4 the Trade Union Federation of Switzerland had seventeen federations of trades or industries which organized unemployment insurance funds for about 50,000 members. Sixteen trade unions paid travelling benefit, ten "removal benefit" and three "leaving" benefit. The total expenditure for the year I9II-I2 was I40,440 francs, of which $90,85 \mathrm{I}$ were paid in unemployment benefits, the remainder going as travelling benefit and in the exemption of payment of dues to unemployed members.

As in Germany and Belgium, large bodies of Catholics have organized into Christian trade unions. Ten of these unions, comprising a membership of about II,O0O, provided unemployment insurance in I9I4. The Printers' Federation of French-speaking Swiss, and the 
Federation of Draughtsmen of Eastern Switzerland, also have unemploynent funds. There are now twentyseven associations of workers which insure their members against unemployment, with a total membership of about I40,000.

\section{Subsidized Trade Unions.}

The law of 1894, passed in the canton of St. Gall, authorizing it to set up a compulsory scheme of unemployment insurance, also empowered it to subsidize insurance against unemployment provided by voluntary associations. In 1905 the payment of subsidies began. In I9I3 the amount of subsidy voted was 50 per cent. of the benefits paid out of trade union funds as against 35 per cent. during the three previous years. The number of subsidized funds rose from four in rgro to eight in I9I3, and the grants, which in I9ro amounted to 735 francs, figure in the budget for I9I3 at 2,669 francs.

The grants in the canton Appenzel-auser-Rhoden amount to 2,000 francs a year. In the canton of Geneva the subsidy amounts to 60 per cent. of the trade union benefits. The number of subsidized funds has increased. In I9II, I,953 francs were distributed as subsidy.

In the canton of Basle town the subsidy amounts to 40-50 per cent. of the benefits paid to trade unions by the canton. In IgII, the first year of the scheme's operation, the funds of five trade unions were subsidized to the amount of 3,I95 francs; in I9I2 subsidies were distributed amounting to $3,4 \mathrm{I} 2$ francs.

On November 8, I9I3, the Municipal Bureau of Zurich proposed a scheme to the Municipal Council providing for the organization of unemployment insurance on the double basis: (I) of a voluntary unemployment insurance scheme and (2) of communal subsidies to private funds. It was estimated that the scheme would cost 40,000 to 45,000 francs a year. 
Subsidy to workmen making provision against unemployment has been provided through special grants to trade unions and through the institution of special funds which receive public subventions and are inaugurated by some public authority. These voluntary public funds exist only in the town of Berne and in the canton of Basle town.

The former scheme, the first municipal undertaking of this kind, came into operation in 1893 , but has not at any time in its history had as many as 700 members.

The scheme is limited to able-bodied Swiss citizens who are not over sixty years of age and who reside at Berne. Though in theory, at least, workpeople of all industries are allowed to insure themselves, the Municipal Committee has in practice declined to insure such highly casual workpeople as woodchoppers.

Skilled and unskilled workmen pay the same rate of contribution, i.e. about I5 centimes a week. The canton subsidy amounts to more than the contributions of insured members, and until recently the employers in the building trades subscribed an annual voluntary sum of Ioo francs. Benefit is provided only in respect of unemployment during a maximum period of seventy days between December and March. It is confined to those who have paid their contributions regularly for eight months and who have been remuneratively employed for at least six months in the preceding year. It is paid on a different scale for single men and for men with families-I.45 francs for men without, $I \cdot 92$ for men with, dependents. This fact, taken together with the very high subsidy, amounting in some years to over four times as much as is received in contributions from all the insured members, gives the scheme the appearance of a relief measure.

In IgII the number of insured members was 638 . It rose to 675 in I9I2, but fell again to 636 in I9I3. Most of the members are workmen in the building trades, who are specially subject to unemployment. Thus, during the three winters before the war, 57 per 


\section{INSURANCE AGAINST UNEMPLOYMENT}

cent., 5I per cent., and 50 per cent. of its members suffered from unemployment. The sums expended in benefits amounted to respectively $26,6 \mathrm{II}, \mathrm{I} 7,388$, and I9, I30 francs.

At Berne the donations and subscriptions from employers and the public at large have greatly diminished during the last few years.

The marked absence of success of this scheme is highly significant, because not only has it been revised again and again with a view to increasing its efficiency, but because it has avoided almost all the obstacles which have led to the failure of similar schemes. First, the management committee consists of representatives of the town council, of employers and of workmen, and is moreover a really satisfactory body. Second, the committee is also in charge of the employment exchange, and so it has the proper administrative machinery with which to carry out its policies. Third, it has wisely required the verification of the fact of unemployment by insisting that the unemployed workman attend at the municipal employment exchange twice a day. It has even gone further in providing a check to malingering. Public work is specially reserved to be done in the winter by insured persons who are unemployed.

The failure of this scheme is due to the inherent weakness of the principle which it embodies. Voluntary public insurance funds have nowhere been a great success. A movement is now on foot to abandon the present scheme of subsidies, where different occupations are lumped together, in favour of subsidies to each distinct fund of unemployment insurance in the city of Berne.*

The voluntary fund of Basle town, opened in rgro, has been more successful than that of Berne. The scheme of unemployment insurance in the former town differs from that in the latter in three important respects :

Insurance may be effected in Basle town either

* For rules and administrative regulations of the Berne Scheme, see Insurance against Unemployment, by F. 1). Schloss, Appendix I. 
through trade organizations or through a city scheme, but in either case a considerable subsidy is granted.

In the filling of vacancies through the municipal employment exchanges preference is given to persons who are insured against unemployment in either type of institution. Contributions and benefits are different in each of the three wage groups into which workmen are divided.

The voluntary fund of Basle town had 503 members at the end of I9I0. In I9I2 it had I,I08. As in Berne, workmen in the building trades form a majority of the insured members.*

The rates of contribution for those who join the voluntary fund are :-

For persons earning not more than 4.32 francs a day, 0.57 franc a month.

Persons earning between 4.32 francs and 5.75 francs a day, 0.77 franc a month.

Persons earning over 5.75 francs a day, 0.93 franc a month.

The rates of benefit for the first thirty-five days in the three wage groups are 95 centimes, I.I5 francs, and I.35 francs per workday for insured persons without dependents, and $I \cdot 52$ francs, $I \cdot 72$ francs, and $I \cdot 92$ francs per workday for members with dependents. For the remaining thirty-five days for which benefits are provided they are reduced to half these rates.

The benefits paid in I9II-I3 amounted to $I, 065$ francs, I5,070 francs, and 34,510 francs. The cantonal subvention was about 15,000 francs in I9II and 27,000 francs in I9I2.

The Basle scheme is one of the latest and best thought out schemes based on the principle of subsidization to voluntary schemes of insurance against unemployment.

\section{Crisis Funds.}

The most important example of a scheme of unemployment insurance which is organized and supported

* See I. G. Gibbon: Unemployment Insurance, pp. 136-7. 
by employers and workmen without State intervention is the Crisis Fund in the embroidery trade of St. Gall. An association of employers was organized to render financial assistance to provision made against unemployment occurring during years of industrial depression. This assistance was meant at first to equal about 50 per cent. of the total benefit paid to the unemployed members. The subsidy has now been raised to about 60 per cent. of the benefits provided, up to a maximum of $I \cdot 45$ francs per person per day.

By December I9o8 some fifty special crisis funds were formed by trade unions with a membership of 2,000. In I9I the membership of these funds was about 3,000. Their accumulated funds amounted to I38,940 francs.

The benefits are at the rate of $I \cdot 92$ francs a day for men and $I \cdot I_{5}$ francs a day for women.* The usual rates of contribution are 0.47 franc a month for men and 0.30 franc for women. Benefits are paid only to members of six months' standing, and are provided from the second day of unemployment for a maximum period of fifty days in the year.

The comparative success of this scheme is well attested by the fact that those interested in the clockmaking trade in the Jura Mountains of Berne have decided to institute a similar scheme. The income for financing it is to come from workmen's contributions, a cantonal grant of 5,000 francs a year and from the interest on a capital sum of roo,000 francs to be provided by those interested in the industry. Three-quarters of this amount was subscribed by I9I3.

\section{Compulsory Insurance against Unemployment.}

In I894 a scheme of compulsory insurance against unemployment of all workmen earning less than five

* The tendency of unemployment insurance to prevent the continuance of abnormally low wages has been clearly demonstrated in the case of the very badly paid homeworkers who are insured by the " crisis funds." They have refused to work for prices which give them a net wage less than the amount they can receive as benefit, and so the standard conditions in the industry have been improved. 
francs a day was passed in the canton of St. Gall. All insured members were to pay contributions, and the unemployment fund was to be further increased by subsidies from the local commune, the canton, and, if possible, from the national Government, as well as from gifts.

The administration of the scheme was bad from the very outset. Many a workman did not register under the scheme. Others did not pay their contributions. Some even migrated out of the cantonal area. The check on unemployment, now the central part of any scheme for unemployment insurance, was not adequate. Benefits were paid to those who had no right to them, and a few of the members received unduly large amounts from the fund. Malingering was thus encouraged. Indeed, some workmen who usually sought country work when work in the town was lacking now remained there and received benefits. The scheme was administered by the poor law department, and so the better class workmen opposed it from the start.

After two years the palpable defects of the scheme led to its abandonment. At least two questions of interest were presented as a result of the experience of St. Gall.

Can a compulsory scheme of unemployment insurance on a small, circumscribed area of the size of a town or a canton be successful? Should not provision be made in every scheme to encourage rather than to discourage unemployed workmen to adopt an alternative occupation?

In 1898 a scheme of compulsory insurance was brought forward in the town council of Zurich and another in I899 actually passed through the great council, but the former proposal was not ratified and the latter was rejected by a referendum.

For a time the general attitude towards obligatory unemployment insurance, both in Switzerland and abroad, was well represented by the following view.*

* Mr. Touron: Rapporteur-Général before the Conseil Supérieure du Travail, November I0, I9I3. 


\section{INSURANCE AGAINST UNEMPLOYMENT}

" The St. Gall scheme was the only attempt at compulsory insurance made by the State. I believe that it may be said that this example is sufficiently conclusive to put us on our guard against the temptation of renewing that experience. The failure of this compulsory scheme was indeed piteous." * But, as Mr. Gibbon points out, it was particularly unfortunate that it should have been necessary to discard this scheme of compulsory insurance against unemployment "largely because of palpable defects of administration without a fair test of the principles on which it was based." $\dagger$

A scheme which avoids some of the more flagrant opportunities for abuse was proposed on October I2, I9I3, in the city of Neuenberg in the canton of Neuchatel. It is confined to men and women employees in the clockmaking and other small mechanical trades, between the ages of eighteen and sixty-five years, whose annual income does not exceed 4,000 francs. Insured workmen are to pay contributions at the rate of 75 centimes a month. As in the British scheme, the employer is to contribute an amount equal to that of each workman in respect of each workman. The State is also to contribute an amount equal to that of each workman.

The benefits provided under the scheme are to vary according to sex and size of family. Unemployed workmen are to receive 2 francs 50 centimes for each day of unemployment, and insured women members $x$ franc 50 centimes a day. An additional 25 centimes is given for every child under seventeen years of age.

The maximum term for the payment of benefits is fixed, as a general rule, at sixty days. As a check on malingering, benefits were to be paid only in cases of need and after being duly investigated by the administration. It was estimated that about 10,00o persons would be insured under the scheme, including 7,800 men and 2,200 women.

- The employees of the municipality of Berne were compelled to insure in the municipal scheme. The compulsion was removed in 1903, and as soon as this was done they ceased to insure.

$\dagger$ I. G. Gibbon: Unemployment Insurance, p. 35. 
The main criticism of the proposal must be that unemployment insurance is not sufficiently clearly separated from poor relief. By providing benefits " only in cases of need " and by giving additional benefits to those who have children dependent upon them, the necessitous workman is to receive privileged treatment. A sort of pauper branding will tend to attach to those who obtain benefits, and criticism of the whole scheme will probably result from the better class of workman.

It will be interesting to see whether obligatory insurance against unemployment can be limited to one town, as is proposed.

The long-continued interest in the problem of unemployment insurance in Switzerland culminated in the resolutions asking for national intervention in this matter which were passed on June 3, I9I3.

\section{A Federal Subsidy to Unemployment Insurance Funds.}

By a decree dated March 24, I9I7, an additional tax on war profits is to be levied equal to 20 per cent. of that already payable under the decree of September I8, I9I6. The proceeds of this tax, together with three million francs of the proceeds of the war profits tax in r915, are to be devoted to the formation of a Federal unemployment fund. The fund is to be used to subsidize efforts made by cantons, communes or public utility enterprises for the purpose of relieving unemployment and distress.

The fund subsidizes unemployment insurance funds to one-third of the extent of their expenditure on unemployment benefit in I9I7 and I9I8. It is now proposed to bring forward legislation to make the co-operation of the Federal Government in unemployment insurance permanent.

Parallel with this development, progress can be recorded in the establishment of a centralized system of employment offices. The Federal Decree of October 29, I909, provided for Federal subsidies to existing employ- 


\section{INSURANCE AGAINST UNEMPLOYMENT}

ment agencies. A decree of the Federal Council of March 2I, I9I9, created a Federal Office of Assistance against Unemployment, in connection with the Département de l'Economie publique. This office is to develop public employment offices and to act as a central office for both public and private employment offices. 


\section{NORWAY}

THE countries in which the Ghent system has hitherto had marked success are Denmark and Belgium. In France and Norway the results have been disappointing. In the former countries a large proportion of the men and women wage-earners were organized in trade unions before subsidies were provided. In the latter a considerably smaller proportion were organized. Not only does the smallness of the number of union members in these countries affect the possibility of developing a national system of unemployment insurance on the basis of the Ghent scheme, but it has the psychological influence of making unionists suspicious of it. Only where unions ${ }^{-}$ are strong, as in Denmark and Belgium, Great Britain and Germany, have they welcomed State subsidization of unemployment insurance. Where they have been weak, as in France and in Norway, they have been disposed to look at it with suspicion and even with hostility.

Unfortunately for the success of the Norwegian scheme, the unions were, in addition, definitely provoked by a provision requiring them to admit non-union members into their organizations for the purpose of unemployment insurance.

In 1905 the Norwegian Government undertook to subsidize associations providing insurance against unemployment to the extent of one-quarter of the amount distributed by them in unemployment insurance to their members. But members in respect of whom subsidy was claimed must be Norwegian subjects, who had resided 


\section{INSURANCE AGAINST UNEMPLOYMENT}

in the country for five years. The conditions for the receipt of subsidy were:

(I) That benefit be paid only in respect of unemployment due to lack of work, and not paid when unemployment is due to sickness, a strike, a lock-out, or to any person who is a member of more than one association.

(2) That a member has no right to benefit unless he has been a member of the fund for at least six months and has paid his dues for at least twenty-six weeks since last becoming a member.

(3) That benefits (other than travelling benefit) were not payable in respect of unemployment lasting less than three days.

(4) That the amount of the unemployment benefit (including travelling pay) should not exceed onehalf of the average daily wages of the occupation which the recipient of such pay follows.

(5) That no one is entitled to receive more than ninety days' benefit in the year.

(6) That members of the society are obliged, in case of unemployment, to accept the work which the directors of the society regard as suitable for them.

(7) That if the ordinary dues prove insufficient, extra dues may be levied, and if it becomes necessary, a reduction may be made in the amount daily provided as benefits.

The law also requires that in places where a public employment exchange exists, the receipt of unemployment benefits shall be conditional upon the unemployed having registered themselves there as applicants for employment. It is significant here to note that "An Act for the Establishment of Public Labour Exchanges in Norway" was passed on the same day as the Unemployment Insurance Act.

There are other conditions which an unemployment 
insurance fund must fulfil if it is to enjoy the advantages of a public subsidy. At least one-half of the funds must come from the members' contributions. Its accounts relating to unemployment insurance must be kept distinct from its other funds, and its assets must be kept clear from its other assets.

As in Ghent, an attempt was made to extend the benefit of the scheme to unorganized sections of the working classes. With this end in view, the Act required every unemployment society connected with a union, prior to receiving any refund, to give all persons in the same occupation as members of the society access to insurance on the same terms, even though they were not members of the union. But such members were not to possess the right of voting concerning the by-laws of the society, or of taking part in the administration of its property, unless the association itself decided otherwise. In addition, where the association defrayed the necessary expenses of administration in relation to unemployment insurance, it might require from non-members an increase of Io per cent. to the ordinary contributions, and, with the approval of the Ministry, even a I5 $_{5}$ per cent. increase.

Trade union members objected, however, to having non-members entering "their" insurance scheme. The Social Democrat Members of Parliament tried to have the clause sanctioning it repealed. For a time it seemed as if a deadlock had been reached. Finally, the unions agreed to take advantage of the scheme if the subsidy were raised from one-quarter to one-third of the amount distributed. This was agreed to, and provided for in the Act of July 25 , I908. This quarrel was fought almost exclusively over a question of principle and was therefore dear to the combatants. As a matter of fact only one nonunionist actually demanded admission to a trade union fund in IgI2.

Up to I908 only one insurance fund claimed the benefits of the Act. But in I9I2, largely as a result of the increased subventions offered by the Act of I908, there were left only five associations, with a total membership of $\mathrm{I}, 68 \mathrm{I}$, 


\section{INSURANCE AGAINST UNEMPLOYMEN'I}

which were not subsidized by the State. Nineteen associations, having a membership of 27,000, received subsidies. In that year the benefits paid to members of the funds amounted to $\mathrm{r} 44,78 \mathrm{r} \mathrm{Kr}$ * and the subsidies provided by the State to $38,309 \mathrm{Kr}$. Less than 5 per cent. of Norwegian wage-earners enjoy the benefits of this subsidy. Indeed, one of the most marked, features with respect to the developrnent of this scheme on the Ghent plan has been the unwarranted confidence of the authorities in its powers of growth. $\uparrow$

The subsidy to unemployment associations, though paid by the State, falls also in part upon the local authorities (municipal or communal) within whose arcas the insured persons that receive subsidies have resided for a continuous period of six months in the previous five years. The local authority, the law provides, must reimburse to the Treasury two-thirds of the amount paid by the State in respect of these subsidies.

The Government controls the scheme, but gives the local authorities an inducernent for exercising an effective control over the unemployment situation. Of course, the analogy of poor law relicf was constantly before the framers of the Act. Poor law relicf was a charge on the communes, and so they were expected to bear the lion's share of the burden of a scherne which was likely to reduce the demands on it.

The control of the payment of subsidies is thus exercised by four distinct authoritics, i.c. by the trade unions, the public employment exchanges, the local authorities and, lastly, the State.

The law which has been described was in force up to the end of Igr4. A new law, framed by a special depart-

* In Norway and Ienrnark the standard crin is the krone, subdivided into Ion bre. In 1914 it was worth atornat is. I 3 d.

+ In July 1'yos the Reichs-Arbeitsblall, p. 673, wrote of the probable extension of the scheme to 42,000 organized workpeople. In igra Mr. I. (3. Cifibon wrote that at the end of that year 55 ,oro industrial workers and cornmercial employees would be insured. As a matter of fact, in 191227,000 workmen, or half the estimated number, really were insured a.painst unemployment. 
mental committee after conducting investigations, was put into operation in $19 I_{5}$.

Among the changes suggested in the then existing law were the following:

(I) An increase in the subsidies offered by the State and municipalities from one-third to one-half of the benefits to be paid.

(2) The shortening of the period of residence for foreigners who may wish to benefit by the law from five years to one year.

(3) The payment of unemployment benefits from the second day of the period of unemployment (hitherto unemployment benefits had been paid after the third day of unemployment), and if several periods of unemployment occur within the period of six weeks then the waiting period of two days is counted only once.

(4) Continuing the maximum period of ninety days for which unemployment support might be paid, but permitting a longer period as long as the war continued.

The committee stressed the necessity of a close cooperation between both public and private employment offices and between all unemployment insurance funds. To emphasize their interdependence it recommended the appointment of the same inspector to be head of the combined systems. The committee called attention to the fact that this is the method employed in Denmark and urged that this was the secret of the success of its system of unemployment insurance. In I9I9, it should be noted, there were public employment offices in fortyone towns and five communes.

It is impossible to foresee what will be the effect of these innovations, and especially of raising the subsidy. Experience certainly teaches us not to expect a very great increase of those insured.

In I920 there were twenty-nine associations with a 


\section{INSURANCE AGAINST UNEMPLOYMENT}

total membership of about 90,000, practically all of whom benefited by the subsidy.

The acute unemployment suffered in the early part of I92I has again led to the discussion of the necessity of introducing a national comprehensive scheme of unemployment insurance for all wage-earners. 


\section{HOLLAND}

THERE was no national system of State Insurance in Holland in 19I4, although repeated attempts had been made to induce the Dutch national Government to undertake the payment of a subsidy to workmen making provision against unemployment. On the other hand, insurance by municipalities was progressing steadily. The number of municipalities providing subsidy, the number of unions affiliated to funds and the number of individuals insured were increasing.

In February I9ro there were altogether twenty-four communal employment funds. Four more funds were established in Velzen, Flushing, Zwolle, and Baern before the outbreak of the war.

Subsidy is generally granted in proportion to the benefit received by unemployed workmen in respect of unemployment due to lack of work. In most municipalities it is distributed to associations providing unemployment insurance; in a few others it is provided only to insurance effected through associations whose membership is restricted to one trade or to allied trades. In Velzen associations affiliated to the funds must impose upon members the obligation of being also direct members of the unemployment fund. In Flushing and Zwolle subsidy is given only to associations formed for the prime purpose of providing insurance against unemployment.

In order to be affiliated to a fund in The Hague trade unions must provide that all their members are members also of their unemployment insurance scheme. Following the Norwegian system, unions affiliated to the fund are 
obliged, with certain exceptions, to admit also non-unionists of the same trade to their unemployment fund. Nonunionists may be barred entrance into a fund, but not merely because they are non-unionists. The union may charge non-unionists, i.e. those who have joined only for the purpose of insurance against unemployment, ro to I5 per cent. more as their contribution towards the administrative expenses of the scheme.

The number of trade unions affiliated to the unemployment insurance funds increased from 209 in IgII to $28 \mathrm{I}$ in I9I3 and their membership from I8,226 to 29,3I3. In I9II the unions paid 45,968 gulden in unemployment benefits; in I9I2 this amount rose to 50,I90 gulden.*

The subsidy to the unemployment funds was 37,906 gulden in I9II, and 42,070 gulden in I9I2.

There were in addition to these unions affiliated to the unemployment funds others that were not affiliated. They developed steadily between I9II and I9I3. In the diamond industry, where there has been the greatest growth, the amount distributed in benefits increased from 2,804 gulden in I9II to 5 I,806 gulden in I9I3. The growth is well shown by the following table:

January I, I9II : 295 associations, 25,375 insured members.

January I, I9I2: 287 associations, 24,214 insured members.

January I, I9I3: 374 associations, 29,563 insured members.

Some check is as a rule exercised to prevent malingering. In Haarlem, Deventer and Leyden the unemployed must report themselves daily to the employment exchange, and in Ninwegen they must do so twice a week. In Schiedam a committee investigates each case.

In IgIf a special questionnaire was submitted to the administrators of the municipal funds to elicit opinions on the British Insurance Act. It was found that opinion was evenly divided on the principle of compulsory insurance, and that objections were usually raised to the uniformity of the contributions, regardless of the varying unemployment risk in the different trades. Most of the answers

* The gulden or florin (= Ioo cents) was worth about Is. 81. in I9I4. 
approved of the division of the contribution into three parts, payable by employer, workman and the State. They approved of the scheme being administered through the employment exchanges and the recognition of and co-operation with trade unions.

\section{The Unemployment Decree of $191 \%$.}

This decree provided for the subsidizing of unemployment funds by the State. The subsidy is equal to that granted by the commune. The total amount of the subsidy, which is fixed in relation to the amount of members' contributions, may not, however, ordinarily exceed Ioo per cent. of these contributions. The effect of this additional subsidy has been to increase the number of trade unions affiliated to the State Unemployment Insurance Fund.

About ninety-five associations, comprising a quarter of a million members, grant unemployment benefit to their members. Benefits are paid for a period of twentyfour to ninety-one days after a waiting period of a few days. Not all these associations, however, are taking advantage of the subsidies.

In the early part of I92I the drain on the State Unemployment Insurance Funds and on the communal funds was particularly heavy. Thus in Amsterdam 24.5 per cent. of the members of trade unions affiliated to the State fund in that city were out of work in January I92I, as compared with 19.2 per cent. in the preceding month. These figures include diamond workers, of whom $86 \cdot 3$ per cent. were unemployed in January I92I, and 70 per cent. in December I920. 


\section{E N M A R K}

UNTIL the beginning of this century legislative efforts to deal with the problem of unemployment in Denmark were confined to the provision of "exceptional aid" to those who were in need during "dull" times. But this aid was not regarded as poor relief. By the law of March I0, I879, providing for arrangements to relieve distress occasioned by unemployment and the severity of the winter, the authorities of rural communes were authorized to make contributions from the communal funds, without requiring the consent of the county councils, to the local funds for the relief of the poor. At the same time there was given to the parish communes, to Copenhagen and to the provincial towns, full freedom to collect without ministerial consent the funds necessary for this assistance.*

In addition a non-interest bearing loan of one-half million kronen was put at the disposition of the communes by the State. $\dagger$

On April 9, I907, a law was passed whereby it was enacted that a commune which had during the fiscal year made direct cash contributions from its general funds to a fund for insurance against unemployment in the commune (in Copenhagen, to an aid society recognized as such by the Minister of the Interior) might claim

* Twenty-fourth Annual Report of the Commission of Labour, Workmen's Insurance in Europe, p. 649.

$\dagger$ During the opening years of this century the Labour Party agitated in favour of a State-aided subsidy to trade union unemployment funds. The Conservative parties opposed the proposal, especially on the ground that these unions were strongly political in character. 
a refund of one-third of this grant from the State treasury, " but the State grant was not to exceed ro öre per inhabitant of the commune according to the last general census." This was the first plan by which actual subvention from the treasury of the Government was provided for in Denmark.

\section{Trade Union Insurance against Unemployment.}

Before 1907, the most effective instrument for dealing with unemployment was the trade union. A large number of unions, especially those of the bakers, bookbinders, joiners, coopers, vat men in paper factories, typographers, smiths, and machinists, made arrangements for aiding their unemployed, and year by year the unions spent an increasing amount on this object.

The following statement is taken from the year-book of the Bureau of Statistics of Denmark, giving the estimated amount of money expended in benefits to the unemployed (including travelling benefit) by trade unions, each year, from I899 to I907, the year when the new law came into operation.

Trade Union Unemployment Benefits, 1899-1907.*

\begin{tabular}{|c|c|c|c|}
\hline $\begin{array}{l}\text { Year. } \\
1899 \quad . .\end{array}$ & $\begin{array}{c}\text { Öre. } \\
20,238,000\end{array}$ & $\begin{array}{c}\text { Year. } \\
\text { 1904 .. }\end{array}$ & $\begin{array}{c}\text { Öre. } \\
44,162,400\end{array}$ \\
\hline $1900 \ldots$ & $25,446,400$ & $1905 .$. & $49,445,200$ \\
\hline I9OI & $37,196,000$ & $1906 \ldots$ & $3^{2,895,600}$ \\
\hline 1902 & $44,195,600$ & 1907. & $30,254,800$ \\
\hline
\end{tabular}

These amounts were used exclusively for real unemployment benefit, that is, as aid to those who, although fully able to work, were without employment because there was no work to be had in their occupations.

Unemployment benefit has long been a popular feature of trade union activity in Denmark. In I904 there were ninety-four federations and individual societies, with a membership of 90, III organized workmen, and of

* Quoted from the Twenty-fourth Annual Report of the Commission of Labour. Loc. cit. 
these, eighty-three unions with a total membership of 80,205 , i.e. 89 per cent. of the total number, provided some form of unemployment insurance. But the different unions and federations followed their own plans. Some had distinct unemployment funds, whilst others carried unemployment as one of the risks which the general benefit fund had to bear. Some gave aid according to definite rules and others according to no definite rules. Most frequently the fund was controlled by the federation, and on occasion by the separate sections or local unions.

Some funds provided only for travelling aid, whilst others provided also for a maintenance fund. Some funds arranged for benefits under 5 kronen, whilst others again provided for benefits over 15 kronen a week.

But, despite the many legislative efforts along other lines and the voluntary activities of the trade unions, it was generally felt that the evils of unemployment could be more adequately combated only by means of some form of insurance supervised and aided by the State.

It is well to note clearly that the State had already assumed the duty of meeting unemployment, had already contributed largely in an endeavour to combat its evil results, and was therefore concerned merely with the problem of how to make its efforts most effective.

The strength of trade unionism and the prevalence of unemployment insurance suggested the plan.

\section{Provision of Law of April 9, $190 \%$.}

Societies of Unemployment or "Unemployment Insurance Funds" (Arbejdsloshedskasse) are defined as societies of workmen in one or more specified occupations (such as commerce, office work, industry, handicraft, agriculture, hotel work, transport or mining, common labourers included) who have combined to provide, by means of the payment of a specified contribution, mutual assistance in case of unemployment of the kind coming under the law. Such societies existing for this sole purpose 
have a right to receive public recognition and consequently public aid on certain conditions.

To obtain public recognition a society must as a rule have at least fifty members. It might be connected with one or several trades, and might comprise more than one province or else be limited to a given locality.

\section{Statutory Conditions of Admission to Membership.}

Only workmen whose circumstances were such as to entitle them to State aid from an officially recognized sick fund were qualified to claim unemployment benefit. The age-limit for admission to membership in a recognized society was fixed by its by-laws, but no person under eighteen or over sixty years of age might be admitted.

Membership of a society might not be refused to anyone who fulfilled the above conditions and who belonged to the trade or trades or resided within the locality for which the society was established. Societies whose operations were confined to specified occupations were required to be subdivided into local branches.

The amount of the annual membership dues was fixed by the by-laws of each society.

The sick fund committee (mentioned in par. 7 of Act 87, April I2, I892) decides whether a person fulfils the prescribed conditions of membership and whether he may become a participating member or merely a contributing member. With respect to other qualifications the decision rests with the Inspector of Unemployment. An appeal against any particular decision may be lodged with the Minister of the Interior, who may decide the matter after securing an opinion from the jury of unemployment. There is no appeal against this decision.

A provision may be inserted in the rules of a recognized society which shall give it power to refuse admission to anyone who appears to be physically or morally incapable of supporting himself or of working on good terms with his foremen or fellow-workmen.

An appeal against any decision of this nature may be 
lodged with the Unemployment Insurance Committee. A further appeal against a decision of this committee may be lodged, of course, with the Minister of the Interior.

No person is allowed to be at the same time a member of more than one officially recognized Unemployment Society, nor assure himself in case of unemployment of benefits amounting in the aggregate to more than twothirds of the average wage in the trade or trades in the locality concerned.

The contravention of any of the foregoing provisions, as well as dishonest conduct towards the society, is punishable by expulsion from the fund.

\section{Income of Societies.}

The annual income of a recognized society, including the public subsidy, must be fixed at an amount which is regarded in the light of experience as sufficient to pay the benefits prescribed in the by-laws. Such benefits must be large enough to be of some real service to them. In case of need an extra contribution may be required of members.

The income and property of the society must be kept intact and separate from other funds and must not be loaned or used for any unauthorized purpose. State grants, contributions from communes, and gifts from honorary members are the main sources of income. The honorary members who pay contributions may be admitted into an unemployment society but are not entitled to claim benefits.

Recognized societies receive from the Exchequer an annual grant equal to one-third of the total amount of the society's income, fixed as above prescribed. The State grant does not, however, exceed 250,000 kronen. It is divided among the societies in proportion to their incomes.

The commune in which a member lives or in which he is entitled to poor relief is authorized without the consent of a higher authority to contribute not more than one- 
sixth of the amount to the payment of his membership dues for the current year. Communes in which recognized unemployment societies have headquarters or sections are entitled to contribute annually to the society or societies an amount not to exceed, for any one society, one-sixth the amount of the membership dues of those of the society's members who were residents of the commune on the preceding March 3Ist.

The Bill presented to the Landsthing on November I4, I9I3, provided that the communal grants, which were then optional, should be made compulsory under certain conditions.

\section{Benefits.}

The board of managers of recognized societies decide in each individual case the extent and character of the benefit. The following kinds of benefits may be provided, (I) Travelling benefit; (2) assistance in paying rent; (3) daily allowance; (4) assistance in kind. The sum total of all daily allowances, excluding travelling benefit, must not exceed in the case of trade insurance funds twothirds of the average wage current in the particular trade, or in the case of local insurance funds two-thirds of the common daily wages of labour current in the locality for which the society is established: but in either case the amount of such benefits must not be less than $5^{0}$ öre or more than 2 kronen per day.

If a member of a society who is entitled to receive unemployment benefit has work offered to him by the board of managers of the society or procures it by his own efforts, and his wage for it is less than the maximum relief already mentioned, then the society may make up the difference. As a rule, however, trade unionists oppose such a provision, because it implies that standard rates of wages are not being paid.*

* The student of the English Poor Law system will recall the similarity between this device and that effected through the Speenhamland Act of 1795. The latter aggravated the evils it was meant to allay. See First Annual Report of Poor Law Commissioners, 1835. p. 207. 


\section{Conditions for Receipt of Benefits.}

Benefits are not paid to anyone until he has been a member of the society for at least a year and has paid his dues for that period.

Benefits are not paid in any case before the expiration of six days of unemployment, and this "waiting time," by changing the rules of any society, may be made longer, but not exceeding a maximum of fifteen days. This provision does not apply when travelling benefit only is given. After consultation with the Unemployment Insurance Committee the Minister of the Interior may direct that in certain specified seasons no relief shall be granted by the societies which include seasonal workers unless their unemployment lasts longer than fifteen days, and in that case what the exact number of days shall be for which benefits are to be provided.

\section{Cases in which Benefits must not be Given.}

Benefits must not be given to (I) persons taking part in strikes and lock-outs; (2) members whose unemployment is due to illness or infirmity, for as long as such illness or infirmity lasts; (3) members whose unemployment is due to their having left their situations on insufficient grounds, or whose unemployment is caused by quarrelsomeness towards their employers or fellow-workers; (4) members undergoing judicial detention after conviction ; (5) members who are in prison pending trial ; (6) members who are in receipt of poor law relief ; 7 members who refuse to accept work suited to their capacities which may have been offered to them by the society, and (8) members who are performing military service.

If the board of managers of a society refuses benefit to an unemployed member under any of the provisions (I), (3), (6), and (7), their decision may within a month be appealed against and brought before the Unemployment Insurance Committee, which shall give its decision after due consideration of the facts of the particular case. A 
further appeal may be lodged with the Minister of the Interior against the decision of the Committee.

\section{Investigation of Cases.}

On considering the results of the inspection of cases the Committee came to the conclusion in $\mathrm{IgI}_{3}$ that the verification of the cause of unemployment, in order that it may be effective, ought to be carried out, not only in cases where an abuse is suspected, but in all cases, and that it should not be confined only to the interrogation of the party concerned. Also, in inspection of unemployed persons in receipt of benefit, account should be taken not only of the possibilities of employment in their respective occupations but also of the possibility of employment in any other remunerative work.

\section{Amount of Aid during the Year.}

The Act of 1907 provided that the by-laws of a society shall fix the maximum limit of aid to be rendered in twelve successive months at not less than seventy times the daily allowance payable in respect of unemployed benefit, i.e. benefits may be paid for a maximum period of about twelve weeks. By way of exception, the Minister may authorize a society to fix this maximum at fifty times the daily allowance only, but if so, that allowance must not be less than 75 öre per day.

If a member draws the maximum benefits for three years in succession, then he is entitled to no further benefit until he has paid up his contribution to the fund for a full financial year.

\section{Administration.}

The supervision of the working of the insurance scheme as a whole is entrusted to the Inspector of Unemployment. Certain powers are entrusted to the annual meeting of representatives of the various societies, the Inspector of Unemployment presiding over its deliberations. This 
meeting elects the Unemployment Insurance Committee, this body also being presided over by the Inspector of Unemployment. This Committee has very important functions. First, it is its task to form a connecting link between the individual societies, to make rules for their co-operation, including those for transference of members from one society to another, and, so far as possible, to secure uniformity in the rules of the different societies for providing benefits. Secondly, if this committee is of opinion that any recognized society, without actually infringing any of the provisions of the law, nevertheless acts in such a manner as to cause prejudice against the unemployment insurance system as a whole, then it is the duty of the Inspector of Unemployment to make a report on the subject to the Minister of the Interior, in which he must advise whether it is desirable that the official recognition accorded to the society in question shall be cancelled. Thirdly, this Committee acts as a Court of Appeal in regard to decisions of the governors of any society which disqualifies persons from membership or refuses to pay benefits because of alleged strikes or lock-outs.

The Inspector of Unemployment inspects the reports and supervises the activities of the various societies. No very important step can be taken by any society without his consent. $\mathrm{He}$ is responsible to the Minister of the Interior for the proper working of the whole scheme.

\section{The Working of the Act-Numbers.}

The Danish Unemployment Insurance Law came into operation in August I907, and the recognition of societies of unemployment under this law has gone on more rapidly than even ardent advocates of the law anticipated.

During the first administrative year, thirty-four societies received official recognition. In October I908, Mr. Soerenson, the Inspector of Unemployment, presented to the International Congress on Workmen's Insurance at Rome a report stating that by that date thirty-seven 
societies had been organized. Out of these thirty-seven societies thirty-six were trade unions (their membership being confined to particular trades) and one only was a local society (comprising various occupations within a specified area). The law requires that societies seeking recognition shall be specially formed for insurance against unemployment. All but one, however, were practically trade unions organized for general purposes which were prepared to satisfy the conditions provided by the Inspector of Unemployment with respect to this one branch of their work.

There has been a great increase both in the number of societies and the number of individuals affected by the scheme since its inauguration in $\mathrm{I} 907$ to the year I9I4, the latest year for which we have figures.

The number of societies increased from thirty-four in I907-8 to fifty-five in I9I4, the number of insured persons from 70,449 to 120,289 .

At the close of the fiscal year March $3 \mathrm{I}$, I9I $4{ }^{*}$ as reported by the Unemployment Inspector, there were in existence fifty-five recognized voluntary unemployment insurance funds, with a membership of 120,289 ; there was no increase in the number of funds over the preceding fiscal year. Of the total number fifty-one were organized for individual trades and are national in their scope, three were limited to certain trades within a district, and one was a purely local fund. The membership was so proportioned that $45^{\circ} 5$ per cent. were found in Copenhagen and Fredericksberg, 37.8 per cent. in the towns of the provinces, and $15^{\circ} 9$ per cent. in rural localities. The total receipts of the fifty-five funds in the year I9I3-I4 were 2,973,294 kronen; $\dagger$ the total expenses were

* Monthly Review of the Bureau of Labour Statistics, vol. i, No. 4.

+ Administration expenses form 8 per cent. of the total receipts.

In 1907 members' subscriptions amounted to 307,592 kronen, State subventions to 150,083 kronen, and those of the communes to 84,546, a total of $542,22 \mathrm{I}$ kronen.

The benefits paid in that year amounted to 215,794 kronen.

During $1908-9$ to $191 \mathrm{I}-12$ the average contribution per member steadily decreased from $14^{\circ} 07$ to 12.18 kronen. At the end of that period the funds held a reserve of 2,363,046 kronen.-International Bulletin Against Unemployment, Fourth Year, No. I, p. 75 . 


\section{INSURANCE AGAINST UNEMPLOYMENT}

$2,2 \mathrm{I} 8,542 \cdot 48$ kronen. Statistics for the fiscal year I9I2-I3 show that of the total receipts for that year, or $2,725,063 \cdot 17$ kronen, 52 per cent. was contributed by the members, 33 per cent. was provided by State subvention, and I5 per cent. by municipal subsidies. The statistics of the fund show the number of members for the year and for the preceding year, number reported unemployed and in receipt of benefits, number of days for which benefits were paid, total number of days lost by unemployment, and the relative number of days lost for which unemployment benefits were paid, all classified by trades and principal industry groups. The number of unemployed to whom assistance was rendered is also shown by occupation for a period of four fiscal years, according to classified number of weeks during which such members were unemployed. There is here presented a summary table of data for the year I9I3-I4.

NUMBER OF MEMBERS OF UNEMPLOYMENT INSURANCE FUNDS, UNEMPLOYED PERSONS RECEIVING BENEFITS, DAYS OF BENEFITS PAID, AND WORKING DAYS LOST, I9I3-I4.

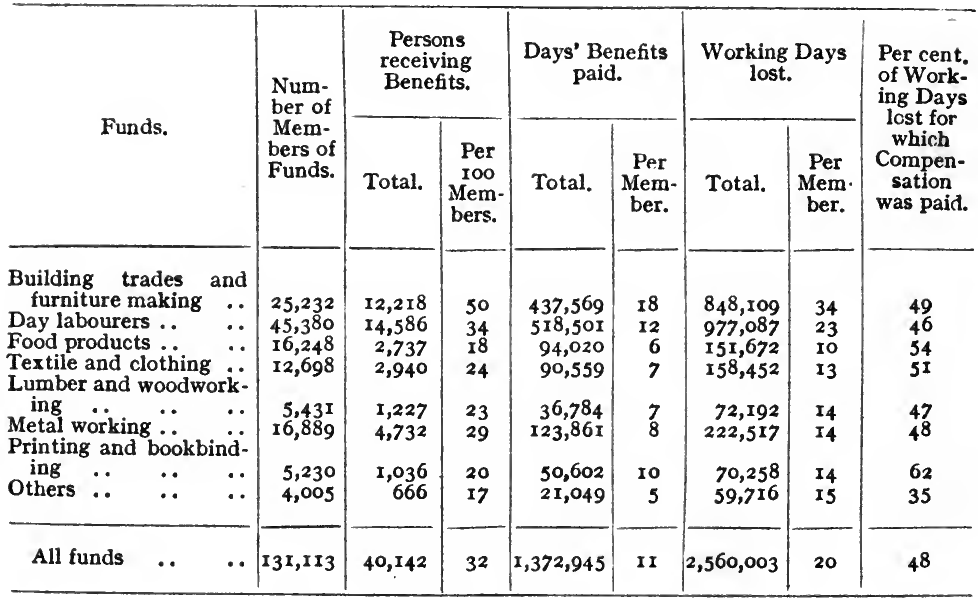

Since the Act of 1907 came into operation the total expenditures, which include grants from the State and 
communes, were, according to a reliable American investigator :

\begin{tabular}{|c|c|c|c|c|c|}
\hline & & & & & \\
\hline $\begin{array}{l}1907-8 \\
1908-9\end{array}$ & .. & $\because$ & $\ddot{.}$ & $\ddot{.}$ & $\begin{array}{r}66,009.2 \\
388,208.2\end{array}$ \\
\hline 1909-10 & .. & .. & .. & .. & $444,360.6$ \\
\hline I910-II & .. & .. & .. & .. & $518,053.4$ \\
\hline $1911-12$ & .. & .. & .. & .. & $516,944 \cdot 4$ \\
\hline $1912-13$ & .. & .. & .. & .. & $730,316.9$ \\
\hline $1913-14$ & .. & .. & .. & .. & $796,84^{2.8}$ \\
\hline
\end{tabular}

A sum of about $£ 700,000$ was thus distributed in addition to that expended by the recognized funds.

The law of 1907 admits as a matter of principle the granting of State subventions only to those funds whose members belong to the same occupation or similar trades.

It appeared that this type of fund would present the maximum of success and of guarantee of control. The risks of unemployment vary greatly in different occupations: in certain occupations the workmen are occupied regularly from one end of the year to the other and are out of work only occasionally; in others the workmen are periodically exposed to long dull seasons: wages also vary from occupation to occupation. In funds composed of persons belonging to different occupations it is difficult to establish the dues required of each one of the members and the amount of relief to which he would have a right in an equitable manner. Each union is therefore best adapted for working out scales of contributions and benefits. Furthermore, the occupational funds are in a better position than other types to control unemployed persons and to ensure finding places for them.

The problem of including in the Danish Unemployment Insurance scheme the unorganized workman was by no means as difficult as it is in other countries. In no nation in the world is the proportion of the working classes who are members of trade unions so large as in Denmark, where it is estimated to be about 55 per cent. By providing that admission into a recognized society 


\section{INSURANCE AGAINST UNEMPLOYMENT}

cannot be refused to any person if he fulfils the conditions specified in the law and by arranging for the establishment of local societies as well as of trade societies, unskilled workers find little difficulty in gaining entrance into some society. On the other hand, the fact that laws granting special assistance had to be enacted during the very severe period of unemployment in I908 and I909 shows that even in socialized Denmark the mass of workmen do not make sufficient provision to enable them to meet severe industrial crises without special aid.

\section{Special Assistance.}

It is interesting to note that a year after the Government had successfully operated this scheme, on May 27. I908, two further laws were passed to deal with the unusually large amount of unemployment of the winter of I907-8. One of them, the law concerning aid during a period of exceptional unemployment, left it to the discretion of communal authorities to give aid to societies (Hjaelpekasser) and benevolent associations so as to enable them to grant benefits in excess of the maximum fixed by the law of 1907. It also permitted the unemployment societies, recognized in the fiscal year $1907-8$, which at the time the law went into effect had existed less than a year, to give aid to their members who were in the society at the time of its recognition, provided it was proved to the inspector that the society had the necessary funds. The communal authorities were authorized, without the consent of a higher authority, to make such societies an unusual grant in excess of the maximum fixed by law, and the Minister of the Interior was empowered to make an advance on the State grant to such societies. The other law empowered the Minister of Finance to make a loan of not exceeding 4,000,000 kronen to communal authorities who started works of construction, in Copenhagen or in other towns. The need for these two laws and their passage in Parliament shows a clear appreciation of the inadequacy of the Unemployment Insurance Act of 1907 
as the sole instrument for dealing with unemployment, and explains the proposal to establish a special fund to be used in time of crises.

There were in I9I2, I39,0I2 workmen belonging to trade unions. No less than I20,29I of these were members of the insurance funds, and the explanation for the abstention of 28,000 from the workings of the scheme lay partly in the nature of the trades in which they were engaged and partly in the rules of the organizations.*

The main features embodied in the Act may be summarized as follows :-

(I) Insurance is voluntary.

(2) By means of fixed maximum and minimum amounts benefits are kept within reasonable but, it is believed, sufficient limits.

(3) The scheme works through independent unemployment societies existing for this purpose only.

(4) State public aid is obligatory and city subsidies to the Insurance Fund are encouraged.

(5) Control over the societies is exercised by the Inspector of Unemployment, who is responsible to the Minister of the Interior.

(6) A large measure of uniformity in the work of the societies has been obtained.

A series of Model Rules for Unemployment Insurance Societies was drawn up by the Minister of the Interior, and the Inspector of Unemployment, in consultation with a Committee appointed by the Control Federation of Danish Trade Unions, and Mr. Soerenson, the Inspector of Unemployment, reports that the results of this collaboration has been that all the officially recognized Unemployment Insurance Funds have adopted almost in their entirety the provisions contained in these Model Rules, with such modifications as were rendered necessary by the different forms of benefit paid by the different funds and the method obtaining in their administration.

* “Unemployment Insurance in Social Denmark," Quarterly Journal of Economics, pp. 6o-3. 


\section{Employment Offices.}

Denmark has been comparatively backward in the development of a system of employment exchanges. On April 29, I9I3, an employment exchange law* was enacted which authorized the Minister of the Interior to create employment exchanges in those localities where no satisfactory ones existed two years after the law came into force. Thus not until I9I5 could a good system-a network of exchanges covering the whole country and strongly centralized-begin to be realized.

In IgII, Denmark had, in addition to the municipal exchange at Copenhagen, two exchanges run by associations of employers and seventeen trade union exchanges. The latter gradually passed over to the unemployment funds, and the Inspector of Unemployment was thus able to exert considerable influence over them. At first the committee of management continued the policy of allowing special employment exchanges to be managed by the several trades themselves. At this time employers of labour regarded these employment exchanges as part of the ordinary trade union activities carried on in the interests of their members. Their disfavour was not greatly lessened when the Inspector of Unemployment began exercising control over them. It was argued in favour of transferring the location of employment exchanges to different premises from those of the union offices, of staffing them with different officers and of bringing them under the State system, that by so doing and by following a policy of absolute impartiality as between employers and workmen they might be successful in winning the sympathy of the large employers.

When the law relating to employment exchanges, passed in I9I3, came into effect this problem lost its significance. To-day there are about seventy communal employment offices controlled by the Central Employment Exchange at Copenhagen. They work in connection

* “Loi Sur le Placement du 29 Avril, I9r3, International Bulletin Against Unemployment, Third Year, No. 3, p. 729. 
with the offices of the unemployment funds. There are three thousand of these branch offices which act also as employment offices.

The State makes a grant of one-third of their total expense towards the upkeep of employment offices. Together with the Danish Statistical Department they publish all information regarding the state of employment. They pay half travelling expenses to workmen travelling to definite jobs at a distance from their homes.

It required only a short experience with the unemployment insurance law to prove the inadequacy of a scheme embodying the Ghent principles. During the last ten years sentiment has increasingly favoured the establishment of a national compulsory scheme on lines similar to the one in operation in Great Britain and those now attempted in Italy and Austria. The Government has, however, merely reorganized the old law in its recent Act. The Socialists have led in this demand for a comprehensive scheme whilst the administrators of the law realize more and more that such a change is almost inevitable, in spite of the fact that the voluntary principle has met with more success in Denmark than in any other country. The inauguration of a national system of employment exchanges was of course necessary before a comprehensive national system of unemployment insurance could be introduced. It remains to be seen whether now that the former has been established the latter will follow. 


\section{H A P T E R X I}

\section{GERMANY}

Although under Bismarck Germany took the lead in inaugurating a national scheme of sickness insurance as early as in $\mathbf{I 8 8 3}$, she is still very backward in the matter of public encouragement of unemployment insurance. This is all the more remarkable when it is learnt that all the different types of working men's unions are in favour of such a measure and demand that the Government introduce a law providing for the subsidizing of unemployment insurance.

The third Congress of German workers, held in December I9I3, representing nearly a million and a half of wageearners, pronounced in favour of unemployment insurance by Imperial law. During the interval which must necessarily elapse before its passing into effect it demanded that the Ghent system be applied, with financial support from cities and States. It also recommended the passing of national law on employment exchanges.*

The "Imperial Union of Liberal Workmen and Employers," with a view to lessening the consequences of unemployment, formulated in its programme a demand for a national law on unemployment insurance which provided for participation by the States, the municipalities, employers and workmen. It asked that unemployment insurance should be bound up with a general organization of employment exchanges, and for public subsidies to union unemployment insurance funds.

* Although Germany has not yet developed a national system of employment exchanges, there is evidence to show that it cannot now long be delayed. On July I, I9 I 5, all free employment offices were obliged to make reports of their activities to the Imperial statistical offices. -Monthly Review of the Bureau of Labour Statistics, vol.,ii, p. 53. 
A special congress of the union of technical and industrial workmen in the Berlin district, held in October I9I3, declared that the organization of unemployment insurance by an imperial law was the only effective way of meeting the problem and that unemployment insurance ought to be associated with a centralized organization of public employment exchanges. It called on the union of Communes of Greater Berlin to endeavour to form an intercommunal organization for unemployment insurance and at the same time to induce the Imperial Government to authorize the municipalities to provide insurance compulsorily.

In December I9r3, the "Christian" unions addressed a petition to the Diet of Baden demanding an Imperial law on unemployment insurance, and, until it was enacted, the creation of communal funds of unemployment insurance. The State was asked to contribute not more than 50 per cent. of the amount spent by unions on unemployment insurance as a subsidy to their funds.

The Gewerkschaften (social democratic trade unions) have declared themselves in favour of the Ghent system frequently since first doing so in I902. They felt that the refusal of the Imperial Government to pass such legislation was due to its antagonism to the radical working men's organizations.

The German Socialist Congress which met at Jena in September I9I3, adopted a resolution which, after having pointed out the necessity for urgent measures to remedy the unemployment situation, and specifically advocating the undertaking of schemes of public works, continued as follows:.

Permanent (chronic) unemployment and periodic unemployment crises are phenomena inseparable from the capitalist mode of production and its inevitable consequences : they will disappear only when production is organized on a socialist basis. Nevertheless, it is necessary to attempt at once the diminution of the harmful consequences of unemployment by an appropriate development of social insurance.

Unemployment insurance is a device to be introduced as a matter of public right for the benefit of all labourers, and it can only be 


\section{2}

realized by legislation for the whole Empire. . . . In looking forward to the realization of a universal and compulsory scheme of unemployment insurance as a public right there is room for a demand for a system of municipal subventions to trade union unemployment insurance funds.

For this purpose it is necessary to insist, above all, in the participation of the Confederated States in these subventions.

In addition to these labour organizations a number of civic bodies have declared themselves in favour of a national scheme.

In IgII the Congress of German municipalities pronounced for an Imperial or State insurance law on unemployment.

The Bavarian congress of public employment exchange officers resolved in May I9I3 that the Confederated States, or the Empire, could alone find a definite solution of the problem of unemployment.

On the other hand, even at the height of the unemployment crisis in the winter of I9I3, groups of employers and the Government leaders showed themselves frankly hostile to national encouragement of unemployment insurance.

A very important body of placement officers of the Union of German Employers' Organizations, at its conference in Hanover, in November I9I3, rejected in principle every form of unemployment insurance organized or subsidized by public bodies, " not only those created by an Imperial law of the State, but also every insurance institution which calls for collective support." The reasons given for this opposition were that: unemployment was never a general phenomenon in Germany; it was not so widespread as was generally believed; the proof of involuntary unemployment could not be satisfactorily obtained, and consequently that the very basis of all insurance, reliable statistics, was lacking.

In answer to the interpellation of M. Silberschmidt, President of the Federated Union of Masons, in the Reichstag on the $5^{\text {th }}$ and 6th of December, I9r3, M. Delbrück, State Secretary of the Interior, retorted that 
the question of a national system of unemployment insurance was not yet ripe, not more so than the idea of a law authorizing cities to introduce compulsory unemployment insurance. The great objection to a scheme on the Ghent lines was that it subsidized organizations entered into for economic combat, whilst a scheme on the British plan would result in great charges on employers. He also pointed out that the country still lacked satisfactory statistics and a well-organized, centralized system of employment exchanges.

Thus, whilst it is an undoubted fact that the labouring and progressive elements were ready for some national scheme of unemployment insurance, the Government and the manufacturing associations showed themselves strongly opposed to it. Opposition to the scheme also comes from the agricultural interests, both from landowners and workmen, on the grounds that it would add to the burden of taxation on the land, whilst it is not likely to benefit the rural labourer.*

Although the Imperial and State Governments have hitherto shown little sympathy with the idea of assisting insurance against unemployment, the municipalities, which in the last resort are forced to deal with the evil, have shown a much greater willingness to gain from the experience of other countries.

Fortunately the cities on the Continent have larger powers, and show a greater faculty for initiative than either the American or British cities. Thus, although some of the largest cities, Berlin, Munich, Düsseldorf and Nuremberg were still discussing the idea in I9I4, other cities, like Cologne, Leipsic, Strassburg, Mülhausen, Erlangen, Mannheim, Schoneberg, Freiburg in Baden, Stuttgart and Offenbach on the Maine, had successfully inaugurated schemes of assisted insurance. We will here examine only a few of the more interesting schemes.

* Relief works have been encouraged by the Government as the best means for meeting unemployment. By undertaking them, the Government did not antagonize employers of labour, and they constituted part of the programme which has made modern Germany into a "feudal State with the view-point of benevolent paternalism." 


\section{INSURANCE AGAINST UNEMPLOYMENT}

The scheme in operation in Strassburg is the oldest German scheme, that in Mülhausen provided a higher percentage subsidy on the trade union benefit than any other municipality. The Cologne scheme limits subsidies to the winter.

\section{Strassburg.}

The first municipality in Germany which introduced and conducted a scheme of insurance against unemployment with success was Strassburg. Other German towns have followed its lead by adopting somewhat similar schemes.

The operation of the Strassburg scheme commenced on January I, I907. It was based on the Ghent model. Like the former, it provides a subsidy not only to trade associations (in practice, trade unions) who pay unemployment insurance benefit to their members, but also offers it in addition to insurance organized either by provident societies or through individual savings.

The subsidy voted by the municipality is 50 per cent. of the unemployment benefit paid to members by trade unions: but the amount of subsidy paid to any one person does not exceed one mark a day. This is payable only to persons who have resided in Strassburg or the neighbouring communes for at least one year. Subsidy is paid for the same period as benefit is provided by the affiliated trade association. Unions desiring to receive such subsidy are required to administer their unemployment funds separately from their other funds.

The check on unemployment has been carefully worked out. All insured persons involuntarily unemployed through lack of employment are required to report themselves daily to the municipal employment exchange. The " unemployed were ordered to report themselves at the labour exchanges, not at the same hour each day, but at a time frequently varied, and not always in working hours, in order to prevent them from being at work while claiming to be unemployed." In some cases men 
were required to report themselves as often as three times a day.*

If an unemployed person is referred to suitable work in his own trade, which he refuses, he forfeits the municipal subsidy. Unmarried persons are required to take work offered to them whether in Strassburg or away from the city, unless they are placed in exceptional circumstances.

Much of the success of the scheme has resulted from the acceptance by trade unions of the control of the employment exchanges. This is largely due to the fact that it is under the management of a committee composed of equal numbers of representatives of employers and workmen and of an impartial chairman.

During the first three years of the scheme's operation the municipality voted an annual sum of 5,500 marks. $\dagger$ This amount was not distributed in subsidy during the first two years, and so the surplus went as a reserve fund to provide against a period of depression, It was drawn upon in rgog.

Practically all of the insured workmen are skilled. It is still believed that for unskilled workmen provision against unemployment is best made through relief work.

STRASSBURG : MUNICIPAL SUBSIDY TO INSURANCE AGAINST UNEMPLOYMENT, 1907-12.

\begin{tabular}{|c|c|c|c|c|c|}
\hline . & 1907. & 1908. & I909. & |rgro-11t & 1911-12. \\
\hline 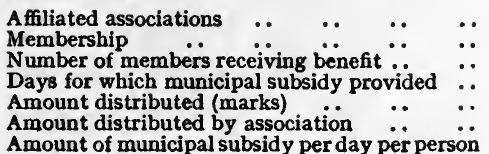 & $\begin{array}{r}20 \\
3,867 \\
153 \\
2,618 \\
1,889 \\
7,726 \\
0.27\end{array}$ & $\begin{array}{r}29 \\
4,872 \\
247 \\
4,989 \\
3,507 \\
14,327 \\
0.70\end{array}$ & $\begin{array}{r}32 \\
5,155 \\
335 \\
8,095 \\
5,998 \\
22,901 \\
0 \cdot 74\end{array}$ & $\begin{array}{r}36 \\
5,856 \\
338 \\
7,362 \\
5,695 \\
27,132 \\
0 \cdot 77\end{array}$ & $\begin{array}{r}36 \\
7,444 \\
288 \\
7,499 \\
6,086 \\
19,951 \\
0.8 x\end{array}$ \\
\hline
\end{tabular}

The number of affiliated trade unions increased from twenty in 1907 to thirty-six in I9I2. The number of members in respect of whom subsidy was provided nearly doubled during the same period, the increase

* See Schloss : Insurance Against Unemployment, p. 37.

+ In 1914 the German mark (= IOO pfennigs) and was worth about II 1 d.

\$ From January I to March 3I, I9II. 


\section{INSURANCE AGAINST UNEMPLOYMENT}

being from 3,867 to 7,444 . One of the effects of the scheme was to encourage insurance against unemployment amongst classes of workmen such as associations of painters, saddlers and office employees, who formerly made no organized provision.

In I9II-I2, 288 members received benefit in respect of 7490 days of unemployment, an average of twenty-six days each. The municipal subsidy amounted to 6,100 marks, and this was equal to an addition to each person's union benefit of 90 pfennigs a day during unemployment. The amount distributed by unions was three or four times as great as that distributed as subsidy.

The Strassburg scheme was rightly regarded as one of the most successful schemes embodying the idea of subsidizing voluntary unemployment insurance. Since, however, it comprises only a fraction of the skilled, organized workers and hardly affects the casual, unskilled, unorganized workmen, it cannot be regarded as at all adequate for dealing with the evils of unemployment.

\section{Mülhausen.}

The Mülhausen scheme for assisting insurance is modelled on that at Strassburg. It came into force on December I, I909, for a period of three years, at the end of which time the labour bureau was instructed to propose amendments to the Municipal Council. The Council voted a credit of 2,160 marks for the purpose. The subsidy was fixed at the rate of 80 per cent. of the benefit paid by the trade unions for persons with dependents, and 70 per cent. for persons without dependents. The subsidy was thus considerably higher than that provided by Strassburg, which was 50 per cent. of the union benefit.

The highest amount which might be granted from the municipal subsidy was one mark per day for every unemployed workman. The subsidy is given only to persons who have resided without interruption for at least one year in Mülhausen, and have been employed in the city during that time. Unemployed persons wishing to claim 
benefit must report themselves at the municipal employment office on the first day after unemployment begins and must register themselves daily whilst out of work.

The Act provides that " unmarried persons must accept employment outside the town, if offered them, unless they can show that special circumstances prevail in their case."

Associations having other objects besides that of unemployment insurance must administer the unemployment funds entirely separately from the funds used for those other purposes.

There is a special arbitration board for the settling of disputes, arising under the scheme, consisting of the Director (dezernenten) of the municipal office of employment, and of an employer and an employee appointed by the municipal council.

The subsidy is distributed through the trade unions, who reclaim part of the amount expended as subsidy from the municipal fund.

It will be noted that this scheme makes no provision for unorganized workmen, but the council directed that steps should be taken to introduce a municipal scheme of insurance for them.

The scheme inaugurated in 1909 was continued for another three years, beginning November 30, I9I2, with three important modifications, and the annual credit was raised to 2,790 marks per annum.

The municipal subsidy was changed from a percentage based on the trade union benefit to a fixed money amount. This alteration was meant to simplify the distribution of benefits. In future the subsidy to members with dependents was to be one mark a day, and to members without dependents 80 pfennigs a day. It was also arranged that there should be a waiting week before benefits could be obtained, and the maximum period for their distribution, which hitherto had varied with the custom of each union, was fixed for all unions at eighty days in the year. These changes were aimed at equalizing the distribution of benefits. 
That these changes were necessary, is clearly seen when it is noted what special privileges the typographical union enjoyed by virtue of its long-established rules. These did not provide for any waiting period and extended the duration of benefits to 280 days in the year, with the result that in I909, three unemployed typographers out of sixty unemployed workmen received I3I marks out of the total of 850 distributed by the municipality; that in I9Io, nineteen typographers out of 92 unemployed members received 693 marks out of the 1,506 marks which were distributed, and in IgII an even greater disproportion took place when fourteen typographers out of 93 unemployed in all trades divided among themselves I,I32 marks out of a total subvention of 2,3I6 marks.

In consequence, the typographical union was instructed, under pain of being excluded from the Municipal Unemployment Fund, to endeavour to provide work, through its employment bureau, to unemployed members domiciled at Mülhausen.

\section{Cologne.}

The City of Cologne's Insurance Fund against Unemployment in Winter, which was called into being in I896, provides, as its name indicates, insurance against unemployment which occurs only in the winter, between the first of December and the first of March. The rates of contribution are 45 pfennigs a week for skilled workmen and 35 pfennigs a week for unskilled workmen. Although they pay different rates of contributions the benefits are the same. This is due to the fact that it is easier to secure work for unskilled workmen during the winter months, when benefits are payable, and in consequence their demands on the fund are smaller.

Revenues for the insurance fund are derived from five sources, from workmen's contributions, from donations by patrons, i.e. persons who have made donations of at least 337 marks, from subscriptions of honorary members, persons who annually subscribe not less than 4.50 marks, from grants of the municipality, and from other gifts offered, 
in addition to the payments of patrons and honorary members. Thus the Cologne scheme, founded by private charity, is now largely supported by private charity.

Members must pay contributions for thirty-four weeks in the year to be entitled to benefit during that year. If unemployed, the employment exchange may find them work, and if it cannot do so, benefits are then payable at the rate of two marks a day for the first twenty days of unemployment, whilst for the rest of the forty-eight days, during which benefits are paid, at the rate of only one mark a day.

Unemployed workmen must wait three days after reporting unemployment before being eligible for benefit.

In order to show that they are bona fide unemployed, workmen must report twice a day at the employment exchange. If they fail to do so on insufficient grounds they forfeit their right to benefit.

The scheme is now administered in a manner calculated to gain the support of trade unions. The work offered by employment exchanges to workmen must be reasonable in kind, i.e. suitable to their training and experience, and in wage, i.e. not likely to lower their standard of wages. Members cannot be compelled to accept vacancies which are due to a strike or lock-out.

Single men without dependents may be required to take jobs outside the city. In this case railway fare is provided. Although supported by private charity the scheme now lies wholly in the hands of the city, and is administered by an executive committee on which the labour organizations are represented. The committee consists of the mayor, the chairman of the municipal employment exchange, and twenty-four elected members, of which one-half are insured working men and one-half honorary members, six of whom are employers and six representatives of the general public.

Special measures are necessary and are put into force to guarantee the solvency of the fund. These were invoked in I9OI-2 and in I902-3. They provide that 
under certain circumstances more members should not be admitted to the benefits of insurance.

STATISTICS OF THE UNEMPLOYMENT FUND IN COLOGNE, I896-IgIr.

\begin{tabular}{|c|c|c|c|c|c|c|c|c|}
\hline \multirow{2}{*}{ Year. } & \multirow{2}{*}{$\begin{array}{c}\text { Number } \\
\text { of } \\
\text { Insured } \\
\text { Workers. }\end{array}$} & \multicolumn{2}{|c|}{$\begin{array}{c}\text { Unemployed } \\
\text { Entitled to } \\
\text { Benefits. }\end{array}$} & \multirow{2}{*}{$\begin{array}{c}\text { Number } \\
\text { of Days } \\
\text { for which } \\
\text { Unem- } \\
\text { ployed } \\
\text { were } \\
\text { Found } \\
\text { Work by } \\
\text { Labour } \\
\text { Exchange. }\end{array}$} & \multirow{2}{*}{$\begin{array}{l}\text { Number } \\
\text { of Days' } \\
\text { Benefit } \\
\text { Paid. }\end{array}$} & \multirow{2}{*}{$\begin{array}{c}\text { Contri- } \\
\text { butions of } \\
\text { Insured } \\
\text { (Marks). }\end{array}$} & \multirow{2}{*}{$\begin{array}{c}\text { Per- } \\
\text { centage } \\
\text { to Total } \\
\text { Benefits. }\end{array}$} & \multirow{2}{*}{$\begin{array}{c}\text { Total } \\
\text { Amount } \\
\text { Distri- } \\
\text { buted in } \\
\text { Benefits } \\
\text { (Marks). }\end{array}$} \\
\hline & & Number. & Per Cent. & & & & & \\
\hline $\begin{array}{l}1896-97 \\
1897-98 \\
1898-99 \\
1899-1900 \\
1900-1 \\
1901-2 \\
1902-3 \\
1903-4 \\
1904-5 \\
1905-6 \\
1906-7 \\
1907-8 \\
1908-9 \\
1909-10 \\
1910-11\end{array}$ & $\begin{array}{r}220 \\
324 \\
347 \\
256 \\
571 \\
1,205 \\
1,355 \\
1,624 \\
1,717 \\
1,610 \\
1,255 \\
1,505 \\
1,957 \\
1,938 \\
1,787\end{array}$ & $\begin{array}{r}96 \\
151 \\
144 \\
154 \\
441 \\
842 \\
1,008 \\
11,64 \\
1,271 \\
1,087 \\
980 \\
1,127 \\
1,481 \\
1,295 \\
1,237\end{array}$ & $\begin{array}{l}72 \cdot 7 \\
64 \cdot 0 \\
51 \cdot 1 \\
68 \cdot 1 \\
82 \cdot 3 \\
76 \cdot 2 \\
79 \cdot 7 \\
77 \cdot 5 \\
79 \cdot 6 \\
74 \cdot 3 \\
84 \cdot 8 \\
81 \cdot 5 \\
82 \cdot 9 \\
71 \cdot 5 \\
76 \cdot 3\end{array}$ & $\begin{array}{r}2,184 \\
2,646 \\
2,857 \\
3,708 \\
6,488 \\
15,853 \\
28,946 \\
26,715 \\
29,648 \\
28,714 \\
18,238 \\
20,042 \\
24,896 \\
24,297 \\
23,814\end{array}$ & $\begin{array}{r}1,408 \\
2,197 \\
2,025 \\
2,772 \\
12,658 \\
18,258 \\
16,045 \\
22,910 \\
25,034 \\
13,414 \\
24,086 \\
29,899 \\
37,971 \\
25,283 \\
25,941\end{array}$ & $\begin{array}{r}1,000 \\
2,213 \\
2,444 \\
2,009 \\
4,561 \\
12,434 \\
14,388 \\
19,772 \\
20,782 \\
21,681 \\
17,194 \\
20,662 \\
26,439 \\
26,542 \\
23,866\end{array}$ & $\begin{array}{l}42 \cdot 5 \\
63 \cdot 5 \\
73 \cdot 1 \\
42 \cdot 7 \\
23 \cdot 6 \\
41 \cdot 4 \\
49 \cdot 7 \\
49 \cdot 5 \\
48 \cdot 5 \\
91 \cdot 7 \\
43 \cdot 0 \\
42 \cdot 5 \\
42 \cdot 7 \\
62 \cdot 5 \\
54 \cdot 9\end{array}$ & $\begin{array}{r}2,355 \\
3,485 \\
3,343 \\
4,708 \\
19,337 \\
30,046 \\
28,807 \\
39,915 \\
42,832 \\
23,645 \\
40,014 \\
48,669 \\
61,934 \\
42,473 \\
43,545\end{array}$ \\
\hline
\end{tabular}

In $1896-7$ there were 220 insured members, and in I9Io-II some 1,787 members. There has been a steady rise in the number of people who took advantage of the scheme. It would seem, however, that the scheme has already attracted all those likely to be interested in joining it. Indeed, between I909 and IgII there was a decline in membership of over 200 .

\section{Amount of Unemployment.}

The scheme is meant to attract workmen likely to suffer unemployment during the winter months. As might be expected, over 70 per cent. of the members belong to the building trades. The percentage of members who become unemployed is very high. In $1906-7$ it was 84.8 per cent.; in I907-8, 8I.5 per cent.; in I908-9, 82.9 per cent.; in I909-IO, $7 \mathrm{I} \cdot 5$ per cent.; IgIO-II, $76 \cdot 3$ per cent.

In I909-10 the average number of days for which 
unemployed members received benefits was nineteen; in I9I0-II, it was twenty-one.

The experience of the new unemployment fund at Cologne shows that insurance does not weaken the efforts of unemployed workmen to find work and that workmen are not prevented from changing their residence in order to find work because by so doing they might eventually lose their right to unemployment benefit.*

Perhaps in no country in the world has so much been written on the subject of unemployment insurance as in Germany. Careful thought and scholarly reports reveal great interest in the subject. Nor has this been confined to the few cities whose schemes are described here. In a number of cities plans have been studied, but not introduced. These include Berlin, Colmar, Dresden, Cassel, Düsseldorf, Essen, Emden, Frankfort on Main, Gerbec, Heidelberg, Mayence, Munich, New Cologne, Neumunster, Nuremberg, Pforzheim, Weissensee. Amongst the cities which have rejected proposals for insurance are Berlin, Witmersdorf, Braunschweig, Danzig, Dessau, Elberfeld, Halle a/S., Hamburg, Hof, Kopernick, Kulmback, Regensburg, Spandau, Wiesbaden, Wurzburg. Actual failure of plans is reported in four cities, in Augsburg, Charlottenburg, Duisburg and Solingen. $\dagger$

\section{A Compulsory Scheme Proposed.}

The German Government introduced a Bill for Compulsory Unemployment Insurance in I920. $\ddagger$ It provided that all manual and non-manual workers in industry and commerce should pay a compulsory contribution for unemployment insurance to the compulsory health insurance funds.

The insurance fund was to be made up of contributions by workmen, by employers, and by the Government.

* International Bulletin Against Unemployment, Fourth Year, No. 2,

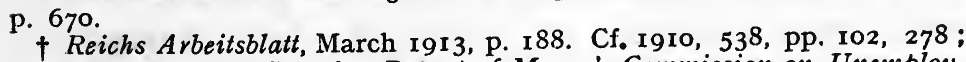
191 1, 538, p. 181. See also Report of Mayor's Commission on Unemployment, Chicago, 1914, p. 90.

$\ddagger$ International Labour Office, Daily Intelligence, February I92I. 
This Bill was, however, withdrawn and another introduced to meet temporary needs.

The workers were opposed to the unemployment Insurance Bill on the ground that no differentiation of trades according to the degree of risk was attempted. But the most serious criticism came from those who insisted that the administrators of the health insurance funds were unable to administer unemployment benefits, since they could not develop a test as to whether workmen are really involuntarily unemployed and unable to find suitable employment.

The Berlin Chamber of Commerce wishes to have unemployment insurance administered by the employment offices. It is calculated that for ro,000,000 insured persons the contribution of the employers and the workers would be 40 marks per year per insured person, whilst the Reich and the commune should pay 20 marks each to provide an adequate system of benefits.

- The Committee of the General Federation of German Trade Unions has addressed a series of demands to the Government for meeting the growing volume of unemployment. They ask that in cases where no other means of providing work for the unemployed can be found the working hours of those fully employed should be curtailed and alternate shifts should, as far as possible, be introduced. This loss of wages due to the curtailed working hours of the short-time workers should be made up to the extent of two-thirds by the employers. The Empire and the Federal States should, from the unemployment relief funds, reimburse the employers to the extent of half the increased expenses thus incurred.*

The decree for meeting temporary needs empowers communes to organize schemes of relief. The expenses are divided between the Empire which provides onehalf, the State one-third, and the municipality one-sixth. In Berlin men are given a donation of 4 marks per day, and women a donation of 3 marks per day. The subsidy is not, as a rule, to be continued beyond six months.

* Korrespondenzblatt, March 5, $192 \mathrm{I}$. 


\section{CHAPTER XII}

\section{CANADA}

THE Ontario Commission on Unemployment reported in I9r6. This report states that " for unemployment resulting from trade depressions or the temporary dislocation of business, working men are not responsible." To meet such conditions the report states: "Your Commissioners are of opinion that some form of unemployment insurance is desirable, in the interest alike of the working men and of the municipalities affected." Representations have been made to the commission in favour of compulsory Government insurance. It is unfortunate that there are no reliable statistics from which to calculate the risk of unemployment.

The Ontario Commission recommended in its report:

I. That financial assistance be given by the Government of Ontario to those voluntary associations of working men which undertake to provide unemployment benefits for their members.

2. That the assistance to such associations should equal 20 per cent. of the sums dispersed by them in unemployment benefits under regulations approved by the Lieutenant-Governor in Council.

In a country which is if anything more individualistic in its outlook than even the United States, great significance attaches to the appointment of a commission to investigate the evils of unemployment and even more significance to its recommendations. Since the armistice a number 


\section{INSURANCE AGAINST UNEMPLOYMENT}

of towns, including the City of Hamilton, have taken steps to put these recommendations into effect.

An unemployment relief fund has been created to which the Dominion Government contributes one-third, provided that the Dominion Government Superintendent issues a certificate that his office has no employment to offer the applicant. The Government of the Province of Ontario agreed to contribute one-third of the unemployment fund, and thereupon the City Council passed a by-law accepting the offer of the Federal Government, and approved the creation of an unemployment fund on condition that all recipients of unemployment pay shall be residents in the City of Hamilton. The by-law has been in effect since about January I4, I920, and the amount paid out by the city to January 2I, I92I, was approximately $\$ 12,000,000$.*

Trade unions in Canada are influenced by those of the United States, so that very few make any provision for insurance against unemployment.

\section{JAPAN}

Interest in unemployment is of recent date because of the comparatively late introduction of the industrial system. Nor has it hitherto been serious because of the possibility of alternating between agriculture and industry. But with the growing development of industrial conditions unemployment has had to receive considerable attention, more especially since 1920. Charitable and religious bodies have hitherto organized employment offices. These proved inadequate, and now there are three under local governments and thirty-nine municipal employment offices as well as eleven under private organizations, and thirty-seven under other agencies. The scheme at first applied only to unskilled and now applies also to skilled labour. There is as yet no scheme of unemployment insurance.

* New Republic, February 9, I92I. 


\section{SPAIN}

A Royal Decree of May 25, I9I7, set up a free employment office in the Ministry of Agriculture and Industry, for the placing of workers in the Public Works, Mines and Agricultural Departments. In IgI9 twenty-two employment offices were established in various towns under joint committees of employers and employees.

A State subsidy to all mutual aid societies, either employers', workmen's or mixed, which provide insurance against unemployment, was decreed on March I9, I9I9. The amount of the subsidy is equal to the subscriptions collected from the members of these societies. The conditions on which it is granted are that unemployment benefits do not exceed 60 per cent. of the daily wage, that they are not paid for more than ninety days in each year, and that the societies guarantee that the State subsidy will not be used to accumulate strike funds.

\section{CZECHO-SLOVAKIA}

In I9I4 there were forty-five out of fifty workmen's associations which provided benefits for their unemployed members. Provision was made in this way for 44,I59 workmen. A committee decides when benefit is to be provided and also fixes the amount to be paid. As a rule benefit is granted only if members are unemployed through no fault of their own.

The period during which benefits may be drawn varies with different associations from six to thirteen weeks.

Private employment offices which are run either as business ventures or as philanthropic organizations also provide insurance benefits. These are distinct from the employment offices established in Bohemia and Moravia which are maintained by the district and State.*

The State grants a subsidy to associations satisfying its regulations. In I9I9, I60,000 crowns were devoted to the State subsidy in the Budget.

* League of Nations' Report on Unemployment, p. 47. 



$$
\text { PART III }
$$

THE BRITISH SYSTEM OF UNEMPLOYMENT INSURANCE 



\section{EMPLOYMENT EXCHANGES AND UNEMPLOYMENT INSURANCE}

\section{Historical Sketch of the Treatment of Unemployment.}

Having briefly reviewed the earlier and less comprehensive schemes of unemployment insurance, we are in a position to examine the biggest and most successful scheme, that now in operation in Great Britain. The question has arisen, both in the daily press and in scientific journals, whether the United States and other countries could not learn from its practice and history in this country. It is therefore necessary to proceed with a very detailed exposition and discussion of the British scheme. In order to understand it fully it will be advisable to precede it by a short outline of the growth of British policy in the treatment of this evil. This will demonstrate that Great Britain no longer relies on charity and relief works as means of meeting it adequately; it will show that a national centralized system of employment exchanges is the machinery with which constructive measures for dealing with unemployment are being attempted; and lastly, that employment exchanges and unemployment insurance are only parts of what may yet be a comprehensive scheme for overcoming the disastrous effects of unemployment to the labouring population.

Great Britain has been the experimental station for measures designed to reduce the suffering resulting from unemployment. Germany claims the lead in establishing Health and Accident Insurance, and Great Britain can 
similarly claim to have led in the fight against unemployment. For the multiplicity and variety of schemes and the long continuation of efforts to solve this problem no country rivals her, and it may be confidently asserted that the devotion of careful thought and action has resulted in grappling with this evil more successfully than in any other country.* This is due in part to the fact that Great Britain having grown into a great industrial power before any other country the problem of unemployment arose here in a more acute form than elsewhere. But even then the evils of unemployment in this country are still sufficiently great to make it into the most serious single problem which challenges the attention of the State. Indeed, during the next two years it might cause the very foundations of civilized life to tremble.

Relief works have a continuous history of failure in Great Britain, and nowhere have they proved particularly successful. $\uparrow$ Their small measure of success in Great Britain at the time of the cotton famine during $1862-4$ gained some support for them as a method of meeting unemployment, until the British had a number of years' experience with the Unemployed Workmen Act. In France, the disastrous experience of the ateliers nationaux of 1848 has resulted in few experiments with such works since then. In Germany, where unemployment has not received very much legislative attention, relief works are still quite common. For a number of years they have been encouraged by the Government in order to

* It is interesting to note the similar views expressed in Conrad's Handworterbuch der Staatswisenshaften: " England may rightly claim to be the model country as regards its legal care of the poor. True, up to the end of the eighteenth and the beginning of the nineteenth century her methods exemplified in a typical form all the evils which opponents of State interference prophesied. But the various improvements introduced since 1834 have most effectually combated those evils." Art. : Armenwesen.

$\dagger$ It was Bismarck who once declared, when someone apologized for a mistake by saying that one must learn from experience, that he preferred to learn from other people's experience. Great Britain has learnt much from her many mistakes in dealing with unemployment. The United States may save much by taking the fullest advantage of British experience. 
avoid the necessity of introducing some large national measure on unemployment.

\section{The Poor Law.}

The circular issued by $\mathrm{Mr}$. Joseph Chamberlain as. President of the Local Government Board in 1886, encouraging municipal authorities to undertake relief work for the unemployed, was the first breach made into the Poor Law defences of Great Britain.

Until then the assumption had been that individual fortune depended on individual character and had little or nothing to do with the structure of the social system. Thrift and self-reliance were therefore to be stimulated and relief was to be discouraged. Since, however, humanity would feel outraged if people in distress were left wholly without help, a minimum of relief under the most irksome conditions was to be allowed. Men without employment, and their families in distress, were therefore provided for by the Poor Law in the workhouse. Here relief was granted upon the condition of performance of a task. The standard of life in the workhouse was high enough not to outrage public sentiment, and low enough to interest the individual in avoiding it. Relief to the ablebodied was made irksome and came to carry with it the stigma of pauperism and certain legal disadvantages. But it was discovered that these punishments did not have a preventive effect. This method of aiding the unemployed resulted in the degradation of those who earnestly desired work, and as a matter of practice allowed the vagrant to live without having to labour very much. The work of all was adjusted to the low abilities of the most inefficient and most indolent, and there was a constant diminution in effort by the inmates of the "Poor House." Soon, in most cases, the work undertaken required little mental effort or mechanical skill. Under these conditions the industrious man deteriorated through lack of useful work and was demoralized by constant association with the habitués of the "workhouse," whilst 
on the other hand, the vagrant could always enjoy a rest at the " home" after doing a few weeks' casual work.

It was part of the indictment of the Poor Law Commission of 1834 that the existing pauperism in the country was largely the product of the existing Poor Law system, and there can be little doubt but that the reformed system introduced after that date had the identical effect on a large number.

Its discouragement of application for temporary relief by the able-bodied, the fundamental feature of the reform, was perhaps more effective with those who were likely to gain by help than with those who were likely to be pauperized by it.*

\section{The Chamberlain Circular.}

"In I886, when the general unemployed percentage of all trade unions rose to $10 \cdot 2$ per cent. of the membership," Mr. Chamberlain issued his famous circular which made incumbent upon local authorities the provision of work in times of exceptional distress. The Chamberlain Circular, as it came to be known, marks the change to the new procedure. $\dagger$

Two new principles were embodied in it. Those receiving this work were not disfranchised, and it became a recognized public duty to assist the unemployed outside of the poor house. Henceforth, to be in need on account of unemployment was not necessarily to be branded as a pauper, or to be a companion of the most degraded members of society.

During the succeeding depression in I892, Sir Henry Fowler, then President of the Local Government Board, reissued the Chamberlain Circular, and, in I904, Mr. Walter Long established semi-official machinery for the better administration of special relief funds. It became the recognized task of the President of the Local Government Board to invite cities to furnish relief work during periods of considerable distress.

* Pitman's Economic History of England, by HI. O. Meredith, p. 29 r. $\dagger$ See Beveridge, pp. 2 and I55, Unemployment: A Problem of Industry. 
But although the principles embodied in the new proposals marked a forward step in the treatment of unemployment, their application was unsatisfactory. Methods and devices for making them effective remained to be discovered. Indeed, the whole subsequent history of governmental activity and much voluntary effort in meeting unemployment may be said to centre round the problem of finding proper administrative machinery for providing relief for the unemployed outside of "the poor house."

There were a number of objections to the working of the scheme. Although "the workhouse test" was dropped, it remained with the "guardians of the poor" to decide who were to be given jobs and who were to be refused. Too often they lacked discrimination and training for selecting workmen for vacancies, an inevitable result of the confused ideas on unemployment then prevalent.

Inadequate relief was granted and no differentiation was made between work seekers and work shirkers. The method of granting only two or three days' work a week resulted in suffering to the former and encouraged applications from the latter, who would not or could not keep a steady job, even if offered to them. There was consequently the demoralizing influence resulting from forcing two such groups of people, of honest working men and of those who through physical or mental infirmities preferred " eating the bread of indolence," to work together.

In a few of the large towns pressure was brought to bear by the vote of the unemployed to have the municipality engage in useless undertakings or in work that would normally have been done by a better class of workmen. This criticism, however, it should be noted, is more severe on the municipalities for not preparing in advance a programme of useful undertakings on which the unemployed might be engaged, than on the workers for demanding employment when involuntarily forced out of work.

Relief works were in practice costly, wasteful, and 
demoralized those whom they were intended to succour. But in spite of these severe criticisms it must be said in their favour that they aided in the development of a recognition by society of its responsibility for lack of employment.*

\section{The Unemployed Workmen Act, 1905.}

The policy of relieving the unemployed without the disqualifications of the Poor Law, first enjoined by Mr. Chamberlain, received legislative enactment in the Unemployed Workmen Act of I905.

This Act aimed to systematize the municipal relief works and at remedying the evils connected with that method of relieving want. Distress Committees composed of " persons experienced in the relief of distress," consisting, that is, of representatives of the Poor Law, of the Municipalities, and of Charity Organizations, were appointed to administer the Act for the local authorities.

The framers of the Act had intended to relieve the unemployed primarily through the provision of relief work and through finding employment for them by means of labour bureaux and even by assisting emigration to districts where labour was in demand.

Emigration, on a large scale, it was soon discovered was impracticable, whilst the few labour bureaux, hardly conscious as yet of their potentialities for good, served predominantly to provide temporary relief work. In effect, the Unemployed Workmen Act must therefore stand or fall with the merits or demerits of the work which was provided.

Under this Act a number of labour bureaux controlled by local authorities were established for the double purpose of acting as registration agencies and of relieving distress arising from unemployment. They failed in both capacities. In I909, twenty-one of such labour bureaux

* The aid given in the Lancashire districts during the special circumstances of the shortage of cotton, and the resulting unemployment during r 862-3 was a very special case where relief funds did not attract to idleness persons who would normally have bẹ engaged in industry.-Pigou, Wealth and Welfare, p. $39 \mathrm{I}$, 
had 103,8 $\mathrm{Ir}$ applications for work. They were able to learn of 34,626 vacancies of which they filled 28,860 . But these vacancies were generally of the nature of relief work rather than of bona fide competitive employment. In addition, the London County Council controlled twenty-two other bureaux. They received I79,I94 applications for work, while 38,865 vacancies were notified to them and 30,580 were actually filled. Both sets of labour bureaux found work almost exclusively for low skilled workmen.

One effect of this ill-considered, inadequate panic scheme was to produce an attitude of mind antagonistic to the new national system of employment exchanges, which was about to be introduced.* Not only was it associated with the idea of relief, but also with very low skilled work. It took some time before employers could be convinced that all kinds of vacancies could be filled by the exchanges, and before skilled artisans could be made to feel that it was not lowering to them to accept such vacancies, or that the exchanges were not to be used for supplying "scab" labour and to break down standard rates of wages. $\dagger$

The chief objection to relief works is that at best they are mere palliatives. They in no way aim at preventing unemployment. The causes of unemployment, the factors making for industrial disorganization, are left untouched and only temporary distress is relieved, with the inevitable result that the problem becomes acute again during the following winter, and menacing during the succeeding depression. Relief works deal only with those whom competitive industry has no use for at that particular time. It, therefore, follows that managers of relief works are left to find work for a miscellaneous group of workmen from a variety of trades, few if any of whom have had previous experience at any work which can be allotted to them. Consequently, work that requires very little

* Cf. with situation in United States to-day.

$\dagger$ For a clear criticism of the old Poor Law, see Alden's Democratic England "The Problem of the Unemployed." 


\section{INSURANCE AGAINST UNEMPLOYMENT}

skill must be undertaken, so that it is usually of little practical utility and generally proves to be very expensive.

So far, at least, as the experience of Great Britain goes, competent opinion is now fairly well in agreement that relief work except in very special circumstances is an unmitigated evil. It is both costly and demoralizing to the men employed and to the community, which is apt to resort to it instead of organizing its labour market in such a way as to reduce the evil of unemployment or at least of mitigating its effects by some more systematic method. The Poor Law Commission of I909 was of opinion that relief works had served on the whole to aggravate rather than to relieve the problem of unemployment.

But although the Unemployed Workmen Act proved a failure, it did good service in collecting a body of information which acted as a basis for discussion of the whole problem. Measures of relief came to be regarded as inadequate and misdirected means for treating unemployment, and henceforth the great causes of unemployment, rather than the human suffering in which it resulted, were to be attacked. The experiments which the Act made possible, rate-aided emigration, farm colonies, and employment exchanges, proved of substantial and lasting value. Along those lines progress lay in the fight against some of the causes of unemployment. The State was now embarked on that task. It had assumed a responsibility and it was difficult if not impossible to draw back. If measures of relief were proven to be inadequate or inadvisable, constructive schemes of meeting unemployment had to be discovered.

\section{Period of Investigation and Study.}

The progress which a country bas made in meeting unemployment is frequently measurable by inquiring whether its proposals for treating it followed immediately on the heels of an industrial depression, or whether it followed as the result of careful study. During the early 
handling of this problem legislation is apt to be panic legislation.

Mr. Chamberlain's circular followed a depression. It was repeated by Sir Henry Fowler during the succeeding depression, whilst the Unemployed Workmen Act of 1905 was the answer to the depression of r904. The years after 1905 were more important for the theoretical study of the problem of unemployment than for any administrative reforms. The Poor Law Commission and the masterly Majority and Minority Reports which were issued after its protracted sittings stimulated much vigorous discussion and encouraged a number of timely original studies and investigations.* Equal in importance to the work of the Commission was the now classic treatise of $\operatorname{Sir} \mathrm{W} . \mathrm{H}$. Beveridge, entitled Unemployment, a Problem of Industry.

As a result of this intellectual ferment, five main propositions stood out with great clearness.

First:- That a different policy must be adopted in treating unemployment amongst employables and " unemployables."

Second:- That measures must be taken to train the inefficient labourer, and to raise the standard of wages in seasonal occupations, so that the average wage will be high enough to enable adequate provision to be made against periods of unemployment.

Third:-That steps should be taken to regularize industry and to eliminate blind alley occupations.

* We will mention only a few :

Beveridge : Unemployment.

Rowntree and Lasker: Unemployment.

Chapman: Unemployment in Lancashire.

Sidney and Beatrice Webb: Prevention of Destitution.

Pigou: Unemployment and Wealth and Welfare.

D. F. Schloss : Insurance against Unemployment.

I. G. Gibbon: Unemployment Insurance.

Cyril Jackson: Trade Union Benefits.

There have also been a number of valuable studies dealing with the relation of the British educational system to " blind alley" occupation. 
Fourth:-That certain specified occupations such as hauling, towing, and carting should be so organized as to concentrate all the labour to be done, at any given moment on the most efficient workmen, and thus to make possible the decasualizing of labour. Fifth:-That the percentage of unemployment, which with our present knowledge and administrative machinery cannot be wholly abolished, should be provided for either by :

(a) Arranging that all workmen should work short time in preference to some working full time, whilst others are dismissed;

(b) Organizing a scheme of unemployment insurance to carry workmen over periods of unemployment; or by a combination of these two methods.

How far progress has been made along each of these five lines of approach will become evident from succeeding chapters.

\section{Objects Aimed at by the Establishment of Employment . Exchanges.}

The Labour Exchanges Act was passed in September 1909, ${ }^{*}$ and the first Exchange was opened on February I, I9I0. The Government of the day, in establishing the exchange system, based their policy largely upon the unanimous recommendation of the Royal Commission on the Poor Laws in favour of such a system, and the objects with which the Labour Exchanges Act was passed have been summarized as follows :-

(a) To bring together employers on the one hand, in need of workers, and workers on the other hand in need of employment, so as to fill up vacancies as speedily as possible and as the result to decrease the periods of waiting between jobs.

* The scheme for unemployment insurance was prepared at the same time, but the Government waited for a more opportune moment for introducing it. 
(b) To provide the less organized classes of labour with assistance in seeking employment of the kind given to their members by the more highly organized trade unions and as the result to avoid the necessity for workpeople to seek employment without knowledge of where it may be found.

(c) To enable the Government to measure the extent of unemployment, so as to be able to provide accordingly for the period of depression.

(d) To operate a system of compulsory and contributory unemployment insurance.*

(e) To provide machinery for dealing with casual labour.

Advisory Committees consisting of employers and workpeople were appointed to assist with the management of these Exchanges. The Ministry of Labour is authorized also to make regulations as to their management with special reference to the question of advancing fares as a loan to workmen proceeding to employment.

\section{Procedure.}

When a man applies for work he is at once registered in the class to which his trade belongs, and any information that he can give as to his trade qualifications is noted, in order to assist the exchange to find him the most suitable situation. This information, together with his name, age, address, previous employers and the periods he worked for them are noted upon his registration card. This card is put away for future reference. When wanted it will be either on the "live list" or the "dead list." The "live list" stands for the list which clamours for immediate attention, the list of those needing work. The " dead list" includes the cards of those who have already found work or who are no longer pressing the exchange for work.

Having registered, the man may be informed at once or at any time that a vacancy occurs. It must be noted,

\footnotetext{
* A scheme for unemployment insurance was prepared at the same time,
} but the Government waited for a more opportune time for introducing it. 
however, that the exchange does not appoint men to particular jobs or even definitely recommend them. All it does is to send to employers those men who are in the judgment of the exchange the best suited for a given vacancy. The responsibility for the choice of any workman always remains with the employer.

The duty of the manager of the exchange is first of all to endeavour to fill such vacancies as may be notified to him from his current register. Should he be unable to do so, he communicates with the divisional centre to which that exchange is attached, which in its turn circulates information of the unfilled vacancies notified from the various exchanges under its control to the other exchanges in its district, where applicants of the class required are likely to be found. Should it not be possible to fill the vacancy within the division, the divisional office circulates it to the other divisions, where a similar procedure is followed. In this way an application for employment or a vacancy notified may be filled by any workman considered suitable, from any part of the country. No longer need shipbuilders on the west coast be at a standstill for lack of men, while boiler-makers, say, I50 miles away are idle.

\section{Organized Migration of Workpeople.}

In I910, 24,990 applicants were placed in districts other than those in which they were registered. They constituted 5.7 per cent. of the total number of vacancies filled. In I9II, 66, I99 or II.I per cent.; and in I9I2, 96,189 or $12 \cdot 2$ per cent. of the total number of vacancies were filled in this way. Loans are made to those found work by the exchanges. Railway fares to the amount of $\{2,803$ were advanced in the financial year I9I2-13, and to the amount of $£ 3$,I5I in I9I3-I4. In I9I9 about 65,000 were transferred from one district to another at a cost of $£ 32,500$, which would mean that they were given work at an average distance of about roo miles from their former jobs. Over 98 per cent. of these loans have been recovered. 
Fully to appreciate how employment exchanges have facilitated the mobility of labour during war conditions, it is best to examine the problem in relation to women's employment where we are free from the disturbing element of people leaving industrial occupations to join the army. During r9r4 the number of women who obtained employment through the employment exchanges in districts other than those in which they registered, was 32,988 ; in I9I5 the number increased to 53,096 , and in I9I6 to I60,003. In I9I7 the number of women being transferred away from home to work at a distance amounted to an average of between 4,000 and 5,000 a month.

This increasing mobility of women's labour was due to war conditions and more specifically to three causes. The high wages paid to women, more especially on Government contract work, provided a strong incentive for women to leave their homes to engage in employment. This was often supplemented by the economic pressure resulting from the loss of a father or a husband or by the desire to release a man for the front. Mobility was facilitated also by the work of local advisory committees on women's war employment. These, in conjunction with other committees of voluntary workers and of the Ministry of Munitions, made special arrangements for the housing; recreation, and general welfare of girls employed in Government factories.

The figures show that there has been a steady rise in the number of vacancies filled by workers from other districts; and it is to be expected that the number of vacancies to be pooled in this way amongst a number of districts will increase. As might be expected builders, fruit growers, and other types of seasonal workers have taken special advantage of this provision.

These results achieved are due not only to the improved sources of information as to where vacancies are available, but also to the increase of workers' facilities to move to jobs outside their districts effected by means of the loans for travelling fares. 


\section{INSURANCE AGAINST UNEMPLOYMENT}

It is particularly interesting to note that the Employment Department was responsible for arranging for the importation of large numbers of workmen from abroad for war work. Thus I,710 workmen came from Canada, 2II from South Africa and 5, I58 from Australia. Portugal contributed 4,682 timber workers and Denmark I,064 workers for timber felling, agriculture, and margarine works. But the largest number of foreign workmen were 6,500 Belgian refugees. In all, some 80,000 foreign workmen were given employment during the war without undue interference with British workmen.

\section{Organization and Staff.}

The staff occupied by the Employment Department of the Ministry of Labour* in June I920 was I2,63I. This department consists of a headquarters establishment, Divisional offices in each of the nine areas into which the country is divided, the employment exchanges and the branch employment offices.

On March 3I, I9IO, 2I4 employment exchanges were open and the staff employed was 528. In June 1920 there were 395 employment exchanges and I,049 branch employment offices situated in less important centres and manned as a rule by part-time officials.

The staff employed by the employment department in June I920 was I2,63I, of whom 8,484 were employed at exchanges and branch offices, I,330 at the divisional offices and $\mathrm{r}, 843$ at the central "Claims and Records Office for Unemployment Insurance." The cause of this great expansion in staff is to be found partly in the necessary completion of the exchange organization, partly the administration of special war-work, and partly the need to administer the unemployment insurance scheme which embraces over twelve million workpeople.

The exchanges in each division are co-ordinated with each other and with a divisional office, or centre, for the

* Report of the Committee of Enquiry into the Work of the Employment Exchanges, p. 5, Cd. I054. 
division, each of the divisional centres being co-ordinated with, and controlled by, a central office in London.*

STATISTICS OF THE MAIN FEATURES OF THE WORK OF EMPLOYMENT EXCHANGES SINCE I9II.

\begin{tabular}{|c|c|c|c|c|c|c|}
\hline \multicolumn{2}{|c|}{$\begin{array}{l}\text { Department } \\
\text { and Year. }\end{array}$} & \multirow{2}{*}{$\begin{array}{c}\begin{array}{c}\text { Number of } \\
\text { Registrations. }\end{array} \\
1,271,756 \\
1,525,223 \\
1,997,819 \\
2,221,651 \\
1,425,556 \\
1,107,565 \\
1,083,664 \\
1,274,076 \\
3,417,899\end{array}$} & \multirow{2}{*}{$\begin{array}{c}\begin{array}{c}\text { Number of } \\
\text { Individuals } \\
\text { Registered. }\end{array} \\
\text { Not available } \\
\text { 1,205,777 } \\
1,321,188 \\
1,012,088 \\
852,037 \\
873,454 \\
1,044,355 \\
2,738,708\end{array}$} & \multirow{2}{*}{ 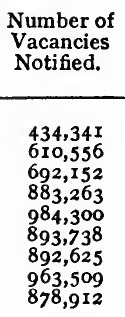 } & \multirow{2}{*}{$\begin{array}{c}\begin{array}{c}\text { Number of } \\
\text { Vacancies } \\
\text { Filled. }\end{array} \\
354,543 \\
503,080 \\
551,577 \\
688,427 \\
701,392 \\
624,892 \\
613,946 \\
660,426 \\
641,307\end{array}$} & \multirow{2}{*}{$\begin{array}{c}\begin{array}{c}\text { Number of } \\
\text { Individuals } \\
\text { Found Work. }\end{array} \\
\text { Not available } \\
37 \ddot{8,805} \\
493,637 \\
564,958 \\
531,050 \\
530,550 \\
574,758 \\
583,251\end{array}$} \\
\hline Men & $\begin{array}{l}1911 \\
1912 \\
1913 \\
1914 \\
1915 \\
1916 \\
1917 \\
1918 \\
1919\end{array}$ & & & & & \\
\hline Womer & $\begin{array}{l}1911 \\
1912 \\
1913 \\
1914 \\
1915 \\
1916 \\
1917 \\
1918 \\
1919\end{array}$ & $\begin{array}{r}400,599 \\
497,880 \\
508,519 \\
681,146 \\
1,198,429 \\
1,846,789 \\
1,831,324 \\
1,774,218 \\
1,860,749\end{array}$ & $\begin{array}{c}\text { Not available } \\
\text { ", } \\
335,605 \\
460,380 \\
897,746 \\
1,439,444 \\
1,456,358 \\
1,444,100 \\
1,512,018\end{array}$ & $\begin{array}{l}173,970 \\
218,794 \\
259,966 \\
302,925 \\
484,356 \\
835,690 \\
807,605 \\
799,088 \\
715,845\end{array}$ & $\begin{array}{l}133,628 \\
164,229 \\
192,598 \\
226,160 \\
377,838 \\
688,538 \\
700,317 \\
617,331 \\
397,881\end{array}$ & $\begin{array}{c}\text { Not available } \\
", \\
\text { 155,868 } \\
301,723 \\
610,978 \\
632,226 \\
545,643 \\
334,037\end{array}$ \\
\hline Boys & $\begin{array}{l}1911 \\
1912 \\
1913 \\
1914 \\
1915 \\
1916 \\
1917 \\
1918 \\
1919\end{array}$ & $\begin{array}{l}177,828 \\
190,256 \\
175,294 \\
199,472 \\
182,512 \\
224,010 \\
254,093 \\
287,196 \\
344,181\end{array}$ & $\begin{array}{c}\text { Not available } \\
\text { "̈, } \\
130,221 \\
149,382 \\
143,038 \\
171,726 \\
196,072 \\
227,288 \\
277,037\end{array}$ & $\begin{array}{l}104,736 \\
126,591 \\
138,020 \\
151,756 \\
156,022 \\
144,099 \\
143,019 \\
145,470 \\
153,205\end{array}$ & $\begin{array}{r}76,301 \\
85,075 \\
86,087 \\
98,957 \\
102,269 \\
113,697 \\
117,931 \\
119,885 \\
115,107\end{array}$ & $\begin{array}{c}\text { Not available } \\
\Rightarrow \# \\
7 \ddot{1}, 534 \\
82,032 \\
87,174 \\
97,667 \\
103,503 \\
104,690 \\
\text { 101,468 }\end{array}$ \\
\hline Girls & $\begin{array}{l}6911 \\
1912 \\
1913 \\
1914 \\
1915 \\
1916 \\
1917 \\
1918 \\
1919\end{array}$ & $\begin{array}{l}115,808 \\
148,866 \\
154,734 \\
202,787 \\
240,528 \\
258,041 \\
263,373 \\
258,893 \\
306,118\end{array}$ & $\begin{array}{c}\text { Not available } \\
\text { 112,348 } \\
145,237 \\
179,518 \\
197,218 \\
203,410 \\
208,728 \\
246,248\end{array}$ & $\begin{array}{r}56,614 \\
77,839 \\
93,218 \\
98,719 \\
136,412 \\
143,836 \\
131,134 \\
131,864 \\
161,527\end{array}$ & $\begin{array}{r}44,003 \\
57,169 \\
65,011 \\
73,194 \\
98,419 \\
107,801 \\
104,189 \\
98,132 \\
104670\end{array}$ & $\begin{array}{c}\text { Not available } \\
\text { \#̈,660 } \\
53,460 \\
60,497 \\
83,834 \\
95,201 \\
93,425 \\
87,488 \\
93,091\end{array}$ \\
\hline Total & $\begin{array}{l}1911 \\
1912 \\
1913 \\
1914 \\
1915 \\
1916 \\
1917 \\
1918 \\
1919\end{array}$ & $\begin{array}{l}1,965,991 \\
2,362,225 \\
2,836,366 \\
3,305,056 \\
3,047,025 \\
3,436,405 \\
3,432,154 \\
3,594,383 \\
5,928,947\end{array}$ & $\begin{array}{c}\text { Not available } \\
\text { 1, } \\
1,783,951 \\
2,076,187 \\
2,232,390 \\
2,660,425 \\
2,729,285 \\
2,924,471 \\
4,774,011\end{array}$ & $\begin{array}{r}769,661 \\
1,033,780 \\
1,183,356 \\
1,436,663 \\
1,761,090 \\
2,017,363 \\
1,974,383 \\
2,039,931 \\
1,909,489\end{array}$ & $\begin{array}{r}608,475 \\
809,553 \\
895,273 \\
1,086,738 \\
1,279,918 \\
1,534,928 \\
1,356,383 \\
1,495,774 \\
1,258,965\end{array}$ & 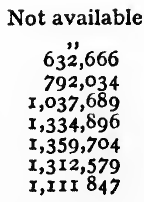 \\
\hline
\end{tabular}

The First Report of the Proceedings of the Board of Trade under Part II of the National Insurance Act, I9II, is the only one yet issued on the working of the British scheme of unemployment insurance. This report (Cd. 6965) was published in July. 1913, but it has been mado 
The number of subdivisions of the exchanges varies with their size. In all the larger exchanges provision is made for dealing separately with insurable and uninsurable workmen, and in the largest these categories are further subdivided between artisans and labourers. Men, women, boys, and girls are each dealt with in separate departments, and the more skilled type of women who - apply in the larger exchanges are dealt with apart from the less skilled, such as charwomen. Moreover, a differentiation by trades is attempted in a considerable number of exchanges, whilst a beginning has been made in specializing certain exchanges to the use of particular industries.

During the period I9II-I4 registrations increased by 69 per cent., the number of individuals registered by 43 per cent., the vacancies notified by 88 per cent., the vacancies filled by 80 per cent., and the number of individuals found work by 74 per cent.

A better index of the success of employment exchanges is given by the following table:-

\section{PROPORTION OF INDIVIDUALS FOUND WORK AND OF VACANCIES FILLED.}

\begin{tabular}{c|c|c}
\hline & $\begin{array}{c}\text { Proportion of Individuals } \\
\text { Found Work to Individuals } \\
\text { Registered. }\end{array}$ & $\begin{array}{c}\text { Proportion of Vacancies } \\
\text { Filled to Vacancies } \\
\text { Notified. }\end{array}$ \\
\hline I91 I & $\begin{array}{c}\text { Per cent. } \\
31^{\circ} 0 \\
\text { I912 }\end{array}$ & $\begin{array}{c}\text { Per cent. } \\
78 \cdot 8\end{array}$ \\
I913 & $34^{\circ} 9$ & $77 \cdot 9$ \\
1914 & $34^{\circ} \cdot 6$ & $75^{\circ} 4$ \\
\hline
\end{tabular}

possible for the author to present information dealing with the administration of the scheme up to date. That report is the only official, public, detailed statement dealing with the inauguration and the working of the scheme. It consists of five parts: A, Introductory; B, Administrative Machinery ; C, Working of Scheme; Preliminary Operations ; D, Working of Scheme, Contributions, Claims, Unemployment Benefits ; E, Summary and Conclusion. It also contains a number of valuable appendices giving detailed statistical tables and copies of memoranda and schedules used in the administration of the Act.

It is extremely desirable that another public report should be issued very soon, 
In I9II, 3I per cent. of the workpeople who registered were given work, which increased to 37.6 per cent. in I9I4; whereas of the number of vacancies notified 78.8 per cent. were filled in Igri but fell to 75.5 per cent. in I9I4. No general conclusions can be drawn from this fact since by the Unemployment Insurance Act registration is made compulsory in the insured trades, but notification of vacancies is still optional.

The summary of figures for I9I4 are shown in the next table for the four separate " departments" of labour exchanges, viz. men, women, boys and girls.

SUMMARY OF WORK DONE IN 1914, DISTINGUISHING MEN, WOMEN, BOYS, AND GIRLS.*

\begin{tabular}{|c|c|c|c|c|c|}
\hline & & Men. & Women. & Boys. & Girls. \\
\hline Number of registrations & .. & $2,316,042$ & 707,071 & 211,898 & 207,441 \\
\hline Number of individuals registered... & .. & $x, 381,694$ & 476,926 & 157,093 & 148,310 \\
\hline Number of vacancies notified & .. & $909,3^{8} 3$ & $3 \sqrt{2,344}$ & 157,278 & 100,019 \\
\hline Number of vacancies filled.. & .. & 706,458 & 232,935 & 103,280 & 74,236 \\
\hline Number of individuals given work & .. & $507,53^{8}$ & 160,145 & 85,068 & 61,320 \\
\hline
\end{tabular}

The " juvenile" work of employment exchanges is, on the whole, more successful than the "adult" side. Of the individuals registered for employment 36.7 per cent. were given work in the case of men, 33.6 per cent. in the case of women, $54 \cdot$ I per cent. in the case of boys, and $4 \mathrm{I} \cdot 4$ per cent. in the case of girls.

It is interesting to learn that the returns for the twelve months ending December I9I2 showed that the vacancies filled were, for the most part, vacancies for skilled labour. For example, out of $80,6 \mathrm{rg}$ vacancies in the building trades, only I9,803 were for labourers.

\section{The Facts about the Exchanges as "Placing" Agencies.}

The results for the last normal year before the war,

* Labour Year Book, r9r5, pp. 228, 229. See also Labour Gazette, February r9r5. It will be noted that these figures differ slightly from those on p. 173 . 
and for the first six months of I920, may be summarized as follows:-

\begin{tabular}{ll|c|c}
\hline & & $\begin{array}{c}\text { Daily Averages (300 } \\
\text { days to a year), I913. }\end{array}$ & January-June 1920. \\
\cline { 3 - 4 } Registrations by workpeople &. & 9,454 & I0,653 \\
Vacancies notified by employers . & 3,944 & 5,021 \\
Placings through exchanges &. & 2,984 & $3,45 \mathrm{I}$ \\
\hline
\end{tabular}

The following table shows for the same periods the average results per exchange per day, the figures for branch offices being credited to the employment exchanges with which they are associated.

\begin{tabular}{ll|c|c}
\hline & $\begin{array}{c}\text { rgr3 } \\
\text { (412 Exchanges). }\end{array}$ & $\begin{array}{c}\text { 1920 } \\
\text { (395 Exchanges). }\end{array}$ \\
\hline Registrations by workpeople & $\ldots$ & 23 & 27 \\
Vacancies notified by employers . & 10 & I3 \\
Placings through exchanges &.. & 7 & 9 \\
\hline
\end{tabular}

These figures indicate that on their present basis the exchange would receive about three million registrations by workpeople and one and a half million notifications of vacancies by employers and would fill a million places per annum. It will be seen that while about two-thirds of employers' notifications are filled through the exchanges only about one-third of the workpeople who register are placed through the exchanges.

Table I on p. I77 shows for the first six months of I920 the use made of the exchanges by different industries.

Table II shows that by men the exchanges are most used by the building industry, by the engineering and ironfounding industry, by employers of general labour, and by the transport industries. For women during this period domestic service accounts for two- 
TABLE I.

VACANCIES FILLED THROUGH THE EMPLOYMENT EXCHANGES IN GREAT BRITAIN DURING THE FIRS'T SIX MONTHS OF 1920.

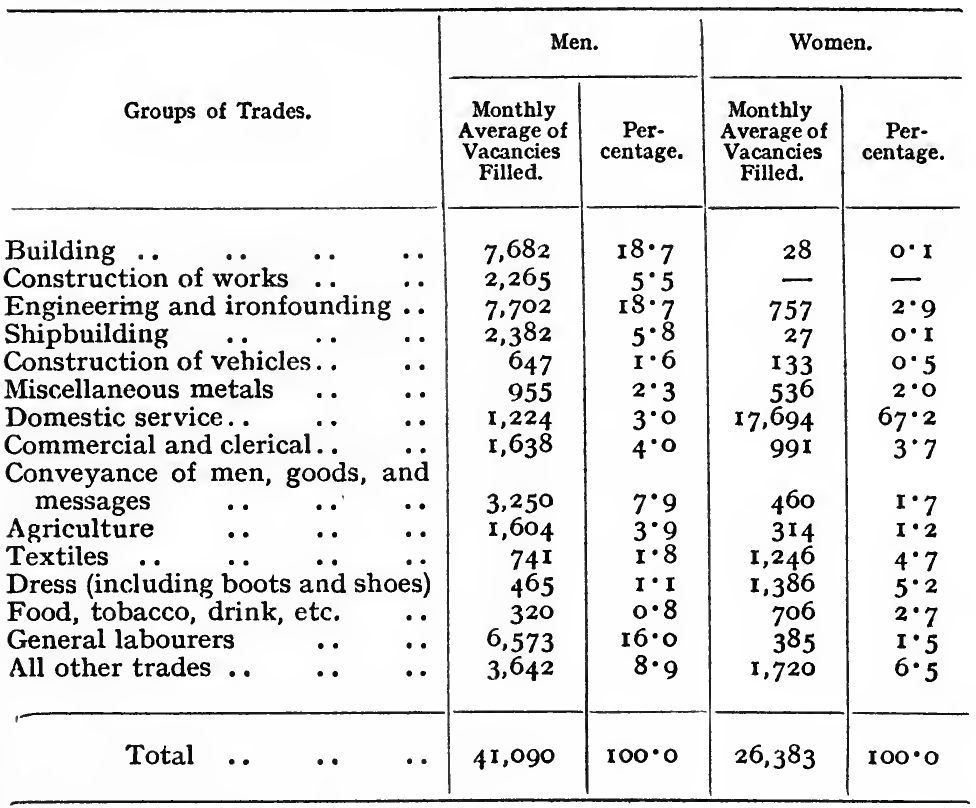

TABLE II.

MEN, WOMEN, BOYS, AND GIRLS.

Groups of Trades.

Building

Construction of works $\quad \cdots \quad \cdots$

Engineering and ironfounding $\quad \ldots \quad$..

Shipbuilding $\quad \ldots \quad \ldots \quad \ldots$..

Construction of vehicles $\quad \ldots \quad$.. $\quad$..

Miscellaneous metals $\quad$. $\quad$.. $\quad$..

Domestic service $\quad . . \quad \ldots \quad \ldots$...

Commercial and clerical $\quad . . \quad \ldots \quad \ldots$

Conveyance of men, goods, and messages. .

Agriculture .. $\quad . . \quad \ldots \quad \ldots$..

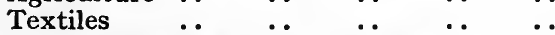

Dress (including boots and shoes).. ..

Food, tobacco, drinks, etc... .. ..

General labourers $\quad . \quad \ldots \quad \ldots \quad$.. $\quad$..

All other trades $\quad \ldots \quad \ldots . \quad \ldots \quad$..

\begin{tabular}{|r|r}
$\begin{array}{r}\text { Monthly Average } \\
\text { of Vacancies Filled. }\end{array}$ & Percentage. \\
\hline 8,195 & $9 \cdot 5$ \\
2,269 & $2 \cdot 6$ \\
11,174 & $13 \cdot 0$ \\
2,607 & $3 \cdot 0$ \\
1,131 & $1 \cdot 3$ \\
2,676 & $3 \cdot 1$ \\
21,286 & $24 \cdot 7$ \\
4,369 & $5 \cdot 1$ \\
6,845 & $7 \cdot 9$ \\
2,111 & $2 \cdot 4$ \\
2,815 & $3 \cdot 3$ \\
2,982 & $3 \cdot 5$ \\
1,568 & $1 \cdot 8$ \\
7,991 & $9 \cdot 3$ \\
8,259 & $9 \cdot 5$ \\
\hline 86,278 & $100 \cdot 0$ \\
\hline
\end{tabular}


thirds of the "Placings," and the industries standing next in point of numbers placed are dress (including boots and shoes) and textiles. For all classes of workpeople after domestic service, which accounts for $24^{\circ} 7$ per cent. of the total placings, the largest proportion of the total is shown to be in the engineering and ironfounding group -r3 per cent.

It is interesting here to note the figures of the employment exchange which specializes in one group of trades. It is the most successful office in the country.

SPECIAL BUILDING TRADES EXCHANGE (TAVISTOCK STREET, LONDON). STATISTICS-rirg.

\begin{tabular}{|c|c|c|c|c|c|}
\hline Month. & & Registration. & $\begin{array}{c}\text { Locals Placed } \\
\text { in other } \\
\text { Districts. }\end{array}$ & $\begin{array}{l}\text { Applicants from } \\
\text { other Districts and } \\
\text { Locals placed } \\
\text { Locally. }\end{array}$ & $\begin{array}{c}\text { Applicants from } \\
\text { other Districts } \\
\text { placed in other } \\
\text { Districts. }\end{array}$ \\
\hline $\begin{array}{l}\text { January } \\
\text { February } \\
\text { March .. } \\
\text { April .. } \\
\text { May . } \\
\text { June .. } \\
\text { July . } \\
\text { August... } \\
\text { September } \\
\text { October.. } \\
\text { November } \\
\text { December }\end{array}$ & $\begin{array}{l}\ldots \\
\ldots \\
\cdots \\
\cdots \\
\cdots \\
\cdots \\
\cdots \\
\ldots \\
\cdots\end{array}$ & $\begin{array}{r}\mathrm{I}, 365 \\
\mathrm{I}, \mathrm{I} 95 \\
936 \\
520 \\
501 \\
\mathrm{I}, 040 \\
630 \\
587 \\
713 \\
553 \\
427 \\
423\end{array}$ & $\begin{array}{l}838 \\
600 \\
415 \\
294 \\
317 \\
523 \\
359 \\
446 \\
372 \\
389 \\
244 \\
346\end{array}$ & $\begin{array}{r}853 \\
942 \\
\mathrm{r}, 623 \\
672 \\
643 \\
\mathrm{r}, 277 \\
\mathrm{r}, 479 \\
\mathrm{I}, 041 \\
\mathrm{r}, 282 \\
762 \\
793 \\
740\end{array}$ & $\begin{array}{l}374 \\
294 \\
307 \\
510 \\
579 \\
632 \\
677 \\
316 \\
318 \\
228 \\
229 \\
277\end{array}$ \\
\hline Total & .. & 8,890 & 5,143 & 12,107 & $4,74 \mathrm{I}$ \\
\hline
\end{tabular}

\section{Employment Exchanges and Trade Union Standards.}

In fairness to the trade unions, provision was made that fares may not be advanced in cases of workmen proceeding to vacancies caused by a trade dispute affecting their trade, or to vacancies where the wages offered are lower than those current in the trade in the district where the employment is found.*

* At first union men had a very real prejudice against the Board of Trade employment exchanges. One cause of their distrust was their association with the bureaux of the Distress Committees, which dealt -with the unemployable and which were, in a measure, relief agencies. The more serious factor was the fear that they would be used for finding " scab" labour during strikes. 
It was, of course, clear from the outset that there was grave danger of employment exchanges being wrecked on the rocks of industrial disputes-strikes and lockouts. The Government, therefore, decided to take an impartial attitude in dealing with cases of this kind and has achieved this difficult task with remarkable success. The cardinal principle governing the administration's attitude with regard to a vacancy or lock-out is to notify the applicant for a job of the statements made concerning it by the secretary of the union of that trade and by the employer. The applicant, having been provided with a full knowledge of the facts, is then at liberty either to accept or reject the vacancy, and "it is specifically laid down in the Labour Exchanges Act that the regulations shall provide that no person shall suffer any disqualification or be otherwise prejudiced on account of refusing to accept such a vacancy."

\section{Juvenile and Women's Employment Exchanges.}

\section{Women.}

The important and special character of the field of women's employment was realized from the first by those responsible for the organization of the employment exchange system. In some districts, exchanges have been opened which deal exclusively with women and girls, whilst in most of the larger exchanges separate departments with separate entrances are run under the charge of special women officers.

The magnitude of this work is appreciated when it is recalled that in I9I4, 232,935 vacancies for women were filled and the daily average during the first six months of I920 was I,055. Before I9I4 the women's branch of the employment exchanges were particularly useful in dealing with occupations of a casual or a seasonal nature, such as charing or fruit picking. In connection with this work there developed a new and interesting feature in exchange activities. Whole families were encouraged to remove from districts where there was little employment 


\section{INSURANCE AGAINST UNEMPLOYMENT}

to districts where the services of many members of the family, particularly the women and juveniles, were in demand. This tendency has been greatly increased by the war with its encouragement to the mobility of women's labour. Thus in July I9I4, 5,020,000 women were engaged in industry and in April I9I6, 5,490,000. Thus in twentyone months of war 470,000 women over and above the normal recruitment went into industry, and there is evidence showing that since the policy of "combing " men out of industry into the army began, the number of women who had gone into competitive labour increased at a much greater rate. Thus by October I9I6 the British Labour Gazette reported that 988,500 women had been drawn into remunerative industry. Moreover about one woman engaged in wage-earning employment in every seven was replacing a man. Women were occupied as compositors, sweepers, car cleaners, postmen, and porters. The exchanges have been used not only to increase the numbers of women wage-earners but to transfer them from process to process and industry to industry.* Since the armistice the condition of women in industry has been uncertain and their presence is being used by unscrupulous employers to lower the wages of ex-service men.

\section{Juvenile Employment Exchanges.}

More important even than assisting adults in finding the employment which they want, is the treatment of juveniles, i.e. boys and girls under eighteen years of age. Their choice of employment can be influenced and the effect of such choice will be cumulative. Casual labour can thus be discouraged and the basic industries of the country can be fed with an adequate quantity of skilled labour. The training which they gain will influence their attitude towards trade union policy and may even affect industrial structure. This would be the case if,

* Labour Finance and War, consisting of a series of reports edited by $R$. W. Kirkaldy. See especially report on "The Replacement of Men by Women in Industry during the War," Board of Trade Labour (iazette, January r9I7. 
for instance, young men and women were taught something of management as well as their craft. Juveniles are therefore treated in a different manner from adults.

In Great Britain three principles have guided the administration's policy.

(I) Not only was information concerning vacancies necessary, but in addition it was important to collect information respecting the conditions, and above all the prospects in the various trades.

(2) It was essential that full particulars should be available not merely as to the youth's previous industrial record, but also as to his ability to learn some new trade.

(3) The juvenile also needs someone to keep in touch with him even after he has found a suitable post, someone who will see that he retains his employment, if it is satisfactory, and to counsel him generally.

In brief, vocational guidance, placement, and " special care" are activities in each of which juvenile employment exchanges are interested. In Great Britain, these three functions are regarded as essential parts of one policy.*

There is a special department for dealing with boys and girls under eighteen years of age at each employment exchange. There are 245 juvenile employment committees working with the exchanges. These committees advise children in the selection of suitable employment and make efforts to improve the conditions of training for local industries. They collect information about the general local conditions of juvenile employment and about opportunities for employment. Of the 245 committees which were at work at the end of I920, I45 were appointed under the Labour Exchanges Act and Ioo under the Education (Choice of Employment) Act, Igro. It is evidently undesirable for two Departments of State

* In New York City these three functions when attended to at all by voluntary organizations are treated as independent. Thus the Scholarship Committee of the Henry Street Settlement helps and advises the young boy or girl, but the Alliance Employment Bureau actually places the juvenile. The Big Brother movement aims to provide this "special care" for the young people who come under their charge. It must, however, be conceded that the promising experiments which these bodies are now conducting are as yet in their infancy. 


\section{2

to be responsible for the supervision of juvenile employment, and an improved centralized system is needed.

It is particularly important to the efficient handling of the unemployment problem that the first of these functions should be properly carried out. In this way casual labour can be made so costly to employers that its amount will be reduced to a minimum, and the gross maladjustments resulting from the existence of too many workmen in some trades and not enough in other trades will perhaps entirely be done away with. This consideration was of marked importance during the period of adjustments necessitated by war conditions. It was obvious that the Board of Trade could be well served by taking advantage of the experience of the educational authorities with regard to the juveniles that passed through their charge, and so special committees were appointed by the Local Education Authorities to co-operate with the committees appointed by the Ministry of Labour.

The "Special Rules" provide that the committees shall include "persons possessing experience or knowledge of education or of other conditions affecting young persons, appointed after consulting such authorities, bodies, and persons as the Board thinks best qualified to advise them, and also persons representing employers and workmen."** Their functions are to give advice with regard to the management of any employment exchange in their district in relation to juvenile applicants for employment, and to give information, advice, and assistance to boys and girls and their parents with respect to the choice of employment. In the majority of the schemes where the Local Educational Authorities and the Ministry of Labour are advising juveniles the following procedure has been developed:

\section{Administrative Procedure.}

The work of advising applicants for employment is reserved to the officer of the Education Authority; the

* In practice, they consist of nominees of the Local Education Authority and representatives of employers and workpeople. 
work of registering particulars of vacancies received from employers and of bringing to the notice of employers the facilities offered by the scheme is reserved to the officer of the employment exchange, while the selection of suitable applicants for a particular vacancy is a matter for consultation between the two officers. The Educational Authority usually organizes Care Committees for the purpose of keeping in touch with boys and girls before and after they leave school.

After the juvenile has been placed, a voluntary worker is expected to keep in touch with the child in order to counteract any tendency towards the-aimless drifting from job to job, and to help, when necessary, in finding him a new situation. The helper also advises and assists the juvenile with regard to bis general welfare, continued education, etc., and reports to the Advisory Committee every six months as to the child's progress.*

Much knowledge is being gained by the Care Committees as to the conditions of juvenile labour, and in many places sub-committees have been formed to deal with special departments of the work. In one large town, for example, sub-committees are dealing with:

(I) Domestic service for girls aged fourteen to seventeen.

(2) Van boy employment.

(3) Permanent after care.

(4) Skilled trades and apprenticeship.

In every case much useful information is being collected and the following points have been brought home to the Advisory Committees:

(I) The appalling amount of unskilled or semi-skilled occupations to which boys and girls go straight from school.

(2) The long hours and heavy work of errand-boys.

(3) The enormous and unsatisfied demand for errandboys.

* In the United States the Big Brother Organizations help to achieve this same object. But there is apparently no channel for pooling the information and experience gained in this way. 


\section{INSURANCE AGAINST UNEMPLOYMENT}

(4) The tendency of boys to shift from employer to employer.

(5) The difficulty of getting accurate information about occupations.

(6) The impossibility of getting boys and girls to attend evening schools in anything like satisfactory numbers.*

One of the results which was anticipated from the formation of these juvenile employment committees, and which has been realized, was the increased attention devoted to the local needs of industry and the arrangements for training boys and girls to satisfy them.

It must, however, be noted, not as a criticism of the work of juvenile employment committees, but rather as a condition of present day industry, that their power for good is limited and that they cannot abolish the existence of occupations of a thoroughly demoralizing type, which offer high wages and no training. All they can do is to save particular boys from them, and perhaps find for a few chosen ones the opportunity of gaining the advantages of apprenticeship. The good that may be done will be to get all the best boys into the best situations. It will not diminish by one the numbers who are demoralized by the bad situations. Yet it might be fairly contended that the policy of juvenile employment exchanges will have a substantial effect in making it more difficult to fill such situations. In that case, industry may be relied upon to pay heavily for such work or to abolish it altogether. This change, however, must necessarily be the result of a slow process.

\section{Employment Exchanges and the Decasualization of Labour.}

The student of unemployment insurance is forced to study the problem of reducing the amount of casual labour because of its direct relation to his own problem.

* The Fisher Education Act was aimed to improve this situation. 
First, the whole system at present in vogue for relieving the " unemployed" is vitiated by the presence of over whelming numbers of short engagement men in need of relief. Second, as long as short engagements continue it will be impossible to measure the extent of the oversupply of labour in any industry. Third, the existence of an overstocked labour market almost necessarily implies a high percentage of unemployment, and this as a rule renders a scheme of unemployment insurance very difficult.*

The cardinal principle of employment exchange administration in Great Britain is, "The first man for each job, regardless of other considerations." Unlike the Massachusetts labour employment bureaux, their policy is " first come, first served." Similarly, the labour bureaux organized by trade unions in France "allot situations to their members strictly in order of priority of application." The labour bureau of Berlin brewers also provides that " a workman must wait his turn before he is placed; i.e. on registration he gets a number and must then wait till all the numbers on the list prior to his own have been satisfied." This policy has been opposed. It is argued that only by maintaining a preference list can regular employment be provided for the best workmen and the problem of the inefficient workman be brought into high light. Whilst this has not been the general policy of the British officials, its working is yet seen most clearly in certain specific British schemes.

In framing the Bill on National Insurance specific proposals were embodied in it with a view to reducing the irregularities in industry. For example, the section proposing to relieve employers of the custody and stamping of the health contribution cards and unemployment books, on condition that the men concerned were to be engaged by the employer through an exchange, has resulted in a large number of arrangements of this kind.

One of these arrangements, that affecting ship-repairers

* See Jackson and Pringle: Commission on the Poor Laws, Appendix, vol. xix, p. 647 . 
in South Wales, related to 8,000 men who were largely employed casually. By coming under the supervision of the employment exchange officials the process of decasualizing labour could be undertaken more easily. Attempts at reducing the number of casual labourers in a given occupation, and of concentrating all the work on the remaining workers, are not new, but the exchanges and the Unemployment Insurance Scheme have provided a necessary stimulus to this process.

The Manchester Cloth Porters' Scheme differs from the above in the fact that cloth porters are liable to insurance under the Health Insurance Act only. A large number of employers agreed to use the employment exchanges for all their labour of this kind. The men actually wait in the exchange and are sent from there as asked for by the employers. They are paid wages by the employers; the exchange keeps and stamps the contribution cards.

One of the first examples of the unification of demand for labour which had previously been separate came about at the London and India Docks after the strike of I889.

Formerly each of the forty-seven departments of the Company's work was a separate unit for the engagement of men; each department had its insignificant nucleus of regular hands, and its attendant crowd of more or less loosely attached casuals ; 80 per cent. of the work was done by irregular labour. Now the whole dock system is, so far as the Company's work goes, the unit for the engagement of men; 80 per cent. of the work is done by a unified staff of weekly servants directed from one spot to another by a central office.*

The most highly developed scheme for decasualizing dock labour and the one most instructive to students in other countries has been put into operation in Liverpool.

The Liverpool Dock Scheme, which embraces nearly all the dock labour of the port, is administered by the Ministry of Labour in co-operation with a Central Joint Committee of Employers and Workmen. Some 68 employers and

* Beveridge: Economic Journal, 1907, p. 73. 
over 31,000 dock labourers are registered under it. There are six clearing houses and fourteen surplus stands. These are situated at convenient points along the eight miles of docks. Each clearing house is co-ordinated with and controlled by a central clearing house. All are in direct telephonic communication with each other and with the fourteen surplus stands.

The main features of the scheme are :

(a) The registration of all dock labourers, and the issue of metal tallies to the men registered.

(b) The limitation of employment to men provided with such tallies.

(c) Systematized engagement of labour.

(d) The custody and stamping of the health insurance contribution cards of dock labourers.

(e) The payment of wages at six convenient centres to all dock labourers.

(f) The automatic deduction of the health insurance contribution at the time of payment of wages.

The clearing houses are used for the following purposes:

(I) Registration of workmen.

(2) Payment of wages.

(3) Fulfilment of employers' obligations under Part I (i.e. the Health clauses) of the National Insurance Act.

(4) Weekly meeting of Clearing House Joint Committees.

Each of the local joint committees issues and withdraws tallies, settles disputes in connection with work done at the clearing house, considers matters affecting its area referred to it by the Central Joint Committee, and suggests improvements of the arrangements. The central feature of the scheme is the undertaking by employers that they will engage only those workmen who are in possession of tallies. Since fresh tallies can be issued only with the approval of the employers' and workers' committee, there is a reasonable prospect that there will 


\section{INSURANCE AGAINST UNEMPLOYMENT}

be a check on that free entry of fresh labourers, irrespective of the real needs of the port, which forms the main evil of casual employment.

At the outset of the scheme each employer was allowed to give a card to every labourer commonly employed by him, whether regularly or casually, and the man on taking this card to a clearing house received a tally. The possession of the tally by the workman is evidence that the workman's health insurance contribution card is deposited for stamping purposes at one of the clearing houses and that he has been registered at the clearing house or exchange.

The men attend for employment in the first instance at the ordinary taking-on place of their usual employer.* If unsuccessful there, they repair at once to one of the fourteen "surplus stands," and from them surplus men are directed to any place where there may be a deficiency of workmen.

Under the scheme, wages are paid by the Ministry of Labour on behalf of the employers in a single sum and in one place to each workman. Great benefits are thus conferred on the men, who are thus rescued from collecting their wages in driblets at a number of places, and protected from the pressure, felt by casual labourers in London and elsewhere, to stamp their contribution cards themselves in order to secure employment towards the end of the week.

It benefits the employers in turn by relieving them of much trouble in connection with the stamping of these cards and by apportioning their contributions equitably. More important is the consideration that they are more likely to be able to engage the kind of labour which they need.

The average number of men paid each week during the period July I3, I9I2, to July II, I9I3, was I9,887. The average number of those receiving wages through the

* In Hamburg alone, of all the ports of the world, a complete and rigid system of engagement exists not merely through, but also at, employment exchanges. For a lucid description of "The Harbour Workers of Hamburg," see pp. 210-28, The Longshoremen, by Charles B. Barnes. 
Board of Trade was 17,555 , and of those paid directly by employers was 3,408 . Some men in each week are paid in both ways, so that the sum of these separate figures exceeds the total given above. The average amount of wages paid out each week in I9I3 through the Ministry of Labour was $£ \mathrm{I} 9,8 \mathrm{I} 8$, being $£_{\mathrm{I}} 2 \mathrm{~s}$. $7 \mathrm{~d}$. for each man who received anything in this way.*

The Goole Dock Labour Scheme, covering about I,500 men, is somewhat similar to that at Liverpool, embodying the same features of limitation of work to registered men with tallies and payment of wages and health insurance contributions by the Ministry of Labour on behalf of the employers. At Sunderland, where the scheme covers the whole of the casual dock labourers, numbering about 1,000 , the first of these features is found, but not the second.

\section{Dovetailing Employments.}

It has been suggested that in addition to the scheme aiming at the decasualizing of dock labour that subsidiary occupations should be provided for them, but this, in so far as it is practicable, can only be very gradually realized. Dovetailing of different kinds of employment is practised now by groups of workmen. Work at the English docks is usually brisk in December and January, and to a less degree in July; it is slack in August and September. Builders' men, therefore, come to the docks in winter when their own trade is slack, and gas-workers are available in July. On the other hand, many dockers go hopping and harvesting in August and September.

Could not this movement of labour be more scientifically organized and the difficulties of seasonal fluctuations

* The first year's working of the Liverpool Dock Scheme showed that many men had become so demoralized by casual labour that although fairly regular work could be had the men would not seek it, but were content with work and earnings for part time. In reply to the demand of employers to increase the number of tallies that were distributed, the divisional officer has rightly insisted that the apparent lack of labourers had best be made up by educating the men to regular work. By substituting a weekly rate for the present hourly wage the men would become habituated to a more normal method of work. Williams : The First Years' Working of the Liverpool Dock Scheme. 
be largely met by dovetailing ? It is not the least of the many merits of schemes of employment exchanges and unemployment insurance that they lay bare even when they don't solve urgent problems.

Hitherto little has been done for those labourers who are squeezed out through the introduction of any scheme for decasualizing labour. As we have seen, schemes of this nature imply so altering the conditions of employment as to give the best men more continuous work, at the cost of depriving others of what employment they have. Surely this interference with industrial organization to the hurt of persons whose only crime is that they are not quite as efficient workmen as the others is certain to breed great discontent. To be fair, a scheme of decasualization ought to be accompanied by some provision for these men and their families.

A number of proposals have been suggested for the absorption of the inefficient workers who are squeezed out of industry because of the decasualization policy which might be pursued by the exchanges. It is not possible to discuss these here. It will suffice to point out that "the absorption of the permanent surplus of efficient, even though unskilled labour, cannot be an insoluble problem unless there is a shortage of one or both of the other two factors in the production of wealth, viz. land and capital. As there is no such shortage in England to-day, it must be possible for statesmanship to bring unemployed labour into union with unemployed land and capital, and so absorb any surplus which might result from decasualization.* There is almost general agreement amongst students of this problem that extremely inefficient workmen who thus lose their chance of a livelihood are as a rule lacking in vitality, and ought to be put under medical treatment and some form of educational discipline until they are fit for a return to industry. $\dagger$

Special schemes applying in the main to only one trade, et seq.

* See Prevention of Destitution, by Sidney and Beatrice Webb, pp. I33,

$\dagger$ See Rowntree and Lasker, op. cit., pp. I4I, et seq. 
dock labour, have been attempted. This is due to the fact that the problem of decasualizing labour at the docks was most pressing. But it is not unlikely that, with a growing knowledge of the characteristics of different trades, special proposals will be developed for dealing with other kinds of unskilled labourers such as, for example, bricklayers' labourers. The experience gathered from the experiment with South Wales ship-repairers and the Manchester cloth porters should prove valuable.

The British employment exchange policy of providing that workmen in all trades should register at the same exchange is justified on grounds of economy. But the great success of the building trade exchange in London, which is carried on under the supervision of a committee of employers and workmen engaged in that trade, and by a staff which has expert technical knowledge, justifies the view that similar specialized exchanges for other industries and in other areas should be developed. These will aid also in the establishment of "industrial insurance for the unemployed."

\section{The Criticism of Employment Exchanges.}

The employment exchanges have laboured under the very greatest difficulties from their introduction in 1909. They have not had any period of normal experience in which to perfect their organization. Thus, first, the Unemployment Insurance Act of I9I2 absorbed the main energies of the headquarters staff. Then came the numerous functions imposed on the exchanges during the war. The great tasks of demobilization have been accompanied by the work of administering the out-ofwork donation to civilians and ex-service men. Now, all the energies of the employment department are taken up with the extension of the unemployment insurance scheme to over twelve million people. There has not yet been a fair period to judge of the results of the working of the exchanges. But it cannot be denied that there has been a steady opposition to employment exchanges 
in Great Britain since their inception. The Press has enlarged on every legitimate grievance and has circulated a great number of satements that are untrue.* An amazing incident of prejudice blinding evidence appeared before the Committee of Enquiry into the " Work of the Employment Exchanges." Professor Macgregor, who was on the Committee, stated that "There was an employer here last time, and we called for a return immediately after his evidence. He said he was positive they never used the exchanges. The return here is 2,000 men." $\dagger$ Indeed a large number of employers say that they never use the exchanges, and yet as a matter of fact the exchanges are doing a very large volume of work filling a large number of vacancies notified voluntarily by employers. The situation arises from the fact that most employers do not know whether they are using the exchanges or not. As Sir William Beveridge pointed out, " no such statement made by an employer ought to be taken without verifying the statement by reference to the exchange records, because it is not a big employer's business to know how his labour is taken on." $\ddagger$

There is still the objection to exchanges that they are a government interference between employers and workmen. There is also the prejudice of the old-fashioned foreman accustomed to his old methods of engaging workmen, who is apt to lose his one-time tyrannical powers. Most important are the causes of prejudice which attach to the very nature of the subject of unemployment. Any organization dealing with it seems doomed to be unpopular. Something has been achieved, seeing that the same profound unpopularity of the workhouse and relief work does not attach to exchanges. Also, the State is obliged to pursue a policy of its own which is often divergent from that of employers and of the workmen.

Especially in times of industrial disputes the exchanges seem doomed to be attacked by one or other of the con-

* Cd. I I40. Appendix I 2 gives examples of investigations by Local Employment Committees into charges against the exchanges.

$\dagger$ Cd. I140, p. I 85. $\ddagger$ Idem. 
tending parties. Moreover, it is a fact that the exchanges do deal with the lower class of labour. Since most employers endeavour to attach their best workmen to themselves during good and bad times, the unemployed fringe is naturally composed on an average of those who are less efficient than the average employed workman. This gives them a certain disrepute amongst the better type of workmen. It should, however, be evident that industry cannot continue without the less efficient workmen. They are needed in busy times, in times when industry is expanding, and provision must be made for them.

It was of course inevitable that the payment of insurance benefits at the low rate of $7 \mathrm{~s}$. a week before I9I4 should result in a considerable amount of dissatisfaction with the exchanges which acted as the paying-out agencies. Similarly, the agitation against the out-of-work benefit, which came to be dubbed "the dole," has also had the effect of making them share their unpopularity.

Two causes of prejudice may, however, be removed. These relate primarily to the personnel of those administering the exchanges. On their initiation a large body of officials had to be collected in a short time to undertake this work, and some of them have not proven suitable for their positions. Similarly during the war, of the many temporary officials taken on to the staff a number lacked the knowledge necessary for their work.

It is also held that a number of employment exchange officials ought to be trained to have a technical knowledge of the trade with which they are dealing, and that exchanges should specialize in certain trades. But it is clear that given a period during which the exchanges could devote themselves to the problems for which they were created they would soon overcome these difficulties.

Another common charge against the exchanges is that they deal chiefly with unskilled men. This is not true. In the insured trades alone about 55 per cent. of skilled workmen and 45 per cent. of labourers were placed by them. Then about 7,000 of all the union branches voluntarily lodge their books with the exchanges and 


\section{INSURANCE AGAINST UNEMPLOYMENT}

their members use them. Of course, under the latest insurance scheme millions of the most skilled workmen are registered by the employment exchanges when unemployed. Indeed, on investigation it was found that skilled labour predominates in the work of the exchanges.

But whilst most of the criticism levelled at exchanges results from sheer prejudice against a new institution, they evidently have much to accomplish before giving general satisfaction. In London alone some six hundred private employment exchanges are still carrying on their placement work for which employers and employees are willing to pay fees.* Moreover, advertisements in the Press are still very common. Nor has the demoralizing tramping from factory to factory in search of employment entirely ceased. These methods are undesirable. But the same objections do not apply to highly skilled organized workers learning of vacancies through their trade union " call houses" or through personal touch with foremen, or through their comrades in various workshops.

Previous to the war the exchanges were making slow and steady progress in gaining the confidence of employers and men. During the war this was shaken and the uphill work has begun once again. There seems no reason to believe that given a period in which they can devote themselves to their main function that they will not gain the confidence of an overwhelming majority of employers and workpeople.

\section{Summary : Effects of Employment Exchanges on Workmen and Employers.}

We are now in a position to summarize what influence in organizing the labour market the employment exchange can exert.

Employment exchanges do not provide, in a strict sense, work for the unemployed. They do, however, obviate the demoralizing tramping system which was humiliating and

* These, however, include a large number of highly specialized exchanges like those for concert artistes, cinema actors, etc. 
disheartening to the labourer. Exchanges may make it easy for operatives seeking work to find it, and those wanting labour might be helped and hastened in their search. By shortening the average interval between the loss of one job by a workman and the finding of another, the social time-lag can be cut down.*

The exchanges find employment for trade unionists and unorganized men more efficiently than the workmen did without their aid. Workmen's organizations could perhaps rarely obtain for their members so complete a survey of the prospects of employment in all parts of the country as the exchanges are able to offer them.

Certain unions have decided to leave their list of unemployed members permanently in the hands of the exchange officials in order to facilitate their work. In other cases exchange officials have free entry into the unions' club to consult membership books with a view to finding suitable applicants for particular vacancies. Such a development was bound to take place, since by holding aloof organized men would only increase the chance of non-unionists getting employment.

To employers of labour the exchanges offer specialized service which result in great economies to them. In some thousands of cases, employers are giving notice that they will fill vacancies only through the exchanges. Hitherto most employers have engaged their labour through private employment agencies or at their own gates. Both these methods proved expensive, in so far as the employer had to pay the costs of choosing from the large numbers who applied for a job. Not even then, however, was he certain of obtaining the kind of help that he needed. But with a national system of exchanges which has knowledge of applicants for work from other parts of the country, there is a much greater likelihood of finding the suitable man for the job. Moreover, because of the large number of men applying to it, constantly, vacancies can be filled sooner and with greater certainty whilst the cost to the employers is eliminated. On the other hand, employers

* See p. 123, Casual Labour at the Docks, by H. A. Mess. 
complain that frequently the most efficient and intelligent workmen who are in constant employment make use of exchanges for the purpose of bettering their position whenever an opportunity offers. It has an unsettling effect upon a man, they contend, to know of vacancies in his trade. Furthermore, it has been urged that the institution of exchanges has encouraged a townward flow. Now whilst the former view can only be urged by those who have a selfish, unsocial outlook, it behoves exchanges to encourage as far as possible a policy likely to prevent rather than to encourage a flow into the cities.

In any consideration of the long time effect of the establishment of exchanges, the influence which they can exert in guiding and placing juveniles is more important than in finding employment for adults. They can help to abolish much of the aimless drifting which now characterizes the early years in industry of many undirected and misdirected young men and women. They can make casual labour extremely costly and thus help to abolish it. Above all, working in conjunction with the educational authorities they can produce fundamental changes in the industrial structure.

\section{Democratic Committees and the Administration of Unem- ployment Measures.}

One of the grave difficulties in the way of dealing withunemployment on a national scale is the fact that it necessitates the establishment of huge and complicated machinery and the employment of thousands of officials. Measures have been introduced for preventing the growth of an army of bureaucrats by attaching a local employment committee to every exchange.

Three important classes of committees representing the public have been established in order to help in the administration of unemployment measures and in order to give the general public an opportunity of controlling the various schemes. The first were known as Advisory Trade Committees, and consisted of an equal number of 
representatives of employers and workmen, appointed by the Board of Trade after consultation with bodies of persons affected. The need for effective local committees, for the normal work of the exchanges, and especially during the period of demobilization, led to the establishment of a system of local employment committees of which there are 302. The second are known as Juvenile Advisory Committees, and are appointed for the purpose of advising the exchanges, especially as regards juvenile employment. The third are known as Courts of Referees. They consist of equal numbers of employers and employees, and have, as we shall see later, as their chief function the consideration of appeals from the decision of the insurance officers who administer the Unemployment Fund.*

The successful working of the different schemes for grappling with unemployment problems has been due in large measure to the wide interest created in them through these committees, representative of all the parties interested. It is evident also that the Government recognizes the right and advisability of having trade unions help in the administration of schemes in which they have a special interest.

One important subject reserved to them is the question of granting accommodation in employment exchanges to outside bodies. Trade unions have made applications to hold their meetings at the exchanges, and "in the large majority of cases the committees have agreed to the use of the exchanges for this purpose, provided that the work of the exchange and the accommodation therein allow of it." $\dagger$ When it is recalled that many unions for want of better accommodation used to meet in beer-houses, and that many unions contain young women members, it is clear that a great social good has been accomplished. The committees have also advised the Ministry of Labour to what extent

* The Statutory War Pensions Committee and the Central Joint Committee of the Liverpool Dock Scheme also have representatives of labourers and of employers.

+ By September 1913, 500 branches of associations had availed themselves of the permission to use the rooms of the exchanges for their evening meetings. A nominal fee only of Is. per meeting is charged. To-day about $r, 500$ branches of unions meet in employment exchange offices. 
it should encourage the movement of labour from one district to another, and as to the possibility and best methods of developing the use of employment exchanges in connection with casual employment. They have, moreover, given help in linking up the exchange system with the smaller towns and with the agricultural districts. In this connection use has been made of the post office and a system of travelling clerks. Before long it is anticipated that there will be an agency within reach of every remote village.*

The war has resulted in increasing the number of joint committees of employers and trade unions in Great Britain. Let us note the functions of one such committee appointed by the Statutory War Pensions Committee in every locality, town and country. It will supplement the separation allowances and inadequate pensions granted by other bodies, and look after the medical care, industrial training, and wage-earning employment of disabled officers and men, and the education and training of soldiers' widows and orphans. Disabled soldiers cannot be expected to gain the standard rate, nor on the other hand would it be wise to permit unscrupulous employers to exploit their partial disability. These local committees determine the rate of wages at which they shall be encouraged or assisted to accept industrial employment.

It is interesting to note the contrast in treatment of the unemployed workmen to-day with what it was in the days of the "Distress Committees." One observant student writes :

All over the country a new class of worker is being evolveda paid Government official who is deeply interested in the steady stream of unemployed who come into the exchanges, and one who in most cases is full of sympathy for them. In many exchanges the men are always addressed as "sir" as they come in, weary and discouraged, to report their need of work, or to claim the unemployed insurance benefit. $\uparrow$

* It is important to note also that Local Employment Committees toegther with certain employment exchanges have been instrumental in starting new industries and factories, and housing and port development schemes. Cmd. I I 40. Appendix II.

$\dagger$ "The Humanity of Labour Exchanges," by Constance Spender, Contemporary Review, May I9I4. 
Municipalities and other large employers of labour are learning to take advantage of the facilities offered by employment exchanges. Large towns like Birmingham are engaging all the casual labour needed for the corporation through the exchanges.*

Advertising for workmen in newspapers, or by signs on factory gates, and "picking up" jobs are, however, still very common, but at last a "labour market" is beginning to have a meaning and functions not unlike those of the cotton market, the grain market, and the stock market. $\uparrow$ The organization of a national system of employment exchanges has been so successful that a proposal is now on foot to establish an Imperial Immigration Bureau and Imperial Employment Exchanges, whose control should be shared between the British and Dominion authorities. $t$

In urging the establishment of a system of employment exchanges its advocates have pointed to the three main functions that it would fill.

First: It would help to place the unemployed workman in the vacant job with the greatest speed.

Second: It could be so managed as to help in the decasualization of labour.

Third: It was the necessary substructure for a plan of unemployment insurance.

We have considered the first two functions and seen that the claim was thoroughly justified, and now we can turn to the relation of employment exchanges to unemployment insurance.

* The employment exchange has been of greatest service to the small employer, who did not have men waiting round his premises as many big firms had. In answer to the opposition of such employers to paying their share towards the insurance of workmen against unemployment, it was frequently advisable to remind them of the services thus rendered them by the State.

$t$ The writer is indebted for some very valuable information dealing with the administration of the British scheme of unemployment insurance to an unpublished memorandum on the subject, written by Olga Halsey of Wellesley College.

$\ddagger$ The New Statesman, February 3, r9i7. Meanwhile, be it noted here, that the United States limps behind England in the matter of exchanges. Many States are still without them. In the others there is no co-ordinated system for the whole of the State. 


\section{OUTLINES OF THE BRITISH UNEMPLOYMENT INSURANCE SCHEME}

IT is evident from the outlines of the history of the treatment of unemployment in Great Britain that the Government was willing, and that the country was anxious, in I9I2, to attempt some bold measure for grappling with it. It soon became evident that the most effective step that the Government was then in a position to take was to establish some system of insurance against the loss of wages caused by unemployment. All the other measures that had been suggested would achieve their object only after years of planning and organizing, whilst the effects of insurance could soon be realized.

Two courses lay open to the Government. It might encourage the voluntary organization of schemes of unemployment insurance, ${ }^{*}$ or it might introduce an obligatory scheme, and though most of the experts advised it to take the more cautious step by introducing the former, i.e. the Ghent plan, the Government decided to take the initiative in putting through the bolder measure. Thus whilst Great Britain now joined the other countries in actively supporting collective provision against unemployment, it broke away from the policy prevalent in them.

The Ghent system, as we have seen, had been instituted in Ghent in I90I, and within seven years was adopted by all the other towns in Belgium. It was imitated by France

* This policy was suggested by the Commission on the Poor I.aw and by such authorities as Sidney and Beatrice Webb, Professors Hobhouse and W. J. Ashley, D. F. Schloss, I. G. Gibbon, and Cyril Jackson. 
in I905; instituted at St. Gall in Switzerland in I905; at Strassburg in Germany in 1906 ; in Norway in 1906, and in Denmark in 1907. In Italy it had been applied by the Societa Umanitaria of Milan in 1905. But there were obvious limitations to the Ghent system no less than to its alternative, a national system of insurance of a compulsory .character.

After all, unemployment insurance could not avoid its Scylla and Charybdis. Either there must evolve a comprehensive scheme which would give insurance during involuntary unemployment to the large mass of workersand that way, it was urged, lay compulsion; or there must evolve a necessarily slow and inadequate means of saving, establishment insurance,. or trade union out-of-work insurance-and that way lay years of half-measures quite inadequate to stem the flood of distress. The British Unemployment fnsurance Act was therefore made to embody the former principle.

Fully to appreciate the boldness of introducing the British scheme of unemployment insurance in I9II it is necessary to recall certain facts : that all the then existing successful schemes were on a voluntary basis, whilst this was the first compulsory scheme, national in scope; the schemes of Belgium, Holland, France, Germany, Norway all put together included perhaps only 300,000 people, whilst this scheme included 2,500,000 people; that in Great Britain there had previously been no public encouragement of unemployment insurance at all; that there was not yet developed an adequate machinery whereby the scheme could be administered and that there was not even a body of satisfactory statistics for estimating the costs of the project. Moreover, the real difficulties of unemployment were not shirked by this scheme. The trades chosen were those with a high percentage of unemployment, and the period during which benefits might be paid was longer than the average period of unemployment suffered by most workmen in the selected trades. Yet, withal, the English scheme was cautious and essentially experimental. It was to be tried only with a few trades. The benefits were to be 
small, the fund was to be protected from the inefficient by strictly limiting the period during which they might claim benefit. Above all, the machinery for establishing whether or not any claimant was unemployed-the very core of the difficulty in a scheme of insurance-had been initiated.

Why, it might well be asked, did the British Government, with its traditional conservatism, undertake such a scheme? Why did it venture on such a proposal in the face of the advice of its leading experts? Unemployment was not more rife, nor was the need greater than it had been for decades. The answer lies rather in the growth of a sense of public responsibility towards social problems and in the conviction that the proper machinery for dealing with unemployment had at last been invented and perfected. The possibilities of the employment exchange having been satisfactorily demonstrated, unemployment insurance on a national scale at last become possible. This fact explains also the cause of the "cataclysmic" introduction of the scheme of unemployment insurance.

After four years' experience with the scheme, embodying seven trades, a temporary scheme insuring certain classes of munition workers was passed in I9I6. Under the Act of 1920 practically the whole industrial population, with the exception of workpeople employed in agriculture and private domestic service, were brought within the scope of compulsory insurance.

\section{Outlines of the British Scheme.}

The National Insurance Act (of which Part II dealing with Unemployment Insurance will be referred to as the Unemployment Insurance Act) was passed by Parliament on December I6, I9II, and came into force on July I5, I9I2; but benefits under it did not fall due until six months later.

It aimed at two distinct objects: the provision of compulsory insurance in seven selected trades and the encouragement by means of governmental subsidies of voluntary insurance through associations in all trades. 
In its desire to guarantee that as many labourers as possible will be insured against unemployment, the Government embodied two distinct proposals, whose underlying principles were different, into one Act.

A temporary scheme was established by the National Insurance (Part II) Munition Workers Act, Igr6. This Act did not substantially differ from the permanent scheme excepting that its duration was limited to three years from the end of the war. The Act of 1920 also follows generally the lines of the previous Unemployment Insurance Acts.

\section{Selected Trades.}

All the workmen in seven selected industries were obliged to insure against unemployment under the I9II Act. These trades were building, construction of works, shipbuilding, engineering, construction of vehicles, ironfounding and sawmilling. Altogether, some two and a half million men and women representing one-sixth of the adults then engaged in industrial occupations, were covered by the Act.

"Workman" is defined as " any person of the age of sixteen or upwards employed wholly or mainly by manual labour, who has entered into or works under a contract of service with an employer, whether the contract is expressed or implied, is oral or in writing." The term is thus seen to have the very widest connotation. It includes men and women, seniors and minors.

Trades outside the building and engineering trades had the "liberty to apply," and if they made out their case and were prepared to make their contribution it was possible to include them in the scheme.

In outlining this scheme before the House of Commons Mr. Churchill asked :

To what trades ought we as a beginning to apply our system of compulsory contributory unemployment insurance? There is a group of trades well marked out for this class of treatment. They are trades in which unemployment is not only high, but chronic, for even in the best of times it persists; where it is not 


\section{INSURANCE AGAINST UNEMPLOYMENT}

only high and chronic, but marked by seasonal and cyclical fluctuations, and whenever and howsoever it occurs it takes the form not of short time or of any of those devices for spreading wages and equalizing or averaging risks, but of a total, absolute, periodical discharge of a certain proportion of the workers. These are the trades to which, in the first instance, we think the system of unemployment insurance ought to be applied.*

The building and engineering trades were thus chosen at the outset because of the great fluctuations of employment which characterize them, and, to a lesser extent, because, whilst the data concerning the amount of unemployment were inadequate, there was a greater amount of information for them than for most other trades. $\dagger$

Wide powers were granted to the Department in deciding which trades and occupations were to be included. It had power to exclude subsidiary occupations, now covered by the scheme, and to exempt those persons who suffer very little unemployment. Moreover, with the consent of the Treasury, but without recourse to Parliament, the Board of Trade, which then administered the scheme, might extend the Act to other trades.

The temporary scheme included workpeople employed on munition work, and workpeople employed in the manufacture of (I) ammunition, fireworks, explosives ; chemicals, oils, soap, candles, etc. ; (3) metals and repair of metal goods; (4) rubber and goods made therefrom ; (5) leather and leather goods (excluding boots and shoes ); (6) bricks, cement and building materials; (7) sawmilling

* Part I of the National Insurance Act deals with the insurance against sickness and disablement, and Part II contains a scheme of insurance against unemployment.

The two evils of sickness and unemployment are in actual life most frequently inseparable. Unemployment, owing to the lack of necessary sustenance, is frequently the forerunner of sickness, and sickness almost invariably results in unemployment.

$\dagger$ The proportion of unionists to non-unionists was one in five in the selected trades. For the country as a whole it was two in seven. It has also been estimated that half of the men in the selected trades earned . less than twenty-five shillings a week, a fact quite sufficient to show that there was no warrant for the view that the trades selected were the most highly paid for the country as a whole. 
and machine woodwork (other than under the Act of IgII). About $1,500,000$ were insured under this Act.

In addition I,500,000 workpeople were insured by trade unions in trades not covered by the above Acts, and therefore, in I9I6, unemployment insurance covered about $4,500,000$ people.

\section{The 1920 Scheme.}

But in 1920 all parties in the State, as well as practically all employers and employees were ready for a national scheme covering the whole of the industrial population. The Act passed in that year provides that all persons of the age of sixteen and upwards who are employed under a contract of service of apprenticeship will be compulsorily insured against unemployment save persons engaged in excepted employments. Persons employed in agricultural work, including horticulture and forestry, are excepted from the scheme,* as well as private domestic servants, outworkers, Government and public corporation employees who are employed continuously, and agents paid by commission or fees or a share in the profit. Under the Act of 1920 about twelve and a quarter million people were compulsorily insured. The Minister of Labour may extend the scheme to any of the excepted employments by issuing an Order to that effect.

ESTIMATED NUMBER OF WORKPEOPLE INSURED AGAINST UNEMPLOYMENT UNDER THE ACTS OF I9II AND I9I6.

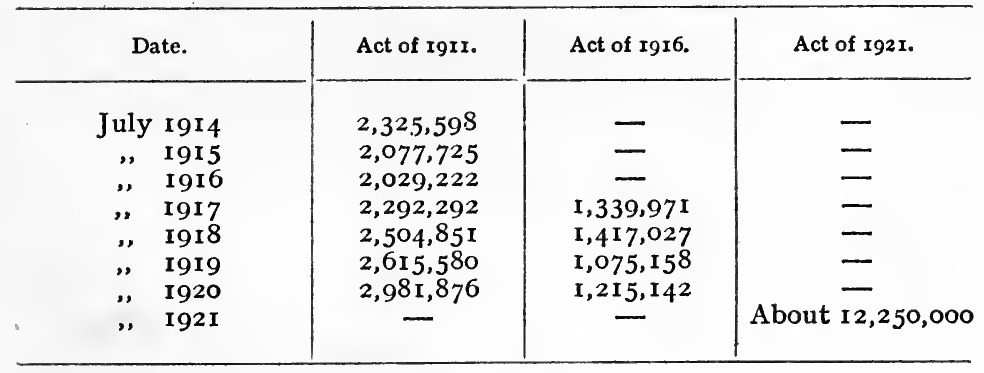

* See Appendix II. 


\section{INSURANCE AGAINST UNEMPLOYMENT}

The State contributes annually, from money granted by Parliament, an amount equal to about one-third of the total contributions of employers and workmen. The contributions from employers, the workmen, and the State together form the Unemployment Fund from which benefits are paid. This fund is controlled and managed by the Ministry of Labour.

\section{Contributions.}

Contributions are levied at a uniform rate for all workmen. There is an obvious objection to having the payment of equal contributions by people subject to different risks. The amount of unemployment varies with the occupation, the age, and probably with the wage of workmen. It might well be contended that a uniform rate which ignores these variations is therefore unfair. It was actually planned at first to meet this variation through differences in the rate of benefits, ${ }^{*}$ but the lack of adequate statistical data made this difficult. Mr. Thomas Ackland, the Government Actuary, said :

No data are available which would enable the rate of unemployment to be deduced on what might be considered an actuarial basis, and (apart from the desirability) it is not possible at present to attempt any differentiation of the rates of contribution or of benefits in respect of $(a)$ the ages, $(b)$ the occupations, and $(c)$ the rate of wages of the workmen engaged.

It will be seen, however, that there are plain indications, from such data as are available, that the rate of unemployment in different trades, and in different branches of the insured and other trades, does, in fact, vary materially, both as to incidence and as to duration. Women and boys and girls under eighteen pay a different rate of contributions from men.

\section{Contributions of employers and workers are paid in}

* It was proposed that seven shillings a week be the benefit for those engaged in engineering, shipbuilding, and in the construction of works, and six shillings a week for those employed in building. 
the first instance by the employers, who are required to purchase and affix to the workmen's " unemployment books " unemployment insurance stamps to the value of the joint contributions of employer and workman. After having fixed the stamps the employer may deduct from the workman's wages one-half of the value of such stamps, but any employer who deducts his own share of the joint contribution from the workman's wages is liable to prosecution. No contributions are required while the workman is out of work.

The unemployment insurance stamps are obtainable at post offices. Unemployment insurance books can be obtained from employment exchanges or other local offices of the unemployment fund. No employer may employ a workman in one of the insured trades who does not have one.

The adoption of this method of collecting the contributions not only saves time, but also dispenses with the need of an army of agents, or of some alternative agency which would otherwise be necessary to collect the contributions of over twelve and a half million members.

An employer or workman who fails to pay any of his contributions or refuses to comply with the Act or regulations thereunder is liable for each offence to a fine of $£ 25$, and in addition, where the offence is failure to pay any contribution he is liable to the unemployment fund for the amount he has refused to pay.

Since July 4, I92I, the weekly rates of contributions have been:

\begin{tabular}{|c|c|c|c|c|c|c|c|}
\hline & & & & & Employer. & Employed. & State. \\
\hline Men & . & .. & .. & . & $8 d$. & . $7 \mathrm{~d}$ & $3 \frac{3}{4} \mathrm{~d}$. \\
\hline Women & . & $\cdots$ & . & .. & $7 \mathrm{~d}$. & $6 \mathrm{~d}$. & $3 \frac{1}{4} \mathrm{~d}$. \\
\hline Bcys & .. & .. & .. & . & $4 d$. & $3 \frac{1}{2} \mathrm{~d}$ & I $\frac{7}{8} \mathrm{~d}$. \\
\hline Girls & .. & $\therefore$ & .. & . & $3 \frac{1}{2} \mathrm{~d}$. & $3 d$. & I $\frac{5}{8} \mathrm{~d}$. \\
\hline
\end{tabular}




\section{Benefits.}

From March 3, I921, the weekly rate of unemployment benefit has been :

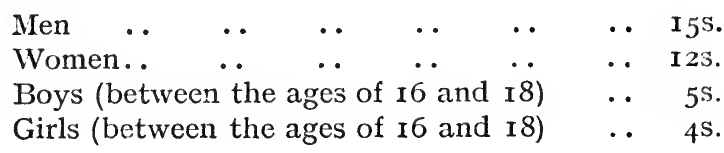

The maximum periods of benefit that may be drawn are as follows :-

Between March 3, I92I, and November 2, I92I (first "special

$\begin{array}{lllllllll}\text { period") .. } & \ldots & \ldots & \ldots & \ldots & \ldots & \ldots & \ldots & \text { I6 }\end{array}$

Between November 3, I92I, and July 2, 1922 (second "special

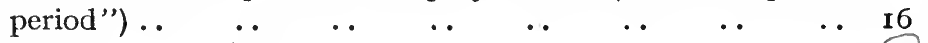
Thereafter, in each insurance year $\quad \ldots \quad$.

The principal preliminary qualification for benefit in the period up to July 2, I922, was the furnishing of proof of employment in insurable work in at least twenty weeks since December 3I, I9I9, and of proof that the applicant was normally in insurable employment, was genuinely seeking whole-time employment, and was unable to obtain it.

The uniform rate of benefit in the I9I2 scheme was 7 s. a week for not more than fifteen weeks in any year, nor in greater proportion than one week's benefit for every five weeks' contributions. The benefits under the I920 Act are I5s. a week.

In the case of workmen under eighteen, who pay at reduced rates, the benefit is half that of the adult workman, but no benefit at all is paid to persons below the age of seventeen.

Benefit is not paid during the first three days of unemployment. Where, however, unemployment occurs again within six weeks of this "waiting period" of three days" unemployment for which benefit is not paid, the applicant does not need to wait again before drawing benefits.

* For scale of benefits, see Appendix III. 
Some such limitation of benefits to a definite period characterizes, as we have already seen, nearly all schemes of unemployment insurance.

Whilst this provision will not be felt by men who work steadily as a rule, and make large claims on the fund only in times of exceptional trade depression, ${ }^{*}$ it will have the very salutary effect of excluding from benefit men who are incompetent or idle and who would therefore be tempted frequently to fall back upon it for support.

The following statutory conditions for the receipt of unemployment benefits are imposed:-

(I) The workman claiming benefit must prove that be has paid not less than twelve contributions under the Act. $\dagger$

(2) He must make an application for benefit in the prescribed manner.

(3) He must prove that since the date of the application he has been continutously unemployed.

(4) $\mathrm{He}$ must prove that he is capable of work but unable to obtain suitable employment.

(5) He shall not have exhausted his right to unemployment benefit.

Even though a workman has fulfilled the requirements of the statutory conditions, a workman is disqualified for benefit :

(a) If he has lost employment by reason of a stoppage of work which was due to a trade dispute at the factory, workshop, or other premises at which he was employed-for so long as the stoppage continues or till he gets work again elsewhere in an insured trade. $\ddagger$

* See Appendix IV.

† At the outset the requirement was that each claimant prove that he was employed as a workman in an insured trade in each of not less than twenty-six separate calendar weeks in the preceding five years. This provision was so difficult of enforcement that it was changed to proof of gainful employment for a given period in one year.

‡ Unemployment directly due to a strike or a lock-out is excluded. Thus it is clear that where a strike or a lock-out of one craft results in 
(b) If he has lost employment through misconduct, or has voluntarily left employment without just cause-for six weeks from the date of so losing employment.

(c) While he is an inmate of any prison, workhouse, or other institution supported out of the public funds, or while receiving sickness or disablement benefits under the Government's Health Insurance Scheme.

Workmen in receipt of compensation for accidents or of old age pensions, if insured, are not debarred from claiming benefit.

The condition that the unemployed workman must make application for benefit in the prescribed manner is the very core of the scheme. $\mathrm{He}$ is obliged to register at the employment exchange the fact of his unemployment. The exchange is in a position to know or discover whether his unemployment is due to lack of work in the establishment in which he has been engaged. It is able to find him work at his own employment in other establishments in the district, if vacancies exist. It might even help him to obtain employment in some other part of the country. The employment exchange thus controls the payment of benefit. It affords the test necessary for benefit. The unemployed workman when he presents himself to the exchange may thus be offered either employment or unemployment benefit. It is unfortunately too often assumed that the employment exchanges only distribute benefits and that this work can be undertaken by local authorities, by the Post Office, or by " approved societies other than trade unions." This idea is entirely erroneous. If the exchanges did only distribute benefits, then indeed any paying agency could easily carry through this task.

But their main function is to decide first whether the

the throwing out of employment other crafts in the same works no State benefit is due. On the other hand, if a dispute in one industry (for instance, coal mining) throws workers in a quite distinct industry (say engineering) out of employment, it is clear that the latter are entitled to State benefit. Naturally there are many doubtful marginal cases. 
workman is really unemployed through no fault of his own and whether he is unable to obtain suitable employment. To be able to decide these questions a national system of employment exchanges is indispensable.*

\section{Elasticity of Scheme.}

As with all other schemes of insurance whether against fire, accident or sickness, care must be taken to guarantee the solvency of the fund, i.e. arrangements must be made whereby a proper balance between the income received and the benefits granted can be provided for and that the benefits will be as large as the contributions will pay for, and yet will not be larger than the contributions will warrant.

Special provisions are therefore introduced into the scheme with a view to making it elastic.

The rates of contribution may be revised, but the equality of contributions between workman and employer, it is provided, must remain, and the rate of contribution for each party may not be increased by more than Id. a week. In addition, the Treasury may direct the Ministry of Labour, when the Unemployment Fund is insolvent, to reduce the benefits. Provision is made for temporary advances to the Unemployment Fund by the Treasury.

Owing to variations in the fluctuations of business and trades from decade to decade some such provisions would seem to be an essential part of all obligatory unemployment insurance measures. These are certainly necessary where actuarial calculations are based on incomplete statistical data, as was the case with the British scheme.

\section{Prevention of Unemployment. $\dagger$}

Devices were introduced into the IgII scheme which aimed at the reduction of the amount of unemployment.

* The Ministry of I,abour is satisfied that " the available evidence tends to show that the various checks and conditions, except in isolated cases; were sufficient to prevent malingering."

$\dagger$ It has been suggested that in the same way as insurance against sickness is known as Health Insurance so insurance against unemployment should be known as Employment Insurance. Direction would thus be drawn to the preventive object of the measure. 


\section{2

It was hoped that the general principle of the Act requiring a contribution from the employer and workman would tend to direct their efforts more than in the past towards reducing unemployment. More specific were the two interesting provisions which affected workmen suffering little unemployment and the employers who reduced the amount of unemployment in their own establishments.

If a workman attained the age of sixty years, and if contributions were paid into the unemployment fund in respect of him for not less than 500 weeks, he was entitled to receive from the unemployment fund the sum which had been paid into the fund as contributions from him, less the amount which he had withdrawn in unemployment benefit, with compound interest at $2 \frac{1}{2}$ per cent. This concession was of significance to the workman who did not suffer much unemployment, and was used as a compensation to him for his being thrown together with the less regularly employed workmen as far as benefits and dues were concerned.

The employer was encouraged to meet periods of slack trade by the method of short time for all rather than by dismissing men. Provision was made in the scheme for a refund to employers who make such socially desirable arrangements. This provision did not affect the policy of employers very much, so that it was not inserted in the revised Act of 1920 .

Other devices in the scheme aimed at the decasualization of labour and at the proper training and technical instruction of inefficient workmen. These will be considered later.

\section{Administration through the Employment Exchanges.}

The Unemployment Insurance Act is administered quite distinctly and apart from Part I of the National Insurance Act dealing with Health Insurance.

Unemployment Insurance is administered for the whole of the United Kingdom by the Board of Trade, through a 
single department, combining the control of Employment Exchanges and of Unemployment Insurance, and is managed from a single Central Office in London. The staff forms a single service for both purposes. For administrative convenience, the United Kingdom is divided into nine divisions. The offices used are of three kinds, viz. Central, Divisional, and Local. There is one Central Office in London. There are nine Divisional Offices, one in each of the divisions into which the country is divided. These divisional offices act as centres for and correlate the work of the employment exchanges and local agencies for the areas which they cover.

The officer in charge of claims at the exchange or the local office is known as the "Insurance Officer." In the case of a direct claim to benefit he decides whether the claimant satisfies the statutory requirements. In any case where the benefit is refused or stopped, the workman has the right of appeal to a Court of Referees, consisting of an equal number of employers and workmen and of an impartial chairman appointed by the Ministry of Labour.

The Court of Referees is appointed from panels of representatives of employers and employees. The names of employers' representatives are placed on the panel by the Ministry of Labour after consultation with the employers' Associations. The names of employees' representatives are placed on the panel as the result of elections held by workmen in the insured trades.

In all cases where the insurance officer and the Court of Referees agree the decision of the court is final. In cases of disagreement the insurance officer has the right of appealing to an umpire, who is appointed by the Crown, and who is not an official of the Employment Department of the Ministry of Labour.

The Umpire is one of the most important officers in the administration of the scheme. Test cases are brought before him, disputes are settled by him, and it is he who must, by his decisions, provide that the same interpretation of the law will be current all over the country. He has also the very delicate task of deciding questions which 


\section{INSURANCE AGAINST UNEMPLOYMENT}

arise between the Ministry of Labour and the unions claiming refunds or benefits under the Act.

The unemployed workman must claim his benefit at the local office or exchange. On registering the fact that he is out of work, his name is at once put on the register of those looking for work. He must then sign a "vacant card" at the exchange each day during working hours. In this way, it is intended, workmen will be unable to claim benefits whilst actually at work. At the same time if a vacancy in his trade occurs he can be directed to it when he calls to sign.

In the case of the unemployed member who is a member of a union he will sign the union vacant book, which may be kept at the exchange or in the union office. Or, in the case of the workman who is travelling in search of work he may be given a vacant ticket which he carries with him and it may be stamped at any exchange in the city. In case he lives more than three-miles from an exchange or local office, he need come only on alternate days to sign the vacant book, or less often. In some cases he is even allowed to send a certificate by post in order to show that he is still unemployed.

No benefit is paid during the first few days of unemployment, but the workman múst prove his bona fides through one of the methods of signing. If the workman neglects to sign as soon as he becomes unemployed, he must wait three days for benefit from the day that he does sign.

As soon as the claim is received, the local office sends a form to the last employer asking him to report if the loss of employment is due to any circumstances that would disqualify the claimant for benefit. When no such disqualification is reported, payment is authorized through the local exchange where the claim was first made. When the worker is a union member, and proper arrangements have been entered into by which the union pays its members, the local exchange authorizes the union to pay on its behalf the amount that would have been paid if the claim had been a direct one. 
If, however, the employer reports that loss of employment was due to some circumstance that would disqualify him for benefit, or the insurance officer is satisfied that the claimant has no title to benefit under the provisions of the Act, the workman has the right to appeal to the Court of Referees against their decision.

Each workman is required to obtain an unemployment book from the exchange. This book is left with the employer during his engagement and is returned to the employee when he leaves for another position.

The responsibility for the payment of the contributions of the employee and employer rest with the latter. $\mathrm{He}$ is empowered to deduct a certain sum per week from the employee's wage and is required to affix special unemployment insurance stamps representing the joint value of his own and the workman's contribution to an unemployment book handed to him by the workman.* It is illegal for the employer to recover his share of the joint contribution from his employee. It is the function of the Ministry of Labour to institute proceedings against employers and employees who seek to avoid their dues and against those who would take illegal advantage of the benefits. It is its function also to administer the unemployment fund, and for this purpose is allowed a sum not exceeding one-tenth of the total receipts of the fund.

\section{Co-operation with Trade Unions.}

One of the most important features of the compulsory part of the scheme is the recognition of the value and expediency of encouraging and co-operating with the trade unions.

* But under Sections Ior-2, if the workman knowingly allows his employer to avoid the payment, provided the payment is not actually made, the workman is ultimately liable. (From Garnet and Taylor.)

This question of ultimate responsibility for payments of dues is of the very essence of the Act. The decision of the Cour de Cassation, removing the responsibility from the French employer, has been an important element in the failure of the French system for compulsory old age insurance. Where the employer is not legally responsible, it is difficult for him to demand the necessary reduction in the weekly wage for the payment of the workmen's contribution. 
The Act provides that any union paying out-of-work benefits to its members, who are workmen in an insured trade, may make an arrangement with the Ministry of Labour to enable it to pay benefits and receive a repayment from the State of three-quarters of the amount which it expends. In order to regain the full State benefit of say 20s. per week, the union is forced, in this way, to pay a weekly benefit of at least 26s. 8d. The Ministry of Labour, of course, reserves to itself the right to determine whether any claimant is qualified for benefit The same qualifications and conditions apply to union and non-union workmen. Only those claims for refunds to unions are honoured which would have been met had the workman claimed directly through a local office or exchange.

\section{Voluntary Unemployment Insurance.}

It is convenient here to treat of the encouragement to schemes of voluntary insurance offered by the I9I I Act

All "associations not trading for profit," whether or not their members were engaged in an insured trade, might claim a repayment of one-sixth of the out-of-work benefits which they paid. This refund was paid only in respect of benefits up to I2s. a week; i.e. the maximum amount which might be claimed under this head was $2 \mathrm{~s}$. a week, even though the union paid a benefit exceeding this amount.*

It is manifest that this subsidy to union out-of-work benefits was smaller than was usually provided under the various types of the Ghent plan. But it is necessary to grasp the fact that this I2s. might already have included $7 \mathrm{~s}$. of State subsidy provided under the other sections of the Act. $\dagger$

This refund was paid from special moneys voted by Parliament, and did not come from the Unemployment Fund mentioned above. It was a subsidy to unions volun-

* The Amending Bill, I9r4, raised the limit to I7s. a week. (National Insurance (Part II, Amendment) Act, I9I4, ss. 14b.)

$\dagger$ White Paper, No. 192, p. 3 . 
tarily paying out-of-work benefit, and therefore differed from the repayment to unions of workmen who were compulsorily insured under the Act.

As an emergency war measure this refund to trade unions was practically withdrawn. Nor is it included in the 1920 scheme of unemployment insurance, since almost all organized workpeople are insured under it. 


\section{CHAPTER XV}

\section{THE PRINCIPLE OF COMPULSION}

HAVING briefly outlined the main features of the British schemes of unemployment insurance, we may now attempt an analysis of the scheme and a discussion in greater detail of the principles underlying it and the aims of its promoters. The next five sections are therefore devoted to a discussion of the "Principle of Compulsion," "The Scope of Unemployment Insurance," "Contributions and Benefits," "The Influence of Unemployment Insurance on Trade Unions," and "Unemployment Insurance as a Device for Reducing Unemployment."

The last two sections are devoted to a discussion of the "Scheme at Work" and "Next Steps in Unemployment Insurance."

\section{A Large Number are Insured by Means of a Compulsory Scheme.}

The Compulsory Principle.-The British Government was driven rather than chose to introduce insurance against unemployment on a large scale. To have subsidized existing voluntary unemployment insurance schemes in I9I2 would have meant influencing only about one million workmen. Even then, it is instructive to note that three times as many would have enjoyed such a State subsidy from the outset as were enjoying State, provincial, or city subsidies in all the other countries of Europe put together, for in Norway, Denmark, Luxemburg, France, Holland, Belgium, Switzerland, Italy, and Germany there were only about 350,000 workmen enjoying public subsidies in I9I3. But unless some such compulsory plan were 
introduced about seven-eighths of the working people in the trades chosen for insurance would have remained without protection.

Great Britain was in a mood to undertake a bolder scheme.* It was prepared to take a leap in the dark. A new plan of insurance covering a considerable proportion of all employees in the country was devised by the Government and enacted. $\dagger$ All the workers in seven selected trades were obliged to insure against unemployment.

\section{The Case for Compulsory Insurance.}

The British system did not, however, make other forms of provision against unemployment superfluous, even for those who were included in the scheme, since it hardly provided for their necessities ; it did not therefore remove the motive for organizing trade union insurance, nor for investing in extra provision through savings. In fact, a special effort was made under the Act to encourage trade union out-of-work insurance by offering a governmental subsidy of one-sixth of the trade union benefit to unemployed members so insured.

The Ghent scheme, or, to be more accurate, the principle of subsidies to trade unions, was in this way adopted in that part of the scheme concerned with voluntary insurance; but as the sole contribution to the great problem of unemployment it was regarded as wholly inadequate.

This characteristic British method of embodying two principles in one scheme had the effect of increasing the number of those directly benefited by the Government

* Speaking of the Health and Unemployment Insurance Act, the Rt. Hon. T. J. Macnamara said : "It is far and away the greatest scheme of State intervention into the condition of the people ever attempted in this country-probably greater than any essayed in any other." " It is startling in its compulsion, sweeping in its inclusion, perplexing in its intricacy, disturbing in its novelty." - Liberal Pamphlets, London, 19r3.

$\dagger$ It was of course true that the introduction of Government subsidies would have encouraged trade unions to extend their activities along the line of unemployment insurance. But as we have already seen, only in one or two countries have such subsidies resulted in increasing the numbers so insured by more than 20 per cent. 
measure ; it included not only all the workmen in the insured trades, but also increased the benefits of those who voluntarily came under it through their unions, and thus indirectly helped the growth of their out-of-work benefit feature.

Compulsory insurance applied in I9I2 to about two and a quarter million workpeople.

The "good times" during the war when unemployment was scarce offered an excellent opportunity for extending the British scheme and for accumulating large reserves in the insurance fund. The neglect of the Government at that time obliged it to insure over twelve million workpeople against unemployment towards the end of I920, just antecedent to a period of extreme and continuing unemployment. It is noteworthy that not one significant protest against the compulsory insurance of about nine million additional employees was raised.

It was urged in I9I 2 that if a scheme of subsidizing existing unemployment insurance funds were attempted, then aid would be given only to those who had been most able and willing to enter into their own organizations for insurance against unemployment, and that the very persons for whom provision was most necessary were least able and willing to avail themselves of the opportunity of gaining the increased benefits due to the State subsidy. Casual and poorly paid labourers, it was pointed out, were not often found in trade unions providing unemployment benefits.

There was in addition the consideration that individuals with conscientious scruples against joining trade unions, or at least the influential supporters of this class of workmen, now as rare as the dodo, would have endeavoured to establish provident societies in which members made provision by individual savings against unemployment-a scheme working with very little success in Ghent. Workmen joining such societies who had not satisfied the union apprenticeship regulations or other methods of guaranteeing their efficiency, would have constituted, it would be safe to assume from the experience of 
other countries, a very bad risk. Those individuals who insured voluntarily were likely, other things being equal, to suffer most unemployment. Only by means of a compulsory scheme could good and bad risks be netted and an undue preponderance of the latter rendered impossible.

Professor Edward Fuster was therefore justified in the view that

in spite of the admirable efforts of the organizers and propagandists of the Ghent system, and in spite of the great experimental and educative value of this endeavour, it was now beginning to be affirmed on all sides that the unions considered only as organizations for recruiting insured members (with all reservations as to their utility as agents for administrative purposes) did not bring together all those menaced by unemployment, and above all those who were most menaced.

In a word, there remained, in addition to those who might enjoy subsidized voluntary insurance, an uninsurable residue, a conglomeration of improvidents, who were often the most menaced, the most unhappy, the most dangerous from the point of view of a sound social order and a good organization of the labour market.*

Another argument urged in favour of a compulsory scheme of unemployment insurance was that the administrative costs might be kept lower than they would be in a voluntary scheme. Contributions might be collected, for instance, through employers, who could be held responsible for the payments of all their workmen, whilst employment exchanges were likely to be able to superintend the scheme for the district more cheaply than the various union offices of the different trades.

Again, by means of a system of compulsory insurance the State could easily keep its finger on the pulse of industry, at least on that part of it over which the scheme had effect. For the first time it would gather complete unemployment statistics. It would learn what percentage of unemployment there was among different wage groups and among different age groups. And, in addition, it would be able to gather information as to the effects of unemployment insurance as well as of other measures on the possible

* Builetin Trimestriel pour la Lutte Contre le Chômage, p. 387, AprilJune $19 r_{4}$. 
reduction of unemployment. It would certainly be possible to discover what influence a period of unemployment had on those subject to it. Moreover, it was evident that to organize the labour market, a pressing reform in itself apart from all considerations of unemployment insurance, it was necessary to institute a system of employment exchanges. Yet for this purpose alone the expenditure on them would be too great. Unemployment insurance was therefore both a cause and an effect of the newly introduced employment exchange system. Incidentally, by administering unemployment insurance exchanges were saved from their besetting sin. It had been feared that " employment exchanges would relapse and fall back into the purely distress machinery, not economic machinery, if not associated with a scheme of unemployment insurance."*

\section{Voluntary Insurance and Saving may Supplement Com- pulsory Insurance.}

Now, although it appears from this discussion that there were many reasons to justify the decision to introduce the principle of compulsion in a national scheme of insurance against unemployment, the British Government encouraged, in addition, as we have seen, voluntary insurance.

It is a characteristic of a compulsory scheme of unemployment insurance that only a minimum of benefits are provided and only a minimum of people are insured : that is to say, numbers of people who do not fall into the groups designated will still need voluntary organiza-

* See Winston Churchill's speech in the House of Commons. Hayes : British Social Politics.

It is instructive to remember also that the British National Insurance Act provided for a scheme of compulsory sickness insurance as well as for unemployment insurance. The inclusion of both measures in one Act of Parliament was not accidental. Not only are the principles involved very similar, and not only do the arguments for both largely overlap one another, but the administration of each is aided by the existence of the other. They aid one another in overcoming the greatest difficulty in the way of schemes of social insurance-the danger of malingering. 
tions, or will be obliged to make other provision for insurance against unemployment, whilst even those who do come under the scheme are not precluded from making their own arrangements for supplementing their benefits from other sources. Thus, in the British scheme, on its inception, only a few trades were selected whose members were to be insured against unemployment, whilst the insurance benefit in I9I2 was placed as low as $7 \mathrm{~s}$. per week for a maximum period of fifteen weeks in any one year. In I92I, with the cost of living index having reached I6I per cent. above that of I9I4, the I5s. a week's benefit bought even less, and later 2os. a week's benefit, not much more than the admittedly very low benefit of I9I3.

\section{Objections to a Compulsory Scheme.}

In the discussion of the first Bill for insuring certain groups of workmen against unemployment two fundamental objections were raised. Their importance is reinforced by the fact that wherever as in Germany or in the United States, a proposal for a compulsory scheme along the lines of the British scheme has been made, it has always been staved off by a reiteration of these arguments.

First, it was alleged that the statistics of unemployment on which to base an actuarial calculation of the risk of unemployment were insufficient, and consequently the cost of any proposed scheme could not be foretold.

Second, it was urged that the Government ought not to make it obligatory on people to insure on the ground that it involved an infringement of individual liberty.

The former argument, whilst it has some little basis in fact, has not proven to be very important. Most industrial countries have certain official statistics on unemployment which, whilst not entirely satisfactory, are sufficient for an estimate of the percentage of unemployment in most trades. Moreover, if this criticism were entirely honest, the attempt would have been made by those urging it to investigate the records of individual 


\section{INSURANCE AGAINST UNEMPLOYMENT}

plants, and the machinery set up for collecting more adequate statistics. This has not been done; nor did they make any serious attempt to calculate the margin of error in the existing statistics. But, as a matter of fact, it is not necessary that the figures should be absolutely exact. It is even doubtful whether, if there were admittedly satisfactory statistics for, say, the last twenty years, that any estimate of unemployment for the coming decade based upon them would give more than a working hypothesis. It follows that every scheme of unemployment insurance should therefore be elastic and arrangements provided whereby contributions and benefits may be altered in order to ensure the liquidation of the fund. It is because some such arrangement will be necessary for schemes of unemployment insurance, whether calculated on the basis of very satisfactory or less satisfactory statistics, that it is safe to say that Germany, France, and many American States can introduce schemes, without danger of their breaking down. Be that as it may, the not altogether satisfactory British figures were used and arrangements in the nature of a safety valve to provide against miscalculations were embodied in the Government's measure.

Perhaps the most important consideration in refutation of this argument is the fact that the mere postponement of a Bill of unemployment insurance would not result in the collection of further information which would make it more practicable later. Those who nevertheless employ this argument land themselves in a vicious circle. Since we have no satisfactory statistics, they say that it is impossible to attempt any scheme. But until we have some such scheme, it is safe to say that we shall not have satisfactory statistics. The circle must be broken somewhere.

The more serious and more significant objection to the British scheme resulted from the necessity of compelling workmen to insure against unemployment.* The strong

* The Labour Party of Great Britain, at its Annual Conference in February I9I I, discussed a resolution calling on the Parliamentary Labour 
opposition to compulsion of a small minority made its acceptance by a majority all the more important, and indicated the more clearly a definite recognition of the growing functions of the State.

The Conservative Party, the party in opposition during the passing of the Bill, was divided on this issue. Thus Mr. F. E. Smith,* now Lord Chancellor, speaking with authority on behalf of the Opposition, said: "We were told that there was something un-English in such a proposal, that is, the proposal of compulsory contribution. I was never convinced by that argument." On the other hand, Lord R. Cecil was the representative of the quickly dying remnant of the laissezfaire school when he opposed it on thorough-going individualistic grounds. He argued that "If you once make the State a partner in private enterprise, it means the absorption of that private enterprise by the State," and further that it would register the death warrant of voluntary organizations. $\dagger$

The opposition to the Bill, based as it was on the ground that it was dangerous to liberty and independence, and that it would result in an increasing control of the State over the lives of its citizens, raised a number of important questions as to the relation of the individual to the State and of the proper functions of the State. These are fundamental problems of statecraft, which each generation and country must set itself and for which it must find its

representatives to have deleted all that part of the projected law on unemployment insurance which was bureaucratic in character. This would have necessitated the elimination of the major part of the scheme, i.e. the part making it obligatory on employees in two large groups of industries to insure. The resolution was rejected by 167 votes to 19.

The views of Mr. Samuel Gompers, President of the American Federation of Labour, on compulsory insurance would therefore seem startling to British Labour representatives. He said to the House Committee on Labour, "As I live, upon the honour of a man, and realizing the responsibility of my words, I would rather help in the inauguration of a revolution against compulsory insurance and the regulation than submit." See also Hearings before the Committee on Labour, H. Res, No. I 59.

* May I9, I9I I, House of Commons. See also "National Insurance and National Character," by J. E. G. de Montmorency, The Edinburgh Review, July r913.

$f$ December 6, igri. See Hansard. 
own answer. Always the quest is for the maximum liberty of the individual and for the highest efficiency of the State. At one time liberty will be sought in some form of polity, at another time in emancipation from the fetters of archaic regulations, and at yet another time in an extension of the forms of governmental control.* We shall see that the efficiency and the probity of Government as well as the workman's wage-level are factors that need to be taken into consideration. $\dagger$ Individuals will therefore often be found whose views on a subject like compulsory contributions will undergo great changes.

Mr. H. H. Asquith, then,Prime Minister, said on December 6, IgII.

As regards the principle of compulsory contribution for the purposes which are contemplated under this Bill, I am not the least ashamed to confess that I was a somewhat reluctant, although I am now a completely convinced convert. I do not think that there is any other way in which we can provide for the risks and hazards of industrial life.

This confession of the then Prime Minister of Great Britain is characteristic of the change in public opinion which has left its impress on British social politics in recent years.

This change of heart has been experienced by some of the leading authorities in insurance. They see the weakness of voluntary insurance in that the masses are not reached by it, and are thus obliged to favour the compulsory principle. Thus Mr. Dawson writes: $\ddagger$

The Congress at Rome will be memorable in the annals of working men's insurance. One session in particular was dramatic in its

* The Underlying Principles of Modern Legislation, p. 40, Professor W. Jethro Brown.

$\dagger$ Professor Maurice Bellom has been called by the Belgian Representative, M. Troclet, "one of the last supporters of the principle of voluntary insurance." Belgium, he pointed out, which had long experimented with voluntary schemes, had through the Belgian Parliament almost unanimously approved of compulsory insurance against sickness, invalidity and old age, whilst its experience with voluntary unemployment insurance was leading it to favour compulsion. See p. 422, April-June 19I4, International Bulletin for Unemployment. 405. 
intensity. In some respects it resembled an old-fashioned religious revival meeting. Doughty campaigners like Luzzatti of Italy, and Mabilleau, Millerand, and Paulet of France, who at previous congresses had fought persistently for the principle of voluntary insurance as applied to sickness, old age and invalidity, admitted their conversion to the doctrine of compulsion or obligation.

\section{The British Workman is not Opposed to Schemes of Compulsory Insurance.}

Since the early days of the factory system and the growth and permeation of the idea of laissez-faire there grew up a conviction in the minds of British statesmen and publicists that the British working man would never submit to compulsion. Germans, natives of a land where conscription prevailed even in peace times and who submitted to an autocratic form of government, might adopt compulsory social insurance, but Britons, it was said, would never tolerate such an infringement of their inherent rights. This view has proven quite unfounded. In fact, Mr. L. G. Chiozza Money, wrote :

I suppose that it never occurred to many persons amongst those leisured classes who in the past have had the entire monopoly of the effective public expression of opinion that compulsion is a common everyday matter to those who work for their living. The great masses of our people labour under a degree of economic compulsion so intense, so effective, and so inexorable, that it would be incredible if it were not an accomplished fact.*

Moreover, in addition to the compulsion of industrial business life, the ordinary working man has long been used to voluntary institutions as a member of which he was bound to observe certain rules and practices. Trade unions, friendly societies, and political organizations have long claimed their millions of workers as members, and the principle of compulsion to certain accepted rules and regulations have been laid down and complied with as a matter of course. It is not therefore a cause for surprise to

* If there still remained any shadow of doubt on this matter, the introduction of conscription and the huge development in Government regulation and ownership during the war must have dispelled it. 


\section{INSURANCE AGAINST UNEMPLOYMENT}

find that as soon as these same workers became conscious of their political rights and elected their own representatives to Parliament that they should submit to its decisions. There is little difference to the average workman in following the mandate of a Trade Union Congress or the Act of a Parliament. This result has followed from the growth of social legislation. The new attitude towards Government measures is due to the fact that " there is stirring amongst the masses of the people a new interest in politics and a new faith in democratic government." * The keener and more general interest in social politics, i.e. in problems that affect the workman very intimately, the control of industry, his conditions and hours of labour, his housing, his wages and his health, has resulted in the workman regarding Parliament as an institution which may help to lighten his economic burdens. He can understand and in a manner take part in its deliberations and feel that with its help there is a means of rising superior to "the majesty of the employer." Instead, therefore, of feeling compelled to accept Old Age Pensions, Workmen's Compensation, Sickness Insurance or Unemployment Insurance, as something forced upon him by some force majeure, they become to his mind objects for which he has himself been striving.

By establishing these positive laws, and by establishing a minimum of social well-being, common rules to which a large number of workmen are quite used, workmen feel that they are increasing rather than lessening their positive freedom. $\dagger$ Indeed, the patience of workmen since I9I9 is being tried by the Government because it is thinking more of economy of a narrow, limited kind than of establishing that larger liberty which will secure at least a minimum of well-being for all. It is the lack of the use of compulsion for this purpose that is rousing the opposition of the great and powerful British Labour organizations.

* Insurance versus Poverty, L. G. Chiozza Money, p. 456. This was, however, written before the war.

$\dagger$ "The discipline which it enjoins is conducive to a larger liberty, viz. that of willing co-operation with his fellows in the production of social welfare."-J. A. Hobson, Work and Wealth, p. 88. 
The term " compulsory" insurance is therefore misleading; "National Insurance" is better. As Professor Henderson says :

No insurance law can be enacted by the legislation of a free people and successfully enforced against the selfishness of exceptional individuals until it has first been accepted by the reason, the conscience and the choice of that people, whether of a commonwealth or a nation. When a law is thus the expression of a deliberate social policy, accepted after investigation and discussion, it is an act of social co-operation on the part of the entire community. It becomes legally obligatory on all in order that the small minority of egoists may not defeat the will of the people, in order that all competitors may be placed on a common level, in order that duties and benefits may be accurately defined, in order that costs of performance of duties may be calculated in advance and adequately provided for in budgets of individuals, corporations, and political organizations.

Our system of "free" schools is felt to be " compulsory" only when the taxpayer is exceptionally stupid or selfish. Our taxation for roads, bridges, lighting of streets, waterworks, police, public sanitation is not felt as compulsory by the ordinary normal citizen, who knows that for every dollar he contributes according to law and in the ratio of his ability the community of which he forms a part will enjoy a corresponding advantage.*

Mr. I. G. Gibbon wrote in opposition to a compulsory scheme of unemployment insurance that there was

the broad objection, of fundamental importance, that it is not generally desirable to exercise coercion in social matters unless there is obvious necessity or very clear and great advantages. Such coercion does not make for ultimate progress, does not make for the growth of that sturdy initiative and self-reliance which are essential if social vigour and democratic control are to flourish together.

There can of course be little doubt that it would be a better state of affairs to have all workmen earning a sufficient wage to enable them to make provision against unemployment without governmental intervention, and to possess the foresight and will necessary actually to make such provision. But failing the possibility of soon realizing

* Professor C. R. Henderson : Industrial Insurance in the United States. 


\section{INSURANCE AGAINST UNEMPLOYMENT}

such a state of affairs, it is submitted that there is " obvious necessity and very clear and great advantages " in taking compulsory measures for the removal of some of the hideous social evils and chaos resulting in hundreds of thousands of blighted lives. Moreover, there can be little doubt but that insurance will prevent the loss of sturdy initiative and self-reliance on the part of those who might otherwise descend into a lower social group. During the stress and strain of unemployment the independence, self-respect, and efficiency of those subjected to it will be preserved. The spirit of mutual helpfulness and mutual confidence is fostered by the undertaking of such a great social measure by the State.

Instead of being regarded as an organization merely for policing the country, the State thus comes to be regarded as the greatest organ for protecting the lives and fortunes of its citizens and for increasing the welfare of the community. Its functions are widened and the active pursuit of social righteousness becomes one of its dominant aims.*

It has been argued against schemes of social insurance that they give control to the State and seem to imply paternal government, but in so far as State help is the result of wide popular desire, and not imposed from above, it is as democratic in spirit as any other State activity. Where the State can do for the workman what he cannot well do for himself, there is prima facie reason for believing that the State should assume that activity. When in addition a majority of those affected demand that it shall be undertaken, there can be little fear of bureaucratic government.

But, after all, most people are nowadays prepared to test schemes for social improvement pragmatically. Do they work well ? is the decisive question which needs answering.

The conclusive proof of the popularity of insurance against unemployment, therefore, is the willingness with which the insured members accepted the obligations

* Government and Industry, by C. Delisle Burns. 
imposed upon them. For nine years compulsory contributions have been levied upon employees and employers alike, and no great difficultes have arisen out of the compulsory nature of the law. It is safe to say that, provided there is added a State subsidy, the working classes of Great Britain are not averse to paying compulsory dues and receiving benefits.

This, it might be added, has also proven to be the experience of Germany and France. As Professor Pigou writes :*

The device of combining with compulsion a certain element of State aid, which has been adopted in the legislation of Germany and France, has apparently sufficed to make the "principle" of compulsion palatable.

There are no valid reasons for believing that the experience of the United States would be different.

Assuming, however, that the "bogey" of compulsion has been laid, we are still confronted with the question as to whether it is possible, and if possible, desirable, for the Government to undertake some scheme of unemployment insurance.

In other words, granted that the objections to coercion are not valid, the question still remains, can the State undertake and successfully carry out a given proposal ? It is manifest that it is doomed to fail, however willing we might be to submit to compulsion, if it endeavoured to-day to carry through a scheme for the complete abolition of unemployment or to guarantee that we all earned an average minimum wage of $£ 5$ a week. There are many valuable reforms, it is necessary to insist, which the State of to-day cannot achieve even if it used all its powers to make them effective.

\section{" Laissez-Faire."}

(Reinterpreted by Dr. Alfred-Marshall.)

The optimistic philosophy of Benjamin Franklin and Samuel Smiles, which is, "Be thrifty, and you will be

* Pigou : W'ealth and Welfare, p. 419. 
happy," does not apply to the millions living below the minimum of existence. Nor would a laissez-faire policy help to solve their problem of unemployment.

The individualistic economist says: " Let the individual alone; in serving his own interest he will be furthering the interests of society."

The socialist retorts: "Let society protect itself against the powerful few; in serving its own interests it will be furthering the interests of the individual." Both these views are now struggling for mastery. Some say: "Let Government keep up its police, but in other matters fold its hands and go to sleep." Others say: "Let Government get us out of the morass in which millions of our fellow citizens are now immersed; let its functions be increased, let it operate industries, and regulate those activities which it does not control." *

Professor Alfred Marshall has given a new emphasis to the term laissez faire which carries with it a policy midway between the above two courses, and which is for the present practicable and helpful and acceptable to a large majority of people.

Let everyone work with all his might; and most of all let the Government arouse itself to do that work which is vital, and which none but Government can do efficiently.

It has thus been converted into a constructive doctrine, one which is elastic and progressive. "Milk inspection may need to be replaced by a communal supply. Medical service may need to become a State function." It is well established that the work which a Government may attempt will vary from time to time.

The probity, the efficiency, and the wealth of a given community will determine what work should be undertaken by the citizens and what services rendered by the

* The war has strengthened the position of the socialists, but it is too soon as yet to foresee how deep and lasting will be its effects. Of course, it is not impossible for a reaction towards individualism to set in, however dangerous this may ultimately prove. 
Government. Thus when Professor Pigou inquired "What line should be drawn between private and public enterprise?" he answered that "The relative efficiency of public enterprise at any time or place is an important factor in determining where that line should be drawn."

Is insurance against unemployment an enterprise in which the Government should engage ?

It is certain that even in Great Britain only a few, about ro per cent., of the working classes were affected by this private enterprise, and it is a fact that the poverty of very large numbers of workmen would have made it impossible for them to secure protection against the injury of unemployment.* Unemployment insurance thus falls under the group of activities which " none but Government can do efficiently." Now, one of the main factors in determining whether or not a Government should undertake certain activities is its probity at that particular period. It does not follow that because a private organization cannot organize some necessary venture that the Government can do so or should do so. It is, however, highly signtficant that during the years in which unemployment insurance was discussed the objection to it that the officials administering the Act might be dishonest, or that the Government would make "political" appointments, was hardly raised. The general excellence of the British Civil Service and of the methods of making appointments almost precludes the possibility of abuse of this nature, excepting during abnormal conditions such as prevailed during the war. The honesty, and of late years the efficiency, of British administrators has hardly been questioned. $\dagger$

Moreover, there could be little doubt that Great Britain was wealthy enough to venture on a scheme of unem-

* Common action could only be encouraged through the intervention of the State.-Alfred Marshall: Economic Chivalry.

$\dagger$ It is the student's function to note that in 192 I the "economy" campaign was accompanied by gross abuse of the Civil Service. This campaign had political ends and its supporters were entirely misinformed about "Whitehall." 


\section{INSURANCE AGAINST UNEMPLOYMENT}

ployment insurance which would cost at most only a few million a year, in addition to her other schemes of social reform. The increased efficiency in the workmen which might be expected to result from it, and the decreased cost of relief of various kinds, would at least equal the Government expenditure.*

* A very small group now charge the Government with having endeavoured to win the support of trade unions by appointing trade union leaders to important posts in the administration of the scheme. Although this charge might have been substantiated before the "Committee of Enquiry into the Work of the Employment Exchanges," which sat in I920, no attempt was made to do so. 


\section{THE SCOPE OF UNEMPLOYMENT INSURANCE}

THF central difficulty in inaugurating any national scheme of insurance has been how to establish the fact of the claimant's unemployment. This was avoided by the smaller and more homogeneous group, the trade union, because the members knew the actual trade conditions, and also, as a rule, the situation of their fellow member who claimed unemployment benefit. It was therefore to be expected that several trade union leaders would urge that the position of the unions with regard to unemployment ought to be that of the approved societies for health insurance. The unions urged that the men were less likely to "bleed" the union funds than the State funds. It was urged that $*$ it would be a great advantage if the insurance fund could be administered by organizations of workers grouped according to trade, which, while their general sympathies would be with the employees, should have given to them a definite inducement to restrict as far as possible the claims upon the fund. Why were not these proposals adopted? First, there was the consideration that since the scheme involved compulsory contributions from the employers and employees and the State, it was not possible that the unions should have the sole power of disposing of the unemployment fund. Employers would object. Second, there were actuarial difficulties in the way of having separate funds and different benefits

* By B. Seebohm Rowntree and Bruno Lasker, p. 148, No. r, Revue Internationale du Chomage. 


\section{6

in different trades. These difficulties are greater in the case of unemployment in different trades than in the case of sickness, because of the greater variation in risk. Actuarial experts decided that in this initial experiment in obligatory unemployment insurance, where the statistical material dealing with different trades was inadequate, it was advisable to pool the risks in all the trades.*

The Government therefore chose to administer the scheme itself, and established the employment exchange and the local office as the unit of administration. Every workman when unemployed, so the scheme provided, must report his lack of work at once to the exchange or officer to show that the claim is bona fide. The claimant must, of course, satisfy all the conditions and regulations laid down by the Act. It is exceedingly difficult in a large number of cases to say whether a man is unemployed through his own fault or not. Since, however, the eligibility for benefits is conditional on the fact of involuntary unemployment due to lack of work being proven, it would seem to many that the superstructure of unemployment insurance schemes, not administered by unions, must rest on an unstable foundation. The British scheme has sought to avoid this difficulty by establishing certain objective tests of involuntary unemployment. Questions as to the man's need or the intentions of the unemployed workman are of secondary importance. What is significant is why he has left his last job and whether he will accept another job offered him by the employment exchange. But before proceeding to discuss what conditions qualify a claimant for benefit, let us firstly remove from the total field of unemployment those periods of unemployment due to such causes which the British scheme assumes had best be met through other means.

* The British Government did, however, avail itself of the existence of labour organizations, and gave them great power and many duties under the scheme. See below, Chapter XVIII. 


\section{Causes of Unemployment not Insurable under the British Scheme of Unemployment Insurance.}

No scheme of unemployment insurance undertakes to ensure workmen against unemployment from all causes. The risk of unemployment against which insurance is offered is always marked out strictly, and in none more so than in the British scheme.* In the inauguration of the scheme of unemployment insurance, insured members were called upon to pay contributions for six months before being eligible for benefit. During these six months the Unemployment Fund was able to accumulate a balance of $E^{I}, I_{5}, 000$. This commencement period had the further advantage of giving the administrators time to decide who were and who were not insurable. It is interesting to note that such a period would be necessary in any scheme which did not apply to the whole of a country.

It is clear that unemployment insurance benefits should not be paid during sickness or invalidity.

There is an overwhelming reason of practical convenience why unemployment insurance and sickness insurance should, if possible, come into force at the same time. It is a necessary condition for receiving unemployment benefit that the unemployed man should be "capable of work" ; on the other hand, it is a necessary condition of the receipt of sickness benefit that the sick man should be "incapable of work." If therefore one-half of the scheme came into force without the other, there would be a strong temptation for unjustified claims to be made upon the fund first set up. If sickness insurance is set up in priority to unemployment insurance, the man who is out of work from purely economic causes will be under an inducement to represent himself as ill. If, on the other hand, unemployment insurance is to be set up in advance of sickness insurance, then the man who loses work through ill health will find it to his advantage to declare that he is perfectly well. The two halves of the scheme ought to work side by side. $\dagger$

* After discussing the conditions under which unemployment benefits are granted, we shall be in a better position to give a definition of unemployment for the purposes of the Act.

$\dagger$ Sir John Simon, Solicitor-General, pp. xvi-xvii, The Law of National Insurance, by Orme Clark. 
At the very outset, therefore, two causes of unemployment can be removed from consideration for purposes of benefit, cases of illness and invalidity. Unless there already exists a system of sickness and invalidity insurance, difficult cases of semi-invalids, people who are not altogether unable to work, yet whose earning power is greatly diminished, will confront the insurance officer. It is the opinion of some authorities that the British method of supplementing unemployment insurance by sickness insurance is essential for the successful working of the former.

On the other hand, insured persons drawing old-age pensions or accident compensation, who are normally employed, are treated as ordinary claimants under the scheme subject to all the same conditions and regulations.*

The Act provides that workmen who have lost employment through misconduct or have voluntarily left employment without just cause shall be debarred from benefits for six weeks from the date of so losing employment. It is important to note that both these ideas are not precise, and that only as the Umpire's decisions are laid down will a precise enumeration of the conditions and facts which constitute "misconduct" and " just cause" be possible.

It has already been observed that after the claim for benefit is made at the employment exchange notice of it is sent to the last employer, with the request that he should return the required form if he has any comment to make in regard to facts which might disqualify the applicant for relief.

During the first year about one in six of the employers did return the form, mainly in the belief that it helped them in maintaining the discipline of the shop.

* An interesting case of a blacksmith of 70 giving up his job in order to claim his old age pension of 5 s. a week, who also claimed unemployment benefit, is reported in Case 123, pp. 61, 62, Decisions of Umpire, vol. i. He was earning $18 \mathrm{~s}$. $5 \frac{1}{2} \mathrm{~d}$. per week, and since he would not be allowed to retain a statutory old age pension of $5 \mathrm{~s}$. a week, he gave up his job. In the judgment of the Umpire he voluntarily left employment without sufficient cause. 
In some instances the employers have even used that as a hold upon the man, saying that if the job were thrown up the man would be disqualified for benefit because they would send in an unfavourable report. Unions object to this weapon being put into the hands of prejudiced foremen. They argue that even though there is the power of appeal against the decision of the insurance officer, the man is forced to wait for his benefit. They complain that no penalty attached to employers who make misstatements. Apart, however, from abuses, this clause results in disqualifying those from benefit who are either cantankerous by nature or lazy, or are shirkers.

Certain employers feel that since they are paying their share towards the Unemployment Fund they should exercise their power to disqualify workmen who leave work without satisfactory reason, in order to safeguard the funds.

Mr. W. A. Bailward, of the Charity Organization Society, urges the tightening up of this provision. $\mathrm{He}$ writes that

it would appear that some sort of report should as far as possible be obtained from employers in every case, and that the administrator should not always rest satisfied with documentary evidence.

A question continually to be faced by the Umpire is whether the employment exchange shall expect the unemployed workman to accept work far away from his home or to take up work in some other trade ? When the distance from his home is short, then, as a rule, workmen are expected to undertake the work offered them. But, on the other hand, when the distance is far or the railway connection bad, then workmen may refuse work in those places.*

The other question, as to whether a workman should take up work in some other trade, is one of the gravest problems that must be faced in dealing with the unem-

* Other grounds for refusal of work have been the less favourable conditions of employment, domestic circumstances, and health. 
ployment problem.* Where the workman himself wishes to learn a new trade, then there is little difficulty and no objection to his doing so. Furthermore, the provision in the Act for giving technical training to inefficient workmen, which unfortunately has not yet been put into effect, is also acceptable to all parties. In like manner, in cases where as a result of technical inventions a trade is ruined, or where as a result of a serious crisis factories are closed down, there seems to be very excellent reasons why workmen who have been affected should be encouraged to adopt a new trade or learn a supplementary one. $\dagger$

But trade unions are strongly opposed to workmen having two trades, i.e. to changing from one trade to another trade as a normal feature of their industrial life. They argue that most workmen will stand out for union conditions in the trade in which they feel themselves to be most efficient, and will be prepared to accept lower wages, longer hours, and non-union conditions of labour in their " secondary" trade. Such a state of affairs would be, they contend very properly, very perilous to trade union standards.

\section{Trade Disputes.}

It is, of course, essential that the administrators of the British scheme of unemployment insurance shall be impartial in cases of strikes and lock-outs. Employers, as well as employees, contribute towards the Unemployment Fund, and therefore would object to their contributions being used against them in industrial disputes. It is therefore unanimously held by students of the problem that benefits shall not be paid during labour conflicts.

* See p. 305 of vol. i Decisions Given by the Umpire Respecting Claims to Benefits for "List of Cases on Refusal of Suitable Employment."

$\dagger$ These workers are somewhat in the position of invalid workmen who may be asked to readapt themselves to the requirements of industry. Monsieur Edouard Fuster rightly asks, Ought not the system of employment exchanges because of such consideration to be supplemented by a system of education and a professional change?-Bulletin pour la Lutte Contre le Chómage, 4 année, No. 2, p. 397. 
The most delicate task which the Umpire is called upon to decide is whether unemployment is due to some cause which does not debar those unemployed from receiving benefit or is due to a trade dispute which does debar from benefits. The Act qualifies " trade dispute" as a stoppage of work which was due to a trade dispute at the factory, workshop, or other premises at which he was employed, i.e. it makes no real attempt to define a trade dispute, nor has the Umpire provided any definition. To every request for a definition of a trade dispute he has replied that each case must be decided on the facts that present themselves. Occasionally the interpretation of these facts leads to disputes between the unions and the Umpire.*

In the dispute in the building trades in London, for example, in the winter of $\mathrm{I} \mathrm{I}_{3}-\mathrm{I}_{4}$, the men held that they were dismissed by the employers, and therefore had a right to claim benefits. On the other hand, the employers contended that a threatened strike terminated in a lock-out before the strike could occur. The Umpire upheld the employers' contention, and no benefits were paid. His decision had the further effect of disqualifying from benefit those who were unemployed before the trade dispute in the building trade occurred. A similar decision was given in the I92I lock-out of the miners.

Now it is well established that lock-outs tend to take place during a slack period when men are likely to be little employed or unemployed. At such times employers seek to reduce wages and threaten dismissal if their terms are not acceded to. The opportunity is thus offered to the employers to break down resistance to their demand for a reduction of wages, by threatening or by declaring a lock-out and thus debarring their workmen from benefits. More irritating even to workers is the consideration that sympathetic lock-outs are apt to take place, and at such times it is exceedingly difficult to discover whether unemployment is due to a trade

* Many have tricd to induce the Umpire to definc a trade dispute, and notably the Amalgamated Society of Engineers, but without avail. 
dispute or to the individual's inability to find employment because of lack of work. This raises the further administrative problem whether all men in the trade are to be disqualified in alleged cases of trade disputes, or whether each individual case is to be decided upon separately. Although there are certain merits in the suggestion that a trade dispute should be clearly defined and some general administrative rules be laid down for the determination of such questions, wisdom will dictate that these cases be left to the decision of a just, impartial umpire. Confidence in the Umpire's fairness is the very corner-stone of the success of the British scheme.*

From the very nature of the case some very hard decisions seem unavoidable. Thus the Amalgamated Society of Engineers report one instance where the engineers went on strike and their labourers were disqualified from benefit. Similarly, where one department in a factory strikes other departments, who may have had nothing at all to do with the dispute, may find themselves unemployed and so disqualified from benefit.

Unfortunately, the atmosphere in which decisions are given on conditions entitling to benefit is apt to lead to biased judgments. Thus Section 7 (V) $b$ of the 1920 Act reads :

Provided that a person shall not be deemed to have failed to fulfil the statutory conditions for receipt of unemployment benefit by reason only that he has declined an offer of employment in the district where he was last ordinarily employed at a rate of wages lower, or on conditions less favourable, than those which he habitually obtained in his usual employment in that district, or would have obtained had he continued so employed.

Women who had left war work and were in receipt of out-of-work donation because of unemployment have had their donation stopped upon their refusal of employment as domestic servants. In a similar manner a

* For the variety, complexity, and subtlety of the cases to be decided upon, see Decisions Given by the Umpire Respecting Claims to Benefit, vol. i, Nos. I-500, together with more recent decisions. 
large section of the Press, stimulated by those who need domestic servants, are urging the view that it is more desirable to employ women at domestic work, since it is suitable for any woman, whatever her previous training or lack of training, rather than pay her unemployment benefit. In spite, therefore, of the definite statutory provision against the disqualification for the receipt of unemployment benefit on the ground of refusal of work which does not offer conditions so good as those to which the applicant is accustomed, a constant pressure is being exerted on all those administering the scheme to bias its working in a certain direction. The Courts of Referees and the Umpire (who is not a Ministry of Labour official) are unable to decide these questions in an atmosphere making for a strict and impartial interpretation of the law.

Although the clause disqualifying from benefit because of a trade dispute affected but 5 per cent. of the men disqualified during the first six months' operation of the Act, and this percentage is likely to decrease, the problem of distinguishing between involuntary unemployment due to lack of work and involuntary unemployment due to a trade dispute remains of the utmost importance. In this penumbra lies the danger-field of industrial life in a capitalist society. Roused passions, questions of honour, a desire for trials of strength, and a host of other difficulties colour the atmosphere when the Umpire must make his decision. Courage, honesty, and a full knowledge of the facts are essential to any fair decision.

The administration of this part of the Act has worked with the utmost smoothness, although a number of disputes have left a passing sense of grievance. Hundreds of claimants have appealed against the decisions of the insurance officers; they have appealed in turn against the Court of Referees and sought decisions from the Umpire. This has been encouraged by the fact that no part of the cost of appeals is paid by the workman, and even when required to attend before a 


\section{INSURANCE AGAINST UNEMPLOYMENT}

Court of Referees workmen may be paid travelling expenses.

It is thus manifest that the problem of developing insurance leads to this : how to check wrongful claims by the unemployed; that is to say, how to avoid frauds, and how to define unemployment subject to insurance. New theoretical definitions, however ingenious they may be, are of no avail. The practical way of detecting involuntary unemployment is to create alongside of unemployment insurance funds, funds insuring also against the neighbouring risks of strikes, lock-outs, sickness, accidents, etc. This is what happened in the case of the more powerful unions, and the claimant of unemployment benefit was known not to be unemployed for any other reason than for lack of work, since for losses sustained through any other emergency he could also claim benefit.

Any workman not unemployed owing to a trade dispute, sickness or accident, who registers at the employment exchange is regarded, therefore, as prima facie a bona-fide unemployed workman for purposes of the British scheme.

\section{Conditions for Receipt of Benefits.}

Having reviewed the types of unemployment that are not insurable, we may now discuss the kind of unemployment that is insurable.

Fortunately the British scheme lays down very definitely the conditions that must be fulfilled for the receipt of benefit. The workman must prove that he has been employed as a workman in an insured trade and that he has paid twelve weeks' contributions. If he has been a member of a union during that period, that fact is sufficient to establish this requirement. He must also prove that he is capable of work but unable to find suitable employment. This apparently embarrassing condition works fairly easily in practice and will work even more easily when objective tests of suitable employ- 
ment are fully worked out. The unemployed workman must prove his willingness to work as soon as the employment exchange offers him "suitable" employment. But what, for purposes of the law, constitutes suitable employment?* In Britain the law does not encourage workmen to accept any work which would tend to weaken the union or the standards of fellowworkmen.

The Act provides that no man shall be compelled to accept work below the rate at which he is accustomed to work in his own district, or below the standard rate in another district. In districts where unions are well organized the union rate is the recognized one; in others the wages paid by the better firms is the accepted standard. This provision, which is satisfactory to the unions, has led to very little friction. The good faith of the officials is relied on both by employers and workmen.

Other conditions for the receipt of unemployment benefit provide that the workman must make his application in the prescribed manner, and must prove that since the date of his application for benefit he has been continuously unemployed. On becoming unemployed the workman is required to report the fact to the employment exchange or he must sign the union vacant book. $\mathrm{He}$ is then allowed to prove that he is continuously unemployed merely by registering once every day during work hours at the exchange or in the union vacant book. It is assumed that persons who satisfy this requirement are unlikely to be engaged at other work whilst. seeking benefit.

Having seen the various conditions and regulations for the receipt of unemployment benefit, let us examine the published table of claims to benefit which were refused.

The principal ground of disallowance in the first scheme was failure to satisfy the first statutory condition in Section 86, i.e. failure to prove employment in an

* Cf. H. J. Res, No. 159, pp. 133, r34*? 


\section{INSURANCE AGAINST UNEMPLOYMENT}

insured trade in each of 26 calendar weeks during the last five years. At the outset union members of long standing were at an advantage in being able to provide this proof. But the difficulties which this requirement created were so great that it was soon amended. The Amending Bill made the statutory qualification for benefit 20 weeks' contributions. In the latest Act this has been diminished to I2 weeks.

The next most important ground of disallowance was

\section{DISALLOWANCE OF CLAIMS TO BENEFIT UP TO MAY 3I, I9I3.}

I. Not worked 26 calendar weeks in insured trade

2. Not capable of work .

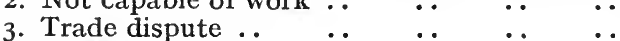

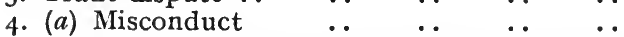

(b) Voluntarily leaving employment without just cause $\quad \ldots \quad \ldots \quad \quad \ldots \quad \quad \ldots$

5. Benefit exhausted $\quad$. $\quad \ldots \quad \ldots \quad \ldots$

6. Other reasons-

(a) Under 17 years of age

(b) Refused suitable employment

(c) Following remunerative occupation ..

(d) Other reasons . . $\quad \ldots \quad$. . .

\begin{tabular}{|c|c}
$\begin{array}{c}\text { United } \\
\text { Kingdom. }\end{array}$ & $\begin{array}{c}\text { Percentage of } \\
\text { Total Dis- } \\
\text { allowances. }\end{array}$ \\
\hline
\end{tabular}

Total number of claims disallowed ..

Total number of claims made in period

Percentage of claims disallowed

-.

$\because$

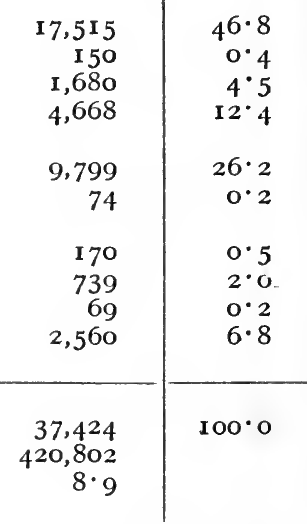

that under Section 87 (2)-that the workman has lost employment through misconduct or left it voluntarily without just cause, e.g. insubordination, wasting time, or negligence. This accounts for 38.6 per cent. of all the disallowances; the percentages attributable to misconduct and to voluntarily leaving employment without just cause are $12 \cdot 4$ and $26 \cdot 2$ respectively.

The trade dispute disqualification accounts for less than 5 per cent. of the whole number of disallowances.

As a rule insurance schemes provide that benefits 
shall be strictly limited either as to their amount or to their duration. The British scheme of unemployment insurance provides that I week's benefit shall be payable for every 5 weeks' contributions paid, and that the maximum period during which benefits may be received shall be limited to $I_{5}$ weeks. This limitation is necessary if the fund is to be protected from ineffcient or very irregularly employed workmen. The workman who is tempted to malinger, as well as the higher type of workman who would much rather be at work, both know that it is to their interest not to claim benefits until they have a real need for it. The number of those who are likely to exhaust the total benefit allowed them is thus likely to be lessened.

Of course, once a workman has exhausted his right to benefit, any claim cannot be considered until he has paid dues for a period at least sufficiently long to give him the right to renew his claim. As before, he may receive a week's benefit for every five weeks' contribution.

It is a cardinal principle of the scheme that, if whilst any workman is in receipt of benefits, employment is offered him which the Umpire regards as suitable, then the workman must accept the proffered work. If he does not, he loses the right to benefit.*

The figures dealing with disallowance of claims to benefit have been published for the first six months of the workings of the Act and are given on p. 246 . There is reason to believe that with the various changes in the scheme and with the greater experience of workpeople the percentage of disallowance under the different headings will change. Thus during a later period in 43 per cent. of the cases of disallowance of benefit the decision was given on the ground of refusal of suitable work as against 2 per cent. in the first half-year. $\dagger$

Thus singled out from unemployment due to other

* Mr. John Burns, then President of the Local Government Board, estimated that 3 per cent. only of the total recorded unemployment was uncovered because of exhausted benefit.-The Times, March 4, 1914.

† Cd. I054, p. Io. 


\section{INSURANCE AGAINST UNEMPLOYMENT}

causes than lack of work, and with the machinery of the employment exchanges thoroughly organized, unemployment insurance has proven itself to be "administratively possible."

\section{Definition of Unemployment Insurance.}

As a result of this discussion we are now in a position to venture on a definition of unemployment insurance. The British scheme of unemployment insurance is a device for making provision against the economic loss to wage-earners resulting from involuntary unemployment due to lack of work in the district where they were last ordinarily employed, and where work was not obtainable otherwise than at a rate lower or on conditions less favourable than those habitually obtained in their usual employment in the district, by means of funds made up of regular compulsory contributions from the insured workmen, their employers, and the State, out of which indemnities for such losses are paid. In this way losses are distributed throughout the entire community instead of being allowed to crush the unfortunate individuals who are unemployed.

There is one further consideration which modifies the view that the British scheme of insurance offers indem. nity for the losses sustained through involuntary unemployment due to lack of work. As a matter of fact it offers only a partial indemnity. There was a period in the inauguration of the scheme during which unemployed workmen could not receive benefits at all, and similarly workmen joining the scheme later cannot obtain benefits for a defined period. There was the first week of unemployment during which no benefit was allowed, a limitation which has now been reduced to three days. There is still, however, the limitation of one week of benefits to every six weeks of the payment of dues, and benefits are limited within a certain maximum period. In this the British scheme is following most trade union systems of out-of-work 
benefits. It is the rule that insurance schemes offer only a minimum of benefits.*

Two main reasons are offered for keeping the scale of benefits low. First, it is argued, if they are considerably lower than their normal wage, workmen have an added interest in remaining at work as steadily as possible and in avoiding unemployment as much as possible. Secondly, the limitation of benefits, as well as their comparative smallness, keeps down the cost of the scheme, and consequently the burden on employers and workmen is more easily carried.

* It must, however, be insisted upon that if benefits are unduly restricted, then the very serious impact of unemployment still falls on the workman. He can, as a rulc, bear it only by lowering his standard of living. If he shifts it on to the charity organizations, then his self-respect, as a rule, suffers. He is still obliged to make provision for additional benefits through some form of saving See Appendix IV for a discussion of "Unemployment Insurance and the Rates." 


\section{CHAPTER XVII}

\section{CONTRIBUTIONS AND BENEFITS}

MODERN industrial conditions are under the triple control of the three parties to the labour contract-the public, the employers, and the workers. This consideration is specially important in its application to the problem of unemployment. The public, the employers, and workmen are deeply concerned in the effects of unemployment. They are also in many ways responsible for it. Should not, therefore, the measures taken to reduce the amount of unemployment, and to provide for those who are likely to suffer from it, be met through the co-operative efforts of these three groups?

Who should contribute to the unemployment fund and to what extent ought each to contribute towards any proposed scheme of unemployment insurance? Three distinct views have crystallized out on this subject. The British scheme is based on the view of the equal responsibility of all parties. A second group has urged that, as in the case of Workmen's Compensation, the industry alone ought to be made to bear the burden. Still a third group urges that the great bulk of unemployment is due to social causes, and ought therefore to be met by the State. No considerable body, be it noted, contends that workmen should bear the burdens of unemployment unaided.

Let us briefly examine the contentions of the second and third groups referred to before discussing the method employed in the British scheme.

The growth of the idea that losses through personal injuries in hazardous occupations should be borne by the 
industry occasioning the hazard has given rise to the parallel idea that personal losses due to involuntary idleness should be borne by the industry occasioning the unemployment. The difficulties of realizing this in some practical policy are perhaps greater, but it is urged as a standard towards which our efforts ought to be bent.

When it is recalled that at present the burden of unemployment is borne either by the workman himself or by his relatives and friends, who thus must lower their standard of life, or by the public through State or private charity, it is manifest that this burden is falling on the wrong shoulders.

Again, if the industry were forced to bear the burden of its own uñemployment, it would, it is urged, take immediate measures to reduce the amount of unemployment, in the same way as workmen's compensation schemes resulted in a reduction of accidents. Then the cost of unavoidable unemployment would come to be regarded as a normal expense of production.

The new theory with regard to the burden of unemployment, it has been proposed, should be: That where a workman who was not at fault is dismissed because of lack of work, then he should be compensated in a reasonable amount for the consequence of unemployment; not in order that the employer should be mulcted because he was at fault, "but in order that this portion of the cost of product or services shall not be transferred from the employer and the ultimate consumer to the working man and his family, crushing them in many cases, and eventually shifting the burden to the community in the most undesirable form of charity."

The main objection to this proposal is that its enactment would revolutionize many branches of industry. Think of what it would mean if an attempt were made to compel builders and dock managers to keep their workmen in work or wages during periods of unemployment! The existing rights of the employer to hire and fire workmen would have to be immediately curtailed,

* See Frankel and Dawson: Workmen's Compensation in Europe. 
the wages level would have to be altered, and the cost of necessary industry to the consumers would be changed. Some transitional stage seems necessary, so it has been argued, during which these industries should pay for part of the burden of unemployment for which they are responsible.

The third group is best represented by the Fabian Society. In criticizing the contributory aspects of the British scheme this Society stated that

most of the burden falls on the individual employer and workman. This is unsound because the great bulk of unemployment is due to causes outside the control of individuals altogether. The fluctuations of trade are considerably influenced by the policy of the State; it is the State which should bear the main responsibility for unemployment. When unemployment is greater than usual, it is not the workman's fault ; moreover, he is in greater need. If, on the other hand, it were only the State whose contribution were increased, there would be a tendency for the State to inquire into the causes of unemployment, and use its influence to root them out.*

The objection to this view results from the failure to appreciate how much the policy of the individual employer affects the quantity and nature of unemployment. It also betrays an expected bias in favour of the expert, and fails to gain the wider interest of employers and employees, which could be secured by allowing them to share in the responsibility both for the cost and for the administration of any proposed plan for treating the evil.

\section{Should the State Contribute?}

The British scheme of unemployment insurance provides that the State, the employer, and the workman shall contribute about equal amounts towards the Unemployment Fund. On what grounds can this be justified?

The State during the last century has assumed a general responsibility for the well-being of its citizens, and more specifically has shared much of the burden resulting

* The Insurance Bill and the Workers, London, I9I 5 
from unemployment. Poor Law organization, relief works, farm colonies, labour bureaux, are but a few of the evidences which demonstrate that the State, as such, did not allow its citizens to suffer the full burdens of a period of unemployment.* The community has long recognized that unless it takes measures for preventing social evils from multiplying, the number of helpless and destitute will grow, enfeeble social life, and poison its future.

This duty has been recognized also in those European schemes where State subsidies supplement voluntary effort at providing unemployment insurance.

An interesting question needs to be treated within any discussion of the advisability of giving public subventions to unemployment insurance. It concerns the public unit which shall provide this subvention. Shall it be the city, the county, or the whole country? The British scheme, when introduced, was superior to most other schemes of unemployment insurance, excepting in this respect Denmark and Norway, in that it regarded the country as a whole as a unit for this purpose. Unemployment is, in certain of its aspects, a national problem affected by foreign relations, by national legislation, by national traditions and peculiarities. It would result in glaring anomalies which would be likely to lead to serious friction if neighbouring cities and counties developed different policies in such matters. Workers in the same trade would perhaps have to pay very different contributions and receive immensely different benefits. Furthermore, a local fund in a city could be completely swamped

\footnotetext{
* The State is going to receive enormous benefits from this Bill, rates are going to be lowered, taxes are going to be made less, all sorts of public changes, necessary on account of unemployment, the low state of vitality and bad state of health, the claims on charity organizations, the increase in crimes, are going to be eased if this Bill is going to do what it is expected it will do. For such a sacrifice-and it is not, I think, an exorbitant one, which, fairly adjusted, will not hamper industry nor burden labour, nor cause undue strain upon the public finances-we believe it possible to relieve a portion of the industrial population of these islands from the haunting dread and constant terror which gnaws out the very heart of their prosperity and content.-Winston Churchill in the House of Commons, May Igr I. See, however, Appendix IV.
} 
by local conditions. It could not, for example, when suffering a high degree of unemployment, gain any relief from the fact that other cities were not suffering to the same extent.*

But the most important reason for having a national scheme of unemployment insurance is that it enables the Government to discover and treat the causes of unemployment. It is impossible to discover those that are widespread throughout a country by merely instituting local funds. To eliminate them, or even to minimize them, it is essential to adopt a national scheme. $\dagger$

Assuming, then, that the State shall administer the scheme, why should the State contribute towards the Unemployment Fund?

In the last analysis large cyclical changes, one of the chief causes of unemployment, are due primarily to the fundamental aim of all business activity-the desire for profits. The competitive system of industry and the resulting industrial organization-not the caprice of individual action-is responsible for unemployment. Moreover, the community plays a more direct part in the ordinary causes of unemployment. Seasonal unemployment is largely due to the habits of the community, whilst changes of fashion, the result of idiosyncrasies, produce great uncertainty and resulting lack of employment. It seems unjust that individual employers, let alone workmen, should be made to bear the burdens of cyclical or seasonal unemployment.

Again, inventions and improved methods of industrial organization, which result in great benefits to the public by markedly reducing the cost of production, are as a rule accompanied by the displacement of workmen who

* The crisis in the administration of the unemployment insurance scheme was reached in August 1921, because the Government contribution of I5s. a week was inadequate, and recourse was had to the Guardians, who gave relief to an amount four and even five times as large as the Government benefit. The central Government, by refusing to deal with the problem aderjuately on national lines, forced the problem on to the local authorities.

$\dagger$ See evidence of Mr. Miles M. Dawson at Hearings before the Committee on Labour.-H. J. Res, No. I 59, p. I I. 
formerly produced the article. Surely the community owes them some debt!

In addition, however, to its contributing towards the causes of unemployment, there is the further consideration that only when the community is made to realize that responsibility by paying part of the loss to the workman in which unemployment results are steps likely to be taken to mitigate the causes of unemployment. More thought will then be given to the problem, and schemes leading to its solution may be expected to follow.

The contribution of the State also entitles it to see that the money is spent on the objects mentioned in the scheme and that it is solvent. The Government justifies its right to intervention by contributing towards the unemployment fund. The grant-in-aid, of which the State's contribution under the Unemployment Insurance Act may be regarded as one form, is a powerful engine for maintaining the honesty and efficiency of public undertakings. Another important effect, however, is to make it worth while for a group of men subject to a low degree of unemployment to pool their luck with the group of men subject to a high degree of unemployment.* In this way the benefits which the former may receive are at least equal to the amount which their unassisted contributions could buy for themselves; while the latter gain in their benefits the full measure of the Government subsidy. $\dagger$

It is highly significant that the British schemes of unemployment insurance and health insurance were

* A compulsory system of insurance, which did not add to the contribution of the workers a substantial contribution from outside, has also broken down, because of the refusal of the higher class of worker to assume unsupported a share of the burden of the weaker members of the community.-Winston Churchill, President Board of Trade, May 19, r909.

See also Grants in Aid, by Sidney Webb.

Undue emphasis has been laid by many writers on the alleged unfairness of pooling the risks of good and bad trades. It is true that the parasitic trades, as regards unemployment, may be supported by the more regular trades. But when trades are selected in which the percentage of unemployment does not vary much, this consideration is not very material. It is sometimes also forgotten that the pooling of good and bad risks is of the very essence of insurance.

$\uparrow$ See Deputation of Social Democratic Party to Mr. Lloyd George, June I 9 I I, Cd. $5^{869 .}$ 


\section{INSURANCE AGAINST UNEMPLOYMENT}

both integral parts of the group of social reform measures which were advocated in Great Britain during the decade preceding the war. To be fully appreciated they must be seen as parts of a comprehensive programme, covering education, health, safety, and insurance against emergencies such as old age, sickness, invalidity, and unemployment. What was the aim in forming the programme and the ideal which gave it momentum? It was to raise the standard of national efficiency and industrial quality. The conception grew more and more prevalent that the chief business asset of the nation was the individual workman, and in order to bring about the maximum of efficiency in production a wholesale public expenditure was entered into to develop his value. It was a far-sighted view of the gains that would result from a national investment of this kind rather than the sweep of a wave of philanthropy which produced this series of reform measures. The overwhelming number of reformers were anxious to increase and strengthen the source of the nation's wealth-the mental and physical fitness of the individual workman. This desire to increase national efficiency was a weighty argument in urging the State's contribution to a scheme of unemployment insurance.

\section{Should the Employer Contribute?}

There were many precedents for requiring the employer to contribute to the insurance of his workmen, notably the insurance schemes of Germany against sickness and invalidity. By imposing this obligation on employers, employees, and the State, and by bringing these three partners in the modern industrial contract together for administrative purposes, their sense of solidarity, it was argued, must grow keener. By working together for a common purpose, viz. for discovering the most satisfactory way of lessening the evil effects of unemployment, considerable social advantage might then be expected to result. Another consideration of a more general kind was that unemployment was a social disease generated by 
modern industry, so that it was proper that the employer should be asked to contribute towards its cost and cooperate in efforts to reduce its evil effects.

But the most convincing reason for asking employers to contribute to the scheme was their responsibility for certain kinds of unemployment. Not only did this result from their present methods of organization, but frequently through a lack of systematic methods of engaging and discharging workmen.

The plentifulness and flexibility of the labour supply is most important for industrial development. This is of particular moment in establishments whose work is subject to rapid fluctuations. These conditions necessarily result in the demand for a reserve army of labour. Then, if business presses, workmen are at hand ; when it slackens, they can be turned off.

The contribution of the employer rests upon the assumption that if a reserve of labour is required by the industry to the disadvantage of workmen, the employer ought to help support this reserve. Even before Government legislation was enacted, many employers supported their workmen during periods of unemployment, thus showing that they recognized an obligation towards those who had been in their employ during the major portion of the year. The practice of chivalrous employers has, through the mandate of the Government, become the general law. It is fair that each industry should bear the full burdens of the industry, and these, experience shows, are most easily introduced when employers share them with workmen. By this means also the likelihood that employers will adopt measures for preventing or mitigating unemployment is greatly increased. In the discussion on unemployment insurance in the House of Commons before the Bill was enacted, Mr. Ramsay Macdonald urged that employers are the managers of industry, and thus are responsible for unemployment:

If the employer pays proper wages, or, in other words, if the workers' share of the national income is adequate, then we do not want charity, and we do not want assistance at all.*

* House of Commons, May 29, I9II. 
But wages to-day are not "proper," it was implied, nor do they, as a rule, include ptovision for periods of unemployment.

It is also anticipated that the employer's contribution will be a good investment. If the scheme produces the expected results, it will undoubtedly mean that it will give to the employer a more and more efficient body of workers than he has now, and it will enable him to run his machinery more efficiently than it is being run to-day.*

Another important reason for obliging employers to contribute is that by so doing the scheme may be administered with greater ease. The employer may be made responsible for his own and his workman's contribution. This has another merit. It is much simpler to collect the dues of the workmen from their employers, who perhaps employ hundreds of workmen, than to collect them from individual workmen. $\dagger$

\section{Should Workmen Contribute ?}

On the whole, it can be asserted that little objection was raised to the contributions of the State and of employers to the Unemployment Fund. Similarly, little objection came from workmen. Yet there has been some questioning as to the justice and desirability of workmen contributing. The arguments urged in favour of their so doing are many and weighty. Since they are the beneficiaries of the scheme, it was contended that

* See Chapter XXIV, below.

$\dagger$ Employers are beginning to see that the social problems of industry must be solved, and that they must contribute to the solution-that unemployment insurance in a state of private industry is one of the necessary guarantees against the extermination of private industry.- $\mathrm{Mr}$. Robert G. Valentine, American Labour Legislation Review, June I9I5, vol. ii, pp. 623-8.

It has been argued that making the employers the channel for the workman's contributions tends to encourage industrial feudalism. The only instance adduced in favour of this view is the case of the workman who is a conscientious objector and refuses to come under the scheme altogether. For him to persist in this course will result in his losing his occupation. But even in this case, it must be noted, that not merely the workman, but both he and his employer are under compulsion. 
they ought to contribute. Again, the law seemed to apply widely what was previously confined to the " aristocrats of labour," who could afford to pay for insurance against unemployment in their trade unions. More important, however, was the view that only by making the workmen themselves contribute would they gain that interest in the administration of the scheme that would lead to its effective enforcement and to the elimination of the abuse of malingering. They gained a legitimate claim to representation in its administration on local employment committees, and their right to labour delegates on the Courts of Referees was guaranteed.*

Organized labour in England has been divided on the question as to who should contribute towards the scheme. The conservative section, consisting of the vast majority, has held that workmen ought to contribute their share towards the Unemployment Fund. That fund is distributed amongst unemployed workmen, and it is essential to their self-respect not to receive something to which they contribute nothing. A State bounty to labour would tend to degrade it. At a conference held on June 20, I9II, in which delegates of the Parliamentary Committee of the Trade Union Congress, of the General Federation of Trade Unions, and of the Labour Party took part, the principle of workmen's contributions was accepted by 223 votes against 44 .

Another widely held view in the ranks of organized labour was, that since workmen were not responsible, and since the industry was responsible for unemployment, that the employer, or, less logically, the employer aided by the State, ought to bear the whole expense. The Labour Party passed a resolution to this effect at its Conference in I9I4.

Mr. Lloyd George, then Chancellor of the Exchequer,

* It has also been suggested that as consumers they, like all other sections of the community, are responsible for fluctuations in the demand for consumers' commodities, and ought therefore to be obliged to contribute towards the upkeep of those who suffer in consequence. 


\section{INSURANCE AGAINST UNEMPLOYMENT}

gave indirect support to this contention when he urged that

whoever is to blame for these great fluctuations in trade, the workman is the least to blame. He does not guide or gear the machine of commerce and industry; the direction and speed are left almost entirely to others. Therefore he is not responsible, although he bears almost all the real privation.*

Similarly, Mr. Chiozza Money urged that there is " a strong case for making the employers' contribution larger." He wrote that

it is the margin of unemployed labour, and the power to employ and dismiss at a moment's notice which goes with it, that is used by the capitalist as the buffer between him and bad times. It is a sort of human reserve fund, far more effective than any financial reserve fund, which helps to adjust the employers' finances as between good and bad years. $\dagger$

Objection to workmen contributing to the unemployment fund rests upon the solid basis that, since they are not responsible for unemployment, they should not be made to suffer for it. Taken in its Jogical completeness, this would imply that the involuntarily unemployed workman should obtain a wage during periods of unemployment equal to that obtained during periods of full employment. The advocates of this doctrine recognize that, however much may be said for it as a theoretical proposition, it is altogether impracticable for the time being because of the grave danger it would have in increasing malingering. They insist, however, that workmen should not be asked to contribute towards a fund which they would not need, nor use, if they were fully employed. The change from the existing situation, where the workmen bear the burdens of unemployment almost alone, to the situation which these sympathizers with labour advocate in which they would not share in its burden at all, is very extreme. Certainly in Great Britain to have proposed a scheme on such a non-contributory basis would have led it to ruin, and have brought

* May 4, I9II, House of Commons.

† Chiozza Money: The Insurance Act, p. 33̧o. 
the idea of State unemployment insurance into disrepute. The English practical sense bowed before the claims of expediency, and a compromise resulted between the then existing state of affairs and the new theory.

It is precisely in this administration that the working men feel themselves to be free agents and intelligent participants in the affairs of their country. There is no taint of charity from first to last; each man pays his share of the cost, has a voice in the control, and can set up a legal claim when he needs his benefits.*

It is therefore incorrect to say that this scheme provides free relief to the unemployed who are in need. One might as well say that if one insures one's house and it burns down and a claim is put in against the insurance society to which one belongs, that the insurance society is making a free gift. There are no free benefits given under this Act at all. It is simply the application of the principle and method of insurance against a contingency -in this case unemployment-which overtakes most workmen during life. "All this removes the insurance system by the diameter of the moral world from poor relief and private charity." Newspapers and politicians who refer to unemployment insurance for which the workman has paid as "doles" or "charity" are ignorant or consciously misleading.

Conceding, however, that all three parties to the labour contract: employers, employees, and the State-which sanctions and if necessary enforces it-are to contribute to the unemployment fund, we are still confronted with the question as to what share they each ought to contribute. The British scheme, as we have seen, imposes on the Government one-third of the total contributions of employer and workman. This sum has been chosen arbitrarily. The balance of advantage seems rather to lie in equal contribution by employer, employee, and State. $\uparrow$

* Charles R. Henderson: Industrial Insurance in the United States.

$\dagger$ This was advocated by the conference representing different labour organizations on June 20, I9II. "When you come to apportionment, it is quite impossible to translate into mathematical relationship and ratio the various benefits to the workman, the employer, and the State respectively."-Winston Churchill in the House of Commons, May 19 II. 


\section{INSURANCE AGAINST UNEMPLOYMENT}

There has been a fair degree of unanimity that the workman's weekly contribution is a serious burden to the lower and more irregular grades of workers. The compulsory stoppage of part of his wage weekly for unemployment benefit, coming at the top of a stoppage for sick and invalid benefit, is a grave burden, and in not a few instances has operated injuriously on the family food supply.*

This is another of the many cases in which the working of the Act has called attention to existing serious defects in the conditions of industry -in this case to the extremely low wages of hundreds of thousands of workers. It is not a blemish in the Act, but rather in the existing conditions that is thus held up to the light.

It would be misleading, however, to argue that because in IgII it was thought desirable that the State, the employers, and the employees should divide the costs of unemployment insurance, that this applies also in I92I, - or is likely to apply in I93I. After all the arguments have been developed by the parties concerned, there can be little doubt that there is a steady growth of the view that the employer must treat unemployment as a charge on industry, and that workmen should not be obliged to pay anything towards the costs of insurance. $\dagger$

\section{Do these Contributions Constitute a New Burden on Society?}

It must be clearly grasped that these new dues or charges are more apparent than real. They indicate rather a reshuffling of existing charges or losses amongst the three parties to the labour contract with a view to making them conform to modern notions of responsibility or to some view as to their capacity to bear them. Unemployment always produces a burden on some one; it represents a considerable deprivation of income to the disadvantage of the individual or of public charity or

\footnotetext{
* See J. A. Hobson, Bulletin pour la Lutte Contre le Chomage, vol. i. $\uparrow$ See Chapter XXI.
} 
private beneficence. Social insurance results in redressing these charges by regularizing the effort to meet these risks. "Instead of paying for unemployment in the lump," one member of the Labour Party in Parliament rightly said, "we are asked to pay it in instalments." This is also the view of the National Civic Federation,* which, in its Report on Social Insurance in Great Britain, writes, that

in the last analysis, the burden of non-employment, poverty, destitution and degradation falls upon society, which is inclusive of all classes of society. Adequate insurance against these conditions will greatly lessen the chances of their existence. In the long run the burden upon society will be less, though temporarily the financial burden may be more.

Of the three methods proposed for providing an unemployment fund the British scheme has two convincing arguments in its favour. It makes it obviously advantageous to all the three parties-to the State, the employers, and the employees-to reduce the amount of unemployment. It will also be a great factor in breaking down the indiscipline and the state-blindness in which millions of people are still permitted to grow up, thinking only of themselves, never being taught that they are a part of a whole, and ignorant of a better conception of citizenship. Through the experiments of unemployment insurance and other measures aiming at the solution of the pressing problems of social disorganization their best discipline will come.

\section{The Incidence of Unemployment Insurance Contributions.}

The Act makes it illegal for the employer to deduct from wages his (the employer's) contribution, but empowers him to deduct the workman's contribution. But in the long run no such legal provisions will affect the incidence of the new tax. In some cases the double contribution

* A body representing employers and certain trade union officials in the United States, whose influence is generally exerted against measures of social insurance. 
will be borne ultimately entirely by employers' profits, in other cases entirely by wages, and in any case no power that law can exercise will keep the real proportions which the scheme provides. Already a certain amount of friction has been produced, and certain employers have even spoken of shifting their payments on to the workmen by postponing salary increases and stopping payments during holidays.* In actual fact, however, there have been only isolated instances where employers have endeavoured to fasten the double burden on organized workmen. $\dagger$

The fear has been expressed that unorganized workmen may have to bear the whole burden of the contribution, since the employer is in a better position for readjusting the wage scale. $\neq$ "But if the unorganized workers realize this, it should increase trade union membership."

These considerations were, however, of significance only during the early days of the enactment of insurance. These causes of "friction" were soon reduced, and the

* Contractors who had undertaken a large contract, requiring some four or five years for completion of the work, must have been hard hit by the increase of 2 or $2 \frac{1}{2}$ per cent. tax upon their wages bill which the sickness and unemployment contributions, it is estimated, amounted to in some trades.

$\dagger$ One case is reported where the employers allege that a strike was due to the worker's contention that the employer should pay the whole of the unemployment and insurance contributions. It is impossible to get at the true facts, because at the same time a rise of wages was demanded.-The Engineer, August 23, 1912.

Another case of this kind is reported by The Building Ner's of August 2, 19 I 2.

The Engineer argues that when insurance becomes compulsory it furnishes a lever for an increase of wages, so that the uitimate burden will rest upon the employer and the State.-The Engineer, May 26, I9II.

The Builder cites the Labour Party's contention that the workers will agitate for a rise in wages to cover the insurance contributions, and adds, "This is precisely the attitude that we predicted would be assumed by the working classes towards the Act."

Mere desire for a rise of wages will not, however, necessarily result in its achievement. But what some of the manufacturers failed to see was the fact that modern society in general approves of the workman's claim for a rising lot in life. In their continual struggle with employers to improve their position, workmen must demand higher real earnings.

$\ddagger$ Report of Special Committee containing representatives of the Labour Party, the General Federation of Trade Unions, and the Parliamentary Committee of the Trade Union Congress. This fear diminishes with the extension of the Trades Boards Act. 
question who actually pays becomes of little importance. The industry adjusts itself to the new conditions.

As to the ultimate incidence of the pecuniary cost, it is doubtful whether there is a single economist who would care to repeat the mistake which Senior made over the Ten Hours Bill, and pronounce dogmatically upon whom the charge will ultimately fall. Insurance may bring about so much greater efficiency of labour that the cost can come out of the increased product without burdening anyone. It may, on the other hand, fall, in whole or in part, upon employers' profits, or upon workmen's wages, or upon the prices paid by consumers. This will depend upon the varying conditions of the several industries and of the business concerns within them.

Professor A. C. Pigou takes this view. He writes:

Whether the funds required to meet compensation or insurance claims are collected from the employers in proportion to the wages they pay, or whether workpeople pay a part and employers another part, is, from a long-period point of view, a matter of small importance, just as it is a matter of small importance whether local rates are collected from landlords or from tenants.*

Many will agree with Professor W. S. Ashley when he urges

that the benefits of insurance are so great that it will be wise to secure them, if it can be done, whoever may have to pay for them ultimately-even the working classes themselves. $\dagger$

Certainly the representatives of labour share this view. In the Labour Year Book of I9I6 we read :

In so far as the cost has been levied, directly or indirectly, on the wage-earner's income, it has meant, we may believe, on the whole, a specific allocation of his resources advantageous to himself and his family as well as to the community. And even allowing for the contributions thus exacted from the class to be benefited, it is probable that most of the developments of social insurance have represented a real addition to the gains of Labour. $\neq$

* Wealth and Welfare, p. 276.

$\dagger$ In Everybody's Guide to the Law, the author writes: "As to who will eventually pay the levy, or whether it will remain equally divided between both parties, will ultimately depend on which side is the stronger and which has the better argument."

‡Labour Year Book, 1916, p. 643 . 


\section{Low Rate of Benefits.}

The writers in the United States who have reviewed the English Unemployment Insurance Scheme of I9II have criticized the very low standard of benefits given under it. Seven shillings a week seemed to them so low that even considering the fact that the whole scheme was avowedly experimental, that it covered at the outset trades in which the average percentage of unemployment was comparatively high, that the workman's contributions were small, and that the cost of living was probably lower than in the United States, the scheme was unduly cautious.

It must, however, be remembered that it is essential to a uniform rate to be so low as to reduce to a minimum the possibility of malingering on the part of any of the beneficiaries of the scheme. It must be so low that even the worst paid labourers will not be greatly tempted to induce their employers to dismiss them, or, being unemployed, from looking for a job.

It is difficult to say what percentage of wages when furnished as a benefit will act as a deterrent to work. To some 90 per cent. of wages would not be desired in lieu of the work and full wages. To others perhaps 50 per cent. of normal wages, especially if it constituted an " existence minimum," might be welcomed if they were then allowed to loaf about without being under the discipline of regular employment. As a result of experience, therefore, rather than of careful forethought, trade unions, municipalities, states, and nations have fixed their benefits as a rule at about 50 per cent. of the normal wages of those insured. With the greatly increased cost of living I $_{5}$ s. a week is worth less than $7 \mathrm{~s}$. in I9I4.

\section{Uniform or Graded Rate?}

Because benefits must be low the well-paid workman will be forced to make extra provision against unemployment. But, it is argued, if saving is still 
necessary, why bother with an insurance scheme at all ? Would it not, therefore, be better to have a graded system so that workmen would obtain benefits in some relation to their standard of living ? The working classes do not constitute, it is urged, a homogeneous mass, and neither their needs nor their paying capacity are the same.

Two radically different plans for the payment of benefits have therefore been suggested-the graded system, as in the German Old Age Insurance Scheme, and the uniform plan, as in the French Old Age Insurance scheme. The comparative advantages of both plans constitute one of the debated questions of the theory of social insurance.*

An ideal scheme of unemployment insurance would have a rate graded in relation to (I) the nature of the workman's trade, (2) his skill and likelihood of being unemployed, (3) his age, and (4) his wage. It is manifest that if his trade has a high percentage of unemployment the dues would have to be high in comparison with the weekly benefit. Again, if he is skilled and a workman with " the right spirit," he is less likely to lose a job than a less skilled workman. It is not yet certain whether age is really a factor in making for unemployment in the individual workman. If it is a factor-and many so regard it-then the aged workman would have to contribute a higher rate than the younger workman ; $\nmid$ whilst, if we are to have any approach to a fully satisfactory scheme, a workman with a high wage needs to receive more, even though he has to pay more than one with a low wage.

To grade a scheme which would take account of any one of these considerations would be difficult owing to our existing very limited statistics. But to arrange a scheme which would take account of all four would to-day be impossible.

We are therefore obliged to follow the dictates of expediency. It is impossible to construct scientific

* See Rubinow, Social Insurance, p. 352.

$\dagger$ See questions of Professor H. R. Seager to Frank J Warne, Hearing on Unemployment, p. I81. Third Report, Unemployment and Lack of Farm Labour in New York State, I9II. 
schemes of unemployment insurance on an actuarial basis, since we cannot discover the unemployment risk.

This difficulty runs through all branches of social insurance. In sickness insurance, for example, it is usual-to establish different rates for men and women because they differ as to their sick rate. But still greater is the difference in the sick rate at different ages, yet an adjustment of dues to ages is rarely attempted. Nor are dues adjusted to different occupations where members of several occupations are found in the sick benefit society.* It is only with growing knowledge of the facts and with increased efficiency of and increased confidence in the Government that finer and more delicate schemes of insurance will be possible.

For many years we shall have to prepare slowly. At first the rate will be graded according to wage-a transitional period where benefits will vary according to levels of wage groups. When sufficient data are accumulated and the administrative machinery is perfected, benefits may take the form of a definite percentage rate of wages. This development will be in harmony with the varying rates of benefits of certain trade unions. One danger will then have to be guarded against, viz. not to accept need as a basis for grading rates of benefits.

In Berne benefits are graded also according as a workman has or has not dependents. The rates of benefits are fixed monthly, but they are not to exceed Is. $2 \frac{1}{2} \mathrm{~d}$. a day per person without dependents and Is. $7 \frac{1}{4} \mathrm{~d}$. for persons with dependents. Since they both pay the same rate of contributions, it is clear that a differentiation is made in favour of those more likely to be in need. This principle, whilst it is an essential guide in the distribution of relief, is opposed to the principle of insurance, and

* In Leipsic, for members insured individually in the fund there are four rates of contribution, graded according to the risk of unemployment in the occupation followed. Benefit is at the same rate for all these members. Persons who have been members for a long time without claiming benefit may be allowed lower rates of premium, or higher rates and longer periods of benefits-a further inducement to "good risks." 
ought not therefore to be invoked in a system of unemployment insurance.

Meanwhile it must be insisted upon that the British Government was justified in initiating a uniform rate system with its comparative simplicity of administration and its avoidance of many technical problems which the grading of contributions, and of benefits creates.

To-day the "contracting out" clause offers the best means of grading benefits, since each trade can adapt itself to the needs of its members. 


\section{CHAPTER XVIII}

\section{THE INFLUENCE OF THE UNEMPLOYMENT INSURANCE SCHEME ON TRADE UNIONS}

IN a democratic country a fundamental consideration with respect to every legislative proposal must be what effect it is likely to have on those spontaneous voluntary associations of free individuals which are the truest expression of personal liberty. Any measure aiming directly at interfering with them, or likely to result indirectly in demoralizing them, is, prima facie, to be accepted, if at all, cautiously. It might result in repressing what has hitherto been regarded as the vital force indispensable to all progress, the impulse of free men to combine for economic and social purposes. There is, therefore, sufficient justification for a careful examination of the probable influence of a scheme of unemployment insurance on trade union activity.

In addition to this general reason, there is the very special consideration of the probable effects of a scheme of compulsory unemployment insurance on the highly developed and long-established schemes of out-of-work benefits carried by a large number of unions.

Sir H. Llewellyn Smith, G.C.B., Economic Adviser to H.M. Government, therefore laid down the condition that

the scheme (of unemployment insurance) must not act as a discouragement to voluntary provision for unemployment, and for that purpose some well-devised plan of co-operation is essential between the State organization and the voluntary associations which at present provide unemployment benefit for their members.*

* Economic Journal, December rigro. 
This was given legislative embodiment in the clause in the Insurance Act providing for a subsidy to voluntary insurance. It provided for a grant in aid which was not to exceed one-sixth of the benefit and was not to be paid on more than I2s. a week. It was to be granted towards the unemployment benefit paid by any organization of workmen, whether within the compulsory scheme or not.

Yet even more difficult than the problem of stimulating voluntary insurance was the development of a scheme of obligatory insurance of such a kind that it would not compete with and adversely affect voluntary associations that provided unemployment insurance. Perhaps the most difficult administrative problem was so to adjust the scheme that while its benefits were not confined to workmen for whom provision was already made by voluntary associations, it would yet operate to encourage the work of these associations and not undermine and destroy them, either by competition or detailed control.*

By inquiring into the attitude of the Labour Party and of the various trade unions towards the scheme, we shall best be able to discover how it has affected these spontaneous associations of workmen.

\section{Trade Union Out-of-work Policies.}

There is considerable variation in the conditions under which unemployment benefit is payable by trade unions, varying, as is to be expected, according to the circum tances of different industries. For instance, as we have already observed in the textile industry and in coal-mining, depression of trade is usually met by working short time, and in these industries many of the unions insure their members not against every form of unemployment but only against mill stoppages, pit stoppages, and the like.

* Monsieur J. Lefort goes further when he writes that "The creation of a State Unemployment Fund, even one working in harmony with other unemployment insurance funds, would result in the apparent disappearance of the latter, and then in their replacement by the former. But he adds an insurance monopoly is bad " ( $L$ 'A ssurance Contre le Chómage a l'Etranger et en France, vol. ii, p. 165 ). This view is, however, proved to be mistaken. 
As is therefore to be expected, the trade unions which make least provision against unemployment are those in the mining and textile industries. Owing to the comparative regularity of employment in the transport industries they also rarely administer out-of-work benefit schemes.

In other industries benefit usually covers all forms of involuntary unemployment.

The period for which benefits are provided and the amounts paid vary with different unions. In some cases they continue for an unlimited period, but there is, as a rule, a limit of between twelve and twenty-six weeks, and there are cases in which benefit is paid only for four weeks. The amount of benefit varied in I9I4 between about $4 \mathrm{~s}$. and I7s., and often a higher rate was paid during the first week of unemployment than in subsequent weeks. Since the war the benefits have been increased in amount. It is noteworthy that only in some cases does out-of-work pay extend to those who are thrown out of work by disputes in another branch of the trade or in another industry.

The following official figures give a total of the amount spent on unemployment insurance by the one hundred principal unions providing unemployment benefit.

OUT-OF-WORK BENEFITS PAID BY SELECTED PRINCIPAL UNIONS, I904-I3.

\begin{tabular}{|c|c|c|c|c|c|c|c|}
\hline I904 & $\cdots$ & $\cdots$ & $\underset{600,000}{£}$ & I909 & $\cdots$ & $\cdots$ & $\stackrel{£}{£}$ \\
\hline 1905 & $\cdots$ & - & 530,000 & I9IO & . & . & 695,000 \\
\hline I906 & $\cdots$ & $\cdots$ & 430,000 & I9II & . & . & 465,000 \\
\hline I907 & $\cdots$ & $\cdots$ & 470,000 & I9I2 & -. & .. & 600,000 \\
\hline I908 & . & .. & $\mathrm{I}, 004,685$ & I9I3 & . & . & 495,000 \\
\hline
\end{tabular}

During the three years I908-I0 a total of $£ 2,645,000$ was expended by the hundred principal unions on unemployment benefits. In the year I908, the year following the crisis of $1907, £ \mathrm{I}, 004,685$ was distributed by these same unions in the form of unemployment benefits.*

* Whilst in Great Britain about one-half of the trade unionists have this unemployment benefit to fall back upon, in the United States, as we shall see later, probably not more than I per cent. of the workmen have any arrangements whereby they can claim unemployment benefit.-Cd. 6 rog. 


\section{State Subsidy to Voluntary Schemes of Unemployment Insurance.}

The Majority and Minority Reports of the Royal Commission on the Poor Laws and the Relief of Distress were in substantial agreement in recommending that insurance should be assisted on the Ghent lines. In this they were supported by all the British authorities on the subject of unemployment insurance.

The majority commissioners considered that assistance should be given to insurance effected through voluntary associations.

If, then, the leading idea be the encouragement of voluntary organizations, it would follow that insurance against unemployment should be developed and encouraged by assisting existing organizations in much the same way as one might develop a system of invalidity pensions through friendly and other kindred societies. This view is supported by trade unionists, by economists, representatives of friendly societies, and other eminent witnesses. The trade unionists consider that they should be the recognized agency to deal with that class of workers described by Mr. Long as respectable men temporarily in distress owing to their inability to obtain employment.*

This recommendation was embodied in Section 106 of the Unemployment Insurance Act, IgII.

Unions paying out-of-work benefits may, as we have already noted, under given conditions claim a reimbursement of one-sixth of the amount so expended, provided that where more than I2s. a week is spent the reimbursement can be claimed only in respect of the I2s. It must be clearly grasped that this encouragement to make voluntary provision against unemployment more common was not restricted to any trades. It covered all trades, and it was significant that a special grant provided by the State and not taken from the Unemployment Fund was voted annually for the making of these repayments. In the year I9I3-I4, Parliament voted $£ 70,000$ for this purpose.

* Report, Part VI, chap. iv, para. 582. 


\section{INSURANCE AGAINST UNEMPLOYMENT}

During the first six months' operation of the Act about one-quarter of all the workmen enjoying union out-ofwork benefits were admitted by the Board of Trade as satisfying the conditions for a repayment. Since then a considerable proportion of the remaining associations have been admitted.*

The conditions for repayment aimed at guaranteeing that those unions should obtain a refund which could be relied upon to distribute out-of-work benefits only in case of involuntary unemployment, who would require from unemployed members that they sign a vacant book in working hours, and thus give evidence that they were unemployed either daily or at other intervals, and that they notified to their unemployed members opportunities for employment.

The failure, wherever it has been tried, as in Cologne and Berne, of direct voluntary insurance, did not justify its encouragement in Great Britain, and so assistance was extended only to insurance through associations. $\dagger$

The total number of associations recognized under Section I06 of the I9I2 Insurance Act were 483 with a membership of $I, 180,000$, of which $32 \mathrm{I}$ men's unions had a membership of 900,000 and 162 women's unions had a membership of 280,000 .

The payments made were as follows :-

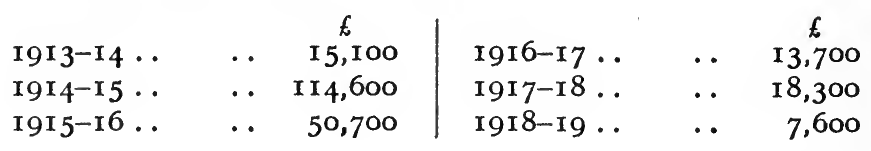

Under pressure from the Committee on Retrenchment, appointed during the war for the purpose of reducing national expenditure wherever possible, the Government contribution of one-sixth of trade union outlay on unemployment benefits, which it had been making under Part II of the Insurance Act, was reduced to one-twelfth.

* This (clause) has enabled some trade unions which did not previously give out-of-work pay to institute it, and others to raise their rates of benefit without raising contributions.-Labour Year Book, 1916, p. 678.

$\dagger$ I. G. Gibbon: Unemployment Insurance, pp. 44 et seq. 
The New Statesman accused the Government of a breach of faith towards the unions.

The contribution to trade unions was merely the equivalent of " the Government penny" contributed to the compulsorily insured trades. It was part of the bargain under which trade unions and the Labour Party accepted the scheme and helped in its administration. Of course, this retrenchment is meant to be temporary, and is excusable only as a war emergency measure undertaken when unemployment was at a minimum.*

The extension of unemployment insurance to practically all industries has resulted in the withdrawal of special subsidies from members of voluntary associations.

\section{Members in Insured Trades may Claim Benefits through their Unions.}

The second provision of the I9II Act dealing with voluntary associations has been continued in the I920 Act. Under it arrangements are permitted whereby members of unions providing out-of-work benefits, instead of drawing benefit from a local office under the rules of the Unemployment Fund, may draw benefit from the union and the union is afterwards able to recover from that fund the amount which the workmen would have been entitled to draw had they claimed direct.

In order not to wean away members from their unions or to interfere unduly with their usual policy unions are at liberty to give such benefits, for such periods and on such terms and conditions as they desire. Having paid out benefits under their own rules, the unions then claim from the Unemployment Fund a repayment of the amount which members had a right to claim under the rules of the fund. This procedure saves the insured members the trouble of attending both the local office of the unem-

* The Labour Party felt very strongly on this subject. In Labour and the New Social Order the Executive wrote: "The arbitrary withdrawal by the Government in I9I5 of this statutory right of the trade unions was one of the least excusable of the war economies; and the Labour Party must insist on the resumption of the subvention immediately the war ceases, and on its increase to at least half the amount spent in outof-work benefit." 
ployment fund to draw State benefit and the union office for trade union out-of-work benefit. It is important, however, to note that every insured workman, belonging to an association or not, retains the right of drawing such benefit as he is entitled to from the Unemployment Fund direct through a local office.

As in the case of the provisions encouraging voluntary insurance, so here there are conditions precedent to the obtaining of a repayment by the unions. They can claim only for well-proven involuntary unemployment; unemployed members must sign the vacant book, and the unions must have a reasonably effective system for the purpose of notifying unemployed members of opportunities for employment.*

Unions could not recover more than three-quarters of what they themselves paid out in out-of-work benefit. In this way they were interested in keeping the claims for benefit low, and corisequently were concerned in keeping the unemployment of their members as low as possible. The Amending Bill of I9I4 provided that workmen claiming seven shillings benefit through labour unions must receive at least 9s. 4d. per week. (It was estimated that in the majority of cases the total benefit, inclusive of the State benefit, was then below I2s.) Under the I920 Act, the union must provide not less than one-third of the State benefit extra if members are to claim through its offices.

The State thus, in effect, allows trade unions to spend the amount which, had the workmen gone direct to the employment exchanges, they would have been entitled to draw, and at the same time it protects itself against the unfairness of subsidizing what after all is admittedly a war-chest, the trade union's general fund.

It is, of course, optional for union members in the insured trades to claim their benefits direct from the employment exchange or to claim them through their unions. Most unionists in the insured trades have elected to claim

* For full statement of conditions under which unions may claim refunds, see Appendix E, First Annual Report. 
their benefits through the institutions with which they were familiar, which had hitherto given them unemployment benefits and towards which they felt a sense of loyalty. Up to July I9r3, I05 associations with a membership of 539,775 in the insured trades made arrangements whereby their members could claim benefits through the unions and they would be refunded from the State Unemployment Fund. Eighty-six thousand members of unions working in the insured trades who had not hitherto enjoyed union benefit had made arrangements to come under the Act. There were in IgI4 considerably over 200 vacant books of associations, having arrangements, lodged at employment exchanges for signature by unemployed members, whilst in 1920 there were some 7,000 books lodged of all union branches. 776 associations with a membership of approximately $2,400,000$ provided for unemployment among their members. The membership of all trade unions at the same date was about 5,250,000.

TRADE UNIONS MAKING VOLUNTARY PROVISION AGAINST UNEMPLOYMENT.

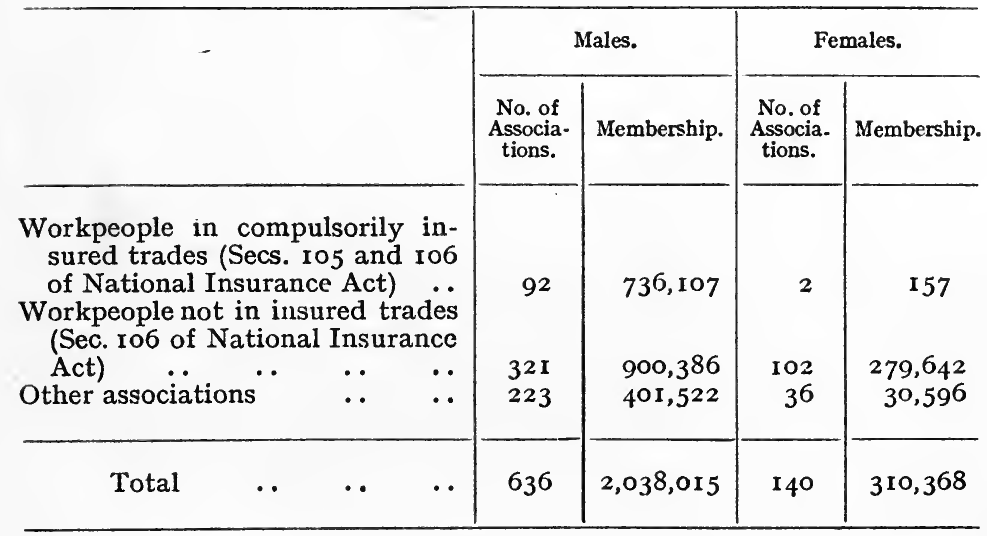

\section{The Entente between Trade Union and Employment Exchange Officials.}

The excellent relations subsisting between the officials of the exchanges and of trade unions is shown by the 
fact that many unions have agreed to adopt the use of the exchanges for purposes of notification of vacancies for unemployment. 6,732 branches of trade unions having a benefit fund of their own, keep their "vacant book," as the unemployment register is known, at the employment exchange. Many of these used to be kept at public houses, a state of affairs which led to much drinking. Again, this system lent itself to great abuse, especially where officials could only inspect the book at intervals of a few days or perhaps of a week. In such cases men would sign two or three days late, and perhaps qualify unfairly for their union unemployment benefit. This abuse is now avoided, since the exchange officials supervise registrations in the vacant book.

These officials prefer to have the union vacant books kept at the exchange, because unemployed workmen may be easily reached in the event of information of a vacancy coming in which they are capable of filling. They are thus more likely to be placed quickly, for the exchange knows from day to day whether or not they have got work independently of the exchange, and not merely from week to week, when the union makes its weekly return.

The stricter control over the vacant books kept by the exchanges is recognized as an advantage to trade unions. This plan ensures that the book is kept more accurately. Union officials for their part recognize the saving in administrative expense by the gratuitous service of the exchanges and the advantage of the Government guarantee that the man signed within working hours and the consequent resulting savings in their own funds. The frequent intercourse between exchange officials and trade unionists, and the strict impartiality which the former have consistently shown when called upon for help by contending parties, have promoted good feeling towards the exchanges and confidence in their policy. It is noteworthy also that about I,500 branches of trade unions use employment exchanges for the purposes of meetings, etc.*

* A very grave charge has been frequently levelled against the Unemployment Insurance Department during I92I. Unions complain 


\section{Membership.}

This provision has resulted in increasing the number of workmen voluntarily insuring against unemployment. This is the view of Mr. Arthur Henderson, who said:

To me one of the most satisfactory results from the introduction of the scheme has been that it has induced many of the unskilled organizations to take up the question of unemployment benefit as they never did before.

It is, however, almost impossible to foresee what direct effects the Insurance Act will have on trade unionism, since bigger forces resulting from the war are likely to swamp them. But it is already certain that an increase in membership in the unions coincided with the introduction of the Government's scheme of sickness and unemployment insurance.* Mr. Thomas Ackland, however, believes that this increase has been most marked in those unions that gave none or very little unemployment benefit. $\dagger$

At the end of I9Io the trade union membership of Great Britain was $2,446,342$, and at the end of 1913 it was $3,987, \operatorname{II} 5$, i.e. within three years there was a growth in membership of 63 per cent. This enormous increase was due in great measure to the industrial revival from I9Io onwards, of which a marked feature was the prevalence of disputes, the occurrence of great national strikes and the steady growth of the amalgamation movement amongst unions. The Insurance Act, both the Health and the

that having voluntarily agreed to bear the costs of administration, and having expended money on benefits, as authorized, the dilatory methods of the Department results in withholding large sums from them for considerable periods. Indeed, the National Sailors and Firemen claim $£ 20,000$ and the Ships Stewards' Union $£ 30,000$. They have both given notice to withdraw from their special arrangement with the Department. Amongst other unions who are complaining are the United Vehicle Workers and the General Workers' Union. See Labour Research Department, Monthly Circular, September I, 1921, p. 35 .

* The Workers' Union increased from 25,000 to 100,000 in about a year's time. The membership of the National Union of Gasworkers has trebled in three years. The Amalgamated Society of Engineers, growth of membership increased after the Insurance Act came into effect. Unions of clerks and iron founders grew more rapidly than previously.

$\dagger$ White Paper, No. 192, p. 4 . 
Unemployment Insurance sections, have had some influence in the increase.* The Minister of Labour states $\dagger$ that

about twenty associations, with a then membership of ror, $\mathbf{r}_{4} 8$, which paid no unemployment benefit before the passing of the Act of I9II, commenced to pay such benefit in order to qualify under Section 105 of the Act. In addition a few associations brought in under the Act of 1916 commenced to pay unemployment benefit for the first time in that year.

It may be added that since the coming into operation of the Unemployed Insurance Act of 1920, 21 additional unions, with a total membership of 518,000 , have made rules for the payment of unemployment benefit in order to satisfy the conditions of Section 17 of the last-named Act.

Although some non-union men now in receipt of a benefit during unemployment will have less reason than before for joining unions, on the whole the tendency will be in the opposite direction. A desire to supplement this benefit because of its inadequacy will lead many to join unions. It is also a well-established fact that once workmen have learnt organization for one purpose, they more easily lend themselves to organization for other purposes. Obligatory State unemployment insurance will lead to voluntary trade union insurance. A new want, as it were, is being created through the State's encouragement, and soon what was a conventional luxury for the aristocracy of labour will become a necessity for the industrial army. It is also urged that unions will be indirectly encouraged in their efforts to raise wages. Nonunion as well as union men, it is pointed out, now enjoying a benefit during unemployment are more likely to refuse a job at low wages which the unemployed man would accept.

\section{Anticipated Effects not Realized.}

In practice, the working of this section of the Act has been different from what was expected. It was intended

* In certain special trades there can be no doubt that the Insurance Act was a factor in the increase (Labour Year Book, I9I6, p. I05). It is impossible to discover how far the large increase in trade union membership in more recent years is due to this factor. It is estimated that the unions now have a membership of five million.

$\dagger$ In a private memorandum prepared for the author. 
that members of the unions should be spared the trouble of carrying in their minds two groups of rules, and of the amounts and periods specified in these rules. Unions, it was contemplated, would pay according to their own rules and recover from the Unemployment Fund the amount which their members could claim from it. It was expected, therefore, that unions would use the repayment, which they could claim from the fund, in raising the general level of their benefits or in reducing their contributions.*

As a matter of fact, however, the general practice of the unions has so far been to continue their existing scales of contribution and benefit without change, and even to increase them, and to undertake in addition to pay over the whole State benefit, in the same way as the State itself would do.

The Amalgamated Society of Engineers, one of the strongest and best administered unions, which usually paid a benefit of ros. a week for any period of unemployment more than three days' duration, has added to the sum the State benefit of $7 \mathrm{~s}$. a week. Similarly, the British Steel Smelters' Union, which paid benefits according to a graded scale, provided a maximum benefit of r2s. a week for thirteen weeks, to which it has now added the State benefit.

These two cases may be taken as typical of what occurred in most of the older unions with well-established systems of benefits. The Government benefit was used not to enable the unions to increase their strike funds, or to lower their dues, but to increasing the benefits provided during periods of unemployment. On the other hand, a few unions did reorganize and lower their scale of unemployment benefits, but the joint benefit from the union and the State is, of course, higher than that previously granted through the unaided efforts of the union. For example, the Society of Coachmakers formerly gave Ios. a week for twenty-six weeks. It now gives I2S. for the first week, the "waiting week," when the State 


\section{INSURANCE AGAINST UNEMPLOYMENT}

gives nothing, 8s. for fifteen weeks, and $5 \mathrm{~s}$. for nine weeks. Now that the State benefit is added, it is seen that the benefit during the first fifteen weeks is very much larger than previously, whilst the amount of total benefits has also increased.* The unions have acted essentially as conduits for the payment of the State benefit to their members. Another reason why most unions merely added the State benefit to their normal benefits, instead of reorganizing the whole of the financial basis of their benefit schemes, was found in the fundamental difference between the conditions on which benefits are granted by the State and by unions. The Government might disqualify from benefit any workman who threw up his job voluntarily, even though his foreman was tyrannous or endeavoured unduly to speed up the particular job. But in a case of that kind the unions would provide benefits. It would therefore seem that there is a "leakage " here which will result in a number of claims being paid by the union which the officials will refuse to refund.

It is because the unions have not hitherto felt able to take any risk of difference between the benefits provided by the State and those provided under their own rules that the full advantages of the scheme have not yet been realized. Instead of arranging that their members will be subject to one set of rules and will be certain of one scale of benefits the unions have allowed them to remain under two sets of rules, those of the union and those of the State.

We have already seen that another result expected to follow from the granting of a subsidy has not been realized. The majority of the Commission on the Poor Laws thought it possible that a new type of friendly society might grow up with the encouragement received

* Another illuminating example of how the Act stimulated insurance among low paid irregular workers was provided by the National Union of Gas Workers and General Labourers. The union's dues in I9I4 were $3 \mathrm{~d}$. a week for non-insured men and $4 \mathrm{~d}$. a week for those in the scheduled trades. The extra Id. provided the means of furnishing $3 \mathrm{~s}$. a week additional benefit to the State $7 \mathrm{~s}$.

Under Section ID6, Is. $6 \mathrm{~d}$. of this extra 3s. was refunded to the union. 
from a State subsidy, a type of trade friendly society for insurance against unemployment, confined to persons belonging to the same or to kindred trades.

It is, of course, arguable that this expectation was not realized because the scheme adopted was in the main of an obligatory nature. But there was little warrant for this anticipation, judging from the experience of other countries. The Commission was betraying more of a hope rather than foresaw an actual likelihood.

\section{Causes of Friction.}

\section{(a) Inadequacy of the Benefit.}

When the smallness of the benefit provided under the scheme was first criticized, it was well pointed out that the 7s. a week was " just 7s. a week better than nothing." It is noteworthy, however, that critics of this amount of benefit have always insisted on its being raised, and not because of its inadequacy, on its being entirely abolished.

As long as the British Government retains its existing scheme of uniform rates of contribution, the benefit cannot be appreciably raised. It must be fixed at such a level that no grade of workmen will be unduly tempted to malinger. Thus it results that the level of benefits in such a scheme must be governed by the group of worst paid labourers.

Compulsory insurance can be intended, therefore, to provide only a minimum benefit. Small as it is compared with what the workman needs to keep in good health, it does not seem small when compared with what even the stronger unions provided. The British Steel Smelters provided I2s. a week for their first class and ros. a week for their second class members for a maximum period of thirteen weeks, whilst the Amalgamated Society of Engineers provided Ios. a week in I9I4. To-day, the I5s. a week benefit buys even less food than $7 \mathrm{~s}$. bought in I9I2. 


\section{INSURANCE AGAINST UNEMPLOYMENT}

\section{(b) Limitation of Trades.}

Since the seven selected trades, really covering only two industries, were chosen with a view to experimenting as to the practicability of a national obligatory system of insurance, it was obvious that room was left for criticism whilst the experiment was proceeding. No really significant reason could be assigned for choosing any specific trades, whilst ignoring others-at least no reason able to convince workmen in the non-selected trades. In addition, there was the friction and impatience resulting from the inevitable anomalies in the decision of the Umpire as to which groups of workmen were engaged in the selected trades. In the I920 comprehensive scheme most of these difficulties are avoided.

\section{(c) Misunderstandings.}

There was also in the early days of the Act a certain amount of dissatisfaction produced through the ignorance or opposition of trade union officials to the regulations on which the Board of Trade insisted.*

Before the union officials really understood the conditions under which refunds would be made they paid benefits in many cases which would have been refused at the local office. Difficulties, largely of a temporary nature, arose as a result of the discrepancies between the interpretation of the scheme on the part of the union officials and of the State officials. It is well attested by many unions that these constituted a real problem in the early days of the working of the Act. It proved to be one of the most serious sources of friction and irritation. During July to December I9I3 the Society of Coachmakers, for example, expended $\epsilon^{\mathrm{I}, 9 \mathrm{I} 4}$ on unemployment benefit, but only $£ 79 \mathrm{I}$ was repaid by the Board of Trade, which then administered the scheme.

The Gasworkers complained that they recovered less than Io per cent. of their expenditure on out-of-work

* Report of the Committee on Preliminary Foreign Enquiry Social Insurance Department, p. 78 . The National Civic Federation. 
benefits. There were three causes in operation which tended to produce these " hard cases."

First: As soon as the payment of benefits came into operation under the Act, many union secretaries failed to pay the necessary attention to the conditions under which associations might pay benefits, with the certainty of being able to reclaim them from the unemployment fund. Many a secretary did not wait for the necessary authorization. Indeed, it was often difficult for them to do so. The personal relationship between himself and the claimant, his knowledge of the man's needs during unemployment, and his natural optimism resulting in the belief that his action would be ratified, explain why many unions when the Act first came into effect disbursed money which they were unable to recover from the State.

Second: Officials were not careful to record the payments made with accuracy and in proper fashion.

Third: Before the administrative machinery worked easily, a week was insufficient time in which to arrange whether a workman had a legal claim to benefit and where he would choose to make his claim.

In $\mathrm{I} 9 \mathrm{r} 2-\mathrm{I} 3$ there were $\mathrm{I}, 260$ appeals by associations to the Courts of Referees in which the decision was in their favour, and 1,225 decisions against them. In I9I3-I4, 4,687 decisions were given in their favour, and 7,836 against them.

Most unions found it advisable to issue a general order to their secretaries not to pay benefits without authorization, and insistence on accurate returns from the secretaries of the branch offices to headquarters had a salutary effect.*.

\section{(d) Cost of Administration to Unions.}

Secretarial work has always been one of the least

* In addition new forms which facilitated accounting were issued. See for example A.S.E. Monthly Journal, January 1914, p. 59. 


\section{INSURANCE AGAINST UNEMPLOYMENT}

important of the many functions which the union secretary has to carry on, with the result that some are not "good writers," whilst few have such a knowledge of accounting as to be able to make all the necessary returns to ensure this refund. The additional clerical work introduced by this scheme has therefore been a source of irritation to many. The extra cost, as well as the difficulty involved in keeping their accounts in such a way that they would pass the Government's auditors, so provoked some unions as to make them talk of throwing up the agreement altogether. But they forgot that every contract implies a consideration in return. This was another of the difficulties which time has removed. Great responsibility rests upon the union officials in meeting the requirements of Government auditors. This prevents any laxness, and indeed sets a high standard of administration likely to affect the unions in other ways.*

Another difficulty during the early days of the scheme was removed by the Amending Act of I9I4. It concerned the union branch secretary, who frequently combined his paid office as secretary with his usual employment. The question arose as to whether when he was an unemployed member of one of the "insured trades" he was to

* Memorandum, Unemployment Insurance, by Olga Halsey. The Society of Coachmakers paid out in I9r3, July, August, and September, $£$ I,200. In October, November, and December, $£ 71.4$. Repayments by the Government were $£ 423$ and $£ 368$. Report, Society of Coachmakers, October I9I3, January I9I4.

The Gasworkers place this extra administration expense so high that they have spoken of throwing up their agreement with the Government under Section 105 of the Unemployment Insurance Act. These, however, are the exceptions.

"Let those who are inclined to place difficulties in the way by not filling in the necessary forms for the general office and the Board of Trade remember that if our society had not entered into an arrangement with the Board of Trade, our members would have been left to draw benefits direct through the labour exchanges. That I am certain would not have been satisfactory to our protestors or advantageous to our members." -A.S.E. Monthly Journal and Report, January rgr4.

Moreover, many believers in the insurance activities of trade unions contend that the more benefits that a member gains from his union the firmer is its hold upon him. For this reason many unions, such as the General Labourers' Union, welcome the opportunity to administer both health and unemployment insurance for their members. 
receive the $7 \mathrm{~s}$. benefit, seeing that he still had his income as secretary. The I9I4 Act provides that a workman is not disqualified from receiving unemployment benefit by reason only of his being still employed at some work which he ordinarily followed outside the working hours of his trade, in addition to his employment in an insured trade, provided that his income from such work did not exceed $€ \mathrm{I}$ a week.

\section{(e) A Possible Danger.}

There is one danger in a scheme of national insurance which as a rule is overlooked. It will require a vigilant democracy to make certain that a scheme aiming purely at social betterment be not used for increasing the burdens upon the shoulders of labour.*

An editorial of the Manchester Guardian of July 24, I915, is highly significant. "In reply to a deputation which asked him for more taxes, Mr. Asquith, then Prime Minister, hinted amongst other things at an acceptance of a plan for utilizing the national insurance machinery for the purpose. 'This point,' adds the Manchester Guardian, 'need be mentioned only to be dismissed.' The insurance machinery covers by no means the whole of the poorer classes. To make it a medium of taxation would be to inflict a definite burden on the insured person as an insured person, and this would generally mean on the employed person as compared with one who works for himself or does not work at all. Taxation through the employer would be with reason disliked, and taxation through an Act professedly passed to confer benefits would be compared with the seething of the kid in the mother's milk. It can only have been through momentary inadvertence that $\mathrm{Mr}$. Asquith half appeared to give a kind of shadow of not wholly unfavourable consideration to this proposal."

* If the unorganized workers realize that their employers may readjust their wages so as to place the whole burden of the contribution on the backs of the workers, an increase in trade union membership may result.

-Revue Internationale du Chomage, vol, i, pp. 134, 140. 


\section{The Labour Party and Unemployment Insurance.}

As was to be expected, the British Government paid special attention to the views of the Labour Party in shaping its scheme of unemployment insurance as well as in its administration. The long experience which the members of that body enjoyed in carrying on trade union out-of-work benefits, its right as the strongest labour organization in the world to speak on behalf of the labouring classes, and its considerable political power, gave the views of its representatives in the House of Commons great weight. The basic principle of unemployment insurance was so readily accepted on all hands that discussion of the Government's scheme has generally been of a constructive nature.

Criticism has been of two kinds. Mr. Arthur Henderson, chairman of the Labour Party, well expressed one type of opposition when he said, "the principle of unemployment insurance is far too limited in its application to the various trades of the country." There has also been a constant stream of fire directed against various details in the scheme and to its administration.

Again and again the attempt has been made to have the scheme extended to other trades.

The following were representative views of Labour Leaders expressed when the Government proposal was first submitted to the country.

Mr. W. A. Appleton, Secretary of the General Federation of Trade Unions, regarded the scheme as unduly limited. "Why," he asked, "were the mining and textile industries, which would have presented no difficulties, excluded? Why were women's trades excluded from the scheme?"

Mr. W. C. Anderson, then President of the Labour Party, was of the opinion that the scheme in general constituted a great step forward, in spite of its weak points.

The late Mr. Keir Hardie, the Nestor of the Labour Party, congratulated the author of the scheme on having avoided State intervention in the financial administration of trade unions. He, as well as others, however, criticized the limitation of obligatory insurance to two groups of industries. He did not at all see why it was not also extended to all the other industries. 
The objection to the scheme of unemployment insurance most often heard amongst labourers and their representatives was the one made by Mr. Appleton and Mr. Keir Hardie-its limitation to two groups of trades. Perhaps, however, Mr. Ramsay MacDonald, one of the leaders of the Independent Labour Party, best expressed "Labour's" sentiment when he said that he would rather vote for the scheme of unemployment insurance as it was, in spite of its faults, rather than ask at once for a bigger measure which would run the risk of being condemned by experience.*

After nearly two years of experience, on March 3, I9I4, Mr. Arthur Henderson, on behalf of the Independent Labour Party, moved: "That in the opinion of this House, the provisions of Part II of the National Insurance Bill, I9I I, should be extended to workmen in certain other trades in order that the scheme of unemployment insurance might more adequately cope with any increase in unemployment; that the scheme should be amended so as to remove existing anomalies and give associations of workmen administering it more financial assistance; and that an inquiry should be held into the general administration of Part II of the Act, particularly of the provision disqualifying from benefit workmen thrown out of employment by reason of a trade dispute."

He said : "We hope that the Government may be able at once to announce their determination to use their power-for happily the Act was so framed that they have not to have an amended Act in order to extend the trades in the schedules-for a considerable extension to bring in the inclusion of new trades. Then, I think, on the general question they ought to give very careful consideration to the question of casual and women workers. I think that the cases of the casual worker with a low rate of pay, and the frequency with which he is forced into idleness, and the women worker with the very small pittance which she so often receives, are very hard if they are at any time the victims of unemployment. These great bodies of workers, to say nothing of trades like the textile, furnishing, and other vast bodies of workmen who have been left entirely outside the Act, ought to receive immediate consideration. I know that the answer would probably be that unemployment insurance, unlike health insurance, was an experiment. We are prepared to admit that it was in the nature of an experiment, but we had the experience of other places where insurance had been tried. It is a good many years since the Ghent system was adopted, and other countries followed that system, and we have now had the experience of the last eighteen months or two years to guide us, and it seems to me that at any rate the Director of Labour Exchanges makes it clear to the House that he is satisfied that the experiment has been a success. That

* These opinions were taken from the Labour Leader, I9Ir. 
being so, I think that the claims of those bodies of workers whom I have already named ought to receive immediate consideration." *

These views show very clearly that the representatives of Labour in Great Britain not only accept the scheme of unemployment insurance, but that it was due very largely to their influence that it was extended to include over twelve million workpeople.

The criticisms of the Labour Party have been directed against the low benefits provided. The I5s. per week is insufficient for the proper maintenance of the family. It will not save the unemployed workman from the deterioration that prolonged unemployment almost inevitably produces. It is suggested that during periods of unemployment the manual worker should have the option of putting in his time at self-improvement, and that he should be able to attend, free of charge, the trade schools, and day technical, and other classes that the local education authority should provide.

In summarizing it may be said that in the launching of the scheme of insurance against unemployment a number of difficulties of a temporary nature were encountered and overcome. Trade unions have grown in numbers and have not diminished in morale as a result of it. Their administrative efficiency has improved and their services to their members have increased. The friction resulting at the outset from the inability of unions to recover all the payments $\dagger$ made in respect of unemployment and those resulting from the extra administrative expenses, as well as through the increased work imposed upon officials, has slowly given way to a hearty co-operation between them and the labour exchanges. $\ddagger$

\footnotetext{
* See p. 680, The Labour Year Book, 19r6. See also Report of Labour Party on Unemployment, $192 \mathrm{I}$.

$\dagger$ This source of friction, as we have noted, is still potent.

Even before the end of the first year's payment of contributions under the Act, Mr. W. A. Bailward, a delegate of the London Charity Organization to the International Conference on Unemployment, and one of the most trenchant critics of the scheme, said : "I have only to add that at all these exchanges (which he visited) I found both managers and staff enthusiastic and confident. I heard on all sides that things were working smoothly with a minimum of complaints, whether by employers or workmen."
} 
The Labour Party of Great Britain is enthusiastically in favour of the national scheme of unemployment insurance, and has successfully exerted its influence to have it extended to all the lower paid occupations and to have the benefits increased. Thus the body more able to speak on this subject with authority than any other in the land testifies to the success of the scheme in its effects on the workmen and on their organizations.

The enthusiastic support given to this scheme by all sections of organized labour in Great Britain is quite easily understandable. Not only does the benefit help the working man materially during periods of unemployment, but it has an indirect influence for good on trade union organization.

Unions suffer severely during times of trade depression because of the inability of members to pay dues and because of the disposition of working men to underbid one another then. In addition, it is a period of constant friction between working men and union officials. Often, the expected support from the unions is not forthcoming, whilst in other cases, where it is forthcoming, its very uncertainty is a source of trouble. The Government benefit will help to keep the union membership more stable, to prevent the lowering of the morale of the workmen and their acceptance of lower standards, and to eliminate a cause of friction between workmen and their organizations.

Some unions will feel the responsibility of taking care of their members during periods of unemployment less urgent. It might even enable them to raise funds for the support of their members while on strikes or during lock-outs. This consideration is only slightly offset by the argument that unemployment insurance will tend to exert a subtle influence to divert militant trade unionism, fighting for the rights of wage-earners, so as to become merely " a fraternal organization principally concerned with drawing small and safe semi-paternal benefits." 


\section{CHAPTER XIX}

\section{UNEMPLOYMENT INSURANCE AS A DEVICE FOR REDUCING UNEMPLOYMENT}

UNEMPLOYMENT, as we have already seen, presents two problems to the legislator. First and foremost, he has the difficult task of reducing the amount of unemployment. Secondly, he must endeavour to lessen the suffering resulting from a period of unemployment through some such device as insurance. We have hitherto been chiefly concerned with the second problem. But these two problems are not entirely distinct from one another. A scheme of unemployment insurance may have a very important influence either in increasing the amount of unemployment or in decreasing it.

When first introduced, schemes of insurance against industrial accidents and of insurance against sickness were meant to soften the effects of industrial life and to keep the labourers above the poor law or charity line, and, later, resulted in an endeavour to raise the national health by immediate prophylactic measures. Thus, whilst they began with an endeavour to treat effects, they resulted largely in treating causes. They not only lessened the suffering resulting from the occurrence of the emergency, but also resulted in a reduction in its occurrence. How far will the British unemployment insurance scheme tend, in a similar manner, to reduce the amount of unemployment ?

Workers subject to unemployment may be divided into two groups: unemployables, i.e. those who through lack of training or loss of efficiency find employment during normal times only on rare occasions, but who are fre- 
quently unemployed or casually employed at a great variety of unskilled jobs; and employables, ${ }^{*}$ i.e. those who are normally employed, but who, owing to fluctuations of industry, are forced from time to time to remain unproductive.

What effect will the British scheme have, firstly, on the problem of the unemployables?

\section{Unemployment Insurance and the Diminution of Unemployables. $\dagger$}

It is a well-established fact that many, if not most, unemployables have become so through having suffered from recurrent periods of unemployment. The lack of proper nourishment, the anguish of uncertainty, and the slow ebbing away of his self-respect, tend to lessen the unemployed workman's ability, and then his desire for work. By providing him with certain benefits during periods of unemployment the workman is very often saved from having to have recourse to public or private charity, and his efficiency is less likely to deteriorate. Moreover, the fact that he must keep in touch with the

* During the war, however, when the demand for labour was very great, all except those who were seriously ill could and did find employment. No unemployables existed then.

$\dagger$ Mr. H. A. Mess, in his recent study on Casual Labour at the Docks, makes some significant comments with respect to unemployable workmen. He writes : "Speaking broadly, one of the most remarkable and encouraging features of the industrial position during the war has been the disappearance of the so-called ' unemployable.' Men have for the most part shown themselves pathetically eager to obtain work. Old men have come out of the workhouse and sick men have come out of the infirmary, and in the latter case there have been remarkable recoveries of health under the influence of the most potent of drugs, new hope. Men felt that there was a chance for them at last, that employers would look at them now. Many miserable homes have been transformed by the war-a strange commentary on our social arrangements in time of peace."

The writer is, however, forced to modify the impression produced by these facts. He adds: "But some men had gone too far in degradation, physical or moral, to recover, and there were many such in the great fringe of labour at the docks."'-Casual Labour at the Docks, 1916, p. 137.

A similar tendency to provide employment to the unemployables was soon evident in the United States when it entered the war. The suction of the negroes northwards and their absorption into trades previously denied them was part of the same tendency. 
employment exchange, which acts as an intelligence department, endeavouring to find him employment and sparing him as a rule the pain of wandering from foreman to foreman, will save him from the despair that once characterized those in his predicament. By lessening the need of appealing to charity, by saving his self-respect, by helping him to retain his efficiency and his status, the unemployed workman is less likely to develop into an unemployable.

The long and successful experience of trade unions with out-of-work benefits has clearly demonstrated the fact that they act as a real preventive against the pauperization and deterioration of workpeople. The well-established claim that few trade unionists have recourse to charity, even during extended periods of unemployment, goes to show that unemployment insurance has been of great assistance to workmen in their efforts to maintain their standard of living. It is, therefore, highly probable that the British scheme, which has now insured most workmen, will result in preventing a very large number from sinking into the class of unemployables.

In addition to preventing the creation of unemployables, the I9I2 scheme made specific provision for lifting certain people out of the class of unemployables into the class of employables. It provided that where unemployment was due to lack of skill or defective ability, and it appeared that training was likely to remedy the defect, and that the burden on the unemployment fund would thereby be diminished, then the insurance officer might make the necessary expenditure for the purpose from the unemployment fund. Unfortunately, practically no attempt was made to give effect to this provision.

By itself such an arrangement, if attempted, could not be expected to achieve much. But if it is only a part of a constructive scheme for dealing with the inefficient workman and it is really operated with a desire to train him under proper conditions, its influence will be great. It is interesting here to recall the provision in the Employment Exchange Act, permitting the exchange to 
provide the necessary cost of transshipment of a worker to any place where work is available. This "encouragement " is likely to be of greatest value to the less efficient workmen, since employers endeavour to attach the best workmen to them in good and bad times. Together, these provisions will not only help to prevent workmen from sinking into the class of unemployables, but will help to make labour more efficient and more mobile and, consequently, help the unemployed workman to gain his competitive wage-rate.

Even more important than both these considerations is the fact that a system of unemployment insurance must bring into high relief the problem of the inefficient and of the unemployable workman. In order to keep the fund-solvent the benefits provided must, necessarily, be restricted to a specific number of weeks; in the case of the British scheme this is I5s. a week up to a maximum of 26 weeks of benefit in any I2 months. It has already been found that certain labourers are apt to claim benefits repeatedly, and others to exhaust all their rights to benefit. Thus the report issued on the first six months' working of the Act states, when I5 weeks' benefit only was allowed,

nearly 30 per cent. of those claiming had already claimed twice or oftener, while some were claiming for the ninth, tenth, or eleventh time ... repeated claims by the same individual are one of the marked features of the experience up to the present time.

It is, of course, clear that a class of inefficient workmen are likely to become unemployable and that in any case they constitute a bad risk. In sheer defence of the scheme its administrators will be compelled to adopt further measures which aim at preventing the manufacture of unemployables. The inefficient and the unemployable will be clearly differentiated, and society will thus be able to treat them along lines likely to prove most effective in rehabilitating them. By separating them from the employables and by regarding them as fit 
candidates for medical and educational treatment the problem of the unemployed will be greatly clarified.

We may, therefore, conclude that the British scheme of unemployment insurance will have the effect of focusing public attention on the problem of the unemployable, that it will tend to prevent the absorption of workmen into that class during periods of unemployment, and that many inefficient workmen in danger of sinking lower will be trained and raised to a higher industrial level.

\section{Unemployment Insurance and the Regularization of Industry.}

The major problem, however, is not the unemployable workman, but it is the employable workman temporarily unemployed. $\mathrm{He}$ is representative of the large body of workers. He is the normal type of unemployed workman to-day, and it is, therefore, necessary to inquire what effect in reducing unemployment a scheme of unemployment insurance will have on him and his group.

\section{Four Groups of Tendencies make for the Diminution of Unemployment.}

Among the influences introduced by the Unemployment Act for the diminution of unemployment it is convenient to distinguish five principal groups :

I. Those arising from the administration of the Act through the employment exchanges.

2. Those due to the fact that the burden of providing benefit is thrown upon workmen, employers, and the State in such a way as to give all concerned an interest in diminishing unemployment.

3. Those which necessarily follow from the greater regularization in the expenditure of the community.

4. Those following from a number of specific provisions directly aimed at encouraging regularity of employment.

On the other hand, there is the apparently inevitable 
tendency of insurance against an emergency which is not altogether accidental and involuntary to increase the occurrence of that emergency. It is, therefore, necessary to consider :

5. Tendencies in the opposite direction making for an increase of unemployment.

\section{Unemployment Insurance maý encourage Unemployment.}

As regards the last of this group of considerations, which will be taken up first, since it constitutes one of the gravest arguments against unemployment insurance, it may be urged that insurance may quite conceivably increase the irregularity of employment by weakening the motives which do at present influence employers to some extent to find their men continuous work.

There are two such groups of motives in operation, one economic, the other human. The economic motive impels employers to take some trouble and incur some risk to keep their labour force together. The advantages of being instantly ready for returning prosperity, the improvement in factory spirit that comes from having a permanent staff, the lessening of cost in running the employment department, the costs involved in training new men unused to the establishment, the diminution in the output and the increase of commodities spoiled through inexperience, are all important considerations to the employer who is anxious to run his plant efficiently.

The human motive frequently forces an employer to pay workmen part wages when not working at all or to manufacture for stock even when it is quite hazardous for him to do so. Sheer humanity will make him desire to prevent his workmen from being destitute and becoming a public burden. But when the employer knows that the workman has an insurance fund to fall back upon he is hardly likely to feel the same responsibility towards him. Especially is this likely to be the case when the employer is himself forced to contribute towards the fund. He may then feel that not only has he the right 


\section{INŚURANCE AGAINST UNEMPLOYMENT}

to engage his workmen just as discontinuously as he sees fit, but that he has actually paid in advance conscience money to soothe him for his misdeeds.

It is quite easy to overrate the importance of these considerations, yet the believers in the absolute selfishness of all employers would be surprised to find the existence of these motives at least occasionally in making any investigations.

To overcome these dangers it has been suggested that employers of irregular labour should be penalized. The minority members of the Poor Law Commission did not go so far, but urged that " no person shall engage any man for less than a month," excepting through the unemployment exchanges. Perhaps now that over twelve million workpeople are obliged to register in the exchanges these special measures will not prove necessary.

In addition to lessening in the motives of employers to keep their men regularly at work opponents of unemployment insurance point out that such a scheme may actually increase unemployment through its influence on workmen. They may be tempted, it is urged, to be unemployed and receive unemployment benefits when wages are low, or to make unemployment last longer than would otherwise have been the case. Even though the most stringent efforts be made to prevent malingering it is asked whether the tragedy of all great reform movements that the unforeseen results will be greater than the foreseen, may not apply also to insurance against unemployment.

The force of this consideration is, however, greatly lessened now that the exchanges may refuse to pay benefits to workmen who, they can prove, are guilty of malingering. A test has been established. Do they refuse suitable employment in the meaning of the Act?

\section{Unemployment Insurance and Employment Exchanges.}

As regards the first of these five groups of influences we may conclude broadly that the linking up of unemploy- 
ment insurance with the machinery of the employment exchanges will help to make them more effective for diminishing unemployment. Over twelve million workers who might not otherwise have registered at the exchanges have been obliged to do so, and, consequently, employers are induced to send to them for the employees who are necessarily registered there, and indirectly exchanges have gained somewhat in popular approval as institutions engaged not merely in gathering statistics of unemployment or in finding employment for a limited number of workmen, but also as the agencies for distributing cash benefits.

It has been rightly pointed out that if employment exchanges depend for their effective initiation or inauguration upon unemployment insurance being associated with them, it is equally true to say that no schemes of unemployment insurance can be worked except in conjunction with some apparatus for finding work and testing willingness to work such as is provided by the exchanges. The two systems are complementary.

One of the immediate results of the Act was to make it obligatory on all insured members to communicate with the employment exchanges as soon as they became unemployed. It thus brought together the workman in search of work and the employer in search of a workman. If in this way suitable work could be found for the unemployed workmen, they were required to take the work offered them and could not then draw benefits. If, however, such work could not be provided, they were held to be unable to obtain suitable employment and benefits were allowed.

The duty of exchange officials to endeavour to find jobs for the unemployed is reinforced by the consideration that the less efficient they are, the larger will be the claims on the fund. It is, indeed, one of the merits of the contributory method of financing the scheme that it makes it the obvious interest of employer, employees and the State to keep unemployment as low as possible, and the State working through employment exchange 
officials has the machinery as well as the motive for trying to reduce unemployment.

The establishment of the British chain of employment exchanges has resulted in two fundamentally important changes in the unemployment situation. First, administrative machinery for dealing with unemployment is being organized and a body of effective data collected. The President of the Board of Trade thus described the readjustment in governmental machinery which the new policy towards unemployment had necessitated. "In the prospect and pressure of the very considerable duties involved in the administration of the exchanges and the scheme of unemployment insurance, the Government reorganized the Labour Department of the Board of Trade so that there should be a distinct section devoted to that work and to kindred subjects. One of the functions of that section is to act as a kind of intelligence bureau, watching the continual changes of the labour market here and abroad, and suggesting any measure which may be practicable, such as co-ordination and distribution of Government contracts and municipal work, so as to act as a counterpoise to the unemployment of the labour market, and it will also, we trust, be able to conduct examinations of schemes of public utility, so that such schemes, if decided upon by the Government and the Treasury, can be set on foot at any time with knowledge and consideration beforehand, instead of the haphazard, hand-to-mouth manner with which we try to deal with these emergencies at the present time." *

The success achieved by the employment exchanges system and of the bold scheme of unemployment insurance has been largely due to the smooth working of this new machinery. It is noteworthy that a committee of experts, including Sir W. H. Beveridge, were at work on the problem of co-ordinating and distributing Government contracts and municipal work, "so as to act as a counter-

* Winston Churchill, President of the Board of Trade, May 19, I909. The Labour Department of the Board of Trade has since been organized into an independent Ministry. The first Minister of Labour was appointed in 1917 . 
poise to the unemployment of the labour market," some time before the war broke out.*

Secondly, the working of the unemployment insurance system will provide, and has already begun to provide, such information as it has never before possessed. The report of the Royal Commission on the Poor Laws in I909 said :

We have found ourselves unable to answer two elementary questions. There are no statistics available which enable us to compute, even within hundreds of thousands, how many persons are at any one time simultaneously in distress from unemployment; or whether this number is or is not greater, relatively or absolutely, than the corresponding numbers for other countries, or for our own country at previous times.

Since the introduction of insurance a source of the most valuable information has been opened out. The first report on the workings of the Unemployment Insurance Act has been hailed as second in importance only to the epoch-making reports on the Poor Law. It is universally conceded that on the basis of established. facts alone can an intelligent and radical handling of every part of the most serious social evil of the day be attempted. Now we are collecting the facts relating to employment and unemployment for over twelve million employees.

\section{All Parties are concerned in reducing the Amount of Unemployment.}

As regards the second group of influences affecting the amount of unemployment the attempt is made to prevent unnecessary idleness, by making it more burdensome to each of the parties interested, if they fail to do so. Workmen and employers pay directly for the benefits given to those who are unemployed. In this way it is clearly to their interest to keep the total amount distributed in benefits as low as possible.

* This committee ceased its deliberations on the outbreak of the war. It is to be hoped that a commission to investigate the whole of this problem will be appointed by the Government very soon. 


\section{2 \\ INSURANCE AGAINST UNEMPLOYMENT}

There is special provision in the Act enabling the authorities to raise the rates of contribution, and of lessening the period of benefit if it is found that the drain on the fund is so large as to threaten to exhaust it temporarily. If, however, it is found over a period of years that the rates of contribution are either too low or too high in view of the established scale of benefits, it is contemplated that there should be a revision of these rates, and that in the revision it was provided in the early Act, though not in the revised scheme, there might be a differentiation between trades and branches of trades according to the amount of unemployment recorded in them. It of course follows that only by reducing unemployment can the contributors to the fund hope to escape with small payments.

The I920 Act contains a clause enabling trades to contract out of the compulsory schemes. It is believed that the joint industrial councils which have been established in a number of trades will desire to develop their own arrangements for meeting unemployment. When those who are best informed about an industry have the management of the unemployment insurance scheme for that industry the likelihood of the best measures being taken for reducing unemployment is perhaps greatest. Certainly the inducement to do so will be greater than it is when the costs of unemployment are pooled between all industries. Also, the costs of administration are expected to be less. A fuller discussion of this question is taken up in the next chapter, but it should be pointed out that perhaps the main purpose of the contractingout clause of the Act is to reduce the amount of unemployment in the trades which take advantage of it.

\section{Regularization of Expenditure will help the Regularization of Industry.}

The third cause tending to reduce unemployment arises from the indirect effect of the regularization of the expenditure of the insured workers. Their benefits, supplemented by their savings and borrowings, would 
help to equalize the amount which they spend during dull times, and in active times. This would necessarily tend to regularize their demand for certain commodities, and consequently to regularize the production of those commodities. The irregularity and consequent elements of uncertainty in the manufacture of commodities consumed by the workers would tend to be diminished.

This consideration would be of greater significance if the scale of benefits was higher. More ingenious, perhaps, is the fourth group of causes consisting of specific provisions directly aimed at encouraging regularity of employments.

\section{Specific Provisions aimed at Regularizing Industry.}

\section{(a) A Refund to Employers.}

The provision of the National Insurance Act of I9I2, to the effect that "When an employer has employed a man continuously throughout a period of at least 45 weeks in the year he may recover one-third of the contributions paid for that man," would undoubtedly strengthen the desire of employers to keep posts occupied as far as possible by the same men. In this way the employer was stimulated to adopt " the concentration method of engagement" to keep a fairly fixed staff regularly employed, and thus to avoid the wastes and uncertainties which result from having a huge labour turnover.* But this part of the Act has not been taken advantage of by employers as much as was expected. $\dagger \mathrm{Mr}$. Lloyd George in his budget provided for a rebate to employers of $£ 200,000$ a year. $\ddagger$ Actually, very much less has been claimed.

* 'See speech in House of Commons, May 4, r9r r.

t White Paper No. 192, p. I.

$\ddagger$ The Amending Act of I9I 4 required that employers shall pay 45 weekly contributions in the year in respect of any workmen, which need not be for 45 weeks of continuous " employment." It fixed a flat-rate rebate of 3 s. for every such employee. This eliminated the need for all calculations of the actual amount which the employer had paid and the proportion of the refund.

An ingenious method for discouraging casual labour was suggested by the Poor Law Commissioners of Great Britain. By levying an " em, 


\section{INSURANCE AGAINST UNEMPLOYMENT}

The number of applications entertained by the Board of Trade in respect of the year I9I2-I3 was about 26,500 , covering 708,500 workmen, in respect of whom a refund of $£_{124,000}$ was claimed. The amount actually refunded was $f_{1} I 44,980$ in respect of 656,577 workmen, or an average of $3 \mathrm{~s}$. $6 \mathrm{~d}$. per head. The refund made constituted $13^{\circ} 6$ per cent. of the estimated total contributions of employers. The administration of this section involved considerable labour, and an attempt was made in the National Insurance (Part II Amendment) Act of I9I4 to simplify it. This provision does not appear in the I920 Act.

One of the motives for including this provision in the original scheme was to lessen the opposition from employers that was expected. As a matter of fact, those responsible for steering the measure through Parliament were astonished to find so little opposition to it.

\section{(b) Encouragement of Short Time.}

The plan of working short time in times of depression, instead of dismissing some men and keeping the rest on full time, was encouraged by the I9I2 Act by offering inducements to employers to adopt it. In the case of workmen put on systematic short time during a period of depression, the contributions both of employers and of workmen might be remitted altogether. This provision also aimed at reducing the labour turnover and at keeping the workman attached to his establishment. Inci-

ployment termination due " on employer and employee at the termination of an engagement it was urged that a threefold advantage would result. First, it would discourage termination of employment on either side without good reason. Secondly, employers would have an inducement to regularize their employment and to lessen the quantity of casual employment as far as possible. The more casual their methods of engagement of labour, the greater would be the amount of " employment termination due" which they would have to pay. A very small expense of this kind at a time when employers are paying careful attention to the problem of eliminating all wastes is calculated to have a greater influence than is at once apparent. And thirdly, in so far as the levying of this due did not have the desired effect in reducing casual labour, it would afford a source of revenue, which might defray the cost of some other proposal aimed at achieving the same result or for paying for the keep of the unemployed. This proposal has not received legislative embodiment,-Report of the Royal Commission on the Poor Laws, pp. 4IQ-II. 
dentally it might be noted that to work a man at short time during a period of depression was by far the most effective and socially advisable method of meeting unemployment that has yet been devised. Casual work was also discouraged to some extent automatically by making casual workmen and their employers pay comparatively heavier contributions than those engaged in more regularized work. This was, of course, justified on the actuarial principle that the greater the risk the higher should be the premium.

An employer before proceeding to put his workmen on short time might make an application to the Department for a ruling that the circumstances are such, and the proposed method of working short time is such, as to make a refund to him possible under the section. Owing to the good state of trade relatively little advantage was taken of this section during the first year's operation of the scheme.

In I9II-I2 30 applications, covering 3, I90 workpeople, were granted, and in I9I3-I4 4I applications, covering 15,009 workpeople, were granted. In the former year refunds were made in ro cases amounting to a total of $E I I 2$ and relating to $49 \mathrm{I}$ workpeople, and in the next year the refunds amounted to a total of $£ 400$ in 19 cases, covering I8 different employers and relating to 2,574 workmen.

This provision does not appear in the 1920 Act.

\section{(c) Casual Labour is Discouraged.}

The I9I2 Act provided that a contribution of $2 \frac{1}{2} \mathrm{~d}$. each was required from employer and workman for every separate period of employment of a week or less, except where the period of employment was two days or less. Thus a workman who had two separate periods of employment of three days each in a week paid two contributions, i.e. 5d. altogether, and his employers also pay 5d.; whereas had he been employed throughout a week continuously by one employer, he and his employer would each have paid $2 \frac{1}{2} \mathrm{~d}$. only. If the workman obtained 


\section{INSURANCE AGAINST UNEMPLOYMENT}

employment for two days or less the rate of contribution was Id. for each day or less. Ordinarily, employers and employees paid at the rate of $\frac{1}{2} \mathrm{~d}$. in respect of a day's employment, and so it resulted that even the reduced daily contribution worked out at a rate considerably above the ordinary weekly rate.* But this clause was not included in the new Act.

Now, in respect of casual work a most ingenious provision was made which shows how carefully thought out this Bill was before being enacted. It is a well-known fact that unemployment is most acute amongst casual labourers, and it is generally accepted that the institution of the employment exchange can be more efficacious in helping them than any other group of labourers. Special provision was, therefore, made not merely for unemployed labourers to register there and for employers to avail themselves of its services whenever they felt disposed to do so, but to make it advantageous to the latter to engage all their workmen through that channel. In this way it was hoped to be able to establish a unified labour market and the means of decasualizing labour.

The provision in question enabled an employer who engaged men through the employment exchange to treat all the periods of employment of the same or different workmen, as though a single continuous period of employment of one workman. It further provided that in respect of men engaged by him through an employment exchange that arrangements may be made whereby it will undertake for him the keeping and stamping of insurance cards and unemployment books. In other words, an employer who used the employment exchange might pay according to the amount of labour he has used, even though the employment has been discontinuous, and though he has not always had the same man, and in

* "The Government now has the power under the amended Insurance Act to offer the London docker, through a scheme of registration, substantial advantages in the shape of absolute security against the possibility of having to stamp his own card in order to obtain work, and the shifting of all except $\mathrm{rd}$. of the $7 \mathrm{~d}$. insurance contributions to the employer in cases where the man only works one day in the week." 
addition the exchange will save him trouble and considerable incidental expenses. Labourers, too, although they have no power to influence employers to avail themselves of these special provisions, are given corresponding rights. Labourers engaged through the exchange by one or more employers with whom an arrangement has been made are allowed to pay at the rate of a single contribution per week, however many separate engagements they may have had. Employers who thus arrange for an exchange to keep and stamp the unemployment books are required to deposit with the Department a sum sufficient to cover the estimated contributions of both employers and workmen for three months, or such lesser period as might be agreed upon between them and the Department.

That this arrangement has been acceptable is proven by the fact that about 300 employers, with over 95,000 workmen, took advantage of it during the first six months of the Act's operation.

As was to be expected, employers of highly casual labour were induced to make arrangements with exchanges.

Some of these schemes* (says the official report) relate to large bodies of casual labour employed in the insured trades, e.g. that of the South Wales ship-repairers, covering altogether about 34 employers and 9,000 men; others, as at Leicester, cover all the building trade employers and workmen of a district. $\dagger$

It is patent that with workmen registering, immediately on becoming unemployed, with employers voluntarily engaging workmen from the exchange, and with provision for insurance during unemployment, that for that group, at least, unemployment as a practical problem is in hand and well on the way to a solution.

* First Report on the Proceedings of the Board of Trade under Part II of the National Insurance Act, I9I I, Cd. 6965.

$\dagger$ It has been suggested that still another rebate might be allowed to employers in return for an agreement to take from the exchange during the year a definite quantum of labour force, with a certain average distribution week by week.-The Prevention of Destitution, pp. 200, 201. 


\section{(d) Rebate to Efficient Workmen.}

The Unemployment Insurance Act aims at fairness as between employers and employees. As we have seen, in respect of the refund for short time and in arrangements with exchanges respecting casual work, employees share with employers the advantages of the special provisions. It was, therefore, to be expected that the benefit of the special refund to employers keeping their workmen regularly employed, who thus prevent a drain on the insurance fund, would be balanced by some special refund to regular workmen who do not have recourse to its aid. This was provided in the clause which allows any workman in respect of whom at least 500 contributions have been paid, at or after the age of sixty, to recover from the unemployment fund the amount, if any, by which his own contributions, exclusive of those of the employers and the State, exceed the amount of benefits drawn by him from the fund with compound interest at $2 \frac{1}{2}$ per cent. If the workman dies after reaching the age of sixty, but before claiming a refund, that amount may be paid over to his personal representatives.*

It has been urged that as employees are themselves unable substantially to influence whether or not they shall be regularly employed, it is inadvisable to make this provision. But it is conceded that within limits employees can and do have some influence to the extent, at least, that the more efficient the workman the less likely he is to be unemployed.

More important is the consideration that unless some special provision is made to placate the employee who is regularly employed, he may object to a scheme of unemployment insurance as being a method of subsidizing the inefficient workman at his expense.

As we have seen, a number of these clauses have been

* Having regard to the provision of this section of the Act, a workman who is entitled to withdraw a part of his contributions should consider very carefully whether it is advisable for him to do so, unless he has finally ceased to follow an insured trade. For every 29s. drawn by him at the age of sixty he loses the right to unemployment benefit to the extent of $£ 3$ 3s. od.- See National Insurance, by Carr, Garnett, and Taylor, p. 369 . 
withdrawn as involving too much labour for the results achieved. But it must not be forgotten that they are not inherent in any scheme of general unemployment insurance. Though they might have resulted indirectly in affecting the number of claims on the insurance fund, they were, strictly speaking, concerned with a totally different problem.

Insurance is a form of saving in advance aǵainst a given exigency. These clauses aimed at preventing the exigency from arising. Insurance applies to large numbers and aims at the sharing of risks. These clauses affect only individual employers and employees. The British unemployment insurance scheme is compulsory now on practically all employers and employees, whilst these provisions affected only those who elected to take advantage of them.

These considerations are all the more important when it is considered that the idea of compulsory unemployment insurance, free from all trappings, cannot yet be said to have emerged from the experimental stage, and to have shown itself convincingly successful. Pessimists, at least, are waiting to see how the fund will weather a protracted period of depression. In order to make certain that the insurance function of the Bill, which is, of course, its primary object, should prove successful, it was suggested that these extraneous matters should be thrown overboard. Certainly, the difficulty of administering some of the clauses aiming at the diminution of unemployment encouraged such an attitude and finally succeeded in its object.

On the other hand, it must be clearly grasped that the provision of insurance does not detract from the urgency of the problem of reducing unemployment to its lowest possible limit. On the contrary, it, as it were, holds up the problem to the white light. The size of the problem, the acceptance of public responsibility for it, the cost to the employer, the cost to the employee, the allotment of State funds and the consequent periodic discussions encourage attention to the problem of eliminating unemployment. 
Now, the importance of these special clauses lies not so much in the fact of what they achieved or failed to achieve, but rather in that they serve as a jumping-off board for a new activity of the State in grappling with certain prospects of the problem. Casual labour, a huge labour turnover, methods of engagement of labour destructive to the workmen, these are the pirblems which unemployment insurance proper cannot attaik. But the British scheme foreshadows the directioss in which their solution will be found.*

REFUNDS UNDER THE ACTS OF I9II AND I9r6.

\begin{tabular}{|c|c|c|c|}
\hline Year. & $\begin{array}{l}\text { Refunds in Respect of } \\
\text { Workpeople Continu- } \\
\text { ously Employed. }\end{array}$ & $\begin{array}{l}\text { Refunds in Respect of } \\
\text { Short Time Workers. }\end{array}$ & $\begin{array}{l}\text { Refunds of Contribu- } \\
\text { tions to Workpeople } \\
\text { aged } 60 \text { and over. }\end{array}$ \\
\hline & $£$ & $£$ & $£$ \\
\hline 1913 & - & II 2 & - \\
\hline 1914 & I I 3,107 & 204 & - \\
\hline 1915 & 120,475 & 2,578 & 245 \\
\hline I916 & 94,035 & 410 & 532 \\
\hline 1917 & 107,405 & - & 773 \\
\hline I9I8 & I I 7,035 & 一 & 3,082 \\
\hline 1919 & I 37,242 & 一 & I 1,253 \\
\hline
\end{tabular}

Sir H. Llewellyn Smith claimed that

the combined effect of these provisions is to give substantial advantage both to the employer and to the workmen in respect of regular and continuous employment as compared with casual engagements. This discrimination is justified both equitably and actuarially by the saving to the Unemployment Fund which results from the diminution of claims for unemployment benefit.

But their administration has proven to be expensive and temporarily at least they have been thrown over. $\dagger$

* One of the reasons for introducing special provisions for refunds in the I9I I Act was to make it more acceptable to representatives of em. ployers' organizations. Now that they are educated as to the need of unemployment insurance these provisions have been withdrawn.

$\dagger$ Return to the House of Commons, containing explanatory memorandum with regard to the scheme for insurance against unemployment, May I9I I, by H. Llewellyn Smith. 


\section{Conclusion.}

We may conclude that the British scheme of unemployment insurance introduces factors which tend to increase the amount of unemployment and others which tend to diminish it.* The latter are more important than the former. The most important effects such a scheme can be made w have on the problem of reducing unemployment are fourfold. The unemployables may be weeded out and their problem thus made more easy of handling. All parties to the wage contract are given an interest in reducing unemployment. Expenditure will be regularized. We shall experiment with and ultimately gain more ability to deal with the problem of regularizing whole industries as well as the output of individual factories. In consequence, the efficiency of the individual plant will be increased, and the national wealth will be increased.

* For a brief and lucid statement of regularity of employment and wages, see chap. ii, Wages and Prices, by Philip Snowden. 


\section{THE SCHEME AT WORK}

\section{The Selection of Trades.}

ONE of the most difficult, as well as the most important, of the tasks which fell to the lot of the Umpire was to decide exactly which groups of workmen came under the I9I2 Act. This particular difficulty would not have arisen if all workmen in all trades earning less than a certain wage had been insured. But since " the Government could not be responsible for a universal scheme of unemployment insurance" * at that time, the necessity for the demarcation of selected trades arose. The complexity of modern industrial conditions made this process extremely difficult, and so an Umpire was appointed in order to give employers and workmen a cheap and expeditious mode of obtaining authoritative rulings as to which trades were included in the scheme.

With regard to the application of the scheme of unenployment insurance to "certain trades," Mr. W. A. Bailward wrote :

Our English experience shows one thing pretty clearly, and that is that there is no halfway house. If the principle of compulsion is once accepted in certain trades, it must eventually be extended to all. The anomalies which have already manifested themselves under a partial scheme make its extension practically inevitable. The decisions of the Umpire as to what is an insured trade and what is not are altogether bewildering both to those who have to administer the Act and to the men themselves. The illustrations given to me by various officers were as follows: A man is working at one end of a drain. He is insured because he is doing new construction work. Meanwhile the man at the other end of the drain is relaying old work. He is not insured.

* Churchill in the House of Commons, May Igr I. 
A French polisher polishing a window frame is insured. The same man polishing a wardrobe is not insured. A large firm of tank-makers in East London are excluded simply because of the thickness of their plates and the length of their rivets. And there are many other similar anomalies arising from day to day. The only possible solution appears to be the extension of the Act to all trades, and that is a very big business.

It has been suggested that the difficulties of legal definition might have been lessened had the business of the employer and not the nature of the work in which the workman is. engaged been the criterion upon which the decision of the Umpire turned. This method was, however, inadmissible for at least two reasons. First, it would operate unfairly as between one employer and another; e.g. if a colliery company repaired its own buildings, insurance contributions would not be payable, whereas they would be payable if the company employed a contractor. Secondly, new difficulties would be created. The difficulties of deciding whether a particular business came under the definition and which of the workmen were included, would probably be in many cases insuperable, e.g. to give a common example, is a "builder, paper-hanger, and undertaker" engaged in the building trade or not?

Despite the great difficulties involved in the proper demarcation of trades at the very inception of the scheme,* it was found that the number of cases which came up for the decision of the Umpire began to diminish after its first year's operation. The cautious views of the administrators of the scheme were summed up as follows: "Compulsory insurance against unemployment in scheduled trades appears to be administratively practicable. Some sort of demarcation of the insured trades has been effected."

* The First Annual Report stated that with regard to mill sawyers and joiners: "It has been hard to draw a line between the furnishing and the building trades, particularly in regard to fittings of wood." "In the case of blacksmiths, the difficulty has been how to differentiate between the smith who is employed in mechanical engineering and the foreman engaged in the manufacture of heavy forgings, the latter trade having been held by the Umpire to be outside the scope of the Act."-First Annual Report, pp. I I, I 2, 46. 


\section{INSURANCE AGAINST UNEMPLOYMENT}

There is, however, some danger in attempting an estimate of a scheme in seeing only the difficult cases on the margin and in over-emphasizing the very real and complex questions that constantly occur there. But whilst these doubts arise in hundreds of cases, millions of individuals from the inauguration of the scheme have known very definitely what were their new obligations and benefits.

At the end of the first year's operation of the scheme about two and a half million workmen in the scheduled trades were insured.

\section{Extending the Scheme.}

But it was evident, as Mr. Bailward rightly pointed out, that once the principle of compulsion was accepted in certain trades, it must eventually be extended to all. About one and a quarter million workpeople were insured under the Amending Act of I9r6. Of the total of about four millions then insured, some half a million were women.

It is noticeable that on the outbreak of the war in August I9I4 the claims for unemployment benefit jumped up and remained high for about four months. This corresponded with the period of uncertainty, when the moratorium was first put into operation, when capital was nervous, and depression was the consequent result. As soon as the demands of war were felt unemployment fell continually, until in the insured trades it was reduced far below the normal in peace time.

The period IgI5 to I920 afforded a good opportunity for passing a measure of universal unemployment insurance. Had this been done, then the fund would have collected very large reserves with which to meet the period of depression that was expected. This was actually recommended by the Reconstruction Sub-Committee at the beginning of I9I8. Unfortunately, however, this advice was not acted upon by the Government until towards the end of I920. Over twelve million workpeople were insured under this new Act, i.e. some 
eight million who were not previously insured against unemployment now have provision made for them. Some three million women are included in the scheme.

The scheme of compulsory insurance embodied in the Unemployment Insurance Act, I920, applied to substantially all the employed persons for whom contributions are payable under the National Health Insurance Acts, except persons employed in agriculture or private domestic service and outworkers. Under this scheme, as from the 8th November, I920, every employer of persons above the age of sixteen who are employed under a contract of service of apprenticeship, whether payment is by piece or by time, who are not in one of the excepted employments, is liable to pay contributions on his own behalf, and (unless that person holds a certificate of exemption) on behalf of the employed persons.

Detailed figures are given for two periods of payments made. Table I, p. 3I6, applies to about two and threequarter million people, and Table II, p. 3I7, from the year I9I6, to about four million insured workpeople. Table III gives the number of payments made and the amounts paid during each week of the period Jan. 2 to June 4, I920, a period of very active employment.

\section{Malingering-Repetition of Claims.}

Sir W. H. Beveridge collected some instructive figures respecting repeated claims in trade unions before the national unemployment insurance scheme was introduced. Their experience with unemployment benefits shows that in most trades there is a small proportion of workmen who through inefficiency or personal habits have unemployment concentrated upon them.

The London Society of Compositors found that about seven-eighths of the total payments in $\mathrm{IgO4}_{\text {( }} \mathrm{f}_{4} 4,000$ out of $\left.f_{1} 6,000\right)$ went to men who had to claim again in r905. It had amongst its members a " small but appreciative body of men who are, to all intents and purposes, 


\section{TABLE I.}

PERSONS INSURED AGAINST UNEMPLOYMENT, CLAIMS MADE, AND BENEFITS PAID UNDER PART II OF THE BRITISH NATIONAL INSURANCE ACT OF IOII AT SPECIFIED PERIODS, JANUARY 3I, I9I3, TO FEBRUARY I9I6.

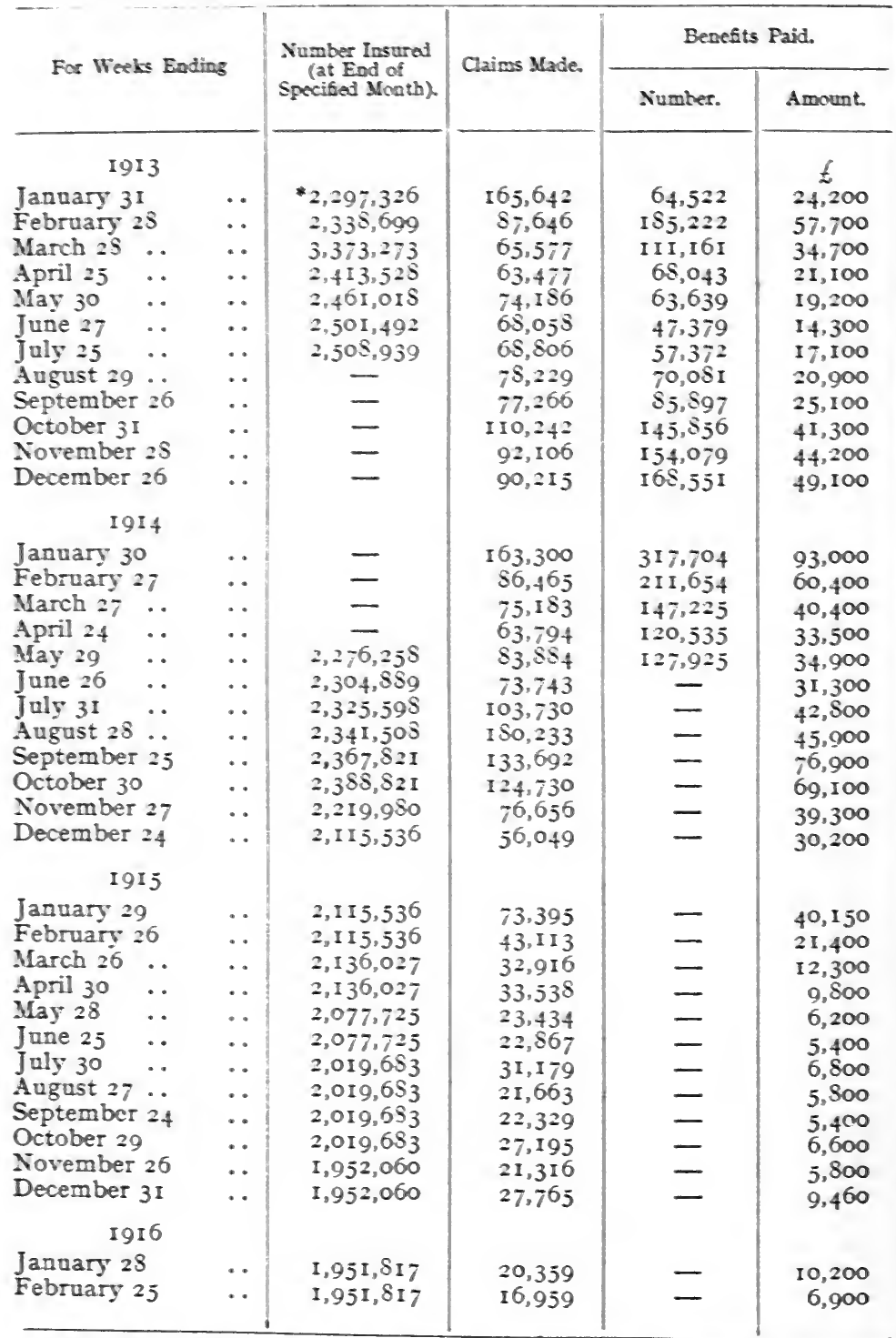

* Including both claims for direct benefits and claims for payment through associations which have made arrangements with the Board of Trade under Section 105 of the National Insurance Act, I9II. 
TABLE II.

INCOME AND EXPENDITURE OF THE UNEMPLOYMENT FUND, 1913-19.*

\begin{tabular}{|c|c|c|c|c|c|}
\hline \multirow{2}{*}{\multicolumn{2}{|c|}{$\begin{array}{l}\text { Year Eaded mil- } \\
\text { Jaly. }\end{array}$}} & \multicolumn{2}{|c|}{ Contributicas trom } & \multirow{2}{*}{$\begin{array}{l}\text { Expenditure } \\
\text { co Benefiti. }\end{array}$} & \multirow{2}{*}{$\begin{array}{c}\text { Balance of } \\
\text { Unempicy west } \\
\text { Fund. }\end{array}$} \\
\hline & & $\begin{array}{l}\text { Earployers and } \\
\text { Woriopeople. }\end{array}$ & State. & & \\
\hline & 1913 & $\underset{1,622,038}{\frac{f}{6}}$ & $\underset{37}{\frac{f}{6}, 000}$ & $\underset{208,318}{\frac{f}{6}}$ & $\underset{1,6,8,907}{\frac{f}{f}}$ \\
\hline & $19 I_{4}$ & $1,802,940$ & 602,000 & 530,593 & $3,2 \mathrm{Ir}, 40 \mathrm{I}$ \\
\hline & 1915 & $1,649,641$ & 546,666 & 418,701 & $4,724,124$ \\
\hline & 1916 & $1,694,115$ & 538.863 & 78,985 & $6,711,50_{4}$ \\
\hline & 1917 & $2,699,932$ & 746,372 & 34,312 & $10,075,467$ \\
\hline & 1918 & $3,277,123$ & $1, \infty 7,5+1$ & 86,159 & $14,222,112$ \\
\hline & I9I9 & $2,8,1,640$ & 994,402 & 152,721 & $18,030,356$ \\
\hline
\end{tabular}

- Prepared by the Ministry of Labour.

\section{TABLE III.}

\section{UNEMPLOYMENT BENEFIT.}

Number of Payments Made and Amownts Paid during Each Week of the Period January 2, 1920, to Jume 4, 1920.

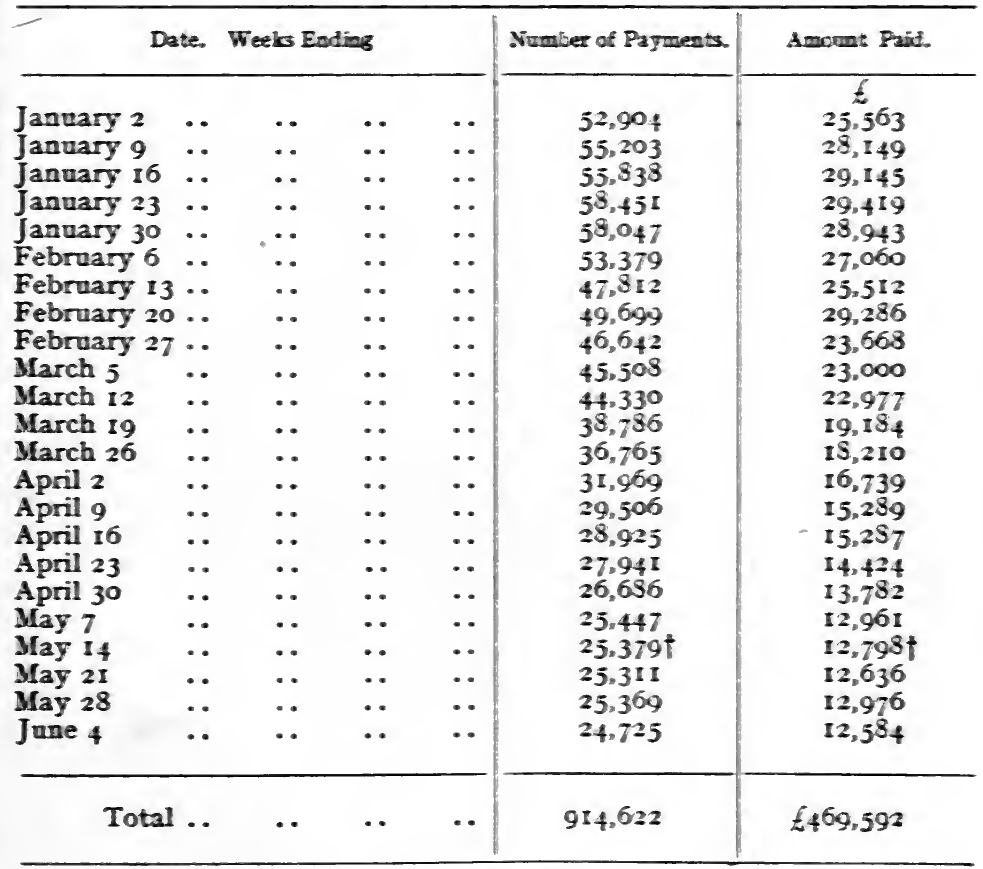




\section{INSURANCE AGAINST UNEMPLOYMENT}

chronically unemployed, and draw full or nearly full benefits every year."

8I members received in 1905 within $2 \mathrm{~s}$. $6 \mathrm{~d}$. of the maximum benefit ( $£ 26$ for 38 weeks out of 52$)$.

58 of these men drew the maximum also in one or more of the years 1903, I904, I906, I907, and I7 others of these men received $£$ r 8 (equal to 26 weeks' benefit) during at least one of these other years. Everyone of the remaining 6 drew substantial though smaller sums.

Of the 58 members who received the maximum benefit in one of the years I903, I904, I905, I906:

21 received the maximum amount in 2 years out of the 5 years 1903-7. 25 received the maximum amount in 3 years out of the 5 years 1903-7.

7 received the maximum amount in 4 years out of the 5 years $1903-7$.

5 received the maximum amount in 5 years out of the 5 years $1903-7$.

Every one of the five received in addition non-provident benefits, special grants from funds raised by voluntary subscriptions ranging from $£ 4$ to $£ \mathrm{I} 4$. The aggregate cost of these five men to the society during five years was $£ 667$, or at the rate of ros. a week each for the whole period. The aggregate cost of the $8 \mathrm{I}$ men in the five years, excluding non-provident benefits, was over $£ 5,500$.

In 1903 the London Consolidated Society of Journeymen Bookbinders had r,342 members.

572 signed for unemployment benefit in 1903 .

Of these 572,377 (65 per cent.) signed for it in 1904 .

Of these 572, 279 (45 per cent.) signed for it in 1905.

Of these 572,298 ( 52 per cent.) signed for it in 1906.

I6o (nearly I2 per cent. of the average membership) signed each of the four years 1903-6. This I2 per cent. of the members sustained 36 per cent. of the recorded unemployment.

Facts such as these indicate a small group of men in regard to whom the function of unemployed benefit is rather to keep them out of the market altogether, lest they cut the rate of wages, than to tide over the seasons.

* See Unemployment : A Problem of Industry, by W. H. Beveridge, I909, pp. I40, I41, I42. 
There can be little doubt that other unions in other trades would also show a fringe of casual workmen attached to them. It is clear that the experience of the national unemployment insurance scheme has not been unlike that of unions providing benefits for unemployment. But the provisions limiting benefits has been a check-a justifiable check-against a repetition of a very large drain on the fund by inefficient workmen.

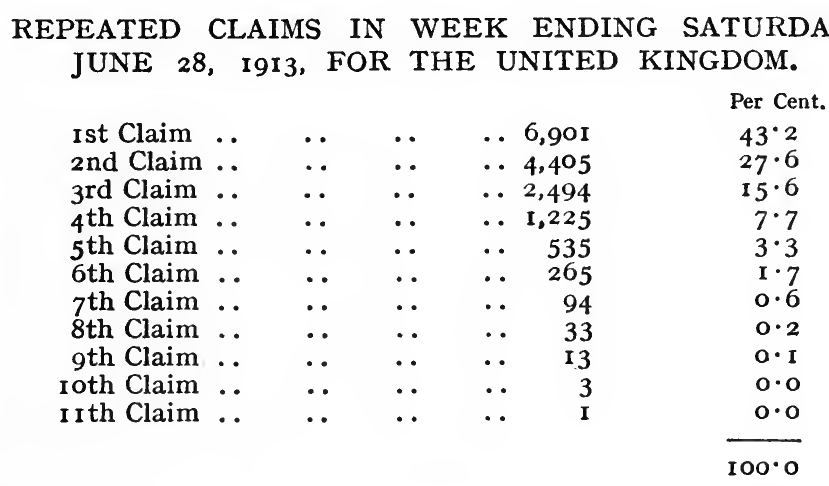

This table shows that, within six months of the commencement of benefits, nearly 30 per cent. of those claiming had already claimed twice or oftener before, while some men were actually claiming for the ninth, tenth, or eleventh time.

There is evidence that repeated claims were most characteristic of the London Division. This was due to the prevalence there of the building trade, and the generally greater instability of London employment.

This interesting sidelight on the industrial quality of the applicants is supplemented by the significant fact of the unexpectedly small average amount of the benefits granted, viz. 8s. 6d., or a little over a week's benefit per claim. Since some drew benefit for as many as 37 days, it is clear that a large number of applicants must have drawn very small sums.*

- In a number of French trade unions the average benefit was even less than it was in England. In 191 I it was 7 days, and in 1912 only 4 days. 
It must, however, be recalled that these figures apply to a period when trade was exceptionally good and unemployment low, also, that the applicants were unemployed for a week before benefits were distributed, and, lastly, that the employment exchange made special efforts to find work for those whose unemployment meant a drain on the unemployment fund.

The whole picture presented by the statistics of men falling out of employment and men remaining unemployed is that of " a constant irregularity of employment even when employment is, at its best, a ceaseless shifting from job to job," a recurrent loss of productive power and of wages in the interval between one job and the next. It seems clear that much could be done, and needs to be done, towards reducing unemployment by shortening these unproductive intervals by hastening through labour exchange organization the passage from employment to employment and by reducing the amount of "labour turnover." Transference from one employment to another would in very many cases be quite unnecessary if employers adopted a more thoughtful policy in their methods of hiring and firing workmen.*

But even though we know that nearly 30 per cent. of those claiming had already claimed twice or oftener before, it is still impossible to give detailed statistics of the number of individual workmen who claimed benefits. We may, however, estimate that only one-tenth of the insured members claimed benefits during the first six months' operation of the benefit features of the scheme. Nine-tenths of all insured workmen claimed no benefit. $\dagger$ Previous to any discussion of the importance of malin-

- From these facts Mr. W. A. Bailward concludes, perhaps hastily, that it is becoming the custom to apply to the fund for benefit even in the shortest periods of unemployment which men would formerly have tided over for themselves without difficulty. See also Revue Internationale, p. 496, April-June r9I4.

† There were 559,02 I claims made during the first six months of the payment of benefits; 2,508,939 unemployment books were distributed by the end of that period. There was thus roughly one workman who claimed benefit for every five workmen. Since, however, some workmen made repeated claims, it is likely that only about one-tenth of the insured workmen claimed unemployment benefit during this period. 
gering we are therefore forced to delimit the question to one-tenth of the insured workmen actually claiming benefit. Nor can it be maintained for one moment that more than a small proportion of this ro per cent. is voluntarily unemployed. As we have already seen, the labour exchanges in their double capacity of finding employment for the insured unemployed and of preventing fraud on the funds tend to keep malingering low. More important even is the fact that no workman may receive more than one week's benefit for every five weeks of contributions. His temptation to claim is thus offset by his fear of exhausting his right to benefit. Lastly, those who are subject to a very high percentage of unemployment are squeezed out, and lose membership. But even though the importance of malingering has been over-emphasized by the opponents of State insurance, its possibility must always be considered and efforts made to prevent its growth. This problem will become more serious as the scale of benefits is increased, as it so clearly is likely to be.

It is, of course, true that even if comparatively few workmen in their desire to gain unemployment benefits are successful in malingering or cheating, their success is sufficient to produce an acute problem because of its seductive effect on others.

On the other hand, fraud and malingering can be prevented if there is adequate and effective machinery for so doing. "It is a definite administrative problem which must be met by appropriate methods of administrative control." *

- See Candid Review, I9I4, pp. 77-108, and also Rubinow, Social Insurance, pp. 496, 497.

Dr. Friedensburg, writing with sickness insurance in mind, says that "Insurance has been the very factor which has led to universal degeneration and demoralization."

In a long pamphlet on the "Undesired Consequences of German Social Policy," Professor Ludwig Bernard, of the University of Berlin, fears that the effect of the sickness insurance schemc is to instil into the insured a nervous hunt for pensions, a consciousness of bodily ills that leads to unconscious or often conscious exaggeration in the hope of higher pensions. "The workers instruct each other in methods of simulation." -Review in Quarterly Journal of Economics, pp. 56r-78, of Ludwig Bernard's Unerwünschte Folger der deutschen Sozialpolitik. See also Malingering and Feigned Sichness, by Sir John Collie, assisted by Arthur 
During the period of intense depression of $\mathrm{I} 92 \mathrm{I}$ a very large number of workpeople exhausted their right to benefit. By August 'I3th over I27,000 unemployed workpeople had exhausted their benefits.*

\section{How Employers' Contributions have Worked in Practice.}

From the introduction of the scheme up to July Igr3, only twenty-four cases of prosecution of employers for not paying dues were reported. One case occurred where the employer deducted his own share from the workman's wages and another that of obstructing an inspector. In the other twenty-two cases the offence charged was failure to pay contributions due. The skilful educative policy of the Board of Trade and the popularity of the scheme accounts for the fact that only one workman was prosecuted and fined for refusing to apply for an unemployment book. $\dagger$

But a proposal so novel in Great Britain as the payment by employers of contributions towards their workmen's unemployment benefit could not be expected to pass without considerable objection. The argument that the extra tax would ruin industry was produced as a matter of course. $\ddagger$

H. Spicer Arnold, 1913, and Uber der Einjluss der Sozialen Gesetze auf den charakter, by Professor H. Quincke, r 905 .

- By September I 2 th over 290,ooo had exhausted their benefits, and it is anticipated that about I00,00o workpeople will fall out of the scheme weekly, until November 3 rd, when they might again claim benefits. See p. 208. The fund of some $£^{20}, 000,000$ accumulated during the war has been exhausted. Benefits are now being paid in part from loans obtained from the Treasury.

$+\mathrm{Cd} .6965$, p. I3. This does not, however, mean that all those who should have been insured became so in fact.

$\ddagger$ Unequal taxation of employers for health and unemployment insurance is illustrated as follows :-

(a) Firm employing roo hands with a profit of $\ell_{1} 0,000$.

Employers' levy: sickness, $£_{65}$; unemployment, $£ 58$. Total, $£$ II 9 , or I'I9 per cent. of profit.

(b) Firm employing 2,00o hands with a profit of $f_{10}, 000$.

Sickness, $£_{1,300 ;}$ unemployment, $£_{1,083}$. Total, $£ 2,383$, or 23.83 per cent. of profit.

See $A$ Tax on Industry, a pamphlet showing the inequality of the employers' contributions to the Health Insurance Act, W. Pretty.

Note also view of Employers' Parliamentary Association. "If employers as such must be taxed for sickness insurance, it should be upon a profit basis, and not upon the number of employees."-Redman Omerod.

Similar views with respect to unemployment insurance are frequently met with. 
Like the employers who opposed the Ten Hours Day Bill on the ground that the profit was made during the last.half-hour of the day, and therefore the working-day could not be shortened, so their prototypes of to-day argued that it was precisely the payment of $2 \frac{1}{2} \mathrm{~d}$. which employers contributed under this scheme which meant the elimination of all profits. A very interesting study published in the Economic Journal shows that this contribution of $2 \frac{1}{2} \mathrm{~d}$. a week for every worker amounted to about I per cent. of the amount expended in wages.*

\section{SHOWING RELATION BETWEEN CONTRIBUTIONS AND WAGES.}

\begin{tabular}{|c|c|c|c|c|c|c|c|c|}
\hline \multirow{2}{*}{\multicolumn{5}{|c|}{ Industry. }} & \multirow{2}{*}{$\begin{array}{c}\text { Average } \\
\text { Weekly } \\
\text { Wage, 1906. }\end{array}$} & \multicolumn{3}{|c|}{$\begin{array}{l}\text { Employers' Contribution as } \\
\text { Percentage of Wage. }\end{array}$} \\
\hline & & & & & & Sickness. & $\begin{array}{l}\text { Unem- } \\
\text { ployment. }\end{array}$ & Total. \\
\hline \multicolumn{5}{|c|}{ Sawmilling and machine-joining } & $\begin{array}{ll}\text { s. d. } \\
22 & 7\end{array}$ & $\begin{array}{l}\text { Per cent. } \\
\mathbf{I} \cdot \mathbf{I}\end{array}$ & $\begin{array}{l}\text { Per cent. } \\
0^{\circ} 9\end{array}$ & $\begin{array}{c}\text { Per cent. } \\
2 \cdot 0\end{array}$ \\
\hline \multicolumn{4}{|c|}{ Engineering and boilermaking } & . & 273 & $0 \cdot 9$ & $0 \cdot 7$ & $I \cdot 6$ \\
\hline \multicolumn{5}{|c|}{ Ship and boat-building and repairing } & 28 I I & 0.8 & $0 \cdot 7$ & $x \cdot 5$ \\
\hline Building & .. & .. & . & - & $28 \quad 6$ & 0.8 & 0.7 & $I \cdot 6$ \\
\hline
\end{tabular}

Perhaps the most persistent complaint against this feature of the Act, the employers' contributions, is due to the fact that they are calculated on the basis, not of the risk of unemployment involved in each shop, as of the risk of accidents under the Workmen's Compensation Act, nor with reference to the profit of the firm, nor of its ability to pay the tax, but merely with reference to the number of workers employed. It is therefore alleged that the existing method of computing the tax is unjust to industry.

The practical difficulty, however, is to provide other methods which will prove more satisfactory. When employers of labour urged Mr. Lloyd George to calculate

- James Cummison, Economic Journal, September 1913, p. 37 I. 


\section{INSURANCE AGAINST UNEMPLOYMENT}

contributions on the basis of profits, he answered that he had been advised that there were great practical difficulties in the enactment of such a proposal. If an income tax is difficult to collect, a tax to be used for the unemployment insurance fund based upon profits would be equally difficult. Such a means of paying the employer"' contributions might, in addition, raise objections among the workers. They would see their contribution deducted from their wages, with no stamp for the employer's share, and could be persuaded only with some difficulty that he was making his contributions by cheque.

Another complaint against the Act frequently made by employers results from their objection to the large amount of clerical work which is involved in the proper administration of the scheme. This, it must be recalled, is due in part to the added burden of the health insurance scheme. It is particularly irritating to them and wasteful of their time to have two different sets of inspectors examining their books for purposes of sickness and unemployment insurance respectively, even though there are obvious administrative difficulties in the way of combining the functions of inspection in one official.

But we have, however, seen that employers who undertake to engage all their workmen through employment exchanges are spared this extra clerical work.

Owing to the expenses involved-the extra labour in keeping the books, the indirect charges and the actual payment for stamps-a weak effort was made by employers to prevent the unemployment insurance scheme from coming into effect. Since most of the fire of the opponents of social insurance was, however, directed against the health insurance proposals of the Government, those dealing with unemployment went by without much attack.

This was due in part to the fact that the unemployment insurance scheme was much better thought out. Even opponents of the scheme write that

the atmosphere surrounding the law, so to speak, is different from that of the health insurance action. The scheme was care- 
fully worked out, was based upon reasonably accurate data, and probable difficulties were foreseen and provided for.*

The most serious argument used against it was perhaps the contention that the increased wages roll which would result from the employer having to pay $2 \frac{1}{2} \mathrm{~d}$. a week extra for every workman in his employ would be shifted on to the community in the form of increased prices. It is a matter of fact that no such rise of prices took place directly traceable to the employers' contributions.

On the whole, however, the traditional reverence for law resulted, first, in the manufacturer's acceptance of the scheme, then in his giving it a fair trial, and finally in his treating it as a part of modern industrial conditions. His attitude was best illustrated by the director of one of the leading machine shops when he said that he considered the Act a necessary evil, and that he thought that most manufacturers shared his opinion. The day has not yet arrived when employers will welcome social measures that impose burdens upon them without at least some complaint. But many employers now recognize the advantages which the scheme yields them.

First, the close contact between employers and the employment exchanges saves them, if they so desire, the expense of advertising for new workmen, and, since the employment exchange can draw workmen from other parts of the country, this important function of industry is accomplished better and without direct expense to themselves.

Second, the record of service and constancy of employment which is furnished them by the unemployment card aids in their choice when hiring workmen. This helps the employer to sift out the good workmen from those whom he regards as shifty, cantankerous, and inefficient men who apply for work. The scheme thus gives him the opportunity of eliminating a serious source of waste. The substantial reduction of the burdens of the Act resulting from the policy of exchanges in stamping

- Report of the Social Insurance Department, National Civic Federation. p. 67 . 
cards for employers has also aided in the smooth working of the scheme.

Although it was assumed that the cost of administration of the scheme would not be more than Io per cent. of the receipts, during its first two years it was about double of that estimate. Mr. Herbert Samuel, Home Secretary, stated that the cost of administration had been about 20 per cent. of the receipts, but that the expenses in future years might be reduced, as the machinery now developed should be able to deal with a larger number of insured persons.

The British Government was wise in beginning its scheme of unemployment insurance during a period of rising prosperity. The demands on the fund were comparatively few, and the contributions regular, so that a reserve was collected which was distributed in times of depression. Indeed, it is now believed by all competent observers that the success of a plan of compulsory insurance against unemployment will depend chiefly upon two things : first, whether or not during times of prosperity contributions will keep up, and large accumulations of funds be thus secured, in order that the heavy pressure during times of depression may be met; second, whether or not boards charged with the administration of the law will encourage special studies and investigations to be made of the causes of unemployment with a view to prevention.

If these things are neglected, it is generally anticipated that the schemes will in the end be disastrous, involving enormous pressure upon the central Government for large funds at a time when business depression is greatest, and contributing little or nothing to the determination of causes or to their removal.

After nine years' experience it is possible to state that compulsory State insurance has proven to be administratively practicable. "No insoluble difficulties have presented themselves as regards the definition and the test of unemployment."

The Unemployment Fund was able to meet the some- 
what heavy call on it during the early days of the war with ease, and the scheme has proven elastic enough to be easily modified to meet conditions which were hardly anticipated when it was instituted.*

The success of the scheme has gained for it the support of all sections in the community. No party or group of individuals exists in Great Britain who want to see its withdrawal. It has with the goodwill of all and with the enthusiasm of many become part of the very texture of industrial life.

At the termination of hostilities in November Igr8 the State scheme of unemployment insurance applied only to a limited number of trades and provided benefits which were entirely inadequate having regard to the increasing cost of living. This provision was evidently insufficient in view of the dislocation of industry and consequent unemployment. The "Out-of-Work Donation" Scheme was passed to meet the special emergency.

\section{Out-of-work Donation Scheme.}

Free unemployment allowance was provided under the scheme of out-of-work donation which was brought into operation on November 25, I918, to non-commissioned members of H.M. Forces and to civilian workers.

The "Original Scheme" for members of H.M. Forces applied for twelve months following their demobilization. Special extension schemes were applied to later periods. Under the "original scheme" the ex-service man who was unemployed within the twelve months following his personal demobilization was able to draw donation up to the following maxima:-

(a) 26 weeks at 29 s. a week, with allowances for dependent children at the rate of $6 \mathrm{~s}$. for the first child and 3 s. for each additional child under the age of 15 .

* The abnormal and feverish activity which has resulted from war conditions had the same effect on the fund as a period of normal trade activity and prosperity, but the continuing depression of $192 \mathrm{I}$ must be met by other means. See Appendix IV. 
(b) For a subsequent $\mathrm{I} 3$ weeks (or in the case of disabled men 20 weeks) at the rate of 20 s. a week, with the same allowances for dependent children.

The out-of-work donation scheme applied to civilian workers between November 25, I9I8, and November 24, I9I9. The first grant of donation to civilian workers was for a maximum period of $I 3$ weeks in respect of unemployment occurring during the six months ending May 24, IgI9. The grant was at the same rate as that provided for H.M. Forces. Applicants between the ages of 16 and 70 were required to show that they had become employed contributors under the National Health Scheme at least three months prior to November 25, I9I8.

The local Employment Committees adjudicated on the grant of donation.

Although the Insurance Acts remained in force and contributions were compulsorily payable by employers and workpeople, payment of benefits was in effect suspended, since the rate of donation was much higher than the rate of benefit and since workpeople could draw donation without exhausting their rights to benefit under the Unemployment Insurance scheme.

\section{Ex-Service Men.}

Special arrangements have been made and are in operation to-day to assist ex-service men to obtain suitable employment; the local employment committees have interviewed the men and have interested employers in the question. Each exchange has a special branch to deal with disabled ex-service men working closely with the Local War Pensions Committee and the Training Branch of the Ministry of Labour. There is a special exchange for disabled men in London. The national scheme for the employment of disabled ex-service men is also administered through the exchanges. 


\section{The War Period Generally.}

The exchanges were an indispensable part of the machinery required for the mobilization of the national resources for the purposes of the war; had they not existed, it would have been necessary to improvise some less adequate machinery for the purpose. It was fortunate for the most effective prosecution of war that they were in existence and that the managers and staffs had acquired some experience of the transfer of labour. "The Committee of Enquiry into the Work of the Employment Exchanges," which reported in I920, states that the war work and the work connected with demobilization was well done under adverse circumstances, such as unsuitable buildings and improvised staffs, and that it must have involved immense strain on the managers and other responsible officials.

\section{Administrative Costs of Exchanges and Unemployment Insurance.}

The five main functions of employment exchanges are usually ignored when criticism of their cost is made. Attention is drawn as a rule only to their placement function, and the whole cost of the exchanges divided by the number of " placings." This is entirely misleading. When, therefore, it is stated that for the year I9I3 the total cost of the department divided by the number of placings gives a quotient of about I7s., and for the year I9I9-20, under the exceptional conditions then prevailing, the figure is just under $£ 3$, it is essential to ask what other activities were attempted by the Department. The accompanying table gives the total cost of the employment exchanges from I909 to I920.

Two suggestions for lowering the cost of "placings" are made. It is found that the Tavistock Street Exchange, which is almost purely a building trade exchange for London, estimates the cost at slightly over 6s. per case. Further specialization of exchanges is likely. to 


\section{INSURANCE AGAINST UNEMPLOYMENT}

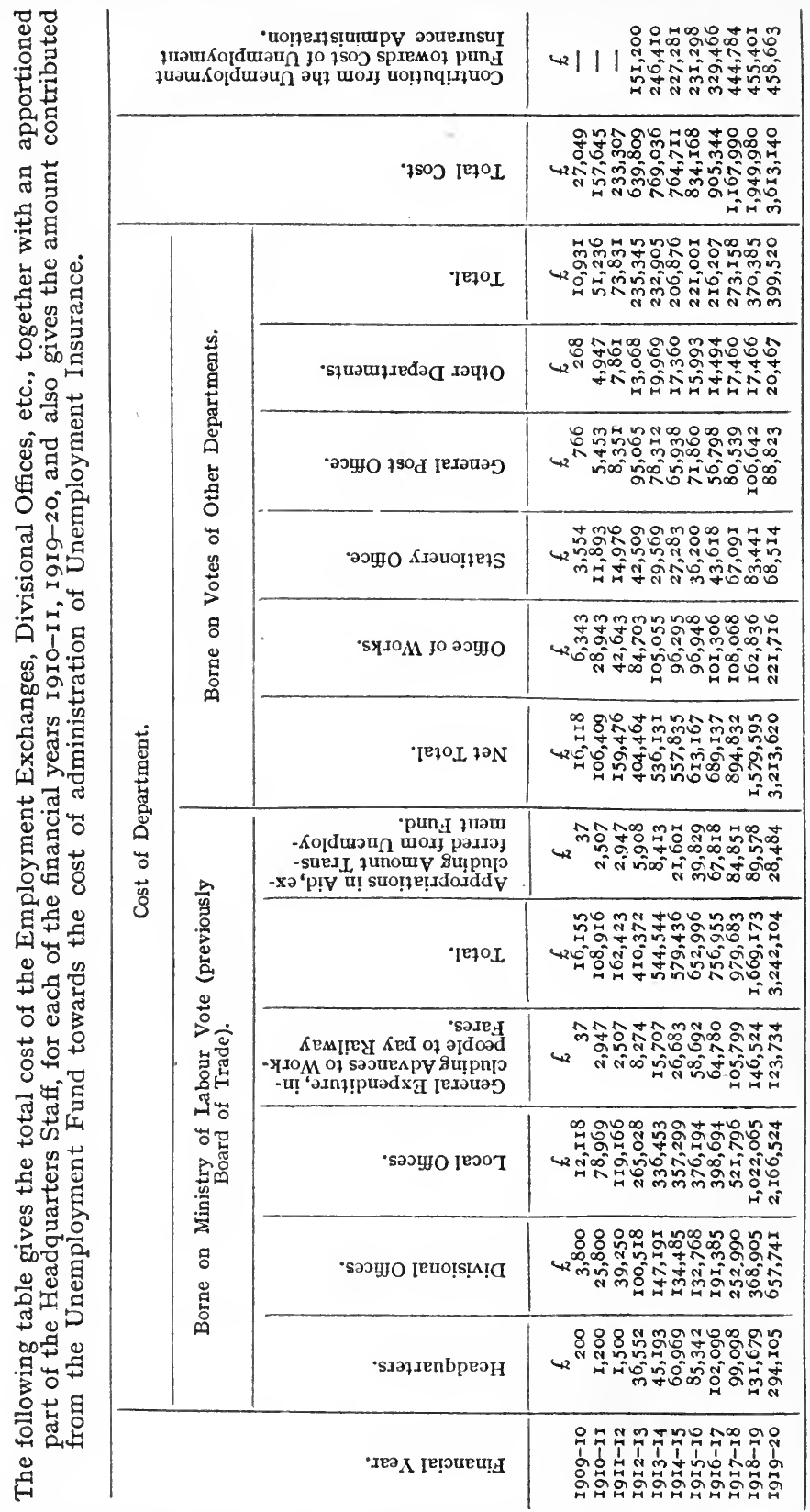

* The national system of employment exchanges in so far as they are successful are expected to result in a great economic saving, partly in 
show a similar reduced cost for " placings." Secondly, the trade unions are the most economic agency for dealing with trade unionists. Special recognition of their work of placement should be made and encouraged.

The total cost of administration of the employment exchange system and unemployment insurance for the financial year I9I3-I4 was $£ 769,036$, of which $£ 545,593$ was attributed to unemployment insurance and $£ 2$ I9,443 to employment exchanges. An appropriation in aid not exceeding Io per cent. of the income of the unemployment fund was made from the fund to the Board of Trade towards the cost of administration.* The State, over and above its contribution of $£ 602,000$ to the Unemployment Fund, paid $£ 303,183$ towards the cost of administration, or $£ 905,000$ altogether. The gross contributions of employers and workmen in that year amounted to about $£ 900,000$ in each case. Thus the three parties contributed roughly the same proportions to the cost of unemployment insurance.

The contributions of employers, workmen, and the State to the Unemployment Fund in the year I9I3-I4 amounted to $£ 2,408$, 000. In addition, $£ 303,000$ of the costs of administration was defrayed by the State over and above the ro per cent. received from the Unemployment Fund, and the sum of $£^{\mathrm{I} 5}, \mathrm{I} 67$ was expended in grants to associations under Section ro6. The total income of the Unemployment Scheme in IgI3-I4 was

time otherwise lost in search of work and partly through the more perfect adaptation of the workman to the job. It is not sufficiently realized that a system on similar lines of a national property (reality) exchange could fulfil similar functions for those who wish to sell or buy property. Indeed, the same underlying idea could be embodied for satisfying a number of general needs.

It will be noted that this system of exchanges offers the means of organizing the labour market by employing the two devices of measurement and publicity. It might very well be that in any attempt to convert a competitive State into a Socialist Commonwealth that machinery similar to that of employment exchanges will be very largely developed and extended.

See $A$ Socialist Commonwealth for Great Britain, by S. and B. Webb.

* In I9I 7 the Ministry of Labour was founded and took over certain departments, including the Employment Department of the Board of Trade. 
$£ 2,726,000$, and the total cost of administration in the same year was $£ 549,593$, i.e. 20 per cent. of the income. It is interesting to compare with these figures the administration expenses of six of the largest fire insurance companies for the year I9I2. They show the costs of management to average $20^{\circ} 2$ per cent., and on commissions I 5.8 per cent.

The total number of claims to benefit was much larger than was anticipated. They are particularly significant as coming in a year of good employment. For the financial year I9I3-I4 the total number of claims to benefit was $\mathrm{I}, 092,288$, being about 50 per cent. of the estimated number of workpeople holding unemployment books. Of course, not one in two actually claimed benefit. Some workmen, however, claimed three, four, and even more times in the year.

Can the costs of administration be lowered ? It is believed that under the I920 Unemployment Insurance Scheme the costs of administration will be substantially reduced for two main reasons. The I5s. a week benefit is as easily distributed as the $7 \mathrm{~s}$. per week benefit, and this change may be expected to reduce the administrative expenditure in proportion to the benefits.

The large increase in the number of trades covered by compulsory insurance will result only in a relatively small increase of the administrative expenditure. It remains to be seen, however, how large this reduction will be. Certain it is that not until the exchanges are allowed to devote themselves to their own specific problems and not used by other State departments for all manner of other tasks shall we obtain the figures for administrative expenses that are really significant. But ro per cent. of the Unemployment Fund will probably suffice to cover the whole of the administrative costs of the scheme. 


\section{CHAPTER XXI}

\section{NEXT STEPS IN UNEMPLOYMENT INSURANCE}

THE Unemployment Insurance Act of 1920 is the result of experience with and criticism of the working of the earlier Acts. Detailed discussion of the older Acts is therefore no longer necessary, whilst it is as yet too early to criticize the workings of the new scheme. But two main problems must be considered, because they foreshadow the most likely developments in unemployment insurance. It is proposed that unemployment benefits should take the form not of a fixed amount, but of a proportion of the worker's regular wage, which should be adjusted to the number of dependents. This benefit, it is suggested, shall in no case be less than half the worker's wage, whilst in the case of married men with children it should rise to a maximum of 75 per cent. of their average earnings. The second proposal is that each industry should be obliged to bear the burden of its own unemployment. The I920 Act permits trades to contract out under certain conditions, and it is urged that the Government should support the establishment of special schemes.

\section{The Meaning of Maintenance.}

One of the most frequent criticisms of the Unemployment Insurance Scheme, has centred on the small benefits which it provides. Fifteen shillings a week benefit is certainly inadequate for the maintenance of the unemployed workman, whilst if he is married and has children it is insufficient to prevent a very grave deterioration of physique and morale. 


\section{INSURANCE AGAINST UNEMPLOYMENT}

It is manifest that to the skilled workman earning an average $£ 4$ a week this benefit is likely to be not only low but subversive of his standard of living, and yet a comparatively low rate seems unavoidable if malingering on the part of low paid workers is not to be encouraged. Thus, to-day the wages of the worst paid workmen are made to control the rate of benefits of the best paid workmen. The question has therefore been raised whether the British Scheme ought not to introduce a rate of benefits graded in relation to the average wage of different groups. Skilled high paid workmen might then have one rate of benefit and low paid unskilled workers another. It would necessarily be more complicated than the existing scheme, but it would more than compensate for that by allowing benefits to have some direct relation to the normal standard of life of those who are insured.

Two methods for achieving this object have been suggested. All insured workmen might be divided into three grades according to their earnings, and a special scale of contributions and benefits calculated for each wage class.* It is evident that difficulties would arise in the case of workmen who shift from one wage group to another. The employer with workmen of different wage groups would have to keep complicated accounts. The classification of workmen into three rigid groups would make a large number of cases seem arbitrary. A man earning, say, $£ 2$ I8s. would be in one wage group, and another earning $£ 3$ might be in a different group.

The second proposal is that "the rate of benefit should be 50 per cent. of the average earnings of the insured person, with Io per cent. additional for a dependent wife and 5 per cent. for each dependent child under sixteen, provided that the total benefit should not exceed 75 per cent. of the average earnings, nor should it in any case exceed $f_{5}$ a week." Here, too, the administration is much more complicated than in the case of a flat-rate benefit, but the arbitrary character of the proposal to classify three wage groups is avoided.

- See the Massachusetts Bill, chap. xxix. 
It may be at once conceded that this proposal does not satisfy the strict theory of insurance. Differentiation on the basis of marriage and of the size of the family savours rather of schemes of relief. It should, however, be noted that on the assumption that all men will marry and have children this proposal can be justified on the principles of insurance. But few will be concerned to defend it on that ground. Its advocates would urge rather that such a rate of benefits would do as much as is administratively possible to lessen the fear of unemployment.

It is pointed out also that we have a considerably increased and improved body of statistical information to enable the risk of unemployment to be calculated. It is, therefore, wholly unjustifiable that the rate of benefit paid to-day should be, in view of the changed level of prices, about the same as, or even less than, it was when the scheme was introduced. Fifteen shillings in I92I bought the unemployed workman less grocery than did seven shillings in I9I2. In order that unemployment insurance shall have its maximum influence for good, benefits must be as high as is possible without unduly stimulating mali gering.*

\section{The Labour Party Proposal.}

The Labour Party, insistent that the present depression was far too serious to be met by drawing on the unemployment insurance fund and its probable loans from the Treasury, proposed, early in $1921,(1)$ that a person for whom no work was available at the employment exchanges, or through his or her trade union, should be entitled to maintenance; and (2) that the rate of maintenance (including benefits under the Unemployment Insurance Act) should be at least 4os. per week for each householder, and 25s. per week for each single man or woman above the age of 18 , with an additional allowances for dependents.

The payment of benefit, it urged, should be continued so long as a person remains unemployed. The additional benefit ought to be a direct charge upon the national revenue.

It will be noted that the Labour Party proposed lower benefits than did the group of employers and employed responsible for the proposal discussed of benefits in proportion to wages. But both insist that the State should admit the claim of all adult wage-earners who are willing to work and capable of working to either suitable employment or adequate maintenance throughout their working lives, and that it should satisfy that claim by legislation. They both agree also in the view that the existing unemployment insurance benefits are not in themselves 


\section{Industrial Maintenance of the Unemployed.}

Criticism of the British scheme of unemployment insurance has not been confined to suggested improvements in detail. Since the war there has been a steadily growing amount of support for the proposal that each industry should bear the burden of its own unemployment. It has received support from many employers and large bodies of employees. As will be seen later, certain employers of labour in Great Britain have already introduced schemes of unemployment insurance independent of the compulsory scheme. They are founded on the view that it is the function of the employer to provide continuous employment or maintenance. The Rowntree scheme, the Cadbury scheme, and the Bradford Dyers' scheme represent only the first results of this idea on the employers' side. The Building Guilds' scheme of industrial maintenance, the programme of a committee representing employers and workmen in the building industry, the scheme for those engaged in the insurance industry, and the proposals of the Transport Workers' Federation, to name but a few of these schemes, are indicative of the direction in which thought on this subject is now turning amongst employees as well as employers.

\section{The "Rota" System of Industrial Maintenance.}

Experience with the "Rota" system of unemployment and maintenance during the war is a precedent influencing those who are proposing the adoption of this principle. It is offered as a justification of the two contentions of its advocates, that each industry is properly liable for the maintenance of its own unemployed and that respon-

sufficient to prevent the household in receipt of them from deteriorating week by week in both physique and morale.

In September, I921, the Labour Party issued a manifesto on the Unemployment Crisis. The last paragraph read: "Our whole emphasis is placed upon the provision of work, either of a kind engaged in the production of commodities for exchange or directed to ends of social utility. If, however, employment is still not forthcoming for all workers, provision for maintenance must be made by means of unemployment insurance benefits on an adequate scale. See Appendix IV. 
sibility for the administration of schemes should be placed on union officials.

Owing to the shortage of raw cotton, the "Rota" system of unemployment was organized in the textile trades. The Cotton Control Board rationed the mills and licensed the percentage of spindles worked week by week. The spindles were, as a rule, licensed to work between 50 per cent. and 80 per cent. of their normal time. Spinners and weavers were " played off " as circumstances dictated, and an arrangement was contrived by which spinners and weavers took turns of unemployment in rotation. From dues levied upon running spindles and looms a fund of over $£ 2,000,000$ was raised and distributed amongst the unemployed. In September IgI7 the rates of unemployment pay amongst spinners and weavers were : Adult men, 25s. ; adult women, I5s. ; young people, full time, I2s.; young people, half-time, $6 \mathrm{~s}$.

In August I9I8 the pay for adults was increased from 25 s. to $30 \mathrm{~s}$., and the others raised in the same proportion.

The rotation system came to an end contrary to the wishes of the union in July I9I9.

Payments to unionists and non-unionists were made wherever possible at trade union offices.*

\section{Special Schemes.}

If it appears to the Minister of Labour that provisions for insurance against unemployment in any industry could be better secured by a special scheme for that industry than by the general scheme, the Minister may approve of a special scheme, which will then have statutory force. It is contemplated that such schemes will ordinarily be drawn up in the first instance by the Joint Industrial Council, or other Association representing a substantial majority of the employed persons in the industry concerned and of their employers, and will be approved, with or without amendment, by the Minister. The Minister also has power to set up a special scheme on his own initiative.

- See National Guilds and the State, S. G. Hobson, pp. 263-7I. 


\section{INSURANCE AGAINST UNEMPLOYMENT}

The main conditions governing the constitution of special schemes are that:

(I) The schemes must cover all persons employed in the industry either throughout the country or over some defined area.

(2) The benefits, which may include payment for short time as well as unemployment benefit must be on the whole not less favourable than those provided under the general scheme.

(3) The State contribution to a special scheme will be limited to an amount not exceeding three-tenths of the contribution that the State would have made if the members had remained under the general scheme.

(4) The scheme will be administered, not by the Ministry of Labour, but by a joint body of employers and employed in the industry specially set up. for this purpose.

(5) In the case of transfers from the General Scheme to a Special Scheme (or vice versa) or from one Special Scheme to another, the scheme from which the transfer takes place will be required to keep the member in benefit for a prescribed period.

The far-reaching possibilities of these provisions in strengthening the sense of solidarity and interest amongst all those employed in a given trade, in enabling each trade to treat its own problems of unemployment, and in increasing the technical knowledge in placing workmen, must not be allowed to hide the fact that they are aimed primarily at improving the administration of the scheme. It is, therefore, very properly provided that the Government shall contribute towards a special scheme about the same amount that would have been paid under the general provisions of the Act.

The wide powers given to the Minister have already resulted in the charge that he is placing undue difficulties in the way of proposed schemes. 
Let us note the outlines of the Printers' Industrial Maintenance Scheme, which is now being considered, as well as the proposal for the building trade.*

The Joint Industrial Council for the Printing Industry has drawn up a scheme to "contract out" of the Unemployment Insurance Act. It is proposed to retain the contributions as at present under the Act and to pay a benefit of 30 per cent. of their average wage to men. When the scheme was drawn up the State benefit was I5s. The scheme is to be worked by a Joint Board of Management, consisting of twelve representatives of employers and twelve of the workers, together with a chairman, vice-chairman, a secretary-accountant, and staff. For unemployment registration it is proposed that the country shall be divided into districts as defined by the existing alliances, the employment exchange for each district to be administered by joint secretaries representing employers and employed. The chief difficulty anticipated is that of obtaining the approval of the Ministry of Labour. $\dagger$ A doubt is expressed by the promoters of the scheme that the Ministry may take exception to the high benefits proposed for a suggested low contribution, but it is hoped that the few months' experience which the trade unions have had under the new insurance scheme will provide sufficient data to overcome the Ministry's objections ‡

As a matter of fact, a number of trade unions have been too optimistic in their calculations as to the incidence of unemployment. They have failed to make sufficient allowance for periods of depression, and the Ministry of Labour has been attacked for insisting that the unemployment percentage must be based on a calculation of the rate of unemployment over a period extending at least one complete trade cycle. In this and in most industrial schemes it is proposed that each industry shall have its own employment exchanges. But it is evident

- See Appendix I. See also Prudential Staff Gazette, March 21, r921.

$\dagger$ See Appendix I.

† Labour News Service, No. 123, March 12, I921. 
that if a large number of special schemes were instituted it would prove uneconomical and perhaps inefficient for each trade to have a separate office and separate staff in every centre where it exists.

The interim report of the Committee on Scientific Management and Reduction of Costs appointed by the Industrial Council for the Building Industry is a clear statement embodying the idea that each industry should bear the burden of its own unemployment.

We recommend that in cases of unavoidable unemployment the maintenance of its unemployed members shall be undertaken by the industry through its Employment Committees, and that the necessary revenue should be raised by means of a fixed percentage on the wages bills and paid weekly to the Employment Committee by each employer on the joint certificate of himself and a shop steward or other accredited trade union representative.

The amount of the percentage charge necessary to raise funds for the maintenance of members unavoidably unemployed will naturally depend upon the amount of the State subsidy for the purpose, and also upon the efficiency of the Employment Committees in the matter of

(a) Regularization of clemand, and

(b) Decasualization of labour;

but it is already evident from past experience that the percentage will certainly be small, and that a charge of 5 per cent. would probably be more than ample. An estimate of the revenue required for the coming year should be laid before the Industrial Council annually and the rate of percentage fixed accordingly.

While the collection of this revenue should be carried out by the Employment Committees, the payments should be made by periodical refund to the trade unions, who would thus become an important integral part of the official machinery, and would distribute the unemployment pay in accordance with the regulations prescribed by the Industrial Council and its Committees.

Every duly registered member, when prevented-for a period to be fixed-from working at the proper craft at the full standard rates of the district, should be entitled to unemployment pay, whether the cause be sickness, accident, shortage of work, or stress of weather. In all cases the amount would be inclusive of any benefit under the State and trade unions schemes.

We recommend that every registered member should be entitled to one week's summer holiday per annum, and at the same scale and from the same fund as the unemployment pay.

For purpose of this scheme "Members of the Industry" would 
be trade unionists engaged therein, including the cleiical, technical, and managerial staffs, who register with the Employment Committees for participation.

During unemployment all men should receive half their full wages, supplemented in the case of a married man by one-tenth of his full wage for his wife and each of his children up to four children, under sixteen years of age. When the industry becomes responsible in this way for unemployment pay, apart from the contributions which it already has to pay under the State unemployment schemes, then two essential conditions must be fulfilled :

(I) The workers by more concentrated effort must increase efficiency beyond the present standard; and (2) management and capital must consent to a limitation being imposed upon their earnings, and should be prepared to adopt methods on their side which will lead to greater output.

We have attempted thoroughly to explore all possible objection to the scheme which we are advocating, but the difficulties are not sufficiently serious to shake our conviction that with increasing goodwill will come higher production, and with better management increasing surplus will be available.

The unemployment scheme recommended will perform two functions at least. It will go far to secure the complete goodwill of the operative, and make unnecessary certain restrictions which exist, either tacitly or otherwise, on output; and secondly, by absorbing a certain amount of the surplus earnings of the industry, it should tend to meet the disinclination on the part of the operatives to make unrestricted profit for private employers.

It has already been recommended that during bad seasons operatives should be encouraged to accept work in other occupations rather than unemployment pay. The question of remuneration under such arrangements require further consideration, and we hope to deal with this in a later report. It is hoped that this scheme will be so satisfactory that it will be finally possible to relieve employers of their liability under the Workmen's Compensation and the Employers' Liability Acts, and to supersede all trade union sickness and unemployment benefits, and that the industry will obtain powers to contract out of the State scheme. The danger of fraudulent claims upon the Unemployment Fund has not been overlooked, but we believe that ample safeguards will be found in the utilization of the trade union organization for the payment of the money and of the existing employment exchange facilities for registration of the unemployed. Moreover, fraudulent claims cannot easily be put forward, because unemployment will only result when the scheme for the regularization of employment has failed to absorb any more labour.

The principle of joint Committees to act as trustees for such a fund does not appear to need any defence. 


\section{INSURANCE AGAINST UNEMPLOYMENT}

We frankly recognize here that we are again faced with the fundamental difficulty that there still exist in the industry large numbers of small non-federated employers, and on the other hand operatives who are not trade unionists. Nevertheless, we feel that the benefits of such a scheme will have a very material effect in inducing employers and operatives to come into their respective associations.

\section{The Scope of Special Schemes.}

The principle of continuous wages and industrial maintenance over periods of employment and unemployment, a principle which has hitherto applied to the armed forces, to the police and, indeed, to all branches of the Civil Service, is being laid down by an increasing number of trades as the basis of remuneration for all their members. The maintenance of the worker is to be a first charge upon the industry to which he belongs, so that weather conditions and financial conditions are not to be immediately flung upon him to bear the full brunt of their burden. The problem of industrial maintenance has been raised in an urgent and practical form, and its success in one trade cannot but result in its establishment in other trades.

It is contended that if each industry is obliged to bear the burden of its own unemployed, the costs are likely to be sufficiently heavy and evident for them to constitute an additional and very potent factor in influencing employers of labour to find means and to invent devices for reducing unemployment in their industry. In this way, it is argued, insurance could be made to react on the causes instead of merely relieving the symptoms of unemployment.

The idea that each industry should be made responsible for its own unemployment may be given effect to in various ways, but hitherto the form most generally advocated provides that workmen and the State shall contribute a fixed sum, and that the employer should contribute whatever is necessary in addition to pay the statutory benefit. His contribution should take the form of a percentage on his wage bill, varying with the 
amount of unemployment. It would thus be very directly to the interest of employers in a given trade to find means of reducing the amount of unemployment.

The chief difficulty with respect to the proposal is the demarcation of trades. Thus, in the case of a scheme for the cotton industry, what will be the position of the engineers and clerks attached to the trade? Will their unions approve of them participating in such a scheme? The General Workers' Union, whose very existence is threatened by the development of this idea, has therefore declared its opposition to such schemes. But as against a few unions which may suffer, the majority of the large unions, of the coal, the cotton, the woollen, and the leather trades, are enthusiastically in favour of it. They point out that a similar problem of demarcation of trades arose with respect to the first Unemployment Insurance Act and the definition of the seven insured trades. Similarly, demarcation has been achieved for the purpose of Trade Boards, by the Ministry of Labour in conference with employers and trade unions. It is suggested that those unregistered in any industry, casual workers, general labourers, and seasonal workers, could be insured in a general scheme. Employers engaging this kind of labour should pay a levy towards their insurance, consisting of a percentage on the wages paid by them. As the percentage of unemployment amongst such workers is high, the levy would be high; the employers would therefore have a strong inducement to employ as large a proportion of regularly employed labour as possible and as small a proportion of irregularly employed as possible.

The Government actuary has based his calculations on the assumption that industries with a maximum of 4 millions out of a total I21 million insured persons will be covered by special schemes. These 4 million people would have an average rate of unemployment of $4^{.5}$ per cent. or less, and would be organized. It would, he calculated, be to the advantage of these people to contract out. It is, however, arguable that he seems to have under-estimated the number of trades that would desire 


\section{INSURANCE AGAINST UNEMPLOYMENT}

to contract out in time. But he is safe in calculating on that number for a number of years. Indeed, owing to the serious state of unemployment in I92I, most of the schemes developed during the period of intense activity of the early part of I920 are being held up for a time. It is evidently unwise to initiate a scheme during a period when the claims on the unemployment fund are likely to be very heavy. Assuming, however, that trade improves, there will remain two large groups of workpeople who for a considerable period will be uncovered by special schemes. These will be engaged in trades which are badly organized or have a high percentage of unemployment, and that large body of workers who cannot be earmarked as belonging to any specified industry. The 8 million who will not contract out will, it is calculated, have an average of unemployment of $5^{\circ} 3$ per cent.*

Difficulties would arise in the decay of old trades. It is also likely that trade unions would tend to close their doors more against newcomers, and that transference from one trade to another, already rare, would become even rarer. The arguments on both sides are now being pressed with great vigour. It would, therefore, be helpful if two or three industries could be induced to contract out under the existing Unemployment Insurance Act, so as to yield some practical results which may guide future action.

On the other hand, it would be extremely unwise to compel all industries to have their own schemes of insurance, as has been suggested. In a number of trades the rate of unemployment is not known with sufficient accuracy to provide a strong enough basis for a scheme, and in consequence if attempted might fail. In a national scheme the errors in calculation with respect to different trades may be relied upon to cancel one another. Moreover, if a voluntary scheme should fail, its members could readily be absorbed back into the national scheme, but the chances of a voluntary scheme failing are small. It can be applied in the first instance to trades where

- Cmd. I I 40, p. 405. 
the rate of unemployment is known or where it is small. It can be chosen under conditions most likely to make for success.

It must be conceded, also, that joint councils of employers and employees are themselves still on their trial, and it would be folly to throw over the old machinery before the new machinery has proven reliable. Granted, however, the difficulties in the way of slowly developing schemes for separate industries, there are strong reasons for forging ahead and overcoming obstacles. First, these special schemes rightly lay emphasis on the industry as the unit to be recognized in the economic problems affecting modern society. Second, they enable the workman to gain a certain amount of control over one of the factors affecting his economic life. Third, the inadequate rate of benefit unavoidable in a scheme which does not differentiate between different trades may be replaced by a rate of benefits not much less than the normal wage of the workman.

\section{Conclusions.}

Specific proposals for dealing with unemployment were discussed in Chapter XIII. Insurance is concerned primarily with distributing the burden of unemployment, not in abolishing or reducing it.

Four main conclusions emerge from this discussion of the scheme of unemployment insurance in Great Britain. First, it is established that the costs of the scheme are more than justified by the suffering which it alleviates.

Second, there is general gratification that the workhouses are falling into disuse, and other antiquated means of caring for the unemployed and needy are practically disappearing. Third, unemployment insurance acts as an incentive to employers to eliminate every removable cause of unemployment as far as in them lies the power to do so.

Fourth, the Unemployment Insurance Fund may be regarded as a wages equalization fund. The variation in 


\section{INSURANCE AGAINST UNEMPLOYMENT}

income between periods of active employment and of unemployment is considerably lessened. It has been compared with a dividends equalization fund, which in a similar manner lessens the variations in the earning capacity of a firm, and which has proven to be a sound financial device. With an increase in the scale of benefits this aspect will grow more important. No body of any consequence is to be found in Great Britain desiring the abolition of the scheme as a whole. Indeed, whilst on the one hand it has been the greatest bulwark against revolution, its withdrawal could not be attempted without precipitating a great crisis. 


\section{CHAPTER XXII}

\section{ITALY}

Italy has introduced a scheme on the British plan, providing for the compulsory insurance against unemployment of large bodies of workers. It is administered through a co-ordinated system of employment exchanges.

\section{Before 1914.}

In Italy the steps taken to palliate the evils of unemployment through insurance before I9I4 were of little importance. Few trade unions had unemployment insurance funds. The significant developments along this line were the measure, in imitation of the French law, which enabled the Government to assist voluntary unemployment insurance, and the scheme of the Humanitarian Society.

M. Luzzati, President of the Council of Ministers, introduced a Bill in July rgro, empowering the national Government to set aside I00,000 lire for subsidizing associations which provided insurance against unemployment. Having passed the Italian Chamber, it was presented to the Senate, but M. E. Conte, of the Central Office of the Upper Assembly, reported unfavourably on this proposal.

The main provisions of M. Luzzati's scheme were:

(I) Associations desiring a subsidy must have at least fifty members, and must be confined to persons following the same or similar occupations. 


\section{INSURANCE AGAINST UNEMPLOYMENT}

(2) The insurance funds of any association desiring to claim benefit must be kept separate from other funds.

(3) Subsidy was not to be paid in respect of seasonal unemployment.

(4) Subsidy was to be paid only to unemployment insurance funds providing benefits during periods of involuntary unemployment due to lack of work.

(5) The maximum period for payment of benefits to be sixty days in the year.

(6) When a workman was only partially employed and his remuneration did not exceed one-half of his usual wage, subsidy was to be provided according to a scale to be determined.

(7) The association was to pay the amount of the State subsidy to the unemployed person and to be reimbursed by the State. This subsidy was not to exceed 50 per cent. of the benefits paid, but the rate would be higher for national federations than for local organizations. It was not, as a rule, to exceed $\mathrm{I} .25$ lire daily per member.

But the movement in favour of granting a State subsidy to unemployment insurance grew steadily. At the Italian Congress of Social Insurance, in October I9I2, a declaration was made that the care of organizing social insurance should be committed to professional associations of workmen.

"Their unemployment insurance should be, in need, subsidized by the public powers." *

Here, as elsewhere, Socialists and Labour leaders took an active part in encouraging schemes of social insurance.

In December I9I2 the Socialist Reform Party, at its first Congress in Rome, recommended the distribution of subventions to union insurance funds after the Liége system, until the results of British experience with compulsory unemployment insurance were available.

- Bulletin pour la Lutte Contre le Chomage, p. 895, vol. ii. 
No such subsidy is yet provided for unions paying out-of-work benefits.

Nor does any governmental institution as yet exist for the insurance of wage-earners against unemployment.

Hitherto, there have been interesting movements for granting relief rather than for organizing insurance, and even this relief has been limited largely to co-operative or humanitarian endeavour. By far the most important effort of this kind is that made by the Humanitarian Society, founded by a bequest of some ro,000,000 lire, left by Prospero Loria, a public-spirited citizen of Milan. This foundation aims at improving the condition of the working classes and, as we shall see, goes further in certain respects in assisting workmen than do most schemes, which, like it, are modelled on the Ghent plan.

Most of the familiar provisions of the Ghent system are met with in the Milan scheme. Subsidy was paid only to associations restricted to persons following the same or similar trades, which were wholly administered by their members. These associations must not be political or religious in character.

Subsidy was provided at the rate of 50 per cent. of the benefit paid by the associations, but must not exceed 0.47 lira per day. When the benefit paid by the association was more than 2.4 lire a day, no subsidy was given. The maximum period for which subsidies could be claimed in any one year was 60 days, but this could be received even when the unemployed person had exhausted his right to benefit from his association.

A very interesting and novel feature of the scheme was the treatment accorded to workmen during periods of trade disputes. Most schemes imposed on the administrators of the schemes strict neutrality during such periods. Together with the scheme of Liége, which granted subsidy in respect of payments made for unemployment due to a lock-out, the Milan scheme formed an exception to the general practice. Because a lock-out was due to the initiative of the employer, subsidy was paid during the period of unemployment in which it resulted. 
A Committee of Four, under the direction of the President of the Humanitarian Society, supervised the schemes : two members represent the society and two the affiliated associations. There has been a steady growth of insurance against unemployment since the scheme was inaugurated in I905. The members cover a large variety of trades, and here, as elsewhere, it was found that the printers' unions were the best organized, and sufficiently alert, to take advantage of this encouragement to an important benefit feature.

During I906, 8,9I3 workmen were insured. They received benefit for 12,242 days of unemployment. The subsidy paid by the Humanitarian Society was 5,828 lire.

During the first ten months of I9I3, I,320 workmen received benefit for a total of 4I,4II days of unemployment. The subsidy paid was $20,6 \mathrm{I} 7$ lire.

Of the total benefits distributed to unemployed workmen the society refunded to the associations about 30 per cent., an amount substantially less than was provided by most public funds.

In Bologna an attempt was made to encourage individual savings as a provision against unemployment. Though in operation since I896, the scheme has met with little success. In I9ro there were 795 people who received as subsidy part of the interest due on 300,000 lire. In I909 there were 542 unemployed persons who received a subsidy of 4,500 lire on 4,977 days of unemployment, 564 out of the 795 members being masons. The scheme has thus been of some little value to the building trade.

There are also unemployment insurance funds in Brescia, Padua and Udine.

In I9I3 the fund in Brescia distributed 224 lire, to I6 workmen of the Typographical Union, covering 448 days of unemployment. Similarly, the fund in Padua was limited to typographers.

On the whole, no substantial relief from the consequences of unemplovment was effected in I9I4, the result 
of efforts being confined to developing unemployment insurance along the Ghent lines through private or public organizations. Both at the International Congress against Unemployment, held in Milan in October I906, and at the International Congress for Social Insurance held in Rome in October I908, the drawbacks of a voluntary scheme of unemployment insurance were pointed out, and the view urged that future progress lay along the path of compulsory schemes.

\section{After-War Developments.}

The transitional period from war to peace necessitated special out-of-work provision. Decrees were passed on April 29, I9I7, November I7, I9I8, and January 5, I9I9. A sum of 98 million lire was voted for the purpose.

The conditions on which donations were granted were that claimants should be able and willing to work, but unemployed through a shortage of work. Payment was made through special unemployment offices, workers' unemployment insurance offices, communal and provincial unemployment insurance offices, communal commissions for finding work, and other organizations authorized by the Minister of Commerce. The amount of the dole varied from 2 to 3 lire a day for a man and I.50 to 2.50 lire for a woman. Additional allowance was given for dependents. It was provided also in respect of illegitimate children under certain conditions.

These doles ceased from January I, I92I, and the effect was to deprive a considerable number of the unemployed of monetary assistance. The Italian journal, Stampa, of $5^{\text {th }}$ January, stated that it would have this effect on 90 per cent. of the unemployed.*

The Royal Decree of I9th October, I9I9, provided. for the compulsory insurance of all workers, and in order to provide for the large number of unemployed deprived of assistance, a supplementary decree

* Daily Intelligence, January 25, 1921. International Labour Office, Geneva. 
was issued on January 30, I92I, which provided that unemployed persons liable to compulsory insurance, and in respect of whom the twenty-four fortnightly contributions entitling them to out-of-work assistance have not been paid, through no fault or negligence of their own, may receive out-of-work donation for a period not exceeding 45 days between February $I$ and June 30 of the present year. In order to be entitled to this donation workmen and employees must show proof that unemployment insurance contributions have been paid in respect of periods of employment after June I, I920, or, in the case of agricultural workers, after July I, I920.

\section{Compulsory Insurance against Unemployment.*}

This decree was modelled after the British scheme. It requires contributions from employers, workers and the State, and out of the resulting fund it provides cash benefits for the workers whilst they are unemployed. It is wider in its scope than the British scheme in so far as it includes agricultural workers, and narrower in so far as it expressly excludes home workers. Unlike the British scheme, rates of contributions and rates of benefits are graded in relation to the wages of the insured persons.

The persons insured include all manual workers of both sexes who are in the employ of another and are paid either a regular wage or piecework wages, as well as all non-manual workers in private undertakings whose wage monthly does not exceed 350 lire. Certain groups of workpeople are specifically exempted. These include persons below the age of fifteen years or above the age of sixty-five years, home workers and domestic servants, workers employed by State, provincial, and communal authorities on regular employment. Casual workers may be exempted from compulsory insurance, but the Minister of Labour, after consultation with the Central Executive Council, may lay down rules for the issue of

* The principle of compulsory insurance had not been adopted in Italy previously to its enactment in this measure. 
State subventions and grants to voluntary insurance funds which are formed to provide against involuntary unemployment among workers not compulsorily insured.

\section{Contributions.}

The contributions to be paid into funds for compulsory unemployment insurance are fixed provisionally as follows:-

\begin{tabular}{|c|c|c|c|}
\hline \multirow{2}{*}{ Wage Groups (by the Day or on a Daily Average). } & \multicolumn{3}{|c|}{ Contributions. } \\
\hline & $\begin{array}{c}\text { Fort- } \\
\text { nightly. }\end{array}$ & Weekly. & Daily. \\
\hline Not exceeding 4 lire $\ldots \ldots \ldots \ldots \ldots$ & $\begin{array}{l}\text { lire. } \\
0.70\end{array}$ & $\begin{array}{l}\text { lire. } \\
0.35\end{array}$ & $\begin{array}{c}\text { lire. } \\
0.06\end{array}$ \\
\hline Exceeding 4 lire, but not exceeding 8 lire & $\mathrm{I} \cdot 4^{0}$ & 0.70 & 0.12 \\
\hline$\ldots \ldots \ldots \ldots \ldots$ & 2.10 & I.05 & 0.18 \\
\hline
\end{tabular}

Half the contribution is paid by the employer and half by the worker or employee; but the employer is responsible for making the actual payment, which must be discharged at latest on the day on which wages are paid.

The proportion for which the worker is liable may be deducted from the wages to which the contribution relates. Contributions are as a rule paid by means of stamps.

\section{Benefits.}

The Unemployment Fund pays unemployment benefit at a daily rate proportionate to the contributions paid, in accordance with the following scale:-

Rate of Contributions.

II
Daily Rate of Benefits.

$$
\begin{aligned}
& \text { I.25 lire } \\
& 2.50 \text { lire }
\end{aligned}
$$$$
3 \cdot 75 \text { lire }
$$

The benefit is not in any case to exceed one-half of the worker's daily wages. 
Unemployment benefit is paid on and after the eighth day of unemployment, for a period not exceeding I20 days in each calendar year.

An employee of a private undertaking is entitled to benefit on and after the eighth day following the expiry of a period corresponding to the amount received by way of compensation for dismissal.* This is proportionate to length of service.

After an insured person has received unemployment benefit for the period specified, he may not receive further benefit until a period of not less than six months has elapsed since the last day of unemployment in respect of which he has previously received benefit.

A worker is not entitled to benefit except when his unemployment is involuntary and due to lack of work.

Seasonal workers are not entitled to benefit in respect of unemployment during the "dead" seasons, unless a special supplementary contribution, at a rate fixed in the rules of each fund, has been paid in respect of them. Schedules of industries and occupations in which seasonal unemployment occurs are issued by decree of the Minister of Labour, after consulting the Central Executive Committee.

Unemployment arising from a dispute between workers and employers does not give workers a right to benefit.

\section{The Insurance Fund.}

A national fund for involuntary unemployment was established in connection with the National Employment Exchanges and Unemployment Department.

It has three sources of income. It absorbed the sums which remained to be disposed of out of the emergency unemployment funds; it will receive a fixed proportion of the contributions for compulsory insurance against unemployment received by joint provincial funds and

- Special compensation for dismissal, proportionate to length of service, is provided for in the decree respecting contracts of employment, February 9, I919, pp. 2-4. - International Labour Office, Legislative Series for I 9 I 9, No. 3 . 
trade funds; it has obtained an annual credit, which is fixed for the first three financial years at 40 million lire. It is provided that this annual credit shall be included in the accounts of the Minister of Labour. It must not exceed one-third of the average amount of subsidies paid during the three preceding years.

\section{Trade Funds.}

Two types of trade funds are provided for under the scheme, those in which special conditions as to locality or risk induce the Minister of Labour to introduce special schemes for specific trades, and those trade funds, already in existence, desiring special recognition.

In any case in which special conditions as to locality or risk, or other circumstances, make such an arrangement necessary or convenient, the Minister of Labour, after consulting the Central Executive Council for employment exchanges and unemployment, may issue a decree providing for the compulsory insurance of particular groups in one or more provinces, in special compulsory trade funds which are to be administered by representatives of the groups concerned and of the State.*

The Minister is obliged to issue, by decree, model rules for such compulsory insurance funds.

The organization of special trade sections of provincial joint funds may be authorized in the same manner in any case in which important groups of workers of a particular trade exist within a province. These are to be administered by the provincial council for employment exchanges and unemployment.

Trade funds established by workers' organizations, or under agreements between employers and workers, may be authorized to undertake insurance against unemployment.

A trade fund for which such authority is desired must forward an application to the National Department,

- Cf. with the special schemes in the British Act. See Chapter XXI and Appendix I. 
accompanied by the rules, by a prospectus showing the number of workers registered with the fund classified by occupations, and the accounts for the preceding years, if the fund has previously been in operation. The rules must conform to the provisions of this Royal Decree, and must provide that both the State and employer, who are required to contribute to the unemployment fund, shall have the same number of representatives as the insured persons on the administrative council of the trade fund. The authorization is granted by a decree of the Minister of Labour after consulting the Central Executive Council for employment exchanges and unemployment, and the Permanent Committee of the Provident and Social Insurance Council.

A trade fund desiring authorization to maintain its independent existence must admit to registration unorganized workers who apply, provided that they belong to the occupational classes with which the fund deals.

\section{Administration.}

The Central Commission and Executive Council constituted to administer the employment exchanges exercise the power also of managing the unemployment insurance service. They exercise this power through provincial councils and local superintending commissaries. It is provided that these provincial councils shall consist of about twelve members, three of whom are appointed by the employers and three by employees. The duties of the provincial council are the following :-

(I) To supervise the administration of local employment exchanges and local commissions for organizing employment.

(2) To act as a clearing house for employment for all workers in the province through an executive office.

(3) To administer the joint unemployment fund for the province and its trade sections, and to control 
and supervise the payment of benefits both by this fund and by the trade funds within the province.

(4) To grant to recognized organizations the requisite authority for the payment of unemployment benefits.

(5) To make proposals and give opinions as to the granting of advances for the execution of public works, and superintend the use and repayment of the sums advanced.

(6) To make proposals and give opinions as to the advancing of capital to co-operative groups and superintend the use and repayment of the sums thus advanced.

(7) To discharge all other tasks and duties specified in the provisions in force or assigned to it by the Minister of Labour (Department of Employment Exchanges and Unemployment) and make proposals to the said Minister which it considers likely to prevent unemployment in the province. 


\section{CHAPTER XXIII}

\section{AUSTRIA}

THE problem of demobilization forced on the authorities the necessity of establishing a co-ordinated and expanded system of employment exchanges. It was decided to provide (I) employment exchanges under the control of employers and workers; (2) transport of workers to fresh employment; (3) supply of food to places where new work was started.

The law for the relief of unemployment which came into force on November I8, I9I8, as well as the law of March 24, I920, establishing a compulsory system of insurance against unemployment, contain special arrangements for providing doles for the period of the economic disturbance due to the war.

Every worker, whether of Austrian nationality or an alien, who comes within the scope of the sickness or old age insurance schemes, was entitled to unemployment pay equal to the sickness benefit up to a period of three months.

\section{The Compulsory Scheme of Unemployment Insurance.}

The compulsory system of unemployment insurance came into operation on May 9, I920. It includes all persons included under the existing systems of sickness and old age insurance. Workers in the following groups of industries are included: Mining, shipyards, quarries, factory and smelting industries, industries using or manufacturing explosives, the building trades, railway, transport, and inland navigation. For those engaged in home 
trades, and in agriculture and forestry, insurance is optional, it being dependent on the joint will of employers and employees. The benefits take the form of a percentage (8o per cent. if he is responsible for the maintenance of a family, and 60 per cent. if he is single) of the sickness benefit to which the unemployed person would be entitled if he were sick.

A worker or employee of Austrian nationality is entitled to unemployment benefit in accordance with the provisions of this Act if

(I) During the last twelve months before his claim becomes effective he has been employed for not less than twenty weeks in all, under a contract of work which renders him liable to compulsory sickness insurance or to pension insurance, or when he is a miner if he is a member of a mutual benefit society; and

(2) He is capable of work, but can find no suitable employment.

This Act is made to apply to aliens from July I, I92I.

\section{Conditions of Benefit.}

The right to unemployment benefit commences on the eighth day after the beginning of unemployment.

An unemployed person is not entitled to unemployment benefit so long as he is in receipt of any statutory sickness insurance benefit.

Unemployment benefit is not to be paid for more than twelve weeks within twelve consecutive months. If, however, he is in receipt of any other payment from public funds, the amount of the benefit is to be reduced by onehalf the amount of the payment, and if he has received compensation * for the dissolution of the contract of work, he is not entitled to benefit until the expiry of a period corresponding to the amount of compensation fixed by agreement.

A person who is unemployed in consequence of a

- By an Administrative Instruction, issued on September 15, I919, and amended on March 20, I920, special compensation for dissolution of contract is fixed in accordance with length of service 
stoppage of work due to a strike or lock-out is not entitled to benefit during the stoppage.

If an unemployed person has been dismissed from his last employment on account of his own misconduct, or if he has voluntarily left his last employment without just cause, he is not entitled to unemployment benefit until the expiry of a period of four weeks reckoned from the date when he was dismissed or left his employment.

If an unemployed person refuses suitable employment notified to him by the unemployment office, he loses his right to benefit for a period of eight weeks. If he refuses to undergo a medical examination to verify his capability of work, he loses his right to benefit for so long as he persists in such refusal.

An unemployed person is bound to accept any suitable employment notified to him by the unemployment office. Any employment is considered suitable which is appropriate to the physical capacity of the unemployed person, does not endanger his health or morals, is properly paid, and does not materially hinder his future return to his own occupation.

$\mathrm{He}$ is bound to accept suitable employment notified to him elsewhere than in his former district of employment or residence provided that it is possible for him to procure proper accommodation and food in the proposed place of employment, and that the welfare of the members of the family for whose maintenance he is responsible is not endangered by the acceptance of this employment.

If it appears that an unemployed person cannot be found suitable employment because he lacks sufficient knowledge and skill for work in his own or another similar trade, the unemployment office may, with the consent of the District Industrial Commission, send him to a trade school, or some other suitable institution for continued education, and pay him unemployment benefit whilst he is training, for not more than twelve weeks.

Unemployed persons notified of suitable employment in works affected by a strike or lock-out may refuse it. 


\section{INSURANCE AGAINST UNEMPLOYMENT 361}

\section{The Unemployment Fund.}

The State advances the sum necessary for the payment of the first year's benefits. But at the end of the administrative year the total costs for benefits and administration are to be borne equally by the State, the employers, and the workers. Provision is made for the collection of not less than 40 million kronen during the first financial year.

The repayable amount is to be raised during the following administrative year by means of contributions. These are calculated as a percentage of the average daily earnings.

\section{Measures for Protecting the Fund.}

The percentage amount of the contributions may be correspondingly increased by administrative instructions for any group of workers which regularly makes claims for unemployment benefit in excess of the general average, and correspondingly reduced for branches of industry in which unemployment is below the average.

After several years' experience of unemployment benefit, the amount of contributions may be fixed for a series of years on the basis of the experience of the previous financial years.

Contributions for unemployment benefit are collected at the same time as contributions for sickness insurance and miners' mutual benefit dues. Employers are entitled to deduct one-half of the amount of contributions from the wages or salary of the employee.

The District Industrial Commission may be empowered to specify industrial groups in its area or workers in special districts, the members of which are not to be granted benefit on account of the favourable condition of the labour market.

Administrative instructions may be issued raising the amount of benefit to the full amount of sickness benefit in the case of workers or employees who are responsible 
for the maintenance of a family, and to 75 per cent. of the daily sickness benefit in other cases, for the duration of the period of economic disturbance due to the war and its after effects.

In like manner an unemployed person may, under administrative instructions, be excluded from benefit if his means of subsistence are not endangered by unemployment.

If an employer, in order to prevent considerable unemployment, refrains from terminating contracts of work though entitled to do so during a period of complete or partial closing down due to lack of raw material or apparatus, he may be guaranteed repayment of part of the charges imposed on him under these contracts of work. The amount repaid must not exceed the total amount of the statutory unemployment benefit which would have been due to the workers affected. In a similar manner the Unemployment Fund may be used to encourage institutions aiming at the reduction of the amount of unemployment. Special mention is made of the education and training of the unemployed.

\section{Making of Claims-Procedure.}

In order to make an effective claim, an unemployed person must report himself at the employment office for his residential district and must notify his right to benefit.

Every employer who terminates a contract of work which involves liability to compulsory sickness or pension insurance is bound to furnish a statement on the request of the worker or employee concerned, in the form prescribed by administrative instructions, regarding the period and nature of the contract of work, the amount of remuneration, and the cause of the termination of the contract.

If an employment office is unable to provide a person entitled to benefit with any suitable employment, it fixes the amount of unemployment benefit due to 
him, and issues him a certificate for the payment of the benefit.

If the unemployed person was last employed in a place outside the area of the employment office, this office may refuse to admit him to benefit if the condition of the labour market is such that suitable employment cannot be provided for him within a definite period. $\mathrm{He}$ may then claim benefit in the district in which he was last employed.

An unemployed person must report in person at least twice a week at the employment office as a candidate for employment, and must present his certificate in order to establish his right to payment of benefit. If he fails to report himself as directed without sufficient reason, he is suspended from benefit for a fortnight.

If an unemployed person considers himself aggrieved by a decision of the employment office, and in particular by a refusal or withdrawal of benefit, or the determination of its amount, or any other order of the office, he may within eight days after the notification of the decision or order lay a complaint before the Arbitration Commission connected with the office. This Commission consists of an equal number of representatives of employers and of workmen.

Within eight days of the notification of the resolution of the Arbitration Commission, the unemployed person or the manager of the employment office may appeal against it to the District Industrial Commission, whose decision is, as a rule, final.

If the District Industrial Commission regards a decision or order of an employment office or a resolution of an Arbitration Commission as not being in accordance with the law, it may, on its own official initiative, cancel or vary the decision at any time.

An objection may be lodged with the State Department for Social Welfare against such action within fourteen days after its notification, by either the unemployed person, the manager of the employment office, or the chairman of the arbitration commission. 


\section{Authorities.}

District Industrial Commissions consisting of an equal number of employers and employees have been established for the purpose of controlling institutions dealing with unemployment benefit, and the State Department for Social Welfare determines their areas and seats, after consultation with the Provincial Governments. Their main function is the supervision of the work of the public employment offices. Payment of benefits is made through offices designated by the Department of Social Welfare and approved of by the Finance Department. These industrial commissions appoint arbitration committees, consisting also of an equal number of employers and employees.

The Secretary of State for Social Welfare appoints members of the District Industrial Commission, or other suitable persons, to act as chairman and deputy chairman of the District Industrial Commission. If the chairman is an employer, then the deputy-chairman must not belong to the same class, and vice versa.

Representatives designated by the Provincial Government and Finance Department, and also the industrial inspector and the district mining official, are invited to attend meetings in an advisory capacity. The representatives of the Provincial Government and of the finance department are entitled to lodge an objection against any resolution of the District Industrial Commission, which must then suspend operation on the matter until the State Department for Social Welfare has decided upon it.

\section{Note on Russia.}

The veil has not yet been lifted from Russia, but sufficient is known to make it certain that unemployment is a problem that would be one of the first to obtain the attention of a Socialist republic.

Soon after the Soviet Government took over the 
administration, a law was passed as to insurance against unemployment. All workers, including agricultural workers, were included. The law came into operation on March I, I9I8. Every employer pays a contribution of 4 per cent. of his total wages bill, or 5 per cent. for seasonal workers. The worker pays nothing. When unemployed, the latter receives from the fourth day an amount representing the average usual wage paid in that occupation, but such amount is not to exceed fourfifths of the wages actually received by him previously to becoming unemployed.

It has not been possible as yet to ascertain how this law is working.*

- See League of Nations' Report on Unemployment, p. 132. 


\section{ESTABLISHMENT UNEMPLOYMENT INSURANCE FUNDS}

LEADING employers appreciate the advantage of keeping a fixed staff regularly employed. They recognize that it is profitable to adopt a policy which will attract the most able and the most ambitious men, and receive from them the greatest output of their productive years. A man does his best work, it is realized, when he can be relied upon to remain at his work and not be tempted to go to some other employer; when he has the necessary skill and strength; when he fits into the organization of the works and knows the methods employed in it; when his goodwill helps the smooth running of the establishment. It is, however, evident that unemployment militates against the development of these qualifications. It leads to frequent changes of employers; it hinders the worker's skill and often results in a reduction of his strength; above all, nothing can make a workman so discontented as a long spell of unemployment, whilst the thought of its possibility is to him so terrifying that it is a continuous irritant, retarding the spirit of mutual trust and confidence at which modern employers are aiming.

Knowledge of these facts has led a number of employers in all parts of the world to endeavour to organize their factories in such a way as to reduce unemployment to a minimum. Nowadays the average well-run factory dismisses part of its staff during the slack season. Assume, however, that the policy of keeping a fixed staff regularly employed is desired. Devices for giving it effect must be perfected. Perhaps the management 
will arrange to work for stock during the slack season. Attention might be devoted to finding markets in different parts of the world, so that when the demands of one market are at a minimum the demands of another are highest. A factory might be able to develop some special line which will give employment during the normal slack season.

These devices are not uncommon amongst the scientifically managed factories of the United States and Great Britain. Reduction of unemployment naturally shows itself in them in a reduction of the labour turnover. Employers really anxious to face and grapple with this problem have the inspiring work and success of others to encourage them. The figures of three establishments are quoted.

LABOUR TURNOVER, I9IO-I4, OF THE CLOTHCRAFT SHOPS OF JOSEPH FEISS, CLEVELAND.

\begin{tabular}{c|c|c|c}
\hline Year. & Stand Pay-roll. & New Hands. & $\begin{array}{c}\text { Per Cent. Labour } \\
\text { Turnover. }\end{array}$ \\
\cline { 2 - 3 } I910 & 1,044 & I,570 & I 50.3 \\
I91 I & 951 & 807 & $84 \cdot 8$ \\
1912 & 887 & 663 & $74 \cdot 7$ \\
1913 & 854 & 569 & $66 \cdot 6$ \\
1914 & 865 & 290 & $33 \cdot 5$ \\
\hline
\end{tabular}

Mr. Feiss writes that in I9r4, with 865 on the payroll, the total number of quitters was 432 . Of " unavoidable" quitters, which included discharges, death, sickness, accident, marriage, retirement, etc., there were 298 , and of avoidable quitters there were I34.

The Ford Company has achieved some remarkable results along the same lines.

\begin{tabular}{c|c|c|c}
\hline & Discharged. & Quitting. & Five-day Men. \\
\cline { 1 - 3 } In March I9I3 & I,276 & 860 & $5, \mathrm{I}_{56}$ \\
In March I9I4 & I66. & I I5 & I66 \\
\hline
\end{tabular}


TURNOVER OF LABOUR FORCE IN THE PLIMPTON PRESS.

\begin{tabular}{c|c|c|c|c|c}
\hline & $\begin{array}{c}\text { Number on } \\
\text { Pay-roll. }\end{array}$ & Number Hired. & Discharged. & Quitting. & $\begin{array}{c}\text { Per Cent. } \\
\text { Labour Turn- } \\
\text { over. }\end{array}$ \\
\hline I912 & 701 & 96 & I 5I & 63 & 214 \\
1913 & 562 & 140 & 81 & 56 & 137 \\
I914 & 533 & 99 & 47 & 80 & 127 \\
1915 & 496 & 51 & 27 & 16 & 43 \\
\hline
\end{tabular}

The employment manager wrote in I9I6:

Conditions in this plant have not been normal during the last nine months, and our labour turnover has been only 8 per cent. I feel, however, that under ordinary conditions it will probably average somewhere from 20 to 25 per cent. per year.

Unfortunately, the interests of employers in lessening the irregularity of employment in their establishments has hitherto been largely overlooked. This is mainly due to the fact that it does seem as if there are distinct tactical advantages in having a large number of unemployed in industry. Employers might expand or contract their demand for labour without any loss to themselves; it enables them to keep wages low and in general aids them to make better terms when bargaining with them collectively or individually.

These advantages are frequently illusory. In many trades it is more profitable to have a stable, fully employed staff of workmen. The cost of hiring and breaking in an employee is in many cases as high as $£$ Io or £20. Besides, employers cannot be certain that they will get workmen when they need them. It is therefore as much to their own advantage as to that of their workmen to establish some scheme which will help them to have a stable personnel.*

Enlightened self-interest which appreciates what might be gained by abolishing this source of waste to the I916.

- See Hiring and Firing, p. 8, by Magnus W. Alexander, Nẹ York, 
factory and to the nation might be supported by the growing desire to solve problems and to attain to industrial leadership, as well as by the impulse of economic chivalry which characterizes a very few of the leading employers of America and to a lesser extent of Great Britain.*

Some of these organize their factories in such a way as to enable their employees to take their holidays during the slack period. Others again give their workers an unemployment bonus, but it is given at the pleasure of the employer, and the workers cannot claim it as a right. This is so unsatisfactory that the beginnings have been made in applying the device of unemployment insurance to individual factories.

There is already a body of experience in the successful working of private insurance funds in Europe, the latest scheme introduced in I92I being a project for insuring two thousand employees at the cocoa works of Messrs. Rowntree in York. There are also other plans in France, Germany and Austria, whilst it is being contemplated in the United States by a number of managers who see in unemployment a challenge to their claim that they manage their businesses scientifically.

\section{United States Establishment Funds.}

The outline of schemes undertaken in the United States proves that this proposal is still in its infancy in that country. One of the largest hat manufacturing establishments in New York City has arranged with the employees' works council to make a 2 per cent. levy on the wages of each employee for a period of ten weeks. The funds so collected are to be loaned to employees who are laid off by reason of the depression.

A large textile establishment in New York State has

- It is regrettable that no method has yet been devised for gaining public recognition for those employers who run their factories efficiently and with a sense of social responsibility and for expressing public disapproval of those who are guilty in the conduct of their business of inefficiency, and who have an unduly high accident list or large labour turnover, who work their employees unduly long hours or pay them low wages. 
instituted an unemployment fund which is built up by a levy of $\mathrm{I}_{5}$ per cent. upon the net profits of the company for the year. An employee laid off because of slack work is to receive half-time pay as long as the fund lasts. Only those who are considered "loyal and permanent" employees are entitled to benefits under this plan.

A large paper manufacturing concern in Massachusetts has set up an unemployment insurance system which is to take care of employees who have been with the company for more than five years. The agreement between the company and the employees provides that when work is sufficient to enable the employee to earn the normal wage he will be paid at the regular wage rate. If by reason of slack work his earnings should fall below the regular normal earnings, he is to receive a salary to be determined in each particular case.

Another company has established an unemployment insurance arrangement under which during the past year approximately $\$ 40,000$ have been distributed. The unemployment funds are built up by setting aside I $_{5}$ per cent. of net earnings.

The growth of this idea amongst employees is clearly reflected by Mr. Sidney Hillman, President of the Amalgamated Clothing Workers of America, who laid before the Board of Arbitrators, the highest tribunal in the industry, a demand for unemployment insurance on the plea that unemployment should be charged against the industry in the same way as wages, as overhead and other charges.

\section{German Establishment Funds.}

Most schemes of unemployment insurance created by employers for their own establishments are to be found in Germany. This type of paternalism was most characteristic of that country before the war.* More than thirty firms have made arrangements of this kind

- On the other hand, it is a truism to say that paternalism of one kind or another is now characteristic of all industrialized countries. 
to provide benefits for workmen whenever their establishments shut down or employees are dropped from the pay-roll because of lack of work. These firms are engaged in productive and in distributive trades, and their methods of organization are characterized by the greatest variety. It is indeed to be expected that elasticity and adaptability will be found to be the sine qua non of any type of scheme which is to be successfully applied to different trades operating under different conditions.

The scheme operated by Karl Zeiss, of Jena, is very liberal ; if any employee is employed regularly for three years and is then dismissed for lack of work, he is given, by the terms of the contract, a legal claim to full wages for the succeeding six months. Here the employer provides the benefits without the employee contributing directly towards it.

The amounts paid out to dismissed workers were as follows :-

\begin{tabular}{|c|c|c|c|c|}
\hline $1902-3$ & 28,675 & $\mathrm{rk}$ & abo & 1 \\
\hline $1903-4$ & 6,700 & " & " & \\
\hline $1904-5$ & 4,000 & ", & $"$ & \\
\hline $1905-6$ & 13,700 & $"$ & " & \\
\hline I906-7 & I 3,900 & $"$ & " & \\
\hline I 907-8 & 2,150 & " & " & \\
\hline $1908-9$ & 6,000 & ", & ", & \\
\hline
\end{tabular}

The Association of Metal Manufacturers of Berlin has a list of unorganized workers who are given assistance in case of unemployment. Nothing definite is known about the actual working of this scheme. The report of the association for I908 states that bad business resulted in a discharge of some workers and many claims were made for unemployment assistance.

Similarly, the firm of Heinrich Lanz at Lindenhof, near Mannheim, machinery manufacturers, has provided unemployment insurance for its workmen, but benefits are paid, as in the city of Cologne's insurance fund, only between December Ist and the end of February. The scheme provides that whenever a married person employed by the firm for at least one 
year is dismissed because of lack of work and is unable to find other employment, he receive benefits beginning fourteen days after the date of dismissal.

On the other hand, the firm of A. L. Mohr, of Altona, Behrenfeld, oleo-margarine manufacturers, has a scheme to which employees and employers both contribute, the former contributing 60 per cent. of the resources of the fund. It is collected in the form of weekly dues, Io pfennigs (Id.) for men and 5 pfennigs ( $\frac{1}{2} \mathrm{~d}$.) for women. The benefits are I.60 marks (Is. 4d.) per day for not more than thirteen weeks after the date of dismissal.

The arrangement in the leather works of Cornelius Heyl is as follows. When, on account of slack business, a part of the staff must be temporarily suspended,

3.50 marks per week are paid to married men ;

3.0o marks per week are paid to single men over 23 years of age.

2.50 marks per week are paid to single men 18-23 years of age.

I.50 marks per week are paid to women over 18 years of age.

r.oo mark per week is paid to women under 18 years of age.

The following information is furnished by the firm with regard to sums previously paid out:-

SUMS DISBURSED DURING PERIODS OF UNEMPLOYMENT BY THE FIRM OF CORNELIUS HEYL, I89I-I909.

\begin{tabular}{|c|c|c|c|c|c|}
\hline Years. & Marks. & $E$. & Years. & Marks. & f. \\
\hline I 89 I-2 & I 6,016 & 696 & I900-I & $7,53^{\circ}$ & 343 \\
\hline $1892-3$ & $24 I$ & I I & $1901-2$ & 5,893 & 268 \\
\hline I $893-4$ & 2,560 & I I I & $1902-3$ & I,758 & 80 \\
\hline I $894-5$ & 2,690 & 117 & $1903-4$ & 7,212 & 328 \\
\hline $1895-6$ & II, 220 & 488 & $1904-5$ & 5,736 & 260 \\
\hline I $896-7$ & 5,428 & 236 & $1905-6$ & I I, 955 & 543 \\
\hline I $897-8$ & 2,184 & 95 & $1906-7$ & 12,310 & 560 \\
\hline I 898-9 & 2,949 & 128 & $1907-8$ & I 8,698 & 868 \\
\hline I 899-I 900 & $48 I$ & $2 I$ & I908-9 & 2,680 & 122 \\
\hline
\end{tabular}

At the firm of Karl Freudenberg, in Weinheim, a workman's insurance fund * has been formed. An employee becomes a member only if he desires to do so.

- Insurance in case of illness, death or unemployment: we speak here of the last only. 
Membership is open to those officials and workers who were with the firm on January I, I906; from those who enter the firm's service later, two years of employment is required. Dismissal for disciplinary reasons or voluntary resignation results in the loss of membership, but absence on leave, illness or interruption of work on account of wreckage of machinery does not entail loss of membership.

As compensation in case of total or even partial unemployment, one-half of the average daily wages for the last quarter of a year are paid to the unemployed for each working day lost, counting a day of ten hours. If a worker is occasionally suspended from work for less than six hours a week, he is not compensated, but if such suspensions occur several weeks in succession, the worker is compensated for each ten hours lost. This benefit is paid only for a maximum period of twenty-four full working days during one calendar year.

No benefit is paid if work is stopped on account of war, "revolt, or other higher forces," or, of course, on account of strike or lock-out.

Members elsewhere insured against unemployment have no claims to benefit here. They are expected to notify their membership in other funds. The benefits are paid by the firm; no dues are paid by the workers, who are the members of the fund. The firm considers the fund as a necessity. According to the statement of officials, it has helped in the preservation of friendly relations between employer and employee. This scheme was clearly meant to aim a blow at trade unionism.

The following benefits have been distributed: In I907, I,758 m. (£76); in $1908,7,921 \mathrm{~m} .(£ 344)$; in I909, 7,II9 m. (£309).

A number of firms have organized saving and mutual assistance funds, one of the most interesting of which is that operated by the Ringhoffer machine and wagon factory at Schmechow, near Prague, in Austria.

This scheme combines the methods of insurance and 


\section{INSURANCE AGAINST UNEMPLOYMENT}

of saving in such manner that if after a period of unemployment a workman returns to the Ringhoffer factory, then only one-third of the sum which he has received in weekly instalments must be repaid, but if he does not return then the employer may reclaim the sum distributed to him as an ordinary loan.

This fund was founded in I886 with a capital of Io,000 florins, from which loans are made without interest to workmen tentatively dismissed through lack of work. When these workmen do not find any other employment and do not present an express demand to be definitely dismissed, they are regarded as unemployed for a maximum period of three months. Benefits are distributed during that period, according to seniority of service, to those who bear a satisfactory record. Two-thirds of the amount distributed is at the expense of the fund, the other third must be reimbursed by the borrowers. The loans granted during the first four years amounted to $343,5 \mathrm{I} 7$ francs $(£ \mathrm{I} 4,935)$.

A paternalistic scheme of savings against unemployment is carried on also in the establishment of Tellman \& Co., at Barmen. Here the workers, on their entry into the house, are forced to accept the fund. Those who already constituted the personnel when the scheme was introduced voluntarily adhered to it until the end of the first year of its operation, when it became obligatory on all.

The lowest deposits are 25 pfennigs a week. They are withheld from the workmen's wages. The interest on these weekly deposits rises until at the end of the first year they are 6 per cent., and the rate of interest after that is fixed as follows :-

Up to 2,000 marks, 5 per cent.; from 2,000 to 4,000 marks, $4 \frac{1}{2}$ per cent.; above 4,000 marks, 4 per cent.

The withdrawal of deposits during unemployment is permitted only to the amount of 9 marks (8s.) at a time, and only with the authority of the house. On the first of July, I9oo, the II 3 depositors owned a fund of $8 \mathrm{I}, \mathrm{I} 64$ marks $(f, 3,529)$. 


\section{French Establishment Funds.}

There are only three schemes of establishment insurance in France. One is at the Havre docks, the other is at the establishment of M. Cottereau, mechanical engineer, at Dijon, and the third at the printing establishment of Herissey, at Evreux.

The atmosphere of France has not been very favourable to the development of such schemes.

It is very probable (wrote M. Fagnot) that if employers endeavoured to make this institution universal, as has been done in the case of mutual societies, they would meet with the opposition of the workers. (He adds): Without contesting their philanthropic character, they have nevertheless the advantage of keeping the individual on the spot in the case of an establishment far from any industrial centre until the day when he can be reabsorbed into the industry.

\section{British Establishment Funds.}

A number of British firms are contemplating the introduction of establishment unemployment funds, and by far the best thought-out scheme has already been introduced by Messrs. Rowntree \& Co., Ltd., cocoa manufacturers, York. It may well be regarded as the model scheme on which new schemes can be based. It avoids most of the dangers of this type of welfare device by making it evident that it is not meant to weaken trade unions. On the contrary, it would strengthen them. Nor would it prevent workmen from leaving the establishment. Necessary arrangements are, of course, introduced for making the fund solvent.

Two points in the scheme, which is self-explanatory, should be noted. The Company has set aside $£$ Io,000 to found the unemployment fund. It will also set aside sums equal to I per cent. of its wages bill until the fund reaches $£ 50,000$. The employees pay no contributions. In a well-organized factory the costs of a scheme of unemployment insurance, more generous than those of the Government, is expected to be only about I per cent. of the wages bill. 


\section{INSURANCE AGAINST UNEMPLOYMENT}

Most members employed in the works obtain benefits under the Government scheme. When it was inaugurated the men obtained benefit at the rate of ${ }_{5} 5$ s. a week and the women I2s. a week. In addition the trade union with the greatest membership in the works provided 6s. a week extra benefit for men and women for a contribution of $2 \mathrm{~d}$. a week. The 2Is: or I8s., as the case may be, is therefore deducted from the scale of benefits laid down, which varies from 50 per cent. to 75 per cent. of the employee's average wage.

\section{The Rowntree Scheme.}

The object of the unemployment insurance scheme of Messrs. Rowntree \& Co. is stated to be the removal as completely as possible from the minds of the Company's workers of any anxiety which they may feel through the possibility of unemployment because of the trade depression.

The scheme came into force on January I, I92I, and applied to all persons (male and female) between the ages of twenty and sixty-five employed by the Company on whole time service within the United Kingdom, who, immediately prior to their unemployment, had been in the employ of the Company for a continuous period of six months, or in the case of the building staff for a period of three years either continuously or broken by periods amounting in the aggregate to not more than two months.

\section{Unemployment Fund.}

The Company set aside on the institution of the scheme a lump sum of $f_{10,000}$ to found the unemployment fund. It also in each year, commencing with the year I92I, set aside sums equal to I per cent. of its wages bill during such year, until the unemployment fund reaches $£ 50,000$, or reaches 5 per cent. of the wages bill for the time being (whichever is the greater). 
Thereafter the Company will set aside annually such sums (not exceeding I per cent. of the wages bill) as are necessary to keep the fund up to $£ 50,000$.

\section{Full Unemployment Benefit.}

Subject to the following conditions, full unemployment benefit will be at the rate of :

(a) 50 per cent. of the average earnings of the unemployed person; and

(b) Io per cent. additional for a dependent wife ; and

(c) 5 per cent. additional for each dependent child who is under sixteen years of age or is receiving fulltime instruction at a school, university, college or other educational establishment, with a maximum of 75 per cent. of the average earnings or $£ 5$ a week, whichever is the smaller, and a minimum of $f_{\mathrm{I}} 5 \mathrm{~s}$. a week.

The full unemployment benefit will be reduced by a sum, in the case of men, of 2Is. a week, and in the case of women of I8s. a week, these amounts being considered to represent the sum to which in most cases trade unionists enjoying the State benefit would be entitled. The amount deducted under this head may be made to vary with the benefits provided by the State scheme.

The conditions for receipt of full unemployment benefit are :

(I) That the unemployed person has made application for benefit in the prescribed manner and proves that since the date of the application he has been continuously unemployed, and

(2) That he is capable of, and available for, work, but unable to obtain suitable employment provided that a person shall not be deemed to have failed to fulfil these conditions by reason only that he has declined :

(a) An offer of employment in a situation vacant in consequence of a stoppage of work due to a trade dispute ; or

(b) An offer of employment at a rate of wage lower, 
or on conditions less favourable, than those generally obtained or observed in the district of such employment by agreement between associations of employers and of employees in employments of the same nature as that of his usual employment, or, failing any such agreement, than those generally recognized in that district by good employers.

A person will not be deemed to be fully unemployed on any day on which he is following any occupation from which he derives remuneration or profit, unless that occupation has ordinarily been followed by him in addition to his employment by the Company and outside the ordinary working hours of that employment.

Full unemployment benefit will not be payable in respect of any period of less than one week, nor for longer than a period or periods amounting in the aggregate in the case of each employed person to:

(I) One week for each two months up to two and a half years for which such person has been continuously employed by the Company immediately before his unemployment and after attaining twenty years of age, and

(2) One week for each complete year, beyond two and a half years, for which such person has been so employed; but

(a) Full unemployment benefit will only be payable during such time as the unemployed person is actually receiving unemployment benefit under the Unemployment Insurance Act, or would have been actually receiving such benefit if the maximum period of benefit under that Act had not expired. This paragraph will not apply, however, to any person included in the " excepted employments" mentioned in Part II of the First Schedule to the Unemployment Insurance Act, Ig20.*

(b) Any time during which a person is under this

- These include such occupations as agriculture, domestic service, and employment by the local and central governments and in public utility corporations of a nature where insurance against unemployment is regarded as unnecessary. 
scheme disqualified for receiving full unemployment benefit shall be excluded in the computation of periods of unemployment, and

(c) A period of full unemployment shall not be deemed to commence until the unemployed person has made application for unemployment benefit in the prescribed manner, and

(d) Any person who, after leaving the employment of the Company, obtains other employment, shall not be entitled to any unemployment benefit after the expiration of a period from so leaving the employment of the Company calculated in accordance with paragraphs (I) and (2) of this clause.

(e) In the case of a person who, during the European War, joined His Majesty's Forces from the employment of the Company, and returned direct from such Forces to such employment, service in such Forces shall be included in calculating his period of employment.

\section{Partial Unemployment Benefit.}

Partial unemployment benefit will be payable in respect of any period during which, owing to shortage of work through depression of trade, a piece worker actually works for less than 85 per cent. of normal full time or any other worker actually works and is paid for less than 90 per cent. of normal full time calculated in each case over such period as may be prescribed by the Company. Time so lost in excess of ro per cent. or I5 per cent. respectively will be paid for at a rate proportionate to full unemployment benefit.

Partial unemployment benefit will not be payable in respect of any part of a week in which the employed person has, without leave, failed to work for the full time for which work was provided for him.

\section{Existing Unemployment Benefit Fund.}

Employees who, as being only on the auxiliary staff, are members of the existing Unemployment Benefit 
Fund,* will have the option of continuing that benefit and being excluded from this scheme. If, however they decide to take advantage of this scheme, the existing Unemployment Benefit Fund (which will henceforth be called "The Auxiliary Retirement Fund" will in their case apply only to retirement on reaching sixty-five.

\section{Disqualifications for Benefit.}

A person is disqualified for the receipt of unemployment benefit :-

(I) If he has lost his employment through his misconduct or misbehaviour, or has voluntarily left the employment of the Company or any other employment which he has obtained after leaving the employment of the Company.

(2) If he fails to prove to the satisfaction of the Unemployment Committee that he has for a period of six months immediately prior to the commencement of his full or partial unemployment, or for the whole period between the expiration of one calendar month from the commencement of the scheme and the commencement of his full or partial unemployment (whichever is the shorter), contributed to a trade union or other society a sum or premium of not less than $2 \mathrm{~d}$. per week for the purpose of assuring a weekly or other periodical payment during his unemployment, or such other sum or premium as shall be sufficient to assure a weekly or other periodical payment equivalent to $6 \mathrm{~s}$. per week.

(3) If he fails to prove to the satisfaction of the Unemployment Committee that he has effected and kept effective a suitable registration at the proper employment exchange and has used his best endeavours to obtain suitable employment.

" "The existing Unemployment Benefit Fund " consisted of an arrangement whereby, in consideration of the contribution of weekly sums, the Company undertook to pay them a bonus not exceeding $£ 5$ a year on their being discharged for shortage of work or on attaining sixty-five. 


\section{INSURANCE AGAINST UNEMPLOYMENT 381}

(4) If he is in receipt of or entitled to any sickness or disablement benefit or disablement allowance under the National Health Insurance Acts, IgII to I920, or any compensation under the Workmen's Compensation Acts.

(5) If his unemployment is owing to a stoppage of work directly due to a trade dispute, whether at the Company's works or elsewhere, but such disqualification shall only apply so long as the trade dispute continues.

(6) If he has exhausted his right to unemployment benefit under this scheme.

(7) Whilst he is an inmate of any institution supported wholly or partially out of public funds or is resident, whether temporarily or permanently, outside the United Kingdom.

\section{General.}

The Company may make and amend regulations, increasing or decreasing the amount of or varying the conditions as to unemployment benefit or for the administration of the scheme, but any regulations decreasing the amount or period of unemployment benefit or increasing the deductions or the period qualifying for unemployment benefit, shall only be made with the consent of the Central Council or after three months' notice by the Company of the intention to make the same.

Unemployment benefit cannot be assigned or charged, and on the bankruptcy of the unemployed person the benefit would not pass to the trustee or other person acting on behalf of his creditors.

Unemployment benefits will be administered by a committee called "the Unemployment Committee," appointed by the Central Council and consisting of nine persons (of whom at least two shall be women and one shall represent the outside advertising and depot staff), whose decision will be final.

No person will be eligible for appointment on the Unemployment Committee unless actively engaged within 


\section{INSURANCE AGAINST UNEMPLOYMENT}

the United Kingdom in connection with the business of the Company, and if any member of the committee ceases to be so engaged his office will be vacated. Casual vacancies on the committee will be filled by the Central Council.

The Company will be entitled to discontinue the scheme if an adequate scheme of industrial or national unemployment insurance comes into force, or may, on giving three months' notice, reduce or discontinue its contributions to or terminate the fund, but such notice will not relieve the Company from contributing to the scheme up to the termination of such notice.

\section{The Cadbury Scheme at Bournville.}

The Company forms its own unemployment fund by a self-imposed tax on every ton of goods passing out of the firm, and the workpeople are not called upon to pay any contribution out of their wages. Out of the fund obtained from this source benefits are to be paid to married men at the rate of 22s. for 6 weeks and of IIs. for a further 6 weeks, and to single men and women at the rate of $16 \mathrm{~s}$. per week and of $8 \mathrm{~s}$. for a further 6 weeks.

These benefits are, of course, in addition to those obtainable under the Government's compulsory scheme.*

\section{The Bradford Dyers' Association, Ltd.}

The Bradford Dyers' Association, Ltd., has offered to provide its employees with benefits additional to those obtained under the Government scheme. It has I0,700 employees, of whom nearly 90 per cent. are males. When in 1907 the works of the Association were being reorganized and there was a likelihood of men being thrown out of work, the Association agreed to pay an amount equal to and in addition to that paid under their out-of-work benefit by the trade union. This

- Woman Worker, p. 5, February I921. 
arrangement continued in force with respect to unemployment until I9I3, when it was abandoned. But specific cases of unemployed workmen have been treated in this way since then, always on the joint contributory basis.

In IgI9 the Association urged upon the unions the necessity of more generous provision being made against unemployment. They advocated that the joint benefits resulting from the union, the State, and the employees should amount to 43s., or nearly two-thirds of the standard wages for a full week.

It is evident that in spite of the efforts of the Association the employees have hitherto suspected their intentions in urging these schemes.

\section{The Social Value of Establishment Funds.}

That many establishment funds created by employers in the supposed interests of their workmen have hitherto had anti-social effects cannot be denied. Only too frequently they have aimed at preventing the complete unionization of the workmen, at weakening their power to strike and at defeating the hope of substantial improvement of their position. But it would be wrong to oppose them without inquiring whether these evils are incidental to or inherent in the schemes.*

Indeed, their discussion might help to answer the question which is being set by employers themselves and now demands a definite solution. How can progressive employers, anxious to solve the problems of unemployment, act fairly towards their workmen during periods of unavoidable unemployment? Absolute dismissal they realize is both unfair and uneconomical. Bonuses or doles, which are in effect forms of charity, are degrading to both employer and workman. State schemes are generally inadequate. They are therefore faced with the question whether some form of estab-

- Reference to work of M. Fagnot, Conseil Supérieur du Travail, 1903, p. 5, November 10, 1903 . 


\section{INSURANCE AGAQINST UNEMPLOYMENT}

lishment fund of insurance, savings or loans ought not to be developed.*

We have already considered reasons for preferring a scheme of unemployment insurance to one of compulsory or voluntary savings. Unless the workman saves a much larger amount than he can usually afford to do, the fear of unemployment will still haunt him, and as a rule workmen can save for the future only by giving themselves and their children insufficient nourishment. Moreover, as they are not responsible for unemployment, it is wrong to make them bear all the burden and to exonerate employers from all responsibility.

It may be urged that unemployment insurance schemes would be introduced by the employer at the expense of wages, and that if the employer were without this particular fad the sum expended on it would be added to wages. $A$ priori argument as well as authority is against this view. It is patent that on the assumption of competition any establishment introducing such a scheme and endeavouring to pay lower wages would be unable to compete in the labour market with the ordinary establishment not operating such a scheme.

Levasseur, an eminent French authority, has recorded of France that it has never been shown that the average wages in welfare establishments are lower than in others. $\dagger$ In the cotton industry in the Southern States of America, quotes another authority, the presence or absence of welfare work bears no relation to wages. $\neq$

On the contrary, it may be argued that assuming the

- "Many employers of labour have arranged schemes whereby unemployed workmen may receive loans. One firm, for example, a Philadelphia firm that manufactures shirt-waists, has for ten years loaned money without interest or collateral to its employees. Assurance is asked that the money is not to be spent viciously: other than that the company does not meddle in the employees' use of the loans. It is a significant commentary that this firm has never lost a dollar during the entire ten years through failure of employees to return what was borrowed-and the firm employs several hundred workers." - Report on Unemployment in Philadelphia, 1917.

† Levasseur: Questions ouvrières et industrielles en France, 1907, p. 808.

$\ddagger$ United States Bureau of Labour Statistics, Bulletin 123, by Elizabeth Lewis Otey, Ph.D. 
existence of a vigilant trade unionism, only progressive and enlightened employers are likely to introduce such schemes. Such employers are likely to be the industrial captains and leaders, bold business men of real ability. In their establishments schemes of sickness or of unemployment insurance are likely to be accompanied by high rather than by low wages.

It is manifestly absurd to claim that establishment schemes of unemployment insurance will necessarily lead to industrial feudalism. The great mobility of labour, essential to modern industrial conditions, the system of general education, the prevalence of political democracy, even with all its deficiencies, and the growth of industrial democracy may be relied upon to prevent a lasting paternalism.

\section{Establishment Funds or Labour Laws?}

Professor John Graham Brooks has rightly pointed out that

benevolent schemes that bear the slightest taint of charity have at last got the contempt of intelligent wage-earners. Importunate, and never again to be silenced, is their demand that they get their benefits, not as gifts or favours, but as recognized rights. Philanthropies are a dangerous substitute for honest wage payment, shorter working time, and increased influence over the conditions of the labour contract. What may be called the great Bluff of our time is to put gratuities and benefactions in the place of Justice. There is no donation, however gaudy, that can fill the place of Justice.*

Attempts to foster paternalistic schemes which offer favours and deny standard conditions of labour are doomed to failure, but the chief merit of some of the schemes outlined is that they recognize the duty of the employer towards his workmen for unemployment. Here the most ardent Socialist and the keenest employer of labour may agree. Both regard unemployment as the result of bad organization. The former thinks it is due to the present capitalistic system, and though the

- Social Unrest, p. 203. 
latter is not necessarily concerned with its wider aspects, he regards it as a source of waste which he ought to eliminate by regularizing employment in his factory.

The introduction of establishment unemployment insurance funds would result in lowering the percentage of unemployment. A second claim is made in favour of such schemes. It is a matter of experience common to most European countries that in all branches of social insurance, in accident, sickness, and maternity insurance, all kinds of experiments, by municipalities, employers' associations, working men's societies, mutual societies, privately run insurance companies, have as a rule preceded the national schemes which absorbed them.

At first the more progressive private establishments introduced the scheme of compensation to workmen maimed or injured in the course of their employment. The principle was recognized that compensation was due to the workman and that the costs of accidents ought to be regarded as a normal cost of production. In this way a certain amount of experience was gained in the administration of compensation schemes before the State was ready for a universal scheme. When society became convinced that justice and equity demanded these schemes for the protection of the workman, it naturally legislated that what was done by the leaders in this field of industry should become the normal practice.

The proposal of establishment unemployment funds must not therefore be meant to retard wise labour laws. If it should have this effect and make the regularization of industry or the insurance of workmen against unemployment more dependent on the employer's kindliness or sympathy, its effects would be deleterious instead of beneficial. Indeed, they would then be a menace to social progress. But it is advantageous, where possible, to have private experiment precede Government undertaking and voluntary effort to guide legislation which must, by its nature, ultimately become obligatory on all.

It does not, however, follow that a country like the 
United States must wait before it can introduce a national scheme until it has had years of experimentation on a small scale. On the contrary, the very fact that the field is clear, comparatively speaking, certainly has many compensating advantages. The friction will be absent which inevitably ensues when vested interests must be placated. Besides, the chief value of such previous activity is its proof that the time has arrived for a radical treatment of the problem. If, however, it is universally conceded that the unemployment problem does demand a solution, then unemployment insurance may be started on a virgin soil. As a matter of fact, there is the experience of other countries by which it can profit. It would be vain to ignore this important fact in any comparison of the introductory stages of a Bill on unemployment insurance in the United States and in other countries. When virgin soil was broken up in the Middle West in the '80's, the primitive instruments of the followers of Hengist and Horsa, or even for that matter of the Pilgrim Fathers, were not employed. The new settlers benefited by the accumulated experience of farming in this and in other countries.

But, taking into account the peculiarities of economic conditions in the United States, it does seem that on the whole the consideration that employers in the country had found unemployment insurance practicable, that it had not resulted in their bankruptcy, that it did not have the terrifying effects prophesied of so-called class legislation, make it valuable to have private schemes of unemployment insurance introduced immediately.

Once inaugurated, such schemes would not need to disappear on the institution of a public system of unemployment insurance. Such a system would necessarily provide only a minimum of benefits which could be supplemented by other means, or, better still, the State could recognize such establishment funds and offer them a subsidy.*

- See Appendix I. 


\section{INSURANCE AGAINST UNEMPLOYMENT}

But as an alternative to State schemes of unemployment insurance, establishment funds are unsatisfactory, because they are possible only in large factories not subject to great fluctuations; they come, as a rule, from above and might be withdrawn; active union members might be, and often have been, treated unfairly ; they are likely to be regarded as having something in the nature of charity about them; there are great difficulties of administration in times of strikes, and only few employers at best could be expected to adopt such a proposal. 


\section{PART IV}

THE UNEMPLOYMENT PROBLEM IN THE UNITED STATES 



\section{CHAPTER XXV}

\section{OUT-OF-WORK BENEFITS IN AMERICAN TRADE UNIONS *}

\section{The Growth of Insurance in the United States.}

THE last quarter of a century has seen a marked growth in the application of the principles of insurance in the United States. Among the types that have reached considerable scope and magnitude is that of "workmen's insurance," by which is meant the insurance of workmen as a distinctive class against sickness, accidents, old age or other adversity. $\dagger$

This insurance has been operated by four kinds of institutions.

First, there are the privately conducted, regular insurance companies which have created special industrial insurance departments.

Secondly, there are the national and local trade unions, which have organized insurance schemes against many of the emergencies which threaten their members.

Thirdly, there are establishment insurance funds, membership in which is limited to the employees of a particular firm.

Fourthly, there are the industrial benefit societies. These are conducted by groups of workmen for their

- An inquiry into union out-of-work benefits was made necessary in 1915 to discover whether the Ghent system was applicable to the United States.

It will become evident from the next two chapters how primitive American trade unions are compared with British unions, and from the two following chapters how backward the United States is in social legislation.

$\dagger$ Twenty-third Annual Report of the Commissioner of Labour, p. I5. 391 
mutual benefit without regard either to membership in a particular union or to employment in a given establishment.

Hitherto the two principal classes of benefit have been those provided in case of death and of temporary disabilities, such as accidents or illness; out-of-work benefits have been provided least of all.

\section{Slow Growth of Trade Union Out-of-work Benefits.}

Indeed, it is a regrettable fact that American trade unions are the most backward of those of all Western countries in organizing unemployment or out-of-work benefits, as they are generally known. Moreover, there is little sign that this form of benefit has been gaining much ground of late. "In I905 the amount expended for out-of-work benefits could not well have exceeded eighty thousand dollars, and of this sum a considerable part was spent by the Amalgamated Society of Carpenters, a British trade union, with branches in the United States." * In I9I4, when unemployment was rife, it is safe to say that not more than one hundred thousand dollars were spent on out-of-work benefits, of which a quarter was spent by the Amalgamated Society of Carpenters and about $\$ 31,000$, i.e. much more than one-quarter, by one union alone, viz. the Cigar Makers' Union.

Less than 3 per cent. of the comparatively small total expenditure of American unions on insurance benefit features is spent on unemployment insurance.

The fact of the small increase, if any, of out-of-work benefits is all the more striking when it is appreciated

- Kennedy, J. B.: Beneficiary Features in American Trade Unions, p. 85 .

See also Unemployment and American Trade Unions, by D. P. Smelser, Johns Hopkins Press, Baltimore, 1919, and League of Nations Report on Unemployment, p. $8 \mathrm{r}$.

"Of the II I national unions affiliated with the American Federation of Labour in 1916,69 reported paying benefits amounting to $\$ 3,545,823$. Only 3 per cent. of this amount, $\$ 120,770$, went for the relief of the unemployed. But even this sum came largely from special assessments, and from the exemption of payment of dues by those out of work." 
that other forms of insurance, mortuary, sickness, etc., have increased a great deal during recent years. There has also been an even greater increase in the number of special levies or special assessments raised for a given definite purpose, but a detailed consideration of such levies for emergency purposes, although by this means more is raised to relieve unemployed workmen than by the method of insurance, does not properly belong to this inquiry.

\section{Unemployment Benefits in America.}

Unemployment benefits in American unions have assumed the three forms which are common in Europe. First, there is the out-of-work benefit of a fixed amount per week for a certain number of weeks. Secondly, some unions arrange for a travelling benefit sufficient in amount to transport the unemployed workman to some place where he is likely to find work. Other unions allow only a loan for this purpose. Thirdly, some unions grant merely an exemption of payment of dues for a definite period to unemployed members. This and the first are generally known as unemployment benefits, the second as a travelling benefit.

The unions that pay money out-of-work benefits are the Cigar Makers, the Deutsch Amerikanischen Typographia, the Iron Moulders' Union, the Amalgamated Society of Carpenters (a British union with branches and a membership of about 4,000 in the United States), the Amalgamated Society of Engineers, the Brewers' Union Local No. I, and the Boston Wood Carvers' Association.

The Cigar Makers' Union is still the only American trade union of national size which pays a weekly money benefit to unemployed members, the others being local unions.

\section{The Cigar Makers' Union.}

Indeed, with respect to the variety, the total expenditure, and the long consecutive history of its benefits, it 


\section{BENEFITS PAID BY THE CIGAR MAKERS' INTERNATIONAL}

\begin{tabular}{|c|c|c|c|c|c|c|}
\hline Year. & $\begin{array}{l}\text { Loans to } \\
\text { Travelling } \\
\text { Members. }\end{array}$ & Strike Benefit. & $\begin{array}{c}\text { Cost per } \\
\text { Member } \\
\text { per } \\
\text { Year. }\end{array}$ & Sick Benefit. & $\begin{array}{c}\text { Cost per } \\
\text { Member } \\
\text { per } \\
\text { Year. }\end{array}$ & $\begin{array}{l}\text { Death and } \\
\text { Total Disability } \\
\text { Benefit. }\end{array}$ \\
\hline & $\$$ & $\$$ & $\$$ & $\$$ & $\$$ & $\$$ \\
\hline $1878^{\circ}$ & - & - & - & - & - & - \\
\hline 1879 & - & $3,668 \cdot 23$ & I. 34 & - & - & - \\
\hline 1880 & 2,808 I 5 & $4,950 \cdot 36$ & I.II & - & $=$ & - \\
\hline I 88rt & $12,747.09$ & $2 \pi, 797.68$ & I. 49 & $3,987.73$ & 0.27 & 75.00 \\
\hline $1882 \ddagger$ & $20,386.64$ & $44,850.4 \mathrm{I}$ & $3 \cdot 92$ & $\mathrm{I} 7, \mathrm{I}_{45} \cdot 28$ & I. 50 & $1,674.25$ \\
\hline $188_{3}$ & $37,135 \cdot 20$ & $27,812 \cdot 13$ & 2.10 & $22,250.56$ & I. 68 & $2,690.00$ \\
\hline 1884 & $39,632.08$ & $143,547 \cdot 36$ & 12.62 & $3 x, 55 x \cdot 50$ & 2.77 & $3,920.00$ \\
\hline 1885 & $26,683 \cdot 54$ & $61,087.28$ & 5.09 & $29,397.89$ & 2.44 & $4,214.00$ \\
\hline 1886 & $3 I, 837 \cdot 5 I$ & $54,402.6 \mathrm{I}$ & 2.20 & $42,225 \cdot 59$ & 1.71 & $4,820.00$ \\
\hline 1887 & $49,281 \cdot 04$ & $13,871.62$ & 6.74 & $63,900.88$ & 3.10 & $8,850.00$ \\
\hline I 888 & $42,894 \cdot 75$ & $45,303.62$ & 2.66 & $58,824 \cdot 19$ & $3 \cdot 40$ & $21,319 \cdot 75$ \\
\hline I 889 & $43,540.44$ & $5,202 \cdot 52$ & 0.29 & $59,519.94$ & $3 \cdot 29$ & $19,175 \cdot 50$ \\
\hline $1890 \$$ & $37,914 \cdot 72$ & $18,414.27$ & 0.74 & $64,660.47$ & $2 \cdot 55$ & $26,043.00$ \\
\hline IS9I & $53,535 \cdot 73$ & $33,531.78$ & $1 \cdot 3^{8}$ & $87,472.97$ & $3 \cdot 40$ & $38,068 \cdot 35$ \\
\hline 1892 & $47,732 \cdot 47$ & $37,477.60$ & I. 40 & $89,906 \cdot 30$ & 3.22 & $44,701.97$ \\
\hline 1893 & $60,475 \cdot I I$ & $18,228.15$ & 0.68 & I04,39I. 83 & 3.68 & $49,45^{8} \cdot 33$ \\
\hline I 894 & $42,154 \cdot 17$ & $44,966.76$ & $\mathrm{I} \cdot 6 \mathrm{I}$ & I06,758.37 & $3 \cdot 64$ & $62,158.77$ \\
\hline I895 & $41,657 \cdot 16$ & $44,039.06$ & I. 58 & $112,567.06$ & 3.82 & $66,725 \cdot 98$ \\
\hline I 896 & $33,076.22$ & $27,446.46$ & 1.00 & $109,208.62$ & $3 \cdot 74$ & $78,768.09$ \\
\hline 897וl & $29,067.04$ & $12,175.09$ & 0.46 & $\mathrm{I} 2,774 \cdot 63$ & 3.99 & $69,186.67$ \\
\hline I 898 & $25,237 \cdot 43$ & $25,118.59$ & 0.94 & III, 283.60 & $3 \cdot 90$ & $94,939.83$ \\
\hline 1899 & $24,234 \cdot 33$ & $12,331.63$ & 0.72 & $107,785.07$ & $3 \cdot 44$ & $98,993.83$ \\
\hline 1900 & $33,23^{8} \cdot 13$ & I $37,823 \cdot 23$ & $3 \cdot 98$ & II $7,455 \cdot 84$ & 3.21 & $98,291.00$ \\
\hline I90I & $44,652 \cdot 73$ & $105,215.71$ & 3.02 & $\mathrm{I}_{34,6} \mathrm{I}_{4}$. II & 3.65 & $13^{8,456} \cdot 3^{8}$ \\
\hline 1902 & $45,314.05$ & $85,274 \cdot 14$ & 2.23 & I $37,403 \cdot 45$ & $3 \cdot 47$ & $128,447.63$ \\
\hline 1903 & $52,52 \mathrm{I} \cdot 4 \mathrm{I}$ & 20,858 . I 5 & 0.51 & $147,054 \cdot 56$ & $3 \cdot 42$ & I $38,975 \cdot 9$ I \\
\hline 1904 & $58,728 \cdot 71$ & $32,888.88$ & 0.76 & I63,226. I 8 & $3 \cdot 59$ & I $51,752.93$ \\
\hline 1905 & $55,293 \cdot 93$ & $9,820.83$ & 0.23 & $165,917.80$ & $3 \cdot 73$ & I $62,818.82$ \\
\hline r9o6 & $50,650.21$ & $44,735 \cdot 43$ & I. IO & $I 62,905.82$ & 3.69 & $185,514.17$ \\
\hline 1907 & $50,063.86$ & $22,644.68$ & 0.52 & I $73,505.67$ & $3 \cdot 72$ & $207,55^{8} .87$ \\
\hline I903 & $46,613 \cdot 44$ & $32,423 \cdot 39$ & 0.77 & $\mathrm{I} 84,755.60$ & 4.02 & $220,979 \cdot 71$ \\
\hline r9o9 & $4 I, 589 \cdot 34$ & $19,999 \cdot 5^{8}$ & 0.43 & $186,983 \cdot 28$ & $3 \cdot 71$ & $238,284 \cdot 47$ \\
\hline 1910 & $39,8 \mathbf{2 8} \cdot 77$ & $221,044 \cdot 70$ & $4 \cdot 90$ & I $89,43^{8} \cdot 59$ & $3 \cdot 77$ & $226,7 \times 7 \cdot 53$ \\
\hline I9II & $38,543 \cdot 47$ & $47,671 \cdot 20$ & I.IU & $201,296.03$ & 4.13 & $25 \mathrm{I}, 677 \cdot 4 \mathrm{I}$ \\
\hline r912 & $33,113 \cdot 10$ & $12,646.87$ & 0.30 & $204,775 \cdot 6 \mathrm{r}$ & $4 \cdot 33$ & $26 \mathrm{I}, 910.2 \mathrm{I}$ \\
\hline I913 & $45,264 \cdot 82$ & $8,877.02$ & 0.21 & $196,853 \cdot 5^{8}$ & $4 \cdot 15$ & $280,555.62$ \\
\hline 1914 & $51,077 \cdot 15$ & $50,898 \cdot 50$ & 1.23 & $207,579.62$ & $4 \cdot 3^{8}$ & $279,746.15$ \\
\hline 1915 & $42,266 \cdot 70$ & $9,947 \cdot 56$ & $0.2,5$ & $210,427.87$ & $4 \cdot 60$ & $278,509.64$ \\
\hline Total & $1,430,788.84$ & $1,562,993.08$ & - & $4, \mathrm{II} 9,806 . \mathrm{I} 8$ & - & $3,945,979 \cdot 77$ \\
\hline
\end{tabular}

- The weekly dues were ro cents.

$\dagger$ The weekly dues were 15 cents.

$\ddagger$ The weekly dues were 20 cents. 
UNION OF AMERICA IN THIRTY-SIX YEARS AND TWO MONTHS.

\begin{tabular}{|c|c|c|c|c|c|c|c|}
\hline $\begin{array}{c}\text { Cost } \\
\text { per } \\
\text { Mem- } \\
\text { ber } \\
\text { per } \\
\text { Year. }\end{array}$ & $\begin{array}{l}\text { Out-of-work } \\
\text { Benefit. }\end{array}$ & $\begin{array}{c}\text { Cost } \\
\text { per } \\
\text { Mem. } \\
\text { ber per } \\
\text { Year. }\end{array}$ & $\begin{array}{l}\text { Total } \\
\text { Cost per } \\
\text { Member } \\
\text { per Year } \\
\text { for all } \\
\text { Benefits. }\end{array}$ & $\begin{array}{c}\text { Members } \\
\text { Contri- } \\
\text { buting } \\
\text { 30 Cents. }\end{array}$ & $\begin{array}{c}\text { 20-cent } \\
\text { Bene- } \\
\text { ficiary } \\
\text { Retired } \\
\text { Mem- } \\
\text { bers. }\end{array}$ & $\begin{array}{l}\text { Mem- } \\
\text { bers } \\
\text { Paying } \\
\text { Dues } \\
\text { of 10 } \\
\text { and 15 } \\
\text { Cents. }\end{array}$ & $\begin{array}{c}\text { Balance at } \\
\text { Close of Fiscal } \\
\text { Year. }\end{array}$ \\
\hline$\$$ & $\$$ & $\$$ & $\$$ & $\$$ & $\$$ & $\$$ & $\$$ \\
\hline 一 & 一 & 一 & - & 一 & - & - & $124 \cdot 55$ \\
\hline 一 & 一 & - & I. 34 & 2,729 & - & 一 & $5,066.22$ \\
\hline- & 一 & 一 & I.II & 4,440 & 一 & 一 & $11,155.62$ \\
\hline 0.00 & 一 & - & 1.77 & $x_{4}, 604$ & 一 & 一 & $37,740 \cdot 79$ \\
\hline 0.14 & 一 & 一 & $5 \cdot 56$ & 11,430 & 一 & - & $77,506.29$ \\
\hline 0.20 & 一 & - & $3 \cdot 99$ & 13,214 & 一 & - & $126,783 \cdot 30$ \\
\hline 0.34 & 一 & 一 & $15 \cdot 74$ & II,37I & 一 & - & $70,078.73$ \\
\hline 0.35 & - & 一 & 7.88 & 12,000 & - & - & 85,5 II. 46 \\
\hline 0.19 & 一 & - & $4 \cdot 10$ & 24,672 & 一 & 一 & $172,8 I_{3} \cdot 25$ \\
\hline 0.43 & 一 & - & 4.21 & 20,560 & - & 一 & $227,228 \cdot 24$ \\
\hline I. 2.3 & 一 & - & 7.29 & 17,133 & I 68 & - & $239,190 \cdot 53$ \\
\hline I. 06 & - & - & 4.65 & 17,555 & 496 & - & $285,136.54$ \\
\hline 1.02 & $22,760 \cdot 50$ & 0.92 & 5.25 & 24,624 & 713 & 一 & $383,072.87$ \\
\hline$I \cdot 5 I$ & $21,223 \cdot 50$ & 0.87 & 7.17 & 24,221 & 957 & 一 & $421,950.06$ \\
\hline 1.60 & $17,460 \cdot 75$ & 0.65 & 6.88 & 26,678 & 1,229 & - & $503,829.20$ \\
\hline $\mathrm{I} \cdot 74$ & $89,402.75$ & $3 \cdot 33$ & $9 \cdot 45$ & 26,788 & 1,518 & - & 456,732 . 13 \\
\hline 2.11 & I $74,517.25$ & 6.27 & 13.64 & 27,828 & 1,497 & 一 & $340,788.66$ \\
\hline 2.27 & $166,377.25$ & $5 \cdot 99$ & 13.67 & 27,760 & $I, 644$ & 一 & $236,213.05$ \\
\hline 2.69 & $x_{75,767.25}$ & 6.43 & 13.87 & 27,318 & 1,873 & 一 & $177,033.12$ \\
\hline 2.44 & II $7,471 \cdot 40$ & $4 \cdot 4^{6}$ & $11 \cdot 36$ & 26,347 & 1,859 & II 8 & $194,240 \cdot 30$ \\
\hline $3 \cdot 30$ & 7.70 & 2.65 & 10.80 & 26,460 & 2,049 & 203 & $227,597.01$ \\
\hline 3.13 & $38,037.00$ & $I \cdot 3 I$ & $8 \cdot 31$ & 28,994 & 2,252 & 341 & $292,407 \cdot 95$ \\
\hline 2.64 & $23,897.00$ & 0.70 & 10.54 & 33,955 & 2,584 & 652 & $3 I_{4}, 806.24$ \\
\hline 3.67 & $27,083 \cdot 76$ & 0.79 & II. I 4 & 33,974 & 2,863 & 860 & $321,124 \cdot 33$ \\
\hline 3.11 & $21,07 x .00$ & 0.56 & $9 \cdot 39$ & 37,023 & 3,105 & 1,103 & $361,8 \times 1.29$ \\
\hline 3.14 & $15,558,00$ & 0.39 & $7 \cdot 47$ & 39,301 & 3,605 & 1,343 & $495,117.91$ \\
\hline 3.24 & $29,872 \cdot 50$ & 0.71 & $8 \cdot 31$ & 41,536 & 3,904 & 1,380 & $589,234 \cdot 20$ \\
\hline 3.56 & $35,168,50$ & 0.87 & 8.41 & 40,075 & 4,297 & 1,312 & $688,679 \cdot 13$ \\
\hline 4.08 & $23,911.00$ & 0.60 & $9 \cdot 49$ & 39,250 & 4,828 & $I, 340$ & $714,506.14$ \\
\hline $4 \cdot 32$ & $19,497.50$ & 0.47 & 9.05 & $4 x, 337$ & 5,266 & $x, 350$ & $775,305.85$ \\
\hline 4.68 & IOI, $483 \cdot 50$ & $2 \cdot 5 I$ & 12.00 & 40,354 & 5,535 & $I, 23 I$ & $705,960.75$ \\
\hline 4.62 & $76,107.25$ & $1 \cdot 71$ & 10.49 & 44,414 & 5,908 & 1,155 & $672,184 \cdot 39$ \\
\hline $4 \cdot 40$ & $39,917.00$ & 0.91 & I3.99 & 43,837 & 6,314 & 1,291 & $489,426.98$ \\
\hline 5.03 & $36,942 \cdot 50$ & 0.87 & II. I 4 & 42,107 & 6,608 & 1,257 & $443,384.62$ \\
\hline $5 \cdot 40$ & $42,9 \times 1 \times .05$ & I.06 & II.IO & 40,373 & 6,846 . & 1,238 & $399,474 \cdot 52$ \\
\hline $5 \cdot 77$ & $3 I, 898.7 I$ & 0.79 & 10.93 & 40,180 & $7, \times 67$ & 1,273 & $414,037 \cdot 45$ \\
\hline $5 \cdot 76$ & $68,198.00$ & 1.70 & 13.08 & 40,001 & 7,344 & $x, 205$ & $319,804 \cdot 75$ \\
\hline $5 \cdot 94$ & $122,954.00$ & 3.23 & 14.02 & 38,044 & 7,692 & 1,150 & $240,791 \cdot 97$ \\
\hline - & $x, 60$ & - & - & - & - & - & 一 \\
\hline
\end{tabular}

The weekly dues were 25 cents.

|| The weekly dues were 30 cents. 


\section{INSURANCE AGAINST UNEMPLOYMENT}

is both the model beneficiary organization of the United States and the pioneer in this field of union activity. It has also fathered a resolution urging the American Federation of Labour to prepare a scheme of social insurance for the whole of organized labour in the country, and its own methods are the most likely to be copied.

It has deliberately adopted the principle of high dues and an elaborate chain of benefits. For over twentyfive years it has provided out-of-work, travelling, strike, sick, death, and disability benefits. The weekly contribution for most members therefore had to be 25 cents a week until I897, and since then it has been 30 cents a week.

The union has grown steadily, its increase in membership being characterized by a steady and continued, though comparatively small, growth. This is in marked contrast with most unions not paying "out-of-work" benefits. These tend to have sporadic increases and decreases of membership.

From the outset, the first benefit being paid on January 22, I890, the out-of-work benefit feature has been successful in operation and very popular amongst the members.

The constitution of the International Cigar Makers' Union provides that unemployed members who have paid weekly dues for a period of two years shall be entitled to $\$ 3$ per week and 50 cents for each additional day, that after receiving six weeks' aid the member shall not be entitled to further benefits for seven weeks, and that no member shall be granted more than $\$ 54$ during any one year.

Members of one year standing are entitled to a loan for transportation to the nearest union in whatever direction they desire to travel, but loans may not exceed $\$ 20$ in the aggregate.

The Amalgamated Society of Carpenters is a British union, providing out-of-work benefits since I86a.

In I9I3 this society had over 4,000 members in 
the United States. More than $\$ 24,600$ was distributed in out-of-work benefits.

Benefits are paid for not more than 18 weeks in a year. During the first 9 weeks benefits are provided at the rate of $\$ 3.50$ per week, and during the second 9 weeks at the rate of $\$ 2.50$ per week.

\section{Out-of-work Benefits provided by Locals.}

In addition to these two national unions which pay out-of-work benefits, there are a number of locals who make provision of this kind for their members. The total amount, however, which is spent for this purpose is very small.

The Amalgamated Society of Engineers was founded in I86r. Shortly after that date out-of-work benefits began to be paid by some of the locals. During I9I3 there were some 2,700 members insured against unemployment, and they were granted $\$ 9,063$ in out-of-work benefits. There are five classes of membership, only the highest class, consisting of members in good standing for ten years, receive $\$ 3$ per week for I4 weeks, \$2.ro for 30 weeks, \$1.80 as long as they are out of work. The other classes of members receive lower benefits. The lowest receives a benefit of 75 cents a week for I4 weeks.

The Brewers' Union Local No. I has I, 150 members. In I9I3 it distributed $\$$ I, IOO in out-of-work benefits, and in I9I4 $\$ \mathrm{I}, 800$.

Unemployed members receive $\$ 4$ per week for a maximum period of I2 weeks, but no member may receive more than $\$ 48$ in two years. If a member exhausts the maximum amount of benefits, he must pay dues for a full year before he will be entitled to benefits again. Whilst in receipt of unemployment benefit the member must report daily at the secretary's office.

The Boston Wood Carvers' Association has 136 members who are insured against unemployment. In I9I4 $\$ 784$ were distributed in benefits under this head. 
Unemployed members receive $\$ 4.50$ per week for a maximum period of $\mathrm{I} 2$ weeks in a year.

Unlike most unions, the Boston Wood Carvers do not pay a weekly fixed due. The dues are raised by collecting 3 per cent. of members' weekly wages, 2 per cent. of which go to the Unemployment Fund.

Typographical Union No. 7, a union of 300 German type-setters, has the most perfect and one of the oldest schemes of unemployment benefit in the country.*

These men pay high union dues, 90 cents a week for members working, and one-half that amount for members not employed. In addition there is an assessment of I per cent. of wages to be contributed to the national organization with which the local is affiliated. $\dagger$

Men who have belonged to the union for Io4 weeks are entitled to I6 weeks' benefit, those belonging for 200 weeks or over are entitled to benefit for an indefinite period, i.e. until they again find work.

The benefit is $\$ \mathrm{I} .25$ a day. At first the unemployed workman receives his benefit from the treasury of the national union. Then, for a period of three weeks, he receives his benefit from the treasury of the local. After that period he again receives his benefit from the treasury of the national union. In this way the burden is shared between the national union and its local, and the respective funds are protected from too speedy exhaustion.

There is a strict test as to whether an unemployed workman is malingering. First, the union secretary is well acquainted with the daily life of the unemployed member, and knows whether he is honestly seeking work. Secondly, the unemployed workman must report daily at the union headquarters or forfeit his claim to

- See The Survey, February 20, r9r6.

† In 1913 the average annual contribution per member in British trade unions was $\$ 6.60$, and the average expenditure $\$ 4 \cdot 56$, but the printing trade group of unions callected $\$ 19,20$ and spent $\$ 21 \cdot 24$.

Unemployment, travelling, and emigration benefit accounted for 13.3 per cent. of the expenditure of all unions in the States, and for one-third of the income of the printing group. 
benefits. Thirdly, the union acts as an employment bureau. Any workman refusing a steady position is fined very heavily, four weeks' benefit. If he does this again he is punished more severely or even suspended.

It is because of the good wages of these men, $\$ 5$ a day for a five-day week (pre-war rate), that the high dues can be paid. But that fact alone would not enable the union to pay such high benefits.

The union has developed a policy whereby unemployment in respect of each workman is lessened, even though the percentage of unemployment for the whole trade is the same. During periods of depression a man after three weeks' employment gives away his place to one of the other unionists who is unemployed. A list of all the unemployed members is kept. By means of a system of rotation the work is divided amongst them. This system applies, however, only to the temporary work.

The five-day week, the high wages, and the fact that employers make no objection to this scheme of sharing the work around amongst the members, are conclusive proof of the peculiar conditions in the trade and of the strength of Typographical Union No. 7, rather than of the possibility of extending such a policy very widely in different trades.

It is at first a baffling problem to understand why the German printers local, Typographical Union Local No. 7, has been able to develop such a thorough organization and to carry out successfully a scheme of unemployment benefit. Nor is it very evident when we learn that printers are a very intelligent and superior class of workmen, since other skilled workmen have not organized for this purpose. The real explanation lies in the fact that this local has inherited an experience and is carrying on a tradition which has fallen to the lot of few other organizations.

In Germany the compositors' craft has been carried on from a remote period, and has almost from the beginning had some form of organization. Moreover, in that country the compositor's craft has been brought 
to a degree of perfection which could hardly be matched by any other trade, and as a result has attracted to itself exceptionally skilled and educated men. It was aristocratic, exclusive, and self-reliant, and its trade union, the Printers' and Typefounders' Union, was in marked contrast with the "free or social democratic Gewerkschaft" that were organized later and were associated with the political movement. The present National Union was formed in I867, the attempted National Union of 1848 having proved abortive.*

Its aims and methods resemble those of English trade unions, inasmuch as disputes and wages are settled by mutual agreements with employers. Local No. 7 is the direct offspring of the most independent, the oldest and the best organized and strongest of the German unions.

Our understanding of trade unionism in the United States will not be complete without further knowledge of the trade associations and customs of the immigrants $\dagger$ of the last fifty years.

New York Typographical Union No. 6.-Established under its modern form in I852, Typographical Union No, 6 was forced during the depression of I857-8 to try to find work for its unemployed members and to distribute out-of-work relief to those who needed it. $\ddagger$

It was after the prolonged and distressful depression following the industrial panic of 1873 that Big Six spent over $£ 500(\$ 2,500)$ in relieving want and in paying for the removal of members to other cities, and, finding that the disbursement of that sum was insufficient, appealed to chapels to make arrangements whereby some portion of the work could be shared with the unemployed.

* See Shadwell's Industrial Efficiency, vol. ii, p. 330.

$\dagger$ The History of the Jewish Labour Movement (published in Yiddish), New York, I9I5, is one necessary study which traces the history of workmen's organizations and their leaders back to Russo-Jewish conditions.

$\ddagger$ The Fundamental Law of the Typographical Association of New York, which was revised in I 833, " provided for the payment of specified benefits to members on strike, besides pecuniary relief for the unemployed. and the siçk." 
Recognizing the fact that hundreds of our members are unable to secure employment sufficient to maintain them and their families and have every prospect of a hard winter before them, while others are working full time, and in some cases overtime, and are therefore unaffected by the general stagnation in business (ran the plea of the association), and believing it will be to the best interest of our union to assist the unemployed members by distributing the surplus work as evenly as possible, we request the different chapels to take such action in this matter as will in some measure assist these men endeavouring to maintain union principles.

It is impossible to know to what extent this was carried out, but instances were numerous. This practice, together with the unemployment benefits, proved sufficient to prevent even one member of Union No. 6 from having recourse to public charity during the period of transition when the linotype machine was replacing hand workers and the depression was greatest.

In explaining its recommendation the committee stated that it had "endeavoured to eliminate all semblance of charity from the fund and make the payment of relief a constitutional right, to which each member is entitled."

The following additions to the constitution were approved by a referendum and went into effect on April 5, 1896.

Section I.-The out-of-work fund shall be maintained by an assessment of I per cent. on the earnings of all members, to be collected weekly, the assessment to be considered a part of a member's dues. The officers of the union shall suspend the assessment when the surplus in the fund shall amount to $\$ 2,500$, and shall renew it when said surplus shall have been reduced to $\$ 500$.

Section 2.-Any unemployed member of the union in good standing who has been a member for at least one year previous to his application shall be entitled to relief. No applicant shall receive more than $\$ 4$ per week, nor more than four payments in any six weeks, nor more than fifteen payments in a year. Only those out of employment for an entire week shall be entitled to benefit. 


\section{INSURANCE AGAINST UNEMPLOYMENT}

"Big Six," the American type-setters' local, has had a more eventful career than the German printers' local. In I907 it was forced to discontinue its benefits.

The stumbling-block in the way of the union unemployment insurance was the fact that some men became parasites and made little pretence to seeking employment when they were assured even so small an allowance as an out-of-work fund could afford. The union found that a number of men drew in each year the full amount that was permitted under the laws regulating the fund. The abuse which resulted from the "Panhandlers " in the society became so flagrant that it led to the abolition of the unemployment fund. The majority of the beneficiaries it was found belonged to this class.*

UNEMPLOYMENT BENEFITS DISBURSED FROM OCTOBER 1893 TO AUGUST 13, 1907, BY NEW YORK TYPOGRAPHICAL UNION NUMBER SIX.

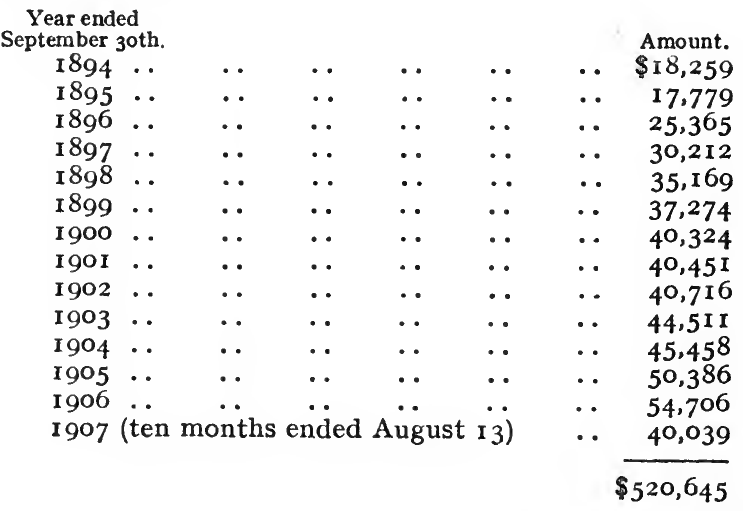

In spite of this experience this union was obliged to take special measures to meet the unemployment crisis of I9I4-I5.

In I9I4 benefits were paid during unemployment by "Big Six," not from members' contributions to a fund, but from a very heavy assessment of 5 per cent. on all wages over \$ro. This raised a revenue of $\$ 20,000$,

- Portenar: Problems of Organized Labour. 
which was distributed according to individual need in amounts varying from $\$ 5$ to $\$ 15$ a week. This cannot, of course, be regarded as a true unemployment insurance scheme, because the fund was financed by means of a special levy and not through regular contributions, because benefits were provided more in accordance with needs than with a sense of the actuarial value of the contributions of members, and because benefits were paid for an indefinite period, as long as the funds held out. It was merely a panic measure for meeting a period of unemployment.

In I9I5 a number of national organizations and a number of locals provided travelling benefits. The Cigar Makers' Union allowed loans amounting to $\$ 56,000$ for this purpose. The Glass Bottle Blowers distributed $\$ 9,000$, the Pattern Makers $\$ 1,2 \% 5$, and the Tunnel and Subway Constructors' Union $\$ 2,000$.

A number of unions allow an exemption of dues during periods of unemployment. The United Shoe Workers of America allows every member in good standing who is unemployed thirteen out-of-work stamps each year.

The Pattern Makers' League of North America exempts unemployed members from paying dues for a maximum period of thirteen weeks in a year. The Piano and Organ Workers' International Union of America exempts members from dues during their whole period of unemployment. This rule is to be found also amongst blacksmiths, boiler-makers, brewery workers, glass workers, granite cutters, iron moulders, leather workers on horse goods, lithographers, locomotive firemen, machinists, metal polishers, united mine workers, photoengravers, pulp, sulphite and paper-mill operatives, stove mounters and the Western Federation of Music.

The building trade unions of New York have no regular established system of unemployment benefits, but assistance is rendered in all cases of distress either by loans or donations. "No worthy applicant is turned away." The building trades unions are estimated to have 


\section{INSURANCE AGAINST UNEMPLOYMENT}

spent over $\$ 250,000$ of union funds (during the crisis I9I4-I5), " some lending their mortuary benefit surplus to the general fund for this purpose."

The so-called unemployment benefits paid by the Glass Bottle Blowers' Association were of this kind. In I908, $\$ 325,000$ was distributed to meet the expenses of many members, and in I9I4 \$70,000. Similarly, the $\$ 6$ weekly benefit paid by the Photo-engravers during the I9I4-I5 depression out of a fund raised by a special weekly tax of 50 cents for I8 weeks from employed members and the benefits provided from special funds by the Blacksmiths' Helpers Local No. I cannot be strictly regarded as out-of-work insurance.

The loss to the union resulting from such an exemption of dues is considerable. This is seen from the figures relating to the Iron Moulders' Union.

EXEMPTION FROM DUES TO UNEMPLOYED MEMBERS BY THE IRON MOULDERS' UNION.

\begin{tabular}{lr|rc}
1900 & $\$ 5,859$ & 1908 & - \\
1901 & 6,587 & 1909 & $\$ 17,444$ \\
1902 & 2,597 & 1910 & - \\
1903 & 6,518 & 1911 & - \\
1904 & 23,171 & 1912 & - \\
1905 & 6,226 & 1913 & 191 \\
1906 & 4,169 & 1914 & 131,877 \\
1907 & - & 1915 & 46,960
\end{tabular}

The International Moulders' Union of North America claims to have lost $\$ 348$, I98 from out-of-work dues since its inception up to December 3I, I9I5. During the year I9I5 alone, $\$ 46,960$ was lost in this manner. Even this form of out-of-work benefit, the exemption of unemployed workmen from paying union fees, is not, in fact, very common in the United States.

During the unemployment crisis of IgI4, it was suggested that the out-of-work stamp should be employed by all unions to prevent members from losing their membership. It was argued that if a member is one or two months in arrears when becoming unemployed and cannot afford to pay up his back dues, it should be the duty of the financial secretary to give him an 
unemployed stamp during the period of unemployment, applying the same on the first month of his arrears in order to keep him from being dropped.

"We are losing hundreds of members who are out of work," said Vice-President Ames of the International Association of Mechanics, "who can't pay their dues and are one and two months behind in their dues, and the third month catches them quick, where if an outof-work stamp could be placed in their book during the time and month they are out of work, then it would be an easier task to get them to pay up for the one or two months they were behind after they get a job than it would be to get their reinstatement fee." *

\section{Problems of Trade Union Out-of-work Benefits.}

Two questions now confront the practical administrator of trade union out-of-work benefits. Should all members pay a fixed weekly due for this purpose or should it vary with their wages? Should national unions or locals administer these funds?

It has been suggested that the percentage plan is the only truly fraternal plan and for that reason best for organizing purposes. The insurance fund would then be collected upon the basis of a percentage of earnings. The man who earns most, it is urged, should pay most. If this method of taxation is not employed, then, it is argued that the less efficient who may be aged, infirm, and those likely to be unemployed often might find the assessment a real burden, and not only their insurance but their membership would be imperilled by inability to pay it.

The percentage plan, it is claimed, is a practical application of the doctrine, "Each for all, and all for each."

Experience is against this view. Most unions successfully operating out-of-work benefit schemes provide

* The objection to this proposal is that it puts a premium on arrears. -Machinist's Monthly Journal, May I914, vol. xxvi, No. 5, pp. 477, 478. This need not lead to abuse if the administration is sound. 


\section{INSURANCE AGAINST UNEMPLOYMENT}

that all members shall pay the same weekly due. Besides, the payment of dues on a percentage of wages basis would necessarily complicate the administration of the scheme. The view that the support of the most needy members of the union is the duty of the most capable contains elements dangerous to trade unionism. It implies functions that rightly belong to national and employers' organizations. The usual view is that unions consist of members not very much unlike one another in ability and all subject to the same risks. It is therefore proper that in insuring against any given emergency they should bear equal burdens. Some members will of course gain more than others by organizing themselves in this way, but it is of the essence of insurance that it should be uncertain as to which individuals are going to benefit most.

Now who should administer out-of-work benefits? Shall it be a national or local organization?

The question is of extreme importance. While there is much to be said for a body like the German Typesetters' Local No. 7 administering its own funds, yet in the main the view of James M. Lynch, former President of the International Typographical Union,* with regard to sick benefit, applies with even greater force to outof-work benefit.

"My own impression," he writes, "is that international benefits are in every way more desirable, have a greater guarantee of permanency and are more efficiently administered than local benefits."

One of the main causes for the comparatively small attention devoted to benefit features by the United States trade unions has hitherto been the inability of the international unions to acquire jurisdiction over the establishment and extension of such features. It is difficult to bring locals that have to support their benefit funds to consent to increase the tax to such an

* Trade unions with members in different States are generally known as International Unions. Justification may be sought for the title in the fact that certain locals of these unions are to be found also in Canada. 


\section{INSURANCE AGAINST UNEMPLOYMENT 407}

amount as would enable the International to secure the means for taking control. It is extremely doubtful whether any great increase in such activities is likely until the national unions gain this function as their own.

The introduction of a national out-of-work benefit has been much discussed in many important unions. Every industrial depression has resulted in deliberation over this matter. But hitherto they have resulted in little more that was concrete than the working out of immediate schemes of relief, the funds for which were collected by raising special assessments.

The International Typographical Union,* the Boot and Shoe Workers' Union, and the Brotherhood of Carpenters have often discussed the question seriously. In I902, for example, at their annual convention the Boot and Shoe Workers' Union recommended that all local unions raise funds for the payment of dues of outof-work members "to the end that from the experience so gained a national plan for relief of unemployed members may be developed."

* Typographical Journal, vol. 46, No. I, p. 47. 


\section{TRADE UNION POLICY AND OUT-OF-WORK BENEFITS}

TRADE unions undoubtedly have certain advantages in operating schemes of unemployment insurance. First, they may realize within their domain "the ideal of universality through compulsion." It becomes obligatory on all members to pay dues and help administer the union scheme. Secondly, by allowing only steady work men to join the union the danger of a certain group of members frequently claiming benefits or of "falling out" of benefits is greatly lessened. Thirdly, the uniformity in exposure to unemployment which must result from all members of the fund belonging to the same trade diminishes, if it does not entirely remove, the likelihood that one group of workmen will in effect be subsidizing another group. Fourthly, and most important, is the fact that many unions act as an employment exchange for their unemployed members, whilst fellow-members assist by informing the union office when vacancies occur. The union member, therefore, other things being equal, has a better chance of finding employment than a non-union workman, and thus, on the whole, is less likely to make as many claims on his insurance fund.* Malingering, too, always a serious matter with respect to private insurance companies, is reduced to a minimum when fellow-workers who know a man intimately have an interest in reporting any lapse from strict honesty.

* Cf., however, First Annual Report on Unemployment Insurance in Great Britain, Cd. 6965 . 
Trade unions also possess an advantage in being able, by means of assessments levied upon members or otherwise, to adjust the income of the union to the demands made upon it by its insurance policy. Such assessments would not need to be levied at all, of course, if actuarially sound schemes were introduced from the very outset. But where this is difficult, and even impossible, the consideration that trade unions can arrange schemes which have a degree of elasticity gives them a great advantage.

Lastly, it must be noted with regard to unemployment in the United States, that the workman has no other means of insuring against it than is offered by his union. Saving is almost impossible to a large percentage of workmen. Even if, therefore, it could be proved that other organizations can provide life or sickness insurance cheaper it might still be better for the workman to obtain trade union insurance, even against these emergencies, since it alone can furnish him also with unemployment insurance.

\section{Insurance is not merely a Method, but the Fundamental Idea Underlying all Trade Union Activity.} that

Mr. and Mrs. Sidney Webb have well pointed out in a certain sense it would not be difficult to regard all the activities of trade unionism as forms of mutual insurance. Whether the purpose be the fixing of a list of piecework prices, the promotion of a new factory bill, or the defence of a member against a prosecution for picketing, we see the contributions, subscribed equally in the past by all the members, applied in ways which benefit unequally particular individuals or particular sections among them, independently of the amount which these individuals or sections may themselves have contributed.

This same characteristic of trade union activity is manifested whenever special assessments are raised. These take the form of levies based on a percentage of wages, or of lump sum assessments, or of the with- 
drawal of an amount from the union's accumulated funds. In America the method of assessment is resorted to very often, certainly much more often than in Great Britain. It is easy to see why. The high contributions and their regularity furnish the British unions with sufficient resources to meet all the expected emergencies of their members. In fact, contributions are calculated on that basis. In America, trade unions endeavour to keep their contributions as low as possible, merely sufficient to carry them over industrial disputes, and thus cannot afford to arrange for a benefit system.

The more trade unions ignore the principle of mutual insurance, however, the more often are they forced to make arrangements embodying its fundamental idea. During periods of unemployment, or when members suffer accidents, or during strikes, in short, whenever the union feels that it is necessary to protect itself or the long-time interests of its members, a post facto distribution of risks actually takes place.

Trade unions do not in practice ignore the emergencies that befall workmen. They cannot, and indeed dare not, do so if they are to remain in existence. The issue is therefore clear between special assessment and mutual insurance as the best means for meeting these emergencies. Shall such emergencies be met through sporadic and intermittent activities or shall they be treated with foresight, and preparations be made before they occur?

\section{Assessments versus Mutual Insurance.}

There can be little doubt that the method of special assessment tends to reduce the stability of trade union organization by subjecting it frequently to severe strains, and it accomplishes its special function, the immediate provision of a minimum of funds to its members, with harmful results to those assessed and to those who receive benefits. First, the assessment is generally levied on workmen who are themselves badly hit by 
the same causes that have produced the given emergency. Thus if out of a local with I,000 members Ioo are out of work, the likelihood is that the other 900 on whom the assessment is levied are themselves working part time. Second, the raising of such levies causes members to leave their unions. Third, it is humiliating to the members temporarily in need to have to be dependent on the goodwill of those who provide the assessment. Fourth, they cannot be sure that the assessment will be raised and the benefits provided, and even if raised once whether it will be raised again sufficiently often to provide for them until they resume normal conditions.

\section{Objections to Mutual Insurance.}

Occasionally, however, it has been urged, more often, be it noted, in the United States than in the western countries of Europe, that collective bargaining for higher wages, lesser hours, and better trade conditions is the sole legitimate method for trade unions to adopt. But surely to ignore the methods of mutual insurance and of legal enactment, and to restrict organized labour in this way, is needlessly to hamper its activity. This policy, if adopted, would tend to stultify trade union growth and make permanent an activity found most suitable at one particular period. All methods are legitimate by which labour can gain " an ever-improving lot," and the method of mutual insurance has long justified itself by experience as one of the most effective weapons for attaining it.

\section{Objections to Union Out-of-work Schemes.}

The usefulness of out-of-work insurance to trade union organization is attested to by its age. "The simplest and universal function of trades societies," it was reported by a British scientific association in I860, "is enabling the workman to maintain himself 


\section{INSURANCE AGAINST UNEMPLOYMENT}

while casually out of employment or travelling in search of it." In Great Britain out-of-work benefits have been provided for some two centuries. In America, too, the one great union that has experimented with out-of-work benefits has now over thirty years of successful experience.

Yet there are some very strong objections from the workman's point of view towards schemes of union out-of-work benefits, regarded merely as a business venture.

He has no legal claim to his benefit, and he is not certain that the policy of the trade union will not necessitate the expenditure of the funds for purposes other than those for which they were raised. Unlike friendly societies and the private insurance companies, trade unions do not enter into any legally binding contract with their members. It follows, therefore, that a member of a union who has paid his dues for years may at any moment be expelled from it, and his rights to insurance benefits may thus be forfeited. Or again, his assessments may be increased against his wishes. On the other hand, his benefits may at any time be altered, even to the extent of their abolition. This actually occurred with the out-of-work benefit scheme of Typographical Union "Six" in 1907.

It is also a great drawback to the member's sense of security that the funds to which he contributed may be used for entirely different purposes. "Funds devoted to life insurance and the money which may have been contributed for the purpose of insuring against sickness or old age may be used in a great strike or expended in out-of-work benefits during a prolonged commercial depression." * In trade unions there is no guarantee that any of the funds will be reserved for the purposes for which they were accumulated. During the winter of I9I4-I5, for example, the Builders' Union took two hundred and fifty thousand dollars from its mortuary fund for the benefit of unemployed members.

- John Mitchell : Organized Labour. 
Perhaps, however, one of the most severe objections to trade union benefit schemes is the one already noted, that in periods of trade depression, when members are in sore straits themselves, they are often forced to pay an increase on their usual dues, or extra levies, on pain of being expelled from the union and thus debarred from benefits.

These theoretical disadvantages, however, do not in actual practice have very much weight. As a rule trade unions have been able to meet the obligations which they have incurred toward their members at least as well as private organizations. They do, however, demonstrate the advisability of unions running separate and distinct funds actuarially sound against different emergencies and of keeping large reserves in order to avoid having recourse to other funds and to the levying of special assessments.

It has been said by opponents of trade union schemes of out-of-work benefits that while sick and death payments bear certain approximate proportions to the membership of the union, the number of unemployed members is dependent solely upon trade conditions which in case of industrial depressions might increase so rapidly as to swamp the union funds. To this there is the ready answer that, taking a long sweep of years, an industrial depression does not appear as an incalculable "act of God." Trade unions can build up reserves to meet these emergencies. It is one of the merits of long-lived organizations such as trade unions that they have a corporate memory and corporate experience, so that the policy of large reserves with which to face trade depressions can easily be transmitted.

There is some force in the argument that high dues tend to lower the membership of unions. But when it is recalled that on the whole the American workman earns about 50 per cent. more than the British workman and that his scale of contributions to his trade union is probably lower, it is seen that this consideration is not important. The experience of the Cigar Makers' 


\section{INSURANCE AGAINST UNEMPLOYMENT}

Union and of Typographical Union Locals No. 6 and No. 7 show that it is not the scale of contributions that matters so much to the member, but rather what is done with them. The advantages offered to members are so very great when the union pursues a sound policy that the absolute amount of contributions matters but little. Indeed, it is a safe conclusion that the advantages resulting from high payments, the creation of a strong organization and the provision of a chain of benefits, tend, on the whole, to attract new members.

\section{Advantages of Out-of-work Benefits.}

The most obvious reason for introducing schemes of out-of-work benefits is to relieve the distress of unemployed members. Benefits granted during an emergency are the most direct benefit derived by workmen from their unions. To prevent members from having to become dependent on charity has long been an aim of workmen's associations, and it is still a frequent claim of trade unions that their members very rarely have recourse to public aid.

It has always been clear that benefits have also a great influence in furthering the main object of the union, viz. the improvement of trade conditions. At the Convention of the Cigar Makers' Union in I885, President Strasser argued that the success of strikes was jeopardized by the existence of unemployed :*

A member of the union (he said), who is out of work for a long period, is in danger of soon being out of the union. If the number of the unemployed is large, demoralization steps in, and it becomes difficult to maintain the rate of wages.

In 1887 he urged the paying of benefits to the unemployed members.

By supporting our members in such emergency they will have no excuse for working below the regular scale; nor will they have an excuse for accepting conditions of employment which are

- Supplement to the Cigar Makers' Official Journal, September 18, 1883. 
injurious to the interests of their fellow-workmen. It will instil into them more manhood and independence to resist encroachments of employers in time of depression. It will be the strongest feature to maintain the rate of wages which has been secured during the favourable seasons of trade.*

Although the cost of providing this benefit is high and although unions providing it generally have an employment office which endeavours to find the unemployed member work and all its members are enjoined to find and have an interest in finding him work, and he is forbidden to refuse a situation when offered to him on pain of very heavy penalties, yet he is warned against accepting it unless it is at the union rate and under union conditions. The chief object of out-of-work benefits in the mind of the most thoughtful trade unionists is to prevent the "nibbling away" of their standard conditions during periods of depression, through the competition of unemployed members.

Mr. John Mitchell also urges that benefits are subordinate to the trade policy of the unions. The workman may derive an advantage from the support of his family and himself when is he out of work; but the aim of the union is not merely to arrange for this benefit, but to protect the wage of the men actually at work.

Thus, if wages in an occupation are twelve dollars a week, the union prefers that an unemployed man receive from union funds an out-of-work benefit of four or five dollars a week rather than accept employment at ten dollars a week, or at any other rate below the union scale. $\uparrow$

Another reason for introducing a chain of benefits which commends itself to the trade union mind is the fact that it tends to have a steadying effect on the growth of the union introducing it. The steady increase in membership of the English organizations contrasts with the fluctuations in the size of the American labour

- Proceedings of the Seventeenth Annual Session of the International Cigar Makers' Union.

$\uparrow$ John Mitchell: Organized Labour, p. 105. 


\section{INSURANCE AGAINST UNEMPLOYMENT}

bodies and the difference may be assigned in a large measure to this cause. This view has been borne out by the slow but certain growth of the Cigar Makers' Union since its formation some thirty-six years ago.

This is seen in a more marked manner when the effects of the industrial depression of I9I4-I5 on the Cigar Makers' Union are compared with their effects on the rest of organized labour. The former suffered the loss of one member out of every three hundred in the union, the latter of eleven out of every three hundred.*

International President Perkins was therefore justified in his view that "The effect upon the loyalty of the members is remarkable, inasmuch as it lessens the suspensions and has a tendency to make the organization more permanent."

\section{Benefits in General.}

It is manifest that " every additional benefit contingent upon membership in a union is an additional tie to be broken before a man can bring himself to the point where he is willing to throw away all that membership means." The existence of benefits is particularly important to a union during long periods of industrial peace. It is then when membership tends to fall off that the presence of tangible common interests keeps members together.

There is also a type of workman who is attracted to a union by benefit features. It is for him the readiest way of insuring against contingencies against which he and his family need protection. $\mathrm{He}$ is anxious to avail himself of the benefits offered, and his enthusiasm is maintained by the thought of securing relief in times

* "Despite the terrific adverse conditions in so far as employment is concerned, we lost during the year only I 79 members" (Cigar Makers" Journal, vol. xxxix, No. 4, p. 2). The total membership during the year was 48,500 .

The Organized Labour Movement lost 75,000 out of a total membership of 2,000,000.-American Federation Annual Report, I9I5. 
of unemployment, of sickness or accident, or provision for his family in case of death.

Furthermore, the discipline of the union is helped by the existence of a scheme of benefits. Obviously, the power of expulsion, always a very significant instrument possessed by unions, becomes much more important when expulsion of the cantankerous member involves for him the loss of insurance benefits. As President Perkins says :

They usually make better fighters during times of strike, and, as they become imbued with the spirit that loss of membership means a serious financial loss both to themselves and their families, they are more loyal.

Benefit schemes thus help the unions to preserve their internal discipline and their ability to face conflicts with greater chance of success.

That trade unions which possess large funds tend to become conservative has often been observed. The hope of securing insurance benefits, it is said, renders members more cautious and less willing to jeopardize the union's funds in useless or unwarranted labour conflicts. On the other hand, when they do engage in any conflict, they are more likely to win than if they were without funds. Their attitude is expressed in the popular song familiar to England during the RussoTurkish War:

We don't want to fight, but by Jingo if we do,

We've got the ships, we've got the men, we've got the money too!

In addition to the strength resulting from the existence of such funds on which the trade unions may draw, there is the more important consideration that their members tend to have a keen sense of loyalty.

In general, there can be little doubt that in the interests of the unions strikes should be entered into only after all the resources of peaceful persuasion have been exhausted, after they are reasonably certain to have the general public with them and their funds are 


\section{8

large enough to hold out for at least as long as the strike is reasonably likely to last.

But it must not be forgotten that it is not a sign of strength, but rather a sign of weakness, for a union to have to declare strikes constantly. "Moral suasion," and the threat of a strike, are, as a rule, capable of achieving as much as an open declaration of hostility, and the presence of a wealthy well-organized union is one of the workman's best arguments.

As the President of the International Moulders' Union of America wrote :

The moral effect of a substantial reserve in the trade union treasury is a powerful one upon the workmen and employers alike. The very fact that the workmen will contribute year after year for the purpose of self-protection conveys the impression that there is something substantial about the men and their organization.*

We can, therefore, understand why, "looking the field over as it is to-day, we find that the international unions, without exception, whose members pay the highest dues and accumulate adequate defence funds, are making the most progress, while the organizations with the poorest financial systems or basis lag farthest behind in the march towards improved terms of employment."

Thus the very conservatism engendered by the possession of funds, and the resources at their disposal, increase the chances of unions with benefit features winning in their struggle with employers.

We now see how what at first sight seems to be nothing more than merely mutual provision of support when out of work, or against some other emergency, is actually one of the most important instruments at the disposal of workmen for maintaining and improving their conditions. $\uparrow$

* Joseph F. Valentine: American Federationist, April 1915, "Make Unionism Effective."

$\dagger$ It is because organized labour as a whole has been slow to appreciate this that out-of-work and other benefits have hitherto played so little part in the growth of trade unionism in the U.S.A. 
As far back as 1887 the President of the Cigar Makers' Union said :

The protective and benevolent features are the corner-stone upon which the structure of our organization rests. They are a means of cementing the feelings of brotherhood throughout the union, and help to encourage every member in the good work of supporting the best interests of the trade.

Mutual insurance as well as collective bargaining have been found to be powerful devices for achieving an improvement in the conditions of labour.*

It should, however, be noted that the actuarial basis of the insurance benefits of certain unions is not sound. Often sickness, accident, old age, and unemployment insurance are indiscriminately treated through one fund. $\dagger$ But with the wisdom that comes from daily experience there comes increasing differentiation. The general fund is divided into different funds for different purposes, until each of the contingencies against which workmen insure is organized on a scientific actuarial basis.

We therefore conclude that trade unions are well advised to employ the method of mutual insurance against unemployment, because by its means the conditions of labour may be improved, and that the organization of the unions is well adapted-towards achieving that improvement.

\section{The Future of Mutual Insurance.}

But will American trade unions employ the method of mutual insurance even though it is advantageous for them to do so ?

That trade unions have in recent years come to appreciate how important benefit features are is clearly demonstrated by the fact that in the majority of the early national trade unions these features were not instituted until many years after such national unions

* President A. Strasser.

+ Whilst criticizing existing schemes of trade union benefit features, it is only proper to keep in mind that private insurance companies too have their faults and drawbacks. 
were organized, while in many of the national unions organized since I880 benefit features were instituted either at the time of organization or shortly afterwards. Moreover, the industrial depressions in I9I4-I5 and $\mathrm{I} 920-2 \mathrm{I}$ have made many unions inquire more particularly into the possibility of instituting out-ofwork benefits.*

At the Annual Convention of the American Federation of Labour held at Seattle in November I9I3 the problem of social insurance was for the first time in the history of that body approached in a manner which indicated a full appreciation of its significance. It was resolved :

That the Executive Council of the American Federation of Labour be and is hereby authorized and instructed to make an exhaustive investigation and study of this whole matter and report to the next convention: First, the cost of the payment of each of these benefits (strike, unemployment, old age, partial disability, sick and death benefit and other benefits) to the union now paying them ; second, a skeleton law covering and applicable to all unions; third, a report on the laws of other countries and cost of insurance to those insured by private companies; fourth, the advisability of the American Federation of Labour establishing an insurance department for the purpose set forth in the foregoing, such department to run without profit, and in which membership in or affiliation to shall be absolutely voluntary.

The executive, in its report on this subject, shows that it paid considerable attention to the problem of social insurance, and that its attitude was not merely that of a group of interested people, but rather of a group growing aware of the difficulties and prepared to face them.

As to the advisability of an insurance department

* It seems that a period of extreme unemployment is necessary before the unions come to appreciate the need of insuring against it. But there can be little doubt that the objections to special assessments, their uncertainty, their inadequacy, and their destructive effect on trade union policy, will compel unions paying them to institute stable schemes of unemployment insurance. Unions forced to raise special assessments or special weekly taxes or to draw on other funds in order to provide relief to unemployed members are well on the way to instituting schemes of unemployment insurance. 
for the American Federation of Labour, the Philadelphia report of I9I4 stated:

We endorse the proposal to the extent of approving of a serious study of the first steps of organization and administration. (It adds) : Insurance should be inaugurated with the straight life, and then extended to other forms of benefits as experience and resources warrant.

Here we have clear evidence of a change of policy or rather of a growth of functions of trade unions, and the fact that there are no signs of objection shows the favourable auspices under which the new departure is taking place.

Of course the customary, and in this case justified, caution of the American Federation of Labour makes it unlikely that unemployment insurance will be included as one of the emergencies against which the new society will insure workmen, at least at the very outset. Yet the growing interest in the unemployment problem, and even its determination to effect some remedy or method of relief, shows that it is merely a matter of time and the finding of available resources before unemployment insurance will be regarded as a normal trade union activity.*

It is evident from what has been said that (I) the amount annually distributed in out-of-work benefits by trade unions is very small; that (2) trade unions are

* It is interesting to recall that Mr. Samuel Gompers, who spent his early years as a workman in London, where he learnt the value of trade union insurance features, and now President of the American Federation of Labour, framed the measure of unemployment insurance for the Cigar Makers' Union which was adopted in r889. Until r915 he did not, apparently, think that the time had come for embarking upon this new activity. But in April I9I6 Mr. Gompers presented a "Bill to create a commission to inquire into the subject of unemployment, of disability and of sickness of wage-earners of the United States, and to what extent the Government of the United States can aid, financially and otherwise, in the mitigation thereof by voluntary social insurance," before the Committee on Labour (see H. J. Res, No. I59, p. I22). We have already seen that although Mr. Gompers is a warm advocate of voluntary insurance schemes he will have nothing to do with compulsory insurance schemes. Indeed, Professor H. R. Seager, in his presidential address to the American Labour Legislation Association in 1916, referred to the policy of that wing of the American Federation of Labour whom Mr. Gompers represents as one of the three great forces hindering progressive labour legislation. 
likely to extend their benefit functions, including outof-work benefits, in the near future; and that (3) trade unions are well adapted for carrying out that activity.

\section{Should Trade Union Out-of-work Funds be Subsidized?}

It has been suggested that since it is a matter of general interest and for the general good that trade unions should carry out insurance activities, therefore public recognition of this fact should take the form of a subsidy to trade unions paying out-of-work benefits. In this way, it is opined, trade unions will extend this feature of their work and thus help in a very large measure to overcome the evils of unemployment, at least for their own members.

There can be little doubt that a scheme which has already proved beneficial in at least nine countries is likely to prove serviceable in the States. Can it, however, be expected that a national system, or even a State system, based on this principle of subsidizing trade unions, will alone achieve substantial results during the next few years? Will this be a measure calculated to enable the community to cope adequately with " the greatest and most extended of social evils?"

Dr. Lee K. Frankel, Vice-President of the Metropolitan Life Insurance Company, has advocated that the Ghent plan of subsidizing trade union out-of-work benefits be adopted in this country. He said: "If unemployment insurance is really considered favourably, the labour unions are the organizations through which it should be conducted, and the Danish scheme, of all that I have had any opportunity of studying, does seem to have given, so far at least, the best results." * It seems clear that Dr. Frankel anticipates that the granting of such subsidies is all that need be done in the U.S.A. in the way of providing unemployment insurance.

* American Labour Legislation Review, vol. iv, Sec. 2, p. 337. 
There are a number of valid objections to this proposal. At the outset it must be insisted upon that there is little comparison in this connection between America and Denmark, for American workmen have hitherto lacked " the high social development of Danish workmen and their comprehension of the importance of unemployment insurance." * In no country in the world is the proportion of the working class that belongs to trade unions so high as in Denmark. There it is estimated to be over 55 per cent. of the wageearning classes. More than half of the trade unions provided out-of-work benefits when the law of 1907 was passed. At the close of that year there were 64,789 members so insured. In the United States it is safe to say that not many more than that number out of a total of some twenty million employees are to-day members of unions granting money out-of-work benefits. Moreover, because of the fact that such benefits are rare it cannot be expected that the mere grant of a State subsidy will have great influence in increasing the number of unions paying benefits for some years to come.

It is a characteristic of trade unions that they rely very much on their own experience and are naturally enough suspicious of outside advice and help. Trade unions will educate one another as to the need for any advantages of unemployment insurance, and until that education is more widely spread subsidies will have comparatively little influence.

Assuming even that within the next few years the trade unions paying death and sickness benefit-generally the first benefit features-extend their benefits to cover out of work, and assuming further that all trade unions will come to develop a complete chain of benefits, we shall then only have subsidized the best organized workmen who are least in need of insurance benefits, since it is universally conceded that trade unions

* Twenty-fourth Annual Report of the Commission of Labour: Workmen's Insurance and Compensation System in Eitrope, vol. i. p. 666. 
generally contain the skilled workers earning comparatively ligh wages.

It is the unskilled casual workers who have little or no organization that constitute the most serious and considerable section of the unemployed. It is they who suffer most in periods of depression, and it is they who have the greatest claim to the legislators' attention. These workers are, as a rule, too badly and irregularly paid to be able to afford labour unions with benefit features. Wherever attempts are being made to introduce organization among unskilled labourers-and this task has been undertaken with great enthusiasm in France, Great Britain, and America in recent years-it has been found necessary to brush aside all thought of plans of insurance against sickness, accident, old age or unemployment. It would be impossible, therefore, to include these organizations or others like them that may grow up under the stimulus of the new unionism in the system of trade union subsidies.

Let us assume that even this difficulty did not exist, we should then have the task of convincing the taxpayer that this subsidy ought. to be made to trade unions, i.e. that trade unions ought to be recognized and supported by the State.

Although this has been effected, as already stated, in nine countries in Europe, it is evident that it will necessitate a great deal of education before the change in public opinion towards trade unions which it implies will take place in the United States.

The recent happenings at Bayonne, the Colorado riots, the railroad riots in New York, and the unscrupulous attitude of certain groups of employers, show that trade unions are not likely to be recognized as the best organizations for carrying out certain necessary functions for both the workers and the State for some. time.

The final objections to Dr. Frankel's proposal follows from the consideration that even those countries which are to-day subsidizing trade unions paying out-of-work 
benefits are contemplating the advisability of introducing national compulsory schemes. The successful working of the British National Insurance Act proved conclusively the practicability of compulsory unemployment insurance, and other countries, in addition to Italy and Austria, conscious through experience of the limitations of the Ghent system, are likely to resort to the compulsory principle. Indeed, the general tendency in Europe is towards compulsory schemes not only of unemployment insurance but of all branches of social insurance.

It is in harmony with this tendency that the International Association on Unemployment " took note" of the following conclusions presented by Professor Fuster at its conference held in Ghent in September I9I3.

The statements made by the authorities who reported on the problem, based as they were on the experience gained in the United Kingdom and elsewhere, lead to the conclusion that there is a general trend of opinion :

I. Towards compulsory insurance at least for certain trades with contributions from the employers, the employees, and the public authorities respectively, supplemented by measures to encourage voluntary insurance.

2. Towards the view that the principal function of a system of insurance against unemployment should be to find work for insured persons, and that the organization of employment exchanges is essential for such insurance.

3. Towards the organization of insurance in co-operation with trade associations.

Factory life and competitive industry forces the workman to submit to conditions in which he is subject to many contingencies. His poverty or indifference have hitherto made him unprepared to meet the burdens of industrial accidents, sickness and unemployment, and so governments have been forced to resort to 
compulsory national schemes as the most effective means of meeting them.

At most Dr. Frankel's proposal, if applied, would help only a very few of the aristocracy of labour within the course of many years. But the need of the United States to-day is for a scheme which will enable it to grapple with the problem of unemployment at once.

Our conclusion must therefore be that while trade unions will gain from engaging in this activity and public encouragement might in time be given them in order to increase it, yet very little can be attained along these lines for reducing the effects of unemployment.

As to the attitude of the trade unionists towards some form of Government scheme of unemployment insurance, the American Federation of Labour, at its convention in Seattle in I9I3, recommended that the executive committee " take up the question of Government pension in some form for those unable to secure employment."

The situation to-day is this: Few trade unionists make any provision against unemployment; they are growing increasingly interested in some Government plan of unemployment insurance.

Let us note the more obvious signs of the growth of a "movement" in favour of unemployment insurance.

\section{Growth of the Movement in Favour of Unemployment Insurance in the United States.}

The successful inauguration of the British scheme of unemployment insurance, as well as the serious unemployment crisis of I9I4-I5 and I920-I, are responsible for the growth of a movement in favour of a scheme of unemployment insurance. Not only were private studies and discussions begun, but even State and national legislatures held hearings on the subject with a view to the appointment of commissions and the suggestion of legislation. We have seen evidence of the growing interest in this problem by the American 
Federation of Labour. The Socialist Party, on its national and State platforms, has declared in favour of national schemes of social insurance, which would, of course, include insurance against unemployment.*

The Oregon Committee on Seasonal Employment recommends both unemployment insurance and compulsory savings as means for lessening the evil effects of unemployment. $\dagger$ A study of The Unemployed in Philadelphia, carried on by the Department of Public Works of that city, concludes that the city government shall " eventually administer unemployment insurance when that plan shall have become practicable." $\ddagger$

The American Federation of Labour, in its recommendations to the New York State Constitutional Convention of $19 \mathrm{I} 5$, proposed that unemployment insurance be held constitutional.

Both the New England and the International Typographical Unions have recently resolved that they are " heartily in favour of the principles of unemployment insurance which gives out-of-work benefits to working men legitimately unemployed, and it is earnestly urged that legislation along these lines may be speedily submitted to the general courts of the different States." A similar expression was adopted at the I9I5 convention of the Massachusetts State Federation of Labour.\|

A State Commission of New York which studied the unemployment problem, whilst commending the principles of subventions to the unions, concluded that the application of the Ghent system would be premature in the United States because of the absence of exact

* The Socialist leader, Mr. Algernon Lee, states: "What the Socialist Party proposes is State insurance of unemployment, the cost to be paid by the industries, without any tax on the workers, a non-contributing system just as we have insurance against accidents." This is the recognized policy of the Socialist Party of America.

+ See Survey, October 17, 1916.

$\ddagger$ See The Unemployed in Philadelphia, p. 9.

$\$$ From this it must not be taken to mean that a scheme of unemployment insurance if proposed in New York State would necessarily be unconstitutional. There is great weight for the contrary view.

II See Massachusetts Committee on Unemployment, Bulletin No. 2, pp. 9, Iо, January I9I6. 


\section{INSURANCE AGAINST UNEMPLOYMENT}

information on the average duration of unemployment in different industries.*

On the other hand, most commissions have been very favourable toward the idea of unemployment insurance.

In Chicago three commissions were appointed to deal with the unemployment situation of I9I5. All three, the Mayor's Commission on Unemployment, the City Markets Commission, and the City Council Advisory Commission, came to the conclusion that unemployment insurance ought to be introduced at the earliest possible moment, "So that when the next great crisis comes in the life of the unemployed and their families a fund will be available to meet the more urgent demands of existence." $\dagger$

The report on unemployment issued by the Commission of Immigration and Housing of California in December I9I4 recommended to the Governor the appointment of a special committee or designation of some existing commission to conduct an extended investigation into "the wisdom of devising some scheme for out-of-work insurance that will not have the effect of drawing into our State the unemployed of the nation."

Whilst, however, it might be said that great interest was evinced in this proposal, Massachusetts was the only State in which a Bill on the subject was proposed to the legislature. The Massachusetts Committee on Unemployment, in co-operation with the American Association for Labour Legislation, proposed a scheme of unemployment insurance for that State.

National bodies have not ignored this problem. The Industrial Relations Commission reported on it and a Congress Committee held hearings on it in I9I6.

* See p. II5. New York State Commission on Unemployment, I9 I , p. I3, Third Report.

$\dagger$ The State of Michigan passed a law in I9I5 authorizing not less than five railway conductors, engineers, and officials to form mutual companies for the purpose of insuring themselves against loss of position by discharge or retirement.--United States Bureau of Labour Statistics, Bulletin, Whole No. 186. 
The final report of the Commission on Industrial Relations recommended the investigation and preparation of plans for insurance against unemployment " in such trades and industries as may seem desirable." *

Congressman Meyer London introduced the following joint resolution in the House of Representatives in February I9I6: "For the appointment of a commission to prepare and recommend a plan for the establishment of a national insurance fund and for the mitigation of the evil of unemployment." This resolution was referred to the Committee on Labour, and hearings were held in April of that year. $\dagger$ This was the first hearing on social insurance ever held by a Congressional Committee.

It is certain that the great depression of I920-I, with the very large amount of unemployment in which it has resulted, will also result in a considerable amount of discussion. Legislation, unless it be provision for relief along the traditional lines, is not to be expected. But it is already evident that unemployment of four to five and a half millions cannot be provided for through such effete machinery.

The schemes that follow for dealing with unemployment are based on a study of the problem in the United States. Two main considerations will influence all proposals for dealing with it. First, there is a bitter hostility between employers and trade unions. The former miss no opportunity of destroying existing trade unions and in preventing the inception of new ones. The trade union officials do not yet put forward the claims that each industry shall bear the burden of its unemployed, and that the trade union is the proper organization through which effect can be given to it. Second, a State scheme of unemployment insurance with contributions from the State, the employers, and the employees is to-day the only feasible one. 


\section{OUTLINES OF A NATIONAL UNEMPLOYMENT PROGRAMME FOR THE UNITED STATES}

THE somewhat lengthy discussions of the efforts to treat the unemployment problem in the United Kingdom and the survey of the experiments of other European countries may help in the development of a programme for the United States. In the United Kingdom, as we saw, there was a general plan with special machinery for treating unemployment in its various manifestations. Then we examined in detail the working of part of that scheme, viz. the unemployment insurance section.* Let us also first endeavour to outline a national programme on the question of unemployment for the United States and take up in a later chapter some consideration of the proposal of unemployment insurance.

The inadequate statistics, the lack of a national centralized system of public employment exchanges, the abuses of private employment exchanges, the still persisting naive faith in the efficacy of relief works, the theoretical nature of most discussions of unemployment in the States, are due to these two fundamental needs, a national programme and one governmental body whose function it is to deal with the evil. At present the national, State, and municipal authorities all pursue their own activities during periods of unemployment, but they do not have a programme which they each can carry out effectively. There must neces-

* Special interest attaches to the Labour Party's Prevention of Unemployment Bill, which obtained a second reading on March 21, I919.

See also Unemployment: A Labour Policy, London, r92. 
sarily be continuous close co-operation between these bodies if satisfactory action is to be taken. In addition a scheme ought to be worked out whereby some one department in the Federal Government will be held responsible for treating with unemployment. Until now little better than a state of chaos may be said to have existed. Thus, for example, the Bureau of Immigration, the Post Office Department and the Department of Labour all have different and changing functions in treating the unemployment problem, whilst the Departments of Commerce, Agriculture, and the Interior, which are very definitely concerned in it, do not co-operate sufficiently in its solution.

All the responsibility of the Federal Government for the problem of unemployment should therefore be centred in a Bureau of Employment. The commissioner of the bureau should be responsible for the four departments into which it should be divided at the outset.*

\section{Information Department.}

II. Employment Exchange Department, with a division to administer unemployment insurance.

* The Ontario Commission on Unemployment, in its report (1916, p. I2), recommended the organization of a permanent Provincial Labour Commission-

(I) To administer a system of free public employment bureaux ;

(2) To control private employment offices ;

(3) To co-operate with rural and urban committees in regard to vocational guidance, extension of the school age, development of local rural interests and the extension of technical, trade, agricultural and domestic training ;

(4) To develop an adequate system of statistics ;

(5) To interpret these statistics so that the causes of unemployment and other features of labour problems may be more generally understood, and that constructive measures of prevention may be brought to the attention of workmen, employers and public authorities ;

(6) To bring the knowledge and experience of other countries to bear upon Canadian labour problems ;

(7) To further the organization of provincial employment bureaux throughout Canada with a view to their ultimate linking together in an effective national system.

Doubtless this Commission would also administer any scheme of unemployment insurance that may be adopted. It is also to study seasonal occupations, "with a view to their greater regularization, and to the better adjustment of the supply of and the demand for labour." 


\section{INSURANCE AGAINST UNEMPLOYMENT}

III. Vocational Guidance Department.

IV. Distribution of Public Works Department.

The work of the proposed Bureau of Employment will be greatly facilitated if those directly interested in it be invited to co-operate. Indeed, the system of democratic committees, which, as we have seen, has worked successfully in the United Kingdom, ought to be adopted and even extended and incorporated into any proposal for establishing such a centralized organization.

Thus a special Federal Employment Board made up of representatives of the Departments of Agriculture, Commerce, Labour, Interior, the Board of Army Engineers, the Immigration Bureau, Census Bureaux, and any other Federal office that distributes substantial orders for work or has means of knowing the state of employment in different parts of the country, should be created to co-operate with the Commissioner of Employment.

The aim of the Board of Employment should be to work out a national scheme for treating unemployment, to develop a programme outlining what the Federal Government should do, and to help States plan their schemes for meeting the problem; to provide a continuous body of information on the condition of employment in the United States and in other countries, and to offer forecasts of trade conditions so that the proper authorities can take suitable measures to avoid unnecessary loss and suffering. The backbone of a national scheme for treating unemployment must be a national centralized system of employment exchanges working in co-operation with State, municipal, and regional groups of employment exchanges. Without such a system, information dealing with unemployment must necessarily be inadequate, vocational guidance, if attempted, largely a matter of chance, the direction and distribution of public works fraught with the danger of aggravating the evils they are meant to diminish, the 
decasualization of labour an unrealized hope, and the separation of employable from unemployable workmen impossible. Nor will it be able to control effectively private employment agencies* until public employment exchanges set them an example of higher standards of efficiency.

\section{Information Department.}

The present lack of statistics dealing with unemployment could be remedied by an information department. In co-operation with the Census Bureau, the Federal Employment Service, the Bureau of Labour Statistics and other interested departments, it could arrange for frequent surveys. Through co-operation with employment exchanges, trade unions, and manufacturers, adequate monthly information dealing with the state of employment could in time be obtained. Perhaps in co-operation with universities in industrial cities studies of special trades could be begun and a satisfactory analysis of the causes of local unemployment obtained. Some of the most valuable information dealing with unemployment has come from the British Employment Exchange Department since its inauguration.

Advice to manufacturers, $\uparrow$ public service corporations, cities, and States could be given with respect to dovetailing work. Information as to the experience of other countries could be gathered and distributed.

* Many of the private cmployment agencies are nothing more nor less than "blackleg" centres, used for breaking strikes; others are part of the machinery of white-slave traffickers; a large number charge high fees for their services. These facts have brought all employment agencies in the United States run for private profit into ill repute.

$\dagger$ Dr. J. W. Schareschewsky, of the United States Marine Hospital Service in Pittsburgh, told the American Chemical Society (September 28, 1916) of one large chemical company which had invited the Federal health authorities to make a survey of their plants with the idea of installing any devices or making any changes which were likely to reduce the losses due to accidents and occupational diseases. This is one example of the effects of the Workmen's Compensation Acts. There is ground for the view that national measures on unemployment insurance could be made to result in a similar desire for information as to devices for the reduction of unemployment. 


\section{The Employment Exchange Department.}

English experience should encourage the United States to organize a comprehensive centralized system of employment exchanges. Much might, of course, be done in developing existing State schemes, but these must be supplemented and so adapted to one another as to be able to marshal all the labour forces in the country. States without any employment exchanges would have to introduce them.

In I9I8 the United States Employment Service had about 850 offices. The Federal employment offices developed under the Immigration Acts, 1907-I7, were taken over by the United States Employment Service of the Department of Labour when the country entered into the war. Special offices dealt with professional men, older men and women in a "handicap bureau," etc. The vacancies notified in I9I8 were 8,799,798, and the number placed was $3,099,295$.

There were only 96 State and city employment offices in I9I6; in the case of 60 the controlling authority was the State and in I5 cases the city.

Efforts were made by officials to find places for workers, and advertisements were used very widely. They did not merely wait for workers and employers to apply. When it is recalled that a small country like Great Britain has twice as many employment offices as the United States had during the war, it is evident that there was still room for great extension of this activity. Unfortunately the whole system of exchanges was dismantled, largely owing to political considerations.

\section{Activities of Employment Exchanges, 1918 to 1920.}

The Annual Report of the United States Federal Employment Service gives the following summary of its activities since its organization in January I9I8:- 


\begin{tabular}{lrr|r|r|r|r|r}
\hline & Year. & Registrations. & $\begin{array}{l}\text { Vacancies } \\
\text { Notified. }\end{array}$ & $\begin{array}{c}\text { Number } \\
\text { Submitted } \\
\text { for Jobs. }\end{array}$ & $\begin{array}{c}\text { Number } \\
\text { Placed. }\end{array}$ & $\begin{array}{c}\text { Total per } \\
\text { cent. of } \\
\text { Registra- } \\
\text { tion. }\end{array}$ \\
\hline I918 & $\ldots$ & $\ldots$ & $4,225,451$ & $8,929,005$ & $3,969,579$ & $3,091,821$ & $73 \cdot 2$ \\
1919 & $\ldots$ & $\ldots$ & $4,367,190$ & $4,857,264$ & $3,807,448$ & $2,920,839$ & $66 \cdot 9$ \\
1920 & (6 months) & $1,338,773$ & $1,496,819$ & $1,152,162$ & 833,368 & $73 \cdot 1$ \\
\hline
\end{tabular}

The understaffing and other evidence of inadequate supplies under which the existing public employment exchanges of the country are suffering would, of course, have to be remedied. It is absurd to allow the appointment of employment exchange officials even now to be part of the system of political spoils. The conditions of service ought to be like those of civil service appointments-adequate salaries to attract competent men, permanency of service during good behaviour, and fair opportunities of advancement.

We have seen that the British employment exchange system is on the whole successful because it is administered by men who are endeavouring to gain a thorough understanding of the needs of industry and who can therefore carefully select applicants and thus satisfy employers' requirements. Their present concentration on administering insurance features may be regarded as temporary, and their service to skilled labourers will increase with the extension of unemployment insurance.

In future, it is highly probable, the employment exchanges will be able to make a complete scientific analysis of the work of labourers in the different fields of industry, if the growth of "scientific management" should warrant it. Indeed, it has already been suggested that "The whole conception of the public employment exchange would be useless unless it were steadily more and more in possession of work analysis."*

* See article by Robert G. Valentine in The Survey, September 9, 1916, and also see British Association Committee, 1915 Report. The Question of Fatigue from the Economic Standpoint (British Ass. Report), Dr. P. Sargent Florence, pp. 7-1o. 


\section{INSURANCE AGAINST UNEMPLOYMENT}

That task, if ever undertaken, cannot and should not be made save by the joint association of labour, the employer, and the public. The employment exchange of the future will be under the supervision of these interests. It will supply labour on the basis of a scientific knowledge of demand and supply. It is manifest that even the best systems of employment exchanges, since they are employed almost exclusively with the placement of workmen, are as yet only in their infancy.

But in addition to this efficient service, neutrality between employers and workmen is essential. Confidence in the absolute impartiality of employment exchange officials, especially during the periods preceding and succeeding strikes, are the corner-stone of the British system.

The importance and prevalence of private employment agencies in the United States makes it essential that they should at the outset be part of the national system of employment exchanges. Their licensing, regulation, and supervision seems inevitable if unemployment is to be faced. Private employment agencies confining their activity to one State should come under State control, whilst those engaging in inter-State business should come under Federal control. It does not seem just to hound those who are engaged in this business out of their occupation, as is occasionally suggested, but all guilty of unfair methods should have their licences withdrawn. Their standards must be raised. If the public employment exchanges with their very great advantages cannot then offer a better service, it will be proof that the private agencies are fulfilling necessary social functions.*

In addition to finding work for unemployed workmen and workmen for vacancies, employment exchanges may aid in the decasualization of labour and thus aid in separating efficient from inefficient workmen. The cardinal principle in the placement of workmen should be " the best man for each job," so as to concentrate

* This argument is based on a realization of what is practicable in the United States to-day. 
employment on the most able workmen. Such a policy of decasualizing labour should be carried out in all parts of the United States.*

When the town of Bayonne (New Jersey) a few years ago went to the managers of the coalyards and asked that, instead of keeping twice the number of men actually needed on an average through the year in the constant expectation of occasional work, they should give notice definitely that they would give preference to married heads of families, and would, to the utmost of their ability, distribute their work in such a way that these permanent resident heads of families should be able to do it, and when the managers of the coalyards gave a favourable response to this suggestion and made it clear to a lot of men whom they had irregularly employed as casual labourers that there would be no work at all for them and that it would be well for them immediately to look elsewhere, there was, although on a small scale, a prophetic advance in the direction of a very essential readjustment. $\dagger$

We have also learnt from the experience of Great Britain that whilst employment exchanges ought as a rule to be open to applicants from all trades, special schemes confined to one class of labourers, such as longshoremen, have justified their inception. Such a scheme, if fully developed, will enable the policy advocated by Mathew Carey $\ddagger$ in his crusade in 1829 to be nearer to fruition. "Those wealthy ladies who employ seamstresses or washerwomen" were especially urged by him to give such wages as would not only yield " a present support" but also provision for times of sickness or scarcity of employment. In England, it has been advocated that

a ring should be drawn round each casual labour market by an efficient system of registration and a control of the entrance

* In carrying out a policy of decasualizing labour it is advisable to concentrate work on the best workmen, so that those who are "squeezed out" of industry might then be given special training or special nourishment to make them more efficient. But in order to lessen the number surrounding a factory or dependent on a given industry, it matters not whether the best or the worst, married or single, tall or short men are given work, as long as the group chosen is not changed.

+ See Misery and its Causes, p. r32, Professor E. T. Devine.

$\ddagger$ Report on Condition of Women and Child Wage-earners in United States, vol. ix, pp. 123, 124 . 


\section{INSURANCE AGAINST UNEMPLOYMENT}

to the occupation. In this way the number engaged may be adjusted to its needs, and if necessary it might be restricted. When this ring is drawn around each casual labour market, the employers should be obliged to make the best of the stagnant pools of labour which they have themselves created. The Government might then contrive that every man within the ring should be able to earn an annual living wage, distributed in approximately equal weekly payments.*

As applied to the best known type of casual labour, viz. dock labour, there are two rights which the dockers could and should demand from the Government. First, the right to limit the number of their competitors, and second, the right to be paid for service in the reserve as well as for service in the active rank. $\dagger$ These rights apply also, of course, to other highly casual employments.

We may summarize our conclusions on employment exchanges for the United States.

The supreme function of employment exchanges is to forestall unemployment as far as possible by a continuous observation and a methodical organization of the labour market.

The employment exchange must have the following principles and objects :-

I. The systematic organization of public employment exchanges according to territorial divisions (local bureaux, State and national), and they must take account of the interests of different trades and professional groups.

2. The unification of administrative technique, with the employment of modern means of communication, telephones, telegraphs, posts, railways.

3. The maintenance of absolute neutrality between contending claims of employers and workmen.

4. The provision of free service to those who seek employment at the public exchanges.

* New Statesman, January 3, I9r4, p. 393, col. 2.

$\dagger$ We are, of course, obliged to feed, clothe and give wages to soldiers during periods of peace as well as during periods of war. 
5. The methodical organization of the labour market, i.e. by the placement and movement of workers according to uniform principles and under the direction of a central office supplying continuous statistics of the labour market.*

6. The expenses should be provided at communal charge (for local exchanges), by the State (for the State exchanges), and by the nation for the central office.

7. Private employment offices ought to be licensed and controlled.

8. Employment exchange authorities should endeavour to decasualize labour.

9. Employment exchanges should be organized to be able to administer schemes of unemployment insurance.

\section{Juvenile Employment Department.}

We have seen that in Great Britain special employment exchanges for women and for juveniles have been inaugurated and are being operated successfully. Not only can boys and girls be warned against entering the blind-alley trades, but with a satisfactory knowledge of the state of the market and the growing needs of industry young people can be trained for those trades where their services are likely to be of the highest value. The overcrowding of certain trades and the insufficient number of workmen in others could thus be avoided. By inviting teachers, business men, and parents to help in administering these exchanges the best interests of industry would be served. The vocational guidance

* During the harvest period of 1917 many State labour departments and bureaux, State agricultural departments and many State Councils of Defence, in conjunction with the Federal Labour and Agricultural Departments, arranged for a better shifting of agricultural labourers in the Western States. From Texas to North Dakota a number of States are dependent upon large bodies of migratory labourers, and a unified comprehensive system for correlating demand and supply has long been necessary. 


\section{INSURANCE AGAINST UNEMPLOYMENT}

agencies which are instituted in most of the large towns of the United States are concerned primarily with the children who leave school under sixteen.

The Federal Employment Service has developed a Junior Guidance and Placement Division. It is only, however, in New York City that special departments for dealing with juveniles are actually at work. A successful scheme of "after care" and "choice of employment" is being adopted in a number of centres. But the extension of these schemes throughout the country still needs to be pressed.

\section{Immigrant Employment Bureaux.}

Hitherto the United States has had the problem of placing the immigrant when he lands. Only too frequently he is permitted to remain in the city, even though he is desirous of going on to the land, and his past training is, therefore, often wasted. The needs of the farmer are not satisfied and the immigrant's stored-up capital in the form of his trade is neglected, so that he drifts into unskilled, ill-paid occupations.* Proper placement and a loan for shipment to a definite job, with perhaps a small amount invested on some appropriate training, would make the immigrant of much greater economic value to the community. The Act of February 20, 1907, established a Division of Information under the Bureau of Immigration "to promote a beneficial distribution of aliens," but little action seems to have resulted.

\section{Distribution of Public Works Department.}

It has frequently been suggested that public works,

* It has been urged that the inauguration of the Imperial insurance scheme in Germany " contributed largely towards the exodus of the rural population into the industrial centres." Unless checked by countertendencies, this might also be the effect of a scheme of unemployment insurance. See The Causes and Consequences of the War, p. I 8 , by Yves Guyot. 
the construction of roads, footpaths, electric and steam railways, of buildings, schools, colleges and hospitals, the improvement of harbours, the development of canals, the undertaking of schemes of afforestation and reclamation, all these could be carried out during periods of depression in private industry. Such undertakings are, of course, now begun at irregular intervals, usually when there is an immediate need for them. Some of these could be postponed without hurt. The problem of the distribution of public works with a view to regularizing industry is, however, complicated by the prevalence of annual budgets for public expenditure. Little could be done apparently along these lines until arrangements for, say, ten-year periods were made in the same way as orders for three-year periods are frequently made for army and navy expenditures.

\section{Democratic Advisory Committees.}

In the administration of the various proposals outlined for dealing with unemployment it is recommended that democratic committees representative of the workmen, the employers, and perhaps of the public be formed to aid the officials.

Four such groups of committees have suggested themselves in the course of the chapter.

Advisory trade committees should advise employment exchange officials. Work analysis committees might describe the requirements for various jobs in the factory. Juvenile advisory committees should help as regards juvenile employment. Unemployment insurance committees should assist in the administration of a scheme of unemployment insurance.*

By these means it will be possible to increase the democratic control of the governmental institutions of the country. Hitherto the workers have gained admin-

* The Industrial Courts, the Whitley Councils, and the Trade Boards show the great extension of this device within recent years in Great Britain. 
istrative education and experience only in trade unions. New opportunities in other directions need to be encouraged in the factory as well as in the municipality and State. In this way we shall be reconstructing " our administrative machinery so as to give power and real expression to the developing collective mind of the community." *

These committees will represent the extension of self-government from the political to the industrial sphere. There are many signs that the recommendation made here with respect to employment problems is gaining ground in other fields, but more especially where the labourers' interests are directly involved. Two instances must suffice. In a memorandum issued by the New York Association for Labour Legislation on "The Reorganization of the Labour Department" it is proposed that this department should be given express authority to create, as deemed desirable by it, volunteer special boards, composed of employers, employed, and others having exceptional knowledge or interest in particular industries; at other times the advisory board should be enabled to call to its aid boards of the best training and skill obtainable in particular matters. $\dagger$

In a similar manner the borough of Manhattan, New York City, has organized a borough advisory commission, consisting of citizens whose function it is to assist and advise the borough officials both in administering existing regulations and in devising new ones.

In Germany the practice of inviting those who are specially interested in, or have special knowledge of, any problem to help in its administration is widely extended. The State-owned railways are largely influenced in their policy by district advisory councils representing the economic interests affected. The scheme of sickness

* See H. G. Wells, New Worlds for Old, and Baker, Political Thought from Spencer to To-day.

+ Second Report of the Factory Investigation Commission of State of New York, 1913, vol. ii, p. 1304. 
insurance is largely controlled by committees elected by employers and employees.*

But the need must be emphasized of reconciling democratic control with expert guidance. A "democracy tempered by respect for the expert" is the ideal at which to aim.

It is well to insist here that there are two safeguards with respect to the administration of the measures outlined in this chapter which are necessary if they are to be of the highest possible utility. It is essential that the responsibility for carrying them out shall be fixed and not shifting, and that appointment, tenure, and promotion of clerks and administrators shall be decided on grounds of merit alone.

For many years to come, however, even if a highly efficient Employment Bureau were created, it is certain that the unemployment problem will remain serious. The fluctuations of industry are long likely to continue as a result of the after-war eruptions, the variations of weather and the demands of fickle dame Fashion. Under such circumstances unemployment insurance is likely to be the best means of overcoming in part the suffering which results to the workman from stoppage and irregularity of income.

In most countries of Europe, $\uparrow$ as we have seen, the working classes most subject to unemployment have made substantial though inadequate efforts to deal with it. Through their trade unions they organized out-of-work benefits in order to lessen the evil effects likely to result from loss of earnings. These have led to State subsidies and to comprehensive national schemes. We have seen that comparatively few American working men have made similar arrangements. We have also seen reasons for believing that State subsidies were not suitable to American conditions, and so we are justified in pushing our inquiry further. Should the Govern-

- Howe: Socialized Germany, pp. II 7 and 195.

$\dagger \mathrm{Cf}$. with the conclusions reached in this chapter, the conclusions of the Commission on Industrial Relations, Final Report, pp. I14, I15. 


\section{INSURANCE AGAINST UNEMPLOYMENT}

ment introduce a comprehensive scheme of obligatory insurance?*

* Although the present writer supports the proposal that whole trades in Great Britain should contract out of the Act, that the Ministry of Labour should initiate special schemes, and that an adequate number of employment exchanges should be assigned to the administration of such schemes, he realizes that it would be futile to make a similar group of proposals for the very different conditions prevailing in the United States. Not until a few State schemes of unemployment insurance have been established, in which public funds are employed, will it be possible to impose on each industry the burden of its own unemployment. It will be made evident in the next part of this study that whilst there is no reason why industries in the United States should not organize their own schemes for bringing together those who want work and those who want workers and for providing insurance against unemployment, there is in fact very little likelihood of this being attempted. It is undesirable to delay dealing with unemployment until private industrial organization is more competent and ready to do so. 


\section{STANDARDS OF UNEMPLOYMENT INSURANCE* PART ONE}

\section{A. Compulsion.}

WHEN Germany alone had a system of compulsory insurance it was customary in the United States to refer to the character and traditions of the Prussiansthe military discipline, the regimentation and the respect for authority-for an explanation why the German people did not oppose it. But since the British have adopted even more comprehensive schemes of compulsory insurance this explanation is transparently inadequate. If the working classes in Great Britain felt the Insurance Act " compulsory" in the sense of oppressive, injurious or excessively costly, it would not have been enacted, and even if enacted, would have been abrogated within ten years. But, as a matter of fact, the compulsory unemployment insurance scheme has proved to be highly popular. Every extension has resulted from the pressure of the workers' representatives. Nor should this be surprising. That wage-earners are prepared to submit to compulsion with respect to measures socially desirable is the very basis of all legislation, and explains more especially why Germany, Austria, Hungary, Luxemburg, Norway, Great Britain, Servia, Russia, Roumania and Holland have schemes of compulsory health insurance. Dr. Rubinow has rightly described

* The method adopted in this and the following chapter of discussing the Massachusetts Bill on Unemployment Insurance is common amongst writers in the United States. 
recent developments in the growth of social insurance schemes as "a wellnigh universal movement of the industrial era," * and one of the characteristics of that movement is the willing acceptance by the working classes of the principle of compulsion. $\dagger$

Professor Henderson has well stated the primary reason for a compulsory scheme of unemployment insurance.

With compulsory insurance laws (he wrote), the end is reached in a comparatively short time, while even with State subsidies voluntary plans have only helped a part of the population imperfectly, and those who most need the protection of insurance not at all. $\ddagger$

There are other weighty reasons for the development of comprehensive schemes of unemployment insurance.

The inclusion of large numbers results in keeping the per capita cost of administration low. It prevents an excess of bad risks. It enables the Government to keep its finger on the pulse of industry, and through employment exchanges and certain special devices affords more scope for the attempt to reduce the amount of unemployment. Above all, compulsion is indispensable if employers are to be made to contribute directly towards the cost of insuring their workmen and to be given an opportunity to help administer proposals dealing with employment problems.

The fundamental justification of compulsion lies in the determination of society to defend itself from the evil effects of unemployment against which workmen cannot or will not insure themselves.

- I. M. Rubinow : Standards of Health Insurance, p. I2.

$\dagger$ Mr. Morris Hillquit writes that Socialists see in " working men's insurance" a patent lever for the elevation of the physical and moral standard of the masses. . . . "The effect of a comprehensive system of State insurance is to remove from the minds of the working men the haunting dread of uncertainty, and to develop in them a certain sense of material security and intellectual independence." - Socialism in Theory

$\ddagger$ Industrial Insurance in the United States, p. 311 . 


\section{B. Scope of Insurance.}

The trades included in the scheme proposed for the State of Massachusetts comprised about half the labourers in that State. Their comparatively large number makes it possible to avoid the undue preponderance of essentially hazardous or badly organized trades, and therefore the area of experiment is more favourable than that chosen in the I9I2 Act of Great Britain. On the other hand, a still more favourable area for experiment might have been chosen, since the selected trades have a higher percentage of unemployment than the non-selected trades. They were chosen because they were the most representative and the biggest trades in the State. It is also noteworthy that the periods of maximum unemployment vary from trade to trade, and therefore the reserve in the unemployment fund need not be so large as in trades which generally fluctuate together. It will be an easy matter, of course, to extend the scheme to include other trades, when it is thought advisable.

The need for the demarcation of trades is greatly lessened in this scheme because groups of occupations are included. But in order to avoid the very serious and complicated problems which arose in the administration of the first British scheme, a thorough investigation of what occupations are included in each trade ought to be undertaken before it is inaugurated. Insurance officers should know the trades and their processes, and where possible have labour analyses of each in order to help them in the adjudication of doubtful points. A concise definition of each of these trades is desirable.

Power is vested with the chief commissioners of unemployment to extend the scheme in such cases where it would help in simplifying its administration. Thus the inclusion of saw-milling with the building trades might on investigation prove advisable, because it lessened the difficulties of demarcation.

The selection of a limited number of trades because 
of the desire to carry out an experiment will probably lead to constitutional difficulties.* It might therefore prove more satisfactory to include under the scheme all manual labourers. This consideration is strengthened in view of the latest British scheme, together with the Italian and the Austrian schemes, which include the vast majority of labourers. This is, however, a question of expediency which does not raise important matters of principle.

Young men and women under eighteen are excluded from the scheme because of their frequent shifting from job to job. To include them would mean the inclusion of members a large proportion of whom would fall out again as they left the selected trades. Administration would thus become more complicated. Besides, it was argued, they do not as a rule need such provision. Frequently they are still dependent on relatives who take care of them when unemployed; rarely do they have anybody dependent on them.

Clerks have been exempted from the operation of this scheme because their work is as a rule not subject to much unemployment. To have included them would have resulted in their subsidizing the highly fluctuating trades. $\uparrow$

* Anything in the nature of class legislation is regarded as anti-constitutional, and some of the judgments on this subject are amazing to Europeans. See the case of People $v$. Havner, I49 New York, I95, 203, and Booth $v$. Indiana, 237 United States, $39 \mathrm{I}$.

In the former case a New York law prohibiting barbers from working on Sunday's was sustained " as a valid exercise of the police power of the State for the promotion and protection of the public health and welfare." The health of a single class of working people, barbers, was held to be a public interest.

In the latter case a statute which provided for wash-houses in coalmines when requested by twenty or more men was objected to as applying only to a particular class and not therefore in the interests of public health. The United States Supreme Court held, however, that its previous decisions disposed of this point in favour of the constitutionality of the law " and further comment is unnecessary."

Quoted from The Constitutionality of Health Insurance, by Joseph P. Chamberlain: Appendix I of Standards of Health Insurance, by I. M. Rubinow.

$\dagger$ It has been frequently suggested that a scheme of unemployment insurance might be introduced as a voluntary system, and with State 
The primary object of the scheme is to provide insurance for workmen against unemployment. When, therefore, workmen have such insurance provided for them in establishment schemes, there is no particular reason why those schemes, if properly administered, should not be recognized. Two conditions must, however, be insisted upon by the Insurance Commissioners. First, the total amounts of benefit provided by such schemes must be equal to or greater than those provided by the State scheme. Second, workmen must not pay higher contributions than they would have to pay under the State scheme. The purpose of this clause is to encourage employers who may be contemplating the introduction of establishment schemes of unemployment insurance to put them into effect without fear that the State scheme will necessarily wipe them out. It is intended to act as an encouragement to the regularization of occupation in certain factories. At the same time amongst the requirements which the Insurance Commissioners will have to lay down will be those guaranteeing the solvency of the scheme and its democratic administration by the insured, together with the management.*

supervision might become a universal insurance measure, much as the Workmen's Compensation Acts have worked out.

But there is a difference in the two situations.

Even before the Workmen's Compensation Acts were passed employers were generally liable for accidents which occurred in the course of the workman's trade. The recent laws held a club over the employer's head by taking away his defences against possible lawsuits, whereas the law recognizes no responsibility on the part of the employers for the continuous employment of their staff.

To make the situation strictly analogous to that which existed before the workmen's compensation legislation was enacted, the employer must have the responsibility, whether assumed voluntarily or compelled by legislation, for the unemployment of his workmen. To wait until employers themselves assume responsibility for unemployment would mean to wait indefinitely, whilst the enactment of legislation making employers fully responsible-for the losses resulting from their workmen's unemployment is not likely to be practicable for years. It is certainly less practicable than the proposed Massachusetts measure on unemployment insurance.

* Cf. Rubinow : Standards of Health Insurance, 1916, p. 198, for the view that establishment funds under certain conditions would be convenient carriers for health insurance. Note also the special arrangements made in the Rowntree establishment unemployment insurance fund (chap. xxiv). 


\section{PART TWO}

\section{Unemployment Fund.}

The Unemployment Fund is the central feature of the scheme. It is the reservoir towards which all the sources flow and from which the pipes take their supply. All the contributions flow into the fund, benefits and expenditures are taken from it.

In order to estimate the contributions that will have to be paid if a certain scale of benefits is to be possible, a trade cycle of, say, ten years will have to be contemplated. A reserve must be accumulated during the prosperous years, so that during the years of depression which are likely to ensue the fund will not become bankrupt.

The inadequacy of the unemployment statistics of Massachusetts have been so often commented upon that it is necessary to insist that they are probably adequate for a tentative estimate of the cost of the proposed scheme. The available data have been collected through two sources, from trade unions and from manufacturers; they go back for many years and they can be supplemented by special investigations.

It would be wise for the Insurance Commissioners to undertake as thorough an investigation as is possible of the data relating to unemployment in Massachusetts as soon as the scheme is enacted. Under special powers given to the Chief Commissioner on Unemployment Insurance under this Bill (Part XII, Section I6) he will be able to develop sources of continuous information dealing with unemployment.

To avoid any danger of the fund being exhausted, provision is made for the revision of the rates of contribution and of benefits if it is deemed necessary (Part XII, Section I3). Furthermore, it is provided that the Treasury of the commonwealth shall guarantee the solvency of the insurance fund (Part XII, Section I4).

But employers and employees should be made to realize that if the Unemployment Fund were to become 
insolvent the loan of the State Government would have to be repaid by means of a revision of the scale of contributions and benefits.

\section{Contributions and Benefits.*}

The differentiation of contributions and benefits provided in the scheme is the most radical departure from the British plan. $\dagger$ There the scheme is kept simple by making all workmen (as distinct from women and juniors) pay the same weekly contribution. These contributions are accompanied by a system of equal benefits. Even though this was not quite equitable it was felt to be wiser to experiment with as easily administered a scheme as possible.

The change is justified on the grounds that benefits ought to be provided in some proportion to the standard of living, i.e. for most workmen that provided by their average wages. There is also reason for differentiating benefits according to trades, but this would introduce more administrative difficulties than is wise in the launching of a scheme. In order to facilitate the administration provision is made for three wage groups, and it will be seen from the following table how the estimated contributions $\ddagger$ are related to the benefits and the benefits to the wages of workmen.

\begin{tabular}{l|l|l|l}
\hline & Wage. & Benefit. & \multicolumn{1}{c}{ Contributions from each Party. } \\
\hline Class I & $\$ 8$ or less & $\$ 3.50$ per week & IO-I 2 cents per week (about) \\
Class II & $\$ 8$ to $\$ 12$ & $\$ 5.25$ per week & 20 cents per week \\
Class III & $\$ 12$ or more & $\$ 7.00$ per week & 25 cents per week
\end{tabular}

* Owing to the increased cost of living both the benefits and, in consequence, the contributions would have to be raised.

† The British Act has a "flat rate" both of contributions and benefits (except as regards wom:n and juveniles under eighteen years of age). Under the British Health Insurance Act, however, a differentiation by earning is provided for. See National Insurance Act, Part I, Schedule II.

$\ddagger$ These contributions are a tentative estimate calculated from the figures of the Massachusetts Bureau of Statistics. 
Will these contributions* be too great to expect from workmen? Certainly the I2 cents a week from Class I will not be regarded as a very serious matter. Members of some of the unions providing out-of-work benefits already pay that amount for less benefits than the Massachusetts scheme promises.

The following suggestion made by Union No. 4 to the Chicago Commission on Unemployment is interesting in fixing rates of contributions.

The best way to deal with unemployment would be to assess every man who is working, and in case he is out of work assist him for a certain time. Our union applied this plan for twelve years with the best results. We assess every member 50 cents a month, and pay to the members who have been out of work five weeks $\$ 4$ a week during the winter months, December, January, February, and March.

The 20 and 25 cents asked from Classes I and II are considerable amounts for the workmen to pay. Some comfort may perhaps be derived from the thought that these estimates-and it must be remembered that they are nothing more than estimates-err on the side of caution in calculating the costs of the proposed scheme. But in any case the alternatives which must be considered are whether the workman shall have this definite, regular, bearable burden, or an indefinite, irregular, unbearable burden.

These contributions could be lowered if the benefits were reduced. But the standards of living of the working class being higher in the United States than in Europe, a substantially higher scale of benefits is regarded as advisable. There is also the consideration that the results of the experience and experiments of other countries warrant the undertaking of a bolder scheme of unemployment insurance. This encouraged the framers of the Massachusetts Bill to provide a higher scale of benefits.

This scale of contribution may be properly criticized

* In the United States a non-contributory scheme is not likely to be practicable for many years. 
on the ground that the State will subsidize the highly paid workman more than the low-waged one. Thus the one earning more than $\$ \mathrm{I} 2$ a week will have a State contribution of 25 cents added to provide him with insurance benefits, whilst the one earning less than $\$ 8$ per week will receive only I2 cents a week towards his benefit from the State treasury. It would therefore seem to be wiser for the State to provide a uniform subsidy of 20 cents to workmen in each of the three classes.*

\section{Employment Exchanges.}

In Cologne and Berne the Insurance Fund and the public employment exchange are practically amalgamated. In Strassburg, Milan, and Antwerp, receipt of subvention by an unemployed person under the "Ghent system" is conditional upon his registration at the employment exchange.... The State subvention to unemployed benefit in France can only be claimed by unions having an organized method of finding employment for their members. $\dagger$

The success-indeed, the very possibility-of unemployment insurance on a large scale, depends upon the existence of a comprehensive, centralized, well-organized network of public employment exchanges. As in the British scheme, workmen in the insured trades will register that they are unemployed. Thus tens of thousands of workmen who might not otherwise have taken advantage of the employment exchanges will be obliged to do so.

A centralized scheme is necessary in order that workmen may be advised to transfer to places where work can be found for them and in this manner save unnecessary claims upon the fund. Each employment exchange will be able to apply the test of unemploy-

* It should, of course, be one of the earliest tasks of the Insurance Commissioners to provide regulations governing the case of workmen who change from one wage group to another or from insured to noninsured trades or vice versa.

$\dagger$ Cd. 5068, p. 737 . 


\section{INSURANCE AGAINST UNEMPLOYMENT}

ment by offering workmen suitable employment. It will be able to prevent malingering, and to discover when undue claims are being made.

Unemployment insurance is impossible without a system of employment exchanges, but a complete system of exchanges, it might be added, is impossible without unemployment insurance. If employment exchanges are confined merely to placement work, they are not likely to attract the higher grades of workmen, and in any case the cost of the necessary number of offices will be too great for the limited work which they will do. In Great Britain employment exchanges and unemployment insurance were meant to complement one another. In Massachusetts the Bill on Unemployment Insurance was presented to the legislature at the same time that a Bill for the development of a satisfactory State system of employment exchanges was presented.

\section{Determination of Claims.}

The machinery is proposed in the Bill for the establishment of an impartial tribunal from which prompt, inexpensive, final decisions may be obtained on all doubtful questions.

It is provided that a referee shall be appointed by the governor, and not by the board of Unemployment Insurance Commissioners (Part XII, Section IV). Employers or workmen may appeal to the referee for a decision, no fees are to be charged, and he is to give his decision as promptly as possible. Unless he should himself revise that opinion, that decision is final and conclusive for the whole State.

The procedure with respect to the determination of claims is as follows. The workman has an appeal from the insurance officers to the district arbitration committee. If dissatisfied with their decision, the Insurance Officer may appeal to the State referee. This follows the British practice. But a further appeal, following from the similar provisions in the Massachusetts 
Workmen's Compensation Act, may be made from the referee within ten days to the Superior Court "on written request by the referee or by the chairman of an arbitration committee."

\section{Conditions for Receipt of Unemployment Benefit.}

The detailed enumeration of the conditions necessary for the receipt of unemployment are designed to have two effects: to prevent malingering, and to prevent the use of employment exchanges as a means of reducing the standard conditions of workers.

The temptation to malinger is reduced through four groups of provisions in the Bill.

First: Workmen suffering from unemployment due to sickness, accidents, invalidity, old age, are specifically disqualified from receiving unemployment benefits. For these causes of unemployment other methods and schemes of insurance may be devised. The temptation to malinger would, of course, be greatly lessened if the other emergencies in the workman's life were adequately provided for by the Government.

Second : During periods of unemployment, benefits are to be substantially less than the normal wage of workmen; they are limited to a short period and benefits are not to be paid during the first week.

Third: The employment exchanges may offer work to insured workmen.

Fourth: Workmen who have not received more from their unemployment fund than they have paid in as contributions may, on leaving their State, or on reaching the age of sixty, claim a refund equal in amount to the difference between the sum of their contributions and the sum of their benefits. Insured members are thus encouraged to regard the Unemployment Fund as a savings bank, so that the less they withdraw as benefits the more there remains to their account.

The framers of the Bill have outlined the scheme in such a way as to prevent the administrators from 
taking sides during industrial disputes or on questions relating to wages and conditions of labour. They are to remain strictly neutral in such matters.

Workmen are not excluded from receiving benefits if they refuse to accept work which has resulted from labour disputes, or where wages are lower, or conditions less favourable than they are in the district.

\section{The Regularization of Industry. Parts VII, VII, X, XI.*}

Special devices have been introduced into the scheme aiming at the reduction of the amount of unemployment. The Bill as now worded does not include all suggestions that have been gained from experience with the British scheme. It does, however, include some.

The refund offered to employers has been raised to one-half of all their contributions paid in respect of the workmen whom they engage regularly. Employers are also encouraged to work all their workmen short time rather than work some of them full time and dismiss the others. $\dagger$ The refund to employers who do so equals the full amount of their contributions during the period when there would normally have been unemployment. We have already observed that employers with satisfactory establishment unemployment insurance funds may contract out of the scheme.

Refunds offered to workmen are of three kinds :-

(I) Money refund to regularly employed workmen who have reached the age of sixty.

(2) Travelling expenses to migratory workers.

(3) Training to workmen who are inefficient.

* This Bill was framed whilst the experience with the British scheme was limited. Some of its provisions might be amended in view of the conclusions to be drawn from the parent scheme. This applies more especially to the devices suggested for the regularization of industry.

$\dagger$ The wording of Part VII, Section 2, is involved, and its meaning is rather cloudy. The intention of its framers, judging by the corresponding clause in the British Act, was to encourage the working of short time without reference to whether the employers did or did not pay their workmen's contributions. 
They are all aimed at reducing the amount of unemployment. In the previous section we noted the clause providing for repayment to workmen who have reached the age of sixty.

This aims at reducing the danger of malingering. The regularly employed worker would thus receive his insurance free of charge, and his contributions constitute the principal on which he receives 3 per cent. interest.

\section{Migration of Insured Workers.}

It is generally believed that workmen in the United States are more prone to move from place to place, and especially to travel in quest of work, than are people in other Western countries. Though the good and evil effects of such a state of affairs have not yet been established, the framers of the Bill thought it inadvisable to interfere with the mobility of labour in general. On the other hand, where the encouragement of such migration would result in reducing unemployment, it is encouraged. Thus workmen may apply to the fund for one-half of their travelling fare to jobs offered them. Furthermore, by providing that insured workers leaving the State "for over an insurance year" may obtain a refund of the sum of their contributions less any benefits they may have received, migratory workers may be provided with their savings on leaving the State in search of employment.

\section{Unemployment due to Defects in Skill or Knowledge.}

Most schemes of unemployment which have failed, whether compulsory such as at St. Gall, or voluntary such as that of the New York Typographical Union No. 6, have been wrecked through the unduly large demands on the unemployment fund of a few workmen. Such demands have resulted from the inefficiency of these members. To prevent, or at least to avoid this obstacle as much as possible, provisions are made in 
the Massachusetts scheme which enable such workmen to be given technical instruction.

It is obvious that this provision will need to be supplemented by some other proposal if it is to prove of the highest utility of which it is capable. As a small part of the scheme of unemployment insurance it provides an excellent highway into the problem of training inefficient workers.

\section{Encouragement to Associations.}

In no country in the world has the fight against trade unions been so sustained, so bitter, and so determined as in the United States.* It may therefore seem futile to recommend here what has been worked with such great success in Britain as well as in half a dozen other European countries, viz. the recognition and subsidization of trade unions providing out-of-work benefits. Yet not to have done so would have implied absolute despair of convincing the public of the wisdom of such a proposal, and the engendering of the hatred of trade unions towards the scheme.

It was the clear intention of the framers of the Bill to do nothing to lessen the prestige of trade unions. On the contrary, by recognizing them as part of the machinery for distributing benefits to members and by encouraging them to provide unemployment insurance schemes, the State will tend to develop in the public consciousness a recognition of the valuable part which they might, and indeed do actually, play in modern society.

In most countries of Europe the public assumes that it is advisable to encourage the unemployment insurance activities of trade unions. This applies, as we have seen, to Belgium, Luxemburg, Denmark, Switzerland, France, Italy, Holland, Norway, Germany, Austria, Great Britain ; and even in Spain, Finland, South Africa,

\footnotetext{
* The Brass Check, by Upton Sinclair, throws a glaring white light on this subject.
} 
and Canada such encouragement to unions of workmen is being considered.

It is necessary to insist here that the undoubtedly great difficulties involved in convincing public opinion in the States of the need of a similar proposal will be overcome only when the urgency of the unemployment problem is appreciated. When that is done, and measures and machinery are being devised for meeting it, then the saving to the community in using the existing machinery of trade unions will be appreciated and recognition granted them. Trade unions will then be given the same status as establishment funds.

\section{Administration. Parts VI, IX, XII.}

Perhaps in no other branch of social legislation is attention to administrative questions more important than it is with respect to unemployment insurance. Surely Mr. and Mrs. Sidney Webb are justified when they declare that

it just fepends on how it is shaped and administered whether a Government scheme of universal and compulsory insurance turns out to be a useful adjunct and complement of a policy of prevention, or to have the disastrous effects of a gigantic system of indiscriminate, inadequate, and unconditional "outdoor relief" under another name.*

We have already seen that the St. Gall scheme failed because of its badly conceived machinery for administration. The Massachusetts Bill provides for the administration of the scheme by a special commission. Let us inquire into some of the advantages of this type of machinery.

\section{Board of Unemployment Insurance Commissioners.}

The commission form of government, introduced at the time of the Galveston flood, was found to be such an improvement in many respects over the special com-

* Sidney and Beatrice Webb : Prevention of Destitution, chap. vii. 


\section{INSURANCE AGAINST UNEMPLOYMENT}

mittee form that it swept through the whole country and was pretty widely adopted. Commissioners may be specially chosen for their fitness for their particular task. There was no guarantee that committeemen had any special aptitude for the tasks to which they were elected. Commissioners may be appointed for a long period and thus carry out a consistent continuous policy. The changes in policy which frequently elected bodies can indulge in is shown by the eventful tariff history of the country. Commissioners are free from electoral pressure, and since they administer and do not legislate, are more likely to be free from the pressure of private interests than are committees or legislatures. Lastly, it has been urged that a board of commissioners can be given powers over a rationally selected allotted area rather than over some area like the city or county which has frequently been demarcated on no rational basis.

Another recent improvement in the machinery of government is the creation of a body of civil service employees who have special aptitude or training for their work. "The broad result is that modern developments in the structure and method of governmental agencies have fitted these agencies for beneficial intervention in industries, under conditions which would not have justified such intervention in earlier times."* Hitherto unfortunately the commission form of government has frequently been abused. Men have been appointed to serve whose only claim to office was an unthinking political partisanship. But there can be little doubt that with the increasing probity of government the time is not far distant when commissioners will be men owing no allegiance to any special interest, unembarrassed by either financial or political obligation, who will devote themselves with a single purpose to the protection of the rights of the people.

The Massachusetts Bill provides that a network of employment exchanges under the control of a board

* A. C. Pigou : Wealth and Welfare, p. 250. 
of unemployment insurance commissioners should act as the machinery for administering the unemployment insurance scheme.

\section{Federal or State Legislation.}

So much has been written about the constitutional difficulties in the way of introducing social insurance legislation in the U.S.A. as compared with other countries that one great superiority of this country is wholly forgotten.

Provided that the people of this country are fairly united in their endeavour to obtain some reform, collectivist or otherwise, there is no one to say them nay. There is no hereditary Junker class stemming the tide of democratic needs and no Conservative Party as such restraining their every effort; and if they use their power wisely there is no reason to fear any reaction. The difficulty of carrying a national scheme into effect is compensated for to an extent by the fact that any one of the forty-eight States can be used as an experiment station. The experience in any one can then be used in applying the scheme in any other State. Thus, whilst benefiting from the accumulated experience and wisdom of other countries, a scheme ultimately national can be worked out which will more adequately satisfy local conditions and needs. If in addition to experiments in a few States in different sections of the country, say in the East, the Middle West, the West, and the South, it would be possible from the very outset to have neighbouring States engaged in the same trades, e.g. the New England States, introduce similar schemes together, the likelihood of such legislation proving successful would be greatly increased. It was in this manner that a criticism levelled against the Massachusetts scheme of unemployment insurance, viz. that it will tend to penalize the manufacturers of that State by imposing taxes upon them from which employees in neighbouring States will be exempt, has been met. 
When all the New England States are treated as a unit for purposes of social legislation, the most progressive State will not be made to suffer for the most retrograde. Assuming, however, that in parts of the country it will still be impossible to induce a group of States to introduce a scheme of unemployment insurance at the same time, it may well be argued that the better organization of industry to which it will give an impetus both in the individual factory and in the State, as well as the increased efficiency of the workmen in which it will result, may more than compensate for the apparent tax on the employer.

\section{Unemployment Insurance for Other States.}

The scheme of unemployment insurance proposed for Massachussetts would have to be materially changed to be adaptable to the needs of other States. Not only would the trades included have to be different and the scale of contributions and benefits perhaps made to vary, but even the administrative body in charge of the scheme would, probably, at least at the outset, be different in the various States.

On the other hand, the principle of joint compulsory contributions to the fund, the dependence of a scheme of unemployment insurance on a comprehensive system of employment exchanges, the use of the scheme as a means of preventing the emergency from arising rather than merely of alleviating the suffering in which it results, these and other "standards" should apply to all schemes in all the States.

But this country is not the only one in which different States, each with its own laws and customs, ultimately formed a union. In Germany less than a century ago the different States actually lived under different legal systems-German law, Roman law, Code Napoléon, and all kinds of local laws. Yet a commission working for twenty-five years finally completed a national code of laws.

There can be little doubt that the States too will have to adopt some unified system of laws for meeting unem- 
ployment. Vexatious problems resulting from the taxation of employers in neighbouring States at different rates, or of the same employer at different rates for workmen of the same trade who happen to be working in his factories in different States will have to be solved. The only possible way to prevent the confusion in this branch of social insurance from equalling that which exists with respect to the compensation schemes is to introduce national legislation. The growing homogeneity arising from the quick development of industries in all parts of the United States has resulted in making the problem of unemployment a truly national problem-a situation which has received practical recognition in the passage of a federal scheme of vocational training. Further, national legislation to meet this evil, it is safe to assume, can not long be delayed. Whether such legislation will necessitate an amendment to the Federal Constitution is still open to doubt. But it is certain that rather than tolerate the confusion of different laws on this subject an amendment will be passed if that is found to be necessary. On the other hand, it must be insisted that any national scheme will have to recognize the vast territorial area of the United States, the diversity of interests and the different stage of social developments of the different sections.*

\section{Time of Introduction.}

In addition to developing a wise and sound scheme of unemployment insurance in the light of prevailing conditions, there is the further task of introducing it at such a time when it is likely to be free at the outset from having to weather bad times. It is advisable to

* It is conceivable that if a method could be devised whereby the national exchequer would provide "grants in aid" to those States that have different schemes of caring for their unemployed, or for their sick, their aged, or maimed, the undoubted advantages of State initiative and State freedom to experiment would not be lost, whilst on the other hand it would be possible to attain a universal enforcement of the National Minimum of conditions that society now favours. Such a solution might indeed even be advisable for the prevailing conditions, since the different parts of the country are still in different stages of development. 
inaugurate such a scheme before the crest of a rising wave of prosperity is reached, so that a surplus can be collected before the storm comes. During that time the administrators will become used to their work and be ready to cope with the demands made on them by a period of industrial depression.

In Great Britain sickness and unemployment insurance were introduced at the same time, whilst in most European countries insurance against the former contingency has preceded insurance against the latter. Assuming that the United States would be well advised to introduce both schemes of insurance, which should come first?

The growth of compensation schemes against accidents and industrial diseases makes it necessary to provide insurance against sickness from all causes if certain obvious injustices are to be overcome. Moreover, the helplessness of the sick person appeals more easily to the imagination. Yet the problem of unemployment is much greater than both industrial accidents and sickness. As we have seen, the unemployed probably number about six millions in a year of depression, whilst even in prosperous times there are more than a million annually. But a large guess at the number injured would not exceed a million in any one year. "Wage-earners lose five days on account of inability to get work for every two lost through sickness." * Perhaps in the United States, as in Great Britain, the propaganda for both schemes should be carried on together and the decision as to which should come first, if they cannot be attained at the same time, should be left to the chance growth of public opinion resulting from the occurrence of an industrial crisis or to the chance spreading of some disease. In I92I it has become a matter of paramount interest to the State to introduce a scheme of insurance against unemployment. $\dagger$

* Rubinow : Social Insurance. See pp. 68 and 214.

$\dagger$ In September I92I Congress was confronted with a number of proposals, involving over a thousand million dollars, for relief of the unemployed. 
CHAPTER XXIX

\section{THE MASSACHUSETTS BILL ON UNEMPLOYMENT INSURANCE}

THE study of the various European schemes of unemployment insurance is now of direct and immediate importance to the United States. There is a growing willingness to gain from the experience of other countries.

We were apt to think that our problems are peculiar to us and that we must find our own way of solving them. If we had only realized that American and European history is being written with the same ink, that man is man, with similar virtues and similar vices, on both sides of the Atlantic, we might have learned much from experience and might have been able to avoid much amateurish and harmful legislation.*

Do the industrial conditions of the United States warrant the introduction of some scheme of unemployment insurance? If they do, which system would be best adapted to its needs?

Shall a federal measure be attempted or should a State measure be first experimented with? Shall it follow the Ghent model or the British scheme?

A practical turn has been given to the discussion of these problems, if for no other reasons, because Massachusetts has a definite Bill advocating a plan of insurance against unemployment before its legislature and the Committee of Labour of the House of Representatives of the Federal Government has discussed the appointment of a commission on social insurance.

* Paul M. Warburg: The Currency Problem and the Present Financial Situation, p. 147 . 
The concluding chapters of this book are devoted to an analysis of the scheme and to a brief summary of the main arguments employed by its advocates.

\section{Introduction.}

Before stating and analysing the Massachusetts Bill on Unemployment Insurance it is necessary to justify a number of preliminary propositions.*

\section{It is Advisable that Public Provision should be made in the States against Unemployment.}

We have seen that unemployment is one of the most menacing situations that confront the workman in the U.S.A. The most satisfactory way of solving this problem would therefore be to introduce means to avoid the irregularities of industry and to provide work at all times. The systematic distribution of public works, the scientific organization of the sales end of management and the adoption of better thought-out methods of " hiring and firing" workmen will help substantially towards this end. But it is doubtful whether for many years to come means will be found to overcome seasonality in industry due to variations in Nature's bounty, and to our methods of industrial organization and to the habits and customs of modern society.

Assuming then that unemployment should be regarded as a constant feature of modern industry, what methods now in vogue for meeting it should be encouraged? The history of relief works has been that of a succession of failures. At best they are a very poor means of giving the unemployed workman relief in a manner that will save his self-respect. Competent investigators are almost unanimous in condemnation of this method of meeting unemployment. On the other hand, all students of the problem agree that the spreading of unemployment over all workmen in an industry

* To this end some of the arguments already presented in previous chapters are outlined briefly. 
so that systematic short time will prevail, and the concentration of unemployment on any sample group avoided, is one of the best ways of meeting this evil. This is the method advocated by trade unions, but it does not seem to prevail very widely. It is common in the clothing industry of New York, in a few steel works, and in the cigar-making industry.* There is very little likelihood, however, of this practice becoming common, amongst other reasons, because of the increased cost of keeping all the machines running on part time. But even in the industries where it is employed during normal unemployment large numbers are from time to time, during serious depressions, thrown wholly out of employment, and even those partly employed need extra provision against unemployment.

As industry is organized to-day it would be inexpedient to attempt through legal compulsion to extend this practice, though devices for encouraging it are to be welcomed.

One State in the union has aimed to alleviate the problem by making it obligatory on employers to give workmen two weeks notice before dismissing them. It is not to be expected that this proposal can accomplish much. During a period of depression such certainty that the threatened workman will need work in a fortnight's time will not materially help him if there is no vacancy which he can fill.

Public provision of work through the municipalities and the State and organized action by trade unions is not likely, therefore, to affect the problem materially

* It is found also in certain coal mines. The view that trade unions favour this policy was recently expressed by the President of the American Federation of Labour as follows: "During the periods of industrial stagnation or reaction it is a common practice among workers, and particularly among union men and women, to go to an employer and say, " Rather than you let a quarter or a half of our fellow-workers out, divide the work up among us."-Mr. Samuel Gompers : Hearings before the Committee on Labour. H. J. Res, No. I 59, re Commission on Social Insurance, p. I33.

This practice is "not uncommon," and whilst it is certainly growing more common in factories run scientifically, it is still exceedingly rare. See also Protocol Agreement in the Cloak and Suit Industry. 
during the coming decade or so, and we are therefore forced to inquire what provision is made against unemployment by the individual workmen.

\section{Insurance is to be Preferred to Savings as a Means of Providing against Unemployment.}

The most obvious way of providing against a given contingency is for the individual workman to save sufficiently to carry him through the period of stress. Since, however, he cannot foresee with any exactness how long the contingency may last, he is forced to secure himself against the highest risk. Thus with respect to unemployment, whilst the average rate in a given industry may be only five weeks in a year, the workman may not feel safe unless he has made provision for a half-year or more. It is also a fact that few workmen can afford to make such provision through their own savings. It would mean very often having to reduce their standard of living during periods of active employment. Moreover, saving is a disagreeable process to most human beings.

By contributing to a common fund it is found that the maximum of security can be provided at a minimum cost. The individuals insured need not all provide against the highest risk. It is sufficient if they are protected against the average risk in the industry.

Co-operative undertakings for insuring workmen against unemployment are to be preferred to the method of individual savings, since by employing the former, devices might be introduced such as we find in the British scheme which will tend to reduce the amount of unemployment. Of great significance also is the general advantage which comes from the organization of individuals, workmen only, or workers and employers together, for purposes of social betterment. The highest importance attaches to such arrangements when those primarily interested are also empowered to manage the scheme. The social nature of modern industry is clearly evinced and a sense of social responsi- 
bility is thus awakened. Self-government in social and industrial as well as in political matters can be developed in this way.

The strength inherent in the principle of self-help and the destructive, softening influence of State help is the objection often urged against every type of social insurance. This view contains a very obvious fallacy. The individual workman is not an isolated unit. $\mathrm{He}$ is a member of a group. We are too apt to forget that unemployment concerns this group and its solution is therefore a social matter. In the march of history mutual aid has been as great a factor in helping man to conquer his environment as competition. It is obviously foolish to call continually upon the workman to help himself when he is divorced from the opportunity of doing so. A drowning man needs assistance and not the advice that by swimming ashore he will manifest and strengthen his independence, self-reliance, and initiative.

\section{In the United States Insurance against Unemploy- ment should be made Compulsory.}

The phenomenal growth of the Workmen's Compensation Acts in the United States and the steady growth of the movement in favour of health insurance have directed attention to the experience of other countries with schemes of social insurance. In all European countries, as we have seen, there is a growing recognition of the inevitability of compulsory schemes if the vast majority of those usually attacked through the uncertainties of industries are to be protected. In the United States, where trade unions have hitherto made comparatively little systematic provision against unemployment, it would seem to be almost useless to introduce the Ghent scheme for assisting unemployment insurance as the only method of reducing its evil effects. The two main reasons offered in opposition to the proposal that unemployment insurance should be made compulsory are that it is contrary to the American spirit of individualism, and that it would result merely in the 
creation of another source of bribery and corruption. Let us examine both these contentions.

\section{Individualism is not an American Characteristic.}

Individualism is regarded as an American characteristic both by many who are proud of it and by many of those who deplore it. The former believe that it makes for energy, reliance, inventiveness, independence, and national strength; the latter that it often leads to selfishness, localism, class antagonisms, and national weakness. But for good or for bad it is treated as an inherent quality of the American mental make up. This view, like most dealing with national characteristics, is only partially true. It fixes on the transitory and insists that it is permanent. It asserts that they flow from fixed inherent tendencies.

It is, of course, true that during certain periods America has been highly individualistic in its conception of the duties of the State. "That Government is best which attempts least" was for many years a maxim of American statecraft, and, summarized tersely, a widely held view. But it was sandwiched in between two periods when this view was not the predominant one held concerning State functions and activities.

Internal improvements in the form of road building, making rivers more navigable, the construction of canals and railways, were regarded as rightful functions of Government, and between I8I6 and 1835 over $\$ 9,000,000$ were spent on them. Indeed, Jefferson, in his second inaugural address in 1805 , declared "that any surplus of revenue might well be applied in time of peace to rivers, canals, roads, arts, manufactures, education, and other great objects within each State." Later he justified even more emphatically a national system on the ground that the interests of the States would be identified and their union cemented by new and indissoluble ties, suggesting, however, that a constitutional amendment might be necessary. 
In 1807 Gallatin issued a special report in which he outlined proposals for Government undertakings. Van Buren, Clay, John Quincy Adams, and Jackson all favoured expenditures of this kind.* This period of reliance on government was followed by an era of individualism from which the people of the United States have emerged so recently that they have not yet adjusted their vocabulary to the new tendencies. $\dagger$ Let us note the nature and quality of the new strivings and forces making for individualism.

First and foremost was the existence of huge tracts of territory rich and varied, together with an abundance of minerals. Moreover, the railways and the canals already constructed and the excellent natural highways were at the service of those who were prepared to pioneer. What else was necessary but ambition, energy and self-reliance to exploit this "golden country"? It was exactly the type of person possessing these characteristics that the United States has been fortunate in attracting since the landing of the Mayflower. The brain and brawn of Europe have been drawn to it. The vastness of the country, its youth, its inspiring experiment in democracy, the hundred and one misfortunes in older countries, led to America becoming the land where all who were discontented and sick at heart could come and begin life anew. These immigrants were perhaps rich in idealism, but there was no outlet for it in the United States as there was in Europe. Political freedom was already gained, economic security was open to all by working for it. It was a situation where the self-reliant person became more self-reliant. His energy, instead of being directed against a despotism or against unjust taxation or in favour of a wider franchise, was diverted towards attaining a quicker and more thorough exploitation of the country's natural resources. Wave

* McMaster: History of the People of the United States, vol. vi, pp. 347-50.

$\dagger$ The immediate cause of the reaction against Government enterprise resulted from the panic of 1837 , which brought many of the State and city projects to the verge of bankruptcy. 
after wave of immigration swept over the land, only to leave more self-centred, self-reliant characters who strengthened the prevailing attitude. The frugality, energy, and personal independence of the people was not directed towards selfish ends. The very exploitation of the potential wealth of the country was to them an ideal worth striving for and coloured and shaped all their other activities.

Now it is in the nature of the self-reliant person to believe that others are also self-reliant unless indeed the facts to the contrary are very evident. His view of government is inevitably an individualistic view. He needs neither support nor protection, and therefore thinks it safe for the Government not to offer it to others. In so far as he came into touch with the Government he knew himself to be more competent, more honest, and more industrious.

This attitude was reinforced by the necessity of assimilating the immigrant peoples. The striving after national unity became the aim of dominant groups in the country and led to a conscious development of sentiment towards America. In its crudest form it was shown in the encouragement of flag-waving to an extent unknown in European countries. In its highest form it showed itself in the active adaptation of American ideals to everyday life. Democracy and liberty, the ideals of the Fathers of the Constitution, were highly prized. The institutions which they created were treasured, while the instrument of government, the Constitution, was hallowed. It was a symbol of America, an emblem of American ideals, and all who tampered with it were to be regarded with suspicion. The individualistic creed of the reign of George III, enshrined as it was in the Ark of the Covenant, came to have an educative influence and paramount importance even after a century of industrial change had transformed the country out of all recognition. The self-reliance of the pioneer combined with this sentiment of the greatness of America and its ideals to make 
him indifferent to the experience, to the developments, and the experiments of other countries. $\mathrm{He}$ or his immediate ancestor had been sufficiently dissatisfied with things in Europe not to want to borrow many ideas from there. Even the more thoughtful assumed very lightly that conditions in the New World were so different that the experience of other countries was no guide at all. It was the differences from other countries that always obtruded themselves, a self-governing republic, a rigid constitution, a vast unpeopled territory; the heterogeneous elements of the inadequate population, the continual influx of new peoples and their westward march. The fundanentally more important facts, the change from a predominantly agricultural to a predominantly industrial economy, the evolution of the great industry, the rise of great cities, the emergence of an industrial proletariat, the growth of the problems of poverty and uncertainty, in short the emergence of "the Great Society" - these were largely ignored and to-day press for solution.

But this individualism was here as elsewhere only a passing phase. People need different services from the Government at different times, and as a result the Government assumes different functions. * These functions are not fixed and unvarying. The extent to which public authorities therefore interfere with industry is not the same at all times and places. It varies with the efficiency, honesty, and sense of public duty then prevailing. Professor Marshall pointed out that during the last century in England there had been

a vast increase in the probity, the strength, and unselfishness and the resources of Government. . . . And the people are now able to rule their rulers and to check class abuse of power and privilege in a way which was impossible before the days of general education and a general surplus of energy over that required for earning a living. $\dagger$

* The far-reaching measures of Government management and control which have been precipitated by the war demonstrate that there is no reason for believing that Americans will be opposed to the adoption of social measures which they are convinced are necessary to social well-being.

$\dagger$ " Economic Chivalry," in Economic Journal, March 1907. 


\section{INSURANCE AGAINST UNEMPLOYMENT}

This applies equally well to the United States. Indeed, even during the last twenty years there has been a manifest improvement in the whole tone of government. Corruption, spoils and privileges have been largely swept away.* It is therefore clearly safer and more beneficial to entrust the Government with power to-day than it was in the past. And the work of such organizations as the Municipal Research Bureau, the School of Social Research, and the Consumers' League is giving substantial aid to "the general public" to raise the standards of public life. We may therefore conclude that neither individualism nor lapses from honesty are peculiarly American characteristics, that they are of little force in considering proposed extensions of State government to-day, and that they should not therefore prevent its people from boldly grappling with the hideous problems of unemployment.

Having seen some reason for the opinion that it is advisable to make provision against unemployment, that saving is inadequate and that a compulsory scheme as such is not out of harmony with the social spirit of the country, we are now in a better position to analyse the proposed Massachusetts scheme. It has the supreme advantage of being based in very large measure on the experience of Great Britain, and the cautious reader will note which parts of the proposed scheme are new, aiming at its adaptation to local conditions.

* But in 19r4, in his Essays in Social Justice, p. 122, Professor Carver argued that "Government control merely means playing the vote-getting monopolist against the money-getting monopolist. The politician, that is, the vote-getter, cares no more for the people than does the trust magnate. He merely wants their votes as the trust magnate wants their money. He wants their vote in order that he may further his own interests, just as the trust magnate wants their money in order that he may further his own interests." It is, however, exceedingly important to note that the politician derives his power from the public, whilst the magnate derives his from his wealth. The former must cringe to or lie to his master every few years. His fear of dismissal often impels him to serve his master well. The latter, on the other hand, is arrogant and fearless. Whilst according to one theory he is merely a trustee of his wealth, he knows that as society is now organized he is not asked to give an accounting. 


\section{A Brief Summary of the Main Features of the Scheme.}

The Massachusetts Bill on Unemployment Insurance provides for :

(I) a. Compulsory insurance in selected trades.

$b$. Subsidizing of voluntary insurance through associations in all trades.

(2) All workmen in the insured trades are divided into three wage groups. Contributions and benefits* are then calculated for each group on the basis of the average wage of that group. The estimated costs for providing such benefits are 36 cents, 60 cents, and 75 cents per week. This is to be divided amongst employers, workmen, and the State in equal amounts, so that workmen in group (I) will pay I2 cents, in group (2) 20 cents, and in group (3) 25 cents. Payments from all sources flow into the unemployment fund.

(3) The benefits provided by this scheme are: for workmen in group (I), \$3.50 per week; for group (2), $\$ 5.25$ per week; for group (3), $\$ 7.00$ per week for each week of unemployment after the first week up to a maximum of ten weeks in one insurance year, provided also that no workman receives more than one week's benefit for every six weeks' contribution which he pays. No benefit is paid to persons below the age of eighteen.

(4) The benefits are to be paid out direct through the local State employment offices or by way of repayments to associations under Part IX of the Bill.

(5) The conditions for the receipt of unemployment benefit by any workmen are that he has been employed in an insured industry in each of ten weeks in the preceding three years and has paid 26 weekly contributions; that he proves that since his last application for benefit he has been continuously unemployed; that he is capable of work but unable to obtain suitable

* In view of the increased cost of living these contributions and benefits now seem inadequate. 
employment; that he has not exhausted his right to unemployment benefit.

No workman is allowed to receive benefits who is unemployed because of sickness or disablement, or because of a trade dispute, whether it be a lock-out or strike. If he loses employment through his own fault or voluntarily leaves his employment without reasonable cause, he is disqualified from benefit for a period of six weeks from the time that he lost his employment.

(6) In the case of workmen who claim benefit directly any question as to their rights to benefit are decided on first by an insurance officer. The workman then has the right of appeal to an arbitration committee (consisting of an employer, a workman and an impartial chairman). Should the insurance officer and arbitration committee disagree then a decision rests with the referee, who is appointed by the governor. Any question arising with respect to repayments to associations is to be settled between the board of unemployment insurance commissioners and the associations.

(7) In order to encourage voluntary insurance through associations, whether the workmen so insured are employed in insured trades or not, the commissioners are to make a repayment of one-fourth the amount which the association expended on unemployment benefits.

(8) A board of unemployment insurance commissioners is to be created to administer the scheme. It is to divide up the commonwealth into suitable administrative divisions in each of which there is to be a local divisional office. These offices are to be branches of the State employment office.

This board has the supervision and responsibility for the administration of both the local employment offices and unemployment insurance scheme for the whole of the State. 
HOUSE-No. 825.

Bill accompanying the Petition of the Massachusetts ComMITTEE ON UNEMPLOYMENT FOR A SYSTEM OF INSURANCE FOR WORKMEN IN CERTAIN INDUSTRIES WHO ARE TEMPORARILY Unemployed. Social Welfare. January 14.

THE COMMONWEALTH OF MASSACHUSETTS.

In the Year One Thousand Nine Hundred and Sixteen.

AN ACT TO PROVIDE INSURANCE FOR WORKMEN IN CERTAIN INDUSTRIES WHO ARE TEMPORARILY UNEMPLOYED.

$B e$ it enacted by the Senate and House of Representatives in General Court assembled, and by the authority of the same, as follows :

\section{PART I.}

Insured Persons.

Section I. Workmen in insured industries shall be insured under this Act as hereinafter provided.

Section 2. Insured industries within the meaning of this Act shall comprise the following industries :-

(a) Building trades.

(b) Leather products.

(c) Textile products.

(d) Rubber products.

(e) Tobacco products.

(f) Garment manufacturing.

(g) Paper products.

(h) Printing and publishing.

(i) Granite and stone extraction.

(j) Manufacture of motors, engines, machinery, and metals.

(k) Manufacture and repair of vehicles of whatever mode of propulsion, including steam and electric cars, locomotives, automobiles, motor-cycles, carriages, wagons, bicycles.

(l) Construction, reconstruction, or alteration of works, to include railroads, docks, harbours, canals, embankments, bridges, piers, or other works of construction.

(m) Teaming and trucking.

Provided, however, that employers in insured industries who have in operation or who put into operation in their establishments any plan of benefits for their own employees when unemployed, which plan is shown to the satisfaction of the unemployment 
insurance commissioners to offer equal benefits in all respects to those payable under this Act, need not be insured under this Act. The chief commissioner shall have full power to decide the exemptions under this section.

Section 3. Workmen, within the meaning of this Act, shall comprise all men and women over eighteen years of age-

(a) If they are engaged in manual labour in the employ of any person directly operating in an insured industry; or

(b) If, with the exception of clerks, they are in any way occupied in the employ of such person, and receive a wage of twenty-five dollars a week or less; or

(c) If they are actually employed in any one of the occupations scheduled in Section 2, Part I, although they are in the employ of a person who is not operating primarily in an insured industry.

Section 4. "Person," as used in this Act, shall mean any person, firm or corporation which employs labour, unless the context plainly requires another meaning.

\section{PART II.}

\section{UNEMPLOYMENT FUnd.}

Section I. There shall be established under the joint control and management of the Insurance Commissioners hereinafter provided for, a fund called the unemployment fund, into which shall be paid all contributions payable under this Act by employers, workmen, and by the Commonwealth, and out of which shall be paid all unemployment benefits and other payments and expenses which under this Act are payable out of such fund.

Section 2. The accounts of the unemployment fund shall be audited in such manner as the Auditor of the Commonwealth may direct.

\section{PART III.}

\section{Contributions.}

Section I. Insured workmen shall contribute weekly to the unemployment fund the amounts hereinafter specified, except as provided in Section 2, Part VII.

SECTION 2. Employers of insured workmen shall contribute to the unemployment fund a sum in respect of each workman equal to the sum contributed by such workman.

Section 3. Joint contributions on behalf of employer and workman shall be paid by the employer, who shall be legally responsible for such payments. 
Section 4. There shall be annually added to the fund out of the Treasury of the Commonwealth a sum equal to one-half of the total amounts contributed by employers and workmen.

Section 5. Contributions of insured workmen shall be determined on the following basis:-

Group I. Workmen earning wages at the rate of eight dollars a week and less, per week.

Group II. Workmen earning wages at the rate of more than eight dollars and less than twelve dollars a week, per week.

Group III. Workmen earning wages at the rate of twelve dollars a week or more per week.

Section 6. Where, owing to the fact that the wages of a workman are paid at intervals greater than a week, or for any like reason, joint contributions are paid at intervals greater than a week, the amount of such contributions shall be calculated according to the average weekly earnings of such workman during such part of the preceding six months as he has been employed, and each such contribution when paid shall be treated as so many contributions as there are weeks in the period for which the contribution has been paid.

Secrion 7. In respect of workmen employed less than one week, the rate of contribution shall be as follows:-

For one day's employment.

For two days' employment, a sum equal to twice one day's contribution.

For three or more days' employment, a sum equal to regular weekly contribution in Group I in Section 5, Part III.

(a) Provided, that for purposes of reckoning the number of contributions, each contribution at such rate shall be treated as a part of a contribution, such part to be the same as the ratio between such contribution and the regular weekly contribution, in Group I in Section 5, Part III ;

(b) Provided, further, that where workmen are hired by the day, through the State employment offices of the Commonwealth, arrangement may be made with the insurance commissioners that six consecutive days of employment shall be regarded as a week of steady employment, and that the workman's contribution shall be paid on that basis. Where it is impracticable for such contributions to be paid on such basis, the regulations of the insurance commissioners may provide for a proper refund to such workmen so hired; 
(c) Provided, further, that where employers make the necessary arrangements through the State employment offices of the Commonwealth, consecutive engagements of the same or different workmen may be treated and paid for as a continuous employment, but they shall not be so regarded for purposes of a refund of any part of the employer's contribution under Part VII of this Act.

SECTION 8. In any case where an insured workman is engaged in doing piecework and is paid accordingly, or where, for any other reason not provided for in this Part, an insured workman does not receive a weekly wage, he shall be regarded as belonging to that group in Section 5, Part III, which most nearly corresponds to the average weekly earnings of such workman during such part of the preceding six months as he has been employed. Questions as to the determination of wages under this section shall be decided by the insurance officer according to the regulations of the insurance commissioners.

Section 9. Notwithstanding any contract to the contrary, the employer shall not be entitled to deduct or otherwise recover his own contribution from the wages of any workman in his employ except as provided in Section 2, Part VII.

Section ro. An employer in an insured industry may, subject to the regulations of the insurance commissioners, make arrangement with the State employment offices in respect of workmen engaged by him through such offices, whereby the State employment office shall perform all or any of the duties required by this Act to be performed by the employer with respect of those workmen.

\section{PART IV.}

\section{BENEFITS.}

Section I. Benefits shall be paid to insured workmen as hereinafter specified.

SECTION 2. No workman shall receive unemployment benefit for the first week of his unemployment.

Section 3. For each week following the first week of unemployment the benefits shall be determined on the following basis :-

Workmen in Group I of Part III shall receive $\$ 3.5^{\circ}$ per week. Workmen in Group II of Part III shall receive $\$ 5.25$ per week.

Workmen in Group III of Part III shall receive $\$ 7$ per week.

SEction 4. No workman shall receive unemployment benefit for more than ten weeks in one insurance year, nor more than one week's benefit for every six contributions already paid by him. 
Section 5. No benefits shall be paid during the six months next following the date of passage of this Act.

Section 6. No agreement by an employee to waive his rights to benefits under this Act shall be valid, and no benefit under this Act shall be assignable, or subject to attachment, or be liable in any way for any employee's debts.

\section{PART V.}

Conditions for Receipt of Unemployment Benefit.

Secrion I. The conditions for the receipt of unemployment benefit by any workman are :-

(a) That one week of unemployment has elapsed, for which, under Part IV, no benefit has been paid;

(b) That he has been employed in an insured industry in each of ten weeks in the preceding three years and has paid twenty-six weekly contributions ;

(c) That he has made application for unemployment benefit in the prescribed manner, and it is proved that since the date of his last application he has been continuously unemployed ;

(d) That he is capable of work but unable to obtain suitable employment ;

(e) That he has not exhausted his right to unemployment benefit.

Section 2. A workman shall not be deemed to have failed to fulfil the conditions because he has declined-

(a) An offer of employment in a situation vacant in consequence of a stoppage of work to, and forming part of, a labour dispute; or

(b) An offer of employment in the district where he was last ordinarily employed, such offer being at the rate of wage lower, or on conditions less favourable, than those. which he habitually obtained in his usual employment in that district; or

(c) An offer of employment in any other district at a rate of wages lower, or on conditions less favourable, than those generally observed in such district in the industry to which such offer relates.

Section 3. A workman shall be disqualified for receiving unemployment benefit under any of the following conditions :-

(a) While he is an inmate of any prison or almshouse, or other institution supported wholly or partly out of public funds ; 
(b) While he is resident temporarily or permanently outside the Commonwealth ;

(c) If his unemployment is due to sickness or disablement;

(d) If he has lost employment through his own fault or voluntarily leaves his employment without reasonable cause, and in such event disqualification shall last for a period of six weeks from the date when he so lost employment;

(e) If he has lost employment by reason of a stoppage of work which was due to, and part of, a labour dispute at the factory, workshop, or other premises at which he was employed, and in such event disqualification shall last as long as such stoppage continues as a part of such dispute, except in a case where he has, during the stoppage of work, become bona fide employed elsewhere in an insured trade for at least three weeks.

Such disqualification shall not extend to workmen engaged wholly in an occupation different from the one in which the dispute occurred, whether carried on in a separate building or not, provided that the workmen in such different occupation have not become a party to the labour dispute either directly or sympathetically.

The expression " labour dispute" shall mean any dispute between employers and workmen or between workmen and workmen from whatever cause originating, which is connected with the employment, or the terms of employment, or with the conditions of labour, of any workman whether in the employment of the employer with whom the dispute arises or not.

\section{PART VI.}

\section{Determination of Claims.}

Sectron I. All claims for unemployment benefit shall be filed with, and all questions as to such claims shall be determined by, one of the insurance officers appointed under this Act.

SeCtion 2. In any case where unemployment benefit is refused or is stopped, or where the amount allowed is not in accordance with the claim, the workman may require the insurance officer to report the case to an arbitration committee constituted in accordance with this Act. The arbitration committee shall make such investigation as it shall deem necessary, and the decision of the committee, together with a statement of the evidence submitted, its finding of fact, rulings of law, and any other matters pertinent to questions arising before it, shall be filed with the referee appointed under this Act. The finding of the arbitration committee shall be final and conclusive, unless a claim for review is filed by the insurance officer with the referee not later than seven days 
after such finding is so filed. But no party may require the insurance officer to file such claim for review.

Section 3. If a claim for review is filed as provided in Section 2, Part VI, the matter shall come before the referee, whose order or decision shall be final and conclusive (except as provided in Section 4, Part VI), and the referee shall file such order or decision with the records of the proceedings and notify the parties of record thereto. The referee may hear the parties and may take evidence in regard to any and all matters pertaining thereto, and may alter the decision of the committee on arbitration in whole or in part, or may refer the matter back to the arbitration committee for further findings of fact.

SECrION 4. The insurance officer, the workman, or the employer in whose employment the disputed matter arose, if he is aggrieved by an order or decision of the referee, may present a certified copy thereof, and all papers in connection therewith, to the superior court for the county in which the disputed matter arose, or for the county of Suffolk, whereupon said court shall render a decree in accordance therewith. Such decree shall have the same effect, and all proceedings in relation thereto shall thereafter be the same as though rendered in a suit duly heard and determined by said court, except that there shall be no appeal therefrom upon questions of fact, nor if the order or decision of the referee upon which such decree was based was not presented to the court within ten days after the notice of the filing thereof by the referee and except as provided for in Section 5, Part VI. Upon presentation to it of a certified copy of a decision of the referee ending the unemployment benefit, or in any way changing the amount thereof, the court shall revoke or modify the decree to conform to such decision.

SECrion 5. An order or decision of the referee shall have effect, notwithstanding an appeal, until it is otherwise ordered by a justice of the supreme judicial court who may, in any county, suspend or modify such order or decision during the pendency of the appeal. A justice of the supreme judicial court shall also have power, on the application of any interested party, to issue a writ of mandamus to compel the performance of any of the ministerial acts herein provided.

SEction 6. The referee and chairman of the arbitration committees shall have the power to subpœna witnesses, to administer oaths and to examine such books and records of the parties to a proceeding as relate to questions in dispute. Commissions to take depositions and letters rogatory shall be issued by a clerk of the superior court for any county of this Commonwealth on written request by the referee or chairman of an arbitration committee. No entry fee shall be charged in such cases. The insurance commissioners shall have power to make regulations necessary for a proper investigation of all claims. 


\section{INSURANCE AGAINST UNEMPLOYMENT}

SECTION 7. The unemployment insurance commissioners shall determine the remuneration to be paid to the chairmen of the arbitration committees, the members of such committees, and such travelling and other allowances, including compensation for loss of time, to persons required to attend before an arbitration committee or the referee, and all other expenses incidental to hearings before arbitration committees or the referee. All such payments shall be treated as expenses incurred by the insurance commissioners in carrying this Act into effect.

\section{PART VII.}

ReFund of Part of Contribution to Employers.

Section I. The commissioners shall, on the application of any employer made within one month after the termination of any insurance year, refund to such employer out of the unemployment fund a sum equal to one-half of the contributions (exclusive of any contributions refunded to him under any other provisions of this Act) paid by him on his own behalf during that period in respect of any workman who has been in his service during the period, and in respect of which workman not less than forty-eight contributions have been paid during that period.

The commissioners may make regulations for giving effect to, and shall determine all questions arising under this section.

Section 2. If any employer satisfies the commissioners that during any period of depression in his business workmen employed by him have been working short time, and that during such period their contributions under this Act have not been deducted from wages, but have been paid by the employer in addition to those paid by him on his own behalf, there shall be refunded to him out of the unemployment fund, in accordance with regulations made by the commissioners, the contributions so paid by him in respect of those workmen (including those paid on behalf of the workmen as well as those paid on his own behalf) for the period of such part thereof as the aforesaid regulations may stipulate. Any employer who desires to take advantage of this section shall make application to the insurance commissioners to determine whether the requirements of this section are satisfied by the circumstances under which, and the means by which, he proposes to effect a reduction of work hours.

\section{PART VIII.}

Repayment of Part of Contributions to Workmen in Certain Cases.

Sectron I. If it is shown to the satisfaction of the insurance officer by any workman or his personal representatives that the 
workman has paid contributions in accordance with the provisions of this Act for five hundred weeks or upwards, and that the workman has reached the age of sixty, or before his death had reached the age of sixty, the workman or his said representatives shall be entitled to be repaid the amount, if any, by which the total amount of such contributions have exceeded the total amount received by him out of the unemployment fund under this Act, together with compound interest upon such excess at the rate of 3 per cent. per annum calculated in the prescribed manner.

Section 2. In the case of workmen over fifty years of age at the time when this Act goes into effect the insurance commissioners may make provision for repayment as provided in Section I of Part VIII, although less than five hundred weeks' contribution have been paid.

Section 3. Repayment to a workman under Part VIII shall not affect his liability to make future contributions. If, after any such repayment, he becomes entitled to unemployment benefit, he shall be considered for purposes of such benefit as having made for the period for which the repayment has been made the number of contributions which is most nearly equal to two-thirds of the full number of contributions paid during that period.

\section{PART IX.}

\section{Repayments to Associations.}

SECTION I. The commissioners shall on application of any association of workmen in an insured trade which provides payment to unemployed members, arrange, instead of paying benefits as provided in Part IV of this Act, to pay into the treasury of said association periodically out of the unemployment fund such sum as shall be equivalent to the aggregate amount which such workmen would have received in the way of benefit under this Act during periods of unemployment. But in no case shall this amount exceed three-fourths of the amount of the payments made by that association during that period to its unemployed members resident in this Commonwealth.

Section 2. To any association of workmen not trading for profit the rules of which provide for payments to members while unemployed, whether workmen in an insured trade or not, the commissioners shall, upon application of such association, pay out of moneys provided by the treasurer on such conditions, and either annually or at such other intervals as the commissioners may prescribe, an amount not exceeding one-fourth of the aggregate amount which the association has expended on such payments during the preceding year or other prescribed period. No such 


\section{INSURANCE AGAINST UNEMPLOYMENT}

payments shall be made where the benefits were for voluntary unemployment or for unemployment occasioned by a stoppage of work for which benefits would not have been paid directly to insured workmen under Section $3(d)$, Part V.

\section{PART $\mathrm{X}$.}

\section{Migration of Insured Workmen.}

SECTION $r$. If any workman insured hereunder who has not exhausted his benefits has a definite offer of work in any other place in the Commonwealth, he may apply to the fund for half his railway fare to that place, and this amount shall be paid to him forthwith and be deducted from the maximum amount payable to him in respect of unemployment benefit. This section shall apply only to workmen insured hereunder for not less than two years.

Section 2. In any case if it is shown to the satisfaction of the insurance officer that a workman insured hereunder has work offered him in another part of the Commonwealth, his name and record may be transferred to that district.

Section 3. Any workman insured hereunder who leaves the Commonwealth for a period of not more than one insurance year shall be entitled to full benefits after he has become employed again in this Commonwealth in any insured industry for a period of four weeks.

Section 4. Any workman insured hereunder who leaves the Commonwealth for a period of over one insurance year shall be entitled to a refund of all his contributions, less any benefits he may have received, provided that contributions have been made for not less than twenty-six weeks.

Section 5. An "insurance year" shall mean the yearly period dating from the day when benefits are first payable under this Act.

\section{PART XI.}

Unemployment due to Defects in Sirill or KNowledge.

Section $r$. If the repeated failure of any workman insured hereunder to obtain or retain employment appears to the insurance officer to be wholly or partly due to defects in skill or knowledge, the insurance officer may, for the purpose of testing the skill or knowledge of the workman, arrange for the attendance of the workman at a suitable place for the purpose, and may, out of the unemployment fund, pay all expenses incidental to such attendance.

Section 2. If the workman fails or refuses to attend or to produce satisfactory evidence of his competence, or if as a result 
of the test the insurance officer considers that the skill or knowledge of the workman is defective and that there is no reasonable prospect of the defects being remedied, such facts shall be taken into consideration in determining under Part $\mathrm{V}$ what is suitable employment for the workman.

SECTION 3. If in any case as a result of the test the insurance officer considers that the skill or knowledge is defective, but that there is a reasonable prospect of the defects being remedied by technical instruction, the insurance officer may, subject to the regulations of the insurance commissioners, pay out of the unemployment fund all or any of the expenses incidental to the provision of the instruction, if he is of the opinion that the charge on the unemployment fund in respect of such workman is likely to be decreased by the provision of the instruction.

\section{PART XII.}

Administration.

Section I. There shall be established as hereinafter provided a board of unemployment insurance commissioners, which shall consist of a chief commissioner, a financial secretary, and the treasurer of the Commonwealth. It shall be the duty of the unemployment insurance commissioners to supervise the administration of this Act.

Section 2. For purposes of this Act the insurance commissioners shall divide the Commonwealth into suitable administrative divisions. The insurance commissioners shall establish in each such division a local divisional officer to administer this Act in connection with the local State employment office.

Section 3. The chief commissioner shall be appointed and removed by the governor.

SECTION 4. The referee shall be appointed and removed by the governor. He shall hold office during good behaviour. In the event of his removal the governor shall submit a written statement of reasons for so removing him.

Section 5. The chief commissioner shall appoint a financial secretary.

Section 6. He shall also appoint such insurance officers, inspectors and employees for the proper administration of this Act as he may deem necessary, in accordance with provisions of chapter nineteen of the Revised Laws of nineteen hundred and two and Acts in amendment thereof and in addition thereto, and rules adopted thereunder.

SECTION 7. The chief commissioner shall appoint an arbitration committee for each divisional office, as hereinafter provided. An arbitration committee shall consist of representatives of workmen, 


\section{INSURANCE AGAINST UNEMPLOYMENT}

an equal number of representatives of employers, and a chairman. The chief commissioner shall select representatives of workmen from lists submitted by organizations of workmen an equal number of representatives of employers from lists submitted by organizations of employe1s, and the representatives so selected shall choose a chairman. In any case where the workmen or the employers have failed to submit lists on the date set by the chief commissioner for the submission of such lists, the chief commissioner shall select such representatives. In any case where the representatives have been unable in a given length of time to choose a chairman the chief commissioner shall choose such chairman.

Section 8. Salaries and expenses under this Act shall be paid out of the treasury of the Commonwealth for a period of five years after its passage. At the end of such period all such salaries and expenses shall be borne by the unemployment fund except the salary of the referee and the repayment to certain associations as provided in Section 2, Part IX, both of which shall continue to be paid by the Commonwealth.

Section 9. The salary of the chief commissioner shall be ; that of the financial secretary,

that of the referee,

All other salaries shall be determined by the insurance commissioners.

Section ro. The insurance commissioners shall have power to issue orders and regulations for any purposes deemed neccssary for the proper administration of this Act, and such orders and regulations shall have the force of legal enactment.

SECTION II. The insurance commissioners shall make regulations for refunds to employers and employees of contributions paid under a mistake; they may make arrangements for the printing and issuing of special stamps or other evidences of payment as they may require, which shall be used by employers for their own and the workmen's contributions; and they may make arrangements for supplying workmen with cards or books as may be deemed necessary.

SECTION 12. The insurance commissioners shall have power to extend the operation of this Act to workmen in any industry. But no such extension shall be proposed until two years after the passage of this Act. Moreover, no such extension shall become effective until six months after due notice has been given, and an opportunity for a hearing has been given to interested parties or their representatives.

Section 13. The insurance commissioners shall have power to revise rates of benefits and contributions at intervals of five years, on the basis of change of wages or on the basis of an increased permanent expense connected with the administration of this Act, or on the basis of a change in the standards or cost of living of insured workmen : provided, however, no such revision shall become effective until due notice has been given or until an 
opportunity for a hearing has been given to interested parties or their representatives; provided, further, that no order under this section shall increase the rates of contribution from employers or workmen by more than five cents per workman per week above the rates specified in this Act, or reduce the rates of benefit below ninety per cent. of the rates established under this Act, or shall vary such rates unequally as between employers and workmen.

Section 14. The treasury of the Commonwealth shall guarantee the solvency of the insurance fund, but any sum advanced from said treasury under this section shall be repaid by the insurance commissioners out of the insurance fund, who shall have power to safeguard the solvency of the fund by curtailing benefits or increasing contributions. But no order of the commissioners under this section shall reduce the weekly rate of benefit below 90 per cent. of the rate established by this Act, or shall increase the rate of contribution by more than five cents per workman per week, or vary rates unequally as between employer and workmen, and no such order shall remain in force more than three months after all advances and interest thereon have been repaid to the treasury of the Commonwealth.

SECTION 15. The insurance commissioners shall make arrangements with the treasury of the Commonwealth for the repayment of the grant to voluntary associations as provided in Section 2, Part IX.

SEction I6. It shall be the duty of the chief commissioner of unemployment insurance to supervise the administration of this Act. He may issue reports and bulletins on the working of this Act and recommend to the legislature any changes which may be deemed advisable and shall suggest schemes to employers, employees and to the legislature for diminishing unemployment in the State generally, and for diminishing the demands on the fund which arise in the insured industries.

Section 17. It shall be the duty of the referee to consider and determine questions as to whether contributions are payable under this Act in respect of any workmen and to which group such workman or class of workmen belongs; to decide on direct claims for unemployment benefits referred to him by an insurance officer on disagreement with an arbitration committee; to decide all questions concerning the demarcation of industries.

SEctron r8. It shall be the duty of the financial secretary to: (a) arrange for the collection and distribution of all funds as prescribed by this Act according to regulations made by the commissioners ; $(b)$ do any other work in connection with the administration of this Act as the chief commissioner may require.

Section 19. It shall be the duty of the arbitration committees to adjudicate all questions of claims for unemployment benefits and refunds which are appealed from the insurance officer of any divisional office. 
SEcrion 20. It shall be the duty of the insuiance officers to carry out the regulations of the insurance commissioners for the administration of this Act; to adjudicate in the first instance all claims for unemployment benefits and refunds; and in their discretion to file with the refreee claims for review of decisions and orders of the arbitration committee with which such insurance officers do not agree.

Section 2I. The insurance officers shall have all powers delegated to them by the insurance commissioners for the proper administration of this Act.

Section 22. Inspectors shall have power to-

(a) Enter at all reasonable times any premises or place, other than a private dwelling-house not a workshop, where he has reasonable grounds for supposing that insured workmen are employed.

(b) Make such examinations and inquiry as may be necessary to ascertain whether the provisions of this Act are complied with.

(c) Exercise such other powers as the regulations of the commissioners may prescribe.

SECTION 23. An inspector may require any workman or employer subject to this Act to produce all records, books, and other documents which may reasonably be required for the purposes of the office of such inspector.

Section 24. It shall be the duty of inspectors to investigate the causes of the refusal of any workman to accept work offered to him by one of the State employment offices or otherwise; and to report their findings to the insurance officer of that divisional office.

Section 25. Where any premises or places liable to be inspected by inspectors or other officers are under the control of some other State department, the insurance commissioners may make arrangements with that other State department whereby the officers of such other department shall perform the duties of inspectors under this Act.

Section 26. Every inspector shall be furnished with the prescribed certificate of his appointment, and on applying for admission to any premises for the purposes of this Act shall, if so required, produce the said certificate for examination by the occupier.

\section{PART XIII.}

Offences and Proceedings to Enforce Payment of Contributions.

Secrion I. If, for the purpose of obtaining any benefit or payment under this Act, either for himself or for any other person, 
or for the purpose of avoiding any payment to be made by himself, or enabling any other person to avoid such payment, any person knowingly makes any false statement or false representation, he shall be liable to imprisonment for not more than three months, or to a fine of one hundred dollars, or to both.

Section 2. If any employer has failed to pay any contributions for which he is liable under this Act, or if he neglects or refuses to comply with any of the requirements of this Act or of the regulations thereunder, he shall for each offence in respect to each workman be liable to a fine of not more than one hundred dollars : and also where the offence is failure or neglect to make contributions under this Act, he shall be liable to pay to the unemployment fund a sum equal to three times the sum which he has refused or neglected to pay, which sum when paid shall be treated as a payment in satisfaction of the contributions which he has so refused or neglected to pay.

Section 3. Any employer who deducts his own contributions with respect to his workmen from the wages of such workmen, shall for each offence be liable to a fine of not more than one hundred dollars, and shall, in addition, forfeit his right to a refund of contributions under any part of this Act until the end of the next insurance year.

SEction 4. If any workman has failed to make contributions for which he is liable under this Act, or if he or any other person neglects or refuses to comply with any of the requirements of this Act or of the regulations thereunder, he shall for each separate offence forfeit any right to claim or receive benefit during the first week thereafter when he would ordinarily be entitled to claim benefit.

Section 5. Proceedings under the foregoing sections of this part may be instituted only by the insurance commissioners and not later than three months after the offence has been committed.

SECTION 6. Nothing in this part shall prevent the insurance commissioners from recovering any sums due to the unemployment fund by means of civil proceedings, and all such sums shall be recoverable in such proceedings, as debts due to the Commonwealth.

SECTION 7. Any workman who has received unemployment benefit under this Act while the statutory conditions were not fulfilled in his case, or while he was disqualified for receiving unemployment benefit, shall be liable to repay to the unemployment fund any sums so received by him, and the amount may be recovered as a debt due to the Commonwealth.

Section 8. If, in any proceeding under the foregoing sections of this part an issue arises with respect to whether the trade in which the workman is or has been employed is an insured trade, the decision of the referee appointed under this Act shall be conclusive, and if there has been no such decision the question, if 
necessary to the determination of such proceeding, shall be referred to the referee for the purpose of obtaining a decision.

SEction 9. If any person wilfully delays or obstructs an inspector in the exercise of any power granted under this Act, or fails to give such information or to produce such documents as the inspector may lawfully require, or conceals, or prevents, or attempts to prevent any person from appearing before or being examined by an inspector, he shall, on complaint of inspector, be liable to a fine not exceeding fifty dollars.

\section{PART XIV.}

\section{Constitutionality.}

Section I. Should any portion of this Act be adjudged unconstitutional, the remaining portions shall, nevertheless, be valid and of full effect.

Section 2. This Act shall take effect upon its passage.*

\section{The Wisconsin Scheme of Unemployment Insurance.}

Professor John R. Commons has been largely responsible for the Unemployment Prevention Bill now before the Wisconsin State Legislature.

It differs fundamentally in its machinery, though not its underlying idea, from the Bill before the Massachusetts Legislature.

* The Massachusetts Bill on Unemployment Insurance is the joint profuct of the Social Insurance Committee of the American Association for Labour Legislation and of the Unemployment Insurance Committee of the Massachusetts Committee on Unemployment. The Social Insurance Committee, consisting of Professor Edward T. Devine, Professor Henry R. Seager, Dr. I. M. Rubinow, Mr. M. M. Dawson, Mr. J. P. Chamberlain, Professor Carrol W. Doten, Dr. S. S. Goldwater, Dr. Henry J. Harris, Dr. Alexander Lambert, Lilian D. Wald and Dr. John B. Andrews, developed the tentative draft of a Bill on Unemployment Insurance on the basis of memoranda prepared by the author of this volume. The Bill then acted as the basis for discussion for the Massachusetts Committee, the members of which included the late Mr. Robert G. Valentine, Mr. Arthur D. Hill, Mr. Huddell, Professor Felix D. Frankfurter, Mr. Ordway Tead and Miss Olga Halsey, the writer acting as the representative of tile Social Insurance Committee at the meetings of the Massachusetts Committee. Although the Bill was prepared at the invitation of that Committee during the crisis of I9I4-I5, it cannot be regarded in any way as a "panic" measure. Yet there can be little doubt but that in the course of the discussion to which the proposal ought to be subjected, not a few amendments will be found to be necessary. Recent British experience would justify a higher level of benefits. 
The Wisconsin Bill provides that industry must compensate workmen temporarily unemployed, and every employer must insure the liability for payment of benefits during unemployment in a mutual insurance company.

The rates of unemployment compensation provided in the Bill are $\$ 1.50$ for each working day for males and females over 18 years and 75 cents for those between I6 and I8 years. The scheme stipulates that not more than one week's unemployment compensation would be paid for every four weeks of work, and not more than thirteen weeks would be payable in any calendar year.

The Bill aims to encourage regularity of employment. The agencies for carrying the scheme into effect are to be mutual insurance companies run on a non-profit basis. These will devise methods for reducing unnecessary labour turnover. Spasmodic employment of workmen will be discouraged by a system of premium rates which will be based upon and vary with the stability of employment for each establishment.

The author of this Bill has endeavoured to avoid the objections against a measure on the British model by exploiting two ideas with which Wisconsin is very familiar. Compensation for accidents has been long established and is based on common law rights of the workman. The inefficiencies of a heavy labour turnover are also well known. It is argued that unemployment will be reduced if the expense of unemployment insurance be charged against industry just as industrial incidents have been reduced through the "safety first" campaigns following the general adoption of workmen's accident insurance. The Bill embodying these two ideas is unique, and its progress will be watched with interest. 



\section{APPENDIX I}

\section{UNEMPLOYMENT INSURANCE GREAT BRITAIN}

\section{Special Scheme}

The Unemployment Insurance (Insurance Industry Special Scheme)* Order, I921. Draft Special Order dated , I92I, MADE BY THE MINISTER OF LABOUR UNDER THE UNEMPLOYMENT INSURANCE ACT, 1920 (IO AND II GEO. 5, C. 30).

Whereas the Minister of Labour (hereinafter referred to as "the Minister") has determined the classes of undertakings specified in sub-clause (2) of clause three of the Special Scheme set forth in the Schedule hereto to be the Insurance Industry for the purposes of section eighteen of the Unemployment Insurance Act, 1920 (hereinafter referred to as "the Act") ;

And Whereas the said Special Scheme has been made by an Association of employers and employees so constituted that the members of the Association who are employers consist of persons employing a substantial majority of the employees in the said Industry and the members who are employees consist of persons representing a substantial majority of the employees in the said Industry ;

And Whereas the said Special Scheme provides for the insurance against unemployment of all the employed persons in the Industry other than the classes specified in the said Special Scheme and the benefits under the said Special Scheme are in the opinion of the Minister not less favourable on the whole than the benefits provided by the Act;

* As this is the first scheme under Section 18 , it is likely to become the model for future schemes, and is therefore published in detail. Unfortunately, power to make special schemes has been suspended during " the deficiency period." It is not clear from Section 5, Unemployment Insurance No. 2 Act, 1921, whether this scheme for the Insurance Industry will be put into operation for some time. Sanction for the Printers' Industrial Maintenance Scheme has been refused. 


\section{INSURANCE AGAINST UNEMPLOYMENT}

And Whereas it appears to the Minister that insurance against unemployment in the said Industry can be more satisfactorily provided for by a scheme under section eighteen of the Act than by the general provisions of the Act;

Now Therefore the Minister by virtue of the powers conferred on him by section eighteen of the Act and of all other powers enabling him in that behalf hereby makes the following Special Order :-

(I) The Minister hereby approves the Special Scheme set forth in the Schedule hereto.

(2) This Order may be cited as the Unemployment Insurance (Insurance Industry Special Scheme) Order, I921.

Signed by Order of the Minister of Labour this day of , I92I.

Secretary of the Ministry of Labour.

SCHEDULE.

THE INSURANCE INDUSTRY UNEMPLOYMENT INSURANCE SCHEME.

NAME.

I. This Special Scheme (hereinafter referred to as " the Scheme ") shall be called "The Insurance Industry Unemployment Insurance Scheme."

\section{OFFICE.}

2. The principal office of the body charged with the administration of the Scheme shall be situate in London or at such other place in the United Kingdom as such body shall from time to time determine.

\section{Scope of Scheme.}

3. (I) Subject to the provisions of the Scheme and to any regulations made by the Minister under section I9 of the Unemployment Insurance Act, 1920 (hereinafter referred to as " the Act ") the Scheme shall apply in manner provided by section 18 of the Act to all employed persons engaged in the insurance industry and such persons shall be insured against unemployment in manner hereby provided.

(2) For the purposes of the Scheme the expression " employed persons " shall have the same meaning as in the Act as amended 
by any subsequent enactment and the following classes of undertakings shall constitute the insurance industry (that is to say) :-

(a) The insurance undertakings of all persons or bodies of persons whether corporate or unincorporate and whether established within or without the United Kingdom engaged in the United Kingdom in the granting of insurances under contract.

(b) The insurance undertakings of all persons or bodies of persons whether corporate or unincorporate engaged in the United Kingdom in the administration of any system of insurance established by Act of Parliament.

(3) Provided that the Scheme shall not apply to the following classes of persons (that is to say) :-

(a) Persons exclusively engaged in the cleansing repairing or maintenance of premises or buildings or as messengers or as housekeepers or as members of housekeepers' staffs or otherwise in manual labour unless such persons are in the exclusive employment of an employer carrying on an undertaking comprised in the insurance industry and are employed for the purposes of such undertaking;

(b) Persons in the employment of any person or body of persons carrying on in addition to an undertaking comprised in the insurance industry some other undertaking unless such employment is exclusively for the purposes of the first mentioned undertaking ;

(c) Persons employed by or under the Crown; and

(d) Persons in the employment of Insurance Committees established under the National Insurance Acts I9II to 1920 .

(4) Where any employed person to whom the Scheme applies is the holder of a certificate of exemption granted under section 3 of the Act or of a certificate which under the provisions of subsection (2) of that section and any regulations made thereunder for the time being in force is equivalent to such certificate of exemption such person (hereinafter referred to as "an exempt person ") shall not while such certificate of exemption or equivalent certificate is in force be insured under the Scheme.

\section{Body charged with the Administration of the Scheme.}

4. (I) The body charged with the administration of the Scheme shall be a Joint Board of Management (hereinafter referred to as " the Joint Board ").

(2) The Joint Board shall consist of ten members five of whom shall be representatives of the employed persons to whom the 
Scheme applies and five of whom shall be representatives of the employers in the insurance industry.

(3) The members for the time being of the Joint Board shall be a body corporate by the name of The Incorporated Insurance Industry Unemployment Insurance Board and shall have perpetual succession and a common seal and may hold land for the purposes of their powers and duties without any licence in mortmain.

(4) The original members of the Joint Board shall be the persons who at any time prior to the date on which the Scheme comes into force shall have been elected to such membership as to five of such original members by the employers' representatives upon the Joint Committee of Employers and Employees for the Insurance Industry by whom the Scheme has been made and as to the remainder of such original members by the employees' representatives upon such Joint Committee.

(5) Members of the Joint Board shall hold office for two years except that three original employers' representatives and two original employees' representatives shall respectively be selected by lot to vacate office on the thirtieth day of June 1922 and the remainder of the original members of the Joint Board shall vacate office oin the thirtieth day of June 1923.

(6) The places of all retiring members of the Joint Board shall be filled by appointments made before the first day of July in each year in accordance with arrangements to be made by the Joint Board and approved by the Minister of Labour (hereinafter called "the Minister") and failing appointment in such manner as aforesaid by the Minister.

(7) Retiring members of the Joint Board shall be eligible for reappointment.

(8) Casual vacancies on the Joint Board shall be filled in the same manner as the places of retiring members and any person appointed to fill a casual vacancy shall serve for the unexpired period which would have been served by the member replaced.

(9) A member of the Joint Board shall vacate office if such member-

(a) becomes bankrupt,

(b) is found lunatic or becomes of unsound mind,

(c) resigns office by notice in writing, or

$(d)$ is removed by the Minister pursuant to the request in writing of all the other members of the Joint Board for the time being.

(Io) The Joint Board shall elect their own Chairman and Deputy Chairman.

(I I) The quorum necessary for the transaction of the business of the Joint Board shall be five. 
(12) The common seal of the Joint Board shall not be affixed to any instrument except by the authority of a resolution of the Joint Board and in the presence of at least three members and of the secretary or such other person as the Joint Board may appoint for the purpose and the members present and the secretary or other person as aforesaid shall sign every instrument to which the common seal is so affixed in their presence.

(13) The powers and duties of the Joint Board shall be :-

(a) To control and administer the affairs of the Scheme.

(b) To make provision for the working expenses of the Scheme.

(c) To prescribe standing orders governing the conduct of their business.

(d) To keep proper records of their proceedings.

(e) To appoint an actuary, secretary, and such other officers and servants as may be necessary to carry out the provisions of the Scheme, to prescribe their duties, and fix their remuneration.

(f) To appoint such committees consisting of members of their own body as they may consider desirable and subject to the provisions of the Scheme and to any directions from time to time given by the Minister to delegate to such committees any powers and duties they may think fit.

(g) Subject to the approval of the Minister to make rules for any of the purposes for which rules may be made under the Scheme for prescribing anything which under the Scheme is to be prescribed and generally for carrying the Scheme into effect.

(14) Rules made by the Joint Board under the Scheme shall if approved by the Minister have effect as if enacted in the Scheme and may apply with or without modification any of the regulations made by the Minister under the general provisions of the Act.

(I5) Impressions of the common seal of the Joint Board shall be judicially noticed and admitted in evidence.

(16) Prima facie evidence of any rule made by the Joint Board under the Scheme and of the Minister's approval thereof may be given by the production of a copy or copies of the rule and of the instrument or writing containing the Minister's approval purporting to be sealed with the common seal of the Joint Board.

(I 7 ) The Joint Board shall in exercising their powers and in carrying out their duties under the Scheme give effect to any general directions which from time to time may be given by the Minister after consultation with the Joint Board.

(18) A yearly sum not exceeding six hundred pounds or such other sum as the Minister may from time to time allow shall 
be provided as part of the working expenses of the Scheme for the purpose of paying the reasonable expenses of members of the Joint Board incurred in attending its meetings, the balance of the said sum after providing for the said expenses being divisible among the members in such manner and in such proportions as the Joint Board shall from time to time determine.

(I9) If the Minister shall at any time be satisfied that it has become impracticable for the affairs of the Scheme to continue to be administered by the Joint Board or that the affairs of the Scheme are being administered in a manner prejudicial to the interests of persons engaged in the insurance industry the Minister may provide in such manner as he shall think fit for the temporary administration of the affairs of the Scheme, and may for that purpose empower any person or persons selected by him to exercise any of the powers or carry out any of the duties of the Joint Board hereunder.

\section{Contributions.}

5. (I) The funds required for providing the out-of-work benefit payable under the Scheme and for making any other payments which under the Scheme are to be made out of the joint insurance fund established under the Scheme shall be derived partly from contributions by the employers of the employed persons to whom the Scheme applies (hereinafter referred to as "the included employers ") partly from the grant payable to the Joint Board out of moneys provided by Parliament under the provisions of sub-section (7) of section I 8 of the Act as amended by any subsequent enactment and the regulations made under such sub-section and any moneys payable to the Joint Board under sub-section (I0) of such last mentioned section as amended as aforesaid and subject to the provisions of the Scheme partly from contributions by employed persons to whom the Scheme applies.

(2) Subject to the provisions of the Scheme every included employer shall be liable to pay contributions at the rates specified in Part I of the First Schedule hereto.

(3) No contributions shall be payable by employed persons to whom the Scheme applies unless the payment of such contributions and the rates at which such payment is to be made shall be prescribed in manner hereinafter provided.

(4) The provisions of sub-sections (4), (5) and (6) and the first paragraph of sub-section (7) of section 5 of the Act and the rules set out in the Fourth Schedule thereto shall apply for the purposes of the Scheme but the operation of such of the same provisions and rules as relate to contributions by employed persons and the recovery of contributions paid by employers on behalf of employed persons shall be suspended until the payment of such contributions is prescribed under the Scheme. 
(5) The rules set out in Part II of the First Schedule hereto and any further rules in the same behalf from time to time made by the Joint Board either in addition to or in substitution for such first mentioned rules shall have effect with regard to the payment of contributions the rendering of returns and the other matters therein provided for.

\section{OUT-OF-WORK BENEFIT.}

6. Every person who being insured under the Scheme is unemployed and who satisfies the conditions and is free from the disqualifications hereinafter laid down shall be entitled subject to the provisions of the Scheme to benefit (hereinafter referred to as "out-of-work benefit") at weekly or other prescribed intervals at such rates and for such periods as are authorized under the Second Schedule hereto.

7. (I) The conditions for the receipt of out-of-work benefit by a person insured under the Scheme shall be the conditions mentioned in relation to unemployment benefit in section 7 of the Act which section shall apply for the purposes of the Scheme.

(2) The disqualifications for the receipt of out-of-work benefit shall be the disqualifications mentioned in section 8 of the Act, which section shall apply for the purposes of the Scheme.

(3) In calculating the twelve contributions mentioned in subsection (I) (i) of section 7 of the Act and in sub-section (4) of section 8 of the Act a person insured under the Scheme shall be entitled to take into account contributions with which he is entitled to be credited under the rules contained in Part II of the First Schedule hereto.

(4) The provisions of section 9 of the Act shall apply for the purposes of the Scheme.

(5) Provided that during the special periods mentioned in the Unemployment Insurance Act, I92I, a person insured under the Scheme who $(a)$ is normally in employment such as would make him an employed person to whom the Scheme applies; $(b)$ is genuinely seeking whole time employment but unable to obtain such employment; $(c)$ has been engaged at any time in each of not less than twenty separate calendar weeks since the thirty-first day of December r9I9 in any employment which made him or which would if the Scheme had been in force since that day have made him an employed person to whom the Scheme applies, and (d) has not at any time held a certificate of exemption under section 3 of the Act shall notwithstanding the condition mentioned in sub-section ( $\mathrm{r}$ ) (i) of section 7 of the Act as applied for the purposes of the Scheme has not been fulfilled in his case and notwithstanding sub-section (4) of section 8 of the Act and the provisions of the Second Schedule hereto as to proportion of benefit 


\section{INSURANCE AGAINST UNEMPLOYMENT}

to contributions but subject to the other provisions of the Scheme be entitled to receive in each of the said special periods out-of-work benefit for periods not exceeding in the aggregate in each of such special periods sixteen weeks and for the purpose of qualifying any person to receive benefit up to the aggregate amounts aforesaid within each of the said special periods but for no other purpose there shall be treated as having been paid in respect of him such number of contributions as are sufficient to qualify him as aforesaid.

(6) In the application of the last preceding sub-clause to persons formerly engaged in war service within the meaning of the Unemployment Insurance Act, I92I, a period of not less than ten separate calendar weeks shall be substituted for a period of twenty such weeks and if in any particular case a person who has been engaged in war service satisfies the Joint Board that his failure to be employed for the period required by this sub-clause was in consequence of the present war and due to circumstances not within his own control or in the case of a disabled person within the meaning of the last-mentioned Act was due to his disablement that person may if the Joint Board so determine be treated for the purposes of this sub-clause as though he had been engaged for the period aforesaid in such employment as aforesaid notwithstanding he has not in fact been so engaged.

(7) If any question arises under either of the two preceding sub-clauses such question shall be determined by the Minister whose decision shall be final.

\section{Determination of Questions, Claims, Etc.}

8. The provisions of section to of the Act shall apply for the purposes of the Scheme.

9. (I) Every employer of an employed person including an exempt person to whom the Scheme applies shall upon the termination of his employment deliver to him a certificate (hereinafter called a "prescribed certificate") in such form as shall be prescribed signed by or on behalf of the employer and stating :-

(i) The name age and sex of such employed person

(ii) the dates of the commencement and termination of his employment

(iii) whether he is or is not an exempt person, and

such other particulars as shall be prescribed.

(2) Every unemployed person insured under the Scheme who shall upon his applying for out-of-work benefit

(i) present to the Joint Board or their duly authorized representative one or more prescribed certificates 
(ii) make a declaration in the prescribed form that he is unemployed and that he satisfies the conditions and is free from the disqualifications hereby laid down for the receipt of out-of-work benefit

(iii) repeat such declaration whenever called upon so to do by the Joint Board or their duly authorized representative and

(iv) comply with such rules made by the Joint Board relating to applications for out-of-work benefit as are for the time being in force

shall subject to any question arising to suspend the payment of benefit receive out-of-work benefit out of the joint insurance fund hereby constituted to such extent as he shall according to such certificate or certificates and the records and accounts of the Joint Board appear to be entitled.

(3) If any question arises whether the said conditions are fulfilled in the case of any person claiming benefit or whether such conditions continue to be fulfilled in the case of a person in receipt of benefit or whether a person is disqualified for receiving or continuing to receive such benefit or whether the period for which a person insured under the Scheme who has lost his employment through his misconduct or has voluntarily left his employment without just cause is to be disqualified should be some period less than six weeks or as to the correctness of any prescribed certificate (including any question as to whether the person claiming benefit is or is not entitled to benefit to a greater extent than he appears to be according to any certificate) or as to any matter of account or otherwise in connection with a claim to benefit such question shall be determined by the Joint Board and pending such determination benefit shall not be paid except to such an extent (if any) as the claim to the same is undisputed.

(4) The Joint Board shall forthwith take into consideration any claim or question submitted for their determination under the preceding sub-clause and shall so far as practicable give their decision thereon within fourteen days from the date on which the claim or question was so submitted and upon such decision being given payment of benefit shall be made or disallowed in accordance therewith.

(5) The Joint Board may in any case where in their opinion the circumstances so require direct payment of out-of-work benefit without any prescribed certificate having been delivered to them or their representative and upon such other evidence of the claimant's rights as they may deem sufficient.

(6) Any prescribed certificate presented under the foregoing provisions shall be retained by the Joint Board or their duly authorized representatives until the person presenting the same 


\section{INSURANCE AGAINST UNEMPLOYMENT}

has for the time being ceased to receive out-of-work benefit when it shall be returned to such person with an endorsement in the prescribed form of particulars of all payments of out-of-work benefit that have been made to him.

(7) In any case where the person claiming out-of-work benefit or any association of employed persons of which he is a member is dissatisfied with any decision of the Joint Board given under the provisions of this clause such person or association may at any time within twenty-one days from the day on which such decision is communicated to such person or within such further time as the Minister may in any particular case for special reasons allow and the Minister if in any case he shall be of opinion that any such decision of the Joint Board as aforesaid involves some point of general importance may at any time require the Joint Board to refer the question in dispute to the umpire or deputy umpire appointed under the Act whose decision in the matter shall be final and conclusive.

(8) The Joint Board and notwithstanding the provisions of the last preceding sub-clause the umpire or deputy umpire appointed under the Act may on new facts being brought to their or his knowledge revise a decision given in any particular case and where any such revision is made the revised decision shall have effect as if it had been an original decision and as such subject to revision under this sub-clause but without prejudice to the retention of any benefit which may have been received under the decision which has been revised.

(9) The Minister may give such directions as he shall think fit with regard to the conduct of references to the umpire or deputy umpire under the provisions of this clause.

(Io) Rules shall be made by the Joint Board

(i) for prescribing the evidence to be required in addition to such declarations as are provided for under this clause as to the fulfilment of the conditions and the absence of the disqualifications for receiving or continuing to receive out-of-work benefit, and for that purpose requiring the attendance of persons insured under the Scheme at such offices or places and at such times as may be required and, so far as may be necessary, requiring employers to answer inquiries relating to any matters on which the fulfilment of the conditions or the absence of the disqualifications depends;

(ii) for prescribing the manner in which claims for out-ofwork benefit may be made and the procedure to be followed on the consideration and examination of claims and questions to be considered and determined by the Joint Board, and the mode in which any question 
may be raised as to the continuance, in the case of a person in receipt of out-of-work benefit, of the benefit; and

(iii) with respect to the payment of contributions and benefits during any period intervening between any application for the determination of any question or any claim for benefit and the final determination of the question or claim.

(I I) The provisions of sub-sections (9) and (Io) of section II of the Act shall apply to proceedings under the Scheme.

\section{Notification of Vacancies, Etc.}

Io. (I) The Joint Board shall establish such a system of obtaining from employers carrying on undertakings comprised in the insurance industry notification of vacancies for employment and giving notice thereof to employed persons to whom the Scheme applies when unemployed as is in the opinion of the Minister reasonably effective for securing that unemployed persons competent to undertake the particular class of work required shall with all practicable speed be brought into communication with employers having vacancies to fill.

(2) The Joint Board shall make such rules as may be necessary for the purpose of giving effect to the provisions of the last preceding sub-clause and such rules may provide that employers carrying on undertakings comprised in the insurance industry shall notify in the prescribed mannor all suitable vacancies upon the staffs of their respective undertakings.

(3) The Joint Board may enter into any mutual or other arrangement with any person body of persons or Government department whose business functions or powers admit of such an arrangement with a view to the prompt re-employment of unemployed persons insured under the Act.

\section{Financial Provisions.}

II. (I) For the purposes of the Scheme there shall be established under the control and management of the Joint Board a fund called the joint insurance fund into which shall be paid all contributions payable under the Scheme by employers (including contributions for the purpose of restoring the solvency of the fund) and employed persons the grant payable out of moneys provided by Parliament and any moneys payable to the Joint Board under the provisions, of sub-section (I0) of section 18 of the Act as amended by any subsequent enactment and out of which shall be made all payments in respect of out-of-work benefit and subject to the provisions of the Scheme in respect of the working expenses of the Scheme and any other payments which 


\section{INSURANCE AGAINST UNEMPLOYMENT}

under the Scheme or the rules made thereunder are to be made out of the fund.

(2) The Joint Board shall pay out of the joint insurance fund to the aforesaid Joint Committee by whom the Scheme is made such a sum as the Minister may allow in respect of the costs and expenses of such Joint Committee of and incidental to the preparation and making of the Scheme and of the submission thereof to the Minister for his approval.

(3) If the Minister shall with reference to any period direct that the working expenses of the Scheme during such period shall not be in excess of a sum which is a particular proportion of the aggregate of the sums which during the same period are payable into the joint insurance fund in respect of contributions by employers and employed persons (exclusive of any contributions by employers for restoring the solvency of the fund) it shall not be lawful during such period to make any payment out of the joint insurance fund in respect of working expenses which shall be in excess of such first mentioned sum.

(4) The Joint Board may by rules under the Scheme provide for the payment out of the joint insurance fund as part of the working expenses of the Scheme of the travelling and other expenses (including loss of remunerative time) of any person attending the Joint Board or umpire or deputy umpire appointed under the Act upon the consideration of any question which under the provisions of the Scheme is to be determined by them or him.

(5) The Joint Board may from time to time open banking accounts with such bank or banks as they may select and such accounts shall be operated on by such members and officers of the Joint Board authorized in that behalf by the Joint Board and under such conditions as the Joint Board shall from time to time prescribe.

(6) Any moneys forming part of the joint insurance fund may from time to time be invested in the name of the Joint Board upon and in any securities and investments for the time being authorized by law for the investment of trust funds.

(7) The Joint Board may for the purpose of meeting temporary deficiencies or otherwise for the purposes of the Scheme with the consent of the Minister borrow money on such terms and from such persons or banks as they may think fit and may with the like consent secure money borrowed upon the joint insurance fund or any of its assets in such manner as they may deem expedient.

(8) (a) The Joint Board shall cause full and accurate accounts to be kept in such form as the Minister shall approve of all moneys paid into and out of the joint insurance fund of the matters to which the receipts and expenditure relate and of the assets and liabilities of the 
joint insurance fund and such accounts shall be audited by an auditor appointed by the Joint Board and approved by the Minister.

(b) The accounts of the Joint Board shall show separately the respective amounts of contributions paid under the Scheme in respect of men, women, boys, and girls respectively.

(c) The Joint Board shall furnish accounts to the Minister in such form and at such times as he may require.

(d) The Joint Board shall comply with any directions from time to time given to them by the Minister as to the publication of their accounts and auditors' reports thereon.

(e) The Minister may at any time direct such further or special examination of the accounts of the Joint Board to be held as he may think necessary.

12. (I) If at any time and from time to time before the expiration of seven years from the date on which the Scheme comes into force the joint insurance fund shall become insolvent the employers of all persons who at the time of the happening of any such insolvency or at any time previously are or have been insured under the Scheme shall be liable to make good to the joint insurance fund such a sum as will restore its solvency upon the basis of each of such employers contributing for that purpose rateably according to the aggregate amount of the contributions paid by him under the Scheme whether on his own behalf or on behalf of employed persons during the period which has elapsed in the case of a first insolvency between the date when the Scheme came into force and such insolvency and in case of a subsequent insolvency between the date of the last preceding insolvency and such subsequent insolvency.

(2) (a) The amount of the contribution due from each employer liable to contribute for the purpose of restoring the solvency of the joint insurance fund shall be determined by the Joint Board and shall be paid by such employer to the Joint Board at their principal office at such time as they may direct.

(b) An assessment made in the prescribed manner upon any employer liable to contribute as aforesaid shall be prima facie evidence that the sum assessed is due and owing from such employer.

(3) If any question arises as to whether the joint insurance fund is solvent or insolvent or as to the amount required to restore its solvency or as to the proportion of such amount which any employer is liable to contribute or as to the date or dates on 


\section{INSURANCE AGAINST UNEMPLOYMENT}

which the joint insurance fund has become insolvent or othcrwise in relation to the matters provided for by the preceding sub-clauses of this clause such question shall be determined by the Minister whose decision shall be final and conclusive.

(4) The Joint Board shall cause such special accounts audits and valuations to be taken held and made for the purposes of this clause as they may deem expedient or as the Minister may direct.

13. (I) If it appears to the Minister at any time and from time to time after the expiration of seven years from the date on which the Scheme comes into force that the joint insurance fund is in all the circumstances of the case in danger of becoming insolvent the Joint Board shall if the Minister so directs prescribe such one or more of the following things as will in the opinion of the Minister after consultation with the Joint Board be sufficient on the whole to secure the solvency of the joint insurance fund (that is to say) :-

(a) The payment of contributions under the Scheme by employed persons to whom the Scheme applies at such rates as shall be determined by the Joint Board with the approval of the Minister;

(b) The temporary modification to such extent as the Joint Board shall with the approval of the Minister deem expedient of any of the rates of contribution for the time being in force under the Scheme;

(c) The temporary modification to the like extent and with the like approval of any of the provisions contained in the second Schedule hereto.

(2) Provided that nothing shall be prescribed under the provisions of this clause which will

(a) Impose or increase contributions or diminish benefit except to such extent as will in the opinion of the Minister after consultation with the Joint Board be sufficient on the whole to secure the solvency of the joint insurance fund ;

(b) Reduce any weekly rate of out-of-work benefit below a sum exceeding by two shillings in the case of men and women and by one shilling in the case of boys and girls the corresponding weekly rate of unemployment benefit for the time being in force under the general provisions of the Act as amended by any subsequent enactment;

(c) Cause contributions to be paid by any employed person at a weekly rate exceeding one half of the corresponding rate for the time being in force under the general provisions of the Act as amended as aforesaid; or

(d) Impose contributions upon any exempt person. 
(3) For the purposes of the last preceding sub-clause rates of benefit and contribution under the general provisions of the Act as amended as aforesaid and the Scheme respectively shall be deemed corresponding rates when applicable in the case of persons of the same age and sex.

I4. (I) At the expiration of seven years from the date on which the Scheme comes into force and at the expiration also of every subsequent period of seven years or at such other times as the Joint Board may prescribe or the Minister direct the Joint Board shall cause a valuation of the assets and liabilities of the joint insurance fund to be made by an actuary approved by the Minister.

(2) If it appears to the Joint Board or to the Minister upon any such valuation that the joint insurance fund is insufficient or more than sufficient after providing for such reserves as the Joint Board after consultation with the actuary making such valuation shall think proper to discharge the liabilities imposed thereon the Joint Board may with the consent of the Minister and shall if the Minister so requires prescribe such of the following things as circumstances may require (that is to say) :-

(a) In the event of there appearing to be a surplus on such valuation after providing for such reserves as aforesaid the application in any manner of such surplus or of any part thereof for the benefit of persons insured or to become insured under the Scheme and either by way of increase of out-of-work benefit either in duration or amount or of reduction of contributions payable by employed persons or otherwise.

(b) In the event of there appearing to be a deficiency on such valuation and for the purpose of making provision for such deficiency

(i) the revision of the rates of contribution by employers and employed persons for the time being in force under the Scheme;

(ii) the revision of any of the provisions contained in the Second Schedule hereto including any modifications of such provisions for the time being in force;

(iii) the payment of contributions under the Scheme by employed persons to whom the Scheme applies at such rates as shall be determined by the Joint Board.

Provided that

(a) the provisions of sub-clauses (2) and (3) of clause I 3 shall apply to anything prescribed under the 


\section{INSURANCE AGAINST UNEMPLOYMENT}

provisions of this clause with the substitution of the words "provide for such deficiency" for the words "secure the solvency of the joint insurance fund."

(b) Subject to such last-mentioned provisions the revision of contributions and the imposition of contributions upon employed persons under the provisions of this clause shall proceed upon the basis and shall be so connected that after deducting from the amount at the revised rate of any employer's weekly contribution in respect of any employed person the sum of $4 \mathrm{~d}$. in the case of men and boys and the sum of $3 \frac{1}{2} \mathrm{~d}$. in the case of women and girls the remainder shall be a sum equal to the amount of such employed person's weekly contribution at the revised or newly imposed rate.

\section{Determination of Scheme.}

15. (I) It at any time the Joint Board shall for any reason with the consent of the Minister pass a resolution for the winding up of the Scheme the Scheme shall be wound up in such manner as the Minister may direct.

(2) When the affairs of the Scheme have been completely wound up the Minister shall make an order that the Scheme be determined and the Scheme shall be determined accordingly.

(3) A resolution to wind up the Scheme shall not be valid unless one calendar month's notice of the meeting of the Joint Board at which the winding up resolution is passed and of the terms of such resolution has been given to the Minister by the Joint Board.

(4) The Minister may if in his opinion circumstances so require provide by special order for the determination of the Scheme and any matters incidental thereto.

(5) The expression "special order" shall have the same meaning as in section 36 of the Act and that section, section 37 of the Act, and the provisions of the Sixth Schedule thereto shall apply for the purposes of the Scheme.

\section{Statistics of Unemployment.}

r6. The Joint Board shall cause statistics of unemployment arising among employed persons to whom the Scheme applies to be kept in such manner as the Minister may require and shall furnish to the Minister periodical returns relating to such unemployment in accordance with any regulations made under section 21 of the Act for the time being in force. 


\section{INSURANCE AGAINST UNEMPLOYMENT}

\section{Legal Proceedings.}

17. The provisions of section 22 of the Act shall apply for the purposes of the Scheme except sub-section (6) thereof for which sub-section the following provisions shall be substituted:

" Nothing in this section shall be construed as preventing

" the recovery of any sum due to the joint insurance fund " by means of civil proceedings and any such sum shall be " a debt due to the Joint Board and without prejudice to " any other remedy recoverable summarily as a civil debt."

I8. (I) Proceedings for an offence under the Scheme shall not be instituted except by or with the consent of the Minister or by an inspector or other officer of the Joint Board authorized in that behalf by the Joint Board or in Scotland except by the Minister or the procurator-fiscal.

(2) The provisions of sub-sections (2) and (3) of section 23 of the Act shall apply for the purposes of the Scheme.

19. The provisions of section 24 of the Act shall apply for the purposes of the Scheme.

\section{Miscellaneous.}

20. The provisions of section 26 of the Act shall apply for the purposes of the Scheme.

2r. The provisions of sub-section (I) of section 28 of the Act shall apply for the purposes of the Scheme.

22. Inspectors for the purposes of the Scheme may be appointed by the Joint Board and the provisions of section 29 of the Act shall apply to such Inspectors.

Provided that nothing contained in such section shall authorize any inspector appointed under the Scheme to enter any premises or places other than any premises or places in the occupation of employers carrying on undertakings comprised in the insurance industry.

23. (I) Where any person to whom an advance on account of the expenses of travelling to a place where employment has been found for him has been made under sub-section (I) of section 2 of the Labour Exchanges Act 1909 is a person insured under the Scheme who would in the opinion of the Joint Board be entitled to receive or to continue to receive out-of-work benefit if he became or remained unemployed the Joint Board may repay out of the joint insurance fund to the fund out of which the advance was made such part of the advance as may with the consent of the Minister be prescribed but if the person to whom the advance was made fails without reasonable excuse to enter on the employment found for him the sum so repaid out of the joint insurance fund may be recovered from him or deducted from any out-of-work 


\section{INSURANCE AGAINST UNEMPLOYMENT}

benefit which may thereafter become payable to him and if so recovered shall be paid into the joint insurance fund.

(2) The Joint Board may provide by rules made by them for the payment out of the joint insurance fund of a prescribed proportion of the expenses of travelling to a place where employment has been found for him of any person insured under the Scheme.

24. The provisions of section 32 of the Act shall apply for the purposes of the Scheme.

\section{INTERPRETATION, ETC.}

25. (I) The provisions of sub-section (I) of section 47 of the Act as amended by the Unemployment Insurance Act I92I shall apply for the purposes of the Scheme.

(2) The Interpretation Act 1889 shall apply in the construction of the Scheme in like manner as it applies in the construction of Acts of Parliament.

26. (I) In construing the general provisions of the Act which under the foregoing clauses hereof are to apply for the purposes of the Scheme references to $(a)$ regulations under the Act except in sub-section ( $\mathrm{I}$ ) (v) of section 7 (b) contributions rates of contribution and payments under the Act $(c)$ a person or persons insured or liable to be insured under the Act $(d)$ unemployment benefit or benefits conferred by the Act $(e)$ proceedings under the Act $(f)$ requirements of the Act $(g)$ the unemployment fund (h) offences under the Act and (i) special orders under the Act shall be read and construed as referring to $(a)$ rules under the Scheme (b) contributions rates of contribution and payments under the Scheme $(c)$ a person or persons insured or liable to be insured under the Scheme $(d)$ out-of-work benefit or benefits conferred by the Scheme $(e)$ proceedings under the Scheme $(f)$ requirements of the Scheme $(g)$ the joint insurance fund $(h)$ offences under the Scheme and (i) special orders under the Scheme respectively.

(2) In addition to such modifications of the aforesaid general provisions as are provided for by the foregoing clauses of the Scheme the modifications of the same provisions specified in the Third Schedule hereto shall have effect.

27. Where by any special order varying or amending the provisions of the Scheme any clauses sub-clauses paragraphs or words are directed to be added to or omitted from the Scheme or to be substituted for any other clauses sub-clauses paragraphs or words therein, then copies of the Scheme printed under the authority of His Majesty's Stationery Office after such direction takes effect shall be printed with the clauses sub-clauses paragraphs or words so added omitted or substituted and the clauses sub-clauses and paragraphs thereof numbered in accordance with such direction, and the Scheme shall be construed as if it had at the time at which 
such direction takes effect or at such other time as may be directed by the special order been made with such addition omission or substitution.

28. The Scheme shall come into force on the fourth day of July r 921 .

\section{FIRST SCHEDULE.}

\section{PART I.}

Rates of Contribution by Employers.

For each week:-

In the case of men and boys--4d. or such other weekly rate of contribution by employers as shall for the time being be in force under the general provisions of the Act as amended by any subsequent enactment in the case of men.

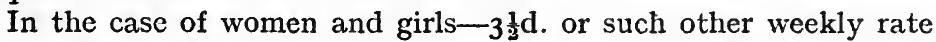
of contribution by employers as shall for the time being be in force under the general provisions of the Act as amended by any subsequent enactment in the case of women.

\section{PART II.}

\section{Rules.}

I. All contributions payable by employers under the Scheme whether on their own behalf or on behalf of employed persons including contributions payable in respect of exempt persons shall be paid to the Joint Board at their principal office by quarterly payments in advance upon the usual quarter days.

2. The amount of each quarterly payment to be made by any employer shall be a sum equal to the aggregate of the amounts which such employer would be liable to pay under the Scheme in respect of the quarter commencing on the day on which payment is due if such quarter consisted of a number of complete calendar weeks (which expression shall in this Schedule have the same meaning as in the Fourth Schedule to the Act) equal to the number of Sundays occurring therein and if all employed persons to whom the Scheme applies including exempt persons in the employment of such employer at any time on the day on which payment is due continued in the same employment and under the same liability to be or with the like exemption against being insured against unemployment during the whole of the ensuing quarter.

3. A quarterly payment made in accordance with the foregoing rules shall satisfy the liability under the Scheme of the employer making the same in respect of the quarter commencing on the day on which payment is due notwithstanding changes during 


\section{INSURANCE AGAINST UNEMPLOYMENT}

such quarter in the number or personnel of such employer's staff or in the status of any member thereof as regards insurance against unemployment.

4. Every employer liable to pay contributions under the Scheme shall from time to time render to the Joint Board returns of all employed persons to whom the Scheme applies including exempt persons in the service of such employer on any day which may be prescribed generally for the insurance industry or for any particular employer or class of employers carrying on an undertaking or undertakings comprised in the insurance industry.

5. Returns rendered under the preceding rule shall state

(i) the name age and sex of each employed person included therein and whether he is or is not an exempt person

(ii) the date of the commencement of his service where such service commenced after the commencement of the Act

and such further particulars as the Joint Board shall prescribe.

6. Every employer liable to pay contributions under the Scheme shall upon the occasion of any employed person to whom the Scheme applies including an exempt person entering or leaving the service of such employer or while in the service of such employer dying or ceasing to be a person to whom the Scheme applies or becoming an exempt person and upon the occasion also of any person in the service of such employer becoming liable to be insured against unemployment under the Scheme either by reason of his ceasing to be an exempt person or otherwise notify the occurrence to the Joint Board at their principal office in such manner as they shall require.

7. No employer shall in any event become entitled to the return of any part of any quarterly payment made by such employer under the foregoing rules.

8. An employed person to whom the Scheme applies including an exempt person continuing in the service of the same employer throughout an entire quarter shall be entitled to have all contributions actually paid in respect of him included in his employer's quarterly payment for that quarter taken into account for the purposes of the Scheme.

9. An employed person to whom the Scheme applies including an exempt person entering the service of an employer upon some day between the two quarter days shall in respect of the period between the day of the commencement of his employment and the day preceding the next quarter day (both of such days inclusive) be entitled to have such number of contributions as is equal to the number of Sundays in such period upon which he continues in the same employment credited as having been paid in respect of him under the Scheme. 
I0. For the purposes of the last proceding rule a person already in the service of an employer who becomes liable to be insured against unemployment under the Scheme otherwise than by reason of his ceasing to be an exempt person or who would become so liable were he not an exempt person shall be deemed to enter such employer's service on the day on which such liability arises or would arise but for the exemption of the person concerned.

I I. An employed person to whom the Scheme applies including an exempt person leaving the service of an employer at any time except at the termination of a quarter shall in respect of the period between the quarter day immediately preceding the termination of his employment and the date of such termination inclusive of such quarter day and date of termination be entitled to have such number of contributions only as is equal to the number of Sundays in the said period treated as having been paid in respect of him under the Scheme and shall not be entitled to have any further contributions which may in fact have been paid in advance in respect of him taken into account or notwithstanding the provisions of the Fourth Schedule to the Act be under any liability in respect of such of the same as may have been paid on his behalf.

I2. Contributions credited to be taken into account or treated as having been paid in respect of exempt persons under the foregoing rules shall have effect as contributions paid under sub-section (7) of section 5 of the Act as applied for the purposes of the Scheme.

13. For the purposes of this Schedule the day on which the Scheme comes into force shall be substituted as a quarter day for the twenty-fourth day of June I92I and the third quarter of the year I92I shall be deemed to be the period commencing on the day on which the Scheme comes into force and ending at midnight on the day preceding the next ensuing quarter day.

I4. The first of the rules contained in the Fourth Schedule to the Act as applied for the purposes of the Scheme shall so long as the foregoing rules of this Schedule continue in force take effect subject to the provisions thereof.

\section{SECOND SCHEDULE.}

Rates and Periods of Out-of-work Benefit.

I. Out-of-work benefit shall be payable in respect of each week of any continuous period of unemployment after the first three days of unemployment and shall be at the weekly rates following :-

\section{Ordinary Rates.}

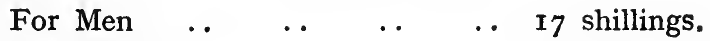

For Women $\quad \ldots \quad$. . . I4 shillings. 


\section{INSURANCE AGAINST UNEMPIOYMENT}

\section{Rates in Cases of Persons under Eighteen.}

$\begin{array}{llllll}\text { For Boys } & \ldots & \ldots & \ldots & \ldots & 8 \text { shillings and } 6 \text { pence } \\ \text { For Girls } & \text {. } & \ldots & \ldots & \ldots & 7 \text { shillings. }\end{array}$

2. No person shall receive out-of-work benefit for more than sixteen weeks in either of the special periods mentioned in the Unemployment Insurance Act I92I and thereafter for more than twenty-six or such other number of weeks as may be prescribed by any rule made by the Joint Board (either generally for the insurance industry or for any particular branch thereof) within any insurance year or in respect of any period less than one day.

Provided that in any case where out-of-work benefit is payable for a period of less than a week it shall be paid at a daily rate equal to one-sixth of the weekly rate applicable to the person receiving the benefit.

3. No person shall receive more out-of-work benefit than in the proportion of one week's benefit for every six contributions paid or credited as paid in respect of him under the Scheme.

Provided that for the purpose of determining the amount of out-of-work benefit to which having regard to the aforesaid proportion any person is entitled after the second day of July 1922 no account shall be taken of any benefit which may have been received by that person at any time in respect of the period between the date upon which the Scheme comes into force and the third day of July 1922 or of any unemployment benefit received by him under the general provisions of the Act and there shall be deemed to have been paid previously to that date in the case of every person who is insured under the Scheme at that date twenty-five contributions in addition to the contributions actually paid or credited as paid in respect of him under the Scheme and in addition also to the contributions paid in respect of him under the general provisions of the Act between the eighth day of November 1920 and the day on which the Scheme comes into force but such twenty-five contributions shall not be taken into account for the purpose of determining whether any person satisfies the first of the conditions mentioned in sub-section (r) of section 7 of the Act as applied for the purposes of the Scheme.

4. Any time during which a person is under the Scheme disqualified from receiving out-of-work benefit shall be excluded in the computation of periods of unemployment under this Schedule.

5. A period of unemployment shall not be deemed to commence until the unemployed person has made application for out-of-work benefit in the manner provided by the Scheme.

6. Notwithstanding anything contained in the foregoing para- 
graphs of this Schedule out-of-work benefit shall until the Ist day of July 1923 be at the weekly rates following :-

$$
\begin{aligned}
& \text { Ordinary Rates. }
\end{aligned}
$$

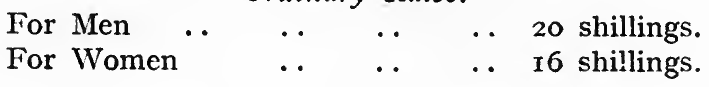

\section{THIRD SCHEDULE.}

Minor Modifications of Provisions of the Unemployment Insurance Act Applied for the Purposes of the Scheme.

Section 5 (7) Omit the word "full."

For "the other provisions of this Act" substitute " the other provisions of the Scheme." Section 7 (I) (ii) For "prescribed manner" substitute "manner provided by the Scheme."

Section 8 (2) For "under the provisions of this Act" substitute " under the provisions of the Scheme."

Section 8 (3) Omit "subject to the provisions of this Act."

Section 9 Omit "subject to the provisions of this Act."

Section 22 (4) For " unemployment card" substitute " prescribed certificate."

Omit " unemployment book or used unemployment insurance stamp" and all words after "twenty pounds."

Section 22 (5) For "statutory conditions" substitute "conditions laid down by the Scheme."

Section 23 (2) In the first paragraph for "Minister" and " his " substitute " Joint Board " and " their" and in the second paragraph for "by the Minister" and "his" substitute "on behalf of the Joint Board" and "their."

Section 24 (I) " For "any regulations" substitute " the Scheme or any rules made thereunder."

Section 28 (I) For "the general provisions of this Act" substitute "the provisions of the Scheme."

Section 29 For "this Act" wherever occurring substitute " the Scheme."

Section 29 (4) Omit "other" before "Government department " wherever occurring and for " Minister" substitute "Joint Board."

Section 32

For " the purposes of this Act" substitute the purposes of the Scheme," 


\section{INSURANCE AGAINST UNEMPLOYMENT}

Section 37

Omit " order or" where these words first occur and for " an order or " substitute "a."

Section 47 (I) (e) Omit the first and second provisos and in the third proviso for "Minister" and "him" substitute "Joint Board" and "them."

(g) For "Minister" substitute " Joint Board."

Fourth Schedule

Paragraph (I) Omit the proviso to such paragraph.

Paragraph (5) For "this Act" substitute " the Scheme."

Paragraph (6) For " provisions of this Act" substitute "provisions of the Scheme." 


\section{APPENDIX II}

\section{UNEMPLOYMENT INSURANCE IN AGRICULTURE *}

A committee representing employers and workers in agriculture was appointed by the Agricultural Wages Board on December 2, 1920, "To inquire into and report upon the extent to which the Unemployment Insurance Act might be made applicable and beneficial to agricultural workers."

There are three methods by which insurance against unemployment may be possible :-

(I) By the inclusion of the industry of agriculture in the general scheme provided by the Unemployment Insurance Act, 1920, on the initiative of the Minister of Labour.

(2) By the adoption of a special scheme for agriculture under Section 18 of the Act; or

(3) By a purely voluntary scheme outside the Act.

The Committee concluded that employers and workpeople were not sufficiently in accord to make any one of these methods practicable. It is noteworthy that the statistics dealing with unemployment in agriculture were found to be very deficient. Employment exchanges are scarcely used either by those seeking work or by those needing help. The main difficulty in drafting a Special Scheme would be the submission of actuarial calculations as to the rate of contributions, the amount of unemployment, etc.

On inquiry, the Committee discovered that Italy is the only country which compulsorily insures agricultural workers. The Royal Decree of October 19, 1919, provided for the compulsory insurance of all workers, and those engaged in agriculture number more than half the total working-class population. On the other hand, those "working at home" are specifically excluded from

* Report of the Committee on Unemployment Insurance in Agriculture. Cmd. I344. 


\section{INSURANCE AGAINST UNEMPLOYMENT}

the scheme, and there is not yet sufficient experience to judge to how many this will apply in a country of smallholders.

It is noteworthy that the Italian scheme, which is framed after the British model, provides no special machinery for dealing with agricultural unemployment, but deals with it in the same way as unemployment in other trades. 


\section{APPENDIX III}

\section{THE SCALE OF BENEFITS}

THERE have been a number of changes in the rates of benefits allowed under the British scheme.

During March 3 rd-July ist the weekly rate of unemployment benefit has been:-

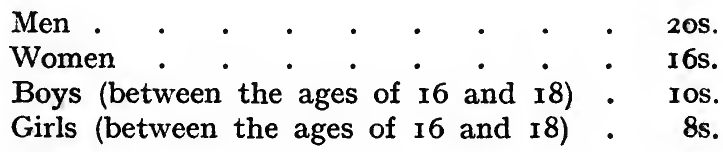

This scale was reduced from July Ist, see Chapter XIV.

It is now clear that the scheme of unemployment insurance needs to be supplemented by some measure of unemployment relief. Mere reduction of the rates of benefits will neither make the unemployment fund solvent nor meet the needs and demands of the unemployed. 


\section{APPENDIX IV}

\section{THE I92I CRISIS}

\section{UNEMPLOYMENT. A NATIONAL OR LOCAL PROBLEM.}

UNEMPLOYMENT insurance is a device for meeting the loss in wage during normal periods of unemployment. None amongst even its most enthusiastic advocates have urged that it is either possible or desirable to meet a period of heavy and continuous unemployment by this means.

Special measures must be taken to restart the wheels of commerce and industry, and, it is possible that, in addition, emigration on a large scale will sooner or later be found to be necessary. But whilst these measures are being sought and are being put into operation, unemployed workmen and their families must be maintained. Wild attacks in the name of " anti-waste " notwithstanding, the community will not allow workmen to starve, nor will workmen who recently risked so much quietly yield themselves, their wives and children, upon the altar of economy. An "anti-waste" policy, interpreted in the spirit of the day, threatens to create a situation menacing to ordered government. An unemployment crisis of exceptional gravity was reached in September I921.* In that month there were two million workmen wholly unemployed in Great Britain, over two hundred thousand of these had exhausted their right to benefit under the unemployment insurance scheme, Poor Law Guardians were besieged with demands for adequate maintenance, which were to be on a scale between $£ 3$ and $£ 5$ a week, i.e. equal in amount to the wages paid to fully employed workmen, over twenty members of the Poplar Borough Council were sent to gaol for giving relief to the workless and then for refusing to levy the rates demanded by the central local authorities, rent strikes were being prepared and processions and demonstrations every. where being organized by the unemployed. Rioting by the men, and baton charges by the police, occurred in a number of cities.

Workmen who have exhausted their right to benefit under the

* President Harding appointed a committee to investigate the amount of unemployment and to propose measures for dealing with it. 
unemployment insurance scheme, and even many who still have that inadequate income, are obliged to turn to the local Guardians of the Poor for relief. What has rightly come to be regarded as a national problem is thus left to local authorities, when it is well established by the experience of Lord St. David's Committee that the latter cannot make any appreciable contribution for dealing with it. Notwithstanding this consideration, the Guardians in a number of London boroughs decided to make allowances from the funds, obtained by increasing the rates. It seems likely that certain boroughs in other parts of the country will also adopt this policy. The Islington Board of Guardians decided to allow each unemployed workman 12s. 6d. per week in addition to an allowance for rent and coal. If the unemployed workman is married he is to obtain 25s. a week in respect of himself and his wife, his rent (which must not exceed I5s. per week), and 1 cwt. of coal free, which in September I921 cost about 3s. 6d. An additional $5 \mathrm{~s}$. is to be allowed in respect of each child under $\mathrm{I} 6$.

It is provided .that these grants are to be made irrespective of any benefits the unemployed workman may draw under the Unemployment Insurance Act.

The estimated allowance for each unemployed workman who has a wife and three children is $\hbar^{2}$ r6s. per week.

An outcry was raised by a certain section of the Press against these allowances as being too liberal. On the other hand, in some boroughs, such as Woolwich, the unemployed have demanded a higher scale of relief than that allowed at Islington. The Ministry of Health has, however, disallowed the Islington scale of relief.

\section{POWER OF THE GUARDIANS TO RELIEVE THE POOR.}

The Guardians of the Poor are the elected representatives of the ratepayers, and the law empowers them to give adequate relief to the unemployed. The Guardians must notify the Ministry of Health within twenty-one days of any very unusual expenditure. It has power to suggest an interpretation of the term " adequate" to the Guardians. Where, however, they grant liberal relief the local auditor may disallow the amount and surcharge the guardians, making them personally liable for the excessive expenditure. The Guardians may then appeal to the Ministry of Health, and, if it thinks they acted in ignorance or without blame in the matter, it may decide that the Guardians shall not be compelled to meet the surcharge. If the Ministry decides that the Guardians deliberately acted wrongly it can then permit the auditor to sue the Guardians personally as for a civil debt.

It should be noted, however, that if there is a disposition to challenge the decision of the Ministry, the allowances will be paid 


\section{INSURANCE AGAINST UNEMPLOYMENT}

and the rates will be levied, and then when legal proceedings be taken against the Guardians, and the surcharge be imposed on them, they may be found to be themselves men who have little with which to meet the verdict.

Already, it is being proposed that the powers of Guardians to levy rates for the relief of the unemployed and for granting " liberal " allowances be restricted by Parliament.

\section{UNEMPLOYMENT: A NATIONAL RESPONSIBILITY.}

The local authorities are incompetent to deal with the situation satisfactorily because they are destitute of resources, and because they lack the necessary machinery for ascertaining whether the man who claims relief is bona fide unemployed. To build up such machinery during the crisis, as is proposed, would be costly and it is certain to prove inefficient. Moreover, the causes making for our present unemployment are national, and its effects should therefore be borne by the central Government.*

The Government might elect to provide relief to all who are registered under the unemployment insurance scheme, and provide maintenance for them on a scale higher than the present insurance benefits but substantially lower than the average wage of employed workmen. Whilst such a scheme of relief would best be administered by the employment exchanges, its costs would be enormous. Thus, assuming that the average number of unemployed for the next twelve months will be one million, and the weekly allowance as low as 3 os. per week, the cost will be $f 78,000,000$.

If, as is more likely, the Government will attempt to develop a scheme of relief works so as to give effect to the principle of maintenance through work the costs involved may be even greater. But if these works make for the permanent enrichment of the country, they will be more desirable than either, work for maintenance, or relief without work.

- Note manifesto of Labour Party issued September 21, 1921. 


\section{CHIEF BOOKS AND PAPERS USED}

Where not given, the place of publication is London.

Alden, P. Democratic England. New York, I9I2.

The Unemployed : a National Question. Second edition, 1905.

Alden, Percy, and Hayward, E. E. The Unemployable and Unemployed. 1908.

Alexander, Magnus W. Hiring and Firing. New York, 19r4.

BARKer, ERnest. Political Thought in England from H. Spencer to the Present Day. 19r6.

Barnes, Charles B. The Longshoremen. New York, ror5.

BeCKer and Bernhardt. Die gesetzliche Regelung der Arbeitsvermittlung in den wichtigsten Länden der Erde.

Beveridge, Sir W. Unemployment: a Problem of Industry. Third edition, I9I2.

Brandeis, Louis D. The Outlook. New York, Igri.

Brandeis, Louis D., and Prof. Felix Frankfurter and JosePHINE Goldmark. Brief of Franklin O. Bunting $v$. State of Oregon. Washington, I9I6.

Brown, Prof. W. Jethrow. The Underlying Principles of Modern Legislation. I9I5.

Brooks, John Graham. Social Unrest. New York, I9I2.

Butlding Trades Industrial Council. Interim Report of the Committee on Scientific Management and Reduction of Costs. r920.

Burns, C. Delisle. Government and Industry. I92I.

Burton, T. E. Financial Crises and Periods of Industrial and Commercial Depression. New York, 1902.

Carr, A. S. C., Garnetr, W. H. S., and TAYlor, J. H. National Insurance. 1912.

Chapman, Sir S. J., and Hallsworth, H. M. Unemployment. The results of an investigation made in Lancashire. 1909.

Clarke, Orme. The Law of National Insurance. Igr2. 


\section{INSURANCE AGAINST UNEMPLOYMENT}

Conen, Joseph L. New York Evening Post. September 4 and September 9, 1915. Socialism and Unemployment. Scientific Management and Unemployment. Bulletin of the Society for the Promotion of the Science of Business Management. Massachusetts, 1915.

Commons, Prof. J. R., and Andrews, J. B. Principles of Labour Legislation. New York, 1920.

Cole, G. D. H. Unemployment and Industrial Maintenance. I92I.

Dawson, W. H. The Vagrancy Problem. I9ro.

Dearle, N. B. Unemployment in the Building Trades. I909.

Devine, Prof. E. T. Misery and its Causes. New York, 1909.

Frankel, L. K., and Dawson, M. M. Working Men's Insurance in Europe. New York, 19ro.

Gephart, W. F. Principles of Insurance. New York, I9I7.

GibBon, I. G. Unemployment Insurance. 1911 .

Greenwood, Arthur. Juvenile Labour Exchanges and After Care. IgIr.

Grenfell, A. P. Afforestation and Unemployment. Fabian Tract No. I6I. I9I2.

Guyot, Prof. Yves. Causes and Consequences of the War. r9r5.

Hart, Hamilton. Fluctuations in Unemployment in Cities of the United States. 1902-17. Cincinatti, I918.

Hayes, Prof. C. J. British Social Politics. I9I4.

Henderson, Prof. C. R. Industrial Insurance in the United States. Chicago, I9II.

Henry Street Settlement, New York. Reports of Committee for Vocational Scholarships.

Hillquit, Morris. Socialism in Theory and Practice. New York, I909.

Hobson, John A. Work and Wealth. I9I4.

The Problem of the Unemployed. I908.

Hobson, S. G. National Guilds and the State. 1920.

Hourwich, Prof. I. A. Immigration and Labour. New York, I912.

Howe, F. G. Socialised Germany. I9I5.

Hull, George H. Industrial Depressions, I9II. New York.

JaCkson, Cyril. Unemployment and Trade Unions. I9Io.

Jevons, H. S. Trade Union Policy and Unemployment. Contemporary Review. July 1909.

Trade Fluctuations and Solar Activity. Contemporary Review, August 1909. 
Keller, H. Out of Work. New York, I9r5.

Kennedy, J. B. Beneficiary Features in American Trade Unions. (John Hopkins University Studies.) Baltimore, 1908.

Kirkaldy, A. W. British Labour Replacement and Reconstruction, 1914-21. British Association.

Kirson, Arthur. Unemployment. 1921.

Kumpfmann, Paul. Die Arbeitslosenversicherung. Tübingen, I9!3.

Labour Party, The. British Trades Union Review (Monthly).

Labour Year Book, r9r6.

Labour and the New Social Order. I9I7.

The War for Coal and Iron, by Dorothy Francis Buxton. I921.

Unemployment: The Peace and the Indemnity. 1921.

Unemployment: A Labour Policy. 1921.

Labour International Handbook, 1921.

Labour Research Department, Monthly Circular. 1921.

Labour Monthly. I921.

LEFORT, J. L'Assurance contre le Chômage en France et a l'étranger.

2 vols. Paris, r9r3.

McMaster, J. History of the People of the United States. Vol. vi.

Marshall, Alfred. Economic Chivalry. Economic Journal, March 1909.

Meredith, H. O. Outlines of the Economic History of England. I9I3.

Mess, H. A. Casual Labour at the Docks. r9r6.

MILLs, F. C. Contemporary Theories of Unemployment and Unemployment Relief. Columbia University, New York, I9r7. Columbia Studies.

Mrtchell, John. Organized Labour. Philadelphia, I903.

Mitchell, Wesley Clair. Business Cycles, 1913. Berkeley.

Money, L. G. Chiozza. Insurance versus Poverty. 1912.

Montmorency, J. E. G. DE. National Insurance and National

Character. The Edinburgh Review. July r9r3.

Moore, Prof. H. L. Business Cycles. New York, 1915.

Pease, Edward R. History of the Fabian Society. 1916.

Pigov, Prof. A. C. The Economics of Welfare. r920.

Unemployment. I9r4.

Wealth and Welfare. r9r2.

Portenar. Organized Labour: Its Problems and How to Meet Them. New York, 1912.

Pretry, A. W. A Tax on Industry. 19i3. 
Robertson, Dennis H. A Study of Industrial Fluctuations. I9i5.

Rowntree, B. Seebohm. The Way to Industrial Peace and the

Problem of Unemployment. I9r3.

Rowntree, B. S., and LAsker, B. Unemployment: a Social Study. I9II.

Rowntree \& Co., LtD., York. Unemployment Benefit Scheme, Explanatory Memorandum. I920.

Rubinow, Dr. I. M. Social Insurance. New York, I9I4.

Standards of Health Insurance. New York, I9I6.

Sargent Florence, Dr. P. The Question of Fatigue from the Economic Standpoint. British Association Report, I9I6.

Schanz, Prof. Dritter Beitrag zur Frage der Arbeitslosenversicherung.

Schloss, D. F. Insurance against Unemployment. 1909.

Seager, Prof. H. R. Social Insurance. New York, I9I4.

Simons. Social Forces in American History.

Smelser, D. P. Unemployment and American Trade Unions. Baltimore, 1919.

Smith, Sir H. Llewellyn. Economic Journal. December rgro. Snowden, Philip. Wages and Prices. 1920.

Spender, Constance. The Humanity of Labour Exchanges. Contemporary Review. I9I2.

Stone, Dr. N. I. The Costs of Unemployment. The Survey, New York, January 23, I915.

Summer, Helen L. History of Women in Industry: Report on Conditions of Women and Child Wage-earners in the United States.

TAWNey, R. H. The Sickness of an Acquisitive Society. 1920.

Veblen, Prof. Thorstein. The Theory of Business Enterprise. New York, 1915.

Warburg, Paul M. The Currency Problem and the Present Financial Situation. New York, I920.

Webb, Sidney. Grants in Aid. New Edition, 1920.

Reform of the Poor Law. Contemporary Review, I89o.

The War and the Workers. Fabian Tract No. I76. I914 Webb, Sidney, Mr. and Mrs. The Prevention of Destitution. I9r r.

A Constitution for the Socialist Commonwealth of Great Britain. 1920.

Report of National Conference for the Prevention of Destitution. I9I I. 
Webb, S., and Freeman, A., and Juliet Stuart Poyntz. Seasonal Trades. I9I2.

WeLls, H. G. New Worlds for Old. 1908 .

Williams, R. The First Year's Working of the Liverpool Dock Scheme. I9I4.

The Liverpool Docks Problem. Liverpool Economic and Statistical Society. I912.

WiLlits, J. H. Steadying Employment-with a Section devoted to some Facts on Unemployment in Philadelphia. (Annals of American Academy of Political and Social Science.) Philadelphia, r916. 


\section{OFFICIAL PAPERS}

\section{GREAT BRITAIN.}

Unemployed Workmen Act, 1905.

Labour Exchanges Act, I909.

National Insurance Act, I9II, Part II.

National Insurance (Part II Amendment) Act, 1914.

National Insurance (Part II) (Munition Workers) Act, I916.

Unemployment Insurance Act, 1920.

Unemployment Insurance Act, I92I.

Unemployment Insurance (No. 2) Act, I92I.

Report to the Board of Trade on Agencies and Methods for Dealing with the Unemployed in Certain Foreign Countries, by D. F. Schloss, 1904. Cmd. 2304.

Royal Commission on the Poor Laws, Part II, and Minority Report, 1909.

Deputation of Social Democratic Party to Mr. D. Lloyd Gcorge, I9II. Cmd. 5869.

Repayment to Associations under Section 106 of the National Insurance Act, I9II. H.C. I9I of r9I3.

First Report of the Proceedings of the Board of Trade under Part II of the National Insurance Act, I913. Cmd. 6965.

Report with Regard to National Insurance Act, I9II (Part II Amendment Bill), by T. G. Ackland. H.C. I92 of I9I4.

Report of the Committee of Enquiry into the Work of the Employment Exchanges, 1920. Cmd. 1054.

Minutes of Evidence taken before the Committee of Enquiry into the Work of the Employment Exchanges, 1920. Cmd. II40.

Report by the Government Actuary on the Financial Provisions of the Unemployment Insurance Bill, 1921. Cmd. 1336.

Report of the Committee on Unemployment Insurance in Agriculture, 1921. Cmd. I344.

Decisions of Umpire under the National Insurance Act, Part II. Vol. i, I9I4; vol. ii, I9I5; vol. iii, I919.

British and Foreign Trade and Industrial Conditions, 1905. Cmd. 2337.

Board of Trade Report on Cost of Living of Working Classes, Ig08. Cml. 3864 . 
Reports of the Chief Registrar of Friendly Societies.

Report of the Chief Inspector for Great Britain of Factories and Workshops for 1920 . Cmd. I403.

The Labour Gazette is published weekly, and gives a detailed analysis of the employment situation in Great Britain with a short statement as to the situation abroad.

Labour Overseas, published quarterly, devotes more attention to: the employment situation abroad.

\section{UNITED STATES OF AMERICA.}

Twenty-third Annual Report of the Commission of Labour, Workmen's Insurance and Benefit Funds in United States (one volume). Washington, 1908.

Twenty-fourth Annual Report of the Commission of Labour: Workmen's Insurance and Compensation Systems in Europe (two volumes). Washington, I909.

Vol. I. Austria, Belgium, Denmark, France, Germany.

Vol. II. Great Britain, Italy, Norway, Russia, Spain, Sweden.

The Federal Census, 1900. Washington, 1901.

The United States Bureau of Labour Statistics-

No. 76. What is Done for the Unemployed in European

Countries, by W. D. P. Bliss, Washington, 1908.

No. ro9. Statistics of Unemployment and the Work of

Employment Offices in the United States. Washington, I9I2.

No. 172. Unemployment in New York City. Washington, I9I5.

No. 186. Labour Legislation of I9I5. Washington, I9I6.

No. 195. Unemployment in the United States. Washington, I915.

No. 212. National Conference on Social Insurance Proceedings. Washington, I9I7.

Hearings before the Committee on Labour of the House of Representatives on Social Insurance. H. J. Res, No. I59. Washington, 1916.

Industrial Employment Survey, Bulletin No. I. Washington, I92I.

Chicago: Report of Mayor's Committee on Unemployment. Chicago, I9I5.

Massachusetts Bill on Unemployment Insurance, I9r6.

New York Department of Labour, Bulletin No. 69: Idleness of Organized Wage Earners in 1914. New York, 1915.

New York Mayor's Committee on Unemployment, Report, 1915-16. 


\section{2}

New York Mayor's Committee on Unemployment, Adapted Report,

" How to Meet Hard Times." The Survey, New York, r917. Report to Legislature of New York State on Unemployment and the Lack of Farm Labour, 1912. Third Report.

The Unemployed in Philadelphia, r9r5.

Wisconsin Bill on Reducing Unemployment, I92 I.

The American Labour Legislation Review, which is issued monthly, is the best publication in the country devoted to the study of the unemployment problem. Special issues are devoted to it from time to time. See May number, $19 \mathbf{r}_{4}$, and June number, 1915 .

The Survey, The American Federationist, the Reports of the Annual Convention of the American Federation of Labour, also record what progress is being made in that country in dealing with the problem.

\section{INTERNATIONAL.}

Until the outbreak of the War the Proceedings and Bulletin of the International Association for Combating Unemployment contained the most scientific studies of unemployment problems, and remain our best source of information for the period covered.

The International Labour Office of the League of Nations has taken over its functions. Hitherto, however, it has been most serviceable to students by collecting, translating, and publishing laws and decrees dealing with the subject. By means of its regular publications, the International Labour Review, the Official Bulletin, and the Daily Intelligence, it promises to inform all students, administrators, and statesmen interested in this problem of the latest thought and achievement. The following, from irregular periodical publications issued in 1919-2 $\mathrm{r}$, have been of special service in the preparation of this study:-

Report on Unemployment, 1919. (Prepared for the Washington Conference.)

Report II on Unemployment, $192 \mathrm{r}$.

Austria.-Loi et Reglements. Assurance contre le Chômage.

Denmark.-Unemployment Funds.

Finland.-Unemployment Funds.

France.-The Organization of Unemployment Insurance and Employment Exchanges in France, 1921.

Germany.-Arbeitslosenversicherungsgesetz.

Federal Employment Board.

Italy.-Royal Decree on Unemployment Insurance.

The Government Action in Dealing with Unemployment. 


\section{INDEX}

Ackland, Thomas, 279

Andrews, John B., 44

Ashley, Professor W. S., 265

Asquith, H. H., 226, 287

Assessments, Trade Union, 4 Io

Association Internationale pour la lutte contre le chbmage, Bulletin of, $47,85,91,138$, I 51,221 , 235,320

Austria, $35^{8}$

Bailward, W. A., 239, 290, 31 2, 320

Balfour, Arthur James, 49

Basle, 106

Belgium, 5I, 84

Benefits, 129

Berne, 108

Beveridge, Sir W. H., 30, 45, 192, 300

Bounty, 49

Bradford Dyers' Association, Ltd., 382

Brandeis, Louis D., I 8, 54

British Establishment Funds, 375

Brooks, Professor John Graham, 385

Building Industry in Great Britain, 339

Burns, C. Delisle, 230

Burns, John, 28, 247

Cadbury Bros., $3^{82}$

Canada, 153

Ontario Commission on Unemployment, 48

Carver, Professor, 474

Casual Labour, 293, 305

Cecil, Lord Robert, 225

Chamberlain, Joseph, I6r

Chamberlain Circular, 162

Chapman, Professor, 29

Charity, 39, 40

Churchill, W. L. S., 203, 253, 255 , 26r, 312

Cigar Makers, Union of, America, 393 et seq.
Civil Service, 233

Cologne, 148

Commons, Professor John R., 492

Compulsory Insurance against Unemployment, I ro, I5I, 2 I 8, $352,358,445$

Contracts, Government, 45

Court of Referees, 213, 244

Crisis Funds, 109

Cunningham, 19

Cyclical depressions, 22

Czecho-Slovakia, 155

Definition of Unemployment, 28 of Unemployment Insurance, 67

Denmark, I 24

Depravity, 4I

Depressions, 44, 49

Destitution, 4I, 42

Devine, Professor E. T., 4r, 437

Doles, 67, 26r

Dovetailing employments, I 89

Drain on National Wealth, 36

Economy campaign, 233

Emigration, 164

Employers' Contribution towards Insurance, 256

Employment Offices, Bureaux and Exchanges-

and ex-service men, 327

and the decasualizing of labour, 184

and Trade Union Standards, 178

and Trade Union officials, 277

basis for organizing industrial market, 46

costs of, 329

criticism of, 52, I9I

establishment of, 46, I 16,138

for Juveniles, 180

for Women, I 79

in Austria, $35^{8}$

in Belgium, 90

in Czecho-Slovakia, 155

in Denmark, 138 


\section{INSURANCE AGAINST UNEMPLOYMENT}

Employment Offices, Bureaux and Exchanges-

in France, 96

in Germany, 142

in Great Britain, 168

in Italy, 347

in Norway, 1 I 8

in United States, 453

Objects, I 68

Organization and Staff, 172

Placing Agencies, 175

specialized, 178,342

Establishment Funds, 366

Fabian Society, 252

Feiss, Joseph, 367

Fluctuations, 43

Ford Company, 367

France, 92

Establishment funds, 375

National Scheme of subventions for relieving unemployment, 95

Frankel, Dr. L. K., 422

Freudenberg, Karl, 372

Friendly Societies, 75

Fuster, Professor Edward, 22 I, 425

Gephart, 64

German establishment funds, 37 I

Germany, I 40

Ghent Commission on Unemployment, 86

Ghent Scheme, 68, 84 et seq.

Advantages and Disadvantages, 89

Gibbon, I. G., 69, 77, 229

Gompers, S., 225, 421

Hamburg Association of Consumers, 76

Henderson, Arthur, 279, 289

Henderson, Professor C. R., 229, 261

Henry Street Settlement, I8I

Heyl, Cornelius, 372

Hillman, Sidney, 370

Hillquit, Morris, 446

Hiring and Firing, 32, 320

Hobson, John A., 37, 262

Hobson, S. G., 337

Holland, I 21

Hours, reduction of, 42

Hardie, Keir, 288

Illinois, 46

Immigration Employment Bureaux, 440

Imperial Employment Exchanges, I99
Imperial Immigration Bureau, 199

India Relief Works, 48

Industrial Insurance-

Building Industry, 339

Insurance by industries, 333 et seq.

Insurance Trade Scheme (draft), 496

Maintenance, 333

Printers' Scheme, 338

"The Rota System," 336

Special Schemes under the National Unemployment Insurance Act, 337

Industry, regularization of, 45 , 292

Insurance and the prevention of risk, 55

advantages of, $6 \mathbf{r}$

International Association against Unemployment, 65, 425

International Trade Union Statistics, 79

Italy, 201, 347

Japan, I 54

Jevons, H. S., 3 I

Juvenile Employment Offices, 439

Kinds of Unemployment, 30

Labour Party, 45, 259, 263, 290, 335

Labour turnover, 34

Labour Year Book, 265

Lanzt, Heinrich, 37 I

Lefort, S., 27 I

Liverpool Dock Scheme, I 86

Llewellyn Smith, Sir H., 270, 3 ro

Lloyd George, 259, 303, 323

London and India Docks, 186

London, Congressman Meyer, 27, 429

Luzzati, M., 347

Lyons, 99

Macdonald, Ramsay, 257, 289

Macgregor, Professor D. H., 192

Maintenance (see Industrial Insurance)

Malingering, I I I, 3 I 5

Management Department, 367

Manchester Cloth Porters, 186

Marshall, Alfred, 23I, 473

Massachusetts Bill on Unemployment Insurance, 477

Mess, H. A., 293

Metropolitan Life Insurance Co., 24 
Migration of workers, 170,457

Milan, 349

Ministry of Labour, 169, 280, 300

Mitchell, John, 4I2

Mohr, A. L., 372

Money, L. G. Chiozza, 227, 260

Moore, H. L.,3I

Mülhausen, 146

National Civic Federation America, Social Insurance Enquiry, 263, 284

Norway, II 5

Ontario Commission on Unemployment, 1916, Report of, 153

Out of Work Donation Scheme, 327

Out Relief, I62

Panic, 42

Paris, 98

Pennsylvania, 46

Pigou, Professor A. C., 3I, 49, 23I, 265

Poor Law Relief, I 18, I6r

Poor Law Report, 77, 273, 301, 303

Prevention of Unemployment Bill, 45

Private Employment Registries, 439

Programme of Works, long period, 45,49

Prussia, 47

Reconstruction Sub-Committee, 314

Relief Works, 44

France, 92

Great Britain, I60

India, 48

Reserve of Labour, 189 et seq.

Right to work, 22

Ringhoffer, 373

Rota System, 336

Roubaix, roo

Rowntree, 375

Rubinow, Dr. I. M., 62, 448

Russia, 364

St. Gall, I I I

Saving, $55,59,468$

Compulsory, 58, 469

Motives for, $56,57,71$

Schanz, Professor, 58, 71

Schloss, D. F., 108, 167

Scientific Management, 367

Seager, Professor Henry R., 51, 57, 267

Seamen, International System of Insurance for, 68
Seasonal Unemployment, 45

Short time, 44, 304

Small Holdings, $5 \mathrm{I}$

Smith, F. E., 225

Socialism, 42

Societa Umanitaria, 349

Sombart, Professor W., 96

Soviet Russia, 364

Spain, I 55

Standard of Living, 40

State contributions, 88

Statistics concerning unemployment, criticism of, in U.S., 433

Strassburg, 144

Subsidies, 88, 106, I I3, I 29, 135 , 145

Summer, Helen L., 20

Switzerland, I05

Trade funds, 355

Trade Union, $68,75,78,85,93,105$, I $17,122,125,14 \mathrm{I}$

Effect of unemployment on, 38

Training of juveniles, r 8o, 439

Types of Unemployment Insurance, 68

Une mployables, 2 r, 293

Unemployed Workmen Act, 160, I 64

Unemployment-

a problem of capitalism, 17

after the war, 32

an insurable risk, 63

and democratic committees, r96, 441

and regularization of expenditure, 302

causes of, 22, 30, 32

cumulative effect, 38

definition, 28

destitution, 39

economic cost, 36

effect on Trade Unions, 38

effects, 35,37

fallacies repecting, 39,43

historical, 19

human cost, 37

methods for dealing with, 40, 45 , 50

national or local problem, Appendix IV, 522

prevention, 17 et seq., 2 I I

reduction of, 292

statistics, 22

United States, 24 
Unemployment Insuranceand the regularization of industry, 45,292 and trade disputes, 240 compulsory, 68, I IO, I5I, 218 constitutionality of, in U.S., 448 contributions of employers, 256 contributions of workmen, 258 co-operation with Trade Unions, 215 criticism of, 53 definition of, 67,248 exhaustion of claims, 3 I 5

Federal on State legislation in U.S., 461

Ghent, 68

graded rate, 266

in agriculture, 519

incidence of, 263

Massachusetts Bill, 48, 465

rates of benefit, 266

State grant, 88, 97, I I 3, I 36, 145

State intervention in, 8I

the incidence of the burden of, 262 et seq.

the Labour Party and, 288

Trade Union, 68, 75 types of, 68

voluntary, 216,222

Umpire, $24 \mathrm{I}$ et seq.

United Kingdom-

allocation of public contracts, 45 donation scheme, 327

employment offices, 168

extent of unemployment in, 23

juvenile training in, 179

policy, $5 \mathrm{I}$

proposed legislation, 42

statistics in, 22

study of unemployment in, 166
United States of America-

American Federation of Labour, 27,420

American Association for Labour Legislation, 442, 492

Employment Exchanges, 46, 434, 443

extent of unemployment, 24, 27

income of people, 40

Insurance against Unemployment-

Massachusetts Bill, 477

Wisconsin Bill, 492

juvenile training in, 439

movement for unemployment insurance in, 426

Programme on Unemployment, 430

Public Works, $44^{\circ}$

statistics in, 24

Vacation periods, 50

Valentine, Robert G., 258

Veblen, Professor Thorstein, 57

Vocational guidance, I8I

Voluntary employment offices, 436

Wages equalization fund, 345

War, 32

War Pensions Committee, 198

Webb, Sydney, Mr. and Mrs., 42, 409

Wisconsin Scheme, 492

Works, Public-

in Canada, 48

in Great Britain, 49

in India, 48

in United States, $44^{\circ}$

Zeiss, Karl, 371

Zurich, III 
$\bullet$ 

in

;

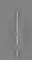

+

,

8

?

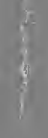




\section{DAY USE}

RETURN TO DESK FROM WHICH BORROWED LOAN DEPT.

This book is due on the last date stamped below, or on the date to which renewed.

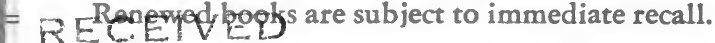

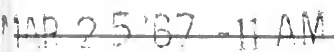

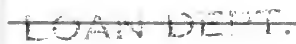

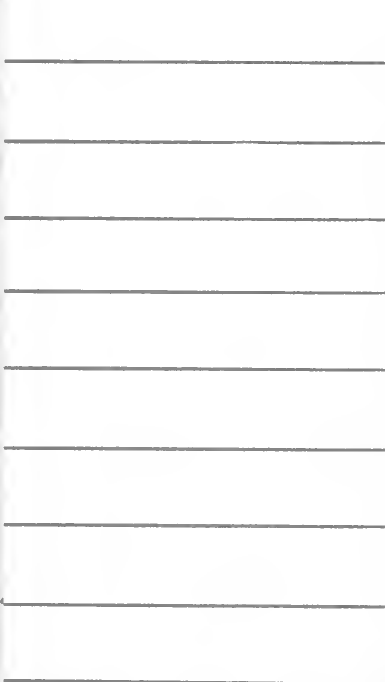

LD 21A-60m-7,'66

(G4427s10)476B

General Library

University of California Berkeley 
